\title{
Environmental Analysis for Pipeline Gas Demonstration Plants
}

\author{
L. H. Stinton
}




\section{DISCLAIMER}

This report was prepared as an account of work sponsored by an agency of the United States Government. Neither the United States Government nor any agency Thereof, nor any of their employees, makes any warranty, express or implied, or assumes any legal liability or responsibility for the accuracy, completeness, or usefulness of any information, apparatus, product, or process disclosed, or represents that its use would not infringe privately owned rights. Reference herein to any specific commercial product, process, or service by trade name, trademark, manufacturer, or otherwise does not necessarily constitute or imply its endorsement, recommendation, or favoring by the United States Government or any agency thereof. The views and opinions of authors expressed herein do not necessarily state or reflect those of the United States Government or any agency thereof. 


\section{DISCLAIMER}

Portions of this document may be illegible in electronic image products. Images are produced from the best available original document. 


\section{Printed in the United States of America. Available from National Technical Information Servicc \\ U.S. Department of Commerce 5285 Port Royal Road, Springfield, Virginia 22161 Price: Printed Copy $\$ 11.75$; Microfiche $\$ 3.00$}

This report was prepared as an account of work sponsored by an agency of the United States Government. Neither the United States Government nor any agency thereof, nor any of their employees, contractors, subcontractors, or their employees, makes any warranty, express or implied, nor assumes any legal liability or responsibility for any third party's use or the results of such use of any information, apparatus, product or process disclosed in this report, nor represents that its use by such third party would not infringe privately owned rights. 
ENERGY DIVISION

\section{ENVIRONMENTAL ANALYSIS FOR PIPELINE GAS DEMONSTRATION PLANTS}

Task Leader

L. H. Stinton ${ }^{a}$

\section{CONTRIBUTORS}

J. N. Baird ${ }^{b, f}$

L. W. Barnthouse ${ }^{c}$

L. G. Berry ${ }^{b}$
H. M. Braunstein ${ }^{b}$

S. G. DeCicco ${ }^{b}$

R. J. Haynes ${ }^{c}$
D. L. Kaserman ${ }^{b}$

D. W. Lee ${ }^{b}$

B. D. Murphy ${ }^{d}$
K. M. Oakes ${ }^{c}$

R. G. S. Rao ${ }^{b}$

R. J. Raridon ${ }^{d}$
R. D. Roop ${ }^{c}$

M. S. Salk ${ }^{c}$

W. P. Staub ${ }^{b}$

\section{INFORMATION SPECIALISTS}
L. W. Rickert ${ }^{e}$
D. J. Wilkes ${ }^{e}$

\section{PROJECT MANAGER}

C. R. Boston ${ }^{b}$

\section{WORK SUPPORTED BY}

Division of Fossil Fuel Processing,

Department of Energy

\section{PREPARED BY}

Fossil tinergy Environmental Project

Environmental Impact Section

\footnotetext{
${ }^{a}$ Engineering Division

${ }^{b}$ Energy Division

${ }^{c}$ Environmental Sciences Division

${ }^{d}$ Computer Sciences Division

Information Division

$f_{\text {Consultant }}$
}

Date Published : September

This report was preparted as an account of work sponsored by the United States Covernment. Neither the Uniced States nor the United States Department of Energy, nor any of heir employes, nor any of their Energ, hor any of their employees, nor any of their contractors, subcontactor, or ted employees, makes liny war ly, express or timpled, or assumes any legal or usefuless of any information, appanitus, product or or usefulness or any informanton, apparalus, product or prosss disclosed. or represents hap ils use woula not infringe privately owned rights.

\footnotetext{
OAK RIDGE NATIONAL LABORATORY

Oak Ridge, Tennessee 37830 operated hy

UNIUN CARBIDE CORPORATION

for the

DEPARTMENT OF ENERGY
} 


\section{THIS PAGE WAS INTENTIONALLY LEFT BLANK}




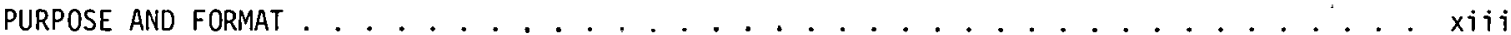

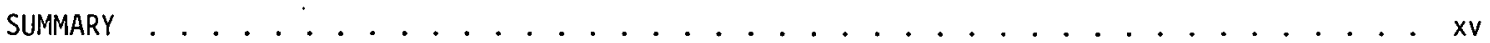

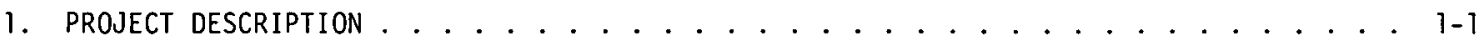

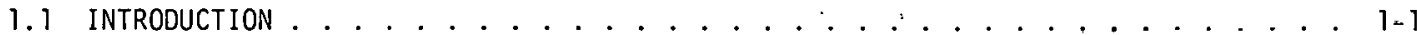

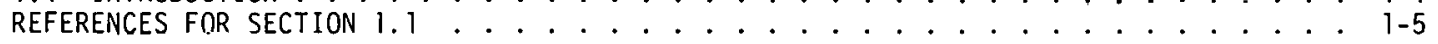

1.2 CONVERSION PLANT DESCRIPTION . . . . . . . . . . . . . . . . . . . . . . . 1-6

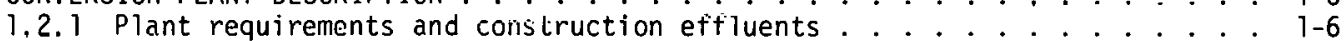

1.2.1.1 Requirements for facilities ................ 1-6

1.2.1.2 Effluents from plant construction ............. . . 1-7

1.2 .2 Description of processes ..................... 1-9

1.2.2.1 $\mathrm{CO}_{2}$ Acceptor process . . . . . . . . . . . . . . . . . . . 1-9

1.2 .2 .2 Hygas process .................... . . 1-11

1.2.2.3 Bi-Gas process......................... . . . . . . . . . . .

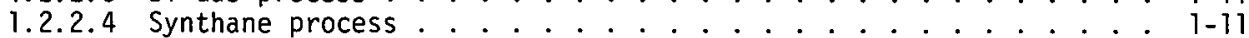

1.2 .2 .5 COGAS process ..................... . . . 1-11

1.2.2.6 Slagging Lurgi process ................... . . 1-11

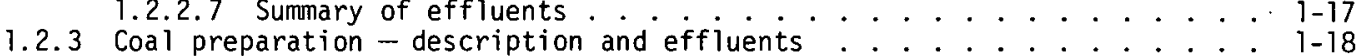

1.2.3.1 Primary size reduction .................. 1-18

1.2.3.2 Washing ...................... . . . . . . . . . .

1.2.3.3 Drying.................... 1-21

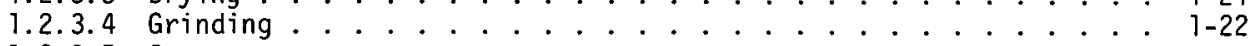

1.2.3.5 Storage . . . . . . . . . . . . . . . . . . . . $1-23$

1.2.4 Gasification - effluents . . . . . . . . . . . . . . . . . . 1-25

1.2.4.1 $\mathrm{CO}_{2}$ Acceptor gasifier and regenerator . . . . . . . . . . . . . 1-26

1.2.4.2 Hygas gasifier ................... . . 1-28

1.2.4.3 Bi-Gas gasifier . . . . . . . . . . . . . . . . . . . . 1.-29

1.2.4.4 Synthane gasifier . . . . . . . . . . . . . . . . 1=30

1.2 .1 .5 Dizcussiun of trace elements . . . . . . . . . . . . . . . $1-30$

1.2.5 Acid-gas treatment and sulfur recovery - description and effiuents. . . $1-35$

1.2.5.1 Acid-gas treatment. . . . . . . . . . . . . . . . 1-35

1.2.5.2 Sulfur recovery ..................... . . . 1-37

1.2.5.3 Tail gas cleanup...................... . . . 1-38

1.2.6 Steam and power production . . . . . . . . . . . . . . . . . . . . . $1-38$

1.2.6.1 Effluents from steam and power production ........... . 1-38

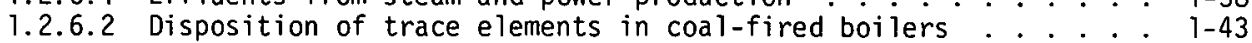

1.2.7 Wastewater treatment - description and effluonts . . . . . . . . . . 1-46

1.2. 0 Cuuling towers - descriptions and effluents................. . . . . . . . . . . .

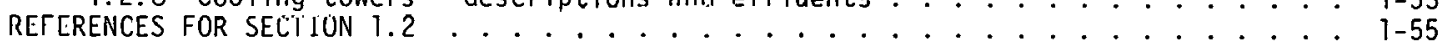

1.3 COAL MINING, BENEFICIATION, AND TRANSPORTATION . . . . . . . . . . . 1-57

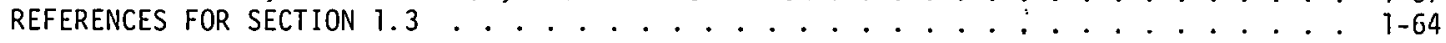

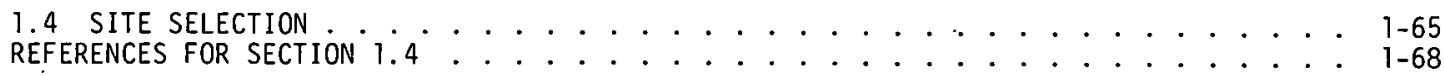

2. DESCRIPTION OF THE ENVIRONMENT . . . . . . . . . . . . . . . . . . . . . . . . . . . . 2-1

2.1 OESCRIPTION OF NEW ATHENS TOWNSHIP IN ST, CLATR COUNTY, ILLINOIS . . . . . . . . . $2-1$

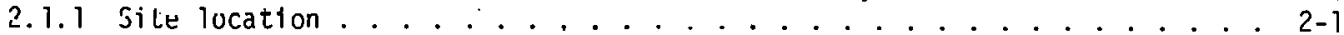

2.1.2 Geology............................. 2-1

2.1.2.1 Coaj reserves . . . . . . . . . . . . . . . . . . . . . . $2-1$

2.1.2.2 Regional geology of the Iilinois Basin............... . . . . $2-5$

2.1.2.3 Stratigraphy........................ . . . . . . 2

2.1.2.4 Tectonic history and seismicity . . . . . . . . . . . . . 2-9 
2.1 .3 Hydrology.................. 2-11

2.1.3.1 Surface water ................... 2-11

2.1.3.2 Groundwater hydrology ................. . . 2-13

2.1. 4 Water quality. . . . . . 2-14

2.1.4.1 Surface water ................. 2-14

2.1.4:2 Groundwater quality ............... 2-15

2.1.5 Land use ... . . . . . . . . . . . . . . . . . . . . . . 2-15

2.1.6 Meteorology and air quality. . . . . . . . . . . . . . . . 2-17

2.1.7 Noise........................ . . 2-18

2.1.8 Sncineconomic structure (St. Clair County, Illinois). . . . . . . . 2-24

2.1.8.1 Local and regional population . . . . . . . . . . . . . . . 2-24

2.1.8.2 Industry structure ..................... . . . 2-27

2.1.8.3 Local infrastructure . . . . . . . . . . . . . . . . . 2-32

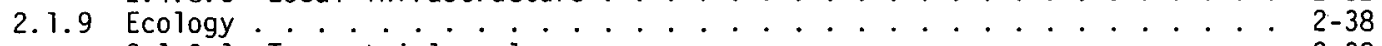

2.1.9.1 Terrestrial ecology .................. 2-38

2.1.9.2 Aquatic ecology .................... . . 2-40

2.1.9.3 Endangered species.................... . 2-44

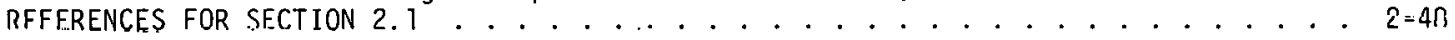

2.2 DESTRIPTION OF LEWIS TOWNSHIP IN MASON COUUNIY, WEST VIRGINIA . . . . . . . . ? 7.51

2.2.1 Site location...................... . . . . 2-51

2.2.2 Geology.................... . . 2-51

2.2.2.1 Coal reserves ..................... 2-. 2- . . . . . . .

2.2.2.2 Regional geology.................... 2-55

2.2.2.3 Stratigraphy ................... . . . 2-57

2.2.2.4 Tectonic history and seismicity .............. . 2-62

2.2.3 Hydrology ......................... . 2-63

2.2.3.1 Surface water .................... . . . 2-63

2.2.3.2 Groundwater hydrulogy . . . . . . . . . . . . . . 2-64

2.2.4 Water quality ........................ 2-. . . . . . . . . . . . . . . . .

2.2.4.1 Surface water ................... . 2-65

2.2.4.2 Groundwater quality ................ . . . 2-66

2.2.5 Land use ... . . . . . . . . . . . . . . . . . . . . 2-68

2.2.6 Meteorology and air quality. . . . . . . . . . . . . . . . . . . . 2-69

2.2.7 Noise......................... . . 2-71

2.2.8 Socioeconomic structure (Mason County, Wcst Virginia)........ . 2-71

2.2.0.1 Local and reginnal demography ............... 2-71

2.2.8.2 Industry structure . . . . . . . . . . . . . . . . . . . 2.73

2.2.8.3 Local infrastructure...................... . . . 2-74

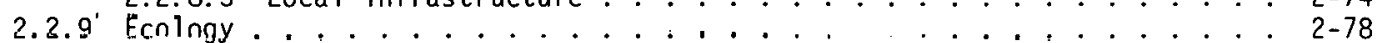

2.2.3.1 Terrestrial erningy ................... . . $2-18$

2.2.9.2 Aquátíc ecoluyy .................. 279

2.2.9.3 [ndangred spesies..................... . 2-83

REFERENCES FOR SECTION 2.2 . . . . . . . . . . . . . . . . . . . . . . . . . . .

2.3 DESCRIPTION OF TOWNSHIP 50N, CAMPBELL COUNTY, WYOMING . . . . . . . . . . . . . 2-88

2.3.1 Site location....................... . . 2- . . . . . . . . . . . .

2.3.2 Geology . . . . . . . . . . . . . . . . . . 2-89

2.3.2.1 Coal reserves . . . . . . . . . . . . . . . . . . . . . 2-89

2.3.2.2 Regional geology and ellergy resources of the

2.3.2.3 Stratigraphy............................. . . . . . . . . . . . . . . .

2.3.2.4 Tectonic history. . . . . . . . . . . . . . . . 2-97

2.3.2.5 Local geology ....................... . 2-98

2.3.3 Hydrology .......................... 2- . . . . . . . . . . . . .

2.3.3.1 Surfar.e water ..................... . . 2-IUI

2.3.3.2 Groundwater hydroloyy ................... . 2=103

2.3.4 Water quality......................... 2-105

2.3.4.1 Surface water j. . . . . . . . . . . . . . . . 2-105

2.3.4.2 Groundwater quality . . . . . . . . . . . . . . . 2-105

2.3.5 Land use ......................... . 2-107

2.3.6 Meteorology and air quality. . . . . . . . . . . . . . . . . . 2-108

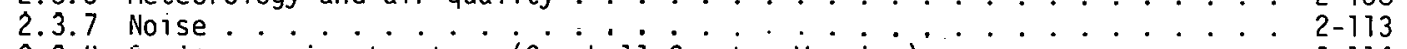

2.3.8 Socioeconumic structure (Campbel1 County, Wyoming) .. . . . . . . . . . . 2-114

2.3.8.1 Local and regional demography ................ 2-114

2.3.8.2 Industry structure .................... 2-115

2.3.8.3 Local infrastructure .................. . . 2-118 
2.3.9 Ecology ............. 2-122

2.3.9.1 Terrestrial ecology ............... 2-. 2- . . . . . . . . . 22

2.3.9.2 Aquatic ecology .................. . 2-125

2.3.9.3 Endangered species................. . 2-127

REFERENCES FOR SECTION 2.3 . . . . . . . . . . . . . . . . . . . . . . 2-129

3. POTENTIAL ENVIRONMENTAL IMPACTS . . . . . . . . . . . . . . . . . . . . . . 3- . . .

3. 1 EFFECTS OF CONSTRUCTION OF HIGH-BtU (PIPELINE) GAS DEMONSTRATION PLANTS . . . . 3-1

3.1.1 Physical environment ........ . . . . . . . . .

3.1.1.1 Physical impacts of site preparation and construction

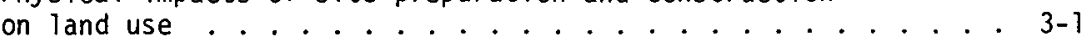

3.1.1.2 Hydrology ................... . . 3-2

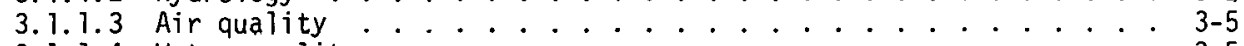

3.1.1.4 Water quality ..................... 3-5

3.1.2 Impacts on the biological environment . . . . . . . . . . . 3-6

3.1.2.1 Impacts caused hy destruction of habital -.

construction phase................ . . 3-6

3.1.2.2 Impacts caused by noise - construction phase . . . . . . . . . 3-10

3.1.2.3 Potential biological impacts caused by atmospheric effluents - construction phase ............. 3-11

3.1.2.4 Construction impacts on the aquatic environment . . . . . . 3-11

3.1.3 Socioeconomic effects .................... . . 3-14

3.1.3.1 Employment and population changes .............. 3-14

3.1.3.2 Impacts on surrogate sites . . . . . . . . . . . . . . . . . . 3-17

3.1.3.3 Summary of construction-related socioeconomic impacts . . . . 3-19

3.1.4 Impacts on archaenlogical, historic, and paleontological sites . . . . 3-19

3.1.5 Mitigating measures - construction phase . . . . . . . . . . . . $3-20$

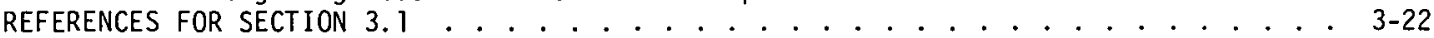

3.2 EFFECTS OF OPERATION OF A HIGH-BtU (PIPELINE) GAS PLANT . . . . . . . . . . . . $3-24$

3.2.1 Physical environment . . . . . . . . . . . . . . . . . . . . . 3-24

3.2.1.1 Impacts of operation on land use . . . . . . . . . . . . 3-24

3.2.1.2 Hydrology ........................... . . . . . . . . . .

3.2.1.3 Impacts caused by atmospheric effluents . . . . . . . . . 3-27

3.2.1.4 Water quality .. . . . . . . . . . . . . . . . 3-28

3.2.2 Impacts on the biologicai environment . . . . . . . . . . . . . . . 3-31

3.2.2.1 Impacts caused by destruction of habitat . . . . . . . . . . . .3-31

3.2.2.2 Imparts cauked by noise . . . . . . . . . . . . . . . . . 3-34

3.2.2.3 Impacts caused by atmospheric effluents . . . . . . . . 3-36

3.2.2.4 Aquatic impar.t. .................. . 3-48

3.2.3 Socioecunumic effects . . . . . . . . . . . . . . . . . . . . . . . . . . $3-52$

3.2.3.1 Employment and population changes . . . . . . . . . . 3-52

3.2.3.2 Impacts on surrogate sites .................. . . 3-54

3.2.3.3 Summary of operation phase socioeconomic impacts . . . . . . . . 3-55

3.2.4 Impacts on archaeological, historic, and paleontological sites ... . 3-56

3.2.5 Mitigating measures - operational................ . . 3-50

3.2.6 Potential accidents . . . . . . . . . . . . . . . . . . 3-57

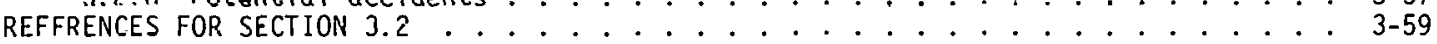

Appendix. METHOD FOR ASSESSING THE EFFECT UF EROSION ON AQUATIC BIOTA . . . . . . . . . . A- I 
Figure

1.1 Major coal fields of the United States . . . . . . . . . . . . . . . 1-2

1.2 Block diagram of the $\mathrm{CO}_{2}$ Acceptor process . . . . . . . . . . . . . . . . 1-10

1.3 Block diagram of layout of Hygas process . . . . . . . . . . . . . . . . 1-12

1.4 Block diagram of Bi-Gas process . . . . . . . . . . . . . . . . . 1-13

1.5 Block diagram of Synthane process . . . . . . . . . . . . . . . . . . . 1-14

1.6 COGAS process: block flow diagram ...................... . . . . 15

1.7 Slagging Lurgl ydsifier. . . . . . . . . . . . . . . . . 1-16

1.8 An overview of effluent streams...................... . . . . . . . . .

1.9 Typical coal preparation plant .................... . . . . . . . . . . .

1.10 Disposition of additional liquid wastes .................. . . . . . . . .

1.11. Wastewater treatment ...................... . . . . . . . . . . . .

1.12 Water preparation . . . . . . . . . . . . . . . . . . . 1-52

1.13 Location of coal resources in the United States . . . . . . . . . . . . . . 1-57

1.14 Coal production in the United States .................. 1-59

1.15. II.S. Fish and Wildlife Service cooperative program for studying the impacts of coal development. . . . . . . . . . . . . . . . . . 1-60

1.16 Overall coal development cycle . . . . . . . . . . . . . . . . 1-62

1.17 High-sulfur coal accessihility in the Uniled States. . . . . . . . . . . . 1-86

2.1 New Athens Township, located in St. Clair County, Illinois .......... 2-2

2.2 The eastern interior coal field of the Illinois Basin............2-5

2.3 Geologic column of Illinois....................... 2-7

2.4 Seismir risk map of the United States.................... . . . . . .

2.8 Annual wind rose for St. Louis, Missouri .................... . 2-17

2.6 Outdoor day-night sound level in $\mathrm{dB}$ at various locations . . . . . . . . 2-20

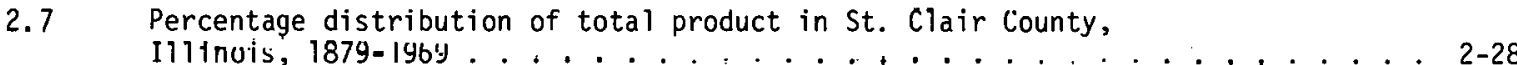

2.8 Industry employment in St. Clair, Madison, and Monroe counties, 1970 . . . . . 2-31

2.9 Remaining woodlands within St. Clair and adjacent counties .......... 2-39

2. 10 Gradient profile of the Kaskaskia River.................. 2-41

2.11 Map of Lewis Township, Mason County, West Virginia . . . . . . . . . . . 2-52

2.12 Generalized geologic map of the coal fields of West Virginia . . . . . . . . 2-53 
2.13 Map showing the position of Mason County with respect to minable low and high volatility coal in West Virginia . . . . . . . . . . . . . . 2-55

2. 14 Relationship between the eastern coal field and major structural features . . . 2-56

2.15 Structure contours on top of the Berea Sandstone, Lewis Township and adjacent regions, Mason County, West Virginia............. . 2-58

2.16 Schematic geologic structure section and regional hydrogeologic systems of eastern Gallia County, Ohio, and western Mason County, West Virginia . . . . 2-59

2.17 Earthquakes in West Virginia and adjacent states from 1758 to 1970 . . . . . 2-63 Huntington, West Virginia, wind rose . . . . . . . . . . . . . 2-70

2. 19 Surrogate site, Township 50N, range $71 \mathrm{~W}$, Campbell County, Wyoming . . . . . 2-88

2.20 Strippable coal deposits of the eastern Powder River Basin, Wyoming . . . . . . 2-90

2.21 Geologic map of the Wyoming portion of the Powder River Basin . . . . . . . . 2-92

2.22 Stratigraphic relation of geologic units in the eastern Powder River coal basin and adjacent areas...................... 2-. . . . . . . . . .

2.23 Seismicity map of Wyoming and adjacent regions . . . . . . . . . . . . 2-99

2.24 Map of Gillette study area showing areas where the Wyodak-Anderson coal bed lies less than $60 \mathrm{~m}(200 \mathrm{ft})$ below the surface............. 2-100

2.25 Water levels and direction of groundwater ................. 2-104

2.26 Map showing landforms, Gillette and four-township vicinity ......... 2-109

2.27 Land-use map of Gillette, Wyoming, and vicinity, 1970 . . . . . . . . . 2-110

2.28 Location of the East Gillette Mine and other operating, proposed, or anticipated coal mines involving Federal coal leases in Campbell County,

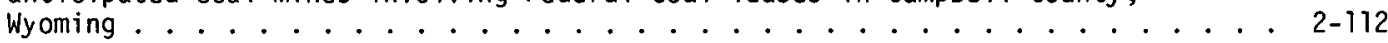

2.29 Casper, Wyoming, annuál wind rose ................... 2-113

2.30 Donkey Creek ............................ . . . . . . . . . . .

2.31 Typical food web of livestock ponds in Campbe11 and Converse counties . . . . . 2-127

3.1 Potential effects of air pollutants on plant communities (chronic or acute exposures) ......................... 3-40

3.2 Lucation of major coal- and oil-fired power units, 1971............ . . . . . .

3.3 Geographic variation in $\mathrm{SO}_{2}$ and $\mathrm{NO}$ emission density and percent of total $\mathrm{SO}_{2}$ and $\mathrm{NO}_{\mathrm{x}}$ emissions per air quality region ............. 3-44

3.4 Isopleths of total number of forecast-days of high meteorological potential for air pollution in a 5 -year period compared with boundaries of forest ecosystems ................... . . . . . . . . . . . . .

3.5 Major crop and foresl productng areas of the United States . . . . . . . . . 3-46

A. 1 Cross sections of the water body available at ench site ............ A-4

A.2 Determination of $D_{65}$ particle size range for Wyoming site . . . . . . . . A-5

A. 3 Determination of $D_{65}$ particle size range for Illinois and West

Virginia sites....................... A-6 
A.4 Annual average ground-level concentration of total suspended particulates $\left(\mu \mathrm{g} / \mathrm{m}^{3}\right)$ from the release of $450 \mathrm{~kg} /$ day $(1000 \mathrm{lb} /$ day $)$ of particulates from a $90-\mathrm{m}(300-\mathrm{ft})$ stack (St. Louis wind rose) . . . . . . . . . . . . . A-8

A.5 Annual average ground-level concentration of $\mathrm{SO}_{2}\left(\mu \mathrm{g} / \mathrm{m}^{3}\right)$ from the release of $450 \mathrm{~kg} /$ day (1000 $\mathrm{lb} /$ day) of sulfur from a $90-\mathrm{m}(300-\mathrm{ft})$ stack (St. Louis wind rose) . . . . . . . . . . . . . . . . . . . . A-9

A.6 Annual average ground-level concentration of $\mathrm{SO}_{2}\left(\mu \mathrm{g} / \mathrm{m}^{3}\right)$ from the release of $450 \mathrm{~kg} /$ day (1000 1b/day) of sulfur from a $90-\mathrm{m}(300-\mathrm{ft})$ stack (Huntington wind rose) . . . . . . . . . . . . . . . . . . . A-10

A.7 Annual average ground-level concentration of total suspended particulates $\left(\mu \mathrm{g} / \mathrm{m}^{3}\right)$ from the release of $450 \mathrm{~kg} /$ day $(1000 \mathrm{lb} /$ day $)$ of particulates from a $90-\mathrm{m}(300-\mathrm{ft})$ stack (Huntington wind rose) .................. A-11

A.8 Annual average ground-level concentration of $\mathrm{SO}_{2}\left(\mu \mathrm{g} / \mathrm{m}^{2}\right)$ from the release of $450 \mathrm{~kg} /$ day $(1000 \mathrm{lb} / \mathrm{day})$ of sulfur from a $90-\mathrm{m}(300-\mathrm{ft})$ stack (Casper

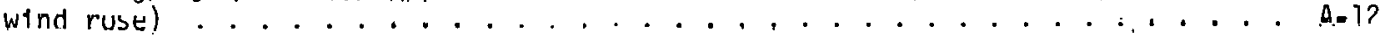

A.9 Annual average ground-level concentration of total suspended particulates $\left(\mathrm{\mu g} / \mathrm{m}^{3}\right)$ from the release of $450 \mathrm{~kg} /$ day $(1000 \mathrm{lb} /$ day $)$ of particulates from a $90-\mathrm{m}(300-\mathrm{ft})$ stack (Casper wind rose) ............... A-13 
1.1 Underground coal reserves and production ................... 1-3

1.2 Surface coal reserves and production .................. . . . . . . . .

1.3 Yearly water requirements for a $1.4 \times 10^{6} \mathrm{~m}^{3} /$ day (STP) (50 $\left.\times 10^{6} \mathrm{scfd}\right)$

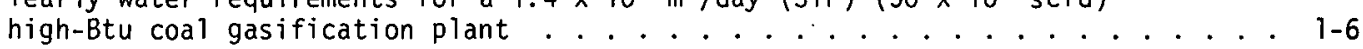

1.4 Construction discharges and emissions..................... 1-8

1.5 Allowable emission rates for thermal dryers for demonstration-size

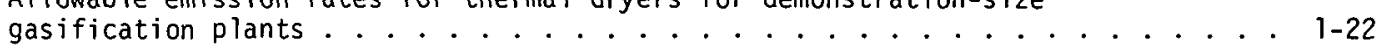

1.6 Analysis of drainage from two industrial coal piles................ . . . 24

1.7 Example of water analys is from gasifier ash slurry tank . . . . . . . . . . 1-25

1.8 Ash and char generation in demonstration gasification plants . . . . . . . . 1-27

1.9 Elemental composition of ash from representative U.S. coals . . . . . . . . . 1-28

1.10 Major components of coal combustion slags . . . . . . . . . . . . . . 1-28

1.11 Trace elements in coal ........................ . . . . . . . . . .

1.12 Disposition of trace elements ...................... . . . . . . . . . .

1.13 Typical modes of occurrence of trace and minor elements in coa 1. . . . . . 1-32

1.14 Thermodynamically stable forms of elements in the process units........ 1-33

1.15 Calculated flow rates of trace and minor elements in a Hygas-based commercial coal gasification plant usinq Illinnis No. 6 bituminous cual..... 1-34

1.16 Summary of selected acid-gas treatment and sulfur recovery processes . . . . . 1-36

1.17 Air emissions (with pollution control) for a 1000-MW power plant . . . . . . 1-39

1.18 Emission limitations for fossil-fuel-fired steam boilers . . . . . . . . . 1-39

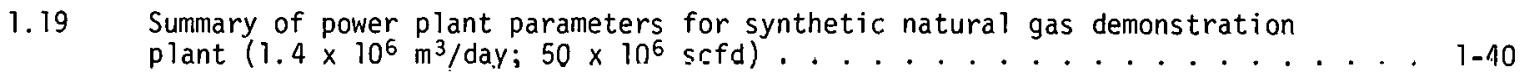

1.20 Chemical analysis of lime process sludges on dry solid basis . . . . . . . 1-12

1.21 Chemical analysis of flue gas desulfurization sludges . . . . . . . . . . . 1-42

1.22 Trace element flows through a coal-fired power plant . . . . . . . . . . . 1-44

1.23 Concentrations and concentration ratios . . . . . . . . . . . . . . . . 1-45

1.24 Wastewater remuval efficiencies of trace elements............... 1-51

1.25 Estimate of trace element effluents from wastewater treatment facility (WWT). . . 1-51

1.26 Estimated wet cooling tower parameters for $7.1 \times 10^{6} \mathrm{~m}^{3} /$ day $\left(250 \times 10^{6} \mathrm{scfd}\right)$ SNG plants ....................... . . . . . . . . . . . . . . . . . . .

1.27 Planned goals and activitles of the U.S. Fish and Wildlife Service coal

project............................. . 1-..61 
1.28 Potential environmental effects resulting from the exploration phases

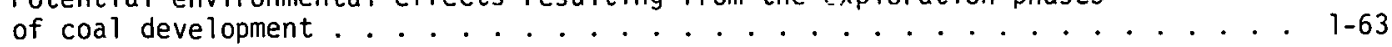

1.29 Potential environmental effects resulting from the development and production phases of coal development . . . . . . . . . . . . . . 1-63

1.30 Potential environmental effects resulting from the postmining phase of coal development........................... 1-64

1.31 Regional siting criteria for a coal conversion facility . . . . . . . . . . . 1-67

2.1 Coal production, St. Clair County, Illinois, 1950-1969 . . . . . . . . 2-3

2.2 Remaining (1975) coal reserves in the six-county region adjacent to

2.3 Active mines near New Álhens . . . . . . . . . . . . . . . . . . . . 2-4

2.4 Modifled Mercálli intencity srale nf 1931 (abridged) . . . . . . . . . . . ?-11

2.5 Kaskaskia River water quality data ..................... 2. . . . .

2.6 Groundwater quality in St. Clair County, Illinois............... 2-15

2.7 Land IIse in St. Clair County, Illinois .................. . . . . . . . .

2.8 Yearly average equivalent sound levels identified as requisite to

2.9 Measured noise levels for selected industrial operations . . . . . . . . . . 2-21

2.10 Sound emitted to class A, B, and C land during daytime hours . . . . . . . 2-23

2. 11 Population distribution by townships in St. Clair County, I11inois, 1970 . . . 2-25

2.12 Age-sex distribution in St. Clair County, Illinois, 1970 . . . . . . . . 2-25

2.13 Projected population increases for St. Clair County, Illinois, 1975 and ..... 2-26

2.14 Unemployment in Madisnn, Monrue, and st. Clair counties, May 15, 1976. . . . 2.26

2.15 First quarter 1971 employment and payroll, St. Clair County, Illinois . . . . 2-29

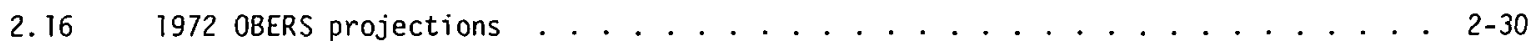

2.17 Capacity of school districts in Madison and St. Clair counties . . . . . . . 2-33

2.18 Summary of the existing recreational land in the St. Louls 3MiA. . . . . . 2-36

2.19 Spnrt fish of the Kaskaskia River . . . . . . . . . . . . . . . . 2-4U

2.20 Fish collected by the Corps of Engineers from the Kaskaskia River
new New Athens, Illinnis (St. Clair County). . . . . . . . . . . . 2-42

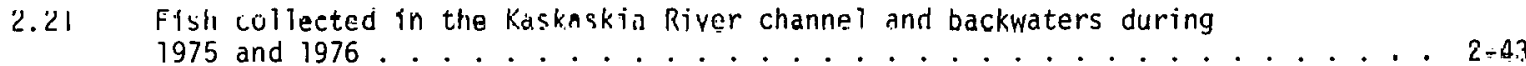

2.22 Illinois plants reported as threatened or endangered by the Smithsonian Institution as published in the July 1, 1975, Federal Register and the occurrence of these plants in Illinois ................ 2-...44

2.23 Endangered species of terrestrial vertebrates thal occur in Illinois and could occur in New Athens Township................. 2-46 
2.24 Vulnerable and rare vertebrates reported in St. Clair County . . . . . . . 2-47

2.25 Recoverable coal reserves and 1974 production for selected counties in Ohio and West Virginia which are potential suppliers for a coal conversion facility in Mason County, West Virginia............... 2-54

2.27 General stratigraphic section from the base to the surface of the Paleozoic in Mason County, West Virginia.................... 2-61

2.28 Ohio River water quality data as measured in 1976 at Addison, Ohio . . . . . 2-66

2.29 Kanawha River water quality data as measured in 1976 at Point Pleasant, West Virginia . . . . . . . . . . . . . . . . . . . . . 2-67

2.30 The National Sanitation Foundation water quality index . . . . . . . . . 2-67

2.31 Summary of chemical analyses of groundwater, Mason County, West Virginia . . . 2-68

2.32 Land use in Mason County, West Virginia . . . . . . . . . . . . . . . 2-69

2.33 A comparison of population, education, and income of Mason County, West Virginia, with adjacent counties in $1970 . . . . . . . . . . . . . .2-72$

2.34 Unemployment rates by county in 1970 . . . . . . . . . . . . . . . . . 2-72

2.35 Number of available local workers by county ................. 2-73

2.36 Employment characteristics for Mason County, West Virginia .......... 2-74

2.37 First quarter 1972 employment and payroll, Mason County, West Virginia . . . . 2-75

2.38 Major employers in the Mason County, West Virginia, area ...........2-76

2. 39 Species composition of the Ohio River Basin commercial fish catch,

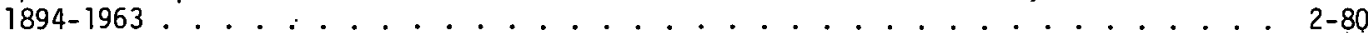

2.40 Relative abundance of fish species collected in the Ohio River in and

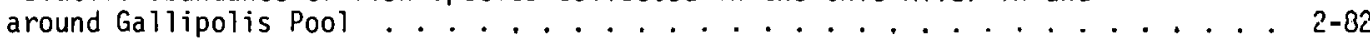

2.41 Rock sequence in the eastern Powder River Basin . . . . . . . . . . . . . . 2-95

2.42 Average thickness of Wyodak-Anderson (Roland-Smith, or D-E) coal beds in mines and proposed mines in the eastern Powder River Basin......... 2-97

2.43 Depths to the tops of important aquifers in the Gillette area.......... 2-101

2.44 A summary of water project proposals for the northern Great Plains . . . . . . 2-102

2.45 Water quality of Donkey Creek . . . . . . . . . . . . . . . . . . 2-106

2.46 Chemical analyses of groundwater in Campbell County, Wyoming . . . . . . 2-107

2.47 Estimates of existing and proposed coal mines in Campbell County, Wyoming, that involve Federal coal leases . . . . . . . . . . . . . 2-111

2. 48 Employment in the eight-county Wyoming Powder River Basin . . . . . . . . 2-116

2:49 Employment summary, Campbell County, Wyoming ................ 2-116

2.50 First quarter 1971 employment and payroll, Campbell County, Wyoming . . . . 2-117 
2.52 Public schools in Gillette, Campbell County, Wyoming, 1974 . . . . . . . . 2-120

2.53 Present and projected needs for health manpower in Campbell County . . . . . 2-121

2.54 Fish species collected from pools in the channel of Caballo Creek,

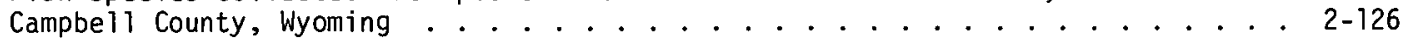

3.1 Potential impacts on groundwater during construction . . . . . . . . . . . . 3-4

3.2 Estimated increase in annual average concentration of suspended solids

in surface water at the three proposed sites ............... 3-5

3.3 Potential environmental impacts resulting from construction practices . . . . . 3-7

3.4 Summary of potential impacts of construction on the aquatic environment . . . . 3-12

3.5 New jobs created for St. Clair County, Illirivis (construction phase) . . . . 3-14

3. . New jobs created for Mason Snunty. West Virginia (constructfon phase) . . . . . 3-14

3.7 New jobs created for Campbell County, Wyoming (construction phasé) . . . . . J-14

3.8 Population change tör st. Clalr Cuunly, Illinois (conctructis!n phase). . . : 3-16

3.9 Population change for Mason County, West Virginia (construction phase) . . . . 3-16

3.10 Population change for Campbell County, Wyoming (construction phase) . . . . . 3-16

3.11 Potable water quality goals . . . . . . . . . . . . . . . . . 3-29

3.12 National ambient air quality standards . . . . . . . . . . . . . . . . 3-37

3.13 Ceilings and increments allowable over baseline air quality levels . . . . 3-37

3.14 Mean analytical values for trace elements found in 101 coals . . . . . . . 3-38

3.15 Distribution of environmentally lidardüus tracc clemente in coa ? . . . . , 3-38

3.16 Some areas of technical weakness and research needs with regard to air emissions from a coal conversion facility (not meant to be all-inclusive). . . . 3-39

3.17 Types of chronic low-level vegetational effects and probable mecharisms involved......................................... 31

3.18. Human populations at high risk to coal gasification plant pollutants . . . . 3-42

3.19 Concentrations of trace elements found to be toxic to aquatic organisms . . . . 3-50

$3 . ? \cap \quad$ Employment and population changes (operalions phase) . . . . . . . . . 3-53

$A=1 \quad V a l u e s$ for the factors involved in sheet erosion . . . . . . . . . . . . A-2

A-2 Values for computing the sediment load transport . . . . . . . . . . . . . . . A-7 
The purpose of this Environmental Analysis for Pipeline Gas Demonstration Plants is to assess the potential environmental and social impacts of pipeline gas production. Evaluation of one principal technology makes possible a thorough analys is of that technology and allows probable impacts of the process to be detailed. A surrogate site approach was used in evaluating pipeline gas demonstration plants to provide specific quantitative details about associated impacts as opposed to a more general qualitative approach. Three surrogate sites, representing three coal provinces, were selected for assessment.

Brief descriptions of construction activities, plant processes, and plant operation are contained in Sect. 1. Section 2 provides environmental descriptions of the three surrogate sites including georaphy, geology, hydrology, water use, land use, meteorology, air quality, noise, socioeconomics, and ecology. Section 3 addresses the potential impacts and risks associated with construction and operation of a pipeline gas demonstration plant. Impacts that are common to the three surrogate sites are discussed, and impacts unique to specific sites are identified.

The analysis contains unique, detailed descriptions of high-Btu gasification processes and unit operations in relation to their associated effluents. The surrogate site approach has allowed a detailed evaluation of impacts caused by construction and operation of a pipeline gas demonstration plant. This analysis does not circumvent the need for site-specific environmental statements but does provide a basis and reference document for site-specific statements. 


\section{THIS PAGE}

\section{WAS INTENTIONALLY LEFT BLANK}




\section{SUMMARY}

The Department of Energy (DOE) has implemented programs for encouraging the development and commercialization of coal-related technologies, which include coal gasification demonstration-scale activities. In support of these activities the Environmental Analysis for Pipeline Gas Demonstration Plants has been prepared as a reference document to be used in evaluating potential environmental and socioeconomic effects from construction and operation of site- and process-specific projects. Effluents and associated impacts are identified for six coal gasification processes at three contrasting settings.

The processes selected for study were: $\mathrm{CO}_{2}$ Acceptor, Hygas, $\mathrm{Bi}$-Gas, Synthane, COGAS, and Slagging Lurgi. Based on existing siting studies in the major coal provinces, geographic distribution, site contrasts, and the availability of site information, Mason County, West Virginia (in the Eastern Province), St. Clair County, Illinois (in the Interior Province), and Campbell County, Wyoming (in the Northern Great Plains Province), were selected as three surrogate sites. These sites were chosen to provide both variation and range of environmental settings.

Specific descriptions of the three surrogate sites were used as a basis for environmental and socioeconomic analyses. This approach provided specific quantitative details on the impacts from pipeline gas demonstration plants but maintained their applicability to a wide range of sites. Siting was identified on a township level, although most data available were on a county level. The selected sites provided contrasting ecological and socioeconomic characteristics to allow analysis over a wide range of settings. For example, land use varied from primarily agricultural to woodlands and farmlands to croplands and ranges. Water availability varied from deficient in Wyoming to plentiful in West Virginia. Socioeconomic conditions ranged from proximity to a highly populated area with large diversified economic structures to a sparsely populated rural agricultural area. Terrestrial fauna ranged from diverse in West Virginia and Illinois to primarily short- and mid-grass prairie in Wyoming, whereas aquatic life varied from diverse and abundant to sparse or nonexistent in Wyoming. Site characteristics summarized in the report include site location, geology, hydrology, water quality, land use, meteorology and air quality, noise, socioeconomic structure, and ecology.

Effluent.s from the gasification processes were identified according to unit operations such as coal preparation and storage, gasification, acid-gas treatment and sulfur recovery, utility production, water and wastewater treatment, and dissipation of waste heat. Where appropriate, effluents from unit operations were bracketed into effluent ranges representative of the six processes. Effluents unique to a particular gasification process were identified as well as unit operation alternatives that affect effluent discharges. Gaseous effluents expected from normal plant operations include drift from cooling towers, particulates, coal dust, and flue. gas. Solid wastes include coal refuse, gasifier and utility ash, elemental sulfur, spent chemicals, and various sludges. 
Liquid effluents consist of process wastewater and leachates from coal storage and solids disposal areas. An overview of the gaseous, solid, and liquid effluent ranges is presented in sect. 1 . In the disposal of all effluents, the occurrence and disposition of trace elements is of particular concern. Analyses of trace elements in coal and gasifier ashes are presented in Sect. 1.

Potential environmental effects from a pipeline gas demonstration plant are divided into construction and operation. Project and site descriptions are intimately associated in environmental and socioeconomic impact analyses. Impacts common to all three surrogate sites are addressed, and those impacts unique to a particular site are identified. A wide range of impacts is analyzed because of the contrasts of the three sites in ecological and socioeconomic settings. Availability of water is an important consideration during both plant construction and operation.

In general, impacts from construction of a high-Btu gas demonstration plant. are similar to those caused by the construction of any chemical plant of similar size. The operation of a high-Btu gas demonstration plant, however, has several unique aspects that differentiate it from other. chemical plants. Offsite development (surface mining) and disposal of large quantities of waste solids constitute important sources of potential impact. In addition, air emissions require monitoring for trace metals, polycyclic aromatic hydrocarbons, phenols, and other emissions. Potential biological impacts from long-term exposure to these emissions are unknown, and additional research and data analysis may be necessary to determine such effects. Possible effects of pollutants on vegetation and human populations are discussed in Sect. 3 . The oecurrence of chemical contaminants in liquid effluents and the bioaccumulation of these contaminants in aquatic organisms may lead to adverse ecological impact. Socioeconomic impacts are similar to those from a chemical plant of equivalent size and are summarized and contrasted for the three surrogate sites. 


\section{PROJECT DESCRIPTION}

\subsection{INTRODUCTION}

Coal is the most abundant energy resource currently accessible within the continental United States. The National Petroleum Council estimates that approximately 136 billion metric tons (150 billion tons) of recoverable coal exists in formations of comparable thickness and depth to those currently being mined. Thus in view of our current national policy to (1) reduce foreign oil imports, (2) store sufficient oil to prevent future disruptions, and (3) develop U.S. technology and resources to ensure energy independence beyond 1985, increased exploitation of domestic coal resources is a necessity.

More recently, these goals have been specifically enunciated in the national energy plan of President Jimmy Carter's administration. The goals for 1985 are:

- reduce the annual growth of total energy demand to below 2 percent;

- reduce gasoline consumption 10 percent below its current level;

- reduce oil imports from a potential level of 16 million barreis per day to 6 million, roughly one-eighth of total energy consumption;

- establish a Strategic Petroleum Reserve of 1 billion barrels;

- increase coal production by two-thirds, to more than 1 billion tons per year;

- bring 90 percent of existing American homes and all new buildings up to minimum energy efficiency standards; and

- use solar energy in more than 2-1/2 million homes.

(Executive Office of the President, Energy Policy and Planning 1977.)

About 95 billion metric tons (105 billion tons) of coal are underground, and 41 billion metric tons (45 billion tons) are near the surface. The geographic distribution of the major coal fields of the United States is shown in Fig. 1.1. Tables 1.1 and 1.2 show reserve figures (1970 production) and estimated life of recoverable reserves at three different rates of consumption growth. Even if coal production expands al what is considered to be the maximum feasible rate of $5 \%$ per year for the conventional domestic market (or $6.7 \%$ with exports and synthetic fuel production included), only 10\% of this resource base will be depleted by 1985 . Further, because this base represents less than $5 \%$ of the 2.9 trillion metric tons ( 3.21 trillion tons) of coal estimated to exist in the United States (including unmapped and unexplored resources), coal price increases and/or mining technology advances are likely to result in significant additions to the resources that are economically recoverable. Thus the U.S. coal resource base is sufficiently large to meet the growing demands that will develop from an attempt to achieve energy independence. Adequate quantities will be available for use by both conventional and emerging technologies during the next 15 years and throughout the rest of the century, with a wide margin of safety (National Petroleum Council 1973). 

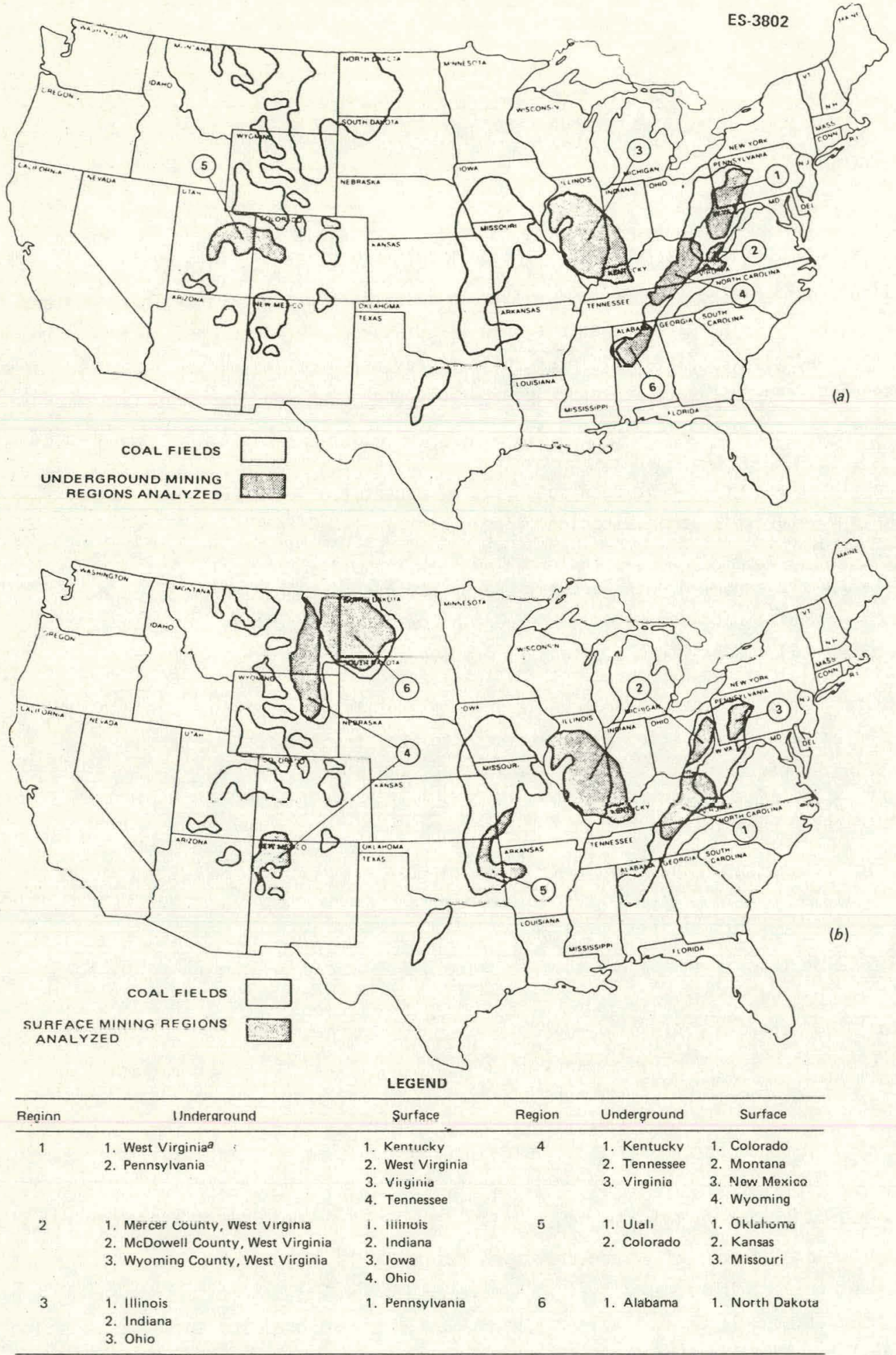

aDoes not include Mercer, McDowell and Wyoming Counties in West Virginia; these three counties produce mainly lowvolatile coking coal and are considered separately in Region 2.

Fig. 1.1. Major coal fields of the United States: (a) underground mining regions; (b) surface mining regions. Source: National Petroleum Council. 1973. U.S. energy outlook: coal availability. A report by the Coal Task Group of the Other Energy Resources Subcommittee of the National Petroleum Council's Committee on U.S. Energy Outlook. Washington, D.C. 
Table 1.1. Underground coal reserves and production

Minable by underground mining methods

\begin{tabular}{|c|c|c|c|c|c|c|c|c|c|}
\hline \multirow[t]{2}{*}{ Region } & \multirow{2}{*}{\multicolumn{2}{|c|}{$\begin{array}{c}\text { Remaining } \\
\text { measured and } \\
\text { indicated } \\
\text { reserves } \\
{[\text { [billions of metric }} \\
\text { (short) tons }]^{\circ}\end{array}$}} & \multirow{2}{*}{\multicolumn{2}{|c|}{$\begin{array}{c}\text { Economically } \\
\text { available } \\
\text { reserves } \\
\text { [billions of metric } \\
\text { (short) tons] }^{b}\end{array}$}} & \multirow{2}{*}{$\begin{array}{c}\text { Recoverable } \\
\text { reserves } \\
\text { [billions of metric } \\
\text { (short) tons] }{ }^{c}\end{array}$} & \multirow[t]{2}{*}{$\begin{array}{c}1970 \\
\text { production } \\
\text { '[millions of metric } \\
\text { (short) tons] }\end{array}$} & \multicolumn{3}{|c|}{$\begin{array}{c}\text { Life of recoverable } \\
\text { reserves at } \% \text { growth } \\
\text { rate (years) }\end{array}$} \\
\hline & & & & & & & $.0 \%$ & $3 \%$ & $5 \%$ \\
\hline 1 & 84.1 & $(92.7\rangle$ & 60.9 & $\{67.1)$ & $30.4 \quad(33.5)$ & $132.2(145.8)$ & 230 & 69 & 50 \\
\hline 2 & 8.3 & $(9.1)$ & 8.3 & $(9.1)$ & $4.2 \quad(4.6)$ & NA & & & \\
\hline 3 & 75.4 & $(83.1)$ & 54.0 & $(59.5)$ & $26.9 \quad(29.7)$ & $47.4 \quad(52.3)$ & 568 & 96 & 68 \\
\hline 4 & 31.3 & $(34.5)$ & 22.1 & $(24.4)$ & $11.1 \quad(12.2)$ & $86.2 \quad(95.0)$ & 129 & 52 & 40 \\
\hline 5 & 19.9 & (21.9) & 12.1 & $(13.3)$ & $6.1 \quad(6.7)$ & $7.8 \quad(8.6)$ & 774 & 106 & 74 \\
\hline 6 & 1.5 & $(1.6)$ & 0.5 & $(0.6)$ & $0.3 \quad(0.3)$ & $8.3 \quad(9.1)$ & 35 & 23 & 20 \\
\hline Other & \multicolumn{2}{|c|}{$96.4(106.3)$} & 31.9 & $(35.2)$ & $16.0,(17.6)$ & NA & & & \\
\hline Total $^{d}$ & \multicolumn{2}{|c|}{$316.6(349.1)$} & \multicolumn{2}{|c|}{$189.7(209.2)$} & $94.9(104.6)$ & $307.3(338.8)$ & 309 & 80 & 58 \\
\hline
\end{tabular}

${ }^{a}$ Bituminous, subbituminous, and lignite in seams of "intermediate" or greater thickness with less than $305 \mathrm{~m}$ (1000 $\mathrm{ft}$ ) overburden.

"Excludes lignite and "intermediate" thickness seams of bituminous and subbituminous coal.

${ }^{c}$ Based on $50 \%$ recovery of economically available reserves.

${ }^{d}$ May not add correctly because of rounding.

Source: National Petroleum Council. 1973. U.S. energy outlook: coal availability. A report by the Coal Task Group of the Other Energy Resources Subcommittee of the National Petroleum Council's Committee on U.S. Energy Outlook. Washington, D.C.

Table 1.2. Surface coal reserves and production

Minable by surface mining methods

\begin{tabular}{lcccccc}
\hline Region & $\begin{array}{c}\text { Recoverable } \\
\text { reserves } \\
\text { [billions of metric } \\
\text { (short) tons] }\end{array}$ & $\begin{array}{c}1970 \\
\text { production } \\
\text { [millions of metric } \\
\text { (short) tons] }\end{array}$ & \multicolumn{3}{c}{$\begin{array}{c}\text { Life of reserves } \\
\text { at \% growth rate (vears) }\end{array}$} \\
\hline 1 & $3.8(4.2)$ & $91.8(101.2)$ & 42 & 27 & 23 \\
2 & $51(5.6)$ & $82.6(91.0)$ & 62 & 36 & 29 \\
3 & $.7(0.8)$ & $22.8(25.1)$ & 32 & 23 & 19 \\
4 & $21.6(23.8)$ & $17.3(19.1)$ & 1246 & 122 & 85 \\
5 & $1.5(1.6)$ & $7.5(8.3)$ & 193 & 65 & 48 \\
6 & $1.9(2.1)$ & 5.1 & $(5.6)$ & 375 & 85 & 62 \\
Other & $6.3(6.9)$ & $12.5(13.8)$ & 500 & 95 & 67 \\
Total & $40.8(45.0)$ & $240.0(264.1)$ & 170 & 61 & 46 \\
\hline
\end{tabular}

Source: National Petroleum Council. 1973. U.S. energy outlook: coal availability. A report by the Coal lask Group of the Uther Energy Hesources Subcommittee of the National Petroleum Council's Committee on U.S. Energy Outlook. Washington, D.C.

Increased coal use necessitates an examination of the technologies that enhance coal use. To encourage efforts in this direction, the Department of Energy (DOE) has implemented a Fossil Energy Research, Development, and Demonstration Program that is designed to provide incentives for the private sector to invest in coal-related technology development and commercialization. The overall objective of this program is

. . . to develop technical options to enhance the availability of fossil sources and to ensure the development of national fossil energy resources on a technically sound, economically feasible, and environmentally acceptable basis (EROA 1976b).

The strategy designed to achieve this objective exhibits three important features. First, the risk of complete failure will be minimized by diversifying investments among alternative technologies. A variety of technological options will be kept open until a clear dominance by one or more alternatives is established. Second, investment in technology development will be phased 
according to the maturity of the various options. Those that appear to be relatively close to successful commercialization will receive attention first. Third, a cost-sharing approach will be adopted to preserve private incentives for commercial success of research, development, and demonstration projects, with the degree of industry participation increasing as the given technology approaches such commercialization. By reducing the costs and the risks of investing in technologies that enhance coal use, this strategy provides the incentives necessary for increased efforts by the private sector.

As part of this effort to encourage a more intensive and efficient use of U.S coal resources, the Fossil Energy Program directs considerable attention to the research, development, and demonstration of high-Btu coal gasification technologies. The objectives of this endeavor are categorized by the projected time frame for achievement. Important near-term objectives include demonstration and evaluation of alternative first-generation technologies, development and demonstration of emerging second-generation technologies, application of advances made in secondgeneration technology development to those first-generation processes that are capable of accommodating such advances, and initiation of research on third-generation gasification technology.

The longer-term objectives of the high-Btu gasification program include assisting the private sector in the commercialization of second-generation processes (about 1985), continuing development and demonstration of promising third-generation processes (by 1990), and assisting private industry in the commercialization of multiproduct facilities (by the year 2000).

As in the overall Fossi] Energy Program, the strategy applied in the high-Btu gasification effort emphasizes diversification among alternative processes and a phased sharing of costs with private industry. The importance of the demonstration phase in the total movement from research to commercialization is readily apparent. Given the large capital investment required to begin commercial-scale production (estimated at approximately $\$ 1$ billion) and the economic uncertainties created by both technological unknowns and rapidly changing market conditions, the information provided by demonstration-scale activities appears necessary to encourage actual commercial application of emerging gasification processes. As this demonstration phase is initiated, it is important to analyze the environmental implications of facility construction and operation so that policy decisions can incorporate all the relevant costs of given technological alternatives. This report describes and analyzes the potential environmental effects of demonstration-scale high-Btu gasification facilities in a generic manner to consolidate the unlikely consequences of implementing this particular phase of the program. 
REFERENCES FOR SECTION 1.1

ERDA (Energy Research and Development Administration). 1976a. A national plan for energy research, development and demonstration: creating energy choices for the future, volume 1 the plan. ERDA 76-1. Washington, D.C.: Energy Research and Development Administration.

- 1976b. A national plan for energy research, development and demonstration: creating energy choices for the future, volume 2 -program implementation. ERDA 76-1. Washington, D.C.: Energy Research and Development Administration.

Executive Office of the President, Energy Policy and Planning. April 29, 1977. The national energy plan. Stock no. 040-000-00380-1. Washington, D.C.: Superintendent of Documents, U.S. Government Printing office.

National Petroleum Council. 1973. U.S. energy outlook: coal avaizabizity. A report by the Coal Task Group of the Other Energy Resources Subcommittee of the National Petroleum Council's Committee on U.S. Energy Outlook. Washington, D.C. 


\subsection{CONVERSION PLANT DESCRIPTION}

\subsubsection{Plant requirements and construction effluents}

\subsubsection{Requirements for facilities}

A typical high-Btu gasification demonstration plant is assumed to produce $1.4^{4} \times 10^{6} \mathrm{~m}^{3} /$ day [standard temperature and pressure (STP)] $\left(50 \times 10^{6} \mathrm{scfd}\right)$ of pipeline gas [heat content about $\left.3.54 \times 10^{7} \mathrm{~J} / \mathrm{m}^{3}(\mathrm{STP})(950 \mathrm{Btu} / \mathrm{scf})\right]$. Facility requirements include coal, water, land, transportation, operating personnel, and construction labor. The amount of coal required depends on the Btu content of the feed coal and the efficiency of the particular gasification process. Coal feed requirements vary from about 1800 to 2700 metric tons (2000 to 3000 tons) per day. Water requirements for a plant of this capacity are shown in Table 1.3.

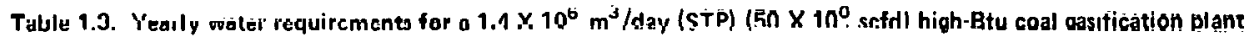
In cubic meters (acre-feet)

\begin{tabular}{|c|c|c|c|c|c|c|c|}
\hline Process $^{a}$ & $\begin{array}{l}\text { Process } \\
\text { water }\end{array}$ & $\begin{array}{l}\text { Cooling } \\
\text { water }\end{array}$ & $\begin{array}{l}\text { Asli, blay, } \\
\text { or sludge } \\
\text { control (or } \\
\text { slurry water) }\end{array}$ & $\begin{array}{c}\text { Boiler feed } \\
\text { water }\end{array}$ & Other & Totals & $\begin{array}{c}\text { Averagè } \\
\text { per } 10^{8} \\
\text { Btu/day output }\end{array}$ \\
\hline $\mathrm{CO}_{2}$ Acceptor & $\begin{array}{c}789,100 \\
(640)\end{array}$ & $\begin{array}{c}0-1,479,600 \\
(0-1200)\end{array}$ & $\begin{array}{c}98,690-147,960 \\
(80-120)\end{array}$ & $\begin{array}{c}123,300-369,900 \\
(100-300)\end{array}$ & $\begin{array}{c}172,620 \\
(140)\end{array}$ & $\begin{array}{c}1,183,700-2,959,200 \\
(960-2400)\end{array}$ & $1.9-4.8$ \\
\hline Hygas & $\begin{array}{c}616,500 \\
(500)\end{array}$ & $\begin{array}{c}0-1,972,800 \\
(0-1600)\end{array}$ & $\begin{array}{c}98,640-j 47,960 \\
(80-120)\end{array}$ & $\begin{array}{c}123,300-369,900 \\
(100-300)\end{array}$ & $\begin{array}{c}172,620 \\
(140)\end{array}$ & $\begin{array}{c}1,011,100-3,279,800 \\
(820-2600)\end{array}$ & $1.6-5.3$ \\
\hline Bi-Gas & $\begin{array}{c}813,800 \\
(660)\end{array}$ & $\begin{array}{c}0-2,219,400 \\
(0-1800)\end{array}$ & $\begin{array}{c}493,200-2,219,400 \\
(400-1800)\end{array}$ & $\begin{array}{c}123,300-369,900 \\
(100-300)\end{array}$ & $\begin{array}{c}172,620 \\
(140)\end{array}$ & $\begin{array}{c}1,602,900-5,795,100 \\
(1300-4700)\end{array}$ & $2.6-9.4$ \\
\hline Synthane & $\begin{array}{c}739,800 \\
(600)\end{array}$ & $\begin{array}{c}0-1,972,800 \\
(0-1600)\end{array}$ & $\begin{array}{c}98,640-14 \overline{7}, 960 \\
(80-120)\end{array}$ & $\begin{array}{c}123,300-36 y, y U U \\
(100-300)\end{array}$ & $\begin{array}{l}1 / 2,620 \\
(140)\end{array}$ & $\begin{array}{c}1,183-700-3,403,100 \\
(920-2760)\end{array}$ & $1.0-5.5$ \\
\hline Lurğı & $\begin{array}{c}887.800 \\
(720)\end{array}$ & $\begin{array}{c}0-1,972,800 \\
(0-16 n n)\end{array}$ & $\begin{array}{c}98,040-147,960 \\
(80-120)\end{array}$ & $\begin{array}{c}123,300 \quad 360,000 \\
(100-300)\end{array}$ & $\begin{array}{c}172,620 \\
(140)\end{array}$ & $\begin{array}{c}1,282,30 n-3,551, \mathrm{nnn} \\
(1040-2880)\end{array}$ & $2.1-5.8$ \\
\hline
\end{tabular}

\footnotetext{
${ }^{\theta}$ Depends on ash and Btu content of coal. Values presented are for use of 10-20\% ash, 13,000 Btu/lb coal.

¿ The range varies between entirely dry cooled and entirely wet cooled.

Source: Adapted from S. G. Miller. 1974. P. 23 in Environmental Impacts of Alternative Conversion Processes for Western Coal Development. Prepared for Old West Regional Commission. Washington, D.C.: Thomas E. Carroll Associates.
}

The amount of land required for a plant varies from 60 to 160 ha ( 150 to 400 acres), depending on plant design, buffer area requirements, and future expansion plans. Less than 40 ha (100 acres) is generally disturbed for demonstration plant facilities.

Transportation facilities are required to move coal to a plant site and to remove products and by-products. Roads, railroads, pipelines, and coal conveyors are among the transportation systems that may be required.

Estimates of total plant investment for a high-Btu gasification demonstration plant range from $\$ 450$ million to $\$ 750$ million ( 1977 dollars).

. The number of personnel required to operate a $1.4^{1} \times 10^{6} \mathrm{~m}^{3} /$ day (STP) $\left(50 \times 10^{6}\right.$ scfd) plant ranges from 400 to 500 . Construction of the plant is estimated to require 1500 to 3000 man-years over a 3-year period. Peak construction manpower ranges from 1500 to 2000 workers. 


\subsubsection{Effluents from plant construction}

Coal gasification plant construction can be divided into preconstruction, site work, construction of permanent facilities, and project closeout phases. Construction emissions and discharges are listed in Table 1.4. Preconstruction may involve site inventory; environmental monitoring; and temporary controls for storm water, erosion, and dust. Primary pollutants during the preconstruction stage consist of visual impacts: dust, noise, and vehicular-traffic and test-pit sediment as well as sediment, nutrients, and solid wastes from the temporary controls.

Clearing and demolition result in dust, sediment, noise, and solid and wood wastes during the. site preparation phase. Construction of temporary facilities including shops and storage sheds, access roads and parking lots, sanitary facilities, and construction utilities may result in emissions of gases, odors, fumes, particulates, dust, deicing chemicals, noise, petroleum products, wastewater, solid wastes, aerosols, pesticides, herbicides, and sediment.

Necessary construction utilities include a water source for drinking, sanitation, soil compaction, and concrete mixing; a septic tank and leach field or chemical toilets; and an electric power source that may consist of portable diesel-powered equipment at the site. Excavation grading, trenching, and soil treatment during the site work phase may result in emissions of dust, noise, sediment, debris', wood wastes, solid wastes, pesticides, particulates, bituminous products, and soil conditioner chemicals. Site drainage, including foundation drainage, dewatering, and stream channel relocation, may result in the release of nutrients and pesticides.

Following the site work, permanent facilities may be constructed. Construction of transportation. and distribution systems create sediment, dust, noise, and particulate emissions. Construction of railroads, roads, and pipelines involves purchasing the right-of-way and clearing it of all vegetative material and litter. After installation of culverts and bridges for roads and railroads and shaping of the road beds, granular material is placed on the bed surface. Roads may then be surfaced with graded aggregate, bituminous, or concrete material. Water trucks control dust by spraying the road surface and adjacent berm. Construction of pipelines requires the building of construction access roads to the right-of-way, which are not intended for public use and are generally built to low standards. Trenches may then be dug, pipe laid along the rightof way, and the trench backfilled.

The construction of buildings and related facilities results in emission of sediment, trace elements, noise, caustic chemical waste, sediment spoil, particulates, fumes, and solid waste. Major facilities to be constructed include coal gasification and associated process equipment, warehouses, water supply and water treatment facilities, water intake and discharge structures, storm drainage, wastewater treatment, dams and impoundments, an oxygen plant, a steam and power plant, ash handling and storage facilities, by-product handling facilities, an evaporation pond, coal handling and processing equipment (including coal conveyors), and waste handling equipment. Construction of security fencing around the plant may result in sediment and wood wastes.

The last phase of construction is project closeout. Noise, dust, and solid waste are created when temporary offices and shops are demolished or relocated. Sediment and dust therefore result from site restoration including finish grading, topsoiling, fertilizing, and sediment controls. Nutrients and petroleum products result from cleaning and flushing during preliminary startup. 
Table 1.4. Construction discharges and emissions

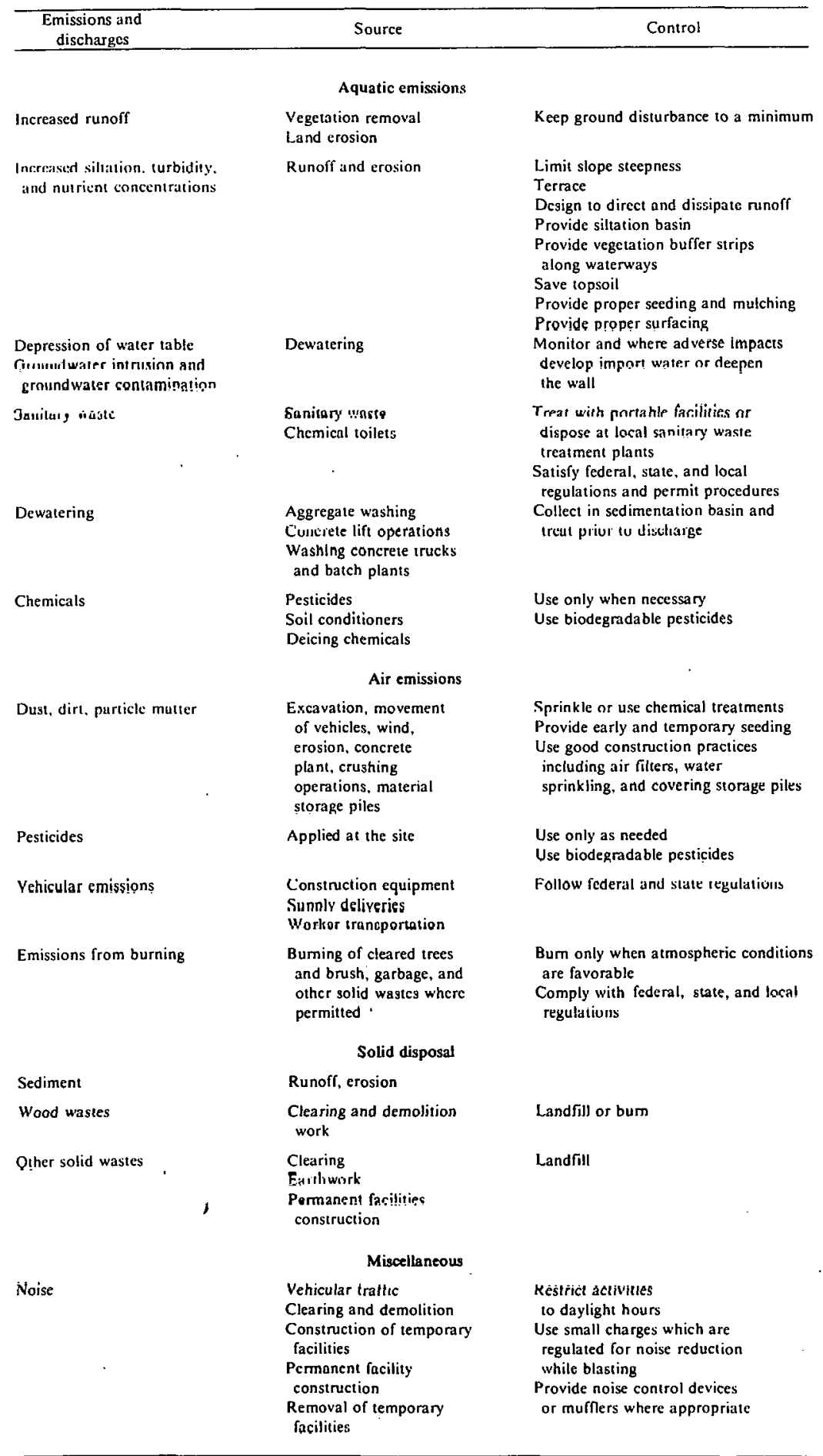

Source: M. S. Salk and S. G. DeCicco. 1978. Environmentalimonitoring handbook for coal conversion facilities, ORNL-5319, Table 3.1.2, p. 3.1.1-4. Oak Ridge, Tenn.: Oak Ridge National Laboratory. 
As construction is completed, disturbed areas should be reseeded to prevent erosion and particulate dispersion. Following demonstration plant operation, the conversion facilities may: (1) continue to produce $1.4 \times 10^{6} \mathrm{~m}^{3} /$ day $\left(50 \times 10^{6} \mathrm{scfd}\right)$ of high-Btu gas on a commercial basis, (2) be expanded to a commercial-size plant $\left(\sim 7.1 \times 10^{6} \mathrm{~m}^{3} /\right.$ day; $\left.250 \times 10^{6} \mathrm{scfd}\right)$, or (3) be retired.

Upon plant retirement, holding ponds are allowed to evaporate and are filled to the natural grade level. If decommissioning measures include removal of all structures, the land area may be returned to other productive uses or revegetated with native foliage. The beneficial uses of the area by future generations should not be significantly affected.

\subsubsection{Description of processes}

With a few exceptions, second-generation high-Btu coal gasification processes comprise (1) coal preparation and storage, during which coal is sized, cleaned, dried, and stored prior to use; (2) gasification, during which coal is devolatilized and reacted in the presence of oxygen and steam to form a low- to medium-Btu synthesis gas (containing carbon dioxide, carbon monoxide, hydrogen, methane, and sulfurous compounds) and a solid residue; (3) quenching and scrubbing to reduce the gas temperature and remove any heavy oils, tars, and particulates; (4) shift conversion, during which synthesis gas is reacted over a catalyst bed to alter the composition of the gas to suit the stoichiometric requirements of the methanation reactions; (5) water scrubbing to remove light oils, ammonia, phenols, and cyanides; (6) acid gas treatment and sulfur recovery, during which carbon dioxide, hydrogen sulfide, carbonyl sulfide, and carbon disulfide are removed from the gas, and elemental sulfur is produced by chemical reaction of the sulfur species; (7) sulfur guards to eliminate trace concentrations of sulfur compounds that are poisonous to downstream methanation catalysts; (8) methanation, during which the synthesis gas is reacted over a catalyst bed to produce a high-methane-content gas with a heating value of at least $35.4 \times 10^{6} \mathrm{~J} / \mathrm{m}^{3}$ (950 Btu/scf); (9) compression and drying to raise the gas pressure to meet pipeline pressure specifications and remove any condensed water vapor; (10) oxygen production, which produces the oxygen required for gasification; (11) utility production, which generates both the electricity needed to operate fans, pumps, blowers, compressors, motors, conveyors, etc., and the steam used in the gasification and shift reactions; (12) cooling towers, which cool recirculating process cooling water; and (13) water treatment, which treats raw water and process wastewater and prepares boiler feedwater. Singular process features are described below. The slagging Lurgi and the COGAS processes have currently advanced beyond others to the point that DOE has initiated demonstration-scale plants to be constructed and operated.

\subsubsection{1 $\mathrm{CO}_{2}$ Acceptor process}

The $\mathrm{CO}_{2}$ Acceptor process produces synthetic natural gas from lignite or subbituminous coal by gasifying it with steam at $850^{\circ} \mathrm{C}\left(1500^{\circ} \mathrm{F}\right)$ and $150 \mathrm{psig}$ (Fig. 1.2 ), a process that requires no oxygen. Circulating dolomite supplies heat indirectly and absorbs carbon dioxide and sulfur. The gas leaving the gasifier does not require shift conversion or $\mathrm{CO}_{2}$ removal prior to methanation. Waste-heat recovery supplies all necessary steam and power, which eliminates the need for auxiliary utility production. By-products are ammonia and sulfur, with minimal accumulation of tars and nils. (For a more detailed process description, see Dravo 1976). 


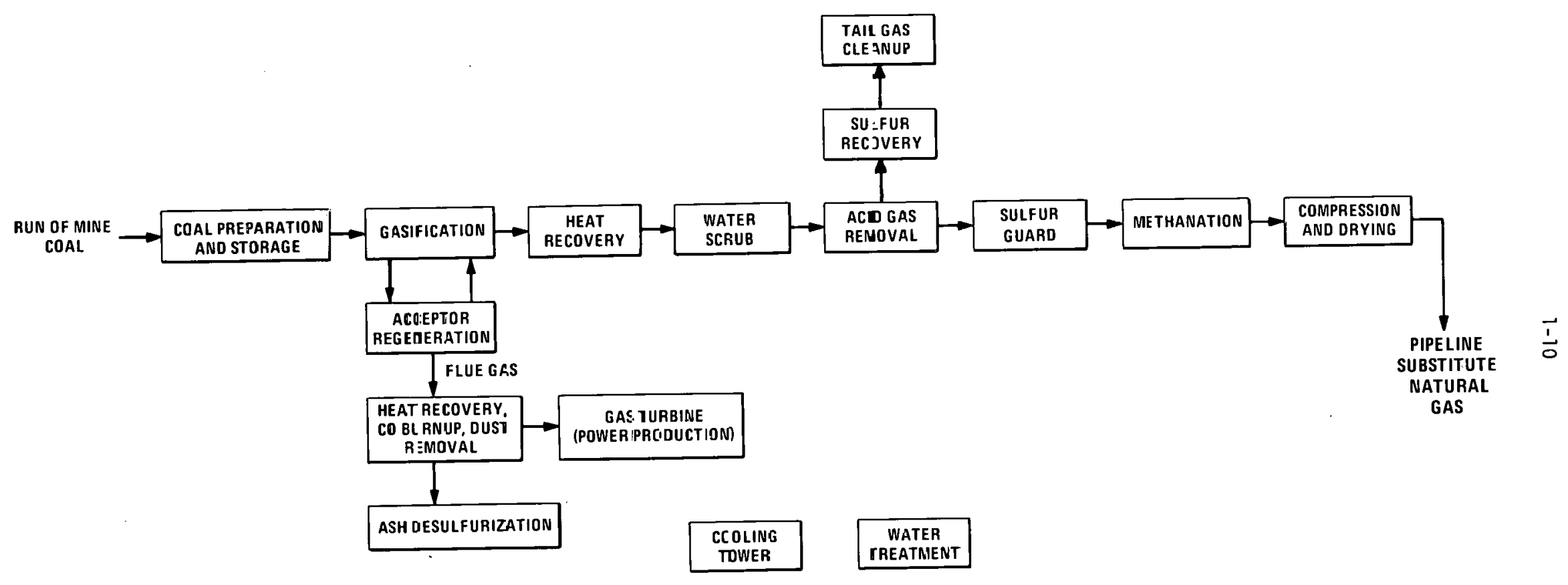

F:g. 1.2. Black diagram of the $\mathrm{CO}_{2}$ Acceptor process. 


\subsubsection{Hygas process}

Three unique features characterize the Hygas design (Fig. 1.3). First, the coal is pressurized and fed to the gasifier in a slurry with by-product oil. Second, the solid residue leaving the gasifier is a char that may contain a 10 to $30 \%$ carbon concentration, which represents 2 to $7 \%$ of the original carbon contained in the coal field. The third feature is a U-gas system that converts feed coal to clean fuel gas for utility production. The Hygas process produces light oils [benzene-toluene-xylene (BTX)], ammonia, phenols, and sulfur as by-products. (For a more detailed process description, see Dravo 1976.)

\subsubsection{Bi-Gas process}

The unique features of the Bi-Gas process (Fig. 1.4) are entrained flow gasification, gasifier operation under slag-forming conditions, the use of sand filters for particulate removal, and the recycle of all sour water for gas quenching. The Bi-Gas process produces by-product ammonia and sulfur, with minimal accumulation of tars and oils. (For a more detailed process description, see Dravo 1976.)

\subsubsection{Synthane process}

A singular feature of the Synthane process (Fig. 1.5) is the combustion of gasifier char to generate the required utilities. The extent of gasification is 1 imited to produce a relatively high carbon char and to balance the overall energy requirements of the plant. The present design features a char letdown system and tar scrubber. The Synthane process produces by-product tar, BTX, phenols, ammonia, and sulfur. (For a more detailed process description, see Dravo 1976.)

\subsubsection{COGAS process}

The COGAS process (Fig. 1.6) converts coal to gas and oil products through multistage fluidizedbed pyrolysis of coal and gasification of reactive char from this pyrolysis. The raw oil and synthesis gas products are produced in a low-pressure system without the use of an oxygen plant. The COGAS concept for coal gasification consists of three subunits: multistage fluid-bed pyrolyzzers, a fluid-bed gasifier, and a slagging-type char fines combustor. (For a more detailed process description, see Dravo 1976.)

\subsubsection{Slagging Lurgi process}

CONOCO Coal Development Company's Slagging Lurgi process is similar to the commercially proven fixed-bed Lurgi process. Because of the proprietary nature of $i$ ts development, few process details are available. It appears safe to assume that the overall process differs from the standard Lurgi process most noticeably in the gasification step. The slagging gasifier has less than one-fifth the steam consumption, produces a gas liquor of twice the strength but onefifth the volume, and has a thermal output per unit cross-sectional area of at least three times that of a Lurgi gasifier. It handles coals with a wide range of ash-fusion temperature if dolomite is used to flux the more refractory ashes. Caking coals can also be gasified. Oxygen consumption is 10 to $12 \%$ greater than a conventional Lurgi. The heating value of the synthesis gas is higher (Hebden 1975). By-products are naptha, oils, ammonia, and sulfur. The Slagging Lurgi gasifier is shown in Fig. 1.7 (Sudburg, Bowden, and Watson 1976). 


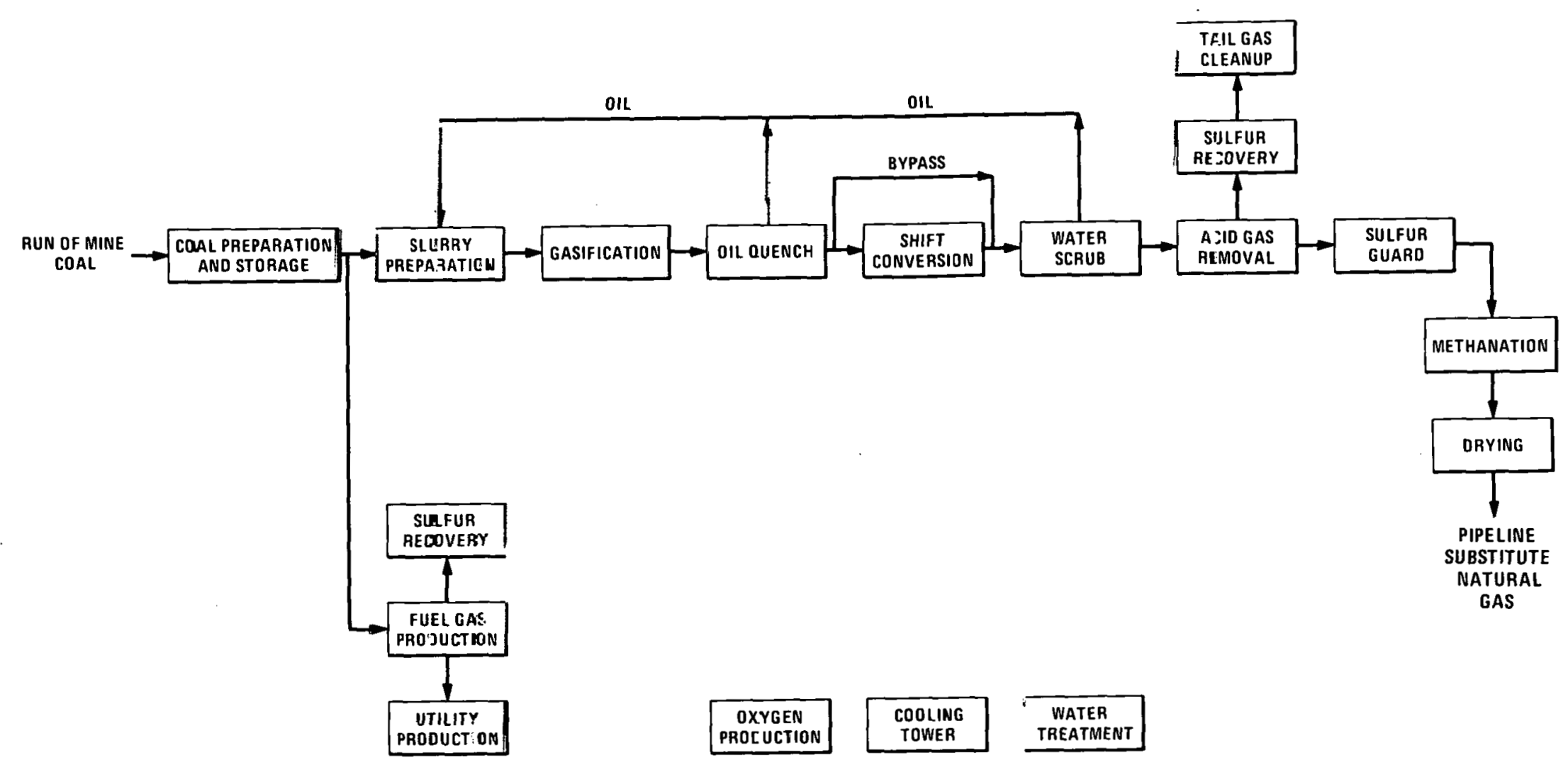

Fig. 1.3. Bl sck diagram oิ layout of Hygas process. 


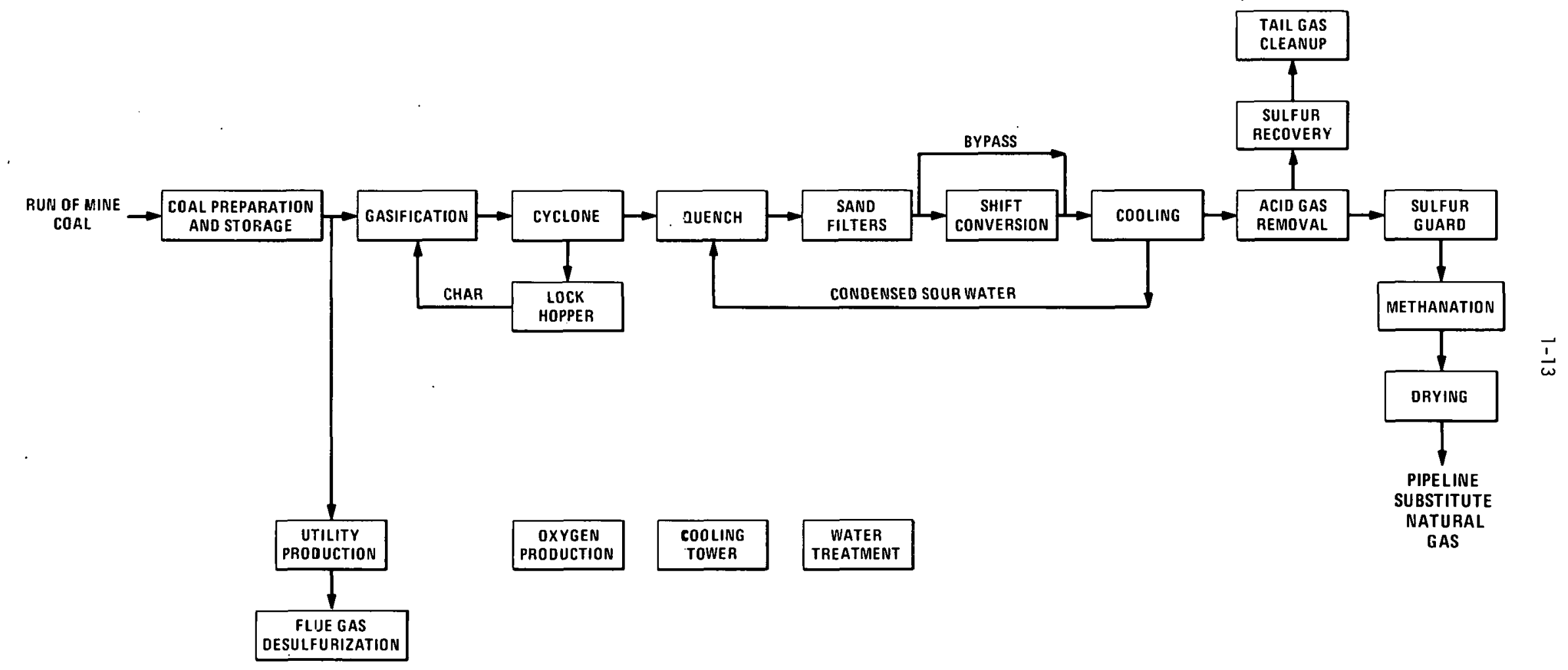

Fig. 1.4. 3lock diagram of Bi-Gas process. 


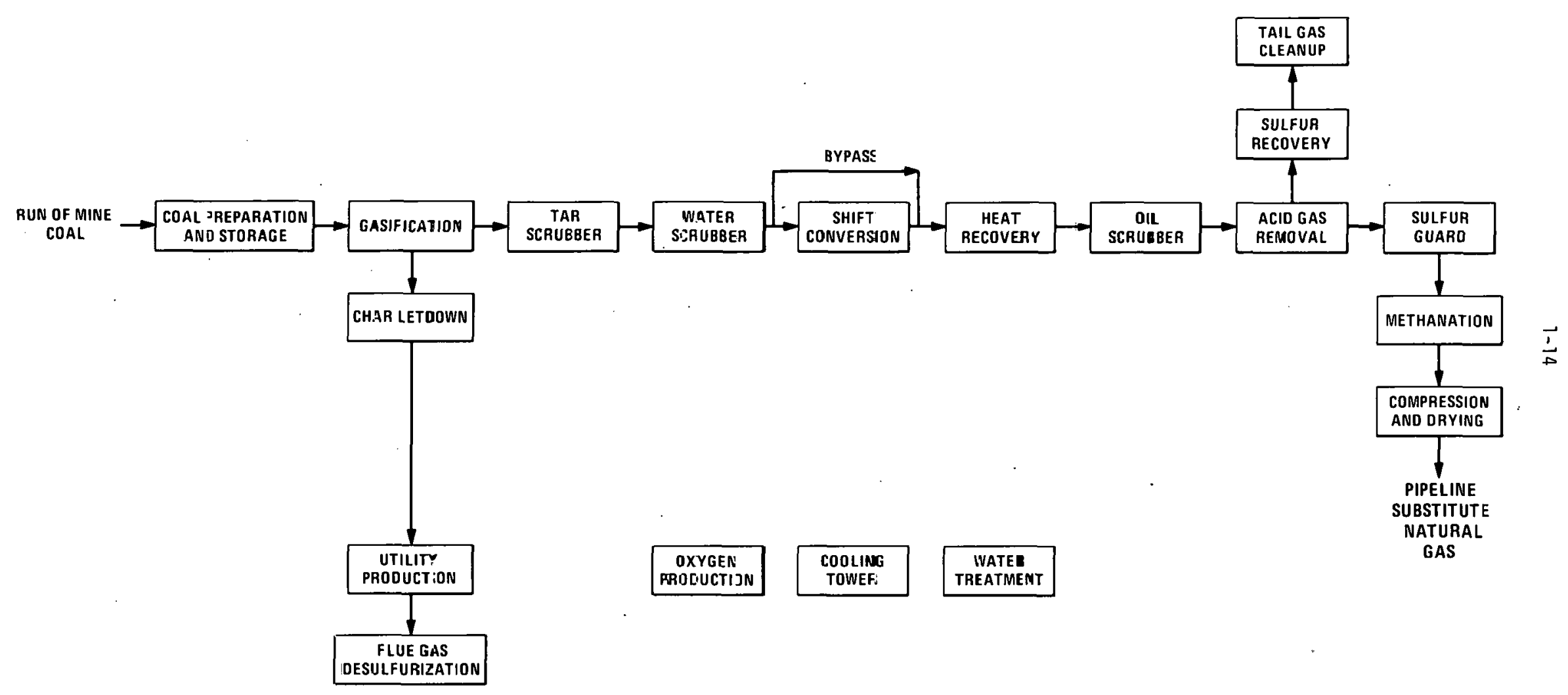

Fig. 1.5. Block diagram of Synthane process. 
ES-3804

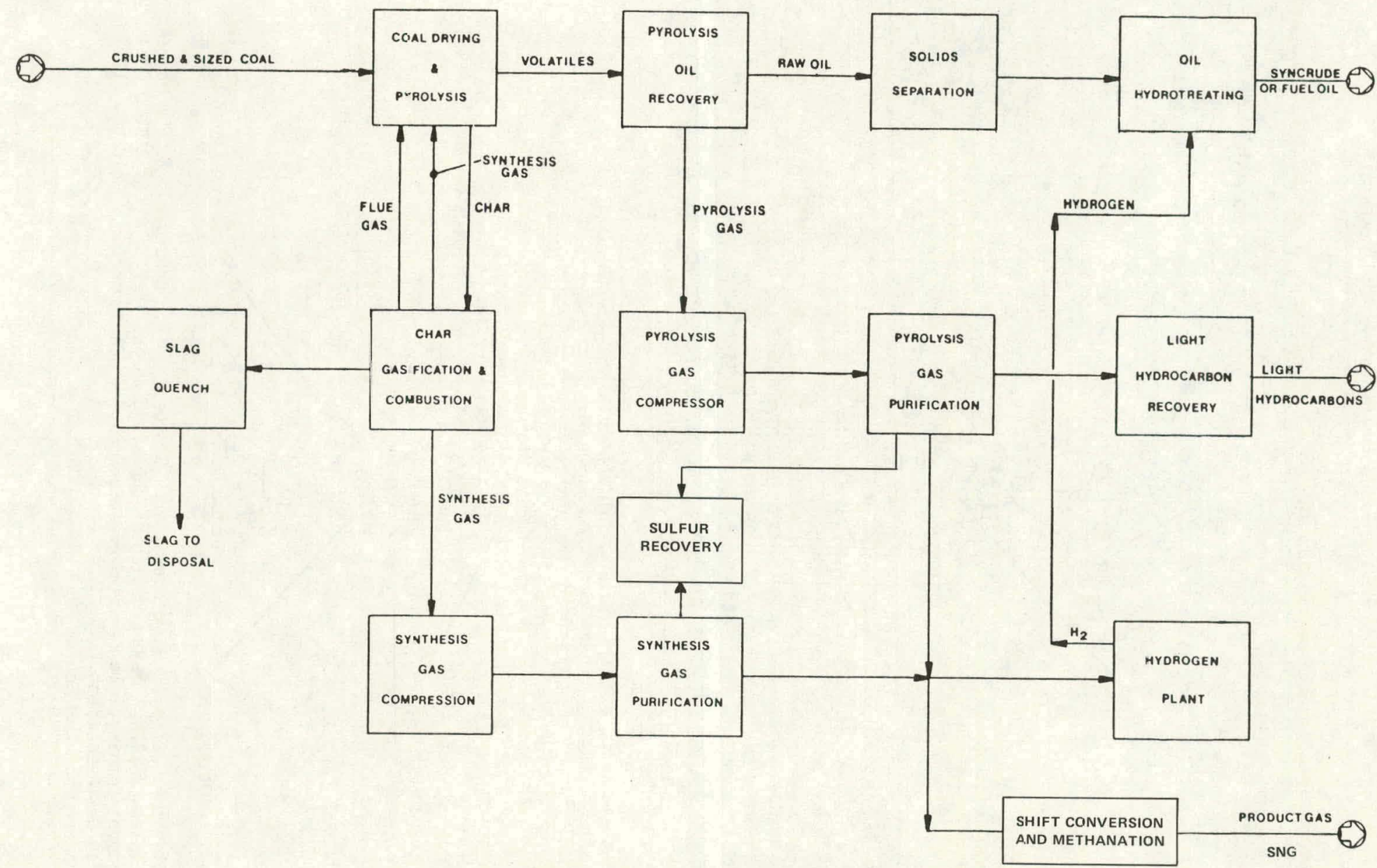

Fig. 1.6. COGAS process: block flow diagram. Source: Dravo Corporation. 1976. Modified from Fig. 1.10-3 in Handbook of gasifiers and gas treatment systems. ERDA Contract no. 3(49-18)1972. Pittsburgh, Pa. 


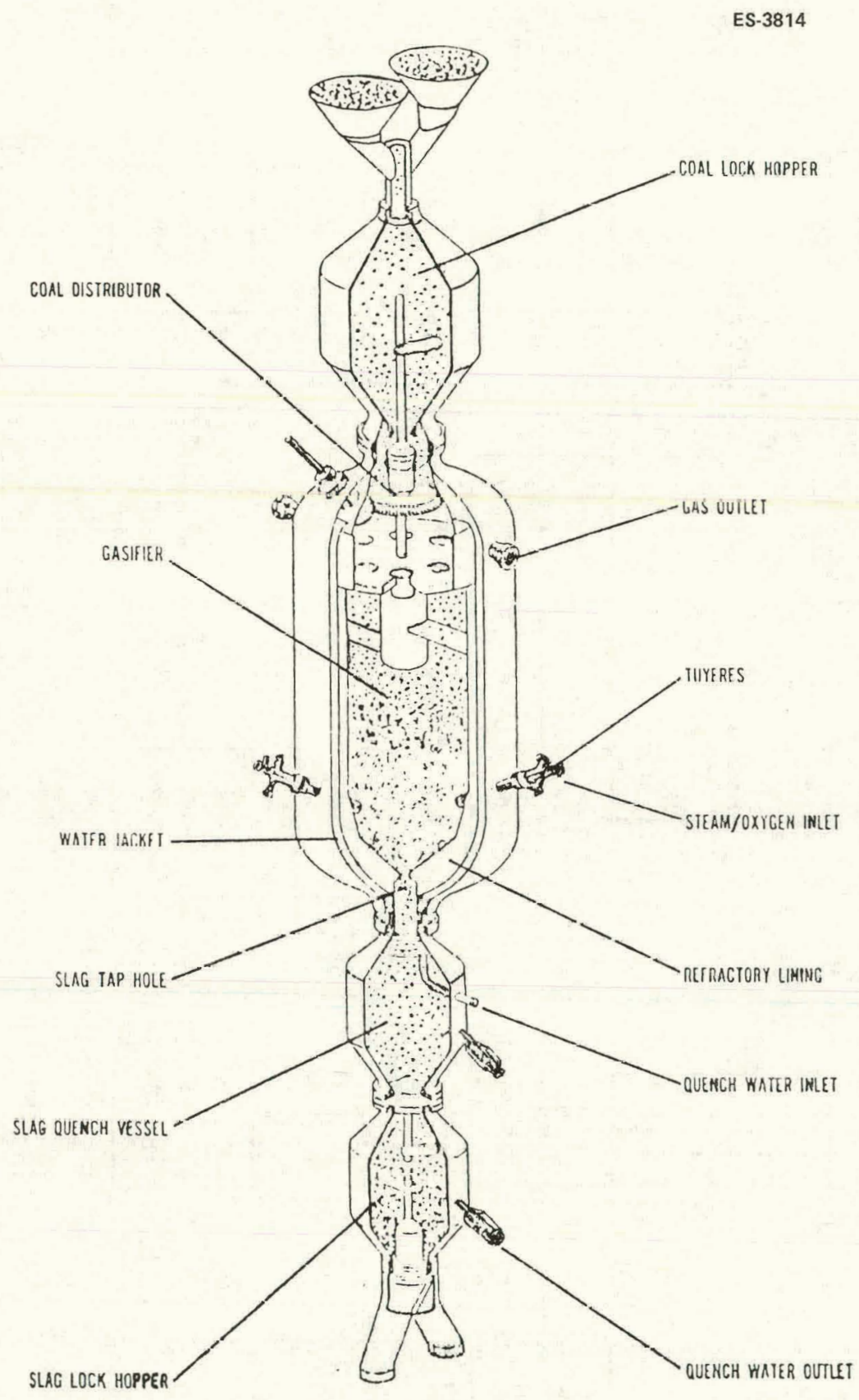

Fig. 1.7. S1agging Lurgi gasifier. Source: J. D. Sudburg, J. R. Bowden, and W. B. Watson. 1976. Demonstration of the slagging gasifier process, CONOCO Coal Development Company. In Eighth Synthetic Pipeline Gas Symposium. Chicago, I11.: American Gds Assocation. 


\subsubsection{Summary of effluents}

As in virtually all chemical plants, coal gasification plants have a number of very small point sources such as vents on machinery and vessels, small pump and piping leaks, and by-product storage vents. Though these sources are not to be discounted or ignored during plant operation, they are not detailed in this report because they cannot be specifically identified or quantified and are discharged at rates that are several times less than the known effluent streams throughout the plant. In some plants, such leaks and fugitive emissions constitute the single largest source of airborne polynuclear aromatic hydrocarbons (PAH). These PAHs pose a potential health and environmental threat both as airborie mists, fumes, and droplets and as a leachable contaminant to groundwater. Pumps of several designs and other high-pressure moving equipment have been identified as sources (Sexton 1960).

Contaminated gaseous effluents may be discharged to the atmosphere from the following sources:

1. coal storage - particulates and odors carried by wind;

2. coal preparation - particulates, sulfur dioxide, and nitrogen dioxide from thermal dryers; particulates from crushing, grinding, and conveying; organics and fumes from spontaneous combustion;

3. Wâstewater treatment - odors from retention ponds and lagoons;

4. by-product storage - vents on storage tanks containing ammonia, phenols, oils, tars, and BTX;

5. utility boilers - particulates, sulfur dioxide, nitrogen oxides, and trace elements;

6. sulfur recovery - final tail gas containing sulfur compounds, hydrocarbons, and possibly fuel gas constituents such as $\mathrm{CO}$ and $\mathrm{H}_{2}$; and

7. cooling towers - air and drift. may carry zinc and chromium compounds, chlorine, sulfuric acid, phosphates, phenols, cyanides, and/or trace elements.

Most of the primary processing steps such as gasification, gas quenching and scrubbing, shift conversion, and methanation produce no gaseous effluents. With the exception of wind, all gaseous effluents receive treatment necessary to comply with current Federal and local emission standards. Many of the estimatcd cmission rates are based un these current legislated standards. Control equipment includes baghouses, electrostatic precipitators, cyclones, wet venturi scrubbers, acid gas removal and sulfur recovery systems, incinerators, and flue gas desulfurization units.

Close examination of process waste streams reveals the close association between solid and liquid effluents. Solid and liquid wastes may leave the process from the following sources:

1. coal storage - excess leachate runoff not collected by storm drainage system, containing pyrites, particulates, acids, minerals, and trace metals;

2. storm pond - wet sludge of deposited solids;

3. coal preparation - refuse from primary size reduction and washing containing rock, gangue, debris, coal, and leachates;

4. raw water treatment - sludge resulting from treating incoming water for hardness and suspended solids containing lime, alum, salts, minerals, and ion exchange resins; 
5. gasification - slurry from ash or slag quenching containing ash, minerals, salts, and trace elements subject to leaching;

6. wastewater treatment-biological oxidation sludge from aeration basins, trace metal sludge, filter cake, and leachates from holding or biological oxidation ponds, which can infiltrate groundwater if uncontrolled;

7. cooling tower - wet sludge from evaporation of blowdown (other alternatives exist for disposal of this blowdown);

8. utility production - ash slurry containing minerals, leachates, and trace metals;

9. sludge from flue gas desulfurization - aqueous slurry of spent 1 ime, limestone, or dolomite, which can infiltrate groundwater if uncontrolled; and

10. catalysts and chemicals - from shift conversion, methanation, acid gas treatment, Claus and Stretford sulfur recovery, tall gas cleanup, and sulfur yuards.

Fiqure 1.8 presents an overview of the effluent streams that are discussed in the main body of this report. Kanges of values on emissiun rates reflect the various grades of cudl aml yasification schemes chosen for these analyses. To achieve some degree of specificity in estimating discharge rates, choices of coal type, gasifier type, and ancillary processing steps were Illade. The ranges shown in Fig. 1.8 thus divide into individual estimates in the body of the report.

It is important that the size and depth of the current data base is small. The quantities given in this report are specifically intended as estimates based on the most current information available; they are not intended for use as design values.

\subsubsection{Coal preparation - description and effluents}

In some cases coal may be received after primary breaking and washing have occurred at the mine site, but it has been assumed here that the coal preparation facflfties are cumplete. This assumption is supported by the idea that a successful demonstration plant could become a modular component of a commercial plant.

Figure 1.9 shows schematically the layout of a typical coal preparation plant. The purpose of coal preparation is to remove impurities such as rock, gangue, tramp iron, pyritic sulfur, and moisture and to reduce the particle size of the coal to meet gasifier requirements. Four primary operations are performed in this area: primary size reduction, washing, drying, and final sizing. Other facilities may include a storm runoff pond, a tailing pond for wash water, flue gas desulfurization for the thermal dryer, a slurry preparation syslem, particulate collection equipment for machinery generating dust and coal fines, dnd exlensive conveying equipment including belt and pneumatic devices. The major effluent in coal preparation is refuse from the primary size reduction and washing operations. The next effluent in order of importance is the vent gas from the thermal dryers.

\subsubsection{Primary size reduction}

The primary breaker receives the raw coal and reduces it to a maximum of 10 to $20 \mathrm{~cm}$ ( 4 to 8 in.) for washing and other preparation. Secondary crushers reduce the size of the products received 

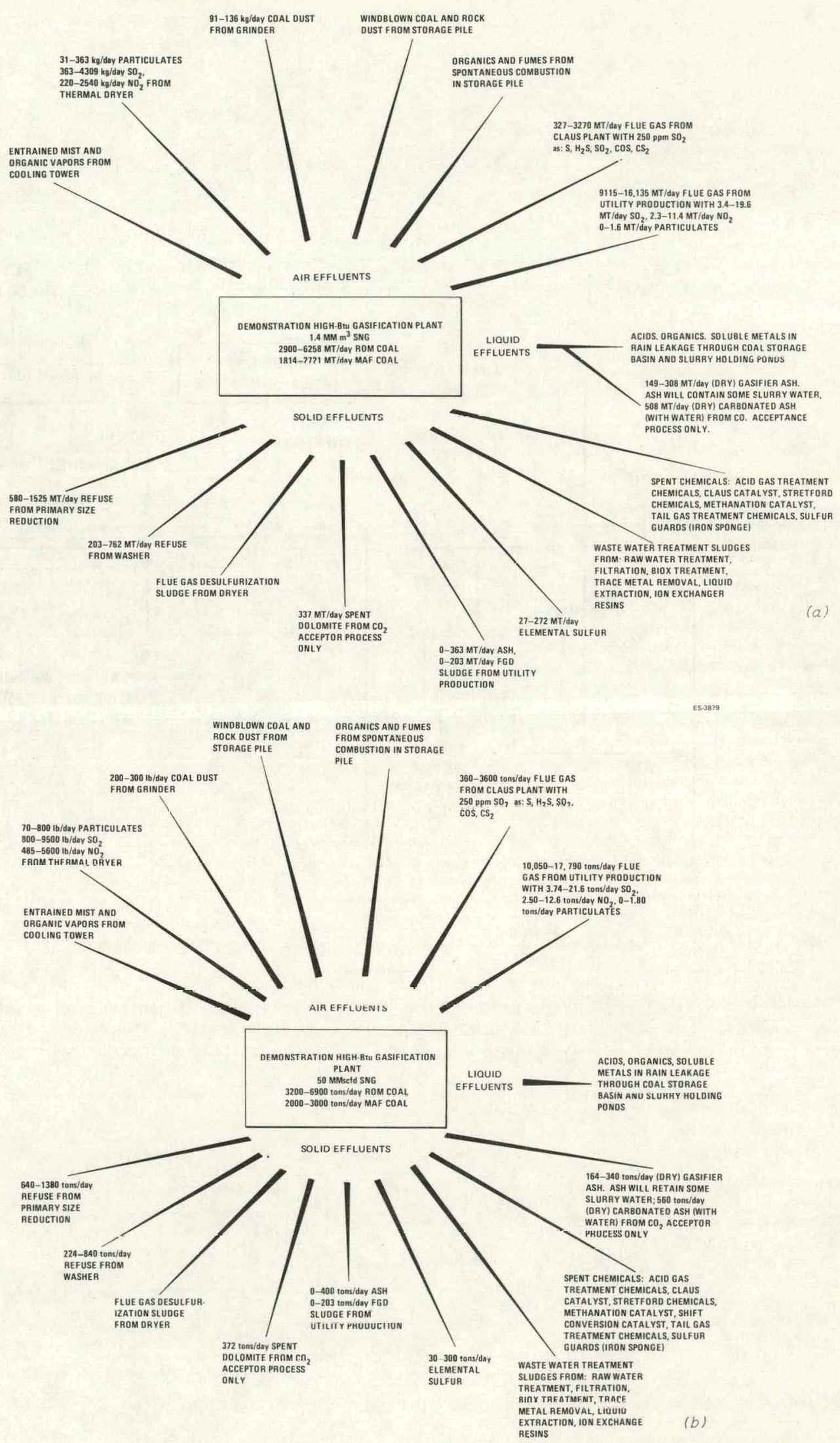

Fig. 1.8. An overview of effluent streams: (a) metric units, (b) English units. 
ES-3816

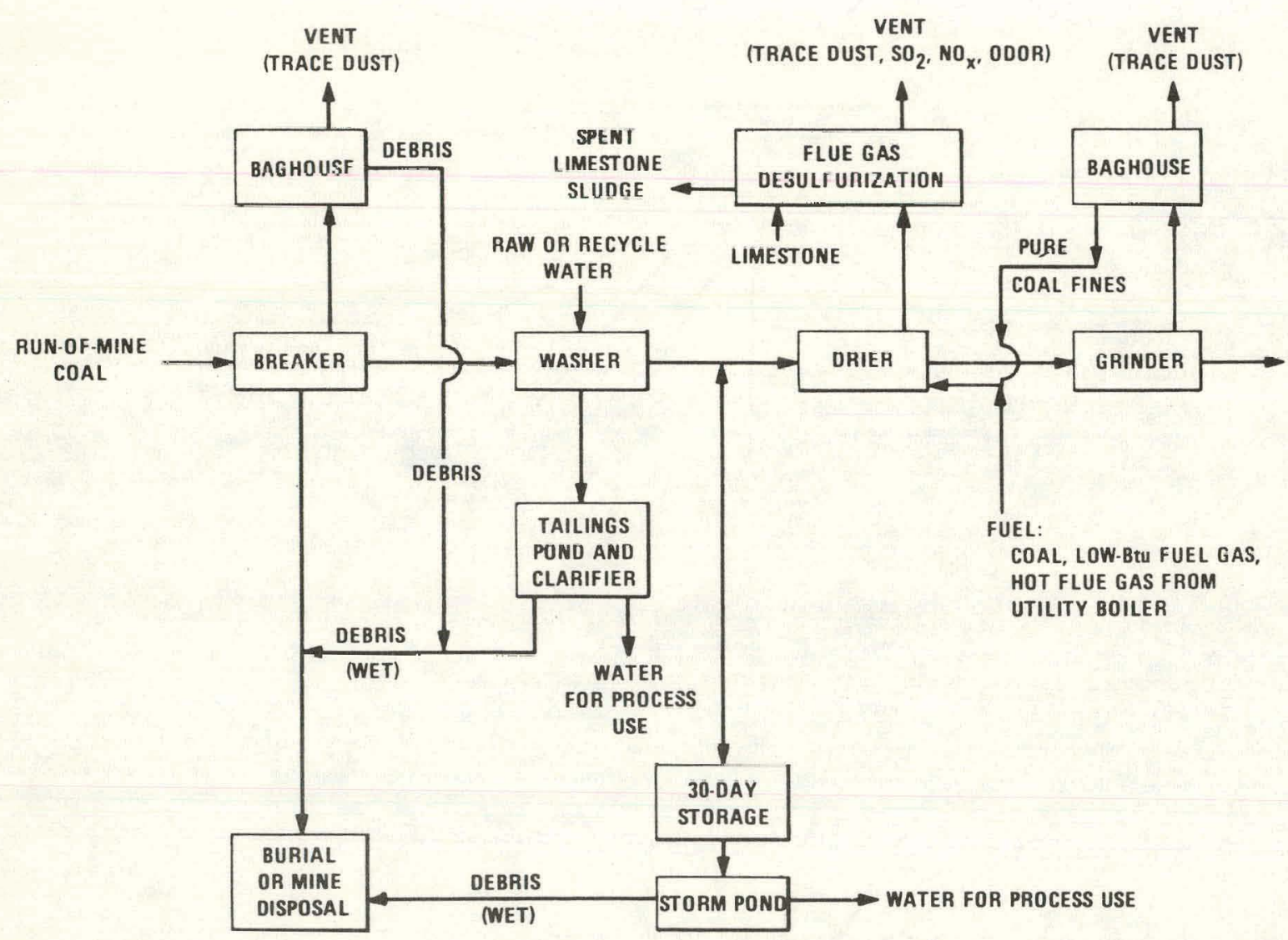

Fig. 1.9. Typical coal preparation plant. Note that (1) the demonstration plant may receive coal that has been crushed and washed at the mine site and (2) the necessily ur flue gas desulfurization will be based upon the method of drying and the choice of heat sources. 
from the primary breakers to about 3.8 to $0 \mathrm{~cm}(1.5$ to $0 \mathrm{in}$.$) . Screening crushers reduce the$ products from the secondary crushers to relatively uniform sizes of 2.5 to $0.95 \mathrm{~cm}$ ( 1 to $3 / .8$ in.).

During size reduction, a large quantity of rock, debris, gangue, and some of the coal are rejected, usually at the primary breaker. This quantity can often be $20 \%$ of the run-of-mine (ROM) coal received at the preparation plant. This represents a significant solid waste stream. For a demonstration plant, refuse production could amount to 580 to 1252 metric tons (640 to 1380 tons) per day. The exact quantity depends almost entirely on the source of the coal and prior treatment. This refuse might be returned to the mine or used as landfill, provided the potential problems of secondary pollution are evaluated and controlled.

Airborne dust and coal fines are generated by the size-reduction operations. The technology to control these emissions is well established; consequently, size reduction should not constitute a significant emission source. Applicable particulate collection equipment includes baghouses, high-pressure drop cyclones, electrostatic precipitators, and wet venturi scrubbers. Selection and use of a control device depends on the temperature, moisture content, dust loading, and particulate characteristics (specific gravity, shape, particle size, abrasiveness, resistivity, viscidity, flammability, and solubility). Recovered solids usually follow the same disposal path as the rejected debris.

The entire size-reduction process can be housed in a building constructed of sound-absorbent materials (where practical) to reduce the inherently high noise levels. Whenever possible, operating equipment is designed with noise-suppression features. It should be feasible to reduce the noise level at the plant boundary to $50 \mathrm{~dB}$ (Ayer 1974).

\subsubsection{Washing}

The washing operation separates raw coal into two categories: clean product and refuse. In the washing operation, wash water is usually sent to a settling pond where fines are removed so that the water can be reused. A clarifier may be used as well. The Interagency Task Force on Synthetic Fuels from Coal (1974) estimates that the solid wastes from coal washing can amount to between 203 and 762 metric tons (224' and 840 tons) of refuse per day based on 1800 to 2700 metric. tons (2000 to 3000 tons) of moisture and ash-free coal fed to the gasifier of a demonstration plant. Disposal of tailings must be carried out in such a way as to avoid spills that would dry out and become subject to wind and truck movement. The system should be designed for complete recycle of the wash water so that there is no water effluent from the operation. Leaching or seepage through the bottom of the tailing pond should also be controlled. A barrier of clay or plastic may be required but should not be considered to be permanent or forever free of leaks.

\subsubsection{Drying}

All industrial coal dryers in use are the continuous contact type with convection as the major mechanism of heat transfer. Thus hot gases and wet coal are brought into intimate contact with each other on a continuous gas flow-coal feed basis. The six basic dryer types are:

(1) fluidized bed, (2) suspension or flash, (3) multilouvre, (4) vertical tray and cascade, (5) continuous carrier, and (6) drum (Leonard and Mitchell 1968). 
The estimated emission rate for particulates, sulfur dioxide, and nitrogen dioxide are shown in Table 1.5 for thermal dryers in $\mathrm{Bi}$-Gas, Hygas, and $\mathrm{CO}_{2}$ Acceptor demonstration plants. Compared with the estimates and measurements by the EPA (USEPA 1972), particulate collection efficiencies of greater than $99 \%$ may be required.

Table 1.5. Allowable emission rates for thermal dryers for demonstration-size gasification plants Based on USEPA new source performance standards

\begin{tabular}{|c|c|c|c|c|c|c|c|c|}
\hline \multirow[b]{2}{*}{ Process } & \multirow{2}{*}{$\begin{array}{l}\text { Coal feed rate } \\
\text { to dryer } \\
{[\text { MTpd (tpd) }]^{a}}\end{array}$} & \multicolumn{2}{|c|}{ Mnisture (\%) } & \multirow{2}{*}{$\begin{array}{c}\text { Heat load } \\
\text { on dryer } \\
{\left[\mathrm{J} / \mathrm{hr} \times 10^{10} \mathrm{Btu} / \mathrm{hr} \times 10^{6}\right]}\end{array}$} & \multicolumn{4}{|c|}{ Emission rate } \\
\hline & & (in) & $\overline{\text { (out) }}$ & & $\begin{array}{c}\text { Particulate } \\
{[\mathrm{kg} / \mathrm{hr}(\mathrm{lb} / \mathrm{hr}]}\end{array}$ & $\begin{array}{r}\mathrm{SC} \\
{[\mathrm{kg} / \mathrm{hr}}\end{array}$ & $(\mid \mathrm{b} / \mathrm{hr})]$ & $\begin{array}{c}\mathrm{NO}_{2} \\
{[\mathrm{~kg} / \mathrm{hr}(\mathrm{lb} / \mathrm{hr})]}\end{array}$ \\
\hline Bi-Gas & $2226(2454)$ & 8.4 & $i .3$ & $3.3(31.2)$ & $1.4 \quad(3.1)$ & 16.9 & $(37.4)$ & $9.9(21.8)$ \\
\hline $\mathrm{CO}_{2}$ Acceptor & $4415(4868)$ & 33.67 & $\mathrm{Ni}^{b}$ & $31 \quad(294)$ & $13.3(29.4)$ & 160 & $(353)$ & $93.4 \quad(206)$ \\
\hline Hygas & $2367(2610)$ & 6.5 & $N I^{b}$ & $3.2(30.4)$ & $1.4 \quad(3.0)$ & & & $2.8 \quad(6.1)$ \\
\hline
\end{tabular}

Metric tons per day (tons per day).

${ }^{b} \mathrm{Nil}$ - that is, virtually nothing, but not zero.

Source: Fed. Regist. 36(247); 40 CFR Part 60, Dec. 23, 1971.

Control of particulates is well within the realm of existing technology. Baghouses, highpressure drop cyclones, electrostatic precipitators, and wet venturi scrubbers are capable of high-efficiency removal of particles in the submicron particle size range. (Because one source of particulates is dust carried off the coal, operating the dryer on relatively large chunks of coal would reduce the particulate loading.) Careful regulation of the combustion parameters controls nitrogen dioxide. Low flame temperature and low excess air are the conventional means of limiting $\mathrm{NO}_{2}$ production. If the emission of sulfur dioxide cannot be limited to comply with Federal regulations through fuel selection, flue gas desulfurization becomes necessary.

\section{$1234^{\circ}$ Frinding}

Grinding is usually the final stage in size reduction. The coal leaving the grinding step has been cleaned, washed, dried, and sized to gasifier specifications. Grinding sometimes precedes thermal drying. Because the ground coal is fine, often resembling powder, the potential exists for dust to become airborne. Additionally, because the dust is "pure" coal dust, it can form explosive concentrations in air. Ball-mills and other grinding devices generate heat while operating, making the concentration of coal dust in the air critical.

The coal/air mixture passes through cyclones in which separation occurs, and the air stream is discharged to the atmosphere through bag filters or an electrostatic precipitator. Such an arrangement is commercialiy proven, although the load on the collection device may amount to about 11 metric tons (12 tons) per day in the case of a demonstration plant. Particulate loading in the vent stream is about $0.05 \mathrm{~kg}$ per metric ton $(0.1 \mathrm{lb}$ per ton) of coal fed to the grinder and 90 to $140 \mathrm{~kg}$ (200 to $300 \mathrm{lb}$ ) of coal dust per day (assuming 99\% collection efficiency). Oniy trace quantities of hydrocarbons have been detected in such commercial streams; odor is not a problem. Collected fines from the filters are recycled to the mill product.

In two pilot plant operations, other solids are ground in addition to coal. The $\mathrm{CO}_{2} \mathrm{Acceptor}$ operation crushes and screens dolomite or limestone to a $2.38 \mathrm{~mm}$ ( 6 to 8 mesh) particle size. 
At the Bi-Gas plant, finely crushed silica is prepared for addition to the feed to alter the coal ash slagging properties. In both cases the problem areas are the same as those previously discussed except that fires and explosions are not anticipated.

All grinding and screening operations are inherently noisy. It is anticipated that the design of such machinery will use sound-absorbing materials and that this area of the plant will be isolated and enclosed within a structure.

\subsubsection{Storage}

Coal storage is necessary and desirable for both production and use. Several undesirable aspects are related to the storage of coal, however, most important of which are oxidation and spontaneous combustion resulting in the evolution of odors; fumes, and volatiles; rain drainage and runoff; windblown dust; changes in properties which may affect the use of the coal; degradation of coal from rehandling; and the added cost of handling and storage facilities.

It is difficult to estimate the quantity or composition of effluents from the storage area because they may often be considered fugitive emissions. When processing 2700 to 6300 metric tons ( 3000 to 7000 tons) of run-of-mine coal per day, it should be conservatively assumed that conveying and transferring equipment (even with well-designed control equipment) emit fugitive coal and rock dust. This dust is deposited on the ground and is subject to wind and rain erosion.

It has been suggested (Shaw and Magee 1974) that effluent limitation guidelines published by EPA for the coal mining industry under the Refuse Act Permit Program apply to gasification plant. storage facilities. Because the volume of the storage pile is large, the residence time of rain is long, allowing the rain to react and form acids; extract organics, sulfur, and soluble metals; and carry away suspended matter. Table 1.6 is an analysis of drainage from two industrial coal piles (Chu, Ruane, and Steiner 1976). A conservative approach would assume some leakage through the storage basin floor in spite of the fact that a design criteria for the basin is prevention. of leakage.

One method of storage operates on the principle that coal from "dead storage" is used only in an emergency when the normal supply of coal is interrupted. Under this arrangement, the daily delivery and use-transfer requirements take place in totally enclosed equipment. The term "dead storage" means that this quantity of coal is held in a compacted and sealed pile that is not susceptible to dusting during wind activity. The coal storage pile is prepared by layering coal in $30-\mathrm{cm}(12-\mathrm{in})$ depths and by compacting each layer to a bulk density of about $1120 \mathrm{~kg} / \mathrm{m}^{3}$. $\left(70 \mathrm{lb} / \mathrm{ft}^{3}\right)$. The height of the pile is set at about $7.6 \mathrm{~m}(25 \mathrm{ft})$, and the length and width are fixed by the tonnage to be stored. To monitor spontaneous combustion, thermocouples are inserted throughout the pile. The outer surface of the pile is sprayed with an organic polymer crusting agent to prevent dusting or rain erosion. Crusting also reduces rainwater penetration of coal particles; water runoff therefore has far less concentration of contaminants than found in mine waters. In addition, the coal pile is located on a waterproof base designed to prevent water seepage into the ground. Thus all runoff water should be contained and used in the process (Ayer 1974). 
Table 1.6. Analysis of drainage from two industrial coal piles

\begin{tabular}{|c|c|c|}
\hline \multirow{2}{*}{ Constituents } & \multicolumn{2}{|c|}{ Concentration (mg/iter) } \\
\hline & Plant J & Plant L \\
\hline Acidity (total), as $\mathrm{CaCO}_{3}$ & 1700 & 270 \\
\hline Calcium & 240 & 350 \\
\hline Chemical oxygen demand & 9 & \\
\hline Chloride & 0 & \\
\hline Conductance. $\mathrm{mho} / \mathrm{cm}$ & 2400 & 2100 \\
\hline Dissolved solids (total) & 3200 & 1500 \\
\hline Hardness, as $\mathrm{CaCO}_{3}$ & 600 & 980 \\
\hline Magnesium & 1.2 & 0.023 \\
\hline $\mathrm{pH}$, unit & 2.9 & 2.9 \\
\hline Potassium & & 0.5 \\
\hline Silicon (dissolved) & 91 & \\
\hline sodium & & 4.1 \\
\hline Sulfate & 2600 & \\
\hline Suspended solids (totäl) & 550 & 810 \\
\hline Turbidity, Jtu & 300 & \\
\hline Aluminum & 190 & \\
\hline Arsenic & 0.01 & 0.009 \\
\hline Barium & & 0.1 \\
\hline Beryllium & & $<0.01$ \\
\hline Cadmium & $<0.001$ & $<0.006$ \\
\hline Chrumium! & $<0.005$ & $<0.005$ \\
\hline Copper & 0.56 & 0.18 \\
\hline Iron & 510 & 830 \\
\hline Lead & $<0.01$ & 0.023 \\
\hline Manganese & 27 & 110 \\
\hline Mercury & $<0.0002$ & 0.027 \\
\hline Nickel & 1.7 & 0.32 \\
\hline Selenium & 0.03 & 0.003 \\
\hline Titanium & $<1$ & \\
\hline Zinc & 3.7 & 1.0 \\
\hline
\end{tabular}

Eourool T: J, Ghu; R, J. Ruane, and F. R. Sțeinạ, 1976 Characteristics of waste water discharges from coal-fired power plants. 31 st annual rurdue industrial waste confercnce, May 4-6, 1976. West Lafayette, Ind.: Purdue University.

The application of "best practicable control technology" requires installation of impounding and settling facilities to be of sufficient size to handle run-off from a once-in-ten-years storm. The operator must provide suitable recording analytical equipment to guarantee compliance with concentration schedules for discharges into waterways (Kalfadelis and Magee 1974). Runoff from the 8 - to 10-ha ( $2 U$ - to $2 b$-acre) àrea required to hóld a $3 U$-dáy supply of feed coál for a coinmercial plant could easily amount to $0.32 \mathrm{~m}^{3} / \mathrm{sec}$ (5000 gpm) during a major storm common to almost all sections of the United States. Residence time for water in the retention pond should be sufficient to permit solids to settle out. Seepage through the base of the pond should be controlled with layers of clay, concrete, or plastic.

Seepage through the process area can be a problem during rainstorms or during leaks, spills, or process upsets. Even though storm sewers collect the runoff in a chemical plant or refinery, leaks and oil spills can release enough material to cause seepage into the groundwater supply. Liquids collected in storm sewers from the processing area can be sent to the storm retention pond, except where spills of oils or phenols can occur. Because of the concentrated nature of such a spill, these drainage sewers should be sent to a separate hoiding pond. It is anticipated that water from the retention pond serving the coal storage area can find several avenues of process reuse after minor treatment (Sect. 1.2.7). 
Although not necessarily considered a part of the gasification facility, the coal mining operation, if located adjacent to the gasification complex, would probably share treatment facilities provided for the plant proper. Hence typical acid mine drainage of perhaps 0.019 to $0.025 \mathrm{~m}^{3} / \mathrm{sec}$ ( 300 to $400 \mathrm{gpm}$ ) might be treated continuously by accepted techniques to produce water suitable for discharge or for plant use. Except for a separate initial holding pond and a small lime-addition facility, all other components of the treatment facility would amount to incremental increases on facilities that must be provided for the parent plant (Kalfadelis and Magee 1974).

\subsubsection{Gasification - effluents}

The principal waste products leaving the gasifier unit are solid ash, char, or slag. The solid is usually slurried with water and the resultant slurry ultimately dewatered to some extent in a retention pond and then disposed of. The slurry water should not be allowed to become a plant effluent because of contamination by solids and leachates from the ash. A partial list of major components in ash slurry water is shown in Table 1.7. Recycle back to the quench tank should be possible, although water treatment and reuse is also a possibility, as is solar evaporation.

\begin{tabular}{|c|c|}
\hline Component & Amount (mg/liter) \\
\hline $\mathrm{\rho H}$ & 8.8 \\
\hline \multirow[t]{2}{*}{ Conductivity, S } & 1.8 \\
\hline & 0.01 \\
\hline $\mathrm{CaO}$ & 101 \\
\hline $\mathrm{MgO}$ & 161 \\
\hline $\mathrm{Ma}$ & 17.5 \\
\hline$K$ & 8.5 \\
\hline $2 n$ & 0.03 \\
\hline $\mathrm{Fe}$ & 0.22 \\
\hline $\mathrm{NH}_{4}$ & 157 \\
\hline $\mathrm{NO}_{2}$ & 0.13 \\
\hline $\mathrm{NO}_{3}$ & 3.32 \\
\hline $\mathrm{PO}_{4}$ (total) & 0.81 \\
\hline $\mathrm{Cl}$ & 85 \\
\hline $\mathrm{SO}_{4}$ & 216 \\
\hline $\mathrm{CN}$ & 0.52 \\
\hline $\mathrm{H}_{2} \mathrm{~S}$ & 9 \\
\hline $\mathrm{KMnO} 4$, consumed & 18 \\
\hline Chemical oxygen demand & 16.0 \\
\hline $\mathrm{SiO}_{2}$ & 4612 \\
\hline Suspended solids & 3918 \\
\hline Stripped residue & 550 \\
\hline
\end{tabular}

${ }^{a}$ Data taken from the Koppers-Totzek plant, Kutahya, Turkey.

Suurce: H. M. Braunstein, E. A. Copenhaver, and H. A. Pfuderer. 1976. Environmental, health, and control aspects of coal conversion: an information overview. (Draft). Vol. 1, Table 4.37, pp. 4-88. Oak Ridge, Tenn.: Oak Ridge National Laboratory. 
Special cases exist for the $\mathrm{CO}_{2}$ Acceptor process in which spent rejector is produced and for the Synthane process in which the gasifier ash and char are fired as fuel in the utility boiler; virtually all ash entering the process in the coal feed leaves through the utility boiler. Table 1.8 summarizes estimates of ash and char generation in the four demonstration-size gasifiers. Tables 1.9 and 1.10 iist major components in ashes and slags from representative U.S. coals. Ash disposal options include return to the coal mine, ponding, use as landfill, or resale to industries. When burial, ponding, or landfill is chosen, either the ash or the site must be treated so that no trace metals can leach from the ash into groundwater systems. Little is known about the environmental density of ash leachates (e.g., calcium chloride, magnesium sulfate, and fluorides). In particular, ash leachates may constitute a significant source of trace metal environmental pollution (Braunstein 1977). A discussion of trace elements is presented in Sect. i.2. $4: 5$.

\subsection{4:1 $\mathrm{CO}_{2}$ Acceptor qașifier and regenerator}

The only discharge stream from the gasifier ilself is the reject acceptor, which is typically replaced at a rate of 360 metric tons (400 tons) per day to maintain activity (Jahnig and Magee 1974). Associated with the reject acceptor is the potential for dusting. Careful handing and controlled use of water sprays should abate this problem if it arises. Based on pilot plant experience, the reject acceptor is stated to be low in sulfur content, $0.084 \%$, which is sufficiently low that there should be no secondary pollution problem upon disposal as 1 landfill.

Regenerator fuel is supplied by feeding the gasifier char to a fluidized bed and burning all carbonaceous material completely. The flue gas is removed lilrough cyclone separators to take out most of the dust, which consists of ash residue from the lignite fed to the gasifier. This ash is removed from the system by way of a fluid bed cooler and is subsequently sent to the ash desulfurization unit (Jahniq and Magee 1974).

Gas from the cyclones passes through heat exchangers wherein steam is superheated to $650^{\circ} \mathrm{C}$ $\left(1200^{\circ} \mathrm{F}\right)$. Additional steam is then generated in a waste-heat boiler. At an appropriate point in this system (e.g., before the waste-heat boiler), additional air can be introduced to burn up residual carbon monoxide. This action is necessary to avoid releasing the carbon monoxide to the atmosphere and at the same time provide a convenient way to recover high-level heat by burning the carbon monoxide.

If the flue gas is sent to an expansion turbine to recover power, noise control for this area requires careful attention in the final plant design. The flue gas contains 470 ppm of total sulfur. Whether or not this stream may be dischidyed to the atmosphere depends on future Federal EPA standards for coal conversion plants. These standards for sulfur oxides, nitrogen oxides, and particulate matter may be more stringent than standards for direct combustion facilities. Further information is needed on these critical items. The $\mathrm{NO}_{x}$ content is expected to be low as a result of the relatively low combustion temperature in the regenerator, but specific data should be obtained in the pilot operations (Jahnig and Magee 1974).

Bottom ash from the regenerator has a high sulfur content in forms such as calcium sulfide, which could result in secondary pollution problems because of the release of hydrogen sulfide. 
Table 1.8. Ash and char generation in demonstration gasification plants

\begin{tabular}{|c|c|c|c|c|c|c|c|c|c|c|}
\hline \multirow{2}{*}{ Process } & \multirow{2}{*}{$\begin{array}{l}\text { Plant size } \\
{\left[m^{3} \times 10^{6}\right.} \\
\left.\left[\operatorname{scfd} \times 10^{5}\right)\right]\end{array}$} & \multirow{2}{*}{$\begin{array}{l}\text { Coal } \\
\text { type }\end{array}$} & \multicolumn{3}{|c|}{ Composition (\%) } & \multicolumn{2}{|c|}{$\begin{array}{c}\text { Coal feed rate } \\
\text { [metric tons/day (tons/day)] }\end{array}$} & \multirow{2}{*}{$\begin{array}{l}\text { Char production } \\
\text { [metric tons/day } \\
\text { (tons/day)] }\end{array}$} & \multicolumn{2}{|c|}{$\begin{array}{c}\text { Ash production } \\
\text { [metric tons/day (tons/day)] }\end{array}$} \\
\hline & & & $\mathrm{H}_{2} \mathrm{O}$ & Ash & s & Gasifier & Utility plant & & Gasifier & Utility plant \\
\hline Bi.Gâs & $1.4(50)$ & $\begin{array}{l}\text { W. Kentucl:y } \\
\text { Po. } 11\end{array}$ & 1.3 & 7.2 & 3.75 & $2070(2280)$ & $\begin{array}{l}390(431) \\
\left(8.4 \% \mathrm{H}_{2} \mathrm{O}\right)\end{array}$ & None & $\begin{array}{l}150(164) \text { slag plus } \\
150(164) \text { quench/ } \\
\text { slurry water }\end{array}$ & $26(29)$ (dry) \\
\hline Synthane & $1.4(50)$ & $\begin{array}{l}\text { Pittsburgh } \\
\text { Seam }\end{array}$ & 2.5 & 7.4 & 1.6 & $2590(2850)$ & None & $\begin{array}{l}790(870) \text { gasifier } \\
\text { char to utility } \\
\text { production }\end{array}$ & None & $190(211)$ (dry) \\
\hline $\mathrm{CO}_{2} 4$ ccepto- & $1.4(50)$ & Lignite & 0 & 11.45 & 0.9 & $2930(3229)$ & None & $\begin{array}{l}1030(1135) \text { to } \\
\text { regenerator }\end{array}$ & $\begin{array}{l}480(532) \text { carbonated } \\
\text { ash plus } \\
480(532) \text { water: } \\
\text { from regenerator }\end{array}$ & None \\
\hline Hygai & $1.4(50)$ & $\begin{array}{l}\text { Illinois } \\
\text { No. } 6\end{array}$ & 0 & 11.54 & 4.2 & $1570(1733)$ & $\begin{array}{l}640(708) \text { to } \\
\text { U.Gas } \\
\text { plant to make } \\
\text { fuel gas }\end{array}$ & $\begin{array}{l}290(321) \text { from } \\
\text { gasifier plus } \\
78(86) \text { from } \\
\text { U.Gas } \\
\text { plant, plus } \\
1110(1221) \\
\text { quench/slurry } \\
\text { water }\end{array}$ & $\begin{array}{l}\text { Ash is contained } \\
\text { in char }\end{array}$ & \\
\hline
\end{tabular}


Table 1.9. Elemental composition of ash from representative U.S. coals

\begin{tabular}{|c|c|c|c|c|c|c|c|c|c|c|c|c|c|}
\hline \multicolumn{2}{|c|}{ Type of coal } & \multicolumn{10}{|c|}{ Analysis of ash (\%) } & \multirow[b]{2}{*}{ Rank } & \multirow[b]{2}{*}{ Source } \\
\hline State & Bed or mine & $\mathrm{SiO}_{2}$ & $\mathrm{Al}_{2} \mathrm{O}_{3}$ & $\mathrm{Fe}_{2} \mathrm{O}_{3}$ & $\mathrm{TiO}_{2}$ & $\mathrm{P}_{2} \mathrm{O}_{5}$ & $\mathrm{CaO}$ & $\mathrm{MgO}$ & $\mathrm{Na}_{2} \mathrm{O}$ & $\mathrm{K}_{2} \mathrm{O}$ & $\mathrm{SO}_{3}$ & & \\
\hline Illinois & No. 6 & 35.8 & 19.9 & 24.2 & & & 5.8 & 2.5 & & & 5.9 & Bit & 3 \\
\hline Pennsylvania & Pittsburgh & 51.7 & 36.4 & 5.5 & & & 1.7 & 1.8 & & & 0.8 & Bit & 3 \\
\hline Ohio & No. 5 & 43.6 & 22.3 & 28.5 & 1.2 & 0.19 & 1.8 & 0.7 & 0.2 & 1.0 & 1.9 & & 1 \\
\hline West Virginia & Eagle & 544 & 31.8 & 7.7 & 2.3 & 0.14 & 2.4 & 0.5 & 0.6 & 1.8 & 1.1 & & 1 \\
\hline Kentucky & No. 9 & 49.3 & 19.4 & 27.4 & 1.0 & 0.03 & 1.8 & 0.7 & 0.2 & 1.9 & 0.2 & & 1 \\
\hline Missouri & Bevier & 37.9 & 16.3 & 41.0 & 0.6 & 0.02 & 1.7 & 0.4 & 0.1 & 1.3 & 1.1 & & 1 \\
\hline North Dakota & Dakota Star & 13.7 & 8.6 & 14.8 & & & 19.3 & 7.2 & & & 28.9 & Lig & 3 \\
\hline Montana & Colstrip & 35.4 & 19.3 & 5.6 & 0.8 & 0.3 & 17.8 & 4.4 & 0.3 & 0.1 & 16.3 & Sub & 2 \\
\hline Wyoming & No 15 & 38.3 & 32.3 & 17.1 & & & 7.2 & 0.7 & & & 2.5 & Bit & 3 \\
\hline New Mexico & Yankee & 57.4 & 30.0 & 6.7 & 1.2 & 0.07 & 1.7 & 2.0 & 0.1 & 1.0 & 0.5 & & 1 \\
\hline
\end{tabular}

Sources: IGT. 196\%. Compiled trom: (1) R. F. Abernathy, M. J. Peterson and F. H. Gibson. 1969. Major ash constituents in U.S. coals. U.S. Bureau of Mines R 1240. Washington, D.C.: U.S. Bureau of Mines. (2) G. H. Gronhord, A. E. Harak, and P. H. Tufte. 1970. Ash fouling and air pollution studies using a pilot plant test furnace. In Technology and use of lignites, eds. J. L. Elder and W. R. Kube. U.S. Bureau of Mines IC8471, pp. 69-77. Washington, D.C.: U.S. Bureau of Mines. (3) W. A. Selvig and F. H. Gibson. 1956. Analvsis of ash from United States coals. U.S. Bureau of Mines bull. 567. Washington, D.C.: U.S. Bureau of Mines.

Table 1.10. Major components of coal combustion slags (wt \%)

\begin{tabular}{llllllllll}
\hline $\mathrm{SiO}_{2}$ & $\mathrm{Al}_{2} \mathrm{O}_{3}$ & $\mathrm{Fe}_{2} \mathrm{O}_{3}$ & $\mathrm{FeO}$ & $\mathrm{MgO}$ & $\mathrm{CaO}$ & $\mathrm{Na}_{2} \mathrm{O}$ & $\mathrm{K}_{2} \mathrm{O}$ & $\mathrm{TiO}_{2}$ & $\mathrm{P}_{2} \mathrm{O}_{5}$ \\
\hline 53.8 & 13.9 & 2.6 & 9.3 & 4.1 & 7.9 & 3.0 & 1.5 & 2.0 & 0.4 \\
48.4 & 15.2 & 6.6 & 6.7 & 6.1 & 8.4 & 2.3 & 0.6 & 1.9 & 0.2 \\
54.54 & 22.97 & 5.91 & & 1.24 & 6.35 & 1.62 & 0.55 & 3.36 & 0.85 \\
51.71 & 21.93 & 5.54 & & 1.21 & 5.87 & 5.87 & 7.17 & 3.19 & 0.78 \\
\hline
\end{tabular}

Source: H. M. Braunstein. 1977. Environmental and health aspects of disposal of solid wastes from coal conversion: an information assessment. (Draft), vol. 1. Oak Ridge, Tenn.: Oak Ridge National Laboratory.

Therefore, ash produced from the coal is processed to remove $98 \%$ of its sulfur by allowing it to react with $\mathrm{CO}_{2}$ at $88^{\circ} \mathrm{C}\left(190^{\circ} \mathrm{F}\right)$ in a water slurry. Uff-gas containing a calculated $27 \% \mathrm{H}_{2} \mathrm{~S}, 7 \%$ $\mathrm{CO}_{2}$, and $66 \% \mathrm{H}_{2} \mathrm{O}$ is sent to a sulfur recovery plant. All of the gas streams in this system are contained and should not cause environmental problems. The carbonated ash is withdrawn at a rate of 483 metric tons (532 tons) per day (dry) as a $50 \%$ slurry in water and is not expected to create odors, although this possibility should be examined further. The water contained in the ash slurry should constitute the predominant water effluent from the plant during normal operation.

\subsubsection{Hygas gasifier}

The major effluent from this area of the plant is spent char, which serves to reject ash brought in with the coal feed. Residual char rejected from the steam-oxygen gasification stage at an estimated rate of 291 metric tons (321 tons) per day (dry) contains 10 to $30 \%$ carbon, corresponding to 2 to $7 \%$ of the original carbon contained in the coal feed. (An estimated 78 metric tons, or 86 tons of char per day, dry, is also rejected from the U-Gas plant, which supplies fuel gas to the utility plant. The two char streams are probably handled and disposed of together.) The char is quenched and slurried in water (25\% solids), depressurized, and discharged through lock hoppers. Steam formed in the char-quenching operation contains particulates and other contaminants and should therefore be returned to the process or collected for treatment and disposal. ( $A$ baghouse operated above the dew point of the gas may provide sufficient cleanup to allow 
the steam to be vented to the atmosphere if only particulate pollution is the overall concern.) The amount of steam produced should be about $4: 5$ metric tons per hour $(10,0001 \mathrm{~b} / \mathrm{hr})$.

Ash in the water slurry is recovered in a settling pond; which is drained so that semidry ash can be removed for burial. Water from the settling pond is recycled to the quench system. Although wet ash is not dusty, parts of the settling basin or spills on the ground can dry out and become a dust nuisance, as has happened in the past (Jahnig 1975b). Consequently, no water effluent from the ash system should remain other than that retained by the ash. However, this may contain soluble salts or trace elements; further information should therefore be obtained on leachables from the wet ash. Exposure to air may be a factor, and tests are needed to determine the extent of problems caused by leaching by rain or groundwater when the char is disposed of by burial or as fill. Potential leaching of calcium chloride, magnesium sulfate, compounds of iron, manganese, fluorine, etc., are a concern (Jahnig 1975b).

The nature of this ash or char warrants further discussion. If the original coal particles maintain their size during gasification, their density decreases as the carbonaceous content falls to $10.3 \%$ carbon. The particles are not only light but are friable as well. Severe turbulence associated with char-quenching and depressurizing of the slurry may create very fine particles. If the char particles break up, then very fine dust may result, with complications in ash handling and disposal. Alternative approaches to this problem have used sintering of fly ash, an agglomerating fluid-bed system, or a slagging gasifier (Jahnig 1975b). Additional information should be obtained on the depressurizing, handling, and disposal operations to ensure that potential problems are satisfactorily resolved.

It has been indicated that the char resembles activated carbon in that it has adsorptive properties and removes phenol from wastewater. If used in this manner, the char could be regenerated, for example, by returning it to the gasifier.

\subsubsection{B1-Gas gasifier}

In normal operation there are no effluents to the air from the gasification section because all of the gas streams are contained and processed in downstream equipment. The major effluent from this section is the slag formed from ash in the coal. Essentially all of the ash in the feed is rejected here after having been fused in the lower'zone of the gasifier. Production of dry slag In a demonstration-size gasifier is 150 metric tons (165 tons) per day, corresponding to about $2.2 \times 10^{4} \mathrm{~m}^{3}$ (18 acre-ft) per year; consequently, adequate provision for dispcsal is needed. The slag leaves the gasifier as a $50 \mathrm{wt} \%$ solid slurry. The slag should be relatively sulfur free and unreactive, having been fused at high temperature. Also, it contains little or no carbon and can therefore be discarded from a process point of view. The water used for quenching and slurrying picks up dust from the slag and leaches out soluble salts and metals; therefore, it should be collected and reused to prevent becoming an effluent from the plant. The ash slurry might be dewatered for mine disposal and the water sent to a holding pond for reuse (Jahnig 1975a). Depending on the final disposition of the slag slurry, dust may or may not be a consideration. For example, if the slurry is used as land-fill or if it is relegated to a storage pile, a dust problem could arise when the slurry dries. The possibility of odors also needs to be defined for the handling. and disposal system (Jahnig 1975a). 
The other major stream leaving the gasifier is the raw gas product. It contains a large amount of char that is blown out of the gasifier and recovered in cyclones for recycling to the lower zone of the gasifier. No other streams are normally released to the environment from the gasification section.

\subsubsection{Synthane gasifier}

There should be no major solid or liquid discharge from the gasification section except the gasifier char stream. It has been assumed that a dry char let-down system can be developed such that char may be ducted to the power plant using stream or inert gas as the transport medium. Char is generated at an estimated rate of 790 metric tons ( 870 tons) per day (dry) (Kalfadelis and Magee 1974). The ash carried in the char is rejected at the power plant at an estimated rate of 191 metric tons (211 tons) per day (dry).

Facilities used to store and compress lock hopper vent gas may generate small solid and liquid effluent streams that would require treatment or alsposition. Hence cual fines fillered rrom such vent gas are recycled to feed. Similarly, water present in such gas may be condensed in a compression process and would be directed to treatment facilities. Water, which may be used as sealing fluid in gas holders, may likewise require periodic treatment and replacement (Kaltadelis and Magee 1974).

\subsection{4:5 Discussion of trace elements}

The concentration of trace elements in coal is given in Table 1.11 , which shows the mean analytical values for 101 coais and the extent to which trace elements are removed through volatilization from coal during gasification in a Hygas gasifier. On this basis, the quantity of trace elements found in the gasifier ash can be estimated. lable 1.12 ists the estimated composition of ash from a gasifier with a capability of 9000 metric tons $(10,000$ tons) per day. Other types of gasifiers may have significant effects on the compositions of the solid residue and gaseous streams. (When estimating actual plant emission, the concentrations of trace elements in the specific coal feed must be known. In many cases a specific coal may have unusually high or low concentrations of a particular element.)

The forms of trace elements leaving the conversion factlity in bottuil ash ur slay are undoubtedly important. Of equal or more importance is identification of those elements and the forms that are associated with the ultrafine gas-entrained ash, which may be not only leachable but also transportable in drainage from a landfil1. Those elemental forms that volatilize during gasification are most likely to condense on and be collected with gas-borne ash (Braunstein 1977). The possibility of deposition on other surfaces should not be overlooked. Section 1.2.7 describes several other pathways for trace elements.

Typical modes of the occurrence of elements in coal are given in Table 1.13. Most trace and minor elements appear as sulfides (or sulfates in weathered coals), oxides, and carbonates. Using the information in Table 1.13, Attari and Meninger (1976) performed free energy calculations to determine the most stable form of the feed species in the pretreater, the hydrogasifier, and the c0-shift reactor in a Hygas plant. 
Table 1.11. Trace elements in coal

\begin{tabular}{|c|c|c|c|c|c|}
\hline \multirow[b]{2}{*}{ Constituent } & \multirow{2}{*}{$\begin{array}{c}\text { Mean } \\
\text { concentration } \\
(\mathrm{ppm})\end{array}$} & \multicolumn{3}{|c|}{ Mean analytical values for $101 \mathrm{coals}^{\partial}$} & \multirow{2}{*}{$\begin{array}{c}\text { Lost during } \\
\text { gasification } \\
(\%)\end{array}$} \\
\hline & & Std. deviation & Minimum & Maximum & \\
\hline As & $14.02 \mathrm{ppm}$ & 17.70 & 0.50 & 93.00 & 65 \\
\hline B & $102.21 \mathrm{ppm}$ & 54.65 & 5.00 & 224.00 & $(10)^{c}$ \\
\hline $\mathrm{Be}$ & $1.61 \mathrm{ppm}$ & 0.82 & 0.20 & 4.00 & 18 \\
\hline $\mathrm{Cd}$ & $2.52 \mathrm{ppm}$ & 7.60 & 0.10 & 65.00 & 62 \\
\hline $\mathrm{Cr}$ & $13.75 \mathrm{ppm}$ & 7.26 & 4.00 & 54.00 & Neg. \\
\hline $\mathbf{F}$ & $60.94 \mathrm{ppm}$ & 20.99 & 25.00 & 143.00 & $(10)^{c}$ \\
\hline$H_{0}$ & $0.20 \mathrm{ppm}$ & 0.20 & 0.02 & 1.60 & $y_{6}$ \\
\hline Mo & $7.54 \mathrm{ppm}$ & 5.96 & 1.00 & 30.00 & $(10)^{c}$ \\
\hline $\mathrm{Ni}$ & $21.07 \mathrm{ppm}$ & 12.35 & 3.00 & 80.00 & 24 \\
\hline $\mathrm{Ph}$ & $34.78 \mathrm{ppm}$ & 43.63 & 4.00 & 218.00 & 63 \\
\hline $\mathrm{Se}$ & $2.08 \mathrm{ppm}$ & 1.10 & 0.45 & 7.70 & 74 \\
\hline$v$ & $32.71 \mathrm{ppm}$ & 12.03 & 11.00 & 78.00 & 30 \\
\hline $\mathrm{Zn}$ & $272.29 \mathrm{ppm}$ & 694.23 & 6.00 & 53.50 & $(10)^{c}$ \\
\hline $\mathrm{Cl}$ & $0.14 \%$ & 0.14 & 0.01 & 0.54 & $>90$ \\
\hline $\mathrm{Ti}$ & $0.07 \%$ & 0.02 & 0.02 & 0.15 & $(10)^{c}$ \\
\hline $\mathrm{Sb}$ & $1.26 \mathrm{ppm}$ & 1.32 & 0.20 & 8.90 & 33 \\
\hline Co & 9.57 ppm & 7.26 & 1.0 & 43.00 & Neg. \\
\hline
\end{tabular}

${ }^{a}$ R. R. Ruch, H. J. Gluskoter, and N. F. Shimp. 1974. Symposium proceedings: environmental aspects of fuel conversion technology, May 1974. EPA 650/2-74-118, p. 52. St. Louis, Mo.: U.S. Environmental Protection Agency.

${ }^{b}$ A. J. Attari. 1973. Fate of trace constituents of coal during gasification. PB 223-001, p. 21. Chicago, III.: Institute of Gas Technology.

${ }^{c}$ Volatalization has not yet been determined. In the absence of data, $10 \%$ is used. Some are expected to be considerably more volatile.

Table 1.12. Disposition of trace elements

\begin{tabular}{|c|c|c|c|c|}
\hline \multirow[b]{2}{*}{ Constituents } & \multirow[b]{2}{*}{$\begin{array}{l}\text { Mean concentration } \\
\text { (ppm) }\end{array}$} & \multirow{2}{*}{$\begin{array}{c}\text { Peed rate }{ }^{2} \\
\text { [kg (lb) per day] }\end{array}$} & \multicolumn{2}{|c|}{ Leaving oasifier. } \\
\hline & & & $\begin{array}{c}\text { In gas stream } \\
{[\mathrm{kg}(\mathrm{lh}) \text { ner day }]}\end{array}$ & $\begin{array}{c}\text { In ash } \\
{[\mathrm{kg} \text { (lb) pcr day] }}\end{array}$ \\
\hline As & 14 & $127(280)$ & $83(182)$ & $44(98)$ \\
\hline B & 100 & $907(2,000)$ & $91(200)$ & $816(1,800)$ \\
\hline $\mathrm{Be}$ & 1.6 & $15(32)$ & $3(6)$ & $12(26)$ \\
\hline $\mathrm{Cd}$ & 2.5 & $23(50)$ & $14(31)$ & $9(19)$ \\
\hline $\mathrm{Cr}$ &, 14 & $137(380)$ & Pleg. & $127(280)$ \\
\hline$F$ & 61 & $553(1,220)$ & $55(122)$ & $498(1,098)$ \\
\hline $\mathrm{Hg}$ & 0.20 & $1.8(4)$ & $1.8(4)$ & Neg. \\
\hline Mo & 7.5 & $68(150)$ & $7(15)$ & $61(135)$ \\
\hline $\mathrm{Ni}$ & 21 & $190(420)$ & $46(101)$ & $144(319)$ \\
\hline $\mathrm{Pb}$ & 35 & $317(700)$ & $200(441)$ & $117(259)$ \\
\hline Se & 2.1 & $19(42)$ & $14(31)$ & $5(11)$ \\
\hline$v$ & 33 & $299(660)$ & $90(198)$ & $209(462)$ \\
\hline$\underline{Z n}$ & 270 & $3160(6,100)$ & $245(540)$ & $2205(4,860)$ \\
\hline $\mathrm{Cl}$ & $0.14 \%$ & $12700(28,000)$ & $>11430(>25,200)$ & $1270(2,800)$ \\
\hline $\mathrm{Ti}$ & $0.07 \%$ & $6350(14,000)$ & $635(1,400)$ & $5715(12.600)$ \\
\hline $\mathrm{Sb}$ & 1.3 & $12(26)$ & $4(9)$ & $8(17)$ \\
\hline Co & 9.6 & $87(192)$ & Neg. & $87(192)$ \\
\hline
\end{tabular}

${ }^{a}$ Feed rate based on 9000 metric tons $(10,000$ tons) per day of cleaned coal (after removal of rock, debris, and yangue). 


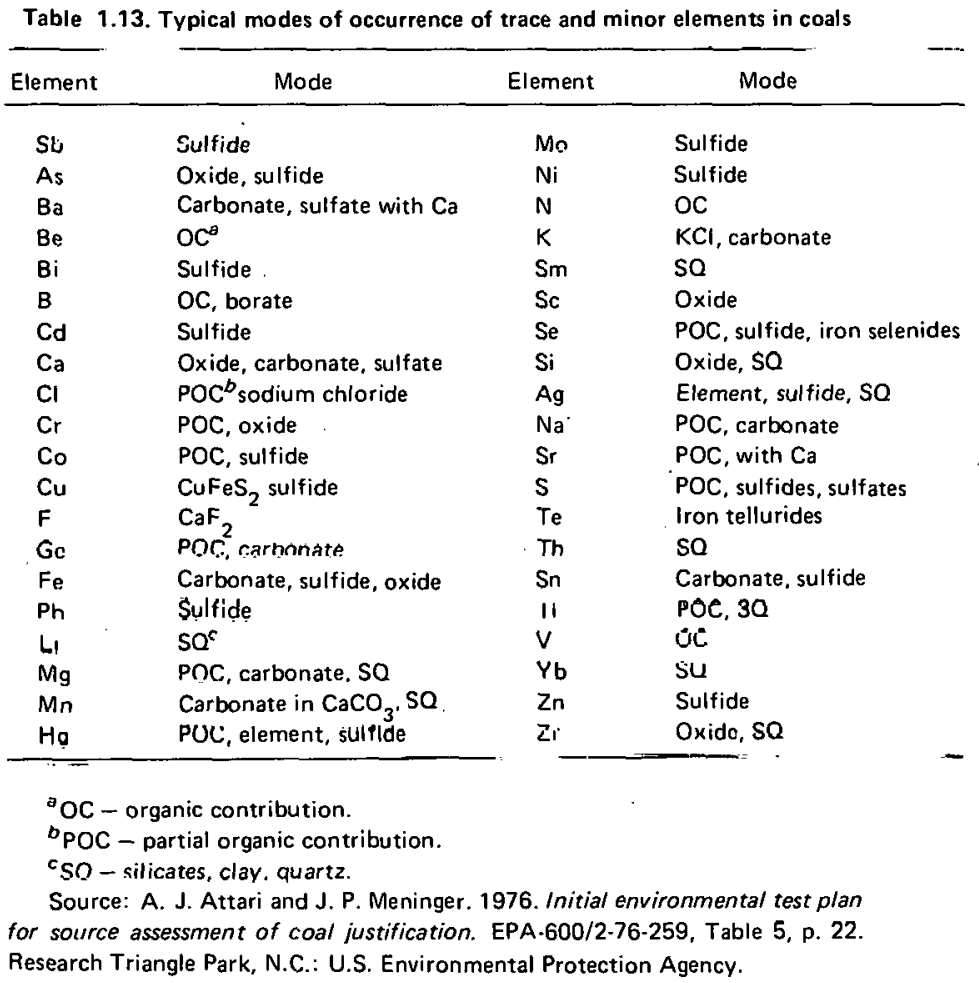

Attari and Meninger (1976) made some generalizations based on their results, which are presented in Tables 1.14 and 1.15. In the hydrogasifier, the alkali metals (sodium, potassium, and 1ithium) and the heavier alkaline earth metals (barium and strontium) favor carbonate formation, whereas beryllium is most stable as the oxide and magnesium as the sulfide. Many heavy metals, such as mercury, bismuth, silver, and tin, tend to remain in the elemental form. The authors caution that the study does not take into account the kinetics and reaction rates of the components; thus it may be that the actual form of an element may be quite different from the calculated form (Braunstein 1977).

In a study of the loss of minor and trace elements from coal under various simulated coal gasification environments, it was found that of 18 elements surveyed, 10 were stable and relatively nonvolatile: aluminum, silicon, potassium, calcium, titanium, iron, copper, rubidium, strontium, and yttrium. These elements would be expected to remain in the bottom ash or slag. Two elements studied, arsenic and zinc, were highly volatile, and the remaining six - phosphorus, sulfur, chrnmium. manganese, nickel, and zirconium - are appreciably volatilized in oxygen or hydrogen atmospheres but appear to remain as solid residue under low-pressure gasification using steam or carbon dioxide. The obviously volatile elements, such as cadmium, mercury, and lead, were apparently not studied (Braunstein 1977). Many of these trace elements do not exist in elemental form; rather, they exist in compound forms that may exhibit quite different volatility curves than do the elemental forms. 
Table 1.14. Thermodynamically stable forms of elements in the process units

\begin{tabular}{|c|c|c|c|}
\hline Element & Pretreater ${ }^{a}$ & Hygas $^{3}$ & Co-Shift ${ }^{a}$ \\
\hline $\mathrm{Sb}$ & SA & $s$ & $s$ \\
\hline As & SA & $E, H$ & E. $H$ \\
\hline $\mathrm{Ba}$ & SA & C & C \\
\hline $\mathrm{Be}$ & 0 & 0 & 0 \\
\hline $\mathrm{Bi}$ & SA & $E, S$ & E. S \\
\hline B & 0 & $F$ & $F$ \\
\hline Cd & SA & S & $s$ \\
\hline $\mathrm{Ca}$ & SA & .5 & c \\
\hline $\mathrm{Cl}$ & $E$ & $\mathrm{HCl}$ & $\mathrm{HCl}$ \\
\hline $\mathrm{Cr}$ & SA & s & 5 \\
\hline Co & SA & $\mathbf{S}$ & $s$ \\
\hline $\mathrm{Cu}$ & SA & $\mathrm{S}$ & $s$ \\
\hline $\mathbf{F}$ & $E$ & $\mathrm{HF}$ & $\mathrm{HF}$ \\
\hline $\mathrm{Ge}$ & 0 & $H$ & $\mathrm{H}$ \\
\hline $\mathrm{Fe}$ & SA & s & $s$ \\
\hline $\mathrm{Pb}$ & SA & $S$ & $\mathrm{~s}$ \\
\hline Li & 0 & r. & C \\
\hline $\mathrm{Mg}$ & SA & $s$ & C \\
\hline$M n$ & SA & $\mathrm{s}$ & S \\
\hline $\mathrm{Hg}$ & $E$ & $E, S$ & $\mathrm{E}$ \\
\hline Mo & SA & $\mathrm{s}$ & S \\
\hline $\mathrm{Ni}$ & SA & $S$ & $s$ \\
\hline$N$ & E. O & $\mathrm{H}$ & $\mathrm{H}$ \\
\hline K & 0 & C & C \\
\hline $\mathrm{Sm}$ & 0 & 0 & 0 \\
\hline Se & 0 & $H$ & $H$ \\
\hline $\mathrm{Si}$ & 0 & 0 & 0 \\
\hline $\mathrm{Ag}$ & SA & $S, E$ & $E$ \\
\hline $\mathrm{Na}$ & $n$ & $r$. & ᄃ \\
\hline $\mathrm{Sr}$ & $S A$ & $r$ & $c$ \\
\hline$S$ & 0 & $H$ & $H$ \\
\hline Te & 0 & $\mathrm{H}$ & $H, E$ \\
\hline Sn & 0 & $\mathrm{E}, \mathrm{Cl}$ & $\mathrm{Cl}$ \\
\hline $\mathrm{Ti}$ & 0 & 0 & 0 \\
\hline v & 0 & 0 & 0 \\
\hline$Y_{b}$ & 0 & 0 & 0 \\
\hline $\mathrm{Zn}$ & SA & $S$ & $S$ \\
\hline $\mathrm{Zr}$ & 0 & 0 & 0 \\
\hline \multicolumn{4}{|c|}{$\begin{array}{l}{ }^{a} \mathrm{C}=\text { carbonate; } \mathrm{E}=\text { element; } \mathrm{H}=\text { hydride; } \mathrm{O}=0 \mathrm{x}- \\
\text { ide; } \mathrm{S}=\text { sulfide; and } \mathrm{SA}=\text { sulfate. } \\
\text { Source: A. J. Attari and J. P. Meninger. 1976. } \\
\text { Initial environmental test plan for source assessment } \\
\text { of gasification. EPA.600/2-76-259. Table E-3, p. } \\
\text { E.35. Research Triangle Park, N.C.: U.S. Environ- } \\
\text { mental Protection Agency. }\end{array}$} \\
\hline
\end{tabular}


Table 1.15. Calculated flow rates of trace and minor elements in a Hygas-based commercial coal gasification plant using Illinois No. 6 seam bituminous coal

\begin{tabular}{|c|c|c|c|c|c|c|c|c|c|c|}
\hline \multirow{3}{*}{ Element } & \multicolumn{2}{|c|}{ Coal feed to pretreater } & \multicolumn{8}{|c|}{ Flow rates $\left(\mathrm{kg} / \mathrm{s} \times 10^{3}\right)$} \\
\hline & $\begin{array}{c}\text { Composition } \\
\text { (ppm) }\end{array}$ & $\begin{array}{c}\text { Flow rate } \\
\left(\mathrm{kg} / \mathrm{s} \times 10^{3}\right)\end{array}$ & \multirow{2}{*}{$\begin{array}{l}\text { Pretreater } \\
\text { losses }^{a} \\
\text { Stream D }\end{array}$} & \multirow{2}{*}{$\begin{array}{c}\text { Oxygasifier } \\
\text { char } \\
\text { Stream G }\end{array}$} & \multirow{2}{*}{$\begin{array}{l}\text { Hot oil } \\
\text { quench } \\
\text { Stream K }\end{array}$} & \multirow{2}{*}{$\begin{array}{c}\text { Water } \\
\text { scrub }^{b} \\
\text { Streams } 12,13\end{array}$} & \multirow{2}{*}{$\begin{array}{c}\text { Acid-gas } \\
\text { effluent }^{c} \\
\text { Streams 11, } 14\end{array}$} & \multirow{2}{*}{$\begin{array}{l}\text { Sulfur } \\
\text { guard } \\
\text { Stream P }\end{array}$} & \multirow{2}{*}{$\begin{array}{c}\text { Methanation } \\
\text { condensate }^{d} \\
\text { Stream } 6\end{array}$} & \multirow{2}{*}{$\begin{array}{c}\text { Product } \\
\text { gas } \\
\text { Stream } 9\end{array}$} \\
\hline & Strean & $\mathrm{m} \mathrm{C}$ & & & & & & & & \\
\hline $\mathrm{Sb}$ & 1.1 & 0.15 & 0.043 & 0.096 & 0.008 & 0.003 & 0.0 & 0.0 & 0.0 & 0.0 \\
\hline$A_{s}$ & 24 & 3.2 & 0.35 & 2.1 & 0.3 & 0.2 & 0.25 & 0.0 & 0.0 & 0.0 \\
\hline $\mathrm{Ba}$ & 31 & 4.1 & 0.0 & 4.1 & 0.0 & 0.0 & 0.0 & 0.0 & 0.0 & 0.0 \\
\hline $\mathrm{Be}$ & 1 & 0.13 & 0.02 & 0.10 & 0.01 & 0.0 & 0.0 & 0.0 & 0.0 & 0.0 \\
\hline $\mathrm{Bi}$ & 1.1 & 0.15 & 0.022 & 0.072 & 0.050 & 0.006 & 0.0 & 0.0 & 0.0 & 0.0 \\
\hline B & 200 & 27.0 & 0.73 & 24.0 & 2.0 & 0.27 & 0.0 & 0.0 & 0.0 & 0.0 \\
\hline Cd & 0.89 & n 12 & $\cap \cap 44$ & 0.028 & 0.040 & 0.008 & 0,0 & 0.0 & 0.0 & 0.0 \\
\hline $\mathrm{Ca}$ & 3500 & 470.0 & 100.0 & 310.0 & 60.0 & 0.0 & 0.0 & 0.0 & 0.0 & 0.0 \\
\hline $\mathrm{Cl}$ & 2300 & 310.0 & 110.0 & 80.0 & 5.0 & 110.0 & 4.0 & 1.0 & 0.0 & 0.0 \\
\hline$r r$ & 15 & $2 . n$ & 0.0 & 2.0 & 0.0 & 0.0 & 0.0 & 0.0 & 0.0 & 0.0 \\
\hline Co & 3.6 & $0.4 \overrightarrow{8}$ & $\dot{U}$ & 0.48 & 0.0 & 0.0 & 0.0 & 0.0 & 0.0 & 0.0 \\
\hline $\mathrm{Cu}$ & 19 & 2.5 & 0.0 & 2.5 & 0.0 & 0.0 & 0.0 & 0.0 & 0.0 & 0.0 \\
\hline$F$ & 61 & 8.1 & 0.29 & 6.0 & 0.5 & 0.81 & 0.5 & 0.0 & 0.0 & 0.0 \\
\hline $\mathrm{Ge}$ & 4.3 & 0.57 & 0.033 & 0.52 & 0.015 & 0.002 & 0.0 & 0.0 & 0.0 & 0.0 \\
\hline $\mathrm{Fe}$ & 14,000 & 1870.0 & 73.0 & 1730.0 & 65.0 & 2.0 & 0.0 & 0.0 & 0.0 & 0.0 \\
\hline$P h$ & 11 & 1.5 & 0.73 & 0.77 & 0.0 & 0.0 & 0.0 & 0.0 & 0.0 & 0.0 \\
\hline · LI & 33 & 4.4 & 0.0 & 4.4 & 0.0 & 0.0 & 0.0 & 0.0 & 0.0 & 0.0 \\
\hline Mg & 570 & 76.0 & 0.0 & 76.0 & 0.0 & 0.0 & 0.0 & 0.0 & 0.0 & 0.0 \\
\hline$M n$ & 48 & 6.4 & 0.60 & 5.2 & 1.1 & 0.1 & 0.0 & 0.0 & 0.0 & 0.0 \\
\hline $\mathrm{Hg}$ & 0.12 & 0.016 & 0.013 & 0.0006 & 0.0013 & 0.0006 & 0.0004 & 0.0001 & 0.0 & 0.0 \\
\hline Mo & 7.0 & 0.933 & 0.02 & 0.906 & U.U07 & 0.0 & 0.0 & 0.0 & 0.0 & 0.0 \\
\hline $\mathrm{Ni}$ & 15 & 2.0 & 0.09 & 1.9 & 0.01 & 0.0 & 0.0 & 0.0 & 0.0 & 0.0 \\
\hline$N$ & 10,400 & 1390.0 & 0.0 & 320.0 & 70.0 & 950.0 & 40.0 & 9.0 & 1.0 & 0.0 \\
\hline$K$ & 1,700 & 227.0 & 0.0 & 227.0 & 0.0 & 0.0 & 0.0 & 0.0 & 0.0 & 0.0 \\
\hline Sm & 0.74 & 0.098 & 0.0 & 0.098 & 0.0 & 0.0 & 0.0 & 0.0 & 0.0 & 0.0 \\
\hline $\mathrm{Se}$ & 13 & 1.7 & 0.24 & 1.0 & 0.1 & 0.20 & 0.16 & 0.0 & 0.0 & 0.0 \\
\hline $\mathrm{Si}$ & 20,000 & 2670.0 & 0.0 & 2670.0 & 0.0 & 0.0 & 0.0 & 0.0 & 0.0 & 0.0 \\
\hline $\mathrm{Ag}$ & 0.1 & 0.013 & 0.0042 & 0.0048 & 0.003 & 0.001 & 0.0 & 0.0 & 0.0 & 0.0 \\
\hline $\mathrm{Na}$ & 1400 & 187.0 & 0.0 & 187.0 & 0.0 & 0.0 & 0.0 & 0.0 & 0.0 & 0.0 \\
\hline$S r$ & 37 & $\Delta 9$ & $n \cap$ & 4.9 & 0.0 & 0.0 & 0.0 & 0.0 & 0.0 & 0.0 \\
\hline$s$ & 38,000 & 5100 & 1150.0 & 1040.0 & 120.0 & 200.0 & 2670.0 & 20.0 & 0.0 & 0.0 \\
\hline $\bar{T}_{p}$ & 8.1 & 1 กR & $0 \% 5$ & II.1i4 & II.Uy & U.Ub & U.U5 & $U, U$ & ư.Ũ & ن. \\
\hline $\mathrm{Sn}$ & 2.0 & 0.27 & 0.07 & 0.13 & 0.06 & 0.01 & 0.0 & 0.0 & 0.0 & 0.0 \\
\hline $\mathrm{Ti}$ & 770 & 103.0 & 0.0 & 100.0 & 3.0 & 0.0 & 0.0 & 0.0 & 0.0 & 0.0 \\
\hline$v$ & 17 & 2.3 & 0.21 & 1.9 & 0.16 & 0.03 & 0.0 & 0.0 & 0.0 & 0.0 \\
\hline Yb & 0.56 & 0.075 & 0.0027 & 0.069 & 0.003 & 0.0003 & 0.0 & 0.0 & 0.0 & 0.0 \\
\hline $\mathrm{Zn}$ & 49 & 6.5 & 0.99 & 4.8 & 0.60 & 0.11 & 0.0 & 0.0 & 0.0 & 0.0 \\
\hline $\mathrm{Zr}$ & 35 & 4.7 & 0.0 & 4.7 & 0.0 & 0.0 & 0.0 & 0.0 & 0.0 & 0.0 \\
\hline
\end{tabular}

${ }^{a}$ Pretreater losses arise from the volatilization of elements at lower temperature $\left(700^{\circ} \mathrm{K}\right)$, and are in the form of tars, oils, fines, and off-gases. All of this material is burned in the steam plant. Volatile compounds may be lost to the stack unless cleaned by scrubbing or some other method.

${ }^{b}$ Two streams are split here: The oil stream is recycled to the slurry preparation and may accumulate trace elements. The water stream contains phenols, $\mathrm{NH}_{1}(\mathrm{~F}, \mathrm{Cl})$ to be separated, and the treated water to be recycled. It is important to note that the by-products may show enrichment of some trace elements.

$\tau^{2}$ The sour gas from the acid-gas treatment unit is sent to the Claus plant. It contains mish nf the arldic compounds of $\mathrm{CO}_{2}, \mathrm{H}_{2} \mathrm{~S}, \mathrm{As}_{2} \mathrm{O}_{3}$ $\mathrm{B}_{2} \mathrm{O}_{3}$, etc., and fine particulates. Oil is separated during regeneration and is recycled. $\mathrm{CO}_{2}$ is released to the atmosphere with trace sulfur compounds. Some gaseous, acidic elements, i.e., $\mathrm{H}_{2} \mathrm{Se}$ and $\mathrm{H}_{2} \mathrm{Te}$, will most likely end up in the Claus plant sulfur product.

${ }^{d}$ Water is condensed during methanation and may carry away other trace elements. Almost total sulfur removal is accomplished during methanation by adsorption onto the catalyst particles. The product gas will be analyzed for the more volatile, toxic elements, but not for the innocuous ones.

Source: A. J. Attari, and J. P. Meninger, 1976. Initial environmental test plan for source assessment of coal gasification. EPA-600/2-76-259, Table 4, pp. 17 and 18. Research Triangle Park, N.C.: U.S. Environmental Protection Agency. 


\subsubsection{Acid-gas treatment, and sulfur recovery - description and effluents}

After the raw gas has been water-scrubbed to remove water soluble compounds such as ammonia, cyanide, and phenols and perhaps oil-scrubbed to remove oily vapors from the gas, it undergoes acid-gas scrubbing to remove sulfurous compounds and carbon dioxide from the gas stream. In the case of gasifying coal to produce a high-Btu gas, the sulfur content must be reduced to low levels to minimize poisoning of sensitive downstream methanation catalysts. Carbon dioxide must also be removed because it would dilute the product gas and compete with the carbon monoxide in the methanation reaction, resulting in higher hydrogen consumption (Glazer, Hershaft, and Shaw 1974). Table 1.16 describes the capability of each process to remove reduced sulfur compounds other than $\mathrm{H}_{2} \mathrm{~S}$.

\subsubsection{Acid-gas treatment}

The four general types of acid-gas treatment processes are:

1. physical solvent processes that dissolve an acid gas in a solvent without undergoing chemical transformation,

2. alkaline salt solution, in which $\mathrm{CO}_{2}$ and $\mathrm{H}_{2} \mathrm{~S}$ combine with $\mathrm{K}_{2} \mathrm{CO}_{3}$ (potassium carbonate) at temperatures of 80 to $120^{\circ} \mathrm{C}\left(180\right.$ to $\left.250^{\circ} \mathrm{F}\right)$,

3. amine processing, which employs amines for the complexing of $\mathrm{H}_{2} \mathrm{~S}$ or $\mathrm{CO}_{2}$ from the gas stream, and

4: indirect oxidation process, in which the hydrogen sulfide in the gas reacts selectively with some constituents in the scrubbing liquor and is removed from the gas stream.

\section{Effluents from acid-gas treatment}

In the treatment of acid gases and the subsequent recovery of sulfur, the primary point of atmospheric emission is the vent stack on the tail gas treatment unit for the sulfur recovery plant. Estimates of off-gas discharge rates for $1.4 \times 10^{6} \mathrm{~m}^{3} /$ day (STP) $\left(50 \times 10^{6} \mathrm{scfd}\right)$ demonstration plants range between 14 and 140 metric tons (15 and 150 tons) per hour. The order-of-magnitude difference in off-gas rates is due in part to the gasification process and in part to the method of acid-gas treatment. The $\mathrm{CO}_{2}$ Acceptor process, for example, produces less carbon dioxide in its product gas stream than do other gasification schemes. Carbon dioxide is removed by the dolomite acceptor.

Because the acid-gas and the final off-gas streams are composed principally of carbon dioxide (and nitrogen to a lesser extent), the off-gas discharge rate for the sulfur recovery unit in a $\mathrm{CO}_{2}$ Acceptor plant is small relative to other processes. Some acid-gas treatment systems such as Lurgi's Rectisol produce twn streams - a $\mathrm{CO}_{2}$-rich stream and an $\mathrm{H}_{2} \mathrm{~S}$-rich stream. In some designs (e.g., the Hygas design; Glazer, Hershaft, and Shaw 1974), only the $\mathrm{H}_{2} \mathrm{~S}-r i c h$ stream is sent to the sulfur recovery unit. The $\mathrm{CO}_{2}$-rich stream is sufficiently low in sulfur compounds to be vented to the atmosphere directly. Under such circumstances the off-gas rate from the sulfur recovery unit is relatively smal1. The undesirable contaminants in the off-gas are sulfur compounds $\left(\mathrm{H}_{2} \mathrm{~S}, \mathrm{COS}\right.$, and $\left.\mathrm{CS}_{2}\right)$. Manufacturers of several systems are currently claiming that the effiluent is equivalent to less than $250 \mathrm{ppm}$ of $\mathrm{SO}_{2}$. 
Table 1.16. Summary of selected acid-gas treatment and sulfur recovery processes

\begin{tabular}{|c|c|c|}
\hline $\begin{array}{l}\text { Type of pollutant or } \\
\text { product stream treatment }\end{array}$ & Contral process & Remarks \\
\hline \multirow[t]{7}{*}{ Acid-gas treatment } & Hot potassium carbonate & $\begin{array}{l}\text { An alkaline salt process that removes } \\
\mathrm{H}_{2} \mathrm{~S} \text { and } \mathrm{CO}_{2} \text { as well as } \mathrm{CS}_{2} \text { and } \mathrm{COS} \text {. } \\
\text { Sulfur compounds can be reduced to } \\
\text { about } 10 \mathrm{ppII}\end{array}$ \\
\hline & Rectisol & $\begin{array}{l}\text { A solvent-based process that removes } \\
\mathrm{CO}_{2}, \mathrm{H}_{2} \mathrm{~S} \text { (down to } 0.1 \mathrm{ppm} \text { ), and } \\
\text { the } \mathrm{COS} \text { present }\end{array}$ \\
\hline & Selexol & $\begin{array}{l}\text { A solvent-based process that can remove } \\
\mathrm{H}_{2} \mathrm{~S}, \mathrm{COS} \text {, and } \mathrm{CO}_{2}\end{array}$ \\
\hline & Sulfinol & 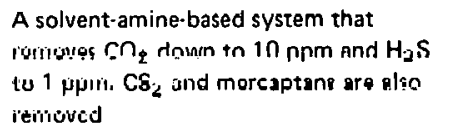 \\
\hline & MEA (monoethanolamine) & $\begin{array}{l}\text { An amine'scrubbing scheme that } \\
\text { reiriuves } \mathrm{CO}_{2} \text { arid cari ieduce sulfur } \\
\text { content to } 1 \mathrm{ppm} \text {. COS, } \mathrm{CS}_{2} \text { and } \\
\text { mercaptans are removed from the } \\
\text { feed stream hut, degrade the MEA }\end{array}$ \\
\hline & DIPA (diisopropanol amine) & $\begin{array}{l}\text { An amine system that removes } \\
\mathrm{H}_{2} \text { and } \mathrm{CO}_{2}\end{array}$ \\
\hline & $\begin{array}{l}\text { MDEA : } \\
\text { (methyldiethanolamine) }\end{array}$ & $\begin{array}{l}\text { A tertiary amine system that is partially } \\
\text { selective in removal of } \mathrm{H}_{2} \mathrm{~S}\end{array}$ \\
\hline \multirow[t]{2}{*}{ Sulfur recovery } & Claus & $\begin{array}{l}\text { Recovers elemental sulfur from } \\
\text { acid-gas streams containing as little } \\
\text { as } 2 \% \mathrm{H}_{2} \text { S. For economical use, } \\
\text { the untreated stream should contain } \\
\text { over } 15 \% \mathrm{H}_{2} \mathrm{~S} \text {. COS and } \mathrm{CS}_{2} \text { can } \\
\text { be removed by special treatment. } \\
\text { Tail gases usually require further trearment }\end{array}$ \\
\hline & stretfurd & $\begin{array}{l}\text { All inditeul usidativis piocess that is } \\
\text { HP to } 99 \% \text { efficient in recovering } \\
\text { elemenlal sulfur fiom low } \mathrm{H}_{2} \mathrm{~S} \text { eontent } \\
\text { streams. It is not effective in reducing } \\
\mathrm{COS} \text { content in the feed stream. The } \\
\text { treated stream can contain as little as } \\
1 \text { ppm } \mathrm{H}_{2} \mathrm{~S} . \mathrm{CO}_{2} \text { is not removed }\end{array}$ \\
\hline \multirow[t]{4}{*}{ Claus tall gas treatment } & Inlcinıèı átiơn & $\begin{array}{l}\text { Converts } \mathrm{H}_{2} \mathrm{~S} \text { to } \mathrm{SO}_{2} \text {, which may be } \\
\text { further treated }\end{array}$ \\
\hline & $\begin{array}{c}\text { Beavon } \\
\text { : }\end{array}$ & 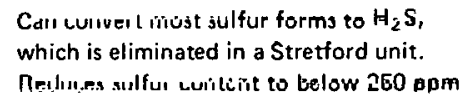 \\
\hline & Sciot & $\begin{array}{l}\text { Sirmilar tu Bedvor prucess but ieciovers } \\
\mathrm{H}_{2} \mathrm{~S} \text { in DIPA for recycle to a Claus unit }\end{array}$ \\
\hline & Wellman-Lord & $\begin{array}{l}\text { A sodium-based scrubbing process; } \\
\text { that caii l'emove } \mathrm{SU}_{2} \text { down tó } \\
\text { less than } 250 \mathrm{ppm} \text {. Can also be used } \\
\text { for Claus tail gas treatment following } \\
\text { incinteration }\end{array}$ \\
\hline
\end{tabular}

Source: F. Glazer, A. Hershaft, and R. Shaw. 1974. Modified from Table $1-1$ in Emissions from processes producing c/ean fue/s. EPA=450/3-75-028. Bethesda, Md.: Buoz-Allen and Hamilton, Ine. 


\subsubsection{Sulfur recovery}

The hydrogen sulfide stream from the acid-gas treatment processes is typically disposed of in either a Claus or Stretford sulfur recovery plant. General rules governing the selection of sulfur recovery plants are (USEPA 1976):

1. Stretford plant.s remove only $\mathrm{H}_{2} \mathrm{~S}$;

2. Claus plants remove $\mathrm{H}_{2} \mathrm{~S}, \mathrm{SO}_{2}$, and (to a lesser degree) $\mathrm{COS}$;

3. Claus plants are not generally used on acid-gas streams containing less than 15 vol \% of $\mathrm{H}_{2} \mathrm{~S}$;

4: Stretford plants are used on all acid-gas streams containing less than 15 vol $\%$ of $\mathrm{H}_{2} \mathrm{~S}$ unless significant amounts of other oxidants (such as $\mathrm{SO}_{2}$ or $\mathrm{HCN}$ ) are also present; and

5. tail-gas treating currently favors oxidation-based systems because of the high $\mathrm{CO}_{2}$ partial pressures in tail gases.

\section{Claus process}

Two of the basic forms of the Claus process are (1) the partial combustion process and (2) the split stream process. The partial combustion process is used for gas streams of high ( $250 \%$ ) $\mathrm{H}_{2} \mathrm{~S}$ content, and the split stream process is used for gas streams with less $\mathrm{H}_{2} \mathrm{~S}$ (Dravo 1976).

In the partial combustion process, the entire acid-gas stream is mixed with a stoichiometric amount of air to burn one-third of the $\mathrm{H}_{2} \mathrm{~S}$ to $\mathrm{SO}_{2}$. In the split stream process, one-third of the acid gas is fed to the reaction burner, and all of the contained $\mathrm{H}_{2} \mathrm{~S}$ is burned to $\mathrm{SO}_{2}$ with stoichiometric air. The split stream process can effectively handle gases with $\mathrm{H}_{2} \mathrm{~S}$ content as low as about 20\%. A combination of partial combustion and split stream processes is also being considered for processing acid-gas streams containing $\mathrm{H}_{2} \mathrm{~S}$ in concentrations of 35 to $50 \%$ (Dravo 1976).

\section{Stretford process}

The purpose of the Stretford process is to remove $\mathrm{H}_{2} \mathrm{~S}$ from gas streams and to recover the sulfur in elemental form. Theoretically, if $\mathrm{H}_{2} \mathrm{~S}$ were the only acid gas present and no side reactions occurred, the Stretford process could operate without producing any waste chemical streams that require disposal or special treatment. However, gas streams from coal processing generally contain HCN and small amounts of other sulfur and nitrogen compounds. These compounds and HCN react in an irreversible manner with the Stretford chemicals (Dravo 1976).

\section{Effluents from sulfur recovery}

An important consideration in sulfur recovery is the ability of the sulfur market to accommodate the large quantities of by-product sulfur that are produced from the combustion and/or conversion of coal projected for the future. For a single $1.4 \times 10^{6} \mathrm{~m}^{3} /$ day (STP) $\left(50 \times 10^{6} \mathrm{scfd}\right) \mathrm{coa}$ to-SNF (synthetic natural gas) demonstration plant, 27 to 270 metric tons ( 30 to 300 tons) of 99.5\% pure sulfur arc produced daily. If this by product cannot find a market, it presents a significant but not insolvable waste disposal problem. 
Other solid effluent streams produced in this area of the plant are the infrequent replacement of iron oxide or buaxite catalyst from the Claus unit (every 5 to 10 years); Stretford chemical purge (containing sodium thiocyanate, sodium thiosulfate, sodium sulfite, sodium citrate, and vanadium salts), and chemical purges from tail gas treatment units.

\subsubsection{Tail gas cleanup}

Claus technology units themselves must have tail gas treatment units to reduce sulfur emission. Unrecovered sulfur in Claus plant tail gas includes primarily hydrogen sulfide, elemental sulfur, sulfur dioxide, and lesser amounts of other sulfur compounds (carbonyl sulfide and carbon disulfide). Stretford units (using Claus technology) are not capable of recovering sulfur from carbonyl sulfide or carbon disulfide. Without tail gas treatment, these compounds would be vented to the atmosphere along with fugitive hydrogen sulfide.

Options for Claus tail gas disposal include venting, incineration (which converts sulfur compounds to sulfur dioxide), or cleanup. Incineration of the tail gas is the method most often used in U.S. Claus plants treating the tail gas.

The two types of Claus plant tail gas cleanup processes are low-temperature Claus and conversionconcentration. The first type promotes sulfur formation by operating a catalytic system at a temperature favoring thermodynamic equilibrium; Topsoe-SNPA and Sulfreen are two such processes. The second type converts sulfur compounds to hydrogen sulfide or sulfur dioxide, which is then converted to elemental sulfur, sulfuric acid, or gypsum. The SCOT, Aquaclaus, Chiyoda Thoroughbred, Cleanair, IFP, Beavon, and Wellman-Lord processes are of the second types (Braunstein, Copenhlaver, and Pfuderer 1976).

A summary of selected acid-gas treatment and sulfur recovery processes is given in Table 1.16.

\section{2 .0 sleall dall püwei production}

Coal gasification plants are designed to be energy self-sufficient. Utility plants, fired by some combination of raw coal, carbonaceous residue, and/or product gas, provide steam for hydrogen production, process heating, and electricity generation. Estimates for electricity requirements for commercial-size synthetic natural gas (SNG) plants $\left(7.1 \times 10^{6} \mathrm{~m}^{3} /\right.$ day; $250 \times 10^{6}$ scfd) have generally ranged between 40 and 60 MWe; high-pressure steam requirements, between $1.1 \times 10^{6}$ and $1.9 \times 10^{6} \mathrm{~kg}(2.5$ and 4.2 million pounds) per hour (Glázer, Hershaft, and Shaw 1974). At several locations throughout the process, high-temperature cooling is necessary, for example, upstream of gas purification, during or after exothermic $\mathrm{CO}$ shift and methanation, regenerator

off-gas for the $\mathrm{CO}_{2}$ Acceptor process, and upstream of sour gas scrubbing. Steall yeneration from waste-heat recovery is used whenever possible. Waste-heat recovery can be very substantial; for the case of the $\mathrm{CO}_{2}$ Acceptor process, all steam and electric needs may be satisfied in this manner. Onsite utility plants take advantage of higher efficiency power production schemes, using combined cycle generators and economizers.

\subsubsection{Effluents from steam and power production}

The primary air pollutants from power plants are sulfur dioxide $\left(\mathrm{SO}_{2}\right)$, sulfur trioxide $\left(\mathrm{SO}_{3}\right)$, nitrogen oxide $\left(\mathrm{NO}_{\mathrm{x}}\right), \mathrm{fly}$ ash, and various trace metals that may vaporize and become gaseous 
pollutants - for example, mercury, beryliium, arsenic compounds, or fluorides. Other trace metals such as nickel, zinc, cadmium, and molybdenum exist in fly ash particles. If gas is the fuel for combustion, only nitrogen oxides are expected as a major pollutant. Table 1.17 shows typical air emissions in pounds per million Btu heat input for coal- and gas-fired boilers, but a conservative approach has been taken here (Hittman 1974). Sulfur dioxide, nitrogen dioxide, and particulate emission rates have been estimated by assuming that the plant emits the largest legal quantity of these effluents. This is a worst-case assumption based on compliance with the EPA New Source Performance Standards (NSPS) for large stationary, direct-combustion, coalfired power plants. Federal standards for coal conversion facilities have not yet been promulgated (Table 1.18).

Table 1.17. Air emissions (with pollution control) for a 1000-MW power plant ${ }^{\circ}$

Pounds per million Btu heat input

\begin{tabular}{|c|c|c|c|c|}
\hline & $\mathrm{SO}_{\mathrm{x}}$ & $\mathrm{NO}_{\mathbf{x}}$ & Particulates & \\
\hline \multicolumn{4}{|c|}{ Conventional coal-fired plant } & . \\
\hline Appalachia & 0.27 & 0.30 & 0.002 & \\
\hline Eastern Interior & 0.62 & 0.30 & 0.003 & \\
\hline Powder River & 0.12 & 0.30 & 0.002 & \\
\hline Fort Union & 0.18 & 0.30 & 0.003 & \\
\hline Four Corners & 0.14 & 0.30 & 0.004 & - \\
\hline \multicolumn{5}{|c|}{ Combined cycle low-Btu gas-fired plant } \\
\hline Appalachia & $0.13^{b}$ & 0.05 & $\mathrm{Nil}$ & \\
\hline Eastern Interior & $0.30^{b}$ & 0.05 & $\mathrm{Nil}$ & \\
\hline Powder River & $0.06^{b}$ & 0.05 & $\mathrm{Nil}$ & \\
\hline Fort Union & $0.09^{b}$ & 0.05 & $\mathrm{Nil}$ & \\
\hline Four Corners & $0.07^{b}$ & 0.05 & $\mathrm{Nil}$ & \\
\hline \multicolumn{5}{|c|}{ EPA new source performance standards } \\
\hline Fur tual & 1.2 & 07 & 0.1 & \\
\hline For gas & & 0.2 & 0.1 & \\
\hline
\end{tabular}

a $1000 \mathrm{MW}$ output is approximately equivalent to $8750 \times 10^{6}$ Btu per hour of heat input $139 \%$ conversion efficiencyl.

${ }^{b}$ From Claus Plant desulfurizing fuel gas.

Source: Hittman Associates, Inc. 1974. Baseline data environmental assessment of a large coal conversion complex. Vols. I and II. ERDA contract no. 14-32-0001-1508. Interim report no. 1. Washington, D.C.

Table 1.18. Emission limitations for fossil-fuel-fired steam boilers Pounds per million Btu heat input

EPA New Source Performance Standards.

\begin{tabular}{ccccc}
\hline & Gaseous fuel & Liquid fuel & Solid fuel & Comments \\
\hline Partlculaie & 0.1 & 0.1 & 0.1 & 2n\% nnarity \\
$\mathrm{SO}_{2}$ & & 0.8 & 1.2 & 2 -tir average \\
$\mathrm{NO}_{2}$ & 0.2 & 0.3 & 0.7 & \\
\hline
\end{tabular}

Sourcc: Fed Regist. 36(247); 40 CFR Part 60, Dec. 23, 1971. 
A11 new coal- and gas-fired power plants are subject to the NSPS for $\mathrm{SO}_{2}$, $\mathrm{NO}_{2}$, and particulate emissions. The NSPS are minimum Federal standards and may be superseded by more stringent state standards to achieve compliance with desired local ambient pollutant concentrations. They may also be superseded by new Federal standards for coal conversion facilities. New Mexico limits emissions on gas-fired boilers to $0.07 \mathrm{~kg}(0.16 \mathrm{lb})$ of $\mathrm{SO}_{2}, 0.01 \mathrm{~kg}(0.03 \mathrm{lb})$ of particulates, and $0.09 \mathrm{~kg}(0.20 \mathrm{lb})$ of $\mathrm{NO}_{2}$ per million Btus of heat input (LHV basis).

Using a scale-down factor of 0.3 , the quantities of effluent stream 1 isted below are derived by reducing the estimates for commercial-size plants to those anticipated from demonstration plants. Although many aspects of a commercial plant $\left(7.1 \times 10^{6} \mathrm{~m}^{3} /\right.$ day; $250 \times 10^{6}$ scfd $)$ may be scaled down by a 0.2 factor for estimating demonstration plant $\left(1.4 \times 10^{6} \mathrm{~m}^{3} /\right.$ day; $\left.50 \times 10^{6} \mathrm{scfd}\right)$ parameters, it may be inaccurate to scale down the power and steam consumption linearly. An added $50 \%$ (above a linear scale-down) has been assumed to account for lower pump and compressor efficiency in small sizes, more overdesign in demonstration plants, and the fact that energy consumption for the motor drives on many pieces of equipment does not increase linearly as equipment capacity increases. Quantities for the Hygas process were originally calculated by Jahnig (1975b); for Synthane by Kalfadelis and Magee (1974); and for Bi-Gas by Jahmig (1975a). Emission rates of solid and gaseous residuals have been estimated and are summarized in Table 1.19 .

Table 1.19. Summary of power plant parameters for synthetic natural gas demonstration plant $\left(1.4 \times 10^{6} \mathrm{~m}^{3} /\right.$ day; $50 \times 10^{6}$ scfd $)$

\begin{tabular}{|c|c|c|c|c|c|c|c|c|c|}
\hline \multirow[b]{2}{*}{ Process } & \multirow[b]{2}{*}{ Fuel } & \multirow[b]{2}{*}{ Feed rate } & \multirow{2}{*}{$\begin{array}{c}\text { Heat input } \\
\left(\text { Btu/hr } \times 10^{6}\right)\end{array}$} & \multicolumn{2}{|c|}{ Solid residuals ${ }^{b}$} & \multicolumn{3}{|c|}{ Air emission (controlled) $)^{b, c}$} & \multirow[b]{2}{*}{ Particulates $^{h}$} \\
\hline & & & & Ash rate & $F G D^{d}$ sludge rate & Flue gas rate & $\mathrm{SO}_{2}$ & $\mathrm{NO}_{2}$ & \\
\hline Synthane & $\begin{array}{l}\text { Gasifier } \\
\text { char }\end{array}$ & $1656^{b}$ & 1500 & 400 & $57-76$ & 17,790 & 21.6 & 12.6 & 1.80 \\
\hline Bi-Gas & Coal & $820^{b}$ & 843 & 55 & 203 & 10,050 & 21.1 & 7.08 & 1.01 \\
\hline Hvaas & Filel gas & $160^{e}$ & 1030 & 0 & 0 & 19,104 & $0.74^{d}$ & 2.50 & INII \\
\hline
\end{tabular}

\footnotetext{
${ }^{a}$ F́lue gas desulfurization.

${ }^{b}$ Tons per day.

${ }^{c}$ Control to the extent necessary to meet the EPA New Source Performance Standards.

$\checkmark$ From Claus Plant desulfurizing fuel gas from Illinois No. 6 coal.

${ }^{e}$ Standard cubic feet per day $\times 10^{6}$.
}

The primary liquid effluent is boiler blowdown, which may be recycled for use as cooling tower makeup water (Sect. 1.2.7). Water is also contained in solid residual sludges from ash or slag quenching and flue gas desulfurization (FGD). Therefore, no water leaves the power plant directly, but wet sludges require disposal externally.

The power plant in the Hygas process is fired by fuel gas $\left(5.6 \times 10^{6} \mathrm{~J} / \mathrm{hr} ; 151 \mathrm{Btu} / \mathrm{scf}\right)$ supplied by an auxiliary IGT U-Gas system. Because of the clean nature of this fuel, no ash, slag, nor FGD sludge is produced. The estimated heat input for a demonstration gasification plant $\left(1.4 \times 10^{6} \mathrm{~m}^{3} /\right.$ day; $\left.50 \times 10^{6} \mathrm{scfd} \mathrm{SNG}\right)$ is $1.096 \times 10^{9} \mathrm{~J} / \mathrm{hr}\left(1.039 \times 10^{9} \mathrm{Btu} / \mathrm{hr}\right)$, producing 11,940 metric tons $\left(13,164^{\circ}\right.$ tons $)$ per day of flue gas.

The power plant for this Bi-Gas demonstration plant is fired by approximately 740 metric tons (820 tons) per day ( $889 \times 10^{6} \mathrm{~J} / \mathrm{hr} ; 843 \times 10^{6}$ Btu heat input per hour) of West Kentucky No. 11 
coal. The plant would produce an estimated 50 metric tons (55 tons) per day of slag, $184^{\circ} \mathrm{metric}$ tons (203 tons) per day of sulfated limestone from FGD, and 9115 metric tons (10,050 tons) per day of flue gas. Tables 1.20 and 1.21 give typical analyses of FGD sludges.

The power plant in a demonstration Synthane gasification complex is fired by gasification char. Process developers have found it optimal to balance overall process energy requirements by incomplete coal gasification, producing a relatively high-carbon-content gasifier char thought to be suitable for firing in a conventional coal-fired furnace to fullfill process utility requirements. Such a power plant would be charged with about 63 metric tons (69 tons) per hour of char $\left(1583 \times 10^{6} \mathrm{~J} ; 1500 \times 10^{6} \mathrm{Btu}\right.$ of heat input per hour). Estimated ash production is 360 metric tons (400 tons) per day. Flue gas desulfurization generates between 52 and 69 metric tons (57 and 76 tons) of sulfated lime per day (see Tables 1.20 and 1.21 for analyses). Both solid residuals require external disposal. Flue gas is discharged from the stack at a rate of 15,140 metric tons $(17,790$ tons $)$ per day.

Current technology exists for 80 to $95 \%$ sulfur dioxide reduction through scrubbing systems using lime/limestone, magnesium oxide, or the Bureau of Mines citrate system. The quantity of sulfur dioxide leaving the stack is a function of the sulfur concentration in the coal and the means of abatement used, if any.

If a wet 1 ime/limestone scrubber is used to remove $\mathrm{SO}_{2}$ from the flue gas, the dry weight of the solid sludge could be four times the weight of the sulfur being scrubbed. Because the actual sludge is wet (water to calcium sulfate/sulfite ratio of unity), the total solid waste problem can be eight times the original weight of sulfur scrubbed (Miller 1974).

If an MgO scrubber is used, a daily sludge production similar to the lime/limestone system would be obtained. In this case the sludge would be regenerated, yielding a commercially salable sulfuric acid by-product and regenerated MgO for reuse. The only solid waste disposal problem for MgO scrubbing would be the purge of spent MgO to maintain activity in the scrubber.

A citrate scrubber yields elemental sulfur as a final product. This sulfur can be stored for future sale but may represent a solid waste problem if the market for by-product sulfur does not exist, albeit a much more minor problemi than FGo sludge disposal.

When a lime/limestone or MgO scrubber is used, the final sludge product contains calcium or magnesium sulfite and sulfate as well as entrained fly ash. The sludge is dewatered in successive stages, with water from the first stage being recycled. Water bleedoff from the last stage may contain as much as 15\% dissolved solids (calcium, magnesium, sodium, potassium, sulfate, sulfite, chloride, and bicarbonate ions). The quantity of such wastewater is dependent on the sulfur and ash content of the coal, the power plant capacity, and the efficiency of the electrostatic precipitator upstream of the suifur scrubber. ine treatment for this wastewater stream has not been specified but should not constitute a problem.

The particulate emission rate is a function of the percentage of ash in the coal, the method of combustion, the nature of the coal, and the means of abatement used. Electrostatic precipitators and wet scrubbers are currently capable of reducing particulate loadings with as high as $99.9 \%$ effictency; usual operating ranges are 98 to $99 \%$. 
Table 1.20. Chemical analysis of lime process sludges on dry solid basis

\begin{tabular}{lcccccc}
\hline \multirow{2}{*}{ Component } & \multicolumn{7}{c}{ Sample $^{a}(\%)$} \\
\cline { 2 - 7 } & $\mathrm{A}$ & $\mathrm{B}$ & $\mathrm{C}$ & $\mathrm{D}$ & $\mathrm{E}$ & $\mathrm{F}$ \\
\hline $\mathrm{CaO}$ & 18.1 & 43.2 & 40.7 & 43.4 & 25.6 & 43.8 \\
$\mathrm{MgO}$ & 2.4 & 0.2 & $b$ & 0.001 & 1.2 & $b$ \\
$\mathrm{Total}$ sulfur & 7.2 & 18.9 & 18.1 & 20.0 & 10.9 & 22.9 \\
$\mathrm{SO}_{2}$ & 12.1 & 33.0 & 32.9 & 29.2 & 10.8 & 45.8 \\
$\mathrm{SO}_{3}$ & 2.9 & 5.9 & 4.8 & 13.6 & 13.6 & $c$ \\
$\mathrm{CO}_{2}$ & 3.2 & 6.7 & 2.3 & 7.1 & 2.2 & 1.0 \\
$\mathrm{Free}_{2}$ carbon & $b$ & $b$ & $b$ & 2.8 & 0.14 & $c$ \\
$\mathrm{SiO}_{2}$ & 31.6 & 4.9 & 3.76 & 0.58 & 21.3 & 0.18 \\
$\mathrm{Al}_{2} \mathrm{O}_{3}$ & 18.3 & 3.4 & 1.71 & 1.21 & 11.3 & 0.39 \\
$\mathrm{Fe}_{2} \mathrm{O}_{3}$ & 4.3 & 0.6 & 0.86 & 0.39 & 5.6 & 0.29 \\
$\mathrm{iva}_{2} \mathrm{O}$ & $b$ & $b$ & $b$ & $0.3 \mathrm{~b}$ & 0.16 & 0.04 \\
$\mathrm{~K}_{2} \mathrm{O}$ & $b$ & $b$ & $b$ & 0.03 & 0.98 & 0.01 \\
$\mathrm{Free}$ & 0.3 & 1.3 & 7.9 & 0.06 & 0.06 & $c$ \\
\hline
\end{tabular}

${ }^{a}$ A - power station prior to fly ash collections; B - power station after fly ash collection; C - Chemico using carbide lime; D - power plant using proprietary scrubbing: E - wet limestone pilot plant scrubber; F - molybdenum sulfide pilot plant scrubbing effluent.

b Not determined.

${ }^{\circ}$ Not detected.

Source: H. M. Braunstein, E. D. Copenhaver, and H. A. Pfuderer. 1976. Tahle 4.7 in Environmental, health. and control aspects of coal conversion: an information overview. (Draft), vol. 1. Oak Ridge, Tenn.: Oak Ridge National Laboratory.

Table 1.21. Chemical analysis of flue gas desulfurization sludges

\begin{tabular}{|c|c|c|}
\hline Parameter & Sludge & Elutriate/leachate \\
\hline Total organic carbon (elutriate only) & & $x$ \\
\hline Total solids & $x$ & \\
\hline Dissolved solids & & $x$ \\
\hline Suspearded sulles (leachate only) & & $\dot{\lambda}$ \\
\hline $\mathrm{nH}$ & & $x$ \\
\hline Hardness (elutriate only) & & $x$ \\
\hline Conductivity & & $x$ \\
\hline Arsenic & $x$ & $x$ \\
\hline Beryllium & $x$ & $x$ \\
\hline Cadium & $x$ & $x$ \\
\hline Chromiım & $x$ & $\mathrm{Y}$ \\
\hline Sepper & $x$ & $x$ \\
\hline Load & $x$ & $x$ \\
\hline Magnesium & $x$ & $x$ \\
\hline Manganese & $x$ & $x$ \\
\hline Mercury & $\mathrm{x}$ & $\mathrm{x}$ \\
\hline Nickel & $x$ & $x$ \\
\hline Şplẹniıım & $x$ & $x$ \\
\hline Zinc & $\mathrm{x}$ & $x$ \\
\hline Chloride & & $x$ \\
\hline Cyanide & $x$ & $x$ \\
\hline $\begin{array}{l}\text { Fluoride } \\
\text { (calcium fluoride sludge only) }\end{array}$ & & \\
\hline Nitrate & $x$ & $x$ \\
\hline Nitrite & $x$ & $x$ \\
\hline Sulfăte & $x$ & $x$ \\
\hline Sulfite & $x$ & $x$ \\
\hline
\end{tabular}

Source: H. M. Braunstein, E. D. Copenhaver, and H. A. Pfuderer. 1976. Table 4.8 in Environmental, health, and control aspects of coal conversion: an information overview. (Draft), vol. 1. Oak Ridge, Tenn.: Oak Ridge National Laboratory. 


\subsubsection{Disposition of trace elements in coal-fired boilers}

In power plants the elements entering the boiler in the coal stream are partitioned between a bottom ash (or slag) stream and a flue gas stream containing suspended fly ash and the vapors of volatile elements or compounds. A further.partitioning of the flue gas stream takes place in the particulate emission control devices (electrostatic precipitators or scrubbers) that efficiently remove larger fly ash particles but are less efficient for vapors and finer particles. Ash from the boiler and ash removed by the precipitators are flushed with water to ash ponds, in which elements may be leached from the ash and enter the aquatic environment in runoff leakage through the pond floor. Small particles and vapors are discharged to the atmosphere and enter the terrestrial and aquatic environments by wet or dry deposition (Klein et al. 1975).

Table 1.22 gives the element flows for the Allen plant. Serious negative imbalances occur for bromine and chlorine; serious positive imbalances are present for chromium and vanadium. Perhaps some excess of these elements in the fly ash is due to corrosion of the boiler tubes. Very little of the arsenic occurs in the vapor phase. Thus the imbalance is probabiy caused by sampling or analytical difficulties. Except for these five elements, no bias in the mass balances was observed, and the standard deviation from balance was 15\% (Klein et al. 1975). Concentration of the trace elements in the feed coal, slag, and inlet and outlet fly ash streams are listed in Table 1.23 along with concentration ratios between slag and coal, inlet fly ash and slag, and outlet vs inlet fly ash. These concentration ratios reflect element partitioning. Klein et al. (1975) observed three general classes of partitioning behavior.

Class I consisted of the elements:

$\mathrm{Al}, \mathrm{Ba}, \mathrm{Ca}, \mathrm{Ce}, \mathrm{Co}, \mathrm{Eu}, \mathrm{Fe}, \mathrm{Hf}, \mathrm{K}, \mathrm{La}, \mathrm{Mg}, \mathrm{Mn}, \mathrm{Rb}, \mathrm{Sc}, \mathrm{Si}, \mathrm{Sr}, \mathrm{Sm}, \mathrm{Ta}$, Th, and Ti. For these elements the concentration ratio of slag to coal was greater than or equal to 6.6 , which indicated that the elemenls were readily incorporated into the slag. These elements were partitioned about equally between the inlet fly ash and slag (concentration ratio equal to 1.2 , standard deviation 0.3 ) but showed no apparent tendency to concentrate on outlet fly ash (outlet to inlet fly ash concentrations equal to 1.3 , standard deviation 0.5 ).

C.1ass II consisted of the elements:

As, $\mathrm{Cd}, \mathrm{Cu}, \mathrm{Ga}, \mathrm{Pb}, \mathrm{Sb}, \mathrm{Se}$, and $\mathrm{Zn}$. These elements are poorly incorporated into the slag, as evidenced by the ratio of concentrations between slag and coal equal to or less than 3.6. These elements concentrated in the inlet fly ash relative to the slag (concentration ratio equal to or greater than 6) and in the outlet fly ash relative to the inlet fly ash (concentration ratio equal to or greater than 3.5 ).

C.lass III consisted of the elements:

$\mathrm{Hg}, \mathrm{Cl}$, and $\mathrm{Br}$. These elements essentially remained only in the gaseous phase.

The remaining elements $(\mathrm{Cr}, \mathrm{Cs}, \mathrm{Na}, \mathrm{Ni}, \mathrm{U}$, and $\mathrm{V})$ do not clearly fall into one of these three observed categories based on data by Klein et al. (1975) but fall intermediate between Classes I and II. 
Table 1.22. Trace element flows through a coal-fired power plant

\begin{tabular}{|c|c|c|c|c|c|c|c|}
\hline \multirow{2}{*}{$\frac{\text { Run }}{8 / 73}$} & \multirow{2}{*}{$\frac{\text { Coal }(\mathrm{g} / \mathrm{min})}{1.47 \times 10^{6}}$} & \multirow{2}{*}{$\begin{array}{l}\text { Slag }(\mathrm{g} / \mathrm{min}) \\
8.43 \times 10^{4}\end{array}$} & \multirow{2}{*}{\multicolumn{2}{|c|}{$\frac{\text { Inlet fly ash }(\mathrm{g} / \mathrm{min})}{7.39 \times 10^{4}}$}} & \multicolumn{2}{|c|}{ Outlet fly ash $(\mathrm{g} / \mathrm{min})$} & \multirow{2}{*}{$\frac{\text { Flue gas }(\mathrm{sct} / \mathrm{min})}{6.21 \times 10^{5}}$} \\
\hline & & & & & & 370 & \\
\hline \multirow[b]{2}{*}{ Element } & \multirow{2}{*}{$\begin{array}{c}\text { Coal } \\
(g / \mathrm{min})\end{array}$} & \multirow{2}{*}{$\begin{array}{c}\text { Slag } \\
(g / \mathrm{min})\end{array}$} & \multirow{2}{*}{$\begin{array}{l}\text { Inlet fly ash } \\
(\mathrm{g} / \mathrm{min})\end{array}$} & \multirow{2}{*}{$\begin{array}{l}\text { Inlet gas } \\
(\mathrm{g} / \mathrm{min})\end{array}$} & \multirow{2}{*}{$\begin{array}{c}\text { Imbalance } \\
(\%)\end{array}$} & \multicolumn{2}{|c|}{ Atmospheric discharge } \\
\hline & & & & & & $(g / \mathrm{min})$ & (Ib/ton of coal fired) \\
\hline Al & 15,340 & 8,620 & 67.20 & & 0 & 30 & $4 \times 10^{-2}$ \\
\hline As & 6.5 & 1.5 & 8.1 & $<0.1$ & +48 & 0.2 & $3 \times 10^{-4}$ \\
\hline $\mathrm{Ba}$ & 96 & 42 & 55 & & +1 & 0.3 & $4 \times 10^{-4}$ \\
\hline $\mathrm{Br}$ & 5.4 & 0.2 & 0.3 & & -90 & $\approx 6$ & $8 \times 10^{-3}$ \\
\hline Go & 6,380 & 3,830 & 2,360 & & $\cdots 2$ & 10 & $1 \times 10^{-2}$ \\
\hline $\mathrm{Cd}$ & 0.69 & 0.09 & 0.59 & $<0.05$ & -1 & 0.02 & $3 \times 10^{-5}$ \\
\hline $\mathrm{Ce}$ & 12.1 & 7.1 & 6.2 & & +10 & 0.04 & $5 \times 10^{-5}$ \\
\hline r. & $1,34 n$ & 8 & 15 & & -88 & $\approx 1300$ & 2 \\
\hline Co & 4.3 & 1.8 & 2.9 & & +9 & 0.02 & $3 \times 10^{-5}$ \\
\hline $\mathrm{Gr}$ & 26 & 13 & 22 & & +33 & 0.3 & $4 \times 10^{-4}$ \\
\hline Cs & 1.6 & 0.6 & 1.0 & . & 0 & 0.01 & $1 \times 10^{-5}$ \\
\hline $\mathrm{Cu}$ & 12.2 & 1.7 & 10.3 & & -2 & & \\
\hline Eu & 0.15 & 0.09 & 0.09 & & +20 & 0.0005 & $7 \times 10^{-7}$ \\
\hline $\mathrm{Fe}$ & 15,950 & 9,440 & 8,940 & & +16 & 60 & $8 \times 10^{-2}$ \\
\hline Ga & 6.6 & 0.4 & 6.0 & & -3 & & \\
\hline $\mathrm{Hf}$ & 0.59 & 0.39 & 0.30 & & +17 & 0.002 & $3 \times 10^{-6}$ \\
\hline $\mathrm{Hg}$ & 0.18 & 0.002 & 0.004 & 0.17 & 0 & $0.1^{a}$ & $1 \times 10^{-4}$ \\
\hline$K$ & 2,260 & 1,330 & 1,480 & & +24 & 9 & $1 \times 10^{-2}$ \\
\hline La & 5.6 & 3.5 & 3.0 & & +16 & & $3 \times 10^{-3}$ \\
\hline $\mathrm{Mg}$ & 1,780 & 1,040 & 780 & & +2 & 0.02 & \\
\hline$M n$ & 49.7 & 24.9 & 22.0 & & -6 & 0.02 & $3 \times 10^{-4}$ \\
\hline $\mathrm{Na}$ & 1,020 & 420 & 750 & & +15 & 4 & $5 \times 10^{-3}$ \\
\hline $\mathrm{Ni}$ & 23 & 7 & 16 & & 0 & & \\
\hline $\mathrm{Pb}$ & 7.2 & 0.5 & 6.9 & $<0.1$ & -11 & 0.2 & $3 \times 10^{-4}$ \\
\hline $\mathrm{Rb}$ & 22.8 & 8.6 & 11.5 & & -12 & 0.07 & $1 \times 10^{-4}$ \\
\hline SL & 0.74 & 0.05 & 0.89 & $<0.1$ & +27 & 0.2 & $3 \times 10^{1}$ \\
\hline Sc & 3.2 & 1.8 & 1.9 & & +16 & 0.01 & $1 \times 10^{-5}$ \\
\hline $\mathrm{Se}$ & 3.2 & 0.0 & 1.8 & 0.53 & -22 & 0.4 & $5 \times 10^{-4}$ \\
\hline $\mathrm{Si}$ & 33,960 & 19,300 & 14,480 & & -1 & & \\
\hline $\mathrm{Sm}$ & 1.47 & 0.69 & 0.78 & & 0 & 0.003 & $4 \times 10^{-6}$ \\
\hline Sr & 34 & 14 & 18 & & -6 & & \\
\hline $\mathrm{Ta}$ & 0.16 & 0.08 & 0.10 & & +12 & 0.0007 & $1 \times 10^{-6}$ \\
\hline Th & 3.1 & 1.3 & 1.5 & & -10 & 0.01 & $1 \times 10^{-5}$ \\
\hline $\mathbf{T i}$ & 740 & 340 & 440 & & +5 & 4 & $5 \times 10^{-3}$ \\
\hline$u$ & 3.20 & 1.26 & 2.22 & & +8 & & \\
\hline v & 41.9 & 21.9 & 32.5 & & +30 & 0.4 & $5 \times 10^{-4}$ \\
\hline$Z_{n}$ & 68 & 8.4 & 55 & $<1.0$ & -7 & 2 & $3 \times 10^{-3}$ \\
\hline
\end{tabular}

${ }^{a}$ Gas only.

Source: D. H. Klein et al. 1975. Modified from Tables I and III in Pathways of 37 trace elements through coal-fired power plants. Environ. Sci. Tech. 9(10): 973-9. 
Table 1.23. Concentrations and concentration ratios

\begin{tabular}{|c|c|c|c|c|c|c|c|}
\hline & \multicolumn{4}{|c|}{ Element concentration ${ }^{2}(\mathrm{ppm})$} & \multicolumn{3}{|c|}{ Consentration ratins } \\
\hline & Coal & Slag & Inlet fly ash & Outlet fly ash & Slag/coal & $\begin{array}{l}\text { Inlet fly } \\
\text { ash/slag }\end{array}$ & $\begin{array}{l}\text { Outlet fly ash/ } \\
\text { inlet fly ash }\end{array}$ \\
\hline Al & 10,440 & 102,300 & 90,900 & 76,000 & 9.3 & 0.9 & 0.8 \\
\hline As & 4.45 & 18 & 110 & 440 & 3.6 & 6.1 & 4.0 \\
\hline $\mathrm{Ba}$ & 65 & 500 & 465 & 750 & 7.7 & 0.9 & 1.6 \\
\hline $\mathrm{Br}$ & 3.7 & 2 & $\sim 4$ & & 0.5 & 2.0 & \\
\hline $\mathrm{Ca}$ & 4,340 & 46,000 & 25,200 & 32,000 & 10.6 & 0.5 & 1.3 \\
\hline Cd & 0.47 & 1.1 & 8.0 & 51 & 2.3 & 7.3 & 6.4 \\
\hline $\mathrm{Ce}$ & 8.2 & 84 & 84 & 120 & 10.2 & 1.0 & 1.4 \\
\hline $\mathrm{Cl}$ & 914 & $\leqslant 100$ & $\leqslant 200$ & & $\leqslant 0.1$ & $\approx 1$ & \\
\hline Co & 2.9 & 20.8 & 39 & 65 & 7.2 & 1.9 & 1.7 \\
\hline $\mathrm{Cr}$ & 18 & 152 & 300 & 900 & 8.4 & 2.0 & 3.0 \\
\hline Cs & 1.1 & 7.7 & 13 & 27 & 7.0 & 1.7 & 2.1 \\
\hline $\mathrm{Cu}$ & 8.3 & 20 & 140 & & 2.4 & 7.0 & \\
\hline Eu & 0.1 & 1.1 & 1.3 & 1.3 & 11.0 & 1.2 & 1.0 \\
\hline $\mathrm{Fe}$ & 10,850 & 112,000 & 121,000 & 150,000 & 10.3 & 1.1 & 1.2 \\
\hline $\mathrm{Ga}$ & 4.5 & 5 & 81 & & 1.1 & 16.2 & \\
\hline$H f$ & 0.4 & 4.6 & 4.1 & 5.0 & 11.5 & 0.9 & 1.2 \\
\hline $\mathrm{Hg}$ & 0.122 & 0.028 & 0.050 & & 0.2 & 1.8 & \\
\hline$k$ & 1,540 & 15,800 & 20,000 & 24,000 & 10.3 & 1.3 & 1.2 \\
\hline La & 3.8 & 42 & 40 & 42 & 11.0 & 1.0 & 1.0 \\
\hline $\mathrm{Mg}$ & 1,210 & 12,400 & 10,600 & & 10.2 & 0.9 & \\
\hline$M n$ & 33.8 & 295 & 298 & 430 & 8.7 & 1.0 & 1.4 \\
\hline $\mathrm{Na}$ & 696 & 5,000 & 10,100 & 11,300 & 7.2 & 2.0 & 1.1 \\
\hline $\mathrm{Ni}$ & 16 & 85 & 207 & & 5.3 & 2.5 & \\
\hline $\mathrm{Pb}$ & 4.9 & 6.2 & 80 & 650 & 1.3 & 12.9 & 8.1 \\
\hline $\mathrm{Rb}$ & 15.5 & 102 & 155 & 190 & 6.6 & 1.5 & 1.2 \\
\hline $\mathrm{Sb}$ & 0.5 & 0.64 & 12 & 55 & 1.3 & 18.8 & 4.6 \\
\hline $\mathrm{Sc}$ & 2.2 & 20.8 & 26 & 36 & 9.5 & 1.2 & 1.4 \\
\hline Se & 2.2 & 0.080 & 25 & 88 & 0.0 & 310 & 3.5 \\
\hline Si & 23,100 & 229,000 & 196,000 & & 9.9 & 0.9 & \\
\hline $\mathrm{Sm}$ & 1.0 & 8.2 & 10.5 & 9 & 8.2 & 1.3 & 0.9 \\
\hline Sr & 23 & 170 & 260 & & 7.1 & 1.6 & \\
\hline $\mathrm{Ta}$ & 0.11 & 0.95 & 1.4 & 1.8 & 8.6 & 1.5 & 1.3 \\
\hline Th & 2.1 & 15 & 20 & 26 & 8.6 & 1.3 & 1.3 \\
\hline $\mathrm{Ti}$ & 506 & 4,100 & 5,980 & 10,000 & 8.1 & 1.5 & 1.7 \\
\hline $\mathbf{U}$ & 2.18 & 14.9 . & 30.1 & & 6.8 & 2.0 & \\
\hline V & 28.5 & 260 & 440 & 1.180 & 9.1 & 1.7 & 2.7 \\
\hline $\mathrm{Zn}$ & 46 & 100 & 740 & 5,900 & 2.2 & 7.4 & 8.0 \\
\hline
\end{tabular}

${ }^{a}$ All analytical data by NAA except $\mathrm{Cu}, \mathrm{Ga}, \mathrm{Ni}$, and $\mathrm{Sr}$ by XRF; $\mathrm{Hg}$ by $\mathrm{AA} ; \mathrm{Se}$ by GCMES and $\mathrm{Cd}, \mathrm{Pb}$, and $\mathrm{Zn}$ by IDSSMS; values for As (73) and for $R b$ are averages of NAA and XRF.

Source: D. H. Klein et al, 1975. Table IV in Pathways of 37 trace elements through coal-fired power plants. Environ. Sci. Tech. 9(10): 973-79. 
Natusch, Wallace, and Evans (1974) studied the relationship between trace element concentration and fly ash particle size. They report that, of the elements studied at the Allen Steam Plant, $\mathrm{As}, \mathrm{Cd}, \mathrm{Cr}, \mathrm{Ni}, \mathrm{Pb}, \mathrm{Sb}, \mathrm{Se}$, and $\mathrm{Zn}$ show a clear inverse relationship between element concentration and particle size. Except for chromium and nickel (which fall between Classes I and II), all of these elements may be found in Class II. Natusch, Wallace, and Evans (1974) also report no trend or poorly defined trends for $\mathrm{Al}, \mathrm{Ca}, \mathrm{Co}, \mathrm{Cu}, \mathrm{Fe}, \mathrm{K}, \mathrm{Mg}, \mathrm{Mn}, \mathrm{Si}, \mathrm{Ti}$, and $\mathrm{V}-\mathrm{all}$ of which are Class I members except $\mathrm{Cu}$ (Class II) and $\mathrm{V}$ (intermediate group).

In the August 1973 runs shown in Tables 1.22 and 1.23 , only about $0.5 \%$ of the incoming fly ash left the precipitator in the outlet flue gas (99.5\% collection efficiency). Mercury and selenium were discharged both as vapor and in fly ash particles, but, because no other metals were detected, Klein concluded that other metals were apparently discharyed only in the fly ash. The quantitics of elements discharged to the atmosphere are given in the last two columns of Table 1.22 as grams per minute and pounds per ton of coal fired.

These results and those of Natusch, Wallace, and tvans (1974) show that the abilily ur the precipitator to remove trace elements from the flue gas stream depends on the specific element as

. well as on precipitator design and operating conditions, with Class I elements removed more efficiently than Class II elements. Measurements made at Allen for the No. 2 Unit electrostatic precipitator during the 1973 sampling trip by Southern Research Institute showed a minimull in precipitator efficiency of about 80 to $85 \%$ for particles 0.15 to $0.5 \mu \mathrm{m}$ in diameter. Mercury and selenium are special cases because they were observed to enter the precipitator partly in the vapor phase. About $20 \%$ of the selenium passes through the precipitator, primarily as the elemental vapor (Klein, Andren, and Bolton 1975). Selenium in both the vapor "state and the fly ash phase appeared to be in the zero oxidation state. No't less than $60 \%$, and probably about $90 \%$, of the mercury entering in the coal stream was discharged to the atmosphere as the vapor. It is unilkely that a change in the precipitator efficiency could have an effect on the relative quantity of these elements discharged as the vapor (Klein et al. 1975).

Thus it appears that electrostatic precipitators can be maide efficient for the removal of most elements, are less efficient for the removal of those elements that concentrate on very fine particulates, and are essentially without effect on such volatiles as mercury. Because.most of the Class I and Class II elements are in the collected ashes from which they may be removed by weathering or biological processes, the fate of the putentially toxic metals in coal depends largely upon how the ashes are stored or disposed of. The stability of the ash under environmental conditions requires further study (Klein et al. 1975).

\subsubsection{Wastewater treatment - description and effluents}

The design goal for water use in coal gasification plants has been to approach'zero discharge. The 1972 Water Pollution Control Act has mandated this goal to táke effect in 1985 . The philosophy in designing a treating facility for liquid wastes has been to purify liquid streams only to the extent necessary for reuse in specific areas of the plant. Examples of contaminated water reuse are shown in Fig. 1.10.

After sedimentation, water from the storm retention pond should be suitable for use as cooling tower makeup. Alternately, this stream can be further treated in a biological oxidation unit, 


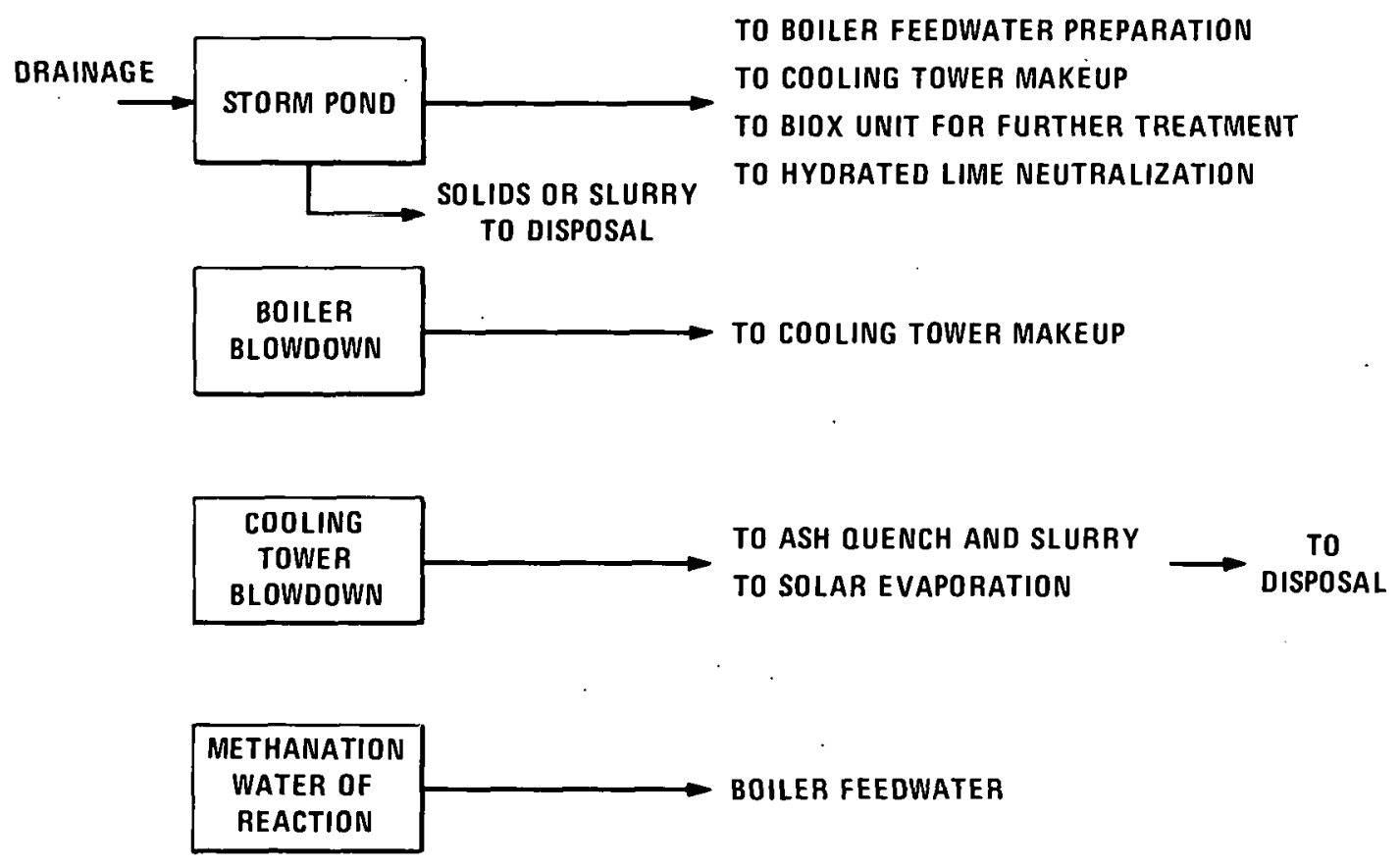

Fig. 1.10. Disposition of additional liquid wastes.

in a hydrated lime neutralization unit, or in the boiler feedwater preparation unit for uses requiring a less contaminated aqueous feed. Boiler blowdown should be acceptable for use as cooling tower makeup without requiring further treatment. Blowdown from the cooling tower has a high level of contamlination but is available to quench and slurry ash dropping out of the gasifier. Solar evaporation is an alternative disposition for this stream in arid Western regions. Water generated by chemical reaction during methane production must be removed from the product gas to produce pipeline-quality SNG. This water is very pure (virtually all contaminants have been removed in previous process steps) and should be suitable for boiler feedwater without additional treatment.

As a special case for Bi-Gas plants, all sour water is continuously recycled for quenching gasifier char and product gas, reducing the need for sophisticated wastewater treatment. Caustic or acidic water used to backwash contaminated ion exchange resins in the boiler feedwater preparation area can be neutralized and used to quench and slurry gasifier ash.

The largest sink for recycled water is the wet cooling tower. Because of the large gas-liquid interfacial area present in wet cooling towers, mass transfer of materials from the liquid to the gas stream has the potential for creating serious environmental emissions, which warrants special care in removing undesirable components from the water before it enters the tower. Contaminated water is therefore subjected to extensive treatment before being recycled to this area.

The largest: source of wastowater in the plant is sour water (gas liquul), which is wi lhidrawn prior to methanation. Depending on process operating conditions, this stream contains greater 
or lesser quantities of tar, oil, BTX, naphtha, phenols, ammonia, hydrogen sulfide, carbonyl sulfide, carbon dioxide, hydrogen, cyanide, trace metals, suspended and dissolved solids, and small quantities of other organic and inorganic compounds.

Figure 1.11 shows the flow of process liquid waste streams through an extensive wastewater treatment facility that may become typical in coal gasification plants. Although facilities are shown for the removal of all valuable by-products and undesirable contaminants, this type of design must be modified to suit a particular plant design. Variable parameters include byproduct formation, generation of specific organic and inorganic compounds, the need for process makeup water, the production rate of sour water, alternative uses for waste liquid streams not requiring extensive treatment $(\mathrm{e} . \mathrm{g} .$, all sour water is used for quenching gas and slag in the Bi-Gas design), alternative treatment methods (e.g., substituting biological oxidation treatment or carbon absorbents with Synthane char for removal of trace phenols, ammonia, and organics), and the potential of the environment to provide solar evaporation and acceptable burial sites.

Contaminated aqueous streams are generated in cual cuiversion processes because product or effluent gases either are water-washed to remove contaminants or are quenched for temperature control. A third potential source of an aqueous stream is from simple condensation of excess steam that might have been used in a gasification process. The type and quantity of contaminants found in the wash water are functions of (1) the chemical characteristics of the initial coal feedstock to the process and (2) the type of subsidiary treatment upstream of the waterwash, quench, or cooling-condensation steps (Glázer, Hershaft, and Shaw 1974).

Processing steps for foul water streams include the following in most cases:

1. pressure reduction by flashing, which releases dissolved sulfur, dissolved carbon dioxide, and desirable gas constituents,

2. solids removal or removal of tars, 0i1s, and BTX, using typical solids-liquids separation equipment such as thickeners, clariflers, ur fillers,

3. liquid-liquid extraction to recover phenols, creosols, and xylenols,

4. steam stripping to remove ammonia, and

5. biological oxidation to remove trace quantities ur rixed and free ammonia, phenols, dind BOD.

The presence and removal of trace elements deserve special attention. Trace elements that enter the process through the coal feed can leave the process through a variety of pathways such as:

- Hepnaition on cquipment surfaces:

- deposition on shift conversion catalyst;

- inclusion in tar and oil (including naphtha and BTX);

- inclusion in oil quench bleed stream (Hygas);

- inclusion in by-product streams (phenols and ammonia) if by-products are withdrawn before trace element removal;

- fugitive emissions;

- sand filtering bleed stream (Bi-Gas); 


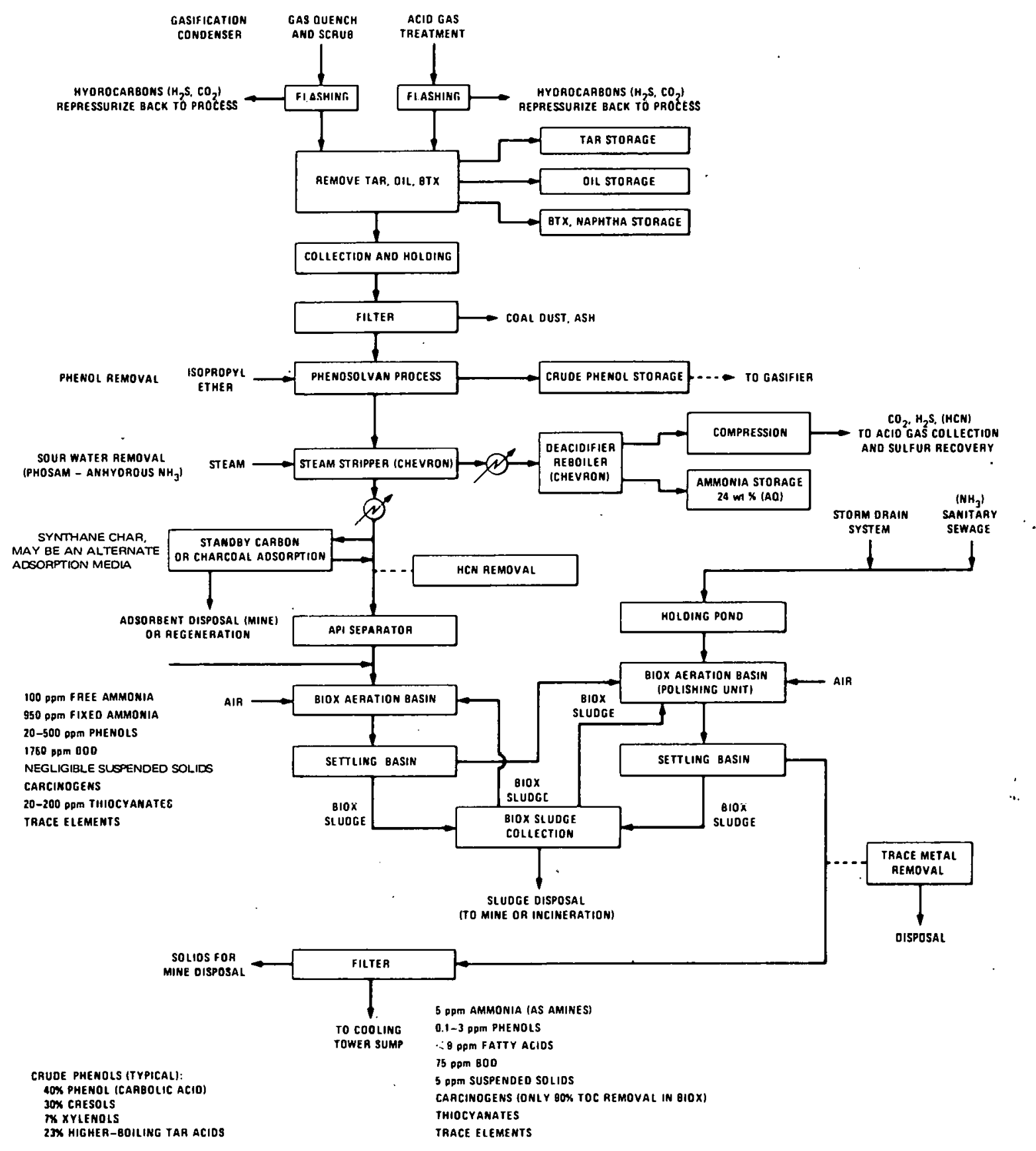

Fig. 1.11. Wastewater treatment. 
- trace elements generated from equipment corrosion and wear $(\mathrm{Cr}, \mathrm{Cu}, \mathrm{Mg}$, and $\mathrm{Ni})$; and

- ash quench water below gasifier (if evolved stream is returned to the gasifier, a closed loop is formed requiring a purge).

The size and composition of these streams has not been empirically determined, nor can it be analytically derived with great certainty. Therefore, it is assumed that trace elements ultimately have two pathways by which to leave the process: (1) gasifier char and (2) treatment sludges from the wastewater treatment plant. Data in Table 1.15 corroborate this assumption, showing that the concentration of trace elements declines drasticaliy during the water scrub. Based on a coal feed rate of 9070 metric tons $(10,000$ tons) per day (cleaned) having trace element concentrations equal to the mean value for 101 coals, Table 1.12 shows the estimated quantity of 17 traçe elements leaving the gasifier in the ash stream and the product gas stream. Downstream gas quenching and scrubbing should transfer these elements from the gas to the 1 iquid ilruill!.

Removal of trace elements from wastewater streams has been demonstrated, usinq lime preçipițatioṇactivated, ferric chloride-activated, and alum-activated carbons and biological oxidation. Comparative removal efficiencies for 14 of the trace elements are shown in Table 1.24. Using the basis of 9070 metric tons $(10,000$ tons) of cleaned coal charged per day, which has a trace element composition equal to the average of 101 U.S. coals, and using removal processes that demonstrate the highest removal efficiency for each element, Table 1.25 shows the. estimated emission rate of 14 trace elements and their rate of accumulation in the treatment sludge.

These are only estimates based on simplified pathways. Also, these removal processes are only contaminant concentrators, and ultimate disposition of the treatment sludge is not clear. Treatment of the entire effluent stream for removai of trace elements may be prohibitively expensive. In this event, some calculated portion of the stream is bled off and purged of contaminants at a rate that prevents the accumulation of trace elements in the water recycle loop.

In addition to treating process-generated liquid wastes, incoming raw water is treated in two separate areas: (1) makeup water preparation and (2) boiler feedwater preparation (Fig. 1.12). Makeup water preparation treats raw or recycled water with various chemicals such as lime and alum to precipitate hardness and cause flocculation. An innocuous mineral sludge is produced from this unit, which is expected to be suitable for burial or landfill.

Requirements for boiler feedwater are more stringent. Raw or recycled water is demineralized with ion exchange resins that are periodically backwashed with sulfuric acid or caustic. The wash is neutralized and may be used to quench and slurry gasifier ash.

Associated with raw coal is such a vast range of chemical compounds that even the action of rainwater may pose an environmental threat. Coal storage piles should be held in basins that are lined with an impermeable barrier. Rain drainage from these basins normally is retained in a separate storm pond, then treated (Fig. 1.11). Coai dust finds its way out of the coalhandling and preparation areas and covers the ground. It is estimated that $8.2 \times 10^{4} \mathrm{~m}^{3} / \mathrm{day}^{2}$ $\left(1.5 \times 10^{4} \mathrm{gpm}\right.$ ) of rain (maximum, $1 \mathrm{hr}$ ) may fall on paved areas of the plant and $32.7 \times 10^{4}$ $\mathrm{m}^{3} /$ day $\left(6.0 \times 10^{4} \mathrm{gpm}\right)$ may fall on unpaved areas (Kalfadelis and Magee 1974). In contact with 
Table 1.24. Wastewater removal efficiencies of trace elements

\begin{tabular}{|c|c|c|c|c|}
\hline Constituent & $\begin{array}{c}\text { 'Lime precipitation- } \\
\text { activated carbon } \\
\text { (\%) }\end{array}$ & $\begin{array}{l}\text { Ferric chloride- } \\
\text { activated carbon }\end{array}$ & $\begin{array}{c}\text { Alum-activated } \\
\text { carbon } \\
(\%)\end{array}$ & $\begin{array}{l}\text { Biological } \\
\text { oxidation } \\
\text { (\%) }\end{array}$ \\
\hline As & 84 & 97.1 & $N / A$ & \\
\hline B & N/A & N/A & N/A & \\
\hline $\mathrm{Be}$ & $99.5^{a}$ & 98.9 & 98.9 & \\
\hline $\mathrm{Cd}$ & $99.6^{a}$ & 98.6 & 55.5 & $20-45$ \\
\hline $\mathrm{Cr}$ & 98.2 & $99.3^{3}$ & $\begin{array}{l}97.4 \mathrm{Cr}^{6+} \\
99.3 \mathrm{Cr}^{3+}\end{array}$ & $40-80$ \\
\hline$F$ & N/A & N/A & N/A & \\
\hline $\mathrm{Hg}$ & 92. & 98. & $98.3^{a}$ & $20-75$ \\
\hline Mo & 5. & $80^{a}$ & 10. & \\
\hline $\mathrm{Ni}$ & $99.5^{2}$ & 37. & 37. & $15-40$ \\
\hline $\mathrm{Pb}$ & $98.4^{a}$ & 99.1 & 96.6 & $50-90$ \\
\hline Se & $95 .^{a}$ & 80. & 56. & \\
\hline$v$ & 91. & $97.8^{\circ}$ & 95.4 & \\
\hline$Z_{n}$ & 76. & $94 .^{a}$ & 28. & $35-80$ \\
\hline $\mathrm{Cl}$ & $N / A$ & N/A & $N / A$ & \\
\hline $\mathrm{Ti}$ & 95.3 & $98.5^{a}$ & 95.8 & \\
\hline Sb & 52. & $72 .^{a}$ & 71. & \\
\hline Co & $955^{\circ}$. & 30. & 56. & \\
\hline
\end{tabular}

"Highest demonstrated removal.

Source: Technology Transfer, USEPA, January 1977, pp. 2-7. Washington, D.C.: U.S. Environmental Protection Agency.

Table 1.25. Estimate of trace element effluents from wastewater treatment facility (WWT)

Based on 10,000 tons per day of cleaned coal feed having a trace element composition equal to the average of 101 U.S. coals and the use of removal processes demonstrating the highest removal efficiency for each element.

\begin{tabular}{|c|c|c|c|c|}
\hline Constituent & $\begin{array}{l}\text { Ouantity entering } \\
\text { WWT Idcility } \\
\text { (Ib/day) }\end{array}$ & $\begin{array}{l}\text { Best removal } \\
\text { efficiency } \\
(\%)\end{array}$ & $\begin{array}{c}\text { Emission rate } \\
\text { in final liquid } \\
\text { effluent } \\
\text { (Ib/day) }\end{array}$ & $\begin{array}{c}\text { Rate of } \\
\text { accumulation } \\
\text { in WWT sludge } \\
\text { (Ib/day) }\end{array}$ \\
\hline As & 182 & 97.1 & 5 & 177 \\
\hline B & 200 & Unknown & Unknown & Unknown \\
\hline $\mathrm{Be}$ & 6 & 99.5 & Negative & 6 \\
\hline Cu & 31 & 99.6 & Negative & 31 \\
\hline $\mathrm{Cr}$ & Negative: & 99.3 & Negative & Negative \\
\hline$F$ & 122 & Unknown & Unknown & I.Jnknown \\
\hline $\mathrm{Hg}$ & 4 & 98.3 & Negative & 4 \\
\hline Mo & 15 & 80 & 3 & 12 \\
\hline $\mathrm{Ni}$ & 101 & 99.5 & 1 & 100 \\
\hline $\mathrm{Pb}$ & 441 & 99.4 & 3 & 438 \\
\hline Se & 31 & 95. & 2 & 29 \\
\hline V & 198 & 97.8 & 4 & 194 \\
\hline $\mathrm{Zn}$ & 540 & 94. & 32 & 508 \\
\hline $\mathrm{Cl}$ & 25,200 & Unknown & Unknown & Unknown \\
\hline$\dot{\mathrm{Ti}}$ & 1400 & 98.5 & 21 & 1379 \\
\hline St & $\dot{y}$ & 72. & 3 & 6 \\
\hline Co & Negative & 95. & Negative & Negative \\
\hline
\end{tabular}

${ }^{a}$ This does not constitute an effluent stream from the plant. 

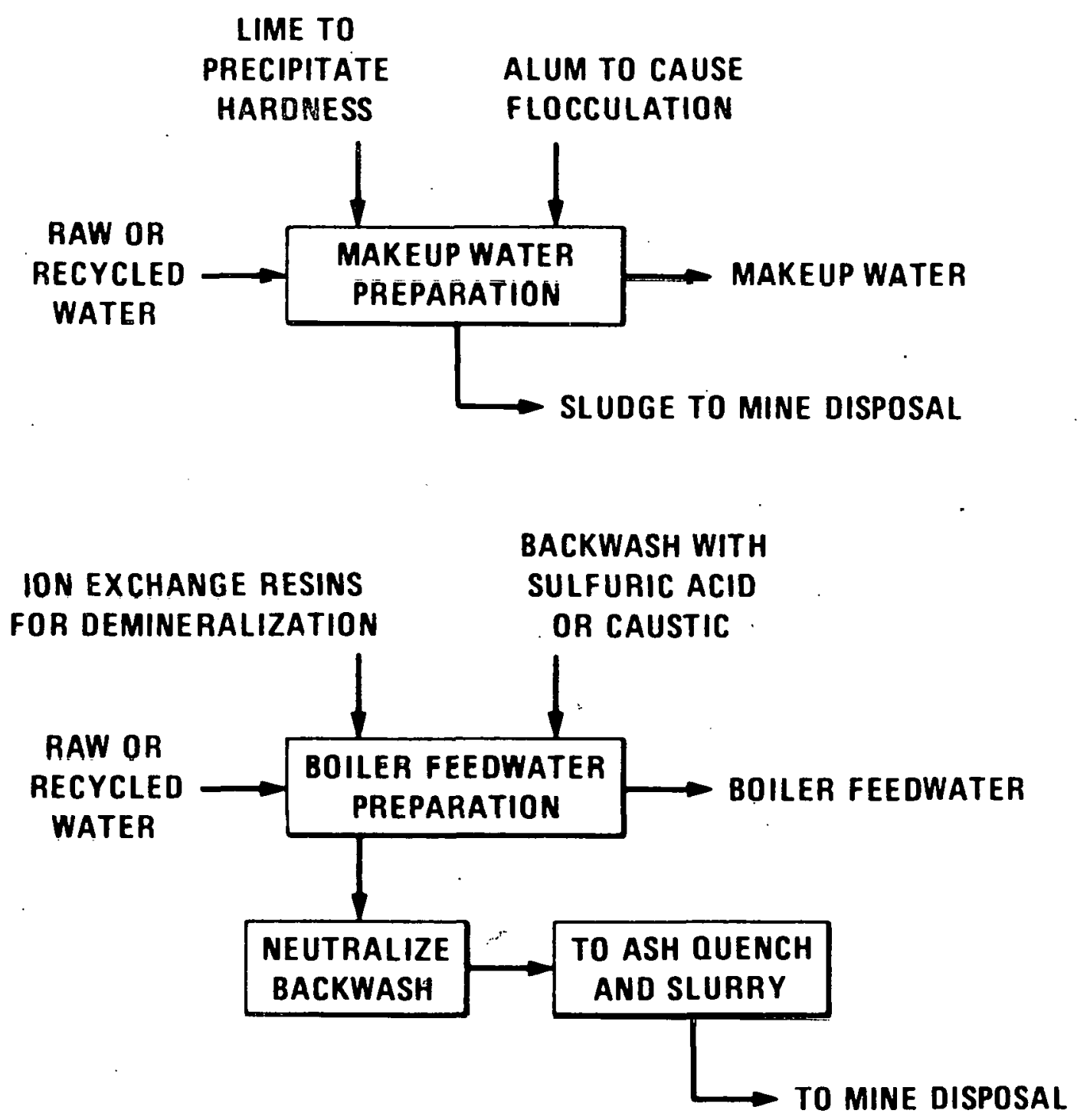

Fig. 1.12. Water preparation. 
fugitive dust on the ground, rain may leach many materials out of the coal. Leakage through the storage basin barrier or basin overflow could also release contaminated rainwater to the environment. Table 1.6 lists the analysis of rain drainage from two industrial coal piles.

\subsubsection{Cooling towers - descriptions and effluents}

Coal gasification plants recirculate large quantities of water through heat exchangers to moderate temperatures in processing equipment such as gas quenchers, reactors, steam condensers, and inter-and after-coolers on gas compressors. Cooling towers are an integral part of the plant's cooling network. Cooling tower designs fall into two principal categories - wet cooling towers and dry cooling towers.

The sources of effluents in wet cooling towers are the discharge plume and the blowdown stream. In addition to water from evaporation and entrainment, the plume may contain various contaminant substances extracted from the cooling water. The cooling water receives these substances from corrosion of heat exchange surfaces; from chemical additives in the water to inhibit fouling, bacterial growth, and corrosion; from residual contaminants in the makeup water [the makeup water requirement is supplied by treated sour water, boiler blowdown, and other process sources (Sect. 1.2.7)]; and from leaks in the heat exchange equipment which allow contaminated gases, usually under high pressure $\left(1.03 \times 10^{6}\right.$ to $8.27 \times 10^{6} \mathrm{~Pa} ; 150$ to $\left.1200 \mathrm{psig}\right)$, to enter the liquid side of the heat exchangers. Once in the tower, the water is in intimate contact with the air, which allows mass transfer to occur across the liquid-gas interface. The air stream may consequently extract contaminants, especially volatile contaminants, from the water. This mechanism of contaminant extraction is often counteracted by the effects of microbial populations in the water. The concentration of certain substances such as phenols and ammonia is often reduced in cooling water through the action of biological oxidation.

Another transport mechanism for contaminants is the entrained water droplets (mist) leaving the tower. These droplets contain dissolved and suspended solids (and virtually any other foreign substance that exists in the water) in concentrations equal to or greater than in the water itself. In contrast to the entrained mist, the water vapor leaving the tower is essentially pure water. The visible fog plumes can produce some significant atmospheric effects such as reduction of visibility to air, ground, and navigational water transportation; ice formation on surfaces; cloud initiation; and augmentation of precipitation. It is important that, while water vapor is innocuous as a chemical substance, it can play an important role in atmospheric chemistry when combined with oxides of sulfur and nitrogen found in the combustion stack gases generated from thermal dryers and utility plants. Drift (which is deposited in the form of droplets of solid particles, depending on atmospheric conditions) may leave precipitants of salts and various chemicals on surfaces downwind from the cooling system. These precipitants may cause damage to the biota, accelerate corrosion of nearby structures, or even contaminate water bodies. Water droplets with diameters less than $20 \mu \mathrm{m}$ are generally considered fog; larger droplets (greater than 20-um particle diameter) are referred to as drift.

As a general rule, drift losses in wet cooling towers are about $0.2 \%$ of the water circulation rate. Ecodyne has developed a mist eliminator system that is able to reduce this entrainment loss to $0.008 \%$ of the circulation rate. With a design estimate of drift loss and knowing the cuncenlration of substances in lhe water wllhln the luwer, a mass emission rate fur each 
contaminant may be calculated by use of the assumption that the concentration within the liquid droplets is equal to that in the tower. Because of the large array of sources for makeup water and the cooling water contamination, reliable estimates of contaminant concentrations and subsequent emission rates are impossible. In addition, estimating the degree of stripping by the air stream and the counteracting microbial reduction of contaminant substances is equally speculative. Table 1.26 gives estimates for wet cooling tower parameters for commercial-size plant designs found in the literature. An important parameter is the quantity of air flow relative to the plant product capacity. The quantity of air discharged from the cooling towers is 55 to 340 times the quantity of SNG produced. The magnitude of this ratio varies with the process heat load, the use of dry cooling towers, and the quantity of waste heat used to generate steam. On a qualitative basis, possible contaminant substances are'zinc and chromium compounds, chiorine, sulfuric acid, phosphates, phenols, copper complexes, ammonia, carbon monoxide, cyanide, thiocyanates, and trace elements.

Table 1.26. Estimated wet cooling tower parameters for $7.1 \times 10^{6} \mathrm{~m}^{3} / \mathrm{day}\left(250 \times 10^{6}\right.$ scfd $)$ SNG plants . In some plant designs, a portion of the heat load is dissipated in dry cooling towers.

\begin{tabular}{|c|c|c|c|c|c|c|c|c|c|c|}
\hline \multirow{2}{*}{ Process } & \multicolumn{2}{|c|}{ Air flow } & \multicolumn{2}{|c|}{ Water flow } & \multicolumn{2}{|c|}{ Vapor loss } & \multicolumn{2}{|c|}{ Drift loss } & \multicolumn{2}{|c|}{ Blowdown } \\
\hline & $\left(\operatorname{scfh} \times 10^{6}\right)$ & $(\mathrm{lb} / \mathrm{hr})$ & (gpm) & (Ib/hr) & $(\mathrm{lb} / \mathrm{hr})$ & (\%) & $(\mathrm{Ib} / \mathrm{hr})$ & $(\%)$ & $(\mathrm{lb} / \mathrm{hr})$ & (\%) \\
\hline $\begin{array}{l}\mathrm{CO}_{2} \text { Acceptor } \\
\text { Synthane }\end{array}$ & 620 & $47.6 \times 10^{6}$ & 42,900 & $2.15 \times 10^{7}$ & 457,000 & 2.13 & 43,000 & 0.20 & 233,000 & 1.08 \\
\hline Synthane ${ }^{b}$ & 833 & $64.0 \times 10^{6}$ & 260,000 & $1.3 \times 10^{8}$ & $1,302,600$ & 1.00 & 150,300 & 0.12 & 260,600 & 0.19 \\
\hline Bi-Gas ${ }^{c}$ & 3542 & $272 \times 10^{6}$ & 262,580 & $1.32 \times 10^{8}$ & $2,6 \overline{2} 6,000$ & 1.99 & 263,000 & 0.20 & GUU,UUU & 0.45 \\
\hline Hygas $^{d}$ & 3067 & $234 \times 10^{6}$ & 200,000 & $1.00 \times 10^{8}$ & $2,260,000$ & 2.26 & 200,500 & 0.20 & 453,000 & 0.45 \\
\hline Lurgie & 576 & $44.2 \times 10^{6}$ & 130.000 & $6.51 \times 10^{7}$ & $1,170,000$ & 1.80 & 130,000 & 0.20 & 105,100 & 0.16 \\
\hline
\end{tabular}

Solurses: (a) C. E. Jahnig and E. M. Magee. 1974. Evaluation of pollution control in fossil fuel conversion processes. Gasification: Section 1, $\mathrm{CO}_{2}$ Acceptor process. EPA-650/2-74-009-d; (b) C. D. Kalfadelis and E. M. Magee. 1974. Evaluation of pollution control in fossil fuel conversion processes. Gasification: Section I, Synthane process. EPA-650/2-74-001-b; (c) C. E. Jahnig. 1975. Evaluation of pollution control in fossil fuel conversion processes. Gasification: Section 5, Bi-Gas process. EPA-650/2-74-009-9: (d) - 1975. Evaluation of pollution control in fossil fuel conversion processes. Gasffication: Section 6 , Hygas process. EPA.650/2-74-009-h, (e) H. Sliavw arod E. M. Magee. 1974. Evaluation of pollution oontrol in forsil fuel conversion processes. Gasification: Section I: Lurgi process. EPA-650/2-74-001-c. Work performed for U.S. Environmental Protection Agency. Linden, N.J.: Exxon Research and Engineering C̈o.

The other major effluent stream in wet cooling towers is the blowdown. Like the entrained mist leaving the tower, the blowdown may contain all cuntaninant substances found in the tower but is a concentrator of solids that precipitate from the water through gravitational settling and the action of chemical additives to the system. This blowdown stream may be recycled for uses elsewhere in the plant such as for gasifier or boiler ash quenching or in the ash desulfurization circuit of the $\mathrm{CO}_{2}$ Acceptor process. Alternatively, bluwduwi llay be sent to a holding pond and evaporated to dryness (where it may reside for the life of the plant or be hauled away for disposal) or treated in the wastewater treatment facility. Il should not be a direct effluent from the plant.

In dry cooling towers, the primary source of contamination to the air stream is leakage across the heat exchanger surface in the tower. Water released from the high pressure side (inside) of the tubes into the air stream introduces substances that have entered the water through heat exchanger leaks in process areas, equipment corrosion, and residuals in the makeup water used to replace the cooling system purge or bleed stream. 


\section{REFERENCES FOR SECTION 1.2}

Attari, A. J., and Meninger, J. P. 1976. Initial environmental test plan for source assessment of coal gasification: EPA-600/2-76-259. Research Triangle.Park, N.C.: U.S. Environmental Agency.

Ayer, F. S. 1974. Symposium proceedings: environmental aspects of fuel conversion technology. EPA-640/2-74-110. St. Louis, Mo.: U.S. Environmental Protection Agency.

Braunstein, H. M.; Copenhaver, E. D.; and Pfuderer, H. A. 1976. Environmental, health, cond control aspects of coal conversion: an information overview. (Draft). Vol. 1. Oak Ridge, Tenn.: Oak Ridge National Laboratory.

Braunstein, H. M. 1977. Environmental and health aspects of disposal of solid wastes from coal conversion: an information assessment. (Draft). Vol. 1. Oak Ridge, Tenn.: Oak Ridge National Laboratory.

Chu, T. J.; Ruane, R. J.; and Steiner, G. R. 1976. Characteristics of wastewater discharges from coal-fired power plants. 31st connul Purdue industrial waste conference, May 4-6, 1976. West Lafayette, Ind.: Purdue University.

Dravo Corporation. 1976. Handbook of gasifiers and gas treatment systems. ERDA Contract no, 3(49-18)1772. Pit.tsburgh, Pa.

Glàzer, F.; Hershaft, A.; and Shaw, R. 1974. Emissions from processes producing clean fuels. EPA-450/3-75-028. Bethesda, Md.: Booz-Allen and Hamilton, Inc.

Hebden, D. 1975. High pressure gasification under slagging conditions. In Proceedings, seventh synthetic pipeline gas symposium. Chicago, I11.: American Gas Association.

Hittman Associates, Inc. 1974. Baseline data environmental assessment of a large coal conversion complex. Vols. I, II. ERDA Contract No. 14-32-0001-1508. Interim report No. 1. Washington, 0.6 .

Interagency Task Force on Synthetic Fuels from Coal. 1974. Project independence. U.S. Department of the Interior. Washington, D.C.: U.S. Government Printing Office.

Jahnig, C. E. 1975a. Evaluation of pollution control in fossil fuel conversion processes. Gasification: Section 5, Bi-Gas process. EPA-650/2-74-009-g. Work performed for U.S. Environmental Protection Agency. Linden, N.J.: Exxon Research and Engineering Co.

- 1975b. Evaluation of pollution control in fossil fuel conversion processes. Gasification: Section 6, Hy-Gas process. EPA-650/2-74-009-h. Work performed for U.S. Environmental Protection Agency. Linden, N.J.: Exxon Research and Engineering Co.

Jahnig, C. E., and Magee, E. M. 1974. Evaluation of pollution control in fossil fuel conversion processes. Gasification: Section I, $\mathrm{CO}_{2}$ Acceptor process. EPA-650/2-74-001-d. Work performed for U.S. Environmental Protection Agency. Linden, N.J.: Exxon Research and Engineering Co.

Kalfadelis, C. D., and Magee, E. M. 1974. Evaluation of pollution control in fossil fuel conversion processes. Gasification: Section I, Synthane process. EPA-650/2-74-001-d. Work performed for U.S. Environmental Protection Agency. Linden, N.J.: Exxon Research and Engineering Co. 
Klein, D. H., et al. 1975. Pathways of 37 trace elements through coal-fired power plants. Environ. Sci. Tech. 9(10): 973-79.

Klein, D. H.; Andren, A. W.; and Bolton, N. E. 1975. Trace element discharge from coal combustion for power production. Water, Air, Soil Polzut. 5: 71-77.

Leonard, J.W., and Mitche11, D. R. 1968. Coal preparation. 3d ed. New York: American Institute of Mining, Metallurgical, and Petroleum Engineers, Inc.

Miller, S. G. 1974. Environmental impacts of altermative conversion processes for westerm coal devetopment. 01d West Regional Commission. Washington, D.C.: Thomas E. Carroll Associates.

Natusch, D. F. S.; Wallace, J. R.; and Evans, C. A. 1974. Science 183: 202.

Sexton, R. J. 1960. The hàzards to health in the hydrogenation of coal. Arich. Environ. Health $\mathrm{I}$.

Shaw, H., and Magee, t. M. 19/4. Evaluátion of pollution cunlrul ln russil fuel culiversion processes. Gasification: Section I, Lurgi process. EPA-650/2-74-001-c. Work performed for U.S. Environmental Protection Agency. Linden, N.J.: Exxon Research and tnginèering Co.

Sudburg, J. D.; Bowden, J. R.; and Watson, W. B. 1976. Demonstration of the slagging gasifier process, Conoco Coal Development Company. In Proceedings, eighth synthetic pipeline gas symposizm. Chicago, I11.: American Gás Association.

USEPA (Environmental Protection Agency). 1972. Compilation of air pollution emission factors. EPA-AP-42. Washington, D.C.: U.S. Environmental Protection Agency.

- 1976. An investigation of the best systems of emission reduction for coal gasification plants. (Draft). Washington, D.C.: U.S. Enviromililal Protection Agency. 


\subsection{COAL MINING, BENEFICIATION, AND TRANSPORTATION}

This brief description is intended to point out that coal mining activities associated with energy development and cual conversion projects can result in major short- and long-term impacts to the affected areas rather than to provide a detailed analysis and evaluation of activities and potential impacts associated with coal mining.

In addition to coal mining in the Eastern United States, development of the large coal deposits in the Western United States can be expected. About $63.3 \%$ of the identified and estimated U.S. coal resources occur in the Northern Great Plains and Rocky Mountain Provinces (Fig. 1.13). Although much of the Western coal is lignite with a low heating value, these resources represent the majority of the nation's low-sulfur coal deposits.

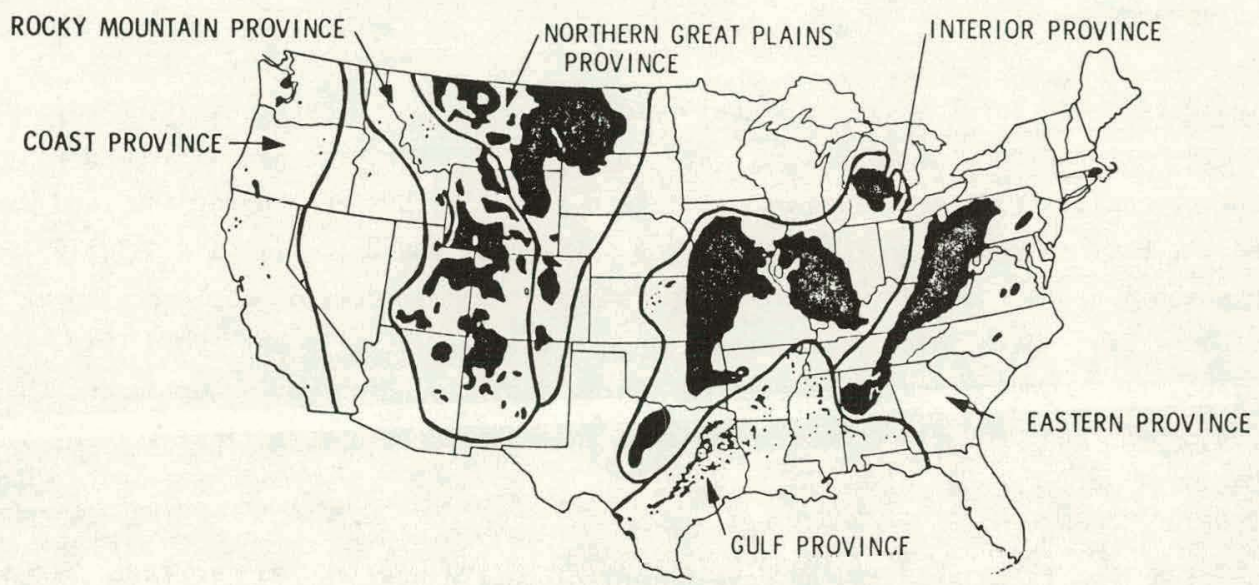

C.OAL RESOURCES

(Billions of tons)

\begin{tabular}{|l|c|c|c|c|}
\hline \multicolumn{1}{|c|}{ PROVINCE } & IDENTIFIED & UNDISCOVERED & TOTAL & $\%$ \\
\hline EASTERN & 276 & 45 & 321 & 10.0 \\
INTERIOR & 277 & 259 & 536 & 16.6 \\
NORTHERN GREAI PLAINS & 695 & 763 & 1.458 & 45.2 \\
ROCKY MOUNTAINS & 187 & 395 & 582 & 18.1 \\
OTHER TOTAL & 146 & 181 & 327 & 10.1 \\
\cline { 2 - 6 } & 1.581 & 1.643 & 3.224 & 100.0 \\
\hline
\end{tabular}

Because available estimates are by state and USGS Provinces cross state boundaries, the figures for these provinces are only approximate.

Fig. 1.13. Location of coal resources in the United States. Source: U.S. Fish and Wildlife Service. 1976. Coal project baskigruurd information (planning and management). FWS/OBS, p. 5. Washington, D.C.: Department of the Interior, U.S. Fish and Wildlife Service. 
Projected coal production estimates (Fig. 1.14) predict that by 1985 about 50\% will come from surface mining. However, the importance of surface mining may be reduced somewhat because of the enactment of stringent legislation. Illinois, West Virginia, and Wyoming (the three states considered in this analysis of a demonstration pipeline gas facility) appear to have good reclamation programs already. (For detailed information on the surface-mined area reclamation programs of these three states, see Imhoff, Friz, and La Fevers 1976, Table 1.) However, the enactment of the Surface Mining Control and Reclamation Act of 1977 and subsequent provisions have defined numerous minimum regulations and environmental performance standards for mining and reclamation (U.S. Congress 1977; U.S. Department of the Interior 1977, 1978a, 1978b; U.S. Department of Agriculture 1978). In general, if a state is to manage its own regulatory program, it must have the program approved by the Federal regulatory authority (i.e., Office of Surface Mining Reclamation and Enforcement within the U.S. Department of the Interior), which was created by the act to implement, regulate, and enforce the various programs of the act. Any part of d slate law that is more stringent than the Federal requirements can supersede Federal requirements if the state. so desires, but a state law must achleve all minimum Fcderal requirement.s specified in the act and subsequent provisions.

Anticipating development of the nation's coal resources, the U.S. Department of Energy, U.S. Department of the Interior, and many other Federal, state, and private groups are current1y involved in the analysis and evaluation of this resource. The Western Energy and Land Use Team (WELUT) and the Eastern Energy and Land Use Group (EELUG) of the U.S. Fish and Wild1ife Service (FWS) have established a cooperative program for studying the impacts of coal development (Fig. 1.15 and Table 1.27). Within the framework of an overall coal development cycle (Fig. 1.16), they have identified some potential effects of mining activity which may occur during the exploration, development and production, and postmining phases of development (Tables $1.28,1.29$, and 1.30).

That coal mining impacts related to the development of coal cunves sion facilities must be an important consideration in drly Environmental Impact Statement is an accepted fact. 

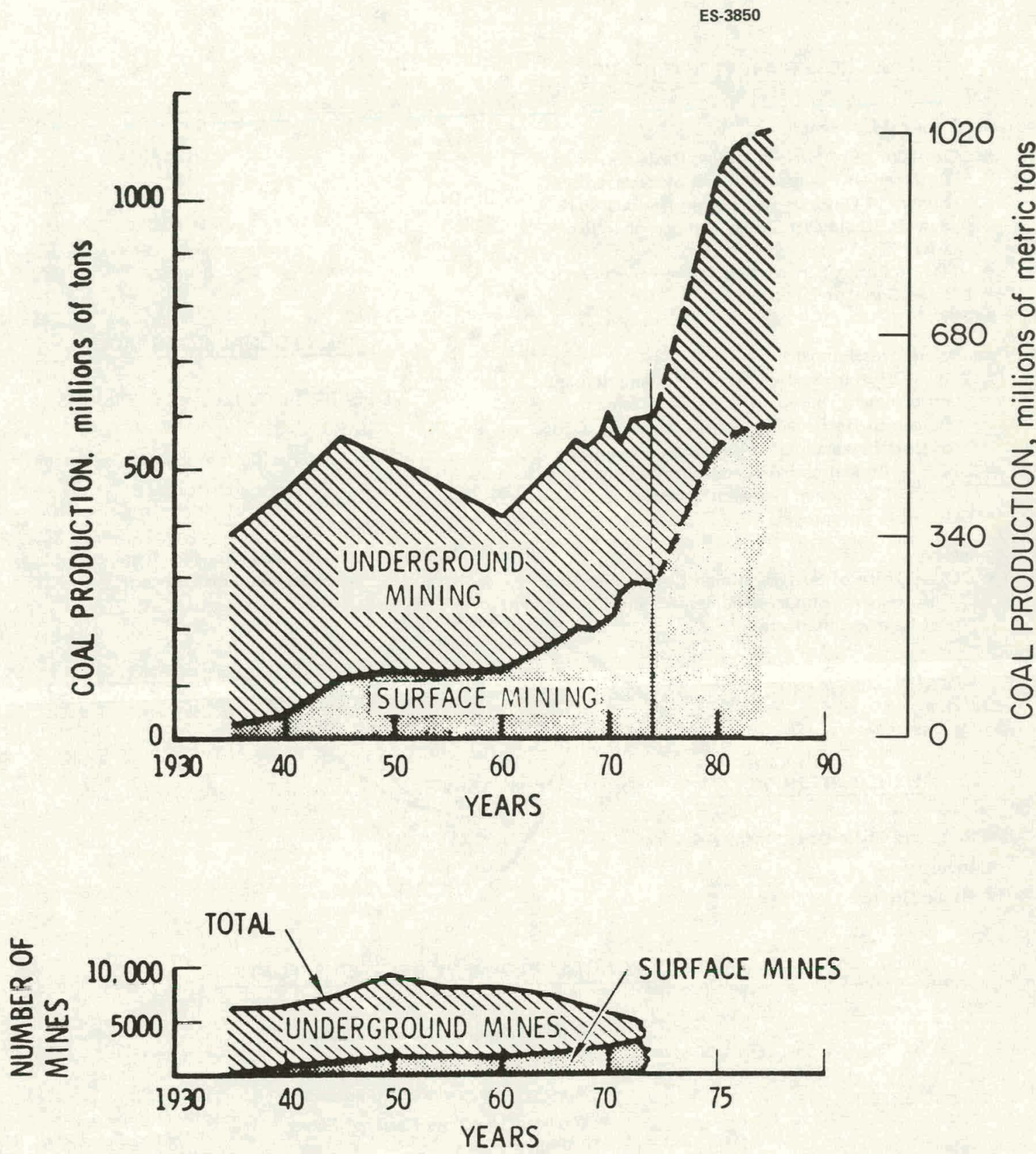

Fig. 1.14. Coal production in the United States. Source: U.S. Fish and Wildlife Service. 1976. Coal project - background information (planning and management). FWS/OBS, p. 3. Developed from data report.en in the Keystone Coal Induslry Manual, Mcliraw-Hi11, Inc. 1y/b. Washington, D.C.: Department of the Interior, U.S. Fish and Wildiife Service. 
- Land Use and Management

- DOI - Office of Surface Mining Reclamation and Enforcement, Bureau of Land Management, Bureau of Outdoor Recreation, National Park Service, Geological Survey, Bureau of Indian Affairs

- USDA - Forest Service, Soil Conservation Service

- vUD - Corps of Enyineers

- TVA

- Research and Devclopment

- DOI - Office of Surface Mining Keclamation and Enforcement, Bureau of Land Management, Bureau of Reclamation, Bureau of Mines, Office of Coal Research, Office of Water Resources - USDA - Agricultural Research Service, Forest Service, Economic Research Service

- DOE, FEA (inventory), EPA

- Regulatory

- DOI - Office of Surface Mining Reclamation and Enforcement, Bureau of Mines, Mining Enforcement and Safety Administration

- EPA

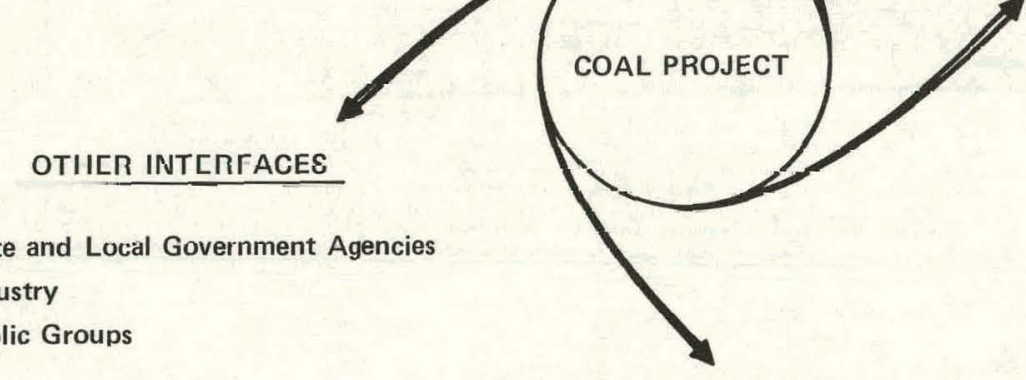

\section{COAL DEVELUPMENI RELATED EFFORTS}

- Old West Regional Commission

- Four Corners Regional Commission

- Appalachian Regional Commission

- Western Governors Regional Energy Policy Office

- Northern Great Plains Resource Program

- Federation of Rocky Mountain States

Fig. 1.15. U.S. Fish and Wildlife Service cooperative program for studying the impacts of coal development. Source: Modified from U.S. Fish and Wildl ife Service. 1976. Coal project - background information (planning and management). FWS/OBS, p. 31. Washington, D.C.: Department of the Interior, U.S. Fish and Wildlife Service. 
Table 1.27. Planned goals and activities of the U.S. Fish and Wildlife Service coal project

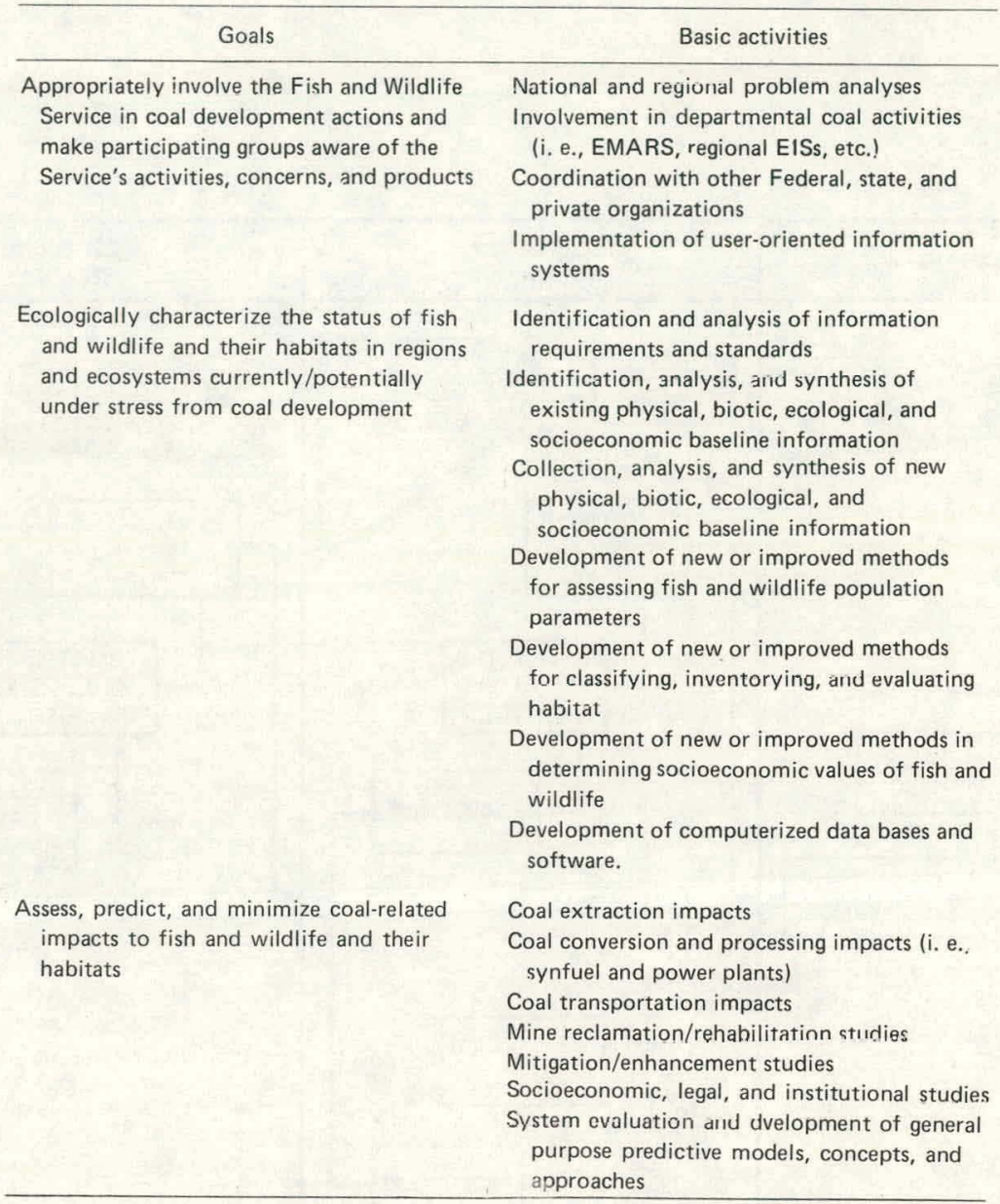

Source: U.S. Fish and Wildlife Service. 1976. Coal project - five year framework (FY 1976 through FY 1980). FWS/OBS-76/17, p. 31. Washington, D.C.: Department of the Interior, U.S. Fish and Wildlife Service. 
ES-3852

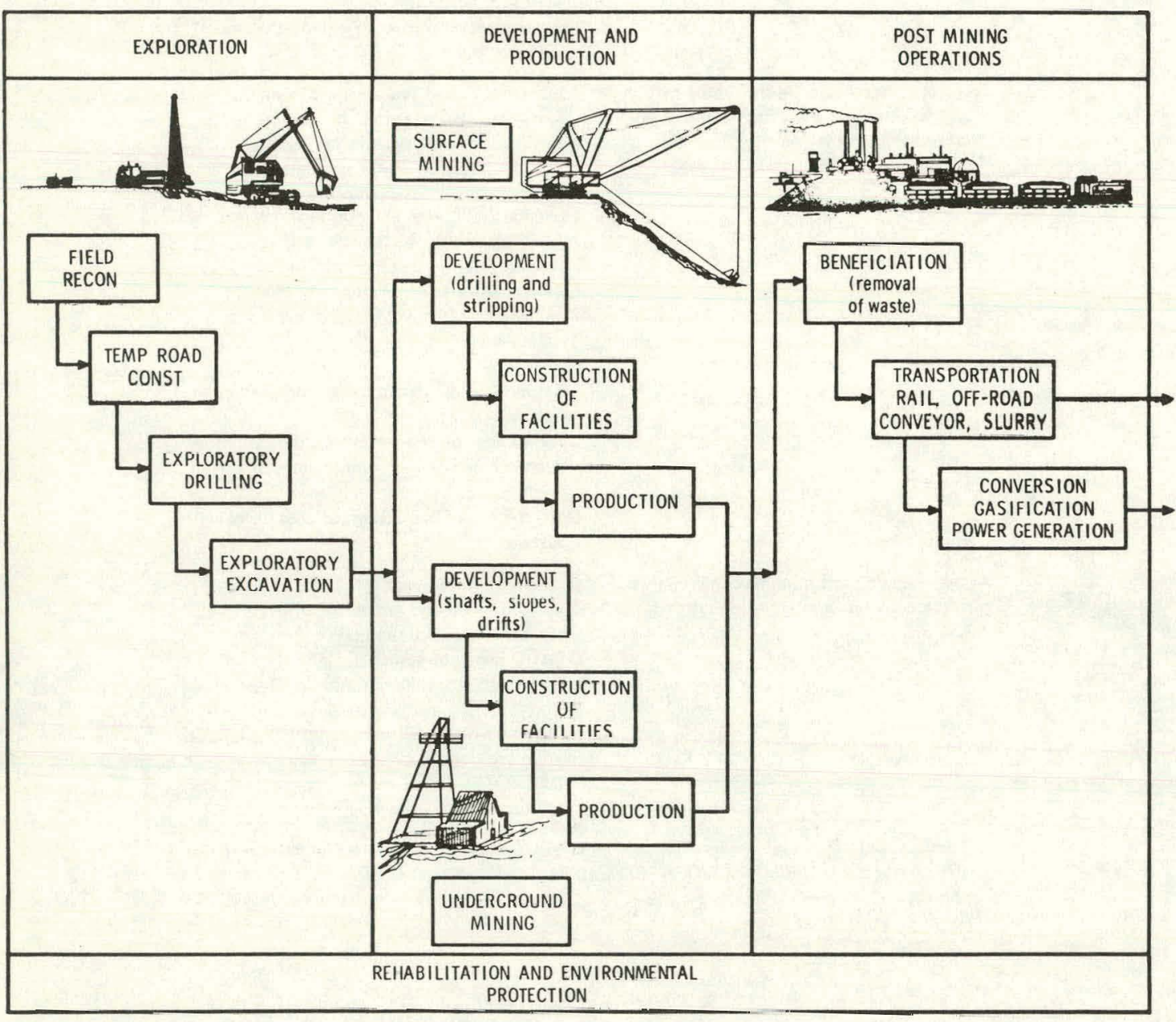

Fig. 1.16. Overall coal development cycle. Source: U.S. Fish and Wildlife Service. 1976. Coal project - background information (planning and management). FWS/OBS, p. 9. Washington, D.C.: Department of the Interior, U.S. Fish and Wildlife Service. 
Table 1.28. Potential environmental effects resulting from the exploration phase of coal development

\begin{tabular}{|c|c|c|c|c|}
\hline \multirow[b]{2}{*}{$\begin{array}{l}\text { Environmental } \\
\text { factors }\end{array}$} & \multicolumn{4}{|c|}{ Mining phases ${ }^{a}$} \\
\hline & $\begin{array}{c}\text { Field } \\
\text { reconnaissance } \\
\text { (off-road) }\end{array}$ & $\begin{array}{l}\text { Temporary } \\
\text { roads } \\
\text { construction }\end{array}$ & $\begin{array}{l}\text { Exploratory } \\
\text { drilling }\end{array}$ & $\begin{array}{l}\text { Exploratory } \\
\text { excavation }\end{array}$ \\
\hline Soil & Compact and disturb & $\begin{array}{l}\text { Erosion of soil } \\
\text { organisms }\end{array}$ & $\begin{array}{l}\text { Erosion from } \\
\text { site preparation }\end{array}$ & $\begin{array}{l}\text { Compaction by heavy } \\
\text { equipment }\end{array}$ \\
\hline Vegetation & $\begin{array}{l}\text { Damage to } \\
\text { sensitive vegetation }\end{array}$ & $\begin{array}{l}\text { Removal of } \\
\text { vegetation }\end{array}$ & $\begin{array}{l}\text { Removal for site } \\
\text { preparation }\end{array}$ & $\begin{array}{l}\text { Removal or destruction } \\
\text { (including trees) }\end{array}$ \\
\hline Surface water & Potential erosion & $\begin{array}{l}\text { Change drainage and } \\
\text { stream pollution }\end{array}$ & $\begin{array}{l}\text { Erosion, flooding, and } \\
\text { stream pollution }\end{array}$ & $\begin{array}{l}\text { Erosion and stream } \\
\text { pollution }\end{array}$ \\
\hline Underground water & Minimal & Minimal & $\begin{array}{l}\text { Penetration of groundwater } \\
\text { aquifers }\end{array}$ & $\begin{array}{l}\text { Penetration of ground- } \\
\text { water aquifers }\end{array}$ \\
\hline Wildlife & $\begin{array}{l}\text { Disturb nesting, } \\
\text { wintering, etc. }\end{array}$ & $\begin{array}{l}\text { Disturb soil-dwelling } \\
\text { animals, organic } \\
\text { soils and foliage }\end{array}$ & Disturb wildlife & $\begin{array}{l}\text { Disturb wildlife, destroy } \\
\text { foliage }\end{array}$ \\
\hline Fish & Minimal & $\begin{array}{l}\text { Stream pollution, } \\
\text { sediment production }\end{array}$ & $\begin{array}{l}\text { Stream pollution, } \\
\text { sediment production }\end{array}$ & $\begin{array}{l}\text { Stream pollution, } \\
\text { sediment pro- } \\
\text { duction }\end{array}$ \\
\hline
\end{tabular}

${ }^{a}$ Human activity in each phase affects the habitat.

Source: U.S. Fish and Wildlife Service. 1976a. Coal project-background information (planning and management). FWS/OBS, p. 10. Washington, D.C.: Department of the Interior. U.S. Fish and Wildlife Service.

Table 1.29. Potential environmental effects resulting from the development and production phases of coal development

\begin{tabular}{|c|c|c|c|c|}
\hline \multirow{3}{*}{$\begin{array}{l}\text { Environmental } \\
\text { factors }\end{array}$} & \multicolumn{4}{|c|}{ Mining phases $^{a}$} \\
\hline & \multicolumn{2}{|c|}{ Underground mining } & \multicolumn{2}{|c|}{ Surface mining } \\
\hline & $\begin{array}{c}\text { Development and } \\
\text { construction }\end{array}$ & Production & $\begin{array}{l}\text { Development and } \\
\text { construction }\end{array}$ & Production \\
\hline Soil & $\begin{array}{l}\text { Disturbance from } \\
\text { construction of } \\
\text { ruad, shafts, } \\
\text { slopes, or drifts }\end{array}$ & $\begin{array}{l}\text { Subsidence creates } \\
\text { or destroys lakes, } \\
\text { springs, ponds, } \\
\text { marshes }\end{array}$ & $\begin{array}{l}\text { Large-scale } \\
\text { stripping of } \\
\text { surface soils and } \\
\text { compaction }\end{array}$ & $\begin{array}{l}\text { Disrupts soil structure } \\
\text { extensively }\end{array}$ \\
\hline Vegetation & $\begin{array}{l}\text { Removal in site } \\
\text { preparation } \\
\text { (including trees) }\end{array}$ & $\begin{array}{l}\text { Acid drainage kills } \\
\text { or inhibits growth }\end{array}$ & $\begin{array}{l}\text { Large-scale } \\
\text { stripping of vegetation }\end{array}$ & $\begin{array}{l}\text { Eliminates existing } \\
\text { vegetation }\end{array}$ \\
\hline Surfare water & $\begin{array}{l}\text { Frnsinn, stream } \\
\text { pollution, and } \\
\text { stream change }\end{array}$ & $\begin{array}{l}\text { Cnllapse of stream } \\
\text { beds; acid } \\
\text { drainage }\end{array}$ & $\begin{array}{l}\text { Stream diversion, } \\
\text { erosion, and sediment } \\
\text { production }\end{array}$ & $\begin{array}{l}\text { Acid mine drainage } \\
\text { and stream pollution }\end{array}$ \\
\hline Underground water & $\begin{array}{l}\text { Drainage or } \\
\text { contamination of } \\
\text { aquifers }\end{array}$ & $\begin{array}{l}\text { Change hydrology } \\
\text { (acid and trace } \\
\text { elements) }\end{array}$ & $\begin{array}{l}\text { Extensive development } \\
\text { drilling can result } \\
\text { in aquifer changes }\end{array}$ & $\begin{array}{l}\text { Extensive changes } \\
\text { possible in all } \\
\text { provinces }\end{array}$ \\
\hline Wildlife & $\begin{array}{l}\text { Disturb wildlife, } \\
\text { destroy foliage }\end{array}$ & $\begin{array}{l}\text { Disturb wildlife, } \\
\text { destroy foliage }\end{array}$ & $\begin{array}{l}\text { Destruction or } \\
\text { dispersion of some } \\
\text { species }\end{array}$ & $\begin{array}{l}\text { Loss of foliage } \\
\text { and food for fowl }\end{array}$ \\
\hline Fish & Stream pollution & $\begin{array}{l}\text { Loss or pollution } \\
\text { of streams and } \\
\text { wetlands }\end{array}$ & $\begin{array}{l}\text { Stream pollution } \\
\text { and sediment }\end{array}$ & $\begin{array}{l}\text { Acid in lakes } \\
\text { and streams }\end{array}$ \\
\hline
\end{tabular}

${ }^{a}$ Human activity in each phase affects the habitat.

Source: U.S. Fish and Wildlife Service. 1976. Coal project-background information (planning and management). FWS/OBS, p. 10. Washington, D.C.: Department of the Interior. U.S. Fish and Wildlife Service. 
Table 1.30. Potential environmental effects resulting from the postmining phase of coal development

\begin{tabular}{|c|c|c|c|}
\hline \multirow[b]{2}{*}{$\begin{array}{l}\text { Environmental } \\
\text { factors }\end{array}$} & \multicolumn{3}{|c|}{ Mining Phases $^{a}$} \\
\hline & Beneficiation & $\begin{array}{l}\text { Transportation } \\
\text { (rail, off-roâd, slurry conveyor) }\end{array}$ & $\begin{array}{c}\text { Conversion } \\
\text { (gasification, liquefaction, } \\
\text { mine mouth power) }\end{array}$ \\
\hline Soil & $\begin{array}{l}\text { Deposit of waste } \\
\text { material on surface }\end{array}$ & $\begin{array}{l}\text { Compaction and potential } \\
\text { erosion }\end{array}$ & $\begin{array}{l}\text { Site preparation and disposal } \\
\text { of waste }\end{array}$ \\
\hline Vegetation & $\begin{array}{l}\text { Waste effects on } \\
\text { vegetation }\end{array}$ & $\begin{array}{l}\text { Removal or effects of } \\
\text { drainage and pollıtinn }\end{array}$ & Removal and effects of waste \\
\hline Surface water & $\begin{array}{l}\text { Water from separation } \\
\text { process can pollute } \\
\text { streduls }\end{array}$ & $\begin{array}{l}\text { Rechannel streams or disposal } \\
\text { of slurry water }\end{array}$ & Thermal and chemical pollution \\
\hline Underground water & $\begin{array}{l}\text { Leach process water } \\
\text { intn aquifers }\end{array}$ & Minimal & Sludge pond seepage \\
\hline Wildlife & $\begin{array}{l}\text { Water use may affect } \\
\text { habitat in arid areas }\end{array}$ & $\begin{array}{l}\text { Noise of transporation can } \\
\text { drive some wildlife from } \\
\text { died }\end{array}$ & Noise and pollution \\
\hline Fish & Stream pollution & Stream pollution & Stream pollution \\
\hline
\end{tabular}

${ }^{a}$ Human activity in each phase affects the habitat.

Source: U.S. Fish and Wildlife Service. 1976. Coal project - background information Iplanning and management). FWS/OBS, p. 11. Washington, D.C.: Department of the Interior, U.S. Fish and Wildlife Service.

REFERENCES FOR SECTION 1.3

Imhoff, E. A.; Friz, I. U.; and La revers, J. R. 1976. A guide to state programs of surfacemined areas. Circular no. 731. Washington, D.C.: U.S. Geological Survey.

U.S. Congress. 1977. The surface mining control and reclamation act of 1977. Public Law 95-87. Washington, D.C.

U.S. Department of Agriculture. 1978. Rural abandoned mine program: proposed policy and procedures for implementing program. Soil Conservation Service. Fed. Regist. 43(70): 1531215318.

U.S. Department of the Interior. 1977. Surface mining reclamation and enforcement provisions. Office of Surface Mining Reclamation and Enforcement. Fed. Regist. 42(239): 62639-62716.

U.S. Uepartment of the Interior. 1978a. Surface coal mining and reclamation operations permanent regulatory program (proposed draft regulations), $386 \mathrm{pp}$. and supplements. Office of Surface Mining Reclamation and Enforcement. Washington, D.C.

U.S. Department of the Interior. 1978b. Abandoned mine land reclamation program provisions. Office of Surface Mining Reclamation and Enforcement. Fed. Regist. 43(81): 17918-17933. 


\subsection{SITE SELECTION}

As indicated in Fig. 1.13, Sect. 1.3, the four provinces with the largest coal resources are the Eastern Province, the Interior Province, the Northern Great Plains Province, and the Rocky Mountains Province. Based on coal reserves and geographic distribution, the first three provinces were selected for locating surrogate sites. The Rocky Mountains Province was not selected because of its proximity to the Northern Great Plains Province and because two environmental impact statements already exist for commercial coal gasification plants in the province.

Existing siting studies in each of the three provinces were used in selecting the surrogate sites. In addition, the availability of information in the surrogate site areas was considered. A study by Battelle entitled Technology Facility Siting Characteristics and Infrastmeture Needs was the basis for surrogate site selection in the Eastern Province (Battelle 1976). The site selection matrix ranked Mason County, West Virginia, highly as a potential site for a coal gasification plant. Siting criteria used included coal quantity and quality, water availability, land availability, transportation, pollution potential, and labor. Lewis Township in Mason County was selected as the surrogate site.

Selection of an Interior Province surrogate site was based on a study by the State of I11inois Institute for Environmental Quality entitled Potential Sites for Coal Conversion Facilities in IZZinois (Hoglund 1974). Six areas were identified as potential sites for coal gasification plants after considering requirements for coal, water, transportation, labor, waste disposal, and land use. One of these sites was in the vicinity of New Athens Township, the proposed site for the Coalcon Plant. This vicinity was therefore selected as the surrogate site for the Interior Province.

The Northern Great Plains Resources Program (Northern Great Plains Resources Program 1975) conducted extensive studies in the Northern Great Plains Province. Several potential sites for coal gasification plants were identified. The vicinity of T50N, R7IW was selected as a surrogate site for this study.

The Oak Ridge National Laboratory (ORNL) is currently working on the National Coal Utilization Analysis. As part of the analysis, the most likely areas of high-sulfur coal use in the Eastern and Central United States have been identified (Fig. 1.17). In addition, the Resource Analysis Group has developed regional siting criteria for a coal conversion facility as presented in Table 1.31 (Dobson 1977). 
ES-3856

ACCESSIBILITY TO HIGH - SULFUR COAL

$0 \quad 1.37$

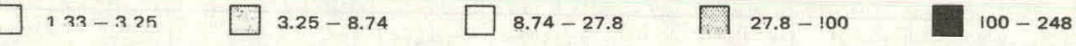

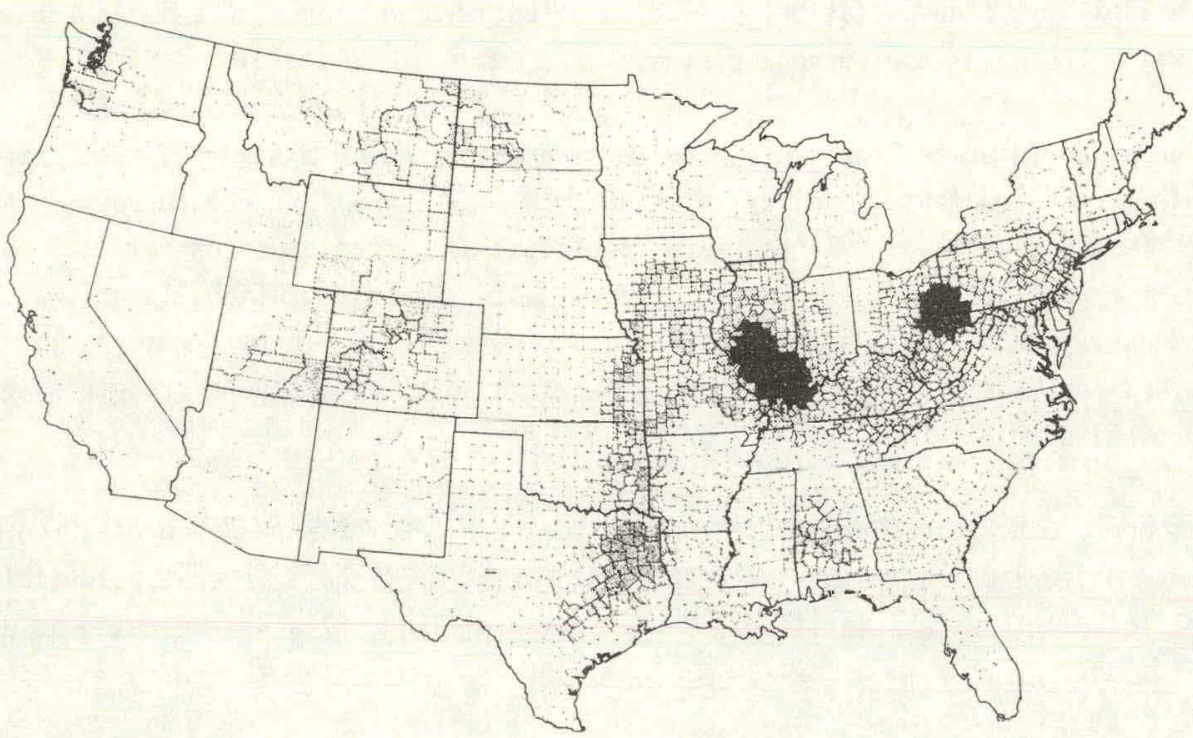

Fig. 1.17. High-sulfur coal accessibility in the United States. Source: J. E. Dobson. 1977. Regional implications of national energy scenarios: eneray capacities and water resource requirements for aggregated subareas in the eastern United States. (Draft). Oak Kidge, lenn.: Oak Ridge National Laboratory. 
Table 1.31. Regional siting criteria for a coal conversion facility

\begin{tabular}{|c|c|c|c|}
\hline Variable & $\begin{array}{l}\text { Importance } \\
\text { weight }\end{array}$ & Category or value & $\begin{array}{l}\text { mpatibility } \\
\text { index }\end{array}$ \\
\hline \multirow[t]{4}{*}{ Water availability } & 10 & $\begin{array}{l}\text { Adjacent to stream with 7-day, } \\
\text { 10-year low flow } \geqslant 194 \mathrm{Mgd}\end{array}$ & 10 \\
\hline & & $\begin{array}{l}\text { Adjacent to stream which could have } \\
7 \text {-day, } 10 \text {-year low flow } \geqslant 194 \mathrm{Mgd} \\
\text { if additional regulation were imposed }\end{array}$ & 4 \\
\hline & & Adjacent to Great Lakes & 8 \\
\hline & & $\begin{array}{l}\text { Adjacent to Atlantic Ocean or Gulf of } \\
\text { Mexico } \\
\text { Other counties }\end{array}$ & 5 \\
\hline \multirow{3}{*}{$\begin{array}{l}\text { Air quality maintenance } \\
\text { areas (AQMA) }\end{array}$} & 10 & Not an AQMA & 10 \\
\hline & & Partially an AQMA & 5 \\
\hline & & Entirely an AQMA & $a$ \\
\hline \multirow[t]{4}{*}{$\begin{array}{l}\text { Accessibility of high- } \\
\text { sulfur coal }(>1.9 \% \mathrm{~S})\end{array}$} & 10 & $\begin{array}{l}\text { Values represent calculations from gravity } \\
\text { model using tonnage of high-sulfur coal }\end{array}$ & \\
\hline & & highest value & 10 \\
\hline & & lowest value & 1 \\
\hline & & $>100$ miles from sulfur coal reserve & $a$ \\
\hline Barge accessibility & 7 & $\begin{array}{l}\text { Adjacent to channel of } \geqslant 2.7-\mathrm{m}(9-\mathrm{ft}) \\
\text { depth }\end{array}$ & $b$ \\
\hline \multirow[t]{3}{*}{ Seismic activity } & 6 & Activity Level I (lowest risk) & 10 \\
\hline & & Activity Level II & 5 \\
\hline & & Activity Level III (highest risk) & 0 \\
\hline \multirow[t]{2}{*}{ Rail accessibility } & 6 & Adjacent to medium or heavy-duty railroad & 10 \\
\hline & & $\begin{array}{l}\text { Not adjacent to medium or heavy-duty } \\
\text { railroad }\end{array}$ & 0 \\
\hline \multirow[t]{4}{*}{$\begin{array}{l}\text { Accessibility of low-sulfur } \\
\text { coal }(\leqslant 1.9 \% \mathrm{~S})\end{array}$} & 5 & $\begin{array}{l}\text { Values represent calculations from gravity } \\
\text { model using tonnage of low-sulfur coal }\end{array}$ & \\
\hline & & highest value & 10 \\
\hline & & lowest value & 1 \\
\hline & & $\begin{array}{l}>100 \text { miles from low-sulfur coal } \\
\text { reserve }\end{array}$ & a \\
\hline \multirow[t]{9}{*}{ Population density } & 3 & $90-100 \%$ of county has $\geqslant 500$ inhabitants $/ \mathrm{mi}^{2}$ & 0 \\
\hline & & $30-90 \%$ & 2 \\
\hline & & $70-80 \%$ & 3 \\
\hline & & $60-70 \%$ & 4 \\
\hline & & $\begin{array}{l}50-60 \% \\
40-50 \%\end{array}$ & $\begin{array}{l}5 \\
6\end{array}$ \\
\hline & & $30-40 \%$ & 7 \\
\hline & & $20-30 \%$ & 3 \\
\hline & & $10-20 \%$ & 9 \\
\hline & & $0-10 \%$ & 10 \\
\hline
\end{tabular}

${ }^{a}$ Excluded from consideration as potential candidate counties.

${ }^{b}$ Score equals number of kilometers (miles) of channel (maximum is $151 \mathrm{~km}$, or $94.5 \mathrm{mi}$ ).

Source: J. E. Dobson. 1977. Regional implications of national energy scenarios: energy capacities and water resource requirements for aggregated subareas in the eastern United States. (Draft). Oak Ridge, Tenn.: Oak Ridge National Laboratory. 


\section{REFERENCES FOR SECTION 1.4}

Battelle Columbus Laboratories. 1976. Technology facility siting characteristics and infrastmcture needs. Project ARC 75-183/4427 prepared for Appalachian Regional Commission, Washington, D.C.

Dobson, J. E. 1977. Regional implications of national energy scenarios: energy capacities and water resource requirements for aggregated subareas in the Eastem United States.

(Draft). Oak Ridge, Tenn.: Oak Ridge National Laboratory.

Hoglund, B. M., and Asbury, J. G. 1974. Potential sites for coal conversion facilities in IZZinois. 74-60. Chicago: Illinois Institute for Environmental Quality.

Northern Great Plains Resources Program water group report. December 1974. P1ate B-5.

Denver, Colo.: Northern Great Plains Resources Program. 


\subsection{DESCRIPTION OF NEW ATHENS TOWNSHIP IN ST. CLAIR COUNTY, ILLINOIS}

\subsubsection{Site location}

New Athens Township (Township 2S, Range 7W) is located in south-central St. Clair County in central Illinois (Fig. 2.1). The center of the township is located at about $38^{\circ} 21^{\prime} \mathrm{N}$ latitude, $89^{\circ} 52^{\prime} 30^{\prime \prime} \mathrm{W}$ longitude, or 4,248,500 m N, 250,800 m E in the UTM (Universal Transverse Mercator) grid system. The closest major metropolitan area is St. Louis, Missouri, about $40 \mathrm{~km}$ (25 miles) to the northwest. New Athens, the largest city within the township with a population of about 2000 , is located in the south-central part of the township (Fig. 2.1). Major highways crossing the township include U.S. 460 and state highway 15 across the northeast corner; state highway 13, which runs across the southern part before turning due north; and state highway 156, which runs west from the point where state highway 13 turns north (Fig. 2.1). The Illinois Central Gulf Railroad enters the township in the south-central portion and crosses to the northwest (Fig. 2.1).

The Kaskaskia River flows through the township from east to southwest. In general, the topography of the area is flat to gently rolling, with a few small hills; much of the land in the township has been strip-mined. The highest elevation in the township is $160 \mathrm{~m}(520 \mathrm{ft})$ above sea level.

\subsubsection{Geology}

\subsubsection{Coal reserves}

Coal is abundant in a six-county region adjacent to the New Athens Township of St. Clair County. Coal reserves are moderate in nearby Randolph County and large in nearby Washington County as well as in eastern St. Clair County. Although Madison, Clinton, and Perry counties are more remote from New Athens, they may be considered as potential suppliers of coal.

From the standpoint of the economics of coal production, New Athens Township is a reasible location for a pipeline gas demonstration plant. The Herrin (No. 6) coal outcrops along a northwest-southeast trend through the middle of St. Clair County (Smith and Stall 1975). To the west of its outcrop, the coal is eroded outcrop; to the east, it becomes progressively more deeply buried. Coal is available to the east in Clinton and Washington counties, but either excessive amounts of overburden must be removed (creating large spoil banks) or underground mines must be develoned.

As of $1975,794 \mathrm{~km}^{2}$ (306.4 sq miles) of coal remain to be mined in St. Clair County. On the other hand, $233 \mathrm{~km}^{2}$ (89.9 sq miles) have been mined out, including approximately $52 \mathrm{~km}^{2}$ (20 sq miles) of strip-mined coal (Jacobs 1971). 

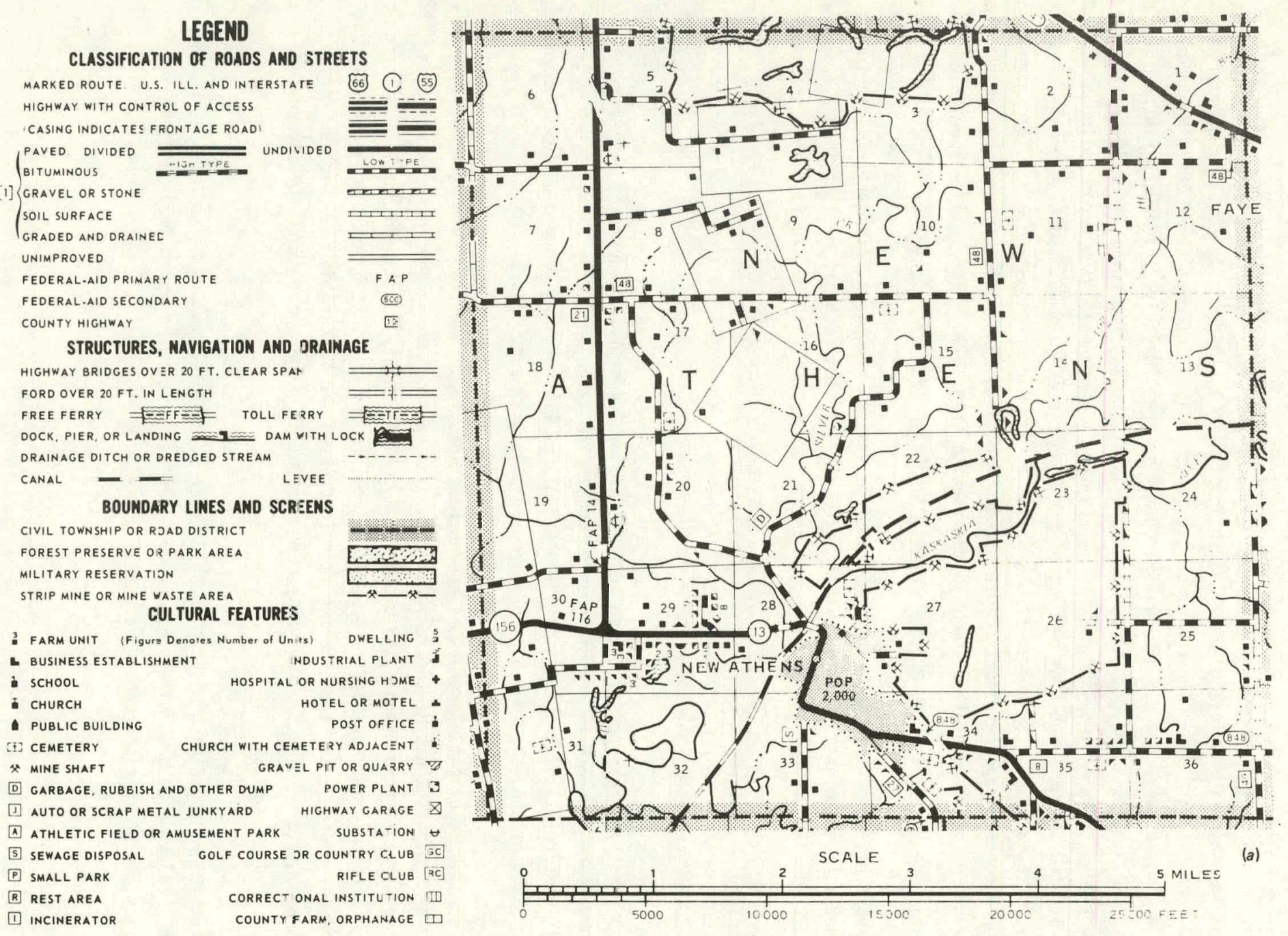

Fig. 2.1. (a) New Atrens Township, located in St. Clair County, I1linois; (b) State of I1lincis vith St. Clair County darkened.

Source: Compiled from àrea map by U.S. Geological Survey. Washington, D.C. 
A greater percentage of coal can be recovered by strip mining than by underground mining (Jacobs 1971), primarily because in underground mines, coal pillars must be left in place to support the roof. Statistics from St. Clair County show that $22 \%$ of the mined-out area was strip-mined, accounting for $69 \%$ of the county's total coal production.

In recent years strip mining has become more prevalent in St. Clair County. Table 2.1 illustrates this trend. During 1969 strip-mined coal accounted for 91\% of the county's total production (Jacobs 1971).

Table 2.1. Coal production, St. Clair County, Illinois, 1950-1969

\begin{tabular}{|c|c|c|c|c|}
\hline Year & $\begin{array}{c}\text { Mined } \\
\text { underground } \\
\text { [metric tons (tons)] }\end{array}$ & $\begin{array}{c}\text { Strip-mined } \\
\text { [metric tons (tons)] }\end{array}$ & $\begin{array}{c}\text { Total mined } \\
\text { [metric toris (toris)] }\end{array}$ & $\begin{array}{c}\text { Strip-mined } \\
(\%)\end{array}$ \\
\hline 1950 & $1,980,284(2,183,334)$ & $1,412,110(1,556,902)$ & $3,392,394(3,740,236)$ & 42 \\
\hline 1951 & $2,013,098(2,219,513)$ & $1,415,085(1,560,182)$ & $3,428,183(3,779,695)$ & 41 \\
\hline 1952 & $1,784,198(1,912,015)$ & $1,418,124(1,563,533)$ & $3,152,322(3,475,548)$ & 45 \\
\hline 1953 & $1,795,126(1,979,191)$ & $1,386,209(1,528,345)$ & $3,181,335(3,507,536)$ & 44 \\
\hline 1954 & $1,407,897(1,552,257)$ & $1,171,669(1,29.1,807)$ & $2,579,566(2,844,064)$ & 45 \\
\hline 1955 & $1,708,968(1,884,198)$ & $1,237,064(1,363,905)$ & $2,946,029(3,248,103)$ & 42 \\
\hline 1956 & $2,136,853(2,355,957)$ & $1,465,767(1,616,061)$ & $3,602,620(3,972,018)$ & 41 \\
\hline 1957 & $1,848,864(2,038,439)$ & $1.787,987(1,971,320)$ & $3,636,851(4,009,759)$ & 49 \\
\hline 1958 & $1,983,312(2,186,673)$ & $2,858,549(3,15.1,653)$ & $4,841,862(5,338,326)$ & 59 \\
\hline 1959 & $1,942,407(2,141,573)$ & $2,844,920(3,136,626)$ & $4,787,326(5,278,199)$ & 59 \\
\hline 1960 & $1,381,912(1,523,607)$ & $3,012,373(3,321,250)$ & $4,394,285(4,844,857)$ & 69 \\
\hline 1961 & $810,201(893,276)$ & $3,197,718(3,525,599)$ & $4,00.7,920(4,418,875)$ & 80 \\
\hline 1962 & $1,036,068(1,142,302)$ & $3,348,444(3,691,779)$ & $4,384,511(4,834,081)$ & 76 \\
\hline 1963 & $1,147,168(1,264,794)$ & $4,033,414(4,446,984)$ & $5,180,583(5,711,778)$ & 78 \\
\hline 1964 & $1,359,895(1,499,333)$ & $3,903,967(4,304,263)$ & $5,263,862(5,803,596)$ & 74 \\
\hline 1965 & $1,173,115(1,293,401)$ & $4,001,776(4,412,101)$ & $5,174,890(5,705,502)$ & 77 \\
\hline 1966 & $351,492(387,532)$ & $5,193,937(5,726,502)$ & $5,545,429(6,114,034)$ & 94 \\
\hline 1967 & $353,841(390,122)$ & $5,842,098(6,441,122)$ & $6,195,938(6,831,244)$ & 94 \\
\hline 1968 & $579,258(638,653)$ & $5,857,825(6,458,462)$ & $6.437,083(7,097.115)$ & 91 \\
\hline 1969 & $468,461(516,495)$ & $4,784,725(5,275,331)$ & $5,253,186(5,791,826)$ & $\theta 1$ \\
\hline Total & $27,212,417(30,002,665)$ & $60,173,760(66,343,727)$ & $87,386,177(96,346,392)$ & 69 \\
\hline
\end{tabular}

Source: A. M. Jacobs, compiler. 1971. Geology for planning in St. Clair County, Illinois. Circular 465, Urbana: Illinois State Geological Survey. (Data are from the annual coal reports for the years 1950-1969 in Coal, Oil, and Gas Reports, State of Illinois Dept. of Mines and Minerals, 1951-1970.)

In 1975 estimated reserves of coal in seams over $107 \mathrm{~cm}$ (42 in.) thick in St. Clair County were 2.1 billion metric tons (2.32. billion tons) (Smith and Stall 1975). The U.S. Bureau of Mines considers a cudl seam to be a reserve if it is greater than $46 \mathrm{~cm}$ (18 in.) thick at depths of less than $46 \mathrm{~m}(150 \mathrm{ft})$ or if it is greater than $71 \mathrm{~cm}(28 \mathrm{in.})$ thick at depths greater than $46 \mathrm{~m}(151 \mathrm{ft}$ ) (Keystone Coal Industry Manual 1976). According to the latter criteria, St. Clair County has 2.6 b1llion metric tons (2.90 billion tons) of reserves, of which 0.95 billion metric tons ( 1.05 billion tons) or $36 \%$ is considered strippable (Smith and Stall 1975). It is evident from the recent trend in mining practice (Table 2.1) that strippable coal reserves in St. Clair County will become depleted much more rapidly than will underground coal.

In the area immediately adjacent to New Athens, there is an estimated 1.1. billion metric tons (1.2 billion tons) of coal. Table 2.2 lists the reserves of the six-county region adjacent to New Athens (Smith and Stall 1975). These counties contain $6.5 \%$ of the strippable and $11 \%$ of the total coal reserves in the United States. These figures compare with $33 \%$ strippable and $10 \%$ total coal reserves for Campbell County, Wyoming (Sect. 2.3.2). 
Table 2.2. Remaining (1975) coal reserves in the six-county region adjacent to New Athens

\begin{tabular}{|c|c|c|c|}
\hline County & $\begin{array}{c}\text { Reserves }{ }^{a} \\
\text { [billions of metric } \\
\text { tons (billions of tons)] }\end{array}$ & $\begin{array}{c}\text { Strippable } \\
\text { [billions of metric } \\
\text { tons (billions of tons)] }\end{array}$ & $\begin{array}{l}\text { Percentaye } \\
\text { strippable }\end{array}$ \\
\hline Clinton & $3.44(3.79)$ & 00 & 0 \\
\hline Madison & $2.35(2.59)$ & $0.56(0.62)$ & 24 \\
\hline Perry & $2.28(2.51)$ & $0.81(0.89)$ & 35 \\
\hline Randolph & $0.54(0.60)$ & $0.34(0.38)$ & 64 \\
\hline St. Clair & $2.63(2.90)$ & $0.95(1.05)$ & 36 \\
\hline Washington & $3.73(4.11)$ & 00 & 0 \\
\hline Total & $14.97\left(16.50^{b}\right.$ & $2.66(2.94)$ & 18 \\
\hline
\end{tabular}

${ }^{a}$ Coal reserves total 1.1 billion metric tons ( 1.2 billion tons) in a six-township region adjacent to and including New Athens.

${ }^{B}$ Totals include seams more than $71 \mathrm{~cm}(28 \mathrm{in}$ ) thick at depths greater than $50 \mathrm{~m}$ (150 ft) and strippable coal more than $46 \mathrm{~cm}$ (18 in.) thick at depths less than $50 \mathrm{~m}$.

Sourca: W. H. Smith and, J. B. Stall. 1973. Caal and water resources for coal oonversion in Illinnis. !!llnols State Water Survoy Cooperative Resources report no. 4. Urbana: Illinois State Geological Surver.

Illinois coal has a competitive advantage over Western coal because of its proximity to industrial markets and an advantage over other Eastern coal because of its thickness. The average thickness of coal seams mined during 1965 in Illinois was $1.8 \mathrm{~m}(6 \mathrm{ft})$, and $95 \%$ of mined seams were thicker than $1.2 \mathrm{~m}(4 \mathrm{ft}$ ). West Virginia (Illinois' nearest Eastern competitor) coal seams are, on the average, about $0.3 \mathrm{~m}(1 \mathrm{ft}$ ) thinner than Illinois coal seams (Risser 1968).

The Herrin (No. 6) coal is the major economically exploitable deposit of St. Clair and adjacent counties (Smith and Stall 1975; Jacobs 1971). Table 2.3 1ists the currently operating coal mines near New Athens. The coal ranges in thickness between 1.2 and $2.7 \mathrm{~m}$ ( 4 and $9 \mathrm{ft}$ ) with an average of $2 \mathrm{~m}(6.5 \mathrm{ft})$. It is classified as a high-volatile $C$ bituminous rank with a calorific value ranging between 10,700 and $11,100 \mathrm{Btu} / 1 \mathrm{~b}$ (compared with $8950 \mathrm{Btu} / 1 \mathrm{~b}$ for the subbituminous WyodakAndersnn rnal of the Powder River Basin, Wyoming). Its princlpal drawback is its high silffur content ( 3 to $5 \%$ over most of St. Clatr Cuunty compared with 0 . b\% for Wyuning coal). Morthe eastern St. Clair County has estimated reserves of 0.36 billion metric tons ( 0.4 billion tons) of coal, with moderate concentrations (1 to 2.5\%) of sulfur (Jacobs 1971). Most of this coa 1 . however, is allocated for use as metallurgical coke (Jacobs 1971).

Table 2,3. Active mines near New Athens

\begin{tabular}{|c|c|c|}
\hline Mine & $\begin{array}{l}\text { Approximoto } \\
\text { distance } \\
\text { (miles) }\end{array}$ & $\begin{array}{c}1974 \\
\text { production } \\
{[\text { metric tons (țons)] }}\end{array}$ \\
\hline Paabody Coal Co. River Kino Tipple & $7-8, \mathrm{NW}$ & \\
\hline Strip mine & & $4,172,000(4,000,887)$ \\
\hline Undergground inirie & & $1,747,571(1,926,760)$ \\
\hline Peabody Coal Co. Baldwin underground & $10, \mathrm{~S}$ & $1,560,822(1,720,862)$ \\
\hline Zeigler Coal Company Spartan underground & $13, \mathrm{SE}$ & $661,091(728,877)$ \\
\hline Consolidation Coal Co. Burniny Star No. 3 strip & 15. SSE & $1,119,196(1,2.33,954)$ \\
\hline Southwestern III. Coal Corp. streamline strip & 21, SE & $1,102,353(1,215,384)$ \\
\hline Curisolidation Coal Co. Buırning Star No. 4 strip & 23, SE & $1,471,246(1,622,101)$ \\
\hline Southwestern III. Cogl Corp. Captain strip & 24, SE & $3,940,888(4,344,970)$ \\
\hline Amax Coal Co. Leahy strip & 26, SE & $2,570,560(2,834,134)$ \\
\hline Consolidation Coal Company Burning Star No. 2 strip & 29, SE & $1,004,713(1,107,733)$ \\
\hline Freeman United Coal Co. Fidelity strip & 30, SE & $1,094,675(1,206,918)$ \\
\hline Total & & $20,445,213(22,541,580)$ \\
\hline
\end{tabular}

Source: Illinois Department of Business and Economic Development. 1976. An Illinois site for coalcon clean boiler fuels project. Urbana. 
The Harrisburg-Springfield (No. 5) coal is obtained from strip mines in Randolph and Perry counties. It is slightly lower in the section than Herrin coal, so that Harrisburg-Springfield strip mines are located farther to the west. It is somewhat thinner and less abundant than Herrin coal, but other characteristics are similar (Jacobs 1971).

\subsubsection{Regional geology of the 11 linois Basin}

St. Clair County is located on the southwest boundary of the Eastern Interior Coal Field (Fig. 2.2). Strip mines of Herrin (No. 6) coal are located immediately inside this boundary (Smith and Stall 1975).

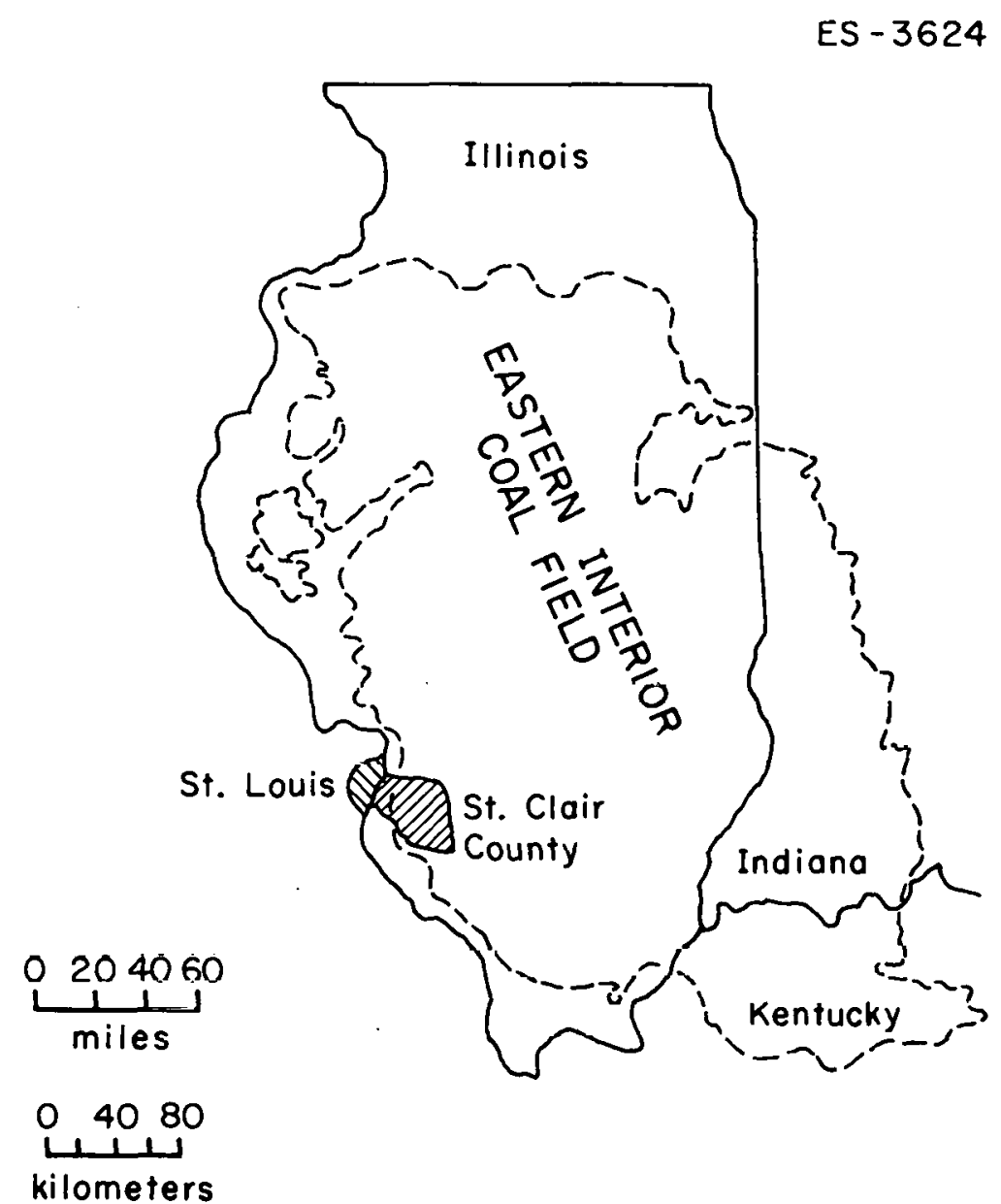

Fig. 2.2. The eastern interior coal field of the Illinois Basin. Source: W. H. Smith and J. B. Stail. 1975. Coal and water resources for coal conversion in IZlinois. Illinois State Water Survey Cooperative Resoures report no. 4. Urbana: Illinols State Geological Survey. 
The Illinois Basin roughly coincides with the Eastern Interior Coal Field. The Paleozoic section of the Illinois Basin is thickest in southeastern Illinois where the base of the Mississippian shales lies about $1500 \mathrm{~m}(4800 \mathrm{ft})$ below sea level. Beneath the Mississippian lie $1100 \mathrm{~m}$ $(3700 \mathrm{ft}$ ) of Ordovician to Devonian age carbonate rocks with some shale and about $600 \mathrm{~m}(2000 \mathrm{ft})$ of Cambrian sandstone, shale, and carbonate rocks. Depth to the pre-Cambrian basement is about $4300 \mathrm{~m}(14,000 \mathrm{ft})$ in White and Wayne counties in the center of the I1linois Basin (Eardley 1951; Heigold 1968).

In St. Clair County, the basement lies between 900 and $1800 \mathrm{~m}$ (3000 and $6000 \mathrm{ft}$ ) deep; it is more nearly $1500 \mathrm{~m}(5000 \mathrm{ft})$ deep in the New Athens region. The Herrin coal is about $300 \mathrm{~m}$ (1000 ft) higher structurally in St. Clair County, and the combined thickness of the Ordovician to Devonian section is $600 \mathrm{~m}(2000 \mathrm{ft})$ less than it is in the center of the Basin. Paleozoic strata become thinner toward the west, pinching out or eroding out against the Ozark Dome in southeastern Missouri where prè-lambrian basement rocks are expused (Smilli drid jlali 1971'; Jacubs 1971).

The general structure of the Illinois Basin is illustrated by depth contours on the Herrin coal (Fig. 2.3), which is easily identified in the subsurface. Although the center of the basin may be farther south in Wayne, Hamilton, and White counties (Eardley 1951), more recent data suggest that the Pennsylvanian section is thickest in Jasper County (Smith and Stal1 1975; Eardley 1951).

The Herrin coal seam is minable virtually throughout the Illinois Basin (Smith and Stal1 1975). It is considered to be economically exploitable to a depth of about $300 \mathrm{~m}(1000 \mathrm{ft})$. The Herrin coal is shallower than $300 \mathrm{~m}(1000 \mathrm{ft})$ except in the deepest part of the Illinois Basin. Illinois coal seams dip about $2 \mathrm{~m}$ per kilometer ( $10 \mathrm{ft}$ per mile); they therefore remain close to the surface for many miles beyond their area of outcrop. In contrast, the Wyodak-Anderson coal bed of the eastern Powder River Basin (Sect. 2.3.2) dips at a rate of 2 to $20 \mathrm{III}$ per kilometer (10 to $100 \mathrm{ft}$ per mile) and is deeply buried within $16 \mathrm{~km}$ ( $10 \mathrm{miles}$ ) of its area of outcrop.

The most prominent geologic structure is the La Salle anticline along the eastern margin of the Illinois Basin. Structural relief on the La Salle anticline ranges between 270 to $430 \mathrm{~m}$ ( 900 and $1400 \mathrm{ft}$ ) above the adjacent basins. Most of the deformation (which was mild) took place from late Mississippian through Pennsylvanian time. Pennsylvanian strata are slightly folded over the axis of the anticitine, suggesting that sone defurmation might have been pust=Pennsylvanian in age (Smith and Stall 1975; Eardley 1951).

Ot.her structures worthy of note are the Lincoln and Dupo-Waterloo anticlines, the Cap au Grés faulted flexure, the Ste. Genevieve fault zone, and the Du Quoin monocline. All of these structures lie within $31 \mathrm{~km}$ (50 miles) of St. Clair County. They were deformed at various times between Devonian and Pennsylvanian time (Smith and Stal1 1975; Eardley 1951).

A number of oil and gas fields and potential gas storage areas are located along the DupoWaterloo anticline in St. Clair County. Coal can neither be mined within $46 \mathrm{~m}(150 \mathrm{ft})$ of an oil well nor above a gas storage area. Gas storage areas might eventually provide convenient depositories for the products of coal-gas conversion, being stored in the summer for peak use in the winter (Smith and Stall 1975; Jacobs 1971). 


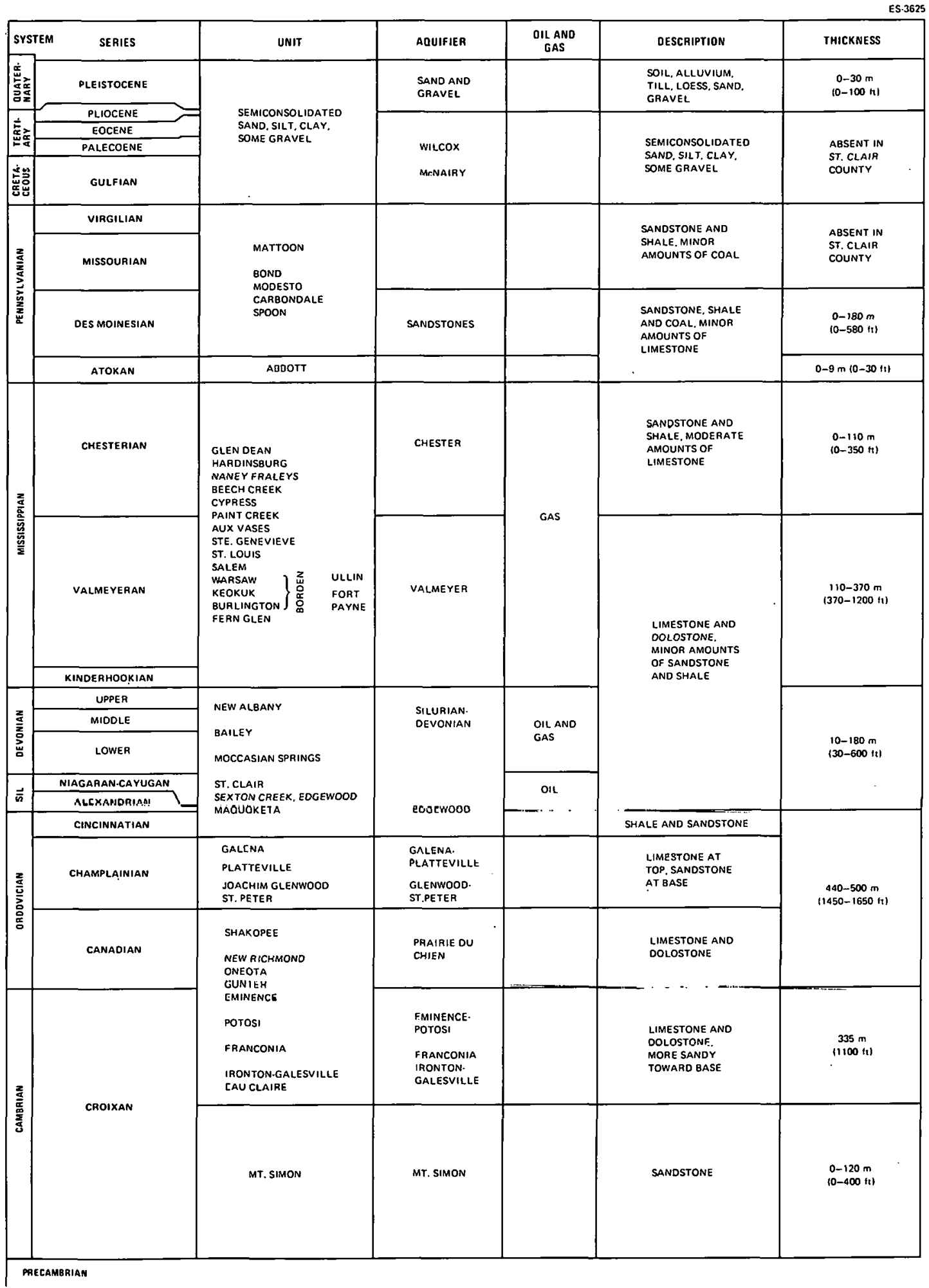

Fig. 2.3. Geologic column of Illinois. The position of the major aquifers and oil and gas production are indicated. Sources: (1) W. H. Simith and J. B. Stall. 1975. Coal and water resources for coal conversion in Illinois. Illinois State Water Survey Cooperative Resources rcport no. 4. Urbana: Illinois State Geological Survey; (2) A. M. Jacobs, compiler: 1971. Geology for plannirly in St. Clair County, ILlinois. Cireular no. 465. Urbana: Illinois State Geological Survey. 
The Rough Creek fault zone and Mississippi embayment are notable structures because of their historical records of seismicity. The Mississippi embayment is a particularly aclive seismic zone. Earthquake risk will be discussed in more detail in a later section (Nuttli 1974).

\subsubsection{Stratigraphy}

Figure 2.3 lists the stratigraphic units of Illinois. Major occurrences of oil, gas, and groundwater are also indicated (Smith and Stall 1975; Jacobs 1971).

In New Athens Township, St. Clair County, the section between the Des Moinesian and Pleistocene series is absent. These post-Pennsylvanian strata are eroded out in St. Clair County, and the younger Pennsylvanian strata are progressively exposed toward the center of the Illinois Basin. Crecaceous and younger strata overiap the eroded southern margin of the basin in the Mississippi embayment region of extreme southern I1linois (Smith and St.all 1975: Jasobs 1971).

$0 i 1$ and gas have been produced in St. Clair County from several rock units. From the bottom to the top of the section these units are:

$\quad$ System
Mississippian
Mississippian
Silurina
Ordovician

\section{Formation or unit}

Cypress sandstone (gas)
Aux Vases sandstone (gas)
Niagaran reefs (oil and gas)
Galena limestone (oil)

Aux Vases sandstone (gas)

Galena limestone (oil)

None of these reservoirs are prolific producers, and most of the wells are either abandoned or shut in at the present time (Jacobs 1971).

A number of units throughout the section are water bearing (Fig. 2.3). However, except for the alluvium of major stream valleys, production is small and the water quality is generally poor. Groundwater is discussed in greater detail in Sect. 2.1.3.

A detailed stratigraphy of the Des Moinesian series (Pennsylvanian system) follows. Most of the coal of the Illinois Basin is derived from the Carbondale formation of the Des Moinesian series. Each cual bed is part of what geologișts from the coal fields of Pennsylvania have popularized as a "cyclothem." Each cyclothem hegins with a marine environment (characterized by the deposition of limestone), which gives way to tidal flat-swamp and deltaic environment.s. The latter environments shift back and forth as the delta shifts its position. Strata that are characteristic of these environments are lacustrine clays and shales, coal hers, channel sands, and (during a period of subaerial erosion) palesols, ancient soils that are often referren to as fireclays or underclays (Smith and Stall 1975).

A new cyclothem begins with the return of a marine environment. Marine conditions may result from rising sea level or a subsiding landmass.

The stratigraphy of the Des Moinesian section has practical importance because of its effect on coal mining operations. Most of the strata (except limestone) are not completely lithified. Although they are not as poorly consolidated as similar but younger strata (such as in the Powder River Basin of Wyoming; Sect. 2.3.2), they are subject to rapid erosion in strip mines 
and to roof collapse in underground mines. If a coal seam is overlain by limestone, the roof is less likely to collapse. Furthermore, a limestone unit that lies beneath the base of a coal seam in a strip mine is more erosion resistant than other rock types. In some places, part or all of a coal seam was eroded out before deposition of a channel sand.

Two serious consequences are produced by channel sands. Their presence results in a reduction in coal production and the threat of roof collapse. Many mine injuries and deaths are caused by roof collapse, which is not as spectacular as methane-dust explosions but dangerous nevertheless. For unknown reasons, low-sulfur coal is usually found near channel sands. Except in the northeast corner of St. Clair County, channel sands do not crosscut the coal seams, and limestone often forms the roof of underground mines. Roof conditions are general satisfactory in St. Clair County, at least by comparison with other coal mining districts (Smith and Stall 1975; Jacobs 1971).

\subsubsection{Tectonic history and seismicity}

During lower Paleozoic pre-Devonian time (greater than 345 million years ago), the Illinois Basin was part of a much larger basin that included the Michigan Basin. Gentle subsidence took place during lower Paleozoic time, and up to $1500 \mathrm{~m}$ (5000 ft) of shallow marine (mainly carbonate) sediments were deposited in the center of the basin. The Kankakee Arch of northern I11inois and Indiana began to rise during Devonian time, and the Illinois and Michigan basins continued to subside separately. An additional $1800 \mathrm{~m}$ (6000 ft) of Devonian, Mississippian, and Pennsylvanian strata accumulated as the region was transformed from a shallow submergent environment to a slightly emergent landmass (Eardley 1951).

Earthquakes have occurred in historical time, especially in southern Illinois. No historical earthquakes are known to be correlated with any structures except perhaps the Rough Creek fault zone and the Mississippi embayment (Nuttli 1974).

According to Alyermissen (1968), St. Clair County is part of a zone of moderate earthquake activity that surrounds a major earthquake zone near the northern edge of the Mississippi embayment (Fig. 2.4). The major earthquake zone, referred to as the New Madrid fault zone by some geologists, is more appropriately called the central Mississippi Valley seismic region by Nuttli in order to include the Ruuyh Creek tault zone (Nuttli 1974; Algermissen 1968).

The only major historic earthquakes were the New Madrid earthquakes of 1811-1812, 1ocated about $160 \mathrm{~km}$ (100 miles) south of New Athens. According to Nuttli (1974), the intensity of the New Madrid earthquake of December 16, 1811, was between X and XI on the modified Mercalli intensity scale (Table 2.4). This earthquake had an intensity of between VIII and IX in the Cape Girardeau, Missouri, region and between VII and VIII in the St. Louis region. New Athens lies about midway between St. Louis and Cape Girardeau. The earthquake intensity experienced at New Athens was probably very close Lu VIII (Table 2.4), strong enough to cause moderate damage (Nuttli 1974).

The most recent damaging earthquake occurred in southern I1linois on November 9, 1968. Its epicenter was in White County (the deepest part of the Illinois Basin) about $24 \mathrm{~km}$ (15 miles) northwest of the intersection of the Rough Creek, Wabash Valley, and Cottage Grove fault systems. Minor damage occurred in St. Clair County, ahout $160 \mathrm{~km}$ (100 milcs) to the nur.lhwest. In the 


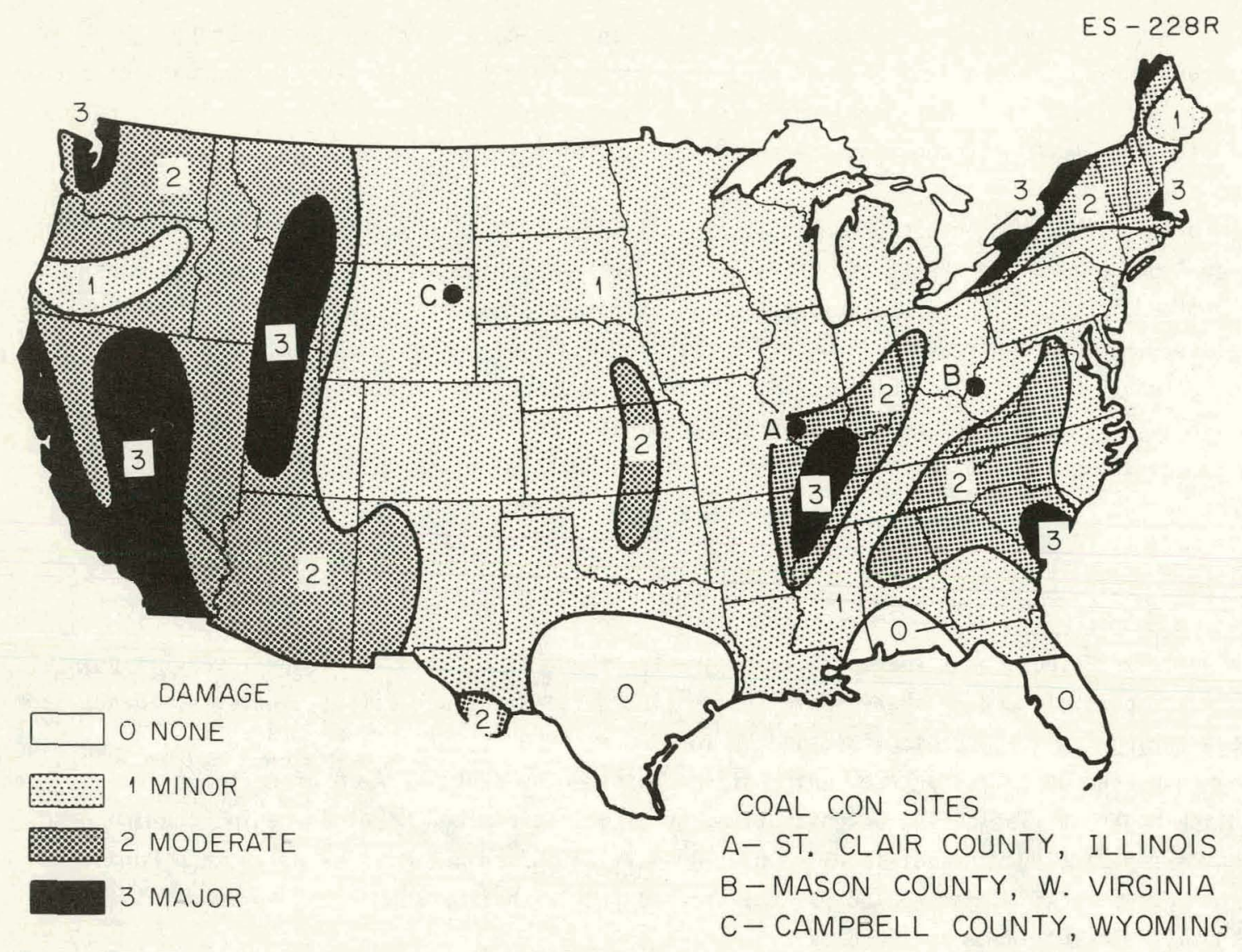

Fig. 2.4. Seismic risk map of the United States. Source: S. T. Algermissen. 1968. Imited States earthquakes. Washington, D.C.: U.S. Government Printing Office.

epicentral region some chimneys fell, tacings on a number of buildings were damaged, plaster and foundations cracked, and plate glass windows were shattered. A maximum intensity of VII was assigned to the earthquake. Roof falls occurred in a number of underground coal mines in a three-county region of southern Illinois (Heigold 1968).

Nuttli calrulated the recurrence rate for earthquakes in Lle central Mississippi Valley seismic region as a whole. His calculations show that within this $250,000 \mathrm{~km}^{2}$ (96,000 sq miles) (imluding Now Athens), the recurrence interval fur an earthquake of between 6.2 and 6.6 magnitude (VIII < I < IX) is 100 and 130 years by the maximum likelihood and weighted least-squares methods respectively (Nuttli 1974).

Algermissen and Perkins (1976) provide recurrence-rate data for the most active part of the central Mississippi Valley seismic region, the New Madrid fault zone. According to their calculations, there is a $90 \%$ probability that horizontal acceleration will not exceed $0.19 \mathrm{~g}$ (an earthquake of intensity VIII is roughly equivalent to $0.20 \mathrm{~g}$ ) over a time interval of 50 years (A1germissen and Perkins 1976).

New Athens, Illinois, is not located in the most active part of the central Mississippi Valley seismic region (Nuttli 1974; Algermissen 1968). Therefore, Algermissen's estimate may be regarded as conservative. Even Nuttli's predictions are probably conservative for New Athens. 
Table 2.4. Modified Mercalli Intensity Scale of 1931 (abridged)

\begin{tabular}{|c|c|}
\hline Intensity rating & Description of severity \\
\hline 1 & Not felt except by a very few under especially favorable circumstances. \\
\hline II. & $\begin{array}{l}\text { Felt only by a few persons at rest, especially on upper floors of buildings. Delicately suspended } \\
\text { objects may swing. }\end{array}$ \\
\hline III. & $\begin{array}{l}\text { Felt quite noticeably indoors, especially on upper floors of buildings, but many people do not } \\
\text { recognize it as an earthquake. Standing motorcars may rock slightly. Vibration like passing of } \\
\text { truck. Duration estimated. }\end{array}$ \\
\hline IV. & $\begin{array}{l}\text { During the day, felt indoors by many, outdoors by few. At night, some awakened. Dishes, win. } \\
\text { dows, doors disturbed; walls make creaking sound. Sensation like heavy truck striking building. } \\
\text { Standing motorcars rocked noticeably. }\end{array}$ \\
\hline v & $\begin{array}{l}\text { Felt by nearly everyone, many awakened. Some dishes, windows, etc., broken; a few instances } \\
\text { of cracked plaster; unstable objects overturned. Disturbances of trees, poles, and other tall ob- } \\
\text { jects sometimes noticed. Pendulum clocks may stop. }\end{array}$ \\
\hline VI. & $\begin{array}{l}\text { Felt by all, many frightened and run outdoors. Some heavy furniture moved; a few instances } \\
\text { of fallen plaster or damaged chimneys. Damage slight. }\end{array}$ \\
\hline VII & $\begin{array}{l}\text { Everybody runs outdoors. Damage negligible in buildings of good design and construction; slight } \\
\text { to moderate in well-built ordinary structures; considerable in poorly built or badly designed } \\
\text { structures; some chimneys broken. Noticed by persons driving motorcars. }\end{array}$ \\
\hline VIII & $\begin{array}{l}\text { Damage slight in especially designed structures; considerable in ordinary, substantial buildings, } \\
\text { with partial collapse; great in poorly built structures. Panel walls thrown out of frame structures. } \\
\text { Fall of chimneys, factory stacks. columns, monuments, walls. Heavy furniture overturned. Sand } \\
\text { and mud ejected in small amounts. Changes in well water. Persons driving motorcars disturbed. }\end{array}$ \\
\hline $1 \mathrm{X}$ & $\begin{array}{l}\text { Damage considerable in especially designed structures; well-designed frame structures thrown out } \\
\text { of plumb; great in substantial buildings, with partial collapse. Buildings shifted off foundations. } \\
\text { Ground cracked conspicuously. Underground pipes broken. }\end{array}$ \\
\hline$x$ & $\begin{array}{l}\text { Some well-built wooden structures destroyed; most masonry and frame structures destroyed with } \\
\text { their foundations; ground badly cracked. Rails bent. Landslides considerable from river banks and } \\
\text { steep slopes. Shifted sand and mud. Water splashed (slopped) over banks. }\end{array}$ \\
\hline $\mathrm{XI}$. & $\begin{array}{l}\text { Few, if any, (masonry) structures remain standing. Bridges destroyed. Broad fissures in ground. } \\
\text { Underground pipelines completely out of service. Earth slumps and land slips in soft ground. } \\
\text { Rails bent greatly. }\end{array}$ \\
\hline$x \| 1$ & $\begin{array}{l}\text { Damage total. Wavos seen on grouitd suifaces. LInes of sight and level distorted. Objects thrown } \\
\text { upward into air. }\end{array}$ \\
\hline
\end{tabular}

Source: S. T. Algermissen .1968. United States Earthquakes. Washington, D.C.: U.S. Government Printing Office.

Seismologists are currently unable to predict recurrence rates for destructive earthquakes such as those of 1811-1812 because of their infrequent occurrence. Nevertheless, experience indicates that major earthquakes originating along the New Madrid fault zone are capable of causing moderate to extensive damage in the New Athens region (Nuttli 1974).

\subsubsection{Hydrology}

\subsubsection{Surface water}

\section{Drainaye area}

The surface waters of the New Athens site area are drained by the Kaskaskia River and its tributaries. The Kaskaskia River drainage basin, which has an area of approximately $13,000 \mathrm{~km}^{2}$ (5000 sq miles), has a very low density of permanent tributaries. The principal drainage is provided by a vast network of wetlands and intermitlent streams. Surface runoff supplies the wetlands and numerous ponds, many of which are the result of extensive strip mining. 
The major tributaries that feed the Kaskaskia River upstream of New Athens are Mud Creek and Shoal Creek. Downstream of the site area, the Kaskaskia is fed by Silver and Richland creeks. Along the Kaskaskia the USGS has placed numerous gaging stations providing extensive historical data on the behavior of the river. Two large reservoirs (Carlyle Reservoir and Lake Shelbyville) are located on the river upstream of the site area. Carlyle Reservoir has a capacity of $3.5 \times 10^{8} \mathrm{~m}^{3}(280,000 \mathrm{acre}-\mathrm{ft})$ and is fed by Lake Shelbyville, which has a capacity of $2.6 \times 10^{8} \mathrm{~m}^{3}(210,752$ acre- $\mathrm{ft})$. Carlyle Reservoir is operated to legally maintain a minimum flow on the Kaskaskia of $1.4 \mathrm{~m}^{3} / \mathrm{sec}(49.5 \mathrm{cfs})$. Since the construction of the reservoir, the average flow has been $74 \mathrm{~m}^{3} / \mathrm{sec}(2612 \mathrm{cfs})$. Both reservoirs are used for water supply (industrial and municipal), recreation, and low-flow augmentation.

The Kaskaskia River has been altered to permit navigation to Fayetteville, which is upstream of New Athens. The channel has a depth of $2.7 \mathrm{~m}(9 \mathrm{ft})$ at normal flows, a bed width of $69 \mathrm{~m}$ $(225 \mathrm{ft})$, and a surface width of $91 \mathrm{~m}(297 \mathrm{ft})$. The construction of the channel has resulted in the normal water surtace being màinealned at 112 III (388 $\mathrm{rL}$ ) M3L, leveés also have becn con structed along the river to prevent flooding.

Surface water availability

The Kaskaskia River is monitored by the USGS upstream and downstream of the proposed pipeline gas demonstration plant site. Station records exist downstream at New Athens and upstream at Venedy Station to provide a river flow history. River events on the Mississippi cause backwater effects on the Kaskaskia which cause shifts in the stage-discharge relation. Also prevalent are shifts caused by a rapidly changing stage from flood waves. The recent modification to the river by the Kaskaskia Navigation Channel has resulted in changes that must be considercd in making forecasts.

The historical records for the Kaskaskia indicate a seven-day, once-in-ten-years $\left({ }_{7} Q_{10}\right)$ low flow of $2.6 \mathrm{~m}^{3} / \mathrm{sec}$ (93 cfs) at New Athens since the construction of the Carlyle Reservoir in 1967. Prior to the reservoir, the $7_{7} Q_{10}$ was $1.8 \mathrm{~m}^{3} / \mathrm{sec}(62.5 \mathrm{cfs})$ at New Athens. Prior to the low-flow augmentation of the Carlyle Reservoir, the one-day low flow was $0.99 \mathrm{~m}^{3} / \mathrm{sec}$ ( $35 \mathrm{cfs}$ ) at New Athens. Based on figures obtained since 1967 at New Athens, the maximum mean average discharge is $695 \mathrm{~m}^{3} / \mathrm{sec}(24,554 \mathrm{cfs})$, the minimum mean average discharge is $4.4 \mathrm{~m}^{3} / \mathrm{sec}$ (157 cfs), and the mean average discharge is $91 \mathrm{~m}^{3} / \mathrm{sec}(3209 \mathrm{cfs})$. The flood of record for New Athens $(121.6 \mathrm{~m}$; $398.8 \mathrm{ft}$ MSL) was established prior to the reservolr's construction. Since the reservoir's completion, the flood of record was $119 \mathrm{~m}(390.4 \mathrm{ft}) \mathrm{MSL}$. The Curps of Engineers and the State of Illinois have agreed to maintain the normal water surface elevation at $112 \mathrm{~m}(368 \mathrm{ft}$ ) MSL and the minimum flow rate of the river, controlled by Carlyle Reservoir, at $1.4 \mathrm{~m}^{3} / \mathrm{sec}(49.5 \mathrm{cfs})$. As a result of the navigation project, the river channel 15 stable and maintained by the lorps of Engineers for navigational use.

A low-flow augmentation agreement exists to maintain aquatic life and to provide for the downstream demand. Forecasts fur duwnstieam industrial and municipal demand are set at $5.86 \mathrm{~m}^{3} / \mathrm{ser}$. (207 cfs) for 1980. Upstream of the site, an excess of $1.8 \mathrm{~m}^{3} / \mathrm{sec}$ (62 cfs) is indicated for use according to the State of Illinois. Additional surface water availability could be generated by the construction of more reservoirs. Sites exist on which these additional reservoirs could be located. Recent studies, based on 40-year drought calculations, indicate that within 
the Kaskaskia River basin additional reservoir capacity could supply flows of about $14 \mathrm{~m}^{3} / \mathrm{sec}$ (500 cfs). Such a flow would require a large number of reservoirs to be built (Kaskaskia River Watershed Act 1972).

The State of 117 inois has established riparian water rights but has not established restrictions on consumptive use. The Ohio River Basin Commission has established consumptive water use for power production at $10 \%$ of the ${ }_{7} Q_{10}$ low flow. This is generally adhered to along the Ohio River. If this legislative concept is adopted by Illinois, a supply of $0.3 \mathrm{~m}^{3} / \mathrm{sec}$ ( $9.3 \mathrm{cfs}$ ) will be available for consumptive use for pipeline gas at the New Athens site. With an efficient use of water, an adequate supply of surface water will be available for the New Athens site.

\subsubsection{Groundwater hydrology}

Groundwater in the New Athens-Fayetteville area is a subdued replica of regional topography. Groundwater leveis are at a higher elevation in upland areas than in lowland areas adjacent to the Kaskaskia River and other perennial streams. Shallow wells dug in the area indicate that groundwater on the nearby upland is commonly encountered 4.6 to $7.6 \mathrm{~m}$ (15 to $25 \mathrm{ft}$ ) below the surface but usually stabilizes at shallower levels. Groundwater levels in the region are influenced by the combined pumping of 1.5 to $3 \mathrm{Mgd}$. from the active strip pit and the long pond, which is necessary to prevent flooding of the mining pits. Dewatering the active strip pit results in groundwater flow into the pit, thereby altering the natural direction of the groundwater flow toward the Kaskaskia River.

Groundwater in the New Athens township is available from both unconsolidated and consolidated formations. Deposits of sand and gravel [up to $12 \mathrm{~m}(40 \mathrm{ft})$ thick] belonging to the Henry and Pearl formations are present in the Kaskaskia River floodplain and adjacent terraces and sand hills. Large quantities of water are available from relatively shallow wells, drilled to depths of less than $91 \mathrm{~m}(300 \mathrm{ft}$ ) (Smith and Stall 1975). According to the Illinois State Geological Survey, these deposits of sand and gravel are capable of well yields of up to $0.000 \mathrm{~m}^{3} / \mathrm{sec}$ $(100 \mathrm{gpm})$, although smaller yields such as $0.0003 \mathrm{~m}^{3} / \mathrm{sec}(5 \mathrm{gpm})$ are more likely. Nevertheless, many shallow, large-diameter domestic wells that rely on storage within the well are present in these low-yield areas. Wells in Solver Creek Valley near Lebanon and Mascoutah have produced $0.006 \mathrm{~m}^{3} / \mathrm{sec}(100 \mathrm{gpm})$, although yields of more than $0.001 \mathrm{~m}^{3} / \mathrm{sec}(20 \mathrm{gpm})$ are relatively rare (Jacobs 1971).

Sandstone and limestone beds yield small quantities of groundwater. Although individual wells in these rocks yield less than $0.002 \mathrm{~m}^{3} / \mathrm{sec}(25 \mathrm{gpm})$, they are the source of water for rural, domestic, and industrial and small municipalities. The average depth of wells in Pennsylvanian rocks is about $52 \mathrm{~m}(170 \mathrm{ft})$, and that in Mississippian rock is about $76 \mathrm{~m}(250 \mathrm{ft})$. Many wells in these formations are about 15 to $30 \mathrm{~cm}$ ( 6 to $12 \mathrm{in.}$ ) in diameter and produce less than $0.001 \mathrm{~m}^{3} / \mathrm{sec}(20 \mathrm{gpm})$. The upland surficial deposits are generally unproductive and produce less than $0.0003 \mathrm{~m}^{3} / \mathrm{sec}$ ( $5 \mathrm{gpm}$ ) (Jacobs 1971).

Groundwater is a relatively scarce commodity throughout most of St. Clair County. Only in the Mississippi River floodplain are large quantities of both surface and groundwater readily available; therefore, maximum use of both surface and groundwater must be made. Groundwater development in the area is often restricted by the presence of highly mineralized water at relatively shallow depths. 


\section{1 .4 Water quality}

\subsubsection{Surface water}

The Kaskaskia River has been monitored regularly for water quality between Fayetteville and New Athens by the USGS, Illinois EPA, and others. The results of two major water quality. studies are included in Table 2.5. The river reach does not contain any major point-source discharges. At the ${ }_{7} Q_{10}$ low flow of the river, about $8 \%$ of the water is wastewater. The majority of the surface drainage is due to agricultural use upstream of New Athens.

Table 2.5. Kaskaskia River water quality data

\begin{tabular}{|c|c|c|c|c|c|}
\hline Paramutur & Inits & Average & Rangr: & $\begin{array}{c}\text { Number of } \\
\text { tests }\end{array}$ & 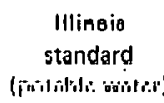 \\
\hline Temperature & ${ }^{\circ} \mathrm{C}\left({ }^{\circ} \mathrm{F}\right)$ & $14.4(57.9)$ & $34-82$ & 70 & $63-93$ \\
\hline $\mathrm{pH}$ & & 7.8 & $7.3-8.3$ & 72 & $6.5-9$ \\
\hline Dissolved solids & $\mathrm{mg} /$ liter & 255 & $78-460$ & 65 & 500 \\
\hline Dissolved oxygen & $\mathrm{mg} / \mathrm{liter}$ & 8.7 & $3.0-14.3$ & 89 & 5 \\
\hline Ammonia-nitrogen & mg/liter & 0.09 & $0.01-0.5$ & 68 & 1.5 \\
\hline Phosphorous & $\mathrm{mg} / \mathrm{liter}$ & 0.30 & $0.02-1.2$ & 70 & 0.05 \\
\hline Phenol & $\mu g / l i t e r$ & 5.5 & $0-20$ & 46 & 100 \\
\hline Cyanide & $\mu \mathrm{g} /$ liter & 0 & $0-\dot{0}$ & 13 & 10 \\
\hline Iron & $\mathrm{mg} /$ liter & 2.7 & $0.7-12$ & 13 & 0.3 \\
\hline Manganese & $\mathrm{mg} /$ liter & 0.42 & $0.8-1.4$ & 13 & 0.05 \\
\hline Boron & $\mathrm{mg} / \mathrm{liter}$ & 0.1 & $0-0.2$ & 9 & 1 \\
\hline Fecal coliform & Number per $100 \mathrm{ml}$ & 300 & $10-2500$ & 57 & 200 \\
\hline Chloride & mg/liter & 211.4 & $8-33$ & 21 & 250 \\
\hline Sulfate & mg/liter & 75 & $42-150$ & 21 & 250 \\
\hline Flouride & mg/liter & 0.17 & $0.2-0.9$ & 11 & 1.4 \\
\hline Nițrațe nitrogen & mgg/litèr & 0.98 & $0.0-3.2$ & 73 & 10 \\
\hline Cadmium & mg/liter & 0 & $0-001$ & 15 & 0.05 \\
\hline Chromium & mg/liter & 0 & $0-0$ & 15 & 0.05 \\
\hline Copper & mg/liter & 0.01 & $0.002-0.05$ & 10 & 0.02 \\
\hline Lead & $\mathrm{mg} /$ liter & 0.02 & $0.0-0.4$ & 16 & 0.05 \\
\hline Mercury & $\mathrm{mg} /$ liter & 0 & $0-0$ & 16 & 0.5 \\
\hline Selenium & $\mu \mathrm{g} / \mathrm{liter}$ & 0 & $0-0$ & 16 & 10 \\
\hline Ziric & $\mathrm{mg} / \mathrm{liter}$ & 0.01 & 0.0 .1 & 16 & 1 \\
\hline
\end{tabular}

Sources: (1) Illinois State Department of Business and Economic Development Divisiun of Erleryy. 1976. An Illinois site for Coalcon clean boiler fuels project. New Athens, IIl.; (2) Coalcon: environmental

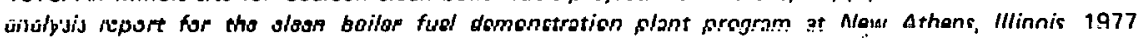
Prepared for the Energy Research and Development Administration, Division of Fossil Demonstration Plants. West Chiester, Pa.. Ruy F̄. Westuiı, lır.

The water quality standards established by the state are satisfied with some exceptions: phosphorous, iron, manganese, and fecal coliform average values are above the established standards of the State of Illinois, and the standards are occasionally exceeded for dissolved oxygen. Although the water quality standards are exceeded on several counts, no major water quality problems are indicated by state authorities. 


\subsubsection{Groundwater quality}

The shallow subsurface glacial aquifer in the New Athens area supplies many residents with potable water. The water quality of groundwater varies considerably (Jacobs 1971). Generally, water is saline (>250 ppm chloride) below a depth of $150 \mathrm{~m}(500 \mathrm{ft}$ ). Total dissolved solids alsn increase with depth and attain a value of 50,000 to $80,000 \mathrm{ppm}$ in rock units found about 300 to $600 \mathrm{~m}$ ( 1000 to $2000 \mathrm{ft}$ ) below the surface.

Groundwater from shallow unconfined formations is generally less mineralized than groundwater from bedrock formations and provides rural residents with drinking water. A summary of groundwater quality in unconfined aquifers within $24 \mathrm{~km}$ (15 miles) of New Athens is given in Table 2.6. These values were based on 12 samples (Jacobs 1971). Generally, the groundwater in the East St. Louis area is of fairly good quality, as shown in Table 2.6.

\begin{tabular}{|c|c|c|}
\hline Parameter & Range & Median \\
\hline \multicolumn{3}{|c|}{ New Athens area } \\
\hline Total dissolved solids, ppm & $364-2608$ & 506 \\
\hline Hardness, ppm & $58-1280$ & 363 \\
\hline Chloride, ppm & $5-475$ & 26 \\
\hline Iron, ppm & $0-37$ & 35 \\
\hline \multicolumn{3}{|c|}{ East St. Lou is area ${ }^{a}$} \\
\hline Total dissolved solids, ppm & & 515 \\
\hline Hardness, ppm & & 429 \\
\hline Alkalinity, ppm & & 307 \\
\hline Iran, mg/liter & & 13.4 \\
\hline Manạgneșe, mg/liter & & 1.0 \\
\hline Chloride, mg/liter & & 43 \\
\hline Fluorine, mitliter & & 0.3 \\
\hline Nitrate, $\mathrm{mg} / \mathrm{liter}$ & & 7.9 \\
\hline Sulfate, $\mathrm{mg} /$ liter & & 72 \\
\hline Temperature, ${ }^{\circ} \mathrm{F}$ & & 56.4 \\
\hline
\end{tabular}

The values of selected parameters of groundwater quality from eight wells at the Coalcon site in the New Athens area indicate that the total dissolved solids vary (in ppm) from 364 to 2376 , hardness from 3 to 1040, chloride from 5 to 970, iron content from 0 to 2.2, and fluorine from 1.8 to 3.8 (Coalcon 1977). The USPHS drinking standards for total dissolved solids (in ppm) is 500; for chloride, 250; for iron, 0.3; and for fluorine, 3.4. Ihe depths of these eighl. wells. range from 9 to $335 \mathrm{~m}$ (30 to $1100 \mathrm{ft}$ ).

\section{1 .5 Land use}

This surrogate site area has a generally rolling terrain characterized by four natural topographic regions: (1) floodplain, (2) terraces, (3) sand areas, and (4) upland till plain. 
Because of the extensive coal extraction activities in the area, reclaimed strip-mined land constitutes a fifth topographic category.

Land in the area is used primarily for general agriculture and strip mining, and may include an active strip mine, reclaimed strip-mine land, agricultural fields, several small woodlots of varying composition, and floodplain.

The most widespread agricultural uses of the land in this part of 111 inois are general farming, dairy, livestock, and poultry. The general vicinity is currently zoned by the St. Clair county zoning ordinance as "A" - agricultural. Coal mining and related activities are the major industrial uses.

The land use in St. Clair County (Table 2.7) is predominantly agricultural. Cropland comprises $61.2 \%$ of the total area, with woodland and similar land totaling $11.7 \%$. When farmsteads, feedlots, and roads are added, the total 1 and in farms comprises $74.2 \%(129,664$ ha; 320,271 acres) of the total acreage.

Table 2.7. Land use in St. Clair County, Illinois

\begin{tabular}{|c|c|c|}
\hline & Hectares (acres) & Percent \\
\hline \multicolumn{3}{|c|}{ Land in farms } \\
\hline Harvested cropland & $86,943(214,750)$ & 49.8 \\
\hline Cropland for pasture/grazing & $5,840(14,424)$ & 3.3 \\
\hline Nonharvested cropland & $14,197(35,067)$ & 8.1 \\
\hline Total crupland & $106,980(264,241)$ & $(61.2)$ \\
\hline Woodland, pastured or not & $9,494(23,451)$ & 5.4 \\
\hline Other land, pastured or not & $10,963(27,079)$ & 6.3 \\
\hline Total woodland and other land & $20.457(50,530)$ & $(11.7)$ \\
\hline Farmsteads, feedlots, roads & $2,227 \cdot(5,500)$ & 1.3 \\
\hline Total land in tarms & $129.664(320.271)$ & $(74.2)$ \\
\hline \multicolumn{3}{|c|}{ Land not in farms } \\
\hline rederally uwried land & $891(2,200)$ & 0.5 \\
\hline Urban areas & $24,382(60,225)$ & 13.9 \\
\hline Small lakes ( $<40$ acres) and rivers & $826(2,010)$ & 0.5 \\
\hline Large lakes ( $>40$ acres) & $570(1.408)$ & 0.3 \\
\hline \multicolumn{3}{|c|}{$\begin{array}{l}\text { (Includes commercial and non- } \\
\text { commercial forests, huuses, swamps, } \\
\text { railroads, unused wastelands, and others }\end{array}$} \\
\hline Tutal land not lin fárms & $45,234(111,729)$ & $(25.8)$ \\
\hline Grand total surface area & $174,899(132,000)$ & 100.0 \\
\hline
\end{tabular}

Source: ORNL geoecology data base. 1977. Oak Ridge, Tenn.: Oak Rịge National Lahoratnry

The remaining land is devoted partially to urban areas $[24,395$ ha $(60,255$ acres or $13.9 \%)]$ and to miscellaneous purposes (10.6\%). Principal crops include $181,979 \mathrm{~m}^{3}(5,199,398$ bu) of corn from 27,223 ha $(67,240$ acres $), 89,736 \mathrm{~m}^{3}(2,563,887$ bu) of soybeans from 35,530 ha $(87,760$ acres), and $58,875 \mathrm{~m}^{3}(1,682,152 \mathrm{bu})$ of wheat from 18,616 ha $(45,981$ acres $)$. Cattle, hogs, and chickens are also raised. A few potatoes but no cotton, peanuts, nor tobacco are grown (ORNL Geoecology Data Base 1977): 


\subsubsection{Meteorology and air quality}

St. Clair County has an annual average precipitation of $102 \mathrm{~cm}$ (40 in.). The monthly rate is higher during the winter and early spring than during the remainder of the year. The average annual snowfall is about $30 \mathrm{~cm}(12 \mathrm{in.})$. The mean temperatures for January are a minimum of $-4^{\circ} \mathrm{C}\left(25^{\circ} \mathrm{F}\right)$ and a maximum of $5^{\circ} \mathrm{C}\left(41^{\circ} \mathrm{F}\right)$. The mean temperatures for July are a minimum of $19^{\circ} \mathrm{C}$ $\left(67^{\circ} \mathrm{F}\right)$ and a maximum of $32^{\circ} \mathrm{C}\left(90^{\circ} \mathrm{F}\right)$.

The wind patterns for St. Clair County would be expected to be similar to those for St. Louis, Missouri, shown in Fig. 2.5. The predominant wind directions are south, west, and west-northwest. The wind velocity is generally moderate, in the range of 2 to $8 \mathrm{~m} / \mathrm{sec}$ ( 5 to $18 \mathrm{mph}$ ).

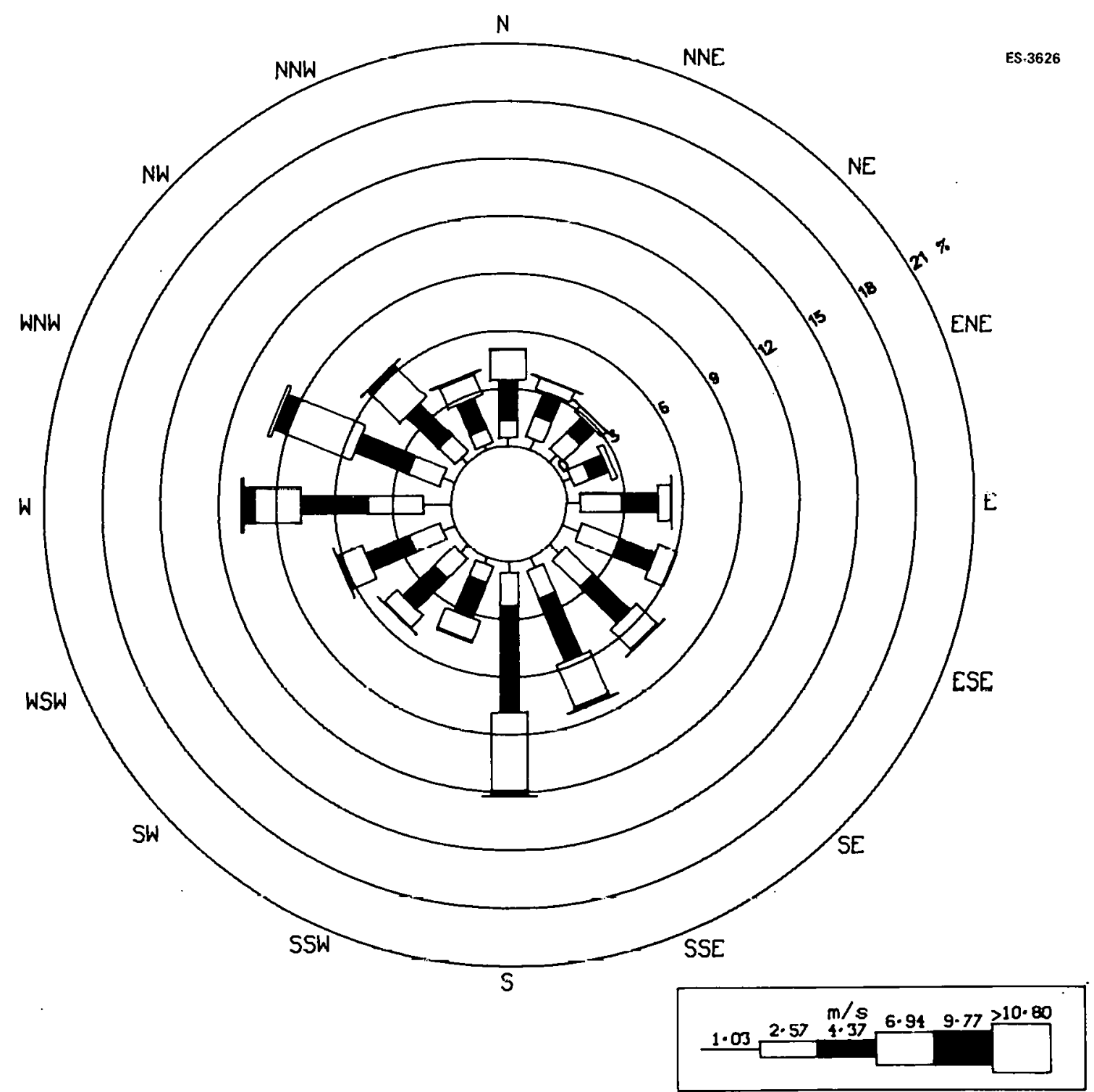

Fig, 2,5. Annual wind rose for St. Louis, Missouri. 
Heavy fog occurs on an average of 17 days annually. Illinois experiences an average of 22 tornadoes ariridily.

In an average year, the number of forecast days of high meteorological potential for air pollution (inversions) would not exceed two (Holtzworth 1972). In 1974 the average annual concentration (USEPA 1976) of total suspended particulates at Belleville in St. Clair County was $72 \mu \mathrm{g} / \mathrm{m}^{3}$, and the 24-hr maximum was $169 \mu \mathrm{g} / \mathrm{m}^{3}$. At nearby East St. Louis, the annual average $\mathrm{SO}_{2}$ concentration in 1974 was $38 \mu \mathrm{g} / \mathrm{m}^{3}$, and the 24-hr maximum was $157 \mu \mathrm{g} / \mathrm{m}^{3}$.

\section{1 .7 Noise}

Because noise is a local phenomenon (with some exceptions such as aircraft noise and thunder) and the surrogate site has been located only approximately, noise will be dealt with on a largely hypothetical basis. Except for local and state laws and factors of terrain and natural barriers, noise statements could be valid for all three surrogate sites.

Noise generation within plant boundaries is an occupational matter generally handled by industrial hygienists, is subject to criteria of the National Institute for Occupational Safety and Health, and is enforced by the Occupational Safety and Health Administration. Noise emanating beyond plant boundaries is generally considered a form of air pollution and becomes the concern of local, state, and Federal environmental authorities.

The Noise Control Act of 1972 provides for a division of powers between the Federal, state, and local governments. Although the primary Federal responsibility is for noise source emission control, the states and other political subdivisions retain rights and authority to control the use of noise sources and the levels of noise to be permitted in their environments (USEPA 1974). Section $5(\mathrm{a})(2)$ of this law provides in part that the Administrator of the Environmental Protection Agency "shall publish information on the levels of environmental noise, the attainment and maintenance of which in defined areas under various conditions are requisite to protect the public health and welfare with an adequate margin of safety" (Noise Control Act. of 1972).

Table 2.8 gives the equivalent sound levels that EPA believes are required to "protect the public heallh and welfare."

Residential areas are defined as areas in which human beings live in year-round or seasonal residences, including apartments and mobile homes. Although there is a separate category for commercial areas, commercial living accommodations such as hotels, motels, cottages, and inns should be included in the residential category because these are places where people sleep and sometimes spend extended periods of time. Hospitals and educational institutions require the same sound levels as residences. A quiet environment in urban and rural residential areas prevents activity interference and annoyance and permits the hearing mechanisms to recuperate if it is exposed to higher levels of noise during other periods of the day.

An indoor $L_{d n}$ (day-night average) of $45 \mathrm{~dB}$ will permit speech communication in the home, and an outdoor $L_{d n}$ not exceeding $55 \mathrm{~dB}$ will permit normal speech communication at about $3 \mathrm{~m}$. Maintenance of this identified outdoor level will provide an indoor $L_{d n}$ of approximately $40 \mathrm{~dB}$ with windows partly open for ventilation. The nighttime portion of this $L_{d n}$ should be about 
Table 28. Yearly average equivalent sound levels identified as requisite to protect the public health and welfare with an adequate margin of safety

\begin{tabular}{|c|c|c|c|c|c|c|c|}
\hline & \multirow[b]{2}{*}{ Measure $^{a}$} & \multicolumn{3}{|c|}{ Indoor } & \multicolumn{3}{|c|}{ Outdoor } \\
\hline & & $\begin{array}{l}\text { Activity } \\
\text { inter- } \\
\text { ference }\end{array}$ & $\begin{array}{l}\text { Hearing loss } \\
\text { considera. } \\
\text { tion }\end{array}$ & $\begin{array}{c}\text { To protect } \\
\text { against } \\
\text { both ef- } \\
\text { fects }\end{array}$ & $\begin{array}{l}\text { Activity } \\
\text { inter- } \\
\text { ference }\end{array}$ & $\begin{array}{l}\text { Hearing loss } \\
\text { considera- } \\
\text { tion }\end{array}$ & $\begin{array}{l}\text { To protect } \\
\text { against } \\
\text { both ef. } \\
\text { fects } b\end{array}$ \\
\hline $\begin{array}{l}\text { Residential with out- } \\
\text { side space and farm } \\
\text { residences }\end{array}$ & $\begin{array}{l}\operatorname{Lan}^{c} \\
L_{e q(24)^{d}}\end{array}$ & 45 & 70 & 45 & 55 & 70 & 55 \\
\hline $\begin{array}{l}\text { Residential with no } \\
\text { outside space }\end{array}$ & $\begin{array}{l}L_{d n} c \\
L_{e q(24)^{d}}\end{array}$ & 45 & 70 & 45 & & & \\
\hline Commercial & $\operatorname{Leq}(24)^{d}$ & $e$ & 70 & $70^{f}$ & $e$ & 70 & $70^{9}$ \\
\hline Inside transportation & $L_{e q(24)^{d}}$ & $e$ & 70 & $e$ & & & \\
\hline Industrial & $L_{e q(24)^{d, g}}$ & $e$ & 70 & $70^{f}$ & $e$ & 70 & $70^{9}$ \\
\hline Hospitals & $\begin{array}{l}\mathrm{L}_{\mathrm{dn}}{ }^{c} \\
\mathrm{Leq}_{\mathrm{eq}}{ }^{d}\end{array}$ & 45 & 70 & 45 & 55 & 70 & 56 \\
\hline Educational & $\begin{array}{l}L_{\text {eq }(24)^{d}} \\
L_{\text {eq }(24)^{d, g}}\end{array}$ & 45 & 70 & 45 & 55 & 70 & 55 \\
\hline Recreational areas & $L_{e q(24)^{d}}$ & $e$ & 70 & $70^{f}$ & $e$ & 70 & $70^{9}$ \\
\hline $\begin{array}{l}\text { Farm land and } \\
\text { general unpopulated } \\
\text { land }\end{array}$ & $\operatorname{Leq}(24)^{d}$ & & & & $e$ & 70 & $70^{g}$ \\
\hline
\end{tabular}

${ }^{a}$ Equivalent Sound Level $\mathrm{L}_{e q}$ is the equivalent steady noise level that in a stated period of time (here, one year) would contain the same noise energy as the time-varying noise during the same time period. The mathematical definition of $L_{e q}$ for an interval defined as occupying the period between two points in time $t_{1}$ and $t_{2}$ is

$$
L_{e q}=10 \log \left[\frac{1}{t_{2}-t_{1}} \int_{t_{1}}^{t_{2}} \frac{p^{2}(t)}{\rho_{0}{ }^{2}} d t\right] .
$$

where $p(t)$ is the time-varying sound pressure and $\rho_{0}$ is a reference pressure taken as $20 \mu \mathrm{Pa}$.

Based on lowest level.

${ }^{c}$ The day-night average sound level; the 24-hour A-weighted equivalent sound level with a 10-dB penalty applied to nighttime (10 p.m. to 7 a.m.) levels. (NOTE: A-weighted equivalent sound pressure level is the simulated human-ear response to sounds at three levels [Hirschorn, 1970] calculated from sound-meter response.)

${ }^{d}$ The equivalent A-weighted sound level over 24 hours.

${ }^{e}$ Since different types of activities are associated with different sound levels, identification of maximum sound levels to prevent activity interference is difficult except when speech communication is critical.

'Based only on hearing loss.

${ }^{g} \mathrm{An} \mathrm{L}_{\text {eq }}(8)$ of $75 \mathrm{~dB}$ may be identified in these situations as long as the exposure (over the remaining $16 \mathrm{hr} / \mathrm{day}$ ) is luw enough to make a negligible contribution to the $24-\mathrm{hr}$ average, that is, no greater than $\mathrm{L}_{\text {eq }}=60 \mathrm{~dB}$.

Source: USEPA (U.S. Environmental Protection Agency), Office of Noise Abatement and Control. 1974. Information un levels of environmental noise requisite to protect public health and welfare with an adequate margin of safety. Document 550/9-74-004. Washingtor, D.C.: U.S. Government Printing Office.

$32 \mathrm{~dB}$, which should, in most cases, protect against sleep interference. An $\mathrm{L}_{\mathrm{eq}}(24)(24-\mathrm{hr}$, A-weighted sound level average) of $70 \mathrm{~dB}$ is identified as protecting against damage to hearing (USEPA 1974). Sound levels produced by certain devices and activities which exist in certain situations are given in Fig. 2.6 (USEPA 1974) and Table 2.9 (U.S. Department of Health, Education, and Welfare 1972). 


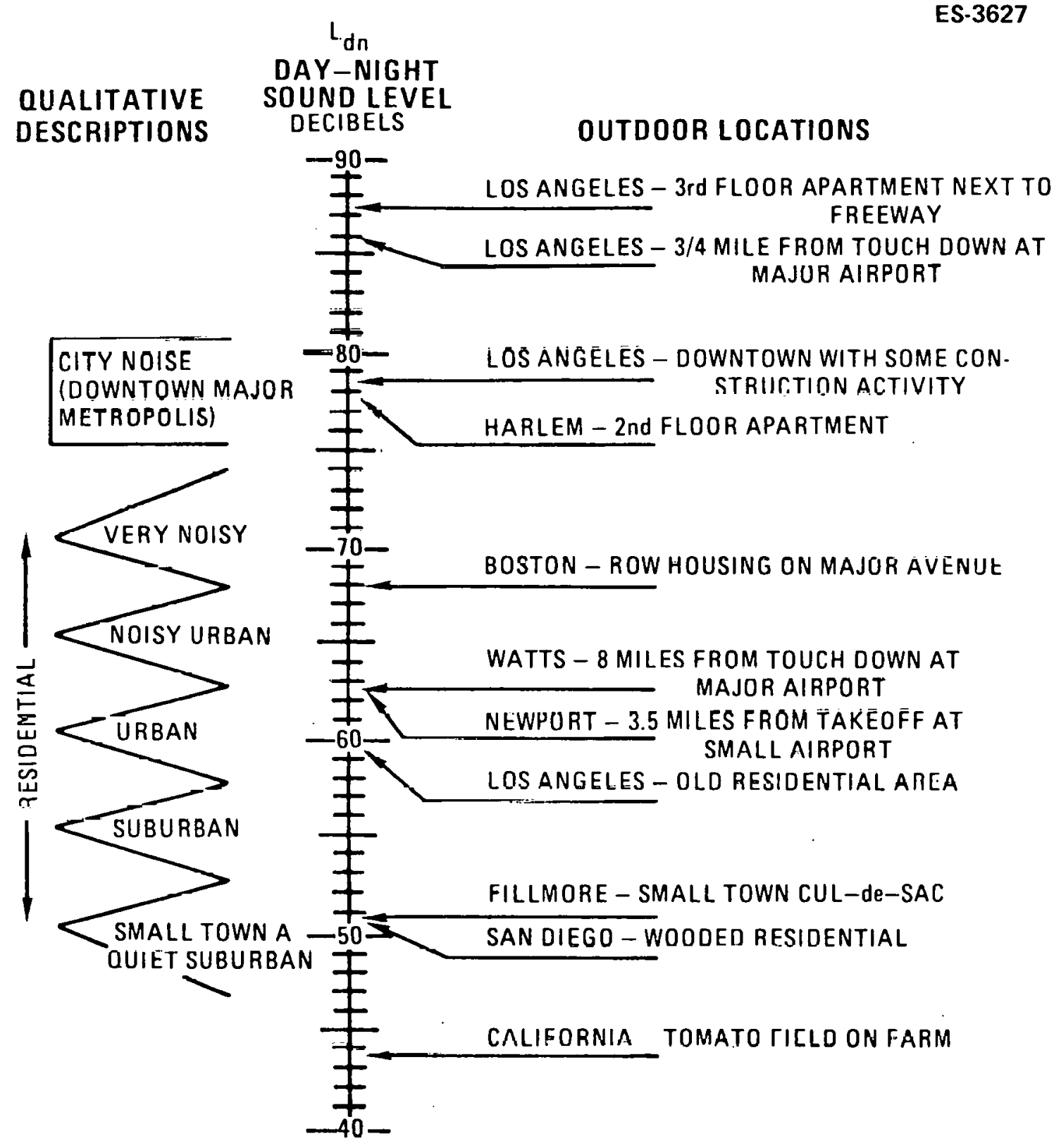

Fig. 2.6. Outdoor day-night sound level in $\mathrm{dB}$ ( $\mathrm{re} 20 \mu \mathrm{Pa}$ ) at various locations. Source: U.S. Environmental Protection Agency, Office of Noise Abatement and Control. 1974. Information on levels of environmental noise requisite to protect public health md welfare with an adequate margin of safety. Document 550/9-74-004. Washington, D.C.: U.S. Government Printing office. 
Table 2.9. Measured noise levels for selected industrial operations

\begin{tabular}{|c|c|}
\hline Source & Sound level ${ }^{\theta}[d B(A)]$ \\
\hline \multicolumn{2}{|l|}{ Textile mill } \\
\hline Loom & 106 \\
\hline Cotton spinning & 83 \\
\hline \multicolumn{2}{|l|}{ Luinber and wood products } \\
\hline Planer & 106 \\
\hline Molder & 100 \\
\hline Router & 93 \\
\hline Shaper & 104 \\
\hline Boring machine & 94 \\
\hline \multicolumn{2}{|l|}{ Furniture products } \\
\hline Cut-off saw & 112 \\
\hline Sander & 97 \\
\hline Radial-arm saw & 98 \\
\hline \multicolumn{2}{|l|}{ Paper products } \\
\hline Paper cutter & 96 \\
\hline Bag and handle former & 89 \\
\hline \multicolumn{2}{|l|}{ Printing and publishing } \\
\hline Newspaper press & 97 \\
\hline Monacasting & 91 \\
\hline Postcard press & 91 \\
\hline Keyboard monotype & 84 \\
\hline Offset press & 88 \\
\hline Small offset press & 82 \\
\hline Folding machines & 85 \\
\hline Binder & 86 \\
\hline \multicolumn{2}{|l|}{ Petroleum refining } \\
\hline Can seaming & 96 \\
\hline Furnace heating distilling columns & 100 \\
\hline Steam letdown & 130 \\
\hline Furnace high speed rotating equipment & 100 \\
\hline Furnace pumps & 103 \\
\hline \multicolumn{2}{|l|}{ Transportation } \\
\hline One-ton truck & 70 \\
\hline Five-ton truck & 73 \\
\hline Twenty-luil liuik & 92 \\
\hline \multicolumn{2}{|l|}{ Glass products } \\
\hline Inflation of containers & 106 \\
\hline Corrugated band saw & 99 \\
\hline \multicolumn{2}{|l|}{ Steel products } \\
\hline Coke ovèn & 83 \\
\hline Blast furnace & 100 \\
\hline Basic oxygen furnace & 91 \\
\hline Electric furnace, 150 tons & 112 \\
\hline One hundred sixty-in. mill & 98 \\
\hline \multicolumn{2}{|l|}{ Various metal products } \\
\hline Milling machine & 90 \\
\hline Turret lathe & 90 \\
\hline Four-in, hand grinder & 85 \\
\hline Riveting machine & 110 \\
\hline Forge drop hammer & 105 \\
\hline Automatic punch press & 95 \\
\hline Pneumatic chisel & 101 \\
\hline \multicolumn{2}{|l|}{ Canning food products } \\
\hline Canning punch press & 97 \\
\hline Can-makiny budy operation & 95 \\
\hline Can-filling machine & 100 \\
\hline
\end{tabular}


Table 2.9 (continued)

\begin{tabular}{|c|c|}
\hline Source & Sound level $[\mathrm{dB}(\mathrm{A})]$ \\
\hline \multicolumn{2}{|l|}{ Mining, underground } \\
\hline Axial vane fan & 107 \\
\hline Stoper drill & 115 \\
\hline Jackhammer drill & 113 \\
\hline Roof bolter & 103 \\
\hline Loader, gathering arm & 96 \\
\hline Conveyor belt & 93 \\
\hline Continuous miner & 99 \\
\hline \multicolumn{2}{|l|}{ Mining, open pit } \\
\hline Jumbo drill & 107 \\
\hline Rotary drill & 93 \\
\hline Crusher & 96 \\
\hline Locomotive & 85 \\
\hline Oxygen torches & 120 \\
\hline \multicolumn{2}{|c|}{ Heavy equipment, earth moving } \\
\hline Double scraper & 92 \\
\hline Sorapor & 117 \\
\hline Bull dozer & $11 n$ \\
\hline Road grader & 95 \\
\hline \multicolumn{2}{|l|}{ rărim èquipment } \\
\hline Tractor & 98 \\
\hline Graın roller mill & 85 \\
\hline Pneumatic conveyor & 100 \\
\hline One-row beet puller & 94 \\
\hline Two-row sorn picker & 106 \\
\hline
\end{tabular}

${ }^{a}$ Noise measurements for the specified uperatiunis wert taken from assorted Public Health surveys and references in acoustical and industrial hygienists literature.

Source: U.S. Department of Health, Education, and Welfare: National Institute for Occupational Safety and Health. 1972. Occupational exposure to noise. Washington, D.C.: U.S. Government Printing Office.

Distance produces a significant attenuating effect. on snund, In a free field such as the outdoors, sound levels decrease approximately $6 \mathrm{~dB}$ for each doubling of distance (Peterson and Gross 1972). Thus if a hammermill emits $96 \mathrm{~dB}(\mathrm{~A})$ of noise measured at. $3 \mathrm{~m}(10 \mathrm{ft})$, the sound would be reduced to the recommended level of $55 \mathrm{~dB}(\mathrm{~A})$ at $390 \mathrm{~m}(1280 \mathrm{ft})$ or about $1 / 4$ mile. The value of a buffer zone in reducing ambient noise becomes obvious.

In siting a plant, it is important to consider distances to residences, schools, hospitals, churches, and other noise sources. Noise Assessment Guidelines, sponsored by the II.S. Mepartment of Housing and Urban Development (Schultz and Mçahon, 1971), gives "c.learly acceptable," "normally acceptable," "normally unacceptable," and "clearly unacreptahle" zones adjacent to highways, based on hourly car and truck traffic rates.

The Illinois Environmental Protection Act, as amended through January 1, 1976, designates in Sect. 4(m), the State Environmental Protection Agency as noise control agency for the state for all purposes of the Noise Control Act of 1972, PL 92-574. This agency is charged with Investigating complaints and enforcing environmental noise regulations. The act also created a Pollution Control Board to "determine, define, and implement environmental control standards" and the Illinois Institute for Environmental Quality "to investigate practical problems and implement studies and programs relating to the technology and administration of environmental protection...." 
Chapter 8, "Noise Regulations of the Rules and Regulations of the Illinois Pollution Control Board," became effective August 9, 1973. This chapter lists sound pressure levels of several categories of properties as follows: Sound Emitted to Class A Land During Daytime Hours (Rule 202), Sound Emitted to Class A Land During Nighttime Hours (Rule 203), Sound Emitted to Class B Land (Rule 204), and Sound Emitted to Class C Land (Rule 205).

The classes of land are defined by numerical designations listed in the Standard Land Use Coding Manual (Federal Highway Administration 1969), which correspond to Standard Industrial Classifications (U.S. Office of Management and Budget 1972).

Class $A$ land is defined as land used for residences, hotels, motels, hospitals, sanitariums, rest homes, churches, synagogues, libraries, museums, schools, and colleges.

Class B land includes certain types of commercial property such as telephone exchanges; radio broadcasting studios, wholesale and retail trading centers of many kinds such as foods, banking and real estate, personal and business services; and recreational facilities.

Class C land includes areas used for agriculture, fishing, forest, mining, manufacturing, and transportation activities.

Class $U$ or unclassified land includes airports, freeways, and unused and water areas.

In the Illinois regulations, sound level limits are not set at the boundaries of. the emitter but at the receiving property, whether Class A, B, or C. Also, Illinois limits differ with frequency and with the land use of the emitter. An example of Rule 202 is shown in Table 2.10 (Illinois Pollution Control Board 1973).

Table 2.10. Sound emitted to class $A, B$, and $C$ land during daytime hours

\begin{tabular}{|c|c|c|c|}
\hline \multirow{2}{*}{$\begin{array}{c}\text { Octave band } \\
\text { center frequency } \\
(\mathrm{Hz})\end{array}$} & \multicolumn{3}{|c|}{$\begin{array}{c}\text { Allowable octave band sound pressure levels of } \\
\text { sound emitted to receiving land (dB) }\end{array}$} \\
\hline & Class C land & Class B land & Class $A$ land \\
\hline 31.5 & 75 & 72 & 72 \\
\hline 63 & 74 & 71 & 71 \\
\hline 125 & 69 & 65 & 65 \\
\hline 250 & 64 & 57 & 57 \\
\hline 500 & 58 & 51 & 51 \\
\hline 1000 & 52 & 45 & 45 \\
\hline 2000 & 47 & 39 & 39 \\
\hline 4000 & 43 & 34 & 34 \\
\hline 8000 & 40 & 32 & 32 \\
\hline
\end{tabular}

Source: Illinois Pollution Control Board. 1973. Noise Pollution Control Regulations. Rule 202. Springfield, III.: Illinois Environmental Protection Agency. 


\section{1 .8 Socioeconomic structure (St. Clair County, Illinois)}

\subsubsection{Local and regional population}

\section{Population size and density}

In 1970 the population of St. Clair County, Illinois, was 285,199. Based on a land area of $1743 \mathrm{~km}^{2}$ (673 sq miles), the population density for the county is 1098 persons per $\mathrm{km}^{2}$ (424 persons per sq mile) (U.S. Bureau of the Census 1973b). The proportion of the population living in urban areas was $83 \%$ (U.S. Bureau of the Census 1973b). For the United States as a whole, in 1971 the population per $\mathrm{km}^{2}$ was 149 (57.5 per sq mile), and the proportion living in urban areas was $73.5 \%$ (U.S. Bureau of the Census 1971b). Thus St. Clair County had a higher population density and a higher percentage of its population living in urban areas than the nation as a whole. It was also much more densely settled than Western states, which had population densities ranging from 12.4 persons per $\mathrm{km}^{2}$ ( 4.8 persons per sq mile) in Montana to 33.4 persons per $\mathrm{km}^{2}$ (12.9 persons per sq mile) in Utah (U.S. Bureau of the Census 1971b).

St. Clair County is one of the eight constituent counties of the St. Louis Standard Metropolitan Statistical Area (SMSA). In 1970 the total population of the SMSA was $2,410,186$, making it the lith most populous area in the country (Coalcon 1977).

New Athens is about $50 \mathrm{~km}$ (30 miles) southeast of St. Louis. Residents of New Athens depend on St. Louis for much of their employment and retail services (Coalcon 1977). Many plant workers would likely commute to and from St. Louis and other nearby towns and cities as well.

Many villages, towns, and cities surround the New Athens area. The 1970 populations of townships in St. Clair County, including New Athens, are given in Table 2.11.

\section{inpulation trends}

Between 1960 and 1970 the population of St. Clair County increased at a rate of 8.6\% (U.S. Bureau of the Census 1973b). During the same period, the national increase was $13.3 \%$ (U.S. Bureau of the Census 1971b). St. Clair County grew less rapidly because about 6000 people moved out of the county during this period. As Table 2.12 shows, this outmigratinn t.nnk place primarily among young men of ages 15-24.

As is shown in Table 2.13, St. Clair County's population is expected to increase by about 81,000 people or $29 \%$ by the year 2000 . New Athens can be expected to share in this future yruwth.

Between 1960 and 1970 the population of New Athens increased less rapidly than that of St. Clair County. In 1960 New Athens township had a population of 2479 and in 1970 one of 2570. The 1960-1970 growth rate for the township was 3.7\%. Most of the other townships in St. Clair County grew mure rapidly than New Athens. In the future New Athens will probably have a slightly higher growth rate than it did between 1960 and 1970 (Koehler 1976). 
Table 2.11. Population distribution by townships in St. Clair County, Illinois, 1970

\begin{tabular}{lr}
\hline \multicolumn{1}{c}{ Township } & Population \\
\hline Belleville & 41,699 \\
Canteen & 20,414 \\
Caseyville & 25,931 \\
Centreville & 40,500 \\
Fast St. I_nulis & 69,996 \\
Englemann & 499 \\
Fayetteville & 1,607 \\
Freeburg & 3,678 \\
Lebanon & 4,244 \\
Lenzburg & 654 \\
Marissa & 2,818 \\
Mascaulgh & 5,967 \\
Millstadt & 4,016 \\
New Athens & 2,570 \\
O'Fallon & 8,662 \\
Prairie du Long & 838 \\
St. Clair & 18,436 \\
Shiloh Valley & 10,767 \\
Smithton & 1,925 \\
Stites & 1,826 \\
Stookey & 9,955 \\
Sugar Loaf & 7,174 \\
Total & 285,199 \\
\hline
\end{tabular}

Source: Coalcon: Environmental analysis ceport for the clean boiler fuel demonstration plant program at New Athens, lllinois. 1977. Pp. 3.222 to $3-223$. Prepared for the Energy Research and Development Administration, Division of Fossil Demonstration Plants. West Chester, Pa.: Roy F. Weston, Inc.

Table 2.12. Age-sex distribution in St. Clair County, Illinois, 1970

\begin{tabular}{|c|c|c|c|}
\hline \multirow[b]{2}{*}{ Year } & \multicolumn{3}{|c|}{ Age } \\
\hline & $5-14$ & $15-24$ & $25-34$ \\
\hline \multicolumn{4}{|c|}{ Male } \\
\hline 1950 & 15,000 & 18,500 & 16,500 \\
\hline 1960 & 27,500 & 15,200 & 16,500 \\
\hline 1970 & 32,500 & 22,000 & 16,000 \\
\hline \multicolumn{4}{|c|}{ Female } \\
\hline 1950 & 13,000 & 14,500 & 17,000 \\
\hline 1960 & 25,000 & 16,000 & 18,100 \\
\hline 1970 & 31,000 & 24,200 & 16,000 \\
\hline
\end{tabular}

Source: Coalcon: Environmental analysis report for the clean boiler fuel demonstration plant program at New Athens, Illinois. 197\%. Prepared for the Energy Research and Develujiment Administration, Division of Fossil Demonstration Plants. West Chester, Pa.: Roy F. Weston, Inc.

Population characteristics

Examination of the composition of the population of St. Clair County by age, race, education, and income reveals that its population structure is similar to that of the nation as a whole. The median age in St. Clair County is 26.8 (vs 28.3 nationally), $9 \%$ (vs $9.9 \%$ nationally) of the population is over 65 years of age, and $31.2 \%$ is under 15 (Coalcon 1977; U.S. Bureau of the Cersus 1971b). Thus llie proportion of the population of st. Clair County in the working ages of 15-65 is about the same as the United States as a whole. St. Clair County has a 
Table 2.13 Projected population increases for St. Clair County, Illinois, 1975 and 2000

\begin{tabular}{lcc}
\hline Year & Population & $\begin{array}{c}\text { Percent } \\
\text { of change }\end{array}$ \\
\hline 1975 & 297,235 & 4.2 \\
1980 & 309,000 & 4.0 \\
1985 & 325,545 & 5.4 \\
1990 & 342,990 & 5.5 \\
1995 & 360,435 & 5.1 \\
2000 & 378,780 & 5.1 \\
Total change & 81,545 & 28.7 \\
\hline
\end{tabular}

Source: Coalcon: Environmental analysis report for the clean boiler fuel demonstration plant program at New Athens, Illinois. 1977. Prepared for the Energy Research and Development Administration, Division of Fossil Demonstration Plants. West Chester $P a$, Roy F. Weston. Inc.

higher proportion of blacks (22\% vs $11.2 \%$ for the United States) but a lower proportion of families below the poverty level $(12.4 \%$ vs $14.9 \%$ for the United States) (Coalcon 1977; U.S. Bureau of the Census 1971b). In 1969 the median family income was $\$ 9540$ (vs $\$ 9586$ nationally), and the median educational level for persons over 25 in St. Clair County was 11.0 years, which was slightly lower than the national median of 12.2 years (Coalcon 1977; U.S. Bureau of the Census 1971b). In 1976 the unemployment rate was $8.2 \%, 1 \%$ lower than the U.S. rate (Koehler iy/b; U.S. Bureau of the Census 1976).

As shown in Table 2.14, over 18,000 people were unemployed in St. Clair County and the two adjacent counties of Madison and Monroe in 1976. In $19705.2 \%$ of the employed labor force in St. Clair County was employed in construction (Coalcon 1977). These figures suggest that in the eight constituent counties of the St. Louis SMSA, there are probably several thousand unemployed construction workers at present. In additinn, there are probably unemploycd wurkers in the SMSA who could also supply demands for an operations work force.

Table 2.14. Unemployment in Madison, Monroe, and St. Clair counties, May 15, 1976

\begin{tabular}{lcc}
\hline County & Percent unemployed & Number unemployed \\
\hline Madison & 7.7 & 8850 \\
Monroe & 3.8 & 300 \\
St. Clair & 8.2 & 9775 \\
\hline
\end{tabular}

Source: George Koehler. 1976. Socioeconomic impact of the Coalcon clean boiler fuels program. New York: Coalcon.

Stenehjem and Metzger (1976) have developed estimates of county labor pools (new labor force entrants plus the currently unemployed) for all U.S. counties for each of ten years after the plant employment begins. Their estimates of the number of local workers who can be expected to to fill new jobs in each of ten years are compiled by

1. computing the labor force participation rates for men and women in a given county, and, if these rates are lower than the corresponding national ratio, adding the incremental workers to the local labor force in year one; 
2. adding the percentage of surviving school-age persons to each future year's estimates of workers likely to seek employment; and

3. subtracting from each year's work-force estimate the number of persons reaching age 65 .

Based on this procedure, Stenehjem and Metzger's (1976, p. 75) estimates of St. Clair County's labor pool are as follows:

\begin{tabular}{cc} 
Year & $\begin{array}{c}\text { Number of } \\
\text { available local workers }\end{array}$ \\
\cline { 2 - 2 } 1 & 9598 \\
2 & 1873 \\
3 & 2315 \\
4 & 2313 \\
5 & 2312 \\
6 & 2310 \\
7 & 2256 \\
8 & 2104 \\
9 & 2103 \\
10 & 2102
\end{tabular}

As Stenehjem and Metzger (1976) state, these estimates do not include workers who would commute from surrounding counties. The labor pool drawn from all counties in the St. Louis SMSA would undoubtedly be several times larger than the St. Clair County labor pool estimates.

\subsubsection{Industry structure}

The impacts of siting a pipeline gas facility in a given area depend, to a large extent, on the ecoriomic or industrial structure of that area. For a given facility, the greater the size and diversity of the existing industrial base, the smaller the generated impacts will be. Larger, more developed economies are more likely to be able to expand production of goods and services (both public and private) to meet the additional demands imposed by the facility without experiencing major adjustment problems. Small undiversified economies, however, will not be equipped to meet these demands, and a situation of disequilibrium will arise in the various input markets. Some of the excess demand for inputs can be satisfied by importing needed materials from outside the local economy. Buy many of the goods and services required by the facility and its employees (particularly those that are derived from the local infrastructure, e.g., housing, education, and transportation) cannot be readily imported. Consequently, the local economy will experience potentially large adjustment costs as the output of these goods and services expands to a new equilibrium level.

The industrial structure of St. Clair County is predominantly oriented toward the manufacturing sector, with durable goods (especially primary metals) accounting for the bulk of the employment within this sector. As shown in Fig. 2.7, the agricultural sector accounts for a small and declining share of the total product of the county (currently about 5\%). A similar statement can be made concerning employment in this sector. 


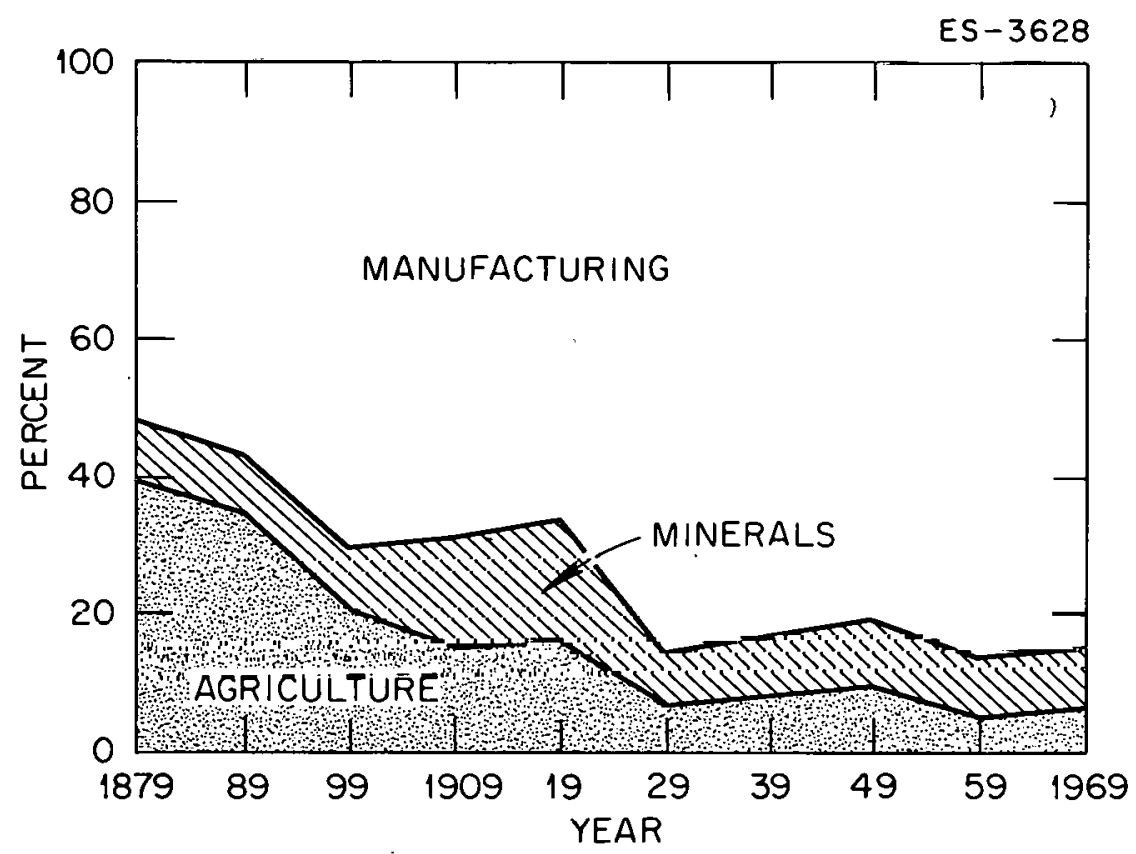

Fig. 2.7. Percentage distribution of total product in St. Clair County, Illinois; 1879-1969. Source: Coalcon: environmental analysis report for the clecon boilor fuel demonstration plant program at New Athens, Illinois. 1977. Prepared for the Energy Research and Development Administration, Division of Fossil Demonstration Plants. West Chester, Pa.: Roy $F$. Weston, Inc.

Employment and payroll figures by major industry in 1971 are reported in Table 2.15 (U.S. Bureau of the Census 1971a). As is evident from this table, St. Clair County is basically urban, with a large diversified industrial structure. Relative to the other two potential sites selected for analysis (to be descrihed in Sects. 2.2 and 2.3), the St. Clair County site represents, by far, the most developed and diversified economic structure. In addition, total employment is projected to increase almost $40 \%$ in the county by the year 2000 (Coalcon 1977). Consequently, one would expect that the adjustment problems associated with the increased demands for goods and services generated by the gasification facility and its employees would be the lowest for this site.

Because St. Clair County is closely integrated with the surrounding counties (particularly those that, with St. Clair County, compose the St. Louis SMSA), one must consider the economic structure of these areas in assessing the potential imparts of a coal gasification facility. Expanding our sccope to include the three-rnunty area of st. clair, Madicon, and Monroe, the basic description remains quite similar to that provided above. As shown in Fig. 2.8, the manufacturing sector also dominates the larger three-county area. Although the relative importance of. the mining sector appears to be less in Madison and Monroe counties, the overall structure of the larger area remains quite similar to that of St. Clair County.

This consistency of economic structure remains intact when we further expand our scope to include the entire St. Louis SMSA. Table 2.16 reports 1972 . OBERS projections of population; employment, personal income, and earnings by industry for selected years from 1950 to 2020 for the St. Louis SMSA (USDC and USDA 1974). Again, we observe the domination of the manufacturing sector and the 
Tab'e 2.15. First quarter 197; employment and payroll, St. Clair County, Illinois

\begin{tabular}{|c|c|c|c|c|c|c|c|c|c|c|c|}
\hline \multirow{2}{*}{ Industry } & \multirow{2}{*}{$\begin{array}{l}\text { Number of } \\
\text { employees, } \\
\text { mid.March } \\
\text { pay period }\end{array}$} & \multirow{2}{*}{$\begin{array}{c}\text { Taxable } \\
\text { payrolls, } \\
\text { January-March } \\
(\$ 1000)\end{array}$} & \multirow{2}{*}{$\begin{array}{l}\text { Towal } \\
\text { reporting } \\
\text { units }\end{array}$} & \multicolumn{8}{|c|}{ Number of reporting units by employment size class) } \\
\hline & & & & 1 to 3 & 4 to 7 & 8 to 19 & 20 to 49 & 50 to 99 & 100 to 249 & 250 to 499 & 500 or more \\
\hline Total & 49,614 & 80,682 & 3776 & 1871 & 820 & 625 & 275 & 76 & 54 & 15 & 10 \\
\hline Agricultural services. forestrv, and fisheries & 109 & 96 & 21 & 13 & 6 & 1 & 1 & & & & \\
\hline Mining & 735 & 2,026 & 9 & 1 & 1 & 1 & 3 & 2 & & & 1 \\
\hline Contract construction & 2,996 & 7.126 & 300 & 149 & 55 & 54 & 31 & 7 & 4 & & \\
\hline Manufacturing & $1<, 485$ & 29,617 & 209 & 38 & 28 & 47 & 44 & 19 & 19 & 8 & 6 \\
\hline Transportation and other pLblic utilities & 4,180 & 7,912 & $i 44$ & 42 & 31 & 31 & 23 & $\varepsilon$ & 7 & 4 & \\
\hline Wholesale trade & 2,317 & 4,506 & $=41$ & 89 & 59 & 64 & 23 & 5 & 1 & & \\
\hline Retail trade & 10,678 & 12,226 & 1304 & 627 & 360 & 207 & 83 & 16 & 10 & 1 & 1 \\
\hline Finance, insurance, and real estate & 2,922 & 4,655 & 341 & 208 & 59 & 41 & 20 & 9 & 4 & & \\
\hline Services & 10,924 & 12,182 & 1131 & 676 & 213 & 173 & 43 & 12 & 9 & 2 & 3 \\
\hline Unclassified estajlishments & 268 & 336 & 46 & 28 & 8 & 6 & 4 & & & & \\
\hline
\end{tabular}

${ }^{a}$ Excludes, for example. government employees, ralroad employees, and self- mmployed persons.

Source: U.S. Bureau of the Census. 1971. Count/ Eusiness Patterns. VJashington D.C.: U.S. Government Printing Office 
Table 2.16. 1972 OBERS projections

\begin{tabular}{|c|c|c|c|c|c|c|c|c|c|c|}
\hline & 1050 & $1962^{\circ}$ & 196 & 1970 & 1971 & 1990 & 1985 & 1990 & 2000 & 3000 \\
\hline \multirow[t]{2}{*}{ 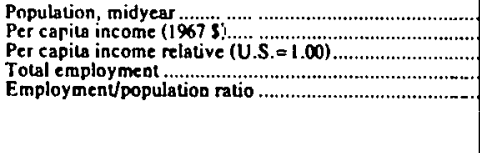 } & $\begin{array}{r}1.799 .719 \\
2.477 \\
1.20 \\
715.566\end{array}$ & $\begin{array}{r}2,175,505 \\
2.875 \\
1.11 \\
785.913\end{array}$ & $\begin{array}{r}: .319 .832 \\
3.765 \\
i .10\end{array}$ & $\begin{array}{r}2,370.219 \\
3,776 \\
i .99 \\
913,889 \\
.39\end{array}$ & $\begin{array}{r}2,392.569 \\
3.828 \\
1.08\end{array}$ & $\begin{array}{r}2,561,600 \\
5,100 \\
1,07 \\
1,098,700 \\
.43\end{array}$ & $\begin{array}{r}2.638 .100 \\
\quad .800 \\
1.07 \\
1,135.600 \\
.43\end{array}$ & $\begin{array}{r}2,716.850 \\
6.500 \\
1.07 \\
1,173,700 \\
.43\end{array}$ & $\begin{array}{r}2.825 .200 \\
8.600 \\
1.06 \\
1,264.600 \\
.45\end{array}$ & 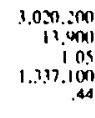 \\
\hline & \multicolumn{10}{|c|}{ In Thousands of 1967 Dollars } \\
\hline Total perrocal locome............. & $4.3: 9,449$ & $6,254,419$ & $\varepsilon, 734,621$ & B.949,239 & $9.158,383$ & $13,154,100$ & $.15,327.800$ & $17,860,600$ & $24,444,700$ & $42.10 \mathrm{m.mn}$ \\
\hline 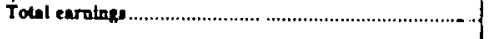 & $3,6: 5,182$ & $5,189,952$ & $.250,292$ & $7,280,440$ & $7,406,292$ & $10.587,200$ & 12,257300 & 14.190 .900 & $19,229.500$ & 32.740 .100 \\
\hline 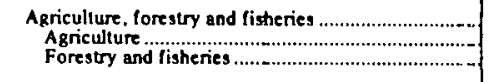 & -7.387 & 38.620 & 33,233 & 35.456 & 36,778 & $\begin{aligned} 45,300 \\
45,100 \\
(\mathbf{S})\end{aligned}$ & $\begin{aligned} 46.000 \\
45.800 \\
(S)\end{aligned}$ & $\begin{array}{r}46,700 \\
46,500 \\
1 S 1\end{array}$ & $\begin{aligned} \$ 1,000 \\
50.800 \\
(\$)\end{aligned}$ & $\begin{array}{ll}62.8 m 0 \\
62.590 \\
151\end{array}$ \\
\hline 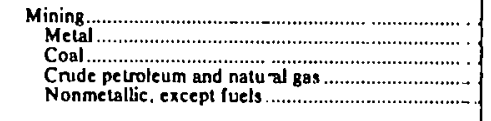 & 30.579 & 24.333 & 28.806 & 31.006 & 33.143 & $\begin{array}{r}36.600 \\
2.300 \\
18.600 \\
1.200 \\
14.400\end{array}$ & $\begin{array}{r}40.200 \\
2.500 \\
20.300 \\
1.200 \\
15.400\end{array}$ & $\begin{array}{r}44.200 \\
2.700 \\
23.500 \\
1.200 \\
16.500\end{array}$ & $\begin{array}{r}53.500 \\
3.300 \\
29.400 \\
1.300 \\
19.300\end{array}$ & 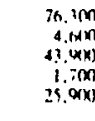 \\
\hline Contract construction....... & 204,639 & 320,310 & $\$ 46,259$ & 446,420 & 456,527 & 657,100 & 749.800 & 854,600 & 1.119 .100 & $1.791 .4 \mathrm{~mm}$ \\
\hline 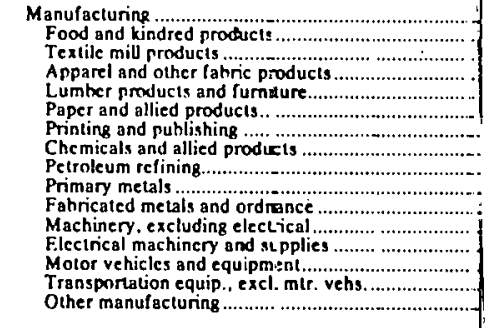 & 1.306 .766 & 1.899 .853 & 2.570 .913 & $2,508,650$ & $2,452,851$ & 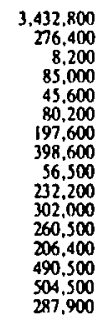 & 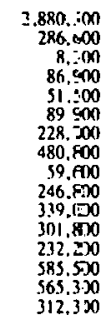 & $\begin{array}{r}4.386 .700 \\
297.300 \\
8.500 \\
89.000 \\
58.200 \\
100.700 \\
264.000 \\
580.000 \\
62.900 \\
262.200 \\
380.2000 \\
349.600 \\
261.400 \\
698.900 \\
633.900 \\
338.700\end{array}$ & 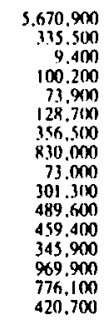 & 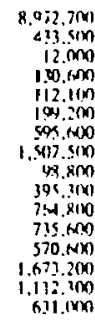 \\
\hline 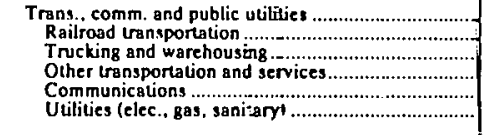 & 347799 & 494,616 & $\cos .591$ & 640,306 & 670.327 & $\begin{array}{l}886,000 \\
112,400 \\
293.700 \\
131,700 \\
195,800 \\
150,200\end{array}$ & $\begin{array}{r}10012,1000 \\
106,700 \\
343,000 \\
150,000 \\
237.900 \\
171,900\end{array}$ & $\begin{array}{r}1.156 .000 \\
101.300 \\
397.800 \\
170.800 \\
289.100 \\
196.600\end{array}$ & $\begin{array}{r}1.539 .6000 \\
93.700 \\
541.300 \\
218.500 \\
424.400 \\
261.500\end{array}$ & $\begin{array}{r}2.541 .990 \\
82.7110 \\
914.500 \\
132.100 \\
80.100 \\
420.400\end{array}$ \\
\hline 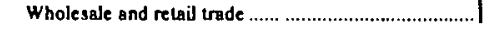 & 782.256 & 943.615 & 12.7 .271 & $1,276,546$ & 1.309 .747 & $1,745,400$ & 1954,400 & $2,199,500$ & 2.847 .200 & 4.414 .400 \\
\hline Finance, insurance and real es ate ...................................... & 159.156 & 265.745 & 307,276 & 349,138 & 370,834 & $\$ 84.300$ & 697.700 & 833.200 & 1.177 .500 & 2.075.9m \\
\hline 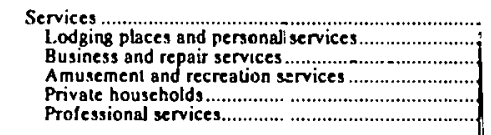 & 383.993 & 669.443 & $\$ 98,942$ & $1,038,251$ & $1,002,409$ & $\begin{array}{r}1.836,000 \\
126.000 \\
320.000 \\
5.3700 \\
42,900 \\
1,289.100\end{array}$ & $\begin{array}{r}2,32,000 \\
134,500 \\
902,300 \\
65.300 \\
43,700 \\
1,303,400\end{array}$ & $\begin{array}{r}2.762 .300 \\
143,000 \\
505.900 \\
74.400 \\
44.500 \\
1.944,300\end{array}$ & $\begin{array}{r}4.111 .100 \\
165.200 \\
7 \times 5.200 \\
9.700 \\
47.600 \\
3.016 .300\end{array}$ & $\begin{array}{r}8.001 .200 \\
218.400 \\
1.611 .2100 \\
151.8 m 0 \\
51.3 m \\
5.96 .1000\end{array}$ \\
\hline 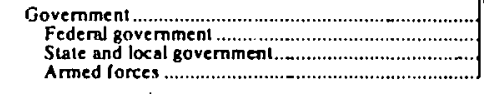 & $\begin{array}{l}352,=10 \\
144,000 \\
125,09 \\
82,83\end{array}$ & $\begin{array}{r}533.420 \\
192.865 \\
290.423 \\
50.132\end{array}$ & $\begin{array}{r}3 \times 1.399 \\
3.093 \\
1990.014 \\
65.302\end{array}$ & $\begin{array}{r}954,667 \\
343,025 \\
934.862 \\
76,778\end{array}$ & $\begin{array}{r}985.680 \\
343.445 \\
571.730 \\
70.506\end{array}$ & $\begin{array}{r}1.363 .200 \\
458,800 \\
840.000 \\
64.000\end{array}$ & $\begin{array}{r}1,512.500 \\
1331.900 \\
1.013 .700 \\
55.900\end{array}$ & $\begin{array}{r}1.907 .400 \\
6166.600 \\
1.222 .900 \\
67,800\end{array}$ & $\begin{array}{r}2.659 .3000 \\
817.300 \\
1,768.900 \\
73,000\end{array}$ & $\begin{array}{l}8.740 .100 \\
1.447 .100 \\
3.24 .710 \\
k 9.1 \mathrm{~m}\end{array}$ \\
\hline
\end{tabular}

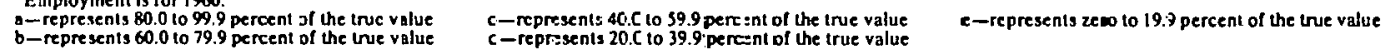

Source: U.S. Department of Commercz and the U.S. Ciepartment of AgricLl:ure. 197L. Vol. 5. SMSA i94. Wiashington, U.C.: U.S. Watzr Resources Council. 


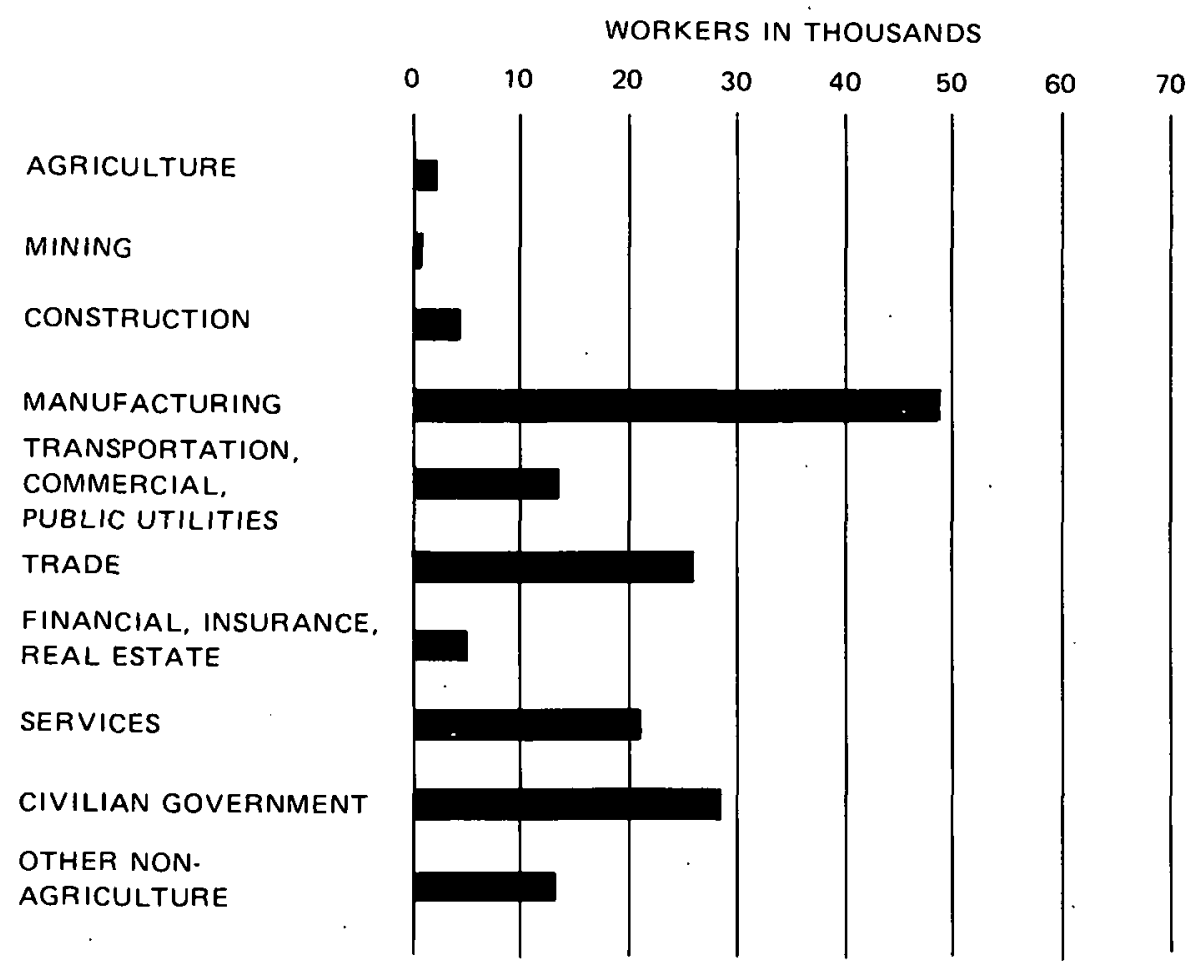

Fig. 2.8. Industry employment in St. Clair, Madison, and Monroe counties, 1970. Source: Coalcon: environmental conalysis report for the clean boiler fuel demonstration plant program at New Athens, Illinois. 1977. Prepared for the Energy Research and Development Administration, Division of Fossil Demonstration Plants. West Chester, Pa.: Roy F. Weston, Inc.

diversified development of the other industrial sectors. As a result of this developed economic structure, the social and economic impacts of siting a pipeline gas facility in the area are likcly to be minimal.

In addition to providing an overall picture of the local community, a description of the industrial structure of the economy of the region provides information that may be used to derive estimates of the extent to which facility construction and operation will lead to additional secondary employment opportunities within the area. Such secondary effects arise from the expansion of output from local firms supplying inputs to the facility (indirect effects) and the increase in general economic activity generated by higher regional income (induced effecls). These secondary effects must be added to the direct employment effect of the facility itself to assess the total impact on local employment opportunities. These, in turn, are employed in forecasting the population inflows from which many of the important social and economic impacts are derived.

The technique used here to forecast these secondary employment effects uses the employment multiplier that is derived from economic base theory. When applied to the direct. facility employment figures, this multiplier yields an estimate of the total (direct plus secondary) employment 
effects of the given facility in a given region. However, the economic base employment multiplier is an equilibrium concept that applies only after long-run adjustments have occurred. Consequently, its application should generally be limited to the operation phase of the given project because the construction phase is relatively short-lived. Secondary employment generated during this temporary construction phase must be estimated on a less formal basis.

The employment multiplier selected for use here is that calculated by Stenehjem and Metzger (1976). The economic structure of the St. Clair County site appears to meet the assumptions required for use of the simple ratio multiplier in lieu of either the complex ratio multiplier or the regression multiplier (Stenehjem and Metzger 1976, pp. 46-53). This multiplier is given as 2.5 for St. Clair County. This implies that for every new job created in the basic (export oriented) sector of the local economy, 1.5 jobs will be created in the service sector in equilibrium.

\subsubsection{Local infrastructure}

Governmental jurisdictions

St. Clair County, consisting of 22 townships, is governed by a county board. Each township has an elected township supervisor who is the chief administrative officer. In addition to the assessment of property for taxing purposes, the townships have twn main funstions: maintcnance of local roads and support of indigents. St. Clair County has 29 school districts and 42 special districts. The special districts provide services such as police, fire, parks and recreation, libraries, water, and solid waste disposal (U.S. Bureau of the Census 1973a).

Housing

According to the Coalcon Environmental Report (Coalcon 1977), a wide variety of housing unit.s in a broad price range exists within the eight-county area of the St. Louis SMSA.

For apartment dwellers garden apartments and high-rise suites are located in the suburbs, in park atmospheres, and in downtown St. Louis. In 1976 rentals varied for garden apartments from $\$ 150$ to $\$ 325$ per month, depending on the location, and for high-rise aparțents from $\$ 175$ tn $\$ 450$ per month, depending on the size.

Financing of homes in the metropolitan area is available through more than 90 financial institutions. Total deposits in these institutions exceed $\$ 5.5$ billion.

Within st. Clair County are a number of housing developments, particularly in the Belleville area where housing units are available for sale or rent. As of the week of March 8, 1976, approximately 180 homes were being marketed by the "multiplc listing realtors" in the Belleville area.

About half of these houses were priced at $\$ 35,000$ or more. In addition to those listed by realtors, it was believed that there were about 90 houses for sale but not listed with realtors. A local paper had 79 houses advertised for sale on March 4, 1976. The same paper also 1isted 48 furnished and/or unfurnished apartments and 17 houses for rent (Coalcon 1977). 
Although at New Athens itself there were no listings in the same period, the local industrial development organization did not believe that this lack would deter industry from moving into the area because of the amount of available land and the expressed interest in building housing developments of a number of reputable contractors.

A number of factors have delayed development of new housing in the New Athens area. One factor has been the lack of employment (Koehler 1976, p. 12). Another reason for limited housing development is the sewer ban that prohibits any major new sewer hookups to the New Athens wastewater treatment facility, which was imposed because of the insufficient capacity of the existing treatment facility. However, new treatment facilities are planned. When this construction is completed, more new housing will probably be developed (Coalcon 1977, p. 3-307).

\section{Education}

The educational system in the St. Clair County area is reasonably well developed, with some excess capacity. One public school in the New Athens Township serves grades $K$ through 12 . In addition, one parochial grade school exists in this township. The nearby Belleville school district has two senior high schools with a total enrollment of 6000 students, two intermediate schools, and nine elementary schools. Also this township has one parochial high school with an enrollment of 1200 students and nine parochial elementary schools. All of these schools are accredited by the State of Illinois (Coalcon 1977). In the larger area including St. Clair and Madison counties, 18 school districts have an existing capacity of 30,440 students (see Table

2.17). Current enrollment is about 25,436 students, leaving an excess capacity of 5004 students.

\begin{tabular}{|c|c|c|c|c|c|c|}
\hline & $\begin{array}{l}\text { District } \\
\text { Inumbe! }\end{array}$ & $\begin{array}{c}1970 \\
\text { Eill ullinent }\end{array}$ & $\begin{array}{c}\text { Current } \\
\text { cnrollmont }\end{array}$ & $\begin{array}{c}\text { Net } \\
\text { change }\end{array}$ & $\begin{array}{c}\text { Total } \\
\text { sapacsity }\end{array}$ & $\begin{array}{c}\text { Growth } \\
\text { capacity } \\
\text { (all +) }\end{array}$ \\
\hline Lebanon $(K-12)$ & 9 & 1,291 & 1,097 & -194 & 1,340 & 243 \\
\hline O'Fallon $(K-8)$ & 90 & 1,766 & 1,748 & -18 & 2,350 & 602 \\
\hline O'Fallon (high school) & 203 & 1,099 & 1,330 & +231 & 1,800 & 470 \\
\hline Central (O'Fallon $K-8)$ & 104 & 395 & 311 & -84 & 500 & 189 \\
\hline Shilnh $(K-8)$ & 85 & 218 & 204 & -14 & 300 & 96 \\
\hline Mascoutah $(K-\mid 2)$ & 19 & 3,963 & 3,054 & -11 & 4,250 & 296 \\
\hline Freeburg $(K-8)$ & 70 & 718 & 711 & -7 & 750 & 39 \\
\hline Freeburg $(K-12)$ & 77 & 417 & 564 & +147 & 630 & 66 \\
\hline Belleville $(K-8)$ & 118 & 4,500 & 3,850 & -650 & 4,700 & 850 \\
\hline Whiteside (Belleville $K-8$ ) & 115 & 282 & 282 & 0 & 330 & 48 \\
\hline Wolf Branch (Belleville $\mathrm{K}-8$ ) & 113 & 281 & 278 & -3 & 470 & 192 \\
\hline Bęlle Valley (Relleville (K-8) & 119 & 753 & 828 & +75 & 966 & 138 \\
\hline High Mount (Swansea K-8) & 116 & 409 & 398 & -11 & 520 & 122 \\
\hline Pontiac (Fairview $K-8$ ) & 105 & 926 & 834 & +12 & 1,134 & 200 \\
\hline Grant (Fairview K-8) & 110 & 1,326 & 1,098 & -228 & 1.350 & 252 \\
\hline Harmony (Edgemont K-8) & 175 & 1,488 & 1,245 & -243 & 1,650 & 405 \\
\hline Signal Hill (Edgemont $(K-8)$ & 181 & 506 & 495 & -11 & 600 & 105 \\
\hline Belleville (high school) & 201 & 5,682 & 6,109 & +427 & 6,800 & 691 \\
\hline Total & & 26,020 & 25,436 & -584 & 30,440 & 5,004 \\
\hline
\end{tabular}

Source: Coalcon: environmentol analysis report for the clean boller flut htamumislialion plant program at New Athens, /llinois. 1977. Prepared for the Energy Research and Development Administration, Division of Fossil Demonstration Plants. West Chester, Pa.: Roy F. Weston, Inc. 
For the St. Louis SMSA, major interstate highways (I-55, I-70, I-64, I-44) provide connecting links to major cities in all directions. St. Clair County has good east-west access but inadequate narrow two-lane facilities for north-south traffic. Another deficiency of the road network is the large number of at-grade rail crossings, which causes conflict of train and automobile traffic and the consequent delay in traffic flow several times during a typical day.

The existing principal and collector systems within the more densely developed urban areas of St. Clair County are inadequate. Many of these routes have limited improvements, with narrow, two-lane pavement carrying the bulk of the traffic. Much of the congestion is a result of the location of these principal routes and collertors. Motorists using thesc routes must drive through the central business districts of virtually all of the cities in the st.udy area. With uncoordinated traffic control devices, numerous stop signs, parallel parking, and no access control, the through-city routes are becoming highly congested. Furthermore, many of these routes are an important part of the total regional highway system. Fxtensive commercial develop* ment along these principal routes and collector streets adds to the congestion and decreases the capacities of the roadways (Coalcon 1977, p. 3-320).

Traffic on the principal and collector urban routes is generally increasing by about $5 \%$ per year. The lack of funds from state and county highway departments prevents improvements to meet the needs of increasing traffic. The rural principal and collector routes in St. Clair County will typically be capable of handling increases in traffic if certain narrow pavements, bridges, and other points of congestion are corrected. Interstate routes are adequate to handle up to three times the present traffic volume (Coalcon 1977. p. 3-322).

The major highway link between New Athens, Illinois, and the city of St. Louis in II.S. 460 . About one-half of the $48 \mathrm{~km}$ (30 miles) between St, Louis and New Athens is divided four-lane highway in excellent condition. The improved stretch of U.S. 460 runs between East St. Louis and a point just northwest of Freeburg. However, in East St. Louis it is currently necessary to travel on city streets because no improvements have been made on this route. Although several state and Federal proposals have been made, none have been implemented. At the present Limle lile stuation is being examined and reviewed by the Illinois State Department of Highways (Coalcon 1977, p. 3-322).

With regard to rail transportation, St. Clair County is served by 16 trunk-line railroads. Only Chicago is served by a larger railway network (Coalcon 1977, p. 3-3.34). This area is a major national rail center.

With regard to water transportation, the Mississippi River connects the St. Louis area to the Atlantic Ocean (through the Illinois River, the Great Lakes, and the St. Lawrence Seaway) and directly to the Gulf of Mexico (Coalcon 1977, p. 3-317). The Kaskaskia River Navigation Froject, wher cumpleted w111 allow barge navigation to the New Athens area. Limited navigation on the Kaskaskia is possible at present, although a part of the channelization work near New Athens remains to be completed (Coalcon 1977, p. 3-332). A barge facility to be located just downstream from New Athens will handle 3.6 to 7 million metric tons (4 to 8 million tons) per year of bulk commodities (Coalcon 1977, p. 3-336). 
Health care

According to Coalcon (1977), health care facilities available to the New Athens are are among the best in the nation. In the metropolitan St. Louis area, there are 13,753 hospital beds and 2181 doctors, representing a broad range of medical specialties. Among the better-known hospitals are such prominent names as Barnes, St. Louis Children's, St. Louis University, and Cardinal Gannon. In Belleville, about $27 \mathrm{~km}$ (17 miles) from New Athens, two hospitals - St. Elizabeth and Memorial - offer more than 900 hospital beds and emergency-room facilities. St. Elizabeth and Memorial function as a medical center for the entire area. Two additional local hospitals are about $16 \mathrm{~km}$ (10 miles) from New Athens; one hospital is also located in Sparta, about $29 \mathrm{~km}$ ( $18 \mathrm{miles}$ ) distant. Most New Athens residents use the hospital facilities at Belleville (Coalcon 1977, p. 3-292).

Ambulance service is provided by the New Athens Volunteer Fire Department and by an ambulance service in Freeburg. The Freeburg-based ambulance service, which is actually owned by the village of New Athens, charges for its service.

New Athens township currently has three medical doctors, one dentist, and one chiropractor to serve the medical needs of the immediate New Athens area (Coalcon 1977, p 3-292).

The existing medical facilities are considered by local employers to adequately meet the current needs of the community. With major facilities 20 to $30 \mathrm{~min}$ away at Belleville, the consensus is that those nearby hospitals sufficiently fulfill the needs of the resident population (Coalcon 1977, p. 3-292).

\section{Police and fire protection}

The New Athens Township Police Department has three full-time police offiers with two radio-equipped patrol cars. In dudition, the St. Clair County Sheriff's Departinent has 102 employees, including 34 full-time deputies. Also, the Illinois State Police force. serves the New Athens/St. Clair County area (Coalcon 1977).

The New Alliens Vuluiiteer lire Department serves the townshin with five pieces of fire-fighting equipment (Coalcon 1977). Rural areas within St. Clair County also have volunteer fire departments, and the major population centers in the surrounding area have full-time firemen working from well-equipped departments.

\section{Recreation}

Recreational opportunities in the New Athens Township include hunting, fishing, water sports, goif, tenn1s, and llikilly. Iii addition to cxisting high school sports, a puhlir. park is planned. In Belleville, three public golf courses, a public swimming pool, four city parks, and several private swimming and tennis clubs exist (Coalcon 1977).

The larger St. Louis SMSA offers professional sporting events, horse racing, and a variety of cultural activities. Table 2.18 describes the existing acreage devoted to recreational purposes in this area. 
Table 2. 18. Summary of the existing recreational land in the St. Louis SMS.A

In acres ${ }^{a}$

\begin{tabular}{|c|c|c|c|c|c|c|c|c|c|c|}
\hline & $\underset{\substack{\text { Re pional } \\
\text { rark }}}{ }$ & $\begin{array}{l}\text { Metro } \\
\text { park }\end{array}$ & $\begin{array}{l}\text { District } \\
\text { park }\end{array}$ & $\begin{array}{l}\text { Neigt borhood } \\
\text { park }\end{array}$ & $\begin{array}{l}\text { Vest Pocket } \\
\text { park }\end{array}$ & $\begin{array}{l}\text { Tot Lot } \\
\text { park }\end{array}$ & $\begin{array}{l}\text { Special } \\
\text { facility }\end{array}$ & $\begin{array}{l}\text { Conservaticos } \\
\text { area }\end{array}$ & $\begin{array}{c}\text { Forest } \\
\text { preserve }\end{array}$ & Total \\
\hline Franklin Cornty & 7.155 .0 & & 450.0 & 16.4 & & & 1704.0 & & & $9,325.4$ \\
\hline Jefferson Co גnty & & & 26.0 & 60.2 & 0.7 & & & & & 86.9 \\
\hline Madison Coumty & $7,301.0$ & 612.0 & 408.6 & 20.5 .4 & 7.3 & & 78.1 & & & $9,212.4$ \\
\hline Monroe County & & & 105.0 & 4.0 & & & & 590.0 & $2,046.0$ & $2,745.0$ \\
\hline St. Charles C.ount, & & s6.0 & 228.0 & 53.0 & & 0.5 & & 7040.0 & & $7,417.5$ \\
\hline St. Clair County & 1.755 .0 & 571.0 & 206.5 & 175.5 & 4.9 & 2.4 & & & 5.475 .0 & 8.210 .3 \\
\hline St. Louis City & $1,293.0$ & 974.0 & 260.7 & $\Xi 85.9$ & 6.4 & 4.9 & 178.4 & & & $3,103.3$ \\
\hline St. Louis County. & 5. .48 .0 & 3694.0 & 1578.0 & $\varepsilon 58.4$ & 8.9 & 15.1 & 875.5 & & $3,100.0$ & 15.522 .7 \\
\hline Total & $23,572.0$ & 5947.0 & 3262.8 & 1758.8 & 28.2 & 22.9 & .2836 .0 & 7630.0 & $10,621.0$ & 55.623 .5 \\
\hline
\end{tabular}

${ }^{*}$ Includes all publicly owned recreation land (schoo facilities excluded). Selected prirately owned recreat onal facilities having a major impact on regional recreation use paterns are inc uded in the "Special tacility" acreage.

Source: Coalcon: enironmenta. asalysis report for :he =laan boifer fuel demonstraticn plant orogram at New Athens, ilitinos. 1977. Prepared for the Energy Reseaxch and Develos:rient Administration, [iivis o 7 of Fosil Cemonstration Plants, West Chester, Py.: Roy F. Weston, Inc. 
Water supply and wastewater treatment

The water supply system that currently serves the New Athens Township has a plant capacity of $1855 \mathrm{~m}^{3} /$ day $(0.49 \mathrm{Mgd})$. Water for this system is withdrawn from the Kaskaskia River. The service area consists of 770 connections in New Athens and 220 connections in Lenzburg. Storage capacity in New Athens is $890 \mathrm{~m}^{3}$ (0.235 million gal), with consumption estimated at $1135 \mathrm{~m}^{3} /$ day $(0.30 \mathrm{Mgd})$, or approximately $60 \%$ of the plant design capacity. New Athens, Lenzburg, Marissa, and Tilden have recently joined to form the Kaskaskia Water District. A new plant to serve these areas has been completed and was scheduled to go into operation May 1, 1976, at which time the New Athens water plant was to be closed (Coalcon 1977).

Although a sewer ban has been in existence in the New Athens Township, plans have recently been completed for a new wastewater treatment facility that is designed to serve a population of about 3000 people (Coalcon 1977). It is expected that this $1135 \mathrm{~m}^{3} /$ day $(0.30 \mathrm{Mgd}$ ) plant will contain excess capacity to that currently demanded.

\section{Historic and archaeological sites}

Historic and archaeological sites in St. Clair County, as listed in the National Register of Historic Places, are as follows:

1. Eads Bridge - Mississippi River at Washington Street,

2. Lunsford-Pulcher archaeological site - Columbia vicinity,

3. Church of the Holy Family - Cahokia,

4. Jarrot-Nicholas house - Cahokia,

5. 01d Cahokia Courthouse (Francois Saucier House) - Cahokia,

6. Cahokia mounds - Collinsville vicinity,

7. Mermaid House Hotel - Lebanon, and

8. Emerald mound and village site - Lebanon vicinity.

None of the historical or archaeological sites listed in the National Register of Historic Places (as of May 1976) are on or in close proximity to the project site. The nearest sites listed are approximately $32 \mathrm{~km}$ (20 miles) from the project site.

According to Coalcon (1977), three buildings in the New Athens area are considered historic sites by the Southwest Illinois Metropolitan Planning Commission, which are

1. a residence at 409 Market Street, New Athens,

2. a residence on Van Buren, New Athens, and

3. the Geiger Store Company, New Athens.

Recent strip-mining activity on the site and in the surrounding vicinity has left no property eligible for inclusion in the National Register of Historic Places. According to Coalcon (1977), the Land and Historic Sites Division of the Illinois Department of Conservation is currently investigating archaeological resources in the project site area. The site and immediate 
vicinity have been previously strip-mined to depths ranging from about 18 to $30 \mathrm{~m}$ (60 to $100 \mathrm{ft}$ ). This previous activity precludes the existence of archaeological sites in the stripmined areas on and around the site. In addition, the access area from the project site to the Kaskaskia River has been disturbed by a U.S. Army Corps of Engineers channelization project and is currently covered by dredged material. Thus the project site and immediate surrounding area contains no known archaeological sites (Coalcon 1977, pp. 3-167 and 3-168).

\subsubsection{Ecology}

\subsubsection{Terrestrial ecology}

The area around New Athens, Illinois, in St. Clair County consists primarily of agricultural lands and surface-mined areas. Agricultural lands are devoted primarily to corn (2ea mays), wheat (Triticum aestivum), soybeans (Glycine max), and hay crops. Most surface-mined areas have been partially graded and planted in lequmes (mostly alfalfa. Medirnon anp.) and/or grasses (mostly Festuca spp. and Bromus spp.). Numerous herbaceous species and young cottonwood trees (Fopulus deltoides) have invaded these mined areas (II s. Army Corps of Engincors 1974; Haynes and Klimstra 1975). The scattered fallow fields on unmined land within the area are dominated by annual vegetative cover with some saplings.

The region lies within the Central Hardwood forest zone (Society of American Foresters 1976), and the Tall Grass Prairie (Coalcon 1977). Patches of both upland and bottomland forests still remain. Upland forests are composed primarily of various oak-hickory associations. Bottomland forests along the water sources and low-lying areas are composed primarily of silver maple (Acer saccharinum), American elm (Ulmus comericana), cottonwood, and willows (SaZix spp.) (Coalcon 1977; U.S. Army Corps of Engineers 1974; Society of Ameris.an Fnrect.ers 1967). The prairie grassland type has been mostly eliminated from St. Clair County. Within the county and in the vicinity of New Athens Township, land use for crops, pastureland, and surface mining has almost eliminated prairie plants such as big bluestem (Andropogon gerardi), little bluestell (A. scoparius), indian grass (Sorghastrom nutms), and prairie cord grass (Spartina pectinata). Scattered remnants of the prairie grassland group are now restricted to roadsides, railroads, and similar unmanaged sites (Coalcon 1977).

The area within the New Athens Township supports a diverse and abundant fauna because it provides an incerspersision of woodlands, croplands, fields, and reclaimed surface-mined lands. Hardin et al. (1976) conducted a survey of mammals and hirds nn the proposod coalcon demonstra tion site near New Athens. They noted 30 species of mammals and 121 species of birds, representing 15 and 33 families respectively. Game species of Illinois such as the bobwhite quail (Colinus virginianus), mourning dove (Zenaida macroura), cottontail rabbit (suluitugus floridonus), gray and fox squirrels (sciumus carolinensis and 5 . niger respectively), waterfowl (family Anatidae), and white-tailed deer (Odocoileus virginiconus) were common. Furbearers such as raccoon (Procyon lotor), mink (Mustela vison), fox (Vulpes fulva and Urocyon cinereoargenteus), and skunk (Mephitis mephitis) were also numerous.

Hardin et al. (1976) noted that upland and lowland woods were extremely important to the diversity of animals in the area. As a result of human manipulations (e.g., channelization, farming practices, and surface mining), woodlands in the region are becoming increasingly 
scarce (Fig. 2.9). Therefore, those that remain are important for wildlife; they provide cover, food, nesting, and roosting areas for many species. If the remaining woodlands were removed, animals such as bats (family Vespertilionidae), white-tailed deer, opossums (Didelphis marsupialis), raccoons, short-tailed shrews (Blarina brevicauda), moles (Scalopus aquaticus), squirrels, and many species of nesting birds might be eliminated from the area. In addition to the woodland areas, the variety of fields in various stages of succession on both mined and unmined land provides important habitat. (food and/or cover) for many small and large mammals (e.g., cottontail rabbits) and granivorous and insectivorous birds such as mourning doves, bobwhite quai1, etc. (U.S. Army Corps of Engineers 1974; Hardin et al. 1976).

ES-3630

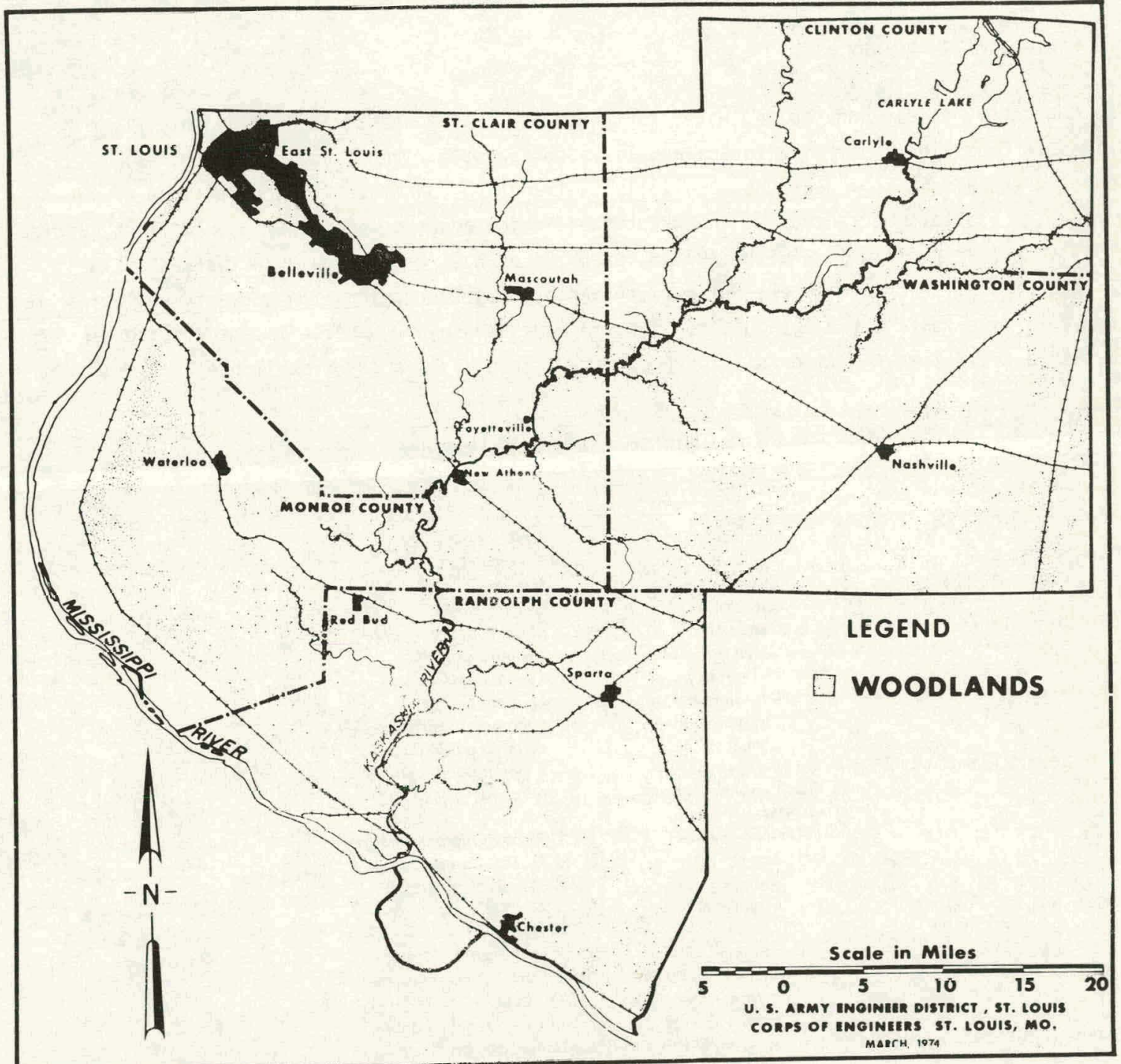

Fig. 2.9. Remaining woodlands within St. Clair and adjacent counties. Source: U.S. Army Corps of Engineers. 1974. Draft environmental statement: Kaskaskia navigation project (operation and maintenance). St. Louis, Mo.: U.S. Army Corps of Engineers, St. Louis District. 
The Kaskaskia River, which runs through the township (see Sect. 2.1), is strategically located in the Mississippi Valley migratory waterfowl flyway (Bellrose 1976). Because of this, the marshes, oxbows, backwater sloughs, river bottom timber, and lakes on surface-mined land provide habitat for migrating waterfowl. Waterfowl, particularly mallard (Anas platyrhynchos), feed on mast in the timbered bottomlands, especially when flooding coincides with spring and fall migrations (U.S. Army Corps of Engineers 1974). Also, these areas provide food, cover, and nesting sites for a smal1 permanent population of wood ducks (Aix sponsa), mallard, and bluewinged teal (Anas discors); wading birds such as herons and egrets (family Ardeidae); and various species of shorebirds.

Section 2.1.9.3 describes the endangered species known or suspected in the township.

\subsubsection{Aquatic ecology}

The source of proress and cooling water for the plant is the kaskaskia River. This river arises in Champaign County, Illinois, and flows southwest for about $560 \mathrm{~km}$ (350 miles), reaching the Mississippi near Chester, Illinois (Randolph County). It once provided a wide variety of habitats and supported an exceptionally rich aquatic fauna. Of the 177 fish species known to occur in Illinois, Smith (1971) listed 104 as having been found in the Kaskaskia drainage basin. Although recent human disturbances (e.g., dredging, impoundment, pollution from coal mine wastes, and agricultural runoff) have had severe adverse impacts on the Kaskaskia ecosystem, the river still supports many species of sport fish (Table 2.19).

Table 2.19. Sport fish of the Kaskaskia River

\begin{tabular}{ll}
\hline Common name & \multicolumn{1}{c}{ Scientific name } \\
\hline Channel catfish & Ictalurus punctatus \\
Flathead catfish & Pylodictis olivaris \\
Black bullhead & Ictalurus melas \\
Whitc bass & Mnrnne chrysops \\
Yellow bass & Morone mississippiensis \\
Green sunfish & Lepomis cyanellis \\
Warmouth & Lepomis gulosus \\
Orangespot & Lepomis humilis \\
Bluegill & Lepomis macrochirus \\
Longear & Lepomis megalotis \\
Redear & Lepumis microlophus \\
Largemouth bass & Micropterus salmoides \\
White crappie & Pomoxis annularis \\
Black crappie & Pomoxis nigrumaculatus \\
Sauyti & Stiznstedinn ranadense \\
Walleye & Stizostedion vitreum \\
Freshwater drum & Apoldinotus grunniens
\end{tabular}

Source: Coalcon: environmental analysis report for the clean boiler tuel demonstration plant pruyı an at New Athens, Illinois. 1977. Table 3-29. Prepared for the Energy Research and Development Administration, Division of Fossil Demonstration Plants. West Chester, Pa.: Roy F. Weston, Inc.

The lower Kaskaskia, including the portion that traverses St. Clair County, has a very gentle gradient (Fig. 2.10) and once meandered over a broad, marshy floodplain. However, the 80-km (50-mile) section between the mouth of the river and Fayetteville (St. Clair County) has been 


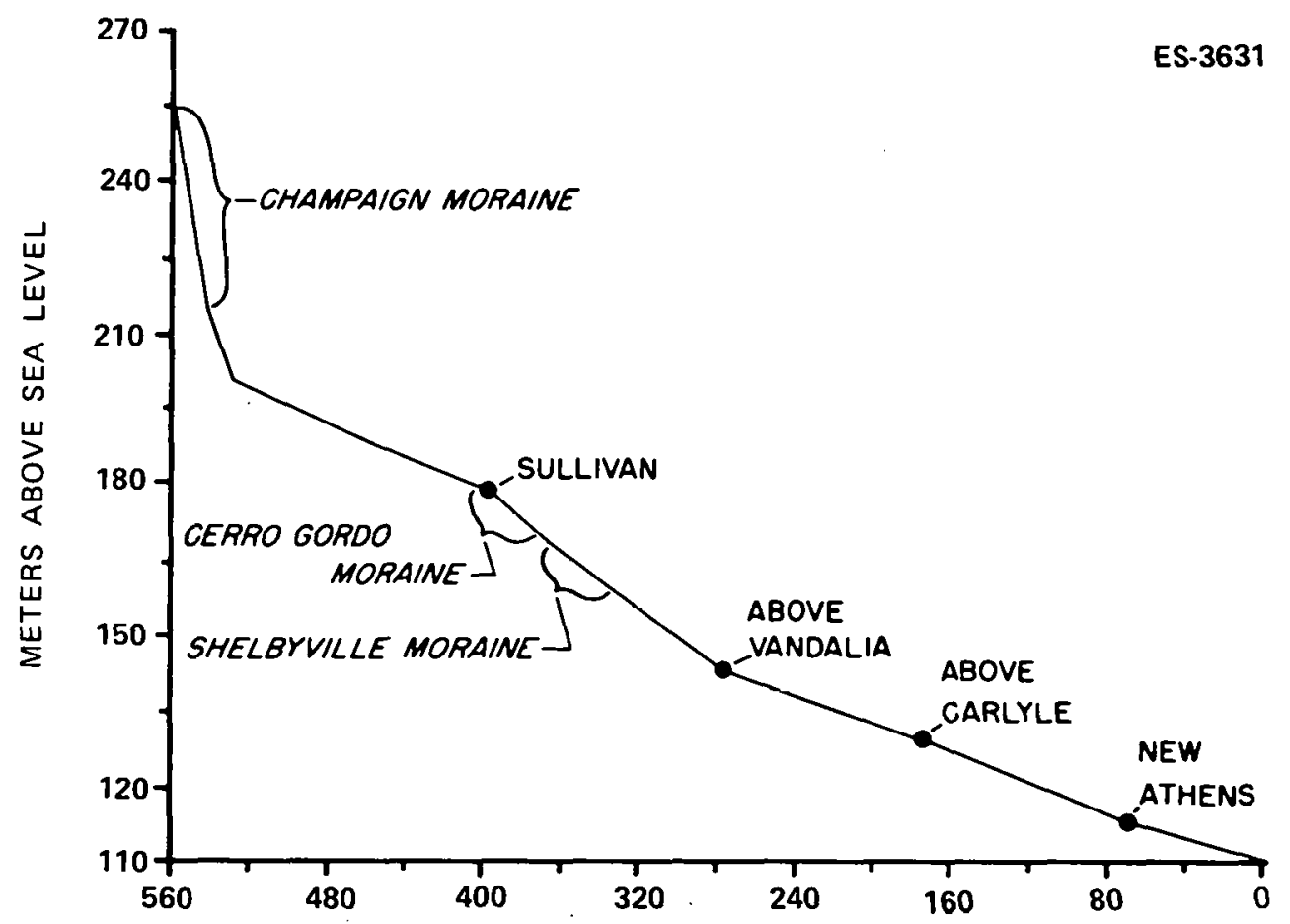

Fig. 2.10. Gradient profile of the Kaskaskia River. Source: D. L. Thomas. 1970. An ecological study of four darters of the genus Percina (Percidae) in the Kaskaskia River, Iizinois. Biological note no. 70, Fig. 3, p. 4. Urbana: Illinois Natural History Survey.

dammed and channelized by the corps of Engineers to facilitate barge traffic. This section now consists of a long, straight channel of uniform depth, devoid of vegctation. The former meanders, which were closed by the Corps at their upstream ends (U.S. Army Corps of Engineers 1974) but are still connected to the channel at their downstream ends, form a series of backwaters. The following sections contain brief biological descriptions of these two habitat types.

\section{Kaskaskia River channel}

The U.S. Army Corps of Engineers (1974) collected biological data at six sampling stations on the lower Kaskaskia, including two stations in the channelized section near New Athens (St. Clair County). Carp (Cyprinus carpio) and gizzard shad (Dorosoma cepedianum) accounted for $60 \%$ of the total fish biomass collected at these two stations (Table 2.20). The abundance of these two species, which are characteristic dominants in channelized, heavily silted rivers (Starrett 1972), indicates that this section of the Kaskaskia has been considerably disturbed by human activities. However, 27 other fish species were collected by the Corps at the two St. Clair County stations, including 13 sport fish (U.S. Army Corps of Engineers 1974, Tables 2.19. and 2.20). In a similar survey conducted in 1975 (Coalcon 1977), 31 fish species, including 14 sport fish, were collected in the channel between New Athens and Fayetteville (Coalcon 1977) (Table 2.21). 
Table 2.20. Fish collected by the Corps of Engineers from the Kaskaskia River near New Athens, Illinois (St. Clair County)

\begin{tabular}{|c|c|c|}
\hline & Total number & Total weight $(g)$ \\
\hline Alosa chrysochloris (skipjack herring) & 2 & 1260.0 \\
\hline Dorosoma cepedianum (gizzard shad) & 1425 & 21014.6 \\
\hline Hiodon alosides (goldeye) & 14 & 451.9 \\
\hline Cyprinus carpio (carp) & 39 & 44635.8 \\
\hline Notropis /utrinsis (red shiner) & 1 & 1.0 \\
\hline Notropis etherinoides (emerald shiner) & 12 & 50.0 \\
\hline Notropis blennius (river shiner) & 2 & 6.0 \\
\hline Pimephales vigilax (bullhead minnow) & 1 & 1.0 \\
\hline Carpiodes carpio (carpsucker) & 1 & 18.0 \\
\hline Ictiobus buba/us (smallmouth buffalo) & 8 & 5063.6 \\
\hline Ictiobus cyprinellus (largemouth buffalo) & 12. & 24440.0 \\
\hline Moxostoma macrolepidotum (northern redhorse) & 1 & 124.0 \\
\hline Ictalurus punctatus (channel catfish) & 4 & 88.3 \\
\hline Ictolurus furostus (blue eatfish) & 1 & 540.0 \\
\hline Pylodictis olivaris (flathead catfish) & 3 & 248.7 \\
\hline Morone chrysops (white bass) & 7 & 1444.5 \\
\hline Morone mississippicnsis (yeilow bass) & 3 & 96.6 \\
\hline Stizostedion canadense (sauger) & 7 & 764.2 \\
\hline Amia calva (bowfin) & 1 & 87.5 \\
\hline Labidesthes sicculus (brook silverside) & 11 & 27.7 \\
\hline Lepomis cyanellus (green sunfish) & 9 & 200.7 \\
\hline Lepomis marronhirus (bluegill) & 55 & 1222.8 \\
\hline Lepnmis megalotis (longear sunfigh) & 3 & 216.3 \\
\hline Lepomis humilis (orangespotted sunfish) & 7 & 43.7 \\
\hline Micropterus salmoides (largemouth bass) & 7 & 3248.8 \\
\hline Pomoxis ammularis (white crappie) & 21 & 3540.5 \\
\hline Pomoxis nigromaculatus (black crappie) & $?$ & 80.5 \\
\hline Aplodinotus grunniens (freshwater drum) & 5 & 661.8 \\
\hline Lepisosteus platostomus (shortnose gar) & 1 & 46.5 \\
\hline Total & & 109,626 \\
\hline
\end{tabular}

Source: U.S. Army Corps of Engineers. 1974. Draft environmental statement: Kaskaskia navigation project (operation and maintenance). Modified from Table II.g. St. Louis, Mo.: U.G. Arny Cüriss ul Erigineers, St. Louls District.

Benthic data collected by the Corps of Engineers (1974) and by Coalcon (1977) indicate a moderate degree of pollution in the channel. Tubificids and sphaeriid clams were the most abundant invertebrates in the Corps' benthic samples, which were collected approximately 1 to $2 \mathrm{~km}(0.6$ to 1.2 miles) downstream from New Athens. Burrowing mayflies (Ephemeroptera: Ephemeridae) were the dominant invertebrates in samples collected by Coalcon between New Athens and Fayettipville Tubificids are indicators of pollution, but sphaeriids and mayfly nymphs are sensilive to oxygen depletion and are generally absent from severely polluted rivers (Starrett 1972).

\section{Kaskaskia River backwaters}

The backwaler's created during the channelization of the lower Kaskaskia differ in many respects from the main channel and are extremely important components of the river ecosystem. Coalcon (1977) collected zooplankton, phytoplankton, benthos, and fish from backwaters of the Kaskaskia (between New Athens and Fayetteville) in September and December 1975. In the September collections, both phytoplankton density and zooplankton density were 4 times higher in the backwaters than in the channel; in December phytoplankton was 3.5 times more abundant and zooplankton 12 times more abundant in the backwaters than in the channel. Tubificids and chironomids constituted more than $95 \%$ of the benthic biomass in Coalcon's backwater samples (Coalcon presented biomass figures for only December). Coalcon collected very few mayfly nymphs and no sphaeriids in the backwaters. 
Table 2.21. Fish collected in the Kaskaskia River channel and backwaters during 1975 and 1976

\begin{tabular}{|c|c|c|}
\hline \multirow[b]{2}{*}{ • } & \multicolumn{2}{|c|}{ Area of capture } \\
\hline & River channel & Backwaters \\
\hline American eel (Anguil/a rostrata) & & $\mathrm{x}$ \\
\hline Paddlefish (Polydon spathula) & & $\mathrm{x}$ \\
\hline Longnose gar (Lepisosteus osseus) & $x$ & $x$ \\
\hline Shortnose gar (Lepisosteus platostomus) & $\mathrm{x}$ & \\
\hline Bowfin (Amia ca/va) & $x$ & $\mathrm{x}$ \\
\hline Gizzard shad (Dorosoma cepedianum) & $x$ & $x$ \\
\hline Threadfin shad (Dorosoma petenense) & $\mathrm{x}$ & $x$ \\
\hline Goldeye (Hiodon alosoides) & $x$ & $x$ \\
\hline Carp (Cyprinus carpio) & $x$ & $x$ \\
\hline Ghost shiner (Notropis buchanani) & $x$ & $x$ \\
\hline Emerald shiner (Notropis atherinoides) & $x$ & $x$ \\
\hline Red shiner (Notropis /utrensis) & $x$ & $x$ \\
\hline Bullhead minnow (Pimephales vigilax) & $x$ & $x$ \\
\hline River carpsucker (Carpiodes carpio) & $x$ & $x$ \\
\hline Quillback (Carpiodes cyprinus) & $\mathrm{x}$ & \\
\hline White surker (Catostomus commersoni) & $x$ & \\
\hline Smallmouth buffalo (/ctiobus bubalus) & $x$ & $\mathrm{x}$ \\
\hline Bigmouth buffalo (/ctiobus cyprine//us) & $x$ & $\mathrm{x}$ \\
\hline Flathead catfish (Pylodictus olivaris) & & $x$ \\
\hline Blue catfish (/ctalurus furcatus) & $x$ & \\
\hline Black bullhead (/ctalurus melas) & & $x$ \\
\hline Yellow bullhead (/ctalurus nata/is) & $x$ & $x$ \\
\hline Brown bullhead (/ctalurus nebulosus) & & $x$ \\
\hline Channel catfish (/ctalurus punctatus) & $x$ & \\
\hline Blackstripe topminnow (Fundulus notatus) & & $x$ \\
\hline Mosquitofish (Gambusia affinis) & $x$ & $x$ \\
\hline Brook silverside (Labidisthes sicculus) & $x$ & $x$ \\
\hline White bass (Morone chrysops) & $x$ & $x$ \\
\hline Yellow bass (Morone mississippiensis) & $x$ & $x$ \\
\hline Longear sunfish (Lepomis megalotis) & & $x$ \\
\hline Redear sunfish (Lepomis microlophus) & $\mathrm{x}$ & \\
\hline Orangespotted sunfish (Lepomis humilis) & $x$ & $x$ \\
\hline Bluegill sunfish (Lepomis macrochirus) & $x$ & $x$ \\
\hline Largemouth bass (Micropterus sa/moides) & $x$ & \\
\hline White crappie (Pomoxis annularis) & $x$ & $\mathbf{x}$ \\
\hline Black crappie (Pomoxis nigromaculatus) & $x$ & $x$ \\
\hline Mud darter (Etheostoma asprigene) & & $x$ \\
\hline Sauger (Stizostedion canatense) & $x$ & $x$ \\
\hline Walleye (Stizostedion vitreum) & $x$ & $x$ \\
\hline Freshwater drum (Ap/odinotus grunniens) & $x$ & $x$ \\
\hline
\end{tabular}

Source: Coalcon: environmental analysis report for the clean boiler fuel demonstration plant program at New Athens, Illinois. 1977. Modified from Tables B5R-R65 Preparent for the Enorgy Roscorch and Develujuirielit Ad: ministration, Division of Fossil Demonstration Plants. Wesl Cliester, Pa.: Roy F. Weston, Inc.

Coalcon (1977) reported that many sport and commercial fish, including largemouth bass, freshwater drum, buffalo, catfish, bullhead, sunfish, bluegill, and white bass, are more abundant in the backwaters than in the channel. In addition to providing habitat for adult fish, the backwaters are extremely important as spawning areas because of the aquatic vegetation present. For example, the nest-building sunfishes (Lepomis spp.), crappies (Pomoxis spp.), largemouth bass (Micropterus salmoides), and bullheads (Tetalurus spp.) most frequently nest among the roots of aquatic plants (Lagler et al. 1962). Most other fish species inhabiling still or sluggish waters spawn on rooted plants (Hynes 1972); few will spawn on silt-covered substrates. The backwaters are also important as nursery areas for young fish. They provide abundant zooplankton (the primary food source for most larval fishes), and their vegetation provides concealment from predators. 
According to Hynes (1972), many fish that inhabit the lower reaches of rivers spawn either in marshes or on the inundated floodplain during spring floods. Prior to channelization of the river, this was probably true of many of the fish of the lower Kaskaskia. Because the marshes have been mostly drained and flooding is now extremely rare, the backwaters are among the few remaining spawning and nursery areas for these fish. The backwaters may also be important for some fish of the Mississippi, because many of these move up into tributary streams to spawn (Hynes 1972).

\subsubsection{Endangered species}

\section{Terrestrial}

Places where proposed threatened and endangered plant species might be found in the New Athens Township are limited to the undisturbed banks of the kaskaskia kiver and to the woodlands (Coalcon 1977). Table 2.22 lists proposed threatened or endangered plant species reported to exist in Illinois. Of these, only the Tubercled orchid (Habenaria flava) has been reported from. St. Clair County. This orchid has not been reported from New Athens Township (Coalcon 1977).

Table 2.22. Iltinois plants reported as threntened or endangered by the Smithsonian Institution as puhlished in the July 1, 1975, Federal Register and the occurrence of these plants in Illinois

\begin{tabular}{|c|c|c|c|c|}
\hline Family & Species & Common name & Status & Occurrence in Illinois \\
\hline Asteraceae ${ }^{a}$ & Aster chasel & Chase aster & Endangered & Wooded ravines in Marshall, Peoria, and Tazewell counties \\
\hline Fabaceae $^{a}$ & Lespedeza leptostachya & Bush-clover $b$ & Endangered & Prairie soil in Cook, McKenry, and Winnebago counties \\
\hline Fabaceae & Petalostemem foliosum & Prairie-clover ${ }^{b}$ & Endangered & River banks and gravelly soil \\
\hline Malvaceae & lliamna remota & Mallowf & Endangered & On an island in the Kankakee River \\
\hline Orchidaceae $^{a}$ & Isotria medeolcides & Little five-leaves & Endangered & Acid soil in dry woods \\
\hline Anacardiaceae & $\begin{array}{l}\text { Rhus trilobata } \\
\text { var. arenaria }\end{array}$ & Sumac $^{\circ}$ & I hréáténeã & $\begin{array}{l}\text { Sandy banks and durles in the wesitell arid rivi llivesteiii } \\
\text { counties }\end{array}$ \\
\hline Asclepiadaceae & Ascleplas meadii & Milkweed & Threatened & $\begin{array}{l}\text { Dry ground; Fulton, Galiatin, Hancock, Henderson, and } \\
\text { Peoria counties }\end{array}$ \\
\hline Asterareae & $\begin{array}{l}\text { Boltonia asteroides } \\
\text { var. decurrens }\end{array}$ & Compoșitae ${ }^{c}$ & Threatened & $\begin{array}{l}\text { Alluvial bottoms along the Illinuis River in Fulton, } \\
\text { La Salle, Mason, Peoria, Tazewell, and Woodford counties }\end{array}$ \\
\hline Cyperaceae $^{a}$ & Cyperus grayioides & Sedge ${ }^{c}$ & Threatened & Sand prairies, Mason and Whiteside counties \\
\hline Fabaceae & Apios priceana & Groundnut & Threaleired & Wolf Lake, Union County \\
\hline Fabaceae $^{a}$ & Astragalus tennesseensis. & Milk-vetch ${ }^{b}$ & Threatened & $\begin{array}{l}\text { On dry slopes or prairie soil; Grundy, Lake, LaSalle, } \\
\text { Lee, and Ogle counties }\end{array}$ \\
\hline Limiaceae $^{a}$ & Synandra hispidula & Mint $^{c}$ & Threatened & Wooded ravines, Jackson County \\
\hline Lauraccac & Lindera melissifolia & Spice-bush ${ }^{b}$ & Threatened & Swamps and pond margins \\
\hline Orchidaceae & Platanthera flava & Tuberçed orrehid & Threatened & $\begin{array}{l}\text { Wet ground; Cook, Hancock, Kankakee, Lake, Ogle, Peoria, } \\
\text { St. Clair, Tazewell, and Wabash countles }\end{array}$ \\
\hline Orchidaceae & Platanthera leucophaea & Fringed orchid & Threatened & Meadows and swamps; Cook, Lake, and Winnebego counties \\
\hline Orchidaceae & Platanthera peramoena & $\begin{array}{l}\text { Fringeless purple } \\
\text { orchid }\end{array}$ & Threatened & Moist wỏōd, sỏuthểrh Illınols \\
\hline Poaseaค & Muhlenberqia curțișetoșa & Grass $^{b}$ & Threatened & Champaign County: type collected in 1891 \\
\hline Poaceae & Poa Paludigena & Blue grass ${ }^{a}$ & Threatened & Wet ground; northeastern Illinois \\
\hline Polypodlacuana" & 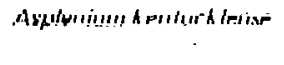 & $\begin{array}{l}\text { Krintuscky } \\
\text { spleenwort }\end{array}$ & Thrọagtonod & Sandrtone sliffs; southern Illinnis \\
\hline Primulaceae & Dodecatheon frenchii & Shooting-star ${ }^{2}$ & Threatened & Rich woods and rocky ledges; southern Illinois \\
\hline Saxifragaceae ${ }^{\theta}$ & Sullivantia ohionis & Saxlfrage $b$ & Threatened & $\begin{array}{l}\text { Cliffs; Carrol, De Kalb, Jo Daviess, Stephenson, and } \\
\text { Winnebago counties }\end{array}$ \\
\hline
\end{tabular}

${ }^{a}$ Not likely to be found on the New Athens site because of lack of suitable habitat.

${ }^{b}$ Generic name.

cFamilial name.

Source: Coalcon: environmental analysis report for the clean boiler fuel demonstration plant program at New Athens, Illinois. 1977. Modified from Table 1. Prepared for the Energy Research and Development Administration, Division of Fossil Demonstration Plants. West Chester, Pa.: Roy F. Weston, Inc. 
The Missouri Botanical Garden (cited in Coalcon 1977) listed five species of plants found in St. Clair County which are considered to be rare and endangered. These plants are as follows:

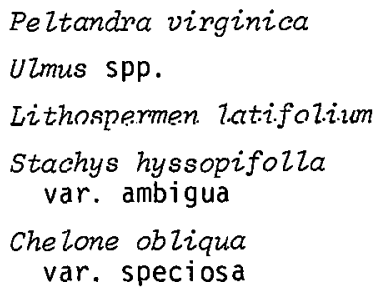

Arrow arum

Elm

Puccoon

Hedge nettle

Rose turtlehead

Four of the species are possible inhabitants of the bottomland wooded areas at the site but were not found. Inclusion of elm on the list may be a result of the widespread reduction of eim in the United States because of Dutch elm disease and various other pathogens. Elm trees were found in the site area (Coalcon 1977).

Five species of terrestrial vertebrates that have been reported from Illinois are listed as endangered by the U.S. Department of the Interior (1977) and are protected by Federal law as well as by the IZlinois Environmental Protection Act (1976). Of these species, only the Indiana bat (Myotis sockizis) has been reported in St. Clair County, and none have been reported in. New Athens Township. However; based on their known distributions and habitat requirements, all of these species except Bachman's warbler (Vermivora bachmani) could conceivably occur in the township (Table 2.23).

In addition to the endangered species listed in Table 2.23, vulnerable and rare species, which are not protected by $1 \mathrm{aw}$, have been reported from New Athens Township and St. Clair County (Table 2.24).

\section{Aquatic}

No nationally listed endangered or threatened aquatic species are known to occur in Illinois (U.S. Department of the Interior 1976). The Illinois Nature Preserves Commission (1976) has compiled a list of fish species that are considered to be vulnerable, rare, or of uncertain status in Illinois. Of these, the bigeye shiner (Notropis boops) and the Western sand darter (Ammocrypta claru) occur in the Kaskaskia River drainage basin. However, neither species has been reported in St. Clair County (Acherman 1975). 
Table 2.23. Endangered species of terrestrial vertebrates that occur in Illinois and could occur in New Athens Township

\begin{tabular}{|c|c|c|c|}
\hline Common name & Scientific name $e^{a}$ & $\begin{array}{c}\text { Illinois } \\
\text { distribution }^{b}\end{array}$ & Habitat ${ }^{b}$ \\
\hline Indiana bat & Myotis sodalis & Statewide & $\begin{array}{l}\text { Hibernates in caves; } \\
\text { bridges, buildings, } \\
\text { and hollow trees prob- } \\
\text { ably used in summęr; } \\
\text { abandoned underground } \\
\text { minoc could pruvidy } \\
\text { roosting and wintcring } \\
\text { a cas }\end{array}$ \\
\hline Gray bat & Myotis grisescens & $\begin{array}{l}\text { Pike and } \\
\text { Hardin counties, } \\
\text { but probably } \\
\text { ranges throughout } \\
\text { southern holf of } \\
\text { state }\end{array}$ & $\begin{array}{l}\text { Winter colonies prefer } \\
\text { deep caves with long } \\
\text { vertical shafts; known } \\
\text { to congregate in lime- } \\
\text { stone caverns in summer; } \\
\text { abandoned undergound } \\
\text { mines could provide } \\
\text { roosting and wintering } \\
\text { areas }\end{array}$ \\
\hline Bald eagle & Halialltus leucocephalus & $\begin{array}{l}\text { Floodplains of } \\
\text { Mississippi, } \\
\text { Illinois, and } \\
\text { Other large } \\
\text { rivers }\end{array}$ & $\begin{array}{l}\text { Most of ten observed near } \\
\text { high concentrations of } \\
\text { waterfowl or places where } \\
\text { dead fish are common; } \\
\text { usually pitsent as migrant }\end{array}$ \\
\hline Peregrine falcon & Fạlço pereqrinus ${ }^{c}$ & Scattered & $\begin{array}{l}\text { Prefers cliffs along } \\
\text { Mississippi River: } \\
\text { migrant }\end{array}$ \\
\hline
\end{tabular}

a These sperips are protected by Federal and llilinois law. An endangered species is one in dangèr ö extinction throughout all or a significant portion of Its range. [U.S. Depat lirient of the Interior. 1976,1977. "Endangercd and threatened wildlifc and plạnts," Fad. Regist. 41(208): 47181-47198 and 42(135): 36421-36431. Illinois Nature Preserves Commission. 1976. Endangered, vulnerable, and rare vertebrates of Illinois. Interim list of species. (Memeo rept., 7 pp.)] Carbondale.

${ }^{b}$ Adapted from the following: D. F. Hoffmeister and C. O. Mohr, 1972. Fielabook of Illinois mamma/s. New York: Dover Publications, Inc. C. S. Robbins, B. Brum, and H. S. Zim, 1966. Birds of North America: a guide to field Identification. New Youk: Golden Press. V. A. Tcrpening, ct al. 1973. A survey of the fauna and flora ocriurring in the Mississippi River floodplain between St. Louis, Missourl, and Cairo, Illinvis. Carbundale, III.: Cooperative Wildlife Rcscorch Loboratory, Southern lilinois Universiry. K. Achurmill, 1975. Raje and endangered vertcbrotcs of Illinoic. Urbania: Illinois Department of Transportation.

${ }^{c}$ Both the Ameriran peregrine falronn (Falro nereorinus anatuml and the Arctic peregrine falcon (F.p. tundruis) could conceivably occur in the New Athens area as migrants. The American pereyi ine falcon should not be expected within the township, because it usually does not migrate beyond the eastern front of the Rocky Mountains. However, the Arctic peregrine folcon is known to migrate south through eastern and middle North America to the Gulf Coast of the United States. (U.S. Department of the Interior, 1973. Threatened wildife of the United States. Washington, D.C.: U.S. Department of the Interior, Fish and Wildife Service.) 
Table 2.24. Vulnerable and rare vertebrates reported in St. Clair County

\begin{tabular}{|c|c|c|c|}
\hline Common name & Scientific name & Habitat & Status ${ }^{a}$ \\
\hline \multicolumn{4}{|c|}{ Mammals } \\
\hline Family: Vespertillionidae (plainnose bats) & & . & . \\
\hline Keen's bat ${ }^{0}$ & Myotic keenii & Caves in winter, unknown in summer & $R$ \\
\hline \multicolumn{4}{|l|}{ Family: Geomyidae (gophers) } \\
\hline Plains pocket gophe ${ }^{\varepsilon}$ & Geomys bursarius & Open grassy areas, fields, levees & $\mathrm{R}$ \\
\hline \multicolumn{4}{|l|}{ Family: Mustelidae (weasels) } \\
\hline Long-tailed weasel $l^{b, d}$ & Mustela frenata & Brushy or shrubby areas, woods & $\mathrm{R}$ \\
\hline \multirow[t]{2}{*}{ River otter } & Lutra canadensis & Permanent water areas bordered by woods & V \\
\hline & Birds & . & \\
\hline \multicolumn{4}{|l|}{ Family: Ardeidae (herons, hitterns) } \\
\hline Little blue heron & Florida caerulea caerulea & $\begin{array}{l}\text { Flooded fields, roadside ditches; summer } \\
\text { resident, post-breeding wanderer }\end{array}$ & V \\
\hline \multicolumn{4}{|l|}{ Family: Accipitridae (kites, hawks, eagles) } \\
\hline Sharp-shinned hawk ${ }^{d}$ & Accipiter striatus. & $\begin{array}{l}\text { Open woodlands, wood margins; permanent } \\
\text { resident }\end{array}$ & v \\
\hline Marsh hawk ${ }^{d}$ & Circus cyaneus & Fields near water; winter resident & v \\
\hline \multicolumn{4}{|l|}{ Family: Laniidae (shrikes) } \\
\hline Loggerhead shrike ${ }^{d}$ & Lanius /udovicianus migrans & Fields; permanent resident & V \\
\hline \multicolumn{4}{|l|}{ Family: Parulidae (warblers) } \\
\hline Nashville warbler ${ }^{d}$ & Vermivora ruficapilla ruficapilla & Deciduous woodlands; migrants & $\mathbf{R}$ \\
\hline \multirow[t]{2}{*}{ Mourning warbler ${ }^{d}$} & Oporornis philadelphis & Underbrush: migrants & $R$ \\
\hline & Amphibians & . & - \\
\hline \multicolumn{4}{|l|}{ Family: Plethodontidae (salamanders) } \\
\hline Dark-sided salamander ${ }^{c}$ & Eurycea longicauda melanopleura & $\begin{array}{l}\text { Rocky, swift streams in dissected, } \\
\text { forested regions; caves }\end{array}$ & $\mathbf{R}$ \\
\hline Family: Ranidae (true frogs) & & $\cdot$ & \\
\hline \multirow[t]{2}{*}{ Eastern wood frog } & Rana sylvatica sylvatica & $\begin{array}{l}\text { Mesic forests with permanent or } \\
\text { semipermanent pools }\end{array}$ & $\mathbf{R}$ \\
\hline & Reptiles & & $\cdot$ \\
\hline Family: Chelydridae (snapping turtles) & . & & \\
\hline Alligator snapping turtle & Macroclemys temmincki & Bottoms of muddy streams & $\mathbf{R}$ \\
\hline \multicolumn{4}{|l|}{ Family: Colubridae (colubrids) } \\
\hline Groat plains rot sirake & Elaphe guttata emoryi & Terrestrial & HV \\
\hline Northern flat-headed snake & Tantilla gracilis hallowelli & Fossorial & $v$ \\
\hline \multicolumn{4}{|l|}{ Family: Crntalidae (crotalids) } \\
\hline Eastern massasauga & Sistrurus catenatus catenatus & $\begin{array}{l}\text { Old fields with heavy bluegrass cover, } \\
\text { bogs, wooded areas }\end{array}$ & $\mathbf{R}$ \\
\hline Timber rattlesnake & Crotalus horridus horridus & $\begin{array}{l}\text { Forested bluffs, rock outcrops, uplanc } \\
\text { forests, cultivated fields, abandoned } \\
\text { buildings, old sawmills, brush piles }\end{array}$ & V \\
\hline
\end{tabular}

${ }^{a}$ Tlie fullowing detınitions are used to describe the status nf Illinois vertcbrates (Illinivis Nature Preserves Commission 1976):

$\mathrm{HV}=$ Highly Vulnerable - Species that are in immediate danger of extirpatiun as breeding species within lllinois, but not necessarily throughout their entire range.

$V=$ Vulnerable - Illinois species that are likely to become highly vulnerable in the future as a result of habitat changes, restricted distributions, spore hunting, commercial or scientific collecting, or other reasons.

$\mathbf{R}=$ Rare, Restricted, or Uncerlain Status - Species that are rare or restricted as breeding species in their Illinois distribution. Also includes species that are present in very low numbers or restricted to very limited portions of Illinois or for whom there is not enough information to categorize them at this time.

${ }^{b}$ Listed as rare in Illinois by Coalcon (1977).

cListed as rait il Illinols by Ackerman (1975).

${ }^{d}$ These species have been recently observed in New Athens Township (Coalcon 1977; Hardin et al. 1976). The remaining species listed in the table have been reported from St. Clair County at some time in the past. and their present occurrcnee in tliè cuurity is not established.

Suurces: K. Acherman, 1975. Rare and endangered vertebrates of Illinois. Urbania: Illinois Department of Transportation. Coalcon: Environmental analysis report for the clean boiler fuel demonstration plant program at New Athens, Illinois. 1977. Prepared for the Energy Research and Development Administration, Division of Fossil Demonstration Plants. West Chester, Pa.; Roy F. Weston, Inc. M. E. Hardin et al. 1976. A field study of selected fauna for the Coalcon clean liquid boiler fuels demonstration plant site: New Athens. Carbondale. III.: IIlinnis Cooperative Wildlife Research Laboratory, Southern Illinois University. Illinois Nature Preserves Commission. 1976. Endangered, vulnerable, and rare vertebrates of Illinois. Interim list of species. [Mimeo Rept., 7 pp.] Carbondale, III. V. A. Terpening et al. 1973. A survey of the fauna and flora occurring in the Mississippi River floodplain between St. Louis, Missouri, and Cairo, Illinois. Carbondale, III. : Cooperative Wildlife Research Laboratory, Southern Illinois University. 
REFERENCES FOR SECTION 2.1

Acherman, K. 1975. Rare and endangered vertebrates of IZlinois. Urbana: Illinois Department of Transportation.

Algermissen, S. T. 1968. United States earthquakes. Washington, D.C.: U.S. Government Printing office.

Algermissen, S. T., and Perkins, D. M. 1976. A probabilistic estimate of maximum acceleration in rock in the contiguous united States. Open file report no. 76-416. Washington, D.C.: U.S. Geological Survey.

Coalcon: environmental analysis report for the clean boiler Suel. ilsmunstration plant prngrm at New Athens, IZZinois. 1977. Prepared for the Energy Research and Development Administration, Division of Fossil Demonstration Plants. West Chester, Penn.: Roy F. Weston, Inc.

Eardley, A. J. 1951. Structural geology of North America. New York: Harper and Row.

Federal Highway Administration. 1969. Standard land use codirng monual (Reprint). Washington, D.C.: U.S. Department of Transportation.

Hardin, M. E., et al. 1976. A fiezd study of selected fauna for the coulcon cleon liquid boiler fuels demonstration plant site: New Athens. Carbondale, 111.: Ill1nois Cooperative Wildlife Research Laboratory, Southern Illinois University.

Haynes, R. J., and Klimstra, W. D. 1975. I7.7.inois Zands surface-mined for coal. Carbondale, I11.: Cooperative Wildlife Research Laboratory, Southern Illinois University.

Helyulu, F. C. 1968, Notor on the errthquake of November 9, 1083, in couthorn T1.i.inois. Environmental geoluyy nưte no. 24. Urbarla: I11 innis State Geolonical Survey.

Hirschborn, M. 1970. The Walsh-Healey and 90 dBA. Nat. Saf. News 101(4): 80-86.

Holtzwnrth, G. C. 1972. Mixing heights, wind speeds, arul potential for urban air pol.7ution throughout the contiguous United States. EPA publ1catiun IU. AF-101. Washington, D.C..: Environmental Protection Aycricy.

Hynes, H. B. N. 1972. The ecology of runtirly wulters. Toronto: Universit.y of Toronto Press.

Illinois Legislature. 1976. Illinois environmental protection act. House Bill no. 3788 (with amerudments).

Illinois Pollution Contrnl Board. 1973. Noise polzution control reguzations. Springfield, I11.: Illinois Environmental Protection Ngency.

Jacobs, A. M., compiler. 1971. Geology for planning in St. Clair County, IZlinois. Circular no. 465. Urbana: Illinois State Geological Survey. 
Kaskaskia River Watershed Act. 1972 (effective date Jan. 1). IZZinois revised statutes.

Chap. 19, pars. 41-44. Urbana: State of Illinois.

Keystone coal industry manual. 1976. New York: McGraw-Hill.

Koehler, G. 1976. Socioeconomic impact of the Coalcon clean boiler fuels program. New York: coalcon.

Lagler, C. F.; Bardach, J. E.; and Miller, R. P. 1962. Ichthyology, 545 pp. New York: John Wiley.

Noise Control Act of 1972. 1972. PL 92-574, amended by PL 94-301, May 31, 1976.

Nuttli, 0. W. 1974. Magnitude-recurrence relation for central Mississippi valley earthquakes. Buzz. Seisinuz. Soc. Am. 64(4): 1189-1207.

ORNL (Oak Ridge National Laboratory). 1977. ORNL geoecology data base land use printout, March 7, 1977, for Mason County, West Virginia. (Data obtained from U.S. Department of Agriculture statistical bulletin no. 461, 1971). Oak Ridge, Tenn.

Peterson, A. B. G., and Gross, E. G., Jr. 1972. Handbook of noise measurement. 7 th ed. Concord, Mass.: General Radio Company.

Risser, H. E. 1968. Gasification and liquefaction - their potential impact on various aspects of the coal industry. Circular no. 430. Urbana: Illinois State Geological Survey.

Ross, C. A. 1964. Geology of the Paducah and Smithlond quadrangles in Illinois. Circular no. 360. Urbana: Illinois State Geological Survey.

Shultz, T. J., and McMahon, N. M. 1971. Noise assessment guidelines. Prepared by Bolt, Beranek, and Newman, Inc. for the U.S. Department of Housing and Urban Development, Washington, D.C.: U.S. Government Printing Office.

Smith, P. W. '1961. The comphibiuns and replizes of IlZinois. Bulletin no. 28(1). Urbana: Illinois Natural History Survey.

- 1971. Illinois streams: a classification based on their fishes and an analysis of factors responsible for disappearance of native species. Biological note no. 76 . Urbana: Illinois Natural History Survey.

Smith, W. H., and Sta11, J. B. 1975. Coal and water resources for coal conversion in .T7.7inoi.s. Illinois State Water Survey Cooperative Resources report no. 4. Urbana: Illinois State Geological Survey.

Society of American Foresters. 1967. Forest cover types of North America (exclusive of Mexico). Bethesda, Md.: Society of American Foresters. 
Starrett, W. C. 1972. Man and the Illinois River. In River ecology and man, eds. R. T. Oglesby, C. A. Carlson, and J. H. McCann. Now York: Academic Press.

Stenehjem, E. J., and Metzger, J. E. 1976. A framework for projecting employment and population changes accompanying energy development. Washington, D.C.: Energy Research and Development Administration.

U.S. Army Corps of Engineers. 1974. Draft environmental statement: Kaskaskia novigation project (operation and maintenance). St. Louis, Mo.: U.S. Army Corps of Engineers, St. Louis District.

U.S. Bureau of the Census. 1973a. Census of govermments, 1972. Vol. 1. Washington, D.C.: U.S. Government Printing Uffice.

- 1973b. County und vity dxita bovk, 1998. Washington, D.C.: U.5. Government Printing Office.

- 1971a. County business patterns. Washington, D.C.: U.S. Government Printing Office.

- 1971b. Statistical abstract of the United States: 1971. Washington, D.C.: U.S. Government Printing office.

- 1976. Statistical abstract of the United States: 1976. Washington, D.C.: U.S. Government Printing office.

U.S. Department of Commerce and the U.S. Department of Agriculture. 1974. 1972 OBERS projections, vol. 5. Washington, D.C.: U.S. Water Resources Council.

U.S. Department of Health, Education, and Welfare: National Institute for Occupationai Safety and Health. 1972. Occupational exposure to noise. Washington, D.C.: U.S. Government Printing office.

U.S. Department of the Interior. 1977. Endangered and threatened wildlife and plants. Fed. Reyist. 42(135): $36421-31$.

USEPA (U.S. Environmental Protection Agency). 1976. Monitoring and air quality trends report, 1974. EPA-450/1-76-001. Research Triangle Park, N.C.

USEIPA (U.S. Environmental l'rotection Agency), Uffice of Noise Abatement and Control. 1974. Information on levels of environmental noise requisite to protect public health and welfare with an adequate margin of safety. Document 550/9-74-004. Washington, D.C.: U.S. Government Printing office.

U.S. Office of Management and Budget. 1972. Standard industrial classification manual. Washington, D.C.: U.S. Office of Management and Budget, Statistical Policy Division. 


\subsection{DESCRIPTION OF LEWIS TOWNSHIP IN MASON COUNTY, WEST VIRGINIA}

\subsubsection{Site location}

Lewis Township is located in Mason County in western West Virginia. Its western and southern borders are formed by the Ohio and Kanawha rivers respectively (Fig. 2.11) (West Virginia Department of Highways 1976). The center of the township is located at about $38^{\circ} 58^{\prime} \mathrm{N} 1$ atitude and $82^{\circ} 05^{\prime} \mathrm{W}$ longitude or 4,301,500 $\mathrm{m} \mathrm{N}, 404,500 \mathrm{~m} \mathrm{E}$ in the UTM (Universal Transverse Mercator) grid system. The closest major metropolitan area, Charleston, is about $72 \mathrm{~km}$ (45 miles) to the southeast. The largest city within the township, Point Pleasant (population about 6000), lies along the Ohio River at its intersection with the Kanawha. The major highways in the township are state highways 2 and 62. A Baltimore and Ohio rail line runs through the township parallel to the Kanawha River and crosses the Ohio River in Point Pleasant. The topography is rolling with a maximum elevation of $255 \mathrm{~m}(830 \mathrm{ft})$ and a minimum of $165 \mathrm{~m}(540 \mathrm{ft})$.

\subsubsection{Geology}

\subsubsection{Coal reserves}

Mason County, West Virginia, is located on the southwest edge of the central part of the Appalachian Basin (Fig. 2.12), defined by the outcrop of the Permian age Dunkard group. As such, Mason County is centrally located within the Eastern Coal Field (Barlow 1974).

The most important local coal beds are the Pittsburg (No. 8) and the Pomeroy (No. 8A) or Redstone of West Virginia. They outcrop in Gallia County, Ohio, as well as in Mason County. The Pittsburg is defined as the base of the Monongahela group (Fig. 2.12), and the Pomeroy lies about $9 \mathrm{~m}(30 \mathrm{ft})$ above the base. In Gallia County, the Pittsburg coal bed is about I to $1.5 \mathrm{~m}$ ( 3 to $5 \mathrm{ft}$ ) thick, dnd lhe uverlying Pomeroy is somewhat thinner (Blake 1952).

Other coals mined in counties adjacent to Lewis Township are the upper Freeport (No. 7), middle Kittanning (No. 6), lower Kittanning (No. 5), and Clarion (No. 4A). These coals all belong to the Allegheny formation, which outcrops in western Gallia and adjacent eastern Ohio counties and throughout central West Virginia. The Allegheny formation is about $120 \mathrm{~m}(400 \mathrm{ft})$ or more deep throughout Mason and adjacent Jackson and northern Putnam counties in western West Virginia. The lower Kittanning is the only Allegheny coal that is minable in the threecounty region of West Virginia adjacent to Lewis Township (Blake 1952; Department of Industrial Relations 1975; Overbey 1961).

Table 2.25 lists the coal reserves and 1974 production of counties in Ohio and West Virginia which are close to Lewis Township and of other highly productive counties from which coal could feasibly be shipped by barge down the Ohio River. A strip-mine moratorium currently exists in most of the West Virginia counties bordering the Ohio River. As shown in lable 2.25, nearby counties are not prolific coal producers, but they do have moderate reserves. A seven-county region near Wheeling, West Virginia, about $160 \mathrm{~km}$ (100 miles) upstream on the Ohio River has at least three times as much reserves. Furthermore, during 1974 they produced 31 million metric tons ( 34.1 million tons) of coal compared with 1 million metric tons ( 1.13 million tons) from six counties near Lewis Township. Figure 2.13 shows the position of Mason County relative to minable coal in West Virginia (Keystone coal industry manual 1976). 

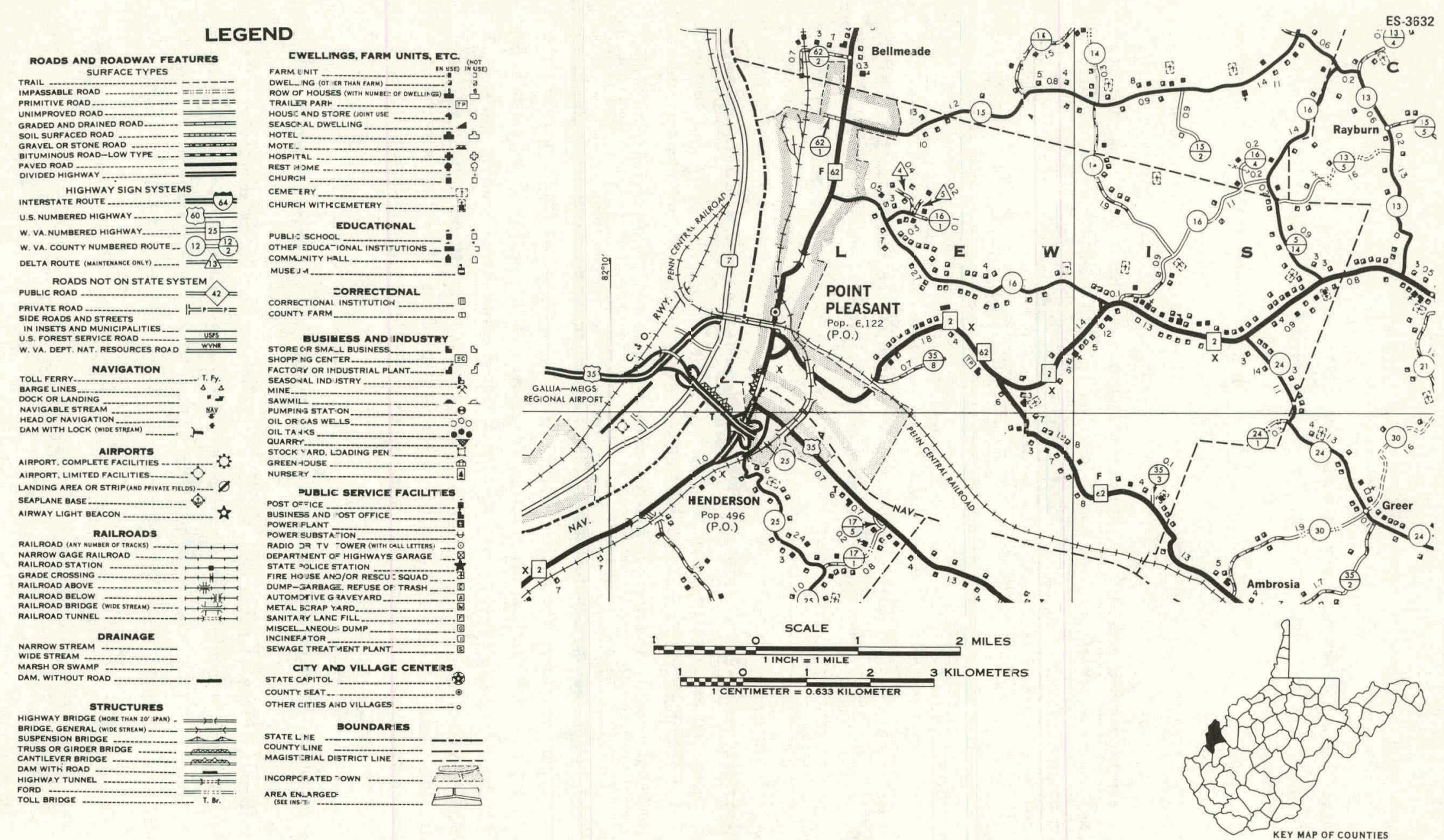

D.C. Fig. 2.11. Map of Lewis Tawnshis, Mason County, West Virginia. Source: Compiled from area map by U.J. Geological Survey. Washington, 


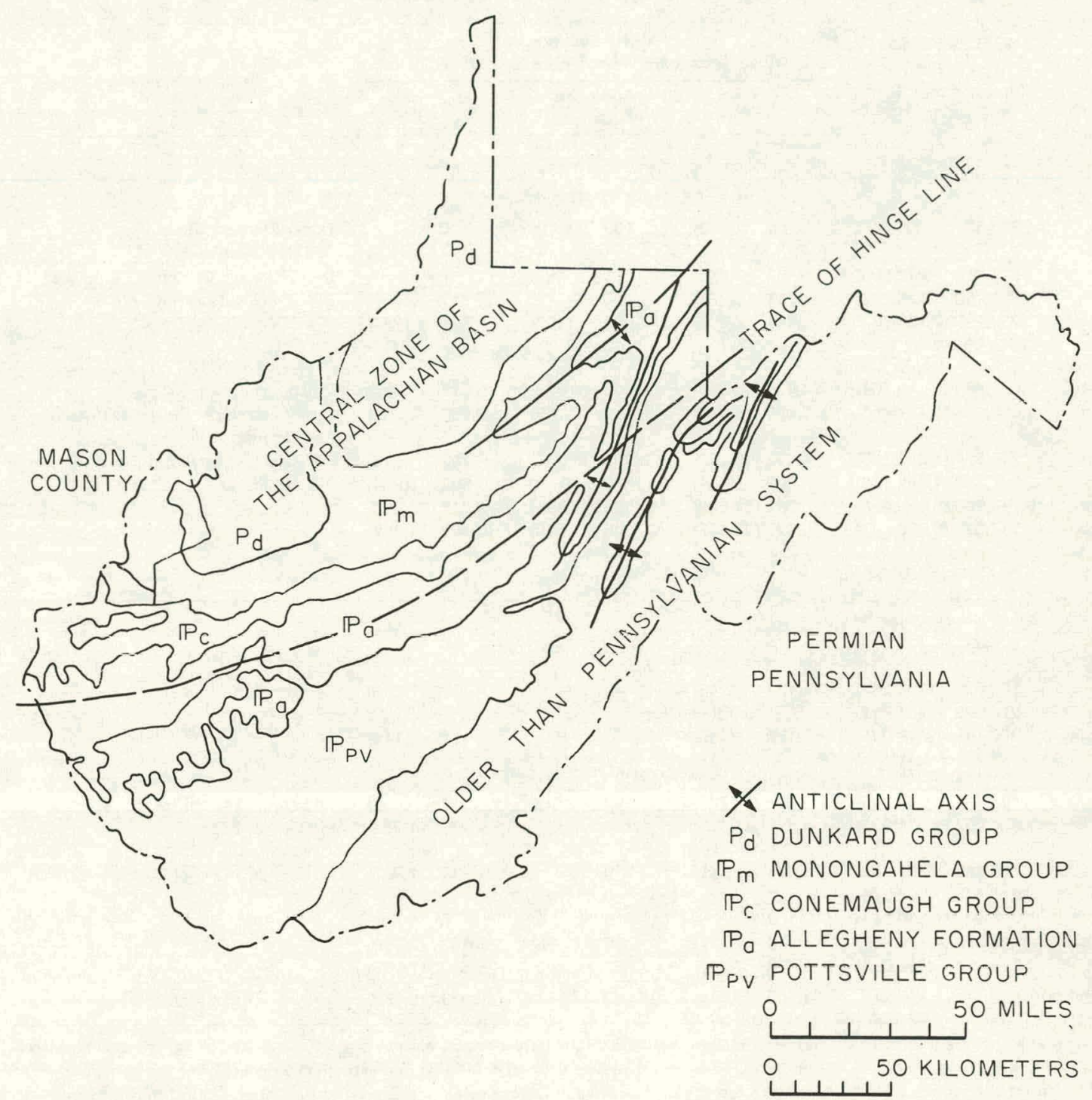

Fig. 2.12. Generalized geologic map of the coal fields of West Virginia. Source: West Virginia Geological and Economic Survey. Wheeling, W. Va.

A Lewis Township coal conversion facility does not have comparable local reserves or current coal production capability with that of St. Clair County, Illinois. The seven-county local region has reserves of 2.3 billion metric tons (2.56 billion tons) compared with 15 billion metric tons ( 16.50 billion tons) for a six-county region including St. Clair County. Local production (1974) in the seven counties surrounding Lewis Township was 1 million metric tons ( 1.13 million tons) compared with 20.4 million metric tons (22.5 million tons) for active mines within $48 \mathrm{~km}$ (30 miles) of the Illinois site. A demonstration size (0.5-million-metric-ton or 0.6-mil1ion-ton-per-year) coal conversion facility in Lewis Township would consume more than half the current production capacity of local mines (Keystone coal industry manual 1976). 
Table 2.25. Recoverable coal reserves and 1974 production for selected counties in Ohio and West Virginia which are potential suppliers for a coal conversion facility in Mason County, West Virginia

\begin{tabular}{|c|c|c|c|c|c|c|c|c|}
\hline \multirow{2}{*}{ County } & \multirow{2}{*}{$\begin{array}{c}1971 \text { recoverable }^{-} \\
\text {reserves } \\
\text { [metric tons } \times 10^{3} \\
\left.\left(\text { tons } \times 10^{3}\right)\right]\end{array}$} & \multicolumn{6}{|c|}{$\begin{array}{l}1974 \text { production } \\
\text { [metric tons } \times 10^{3} \text { (tons } \times 10^{3} \text { )] }\end{array}$} & \multirow{2}{*}{ Principal coal seam } \\
\hline & & \multicolumn{2}{|c|}{ Total } & \multicolumn{2}{|c|}{$\begin{array}{l}\text { Auger and } \\
\text { strip }\end{array}$} & \multicolumn{2}{|c|}{ Deep } & \\
\hline & & \multicolumn{6}{|c|}{ Ohio } & \\
\hline \multicolumn{9}{|c|}{ Within trucking distance } \\
\hline Gallia & $730,534 \quad(805,440)$ & 100 & $(110)$ & 100 & $(110)$ & 0 & & $\begin{array}{l}\text { Upper Freeport, Redstone, Pittsburgh, } \\
\text { Middle Kittanning }\end{array}$ \\
\hline Lawrence & $827,715 \quad(912,585)$ & 83 & $(92)$ & 83 & (92) & 0 & & Brookville and Clarion \\
\hline Meigs & $381,250 \quad(420,342)$ & 711 & $(784)$ & 0 & & 711 & (784) & Brookville and Clarion \\
\hline Subtotal & $1,939,499(2,138,367)$ & 894 & $(986)$ & 183 & (202) & 711 & $(784)$ & \\
\hline \multicolumn{9}{|c|}{ Long distance by barge } \\
\hline Belmont & $2,099,890(2,315,204)$ & 14,426 & $(15,905)$ & 8,908 & $(9,822)$ & 5,517 & $(6,083)$ & Pittsburgh \\
\hline Harrison & $1,086,458(1,197,859)$ & 5,150 & $(5,678)$ & 2,457 & $(2,709)$ & 2,693 & $(2,969)$ & $\begin{array}{l}\text { Lower and Upper Freeport, Meigs Creek, } \\
\text { Pittshurgh }\end{array}$ \\
\hline Jefferson & $1,260,644(1,389,905)$ & 4,655 & $(5,132)$ & 3,955 & $(4,360)$ & 700 & (772) & Pittsburgh, Waynesburg, Upper Freemont \\
\hline Monroe & $1,347,339(1,485,488)$ & 802 & (884) & 0 & 0 & 802 & (884) & Pittsburgh \\
\hline Subtotal & $5,748,980(6,338,456)$ & 25,032 & $(27,599)$ & 15,320 & $(16,891)$ & $9,712($ & $(10,708)$ & \\
\hline Total & $7,733,828(8,526,823)$ & 25,927 & $(28,585)$ & 15,503 & $(17,093)$ & 10,423 & $(11,492)$ & \\
\hline \multicolumn{9}{|c|}{ West Virginia } \\
\hline \multicolumn{9}{|c|}{ Within trucking distance ${ }^{b}$} \\
\hline Cabell & $(26,500)$ & 0 & & 0 & & 0 & & \\
\hline Jackson $^{c}$ & 0 & 0 & & 0 & & 0 & & \\
\hline Mason $^{c}$ & $139,028 \quad(153,283)$ & 132 & $(146)$ & 0 & & 132 & $(146)$ & Pittsburgh, $56 \mathrm{~cm}$ ( 22 in.), two mines \\
\hline Putnam & $216,085 \quad(238,242)$ & & Unlisted & & & & & \\
\hline Subtotal & $379,149 \quad(418,025)$ & 132 & $(146)$ & 0 & & 132 & $(146)$ & \\
\hline \multicolumn{9}{|c|}{ Long distance by barge ${ }^{d}$} \\
\hline Brooke & $83,771 \quad(92,360)$ & 636 & (701) & 89 & (98) & 547 & $(603)$ & Pittsburgh. $142 \mathrm{~cm}$ (56 in.), six mines \\
\hline Marshall $^{c}$ & $1,924,052(2,121,336)$ & 4,476 & $(4,935)$ & 0 & & 4,476 & $(4,935)$ & $\begin{array}{l}\text { Pittsburgh, } 152 \text { to } 168 \mathrm{~cm} \text { ( } 60 \text { to } 66 \text { in.), } \\
\text { five mines }\end{array}$ \\
\hline Ohio $^{c}$ & $318,869 \quad(351,565)$ & 1,434 & $(1,581)$ & 0 & & 1,434 & $(1,581)$ & Pittsburgh, $152 \mathrm{~cm}$ (60 in.), two mines \\
\hline Tyler $^{c}$ & $515.973 \quad(568.879)$ & 0 & & 0 & & 0 & & \\
\hline Wetzel $^{c}$ & $1,506,407(1,660,868)$ & 0 & & 0 & & 0 & & \\
\hline Subtotal & $4,349,979(4,796,008)$ & 6,546 & $(7,217)$ & 89 & (98) & 6,457 & $(7,119)$ & \\
\hline Total & $1,720,128(5,211,033)$ & 6,678 & $(7,363)$ & 89 & (08) & 6,589 & $(7,265)$ & \\
\hline \multicolumn{2}{|c|}{ Grand total } & \multicolumn{2}{|c|}{$32,605(35,948)$} & \multicolumn{2}{|c|}{$15,592(17,101)$} & \multicolumn{2}{|c|}{$17,013(18,757)$} & \\
\hline
\end{tabular}

${ }^{a}$ Recoverable reserves are defined differently in Ohio and West Virginia. Recoverable reserves are defined as $50 \%$ of inplace total reserves in both states. Only seams greater than $46 \mathrm{~cm}$ (18 in.) thick and shallower than $46 \mathrm{~m}$ (150 ft) or greater than $71 \mathrm{~cm}(28 \mathrm{in}$.) thick deeper than 46 $\mathrm{m}(150 \mathrm{ft})$ and shallower than $305 \mathrm{~m}(1,000 \mathrm{ft})$ are considered reserved in Ohio, whereas seams greater than $30 \mathrm{~cm}(12 \mathrm{in}$.$) thick and shallower$ than yIU $\mathrm{m}(3, \mathrm{UUU} \mathrm{ft})$ are considered reserves in West Virginia.

${ }^{b} \mathrm{~A}$ substantial part of West Virginia's reserves and production is found in the southern and central parts of the state where truck or rail transportation exceeds $80 \mathrm{~km}$ (50 uiles).

${ }^{\mathrm{C}}$ Strip-mine moratorium.

${ }^{d}$ Substantial reserves that could be barged are also located in southwestern Pennsylvania.

Sources: Keystone coal industry manual. 1976. New York: McGraw-Hill; J. A. Barlow. 1974. Coal and coal mining in West Virginia, Coal-Geology bulletin no. 2. Morgantown, W. Va.: West Virginia Geological and Economic Survey.

On the other hand, the coal reserves of eastern Ohio, northern West Virginia, and southwestern Pennsylvania have recoverable reserves that compare favorably with the Illinois site. It might be feasible to ship this coal from Wheeling, West Virginia, via barge.

Another prolific coal mining region is that of eastern Kentucky, southern West Virginia, and western Virginia. However, this region is not considered a viable source of supply because of the long rail or truck haulage required. 


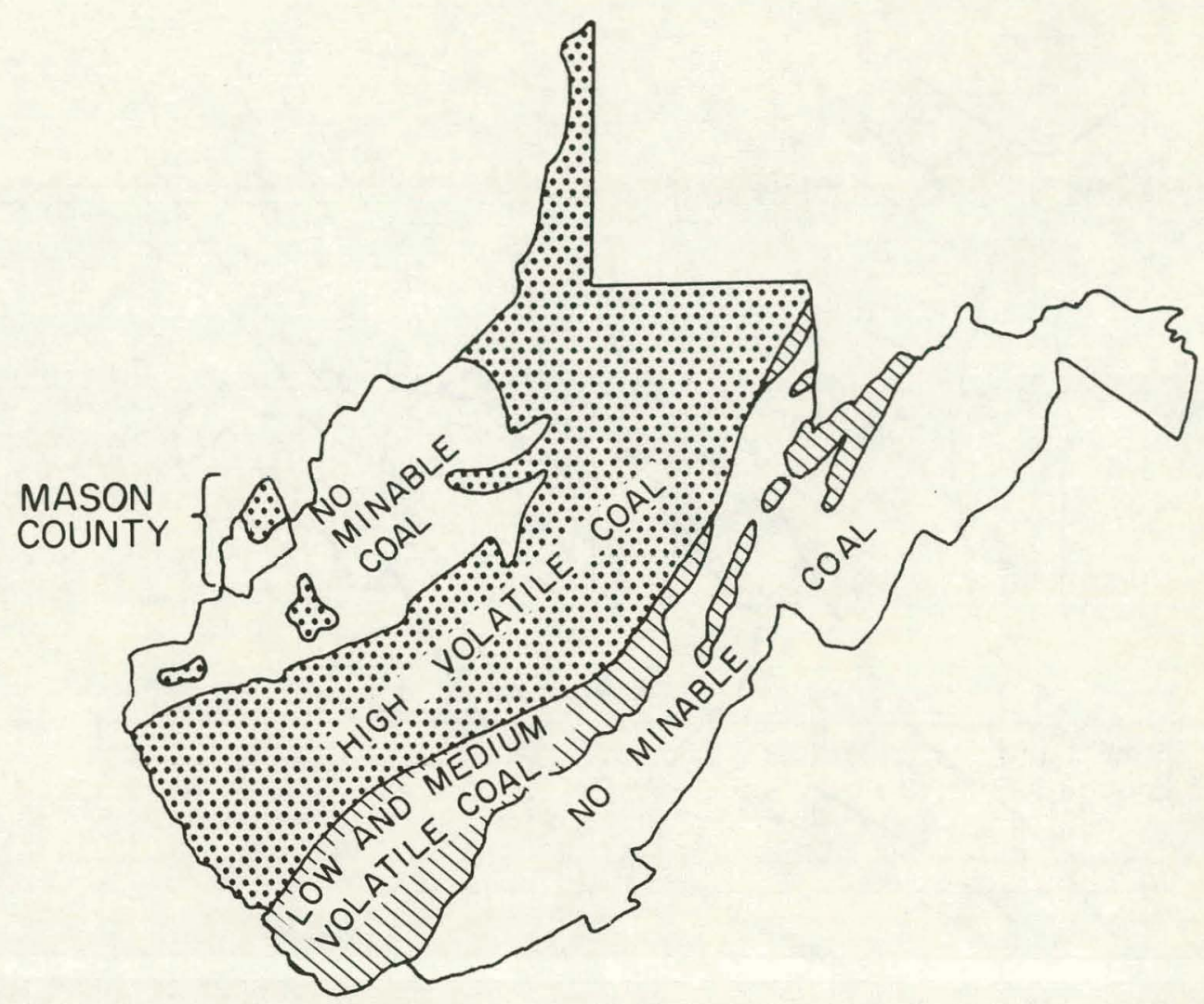

Fig. 2.13. Map showing the position of Mason County with respect to minable low and high volatility coal in West Virginia. Source: Babu et al. 1973. Suitability of West Virginia coals to coal-conversion processes. Coal-Geology bulletin no. 1. Morgantown, W. Va.: West Virginia Geological and Economic Survey.

Coal of central and northern West Virginia, eastern Ohio, and western Pennsylvania is classified as high-volatile C bituminous coal with a calorific value ranging between 11,000 and 13,500 Btu/1b. Figure 2.13 shows the position of Mason County with respect to coals of various volatility in West Virginia (Babu et a1. 1973).

The sulfur content of the coal varies. In Mason and adjacent counties it ranges between 1.5 and $3 \%$. In northern West Virginia along the Ohio River, sulfur content is greater than $3 \%$. Low sulfur $(<1.5 \%)$ coal is found in southern West Virginia (Babu et al. 1973).

\subsubsection{Regional geology}

Mason County, West Virginia, is located on the southwest side of the Appalachian Basin. Figure 2. 14 defines the central part of the Appalachian Basin as the outcrop of the Dunkard group of Permian age. In the deepest part of the basin, between 2700 and $3400 \mathrm{~m}$ (9000 and 11,000 ft) of Paleozoic strata occurs, and in Mason County the strata attain a thickness of $2600 \mathrm{~m}(8500 \mathrm{ft})$ (Overbey 1961). 


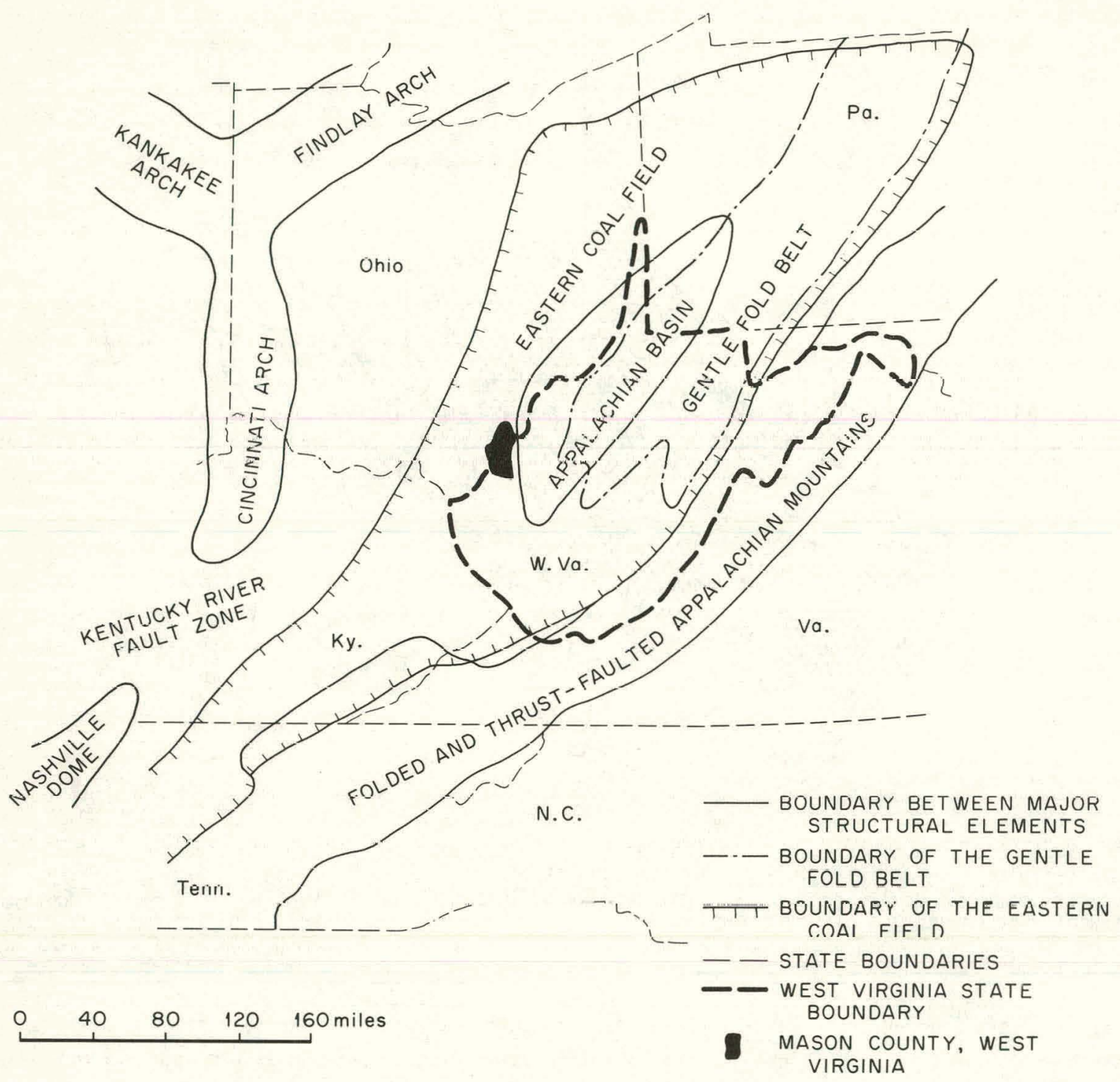

Fig. 2.14. Relationship between the eastern coal field and major structural features. Sources: (1) A. J. Eardley. 1951. Structural geology of Nort.h. Amerien. New York: Harper and Brothers; (2) Keystone coal industry manual. 1976. New York: McGraw-Hi11.

The Appalachian Basin as a whole is coextensive with the Eastern Coal Field (Fig. 2.14) and is defined by the outcrop of Pennsylvania strata from northeastern Alabama to northern Pennsylvania (Keystone coal industry manual 1976; Eardley 1951).

The Appalachian Basin is bordered by several areas of regional uplift. The Findlay and Cincinnati arches lie to the northwest and west respectively. The Cincinnati Arch is separated from the Nashville Dome by the Kentucky River fault zone. 01der Paleozoic strata are exposed in the central zones of these arches, the exposed strata becoming progressively younger as rock units dip gently toward the Appalachian Basin. In Mason County the average dip is about $11 \mathrm{~m} / \mathrm{km}$ 
(36 ft/mile) toward the east. The Appalachian Mountains lie immediately to the southeast of the Eastern Coal Field and, prior to Pennsylvania time, were part of an ancestral Appalachian Basin. Near the close of Paleozoic time, the eastern margin of the Appalachian Basin was deformed into a series of highly folded and thrust-faulted strata. Deformation was culminated by uplift and erosion, removing whatever Pennsylvanian strata were once present. At the same time, the northeastern side of the present Appalachian Basin was deformed into a series of gentle folds.

The broad outcrop patterns of the Dunkard and Monongahela groups along the Ohio River are indicative of very gentle dip and structural features too fine to be revealed on a generalized geologic map. Large folds are indicated by wavy outcrop bands of the Monongahela and Conemaugh groups and the Allegheny formation of northeastern West Virginia (Blake 1952; Eardley 1951).

Most of the oil and gas production of the Appalachian Basin is found in the gentle fold belt. Gallia County, Ohio, and Mason County, West Virginia, have minor oi 1 and gas production that apparently is stratigraphically controlled. Jackson County, immediately east of Mason County and bordering the fold belt, has substantially more oil and gas production because structural control exists there (Overbey 1961).

\section{Incal geologic structure}

Figure 2.15 is a structure contour map of the top of the Berea sandstone in Lewis Township, Mason County. $0 i 1$ and gas are found in the Berea sandstone, but there is little local production because of the lack of structural control. Several dry holes and two abandoned oil wells are located in Lewis Township (Fig. 2.15). The 0il was apparently stratigraphically controlled. The Berea dips gently to the southeast at an average rate of $6.8 \mathrm{~m} / \mathrm{km}$ ( $36 \mathrm{ft} / \mathrm{mile}$ ). This gentle dip is expressed at the surface by the broad outcrop patterns of the Dunkard and Monongahela groups shown in Fig. 2.12 (Overbey 1961).

\subsubsection{Stratigraphy}

Exposed strata of the Ohio River Valley and adjacent uplands are the Conemaugh and Monongahela groups of Pennsylvanian age. Figure 2.16 is a genlogic cross section illustrating the nearsurface hydrogeoloyic units of eastern Gallia County, Ohio, and western Mason County, West Virginia (B1ake 1952).

The Dunkard group (Permian age) occurs as isolated remnants at the crests of hills on the Ohio side of the river. It is more extensively exposed, however, in eastern Mason and Jackson counties, West Virginia, because of a regional dip to the east toward the center of the Appalachian (Pittsburg-Huntington) Basin. A complete section of the Dunkard group is between 300 and $400 \mathrm{~m}$ (1000 and $1200 \mathrm{ft}$ ) thick in northernmost West Virginia, but much of the upper part is eroded out in Mason County, and a maximum of $190 \mathrm{~m}(620 \mathrm{ft})$ remains in northern Jackson County. The Dunkard consists of shale, sandstone, and minor coal seams. Dunkard coal is considered to be minable in northern West Virginia but not in Mason and Jackson counties (B1ake 1952; Overbey 1961).

The Munungahela group extends from about $15 \mathrm{~m}$ (50 ft.) above the valley floor to the highest summits in eastern Gallia County, Ohio, and Mason County. The Pittsburg No. 8 coal member, 


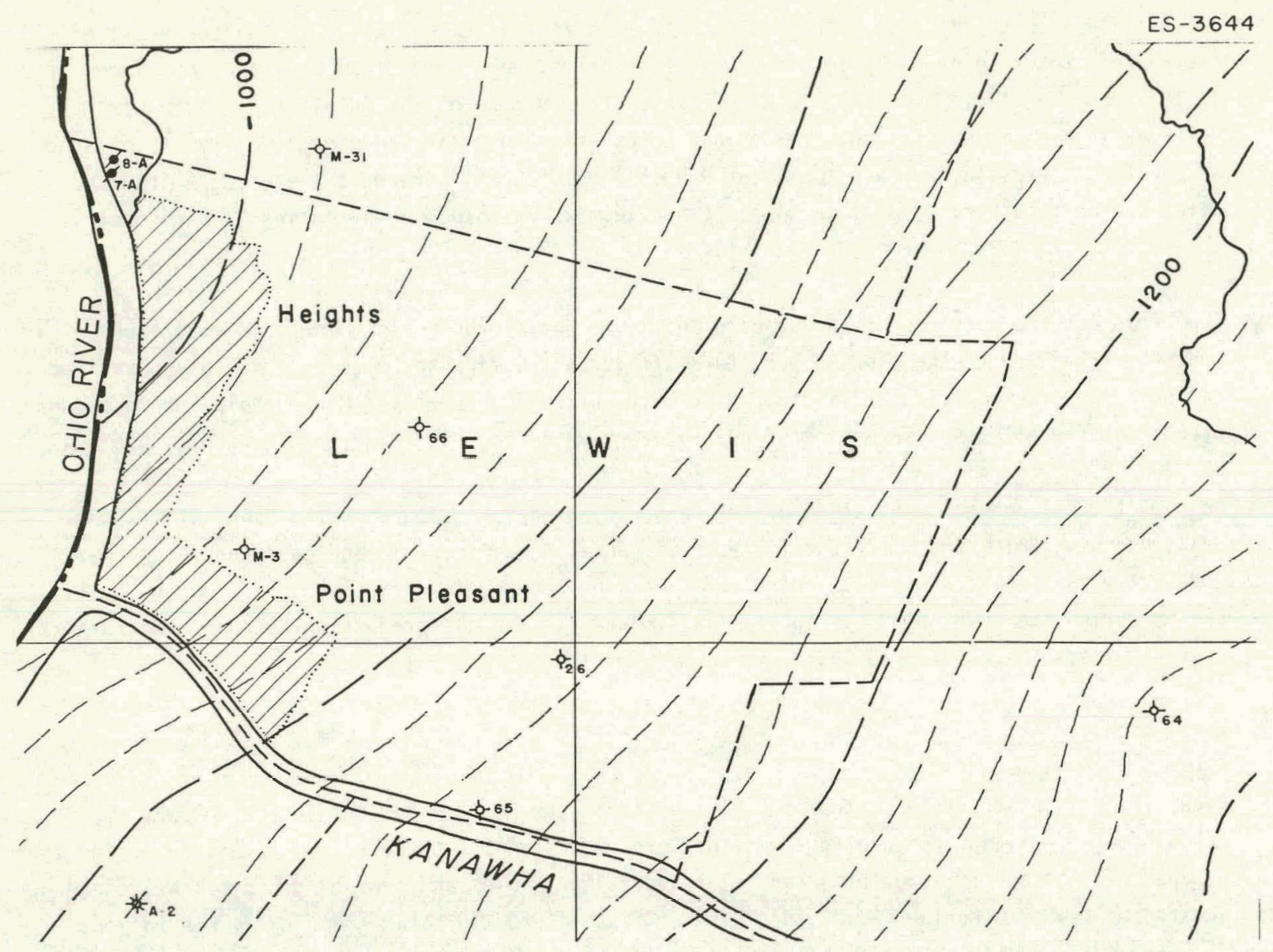

Fig. 2.15. Structure contours on top of the Berea Sandstone, Lewis Township and adjacent regions, Mason County, West Virginia. Source: W. K. Overbey. 1961. Oil and gas report on Jackson, Mason, and Putnom counties, West Virginia. Bulletin no. 23. Morgantown, W. Va.: West Virginia Geological and Economic Survey.

0.9 to $1.5 \mathrm{~m}$ ( 3 to $5 \mathrm{ft}$ ) thick, lies at its base, and another prominent coal member, the Pomeroy No. 8A (Redstone of West Virginia), lies about $9 \mathrm{~m}(30 \mathrm{ft}$ ) above the base. Where a complete section of Monongahela exists, it is about 76 to $90 \mathrm{~m}$ (250 to $300 \mathrm{ft}$ ) thick (Blake 195?)

The underlying Conemaugh group is exposed along the lower slopes and the valley floors except where it is covered by recent colluvium and alluvium and by Pleistocene glacial outwash deposits of the Ohio River Valley. The Conemaugh is approximately $120 \mathrm{~m}$ ( $400 \mathrm{ft}$ ) thick along the valley floor or $137 \mathrm{~m}(450 \mathrm{ft})$ thick from its contact with the Pittsburgh coal to its base. It reaches a maximum thickness of $180 \mathrm{~m}(580 \mathrm{ft})$ in the Mason, Jackson, and Putnam counties region. No significant thick coal members are found in it (Blake 1952).

The rest of the Pennsylvanian system along with the lower part of the Conemaugh is found only in the subsurface of Gallia and Mason counties. These strata are of the Allegheny formation and the Pottsville group. The Allegheny is approximately 60 to $67 \mathrm{~m}$ (200 to $220 \mathrm{ft}$ ) thick. The top and bottom of the Allegheny are identified by the Upper Freeport No. 7 and the Clarion 


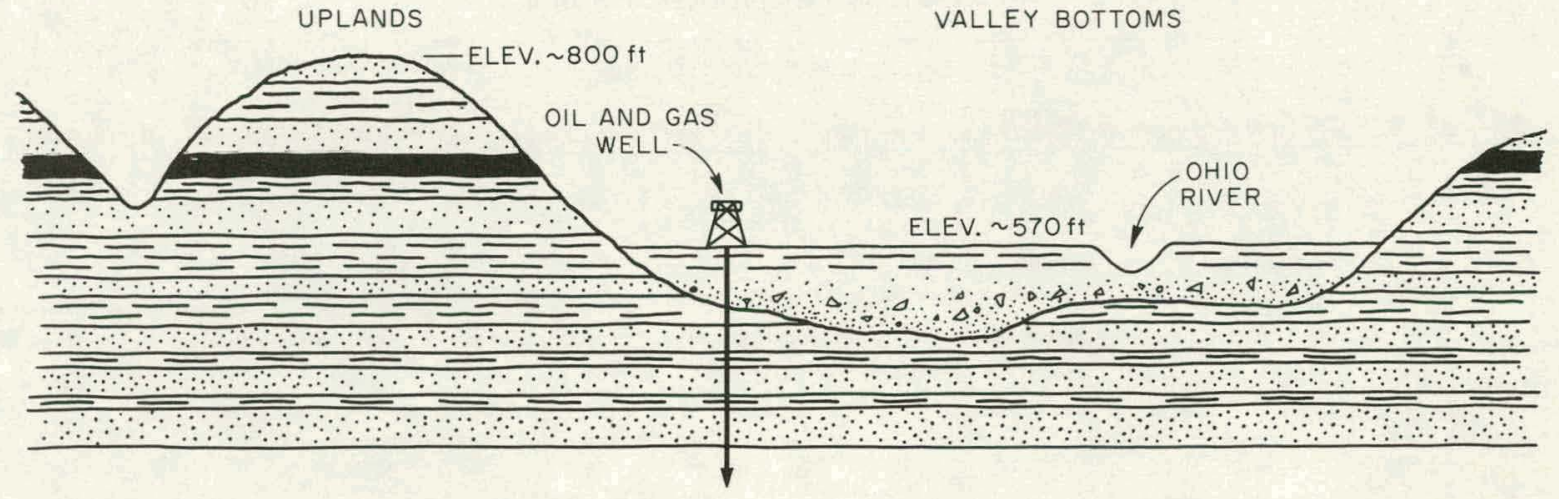

VALLEY BOTTOMS

\section{HYDROGEOLOGIC UNITS}

ALLUVIAL - GLACIOFLUVIAL AQUIFIERS: SILT WITH UNDERLYING SAND AND GRAVEL. AVERAGE THICKNESS $75 \mathrm{ft}$

CONEMAUGH FORMATION: CYCLOTHEMS CONTAINING CYCLIC INTERVALS OF SAND, SHALE AND MINOR COAL SEAMS. TOTAL THICKNESS $=400 \mathrm{ft}$.

\section{HYDROGEOLOGIC CHARACTERISTICS}

WATER OCCURS IN THE INTERGRANULAR PORE SPACES, THE SILT UNIT IS RELATIVELY IMPERMEABLE. THE UNDERLYING SAND AND GRAVEL ARE PERMEABLE. WELLS PRODUCE UP TO $1000 \mathrm{gpm}$, SLIGHTLY ALKALINE BUT HARD WATER $(450 \mathrm{ppm})$.

THE SHALE AND COAL MEMBERS ARE AQUITARDS. WATER OCCURS IN INTERGRANULAR PORE SPACES IN SANDSTONES, WHICH YIELD LESS THAN $5 \mathrm{gpm}$ OF ACIDIC, SULFUROUS, AND BRACKISH WATER.

\section{UPLANDS}

THE SHALE AND COAL MEMBERS ARE AQUITARDS. WATER OCCURS IN INTERGRANULAR PORE SPACES IN SANDSTONES, WHICH YIELD LESS THAN 5 gpm OF ACIDIC, SULFUROUS, AND BRACKISH WATER.

CYCLIC INTERVALS OF AND COAL, ING THE PITTSBURG NO. 8 COAL SEAM AT THE BASE AND THE POMEROY, $30 \mathrm{ft}$ ABOVE THE BASE. MAXIMUM THICK NESS $=250 \mathrm{ft}$.

CONEMAUGH FORMATION: CYCLOTHEMS CONTAINING CYCLIC INTERVALS OF SAND, SHALE AND MINOR COAL SEAIMS. IUIAL I HICKNESSS $=400 \mathrm{ft}$.

THE SHALE AND COAL MEMBERS ARE AQUITARDS. WATER OCCURS IN INTERGRANULAR PORE SPACES IN SANDSTONES, WHICH YIELD LESS THAN 5 gpm OF ACIDIC, SULFUROUS, AND BRACKISH WATER.

Fig. 2.16. Schematic geologic structure section and regional hydrogeologic systems of eastern Gallia County, Ohio, and western Mason County, West Virginia. Source: 0. D. Biake. 1952. Geology of Gallio County. Unpublished dissertation. Columbus: Ohio State University.

No. 4A coal members respectively (where present). In the three-county area of West Virginia,

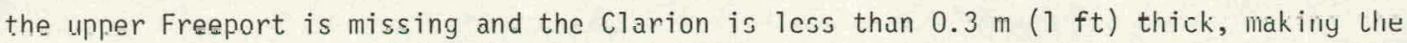
Al legheny Group difficult to distinguish from strata above and below it. Only the lower Kittanning No. 5 coal is minable near enough to supply a coal conversion plant (Blake 1952; Overbey 1961).

The Pottsville group ranges from 76 to $340 \mathrm{~m}$ (250 to $1100 \mathrm{ft}$ ) thick locally but rapidly thickens to $1170 \mathrm{~m}$ (3850 ft) east of the hinge line across central West Virginia. Although there is some Pottsville coal production in nearby counties to the south, no well-developed coal seams are found in this series in Mason, Putnam, and Jackson counties. Pottsville coal is mined extensively farther to the east (Overbey 1961).

Table 2.26 gives the general stratigraphic section from the base of the Mississippian to the surface in eastern Gallia County, Ohio (Stout, Ver Steez, and Lamb 1944; Ohio Division of Geological Survey 1966). Unit thicknesses were obtained from an oil well on the floodplain of the Ohio River opposite Lewis Township. Table 2.27 gives the general stratigraphic section from the base to the surface of the Paleozoic in Mason County, West Virginia. 
Table 2.26. General stratigraphic section from the base to the surface of the Mississippian in eastern Gallia County, Ohio

\begin{tabular}{|c|c|c|c|c|}
\hline \multirow[t]{2}{*}{ System } & \multirow[t]{2}{*}{$\begin{array}{l}\text { Formation } \\
\text { or group }\end{array}$} & \multirow[t]{2}{*}{ Description } & \multicolumn{2}{|c|}{$\begin{array}{c}\text { Depth to top/thickness } \\
\text { at Ohio Valley } \\
\text { Electric Corporation } \\
\text { oil and gas well }\end{array}$} \\
\hline & & & {$[\mathrm{m}$} & $(\mathrm{ft})]$ \\
\hline \multirow[t]{2}{*}{ Quaternary } & Recent & $\begin{array}{l}\text { Soil } \\
\text { Alluvium }\end{array}$ & $\begin{array}{l}0 / 1 \\
1 / 15\end{array}$ & $\begin{array}{l}(0 / 3) \\
(3 / 50)\end{array}$ \\
\hline & Pleistocene $^{a}$ & $\begin{array}{c}\text { Glaciofluvial }^{a} \\
\text { sediments }\end{array}$ & $16 / 5$ & $(53 / 17)$ \\
\hline Permian & Dunkard & $\begin{array}{l}\text { Sandstone } \\
\text { (tops of highest } \\
\text { hills nnly) }\end{array}$ & \multicolumn{2}{|c|}{$\begin{array}{l}\text { Not present in } \\
\text { valley bottoms }\end{array}$} \\
\hline \multirow[t]{5}{*}{ Pennsylvanian $^{b}$} & Monongahela ${ }^{c}$ & $\begin{array}{l}\text { Numerous cyclothems } \\
\text { on hill tops } \\
\text { and slopes only }\end{array}$ & \multicolumn{2}{|c|}{$\begin{array}{l}\text { Not present in } \\
\text { valley bottoms }\end{array}$} \\
\hline & Conemaugh & $\begin{array}{l}\text { Numerous cyclothems } \\
\text { partially exposed } \\
\text { on valley walls }\end{array}$ & $\begin{array}{l}21 / ? \\
235\end{array}$ & $\begin{array}{l}(70 / ?) \\
(770) \text { total } \\
\text { thickness }\end{array}$ \\
\hline & Allegheny ${ }^{d}$ & Numerous cyclothems & $? / ?$ & \\
\hline & Pottsville & Numerous cyclothems & $? / ?$ & \\
\hline & Maıırh Shıık grnup & Shale and sandstone & Absent & \\
\hline \multirow[t]{6}{*}{ Mississippian } & Maxville $e^{e}$ & Limestone & $256 / 28$ & $(840 / 93)$ \\
\hline & Greenbrier group & & & \\
\hline & Logan & $\begin{array}{l}\text { Sandstone and } \\
\text { shale }\end{array}$ & $284 / 17$ & $(933 / 57)$ \\
\hline & $\begin{array}{l}\text { Pocono Group } \\
\text { Cuyahoga } \\
\text { Big Injun }\end{array}$ & $\begin{array}{l}\text { Conglomerate, } \\
\text { sandstone and } \\
\text { shale }\end{array}$ & $3 U</ 154$ & $(990 / / 5006)$ \\
\hline & $\begin{array}{l}\text { Sunbury } \\
\text { Berea }^{\prime}\end{array}$ & $\begin{array}{l}\text { Black shale } \\
\text { Two sandstones } \\
\text { separated by a } \\
\text { shale unit }\end{array}$ & $\begin{array}{l}156 / 2 \\
458 / 24\end{array}$ & $\begin{array}{l}(1496 / 7) \\
(1503 / 79)\end{array}$ \\
\hline & Bedford & Gray shale & $482 / 18+$ & $(1582 / 60+)$ \\
\hline Devonian & Ohio & Black shale & \multicolumn{2}{|c|}{ Not penetrated } \\
\hline
\end{tabular}

${ }^{a}$ Principal source of groundwater, gravel, and sand for concrete aggregate, unimproved roads.

${ }^{b}$ The Pennsylvanian formations are undifferentiated in the driller's log of the Ohio Valley Electric Corporation oil and gas well.

${ }^{c}$ Primary source of strip-mined coal in eastern Gallia County. Principal members are the Pittsburgh No. $8 \mathrm{coal}$ at the base of the Monongahela formation and the Pomeroy, $9 \mathrm{~m}(3 \mathrm{u}+\mathrm{t})$ above the base.

${ }^{d}$ Primary source of strip-mined coal in western Gallia county. Principal members are the Upper Freeport, Middle Kittanning, Lower Kittanning, and Clarion. These members are potentially minable at depth in eastern Gallia County.

${ }^{e}$ Potentially mineable at dopth throughout Gallia County ( $\cap \cap$ Rlake, 1952. Genlngy of Gallia County. Unpublished dissertation. Columbus, Ohio: Ohio State University.

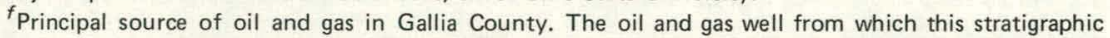
section was compiled has an initial daily production rate of $22,653 \mathrm{~m}^{3}\left(80,000 \mathrm{ft}^{3}\right)$ of gas, $6.36 \mathrm{mi}^{3}(40$ barrels) of oil, and an undetermined amount of salt water (O. D. Blake, 1952. Geology of Gallia County. Unpublished dissertation. Columbus, Ohio: Ohio State University.

Sources: (1) W. Stout, K. Ver Steez, and G. F. Lamb, 1944. Geology of water in Ohio. Bulletin no. 44, Columbus: Ohio Division of Geological Survey; (2) Uhio Divisıon of Geological Survey. 1966. Oil we/l driller's log, SW 1/4, Sect. 12, Addison Township Gallio County. Open file report. Columbus, Ohio. 
Table 2.27. General stratigraphic section from the base to the surface of the Paleozoic in Mason County, West Virginia

\begin{tabular}{|c|c|c|c|c|c|}
\hline System & Group & Formation & Description & $\begin{array}{l}\text { Depth to top } \\
{[\mathrm{m}(\mathrm{ft})]}\end{array}$ & $\begin{array}{l}\text { Thickness } \\
{[\mathrm{m}(\mathrm{ft})]}\end{array}$ \\
\hline Pennsylvanian ${ }^{a}$ & $\begin{array}{l}\text { Monongahela to } \\
\text { Pottsville }\end{array}$ & & $\begin{array}{l}\text { Numerous } \\
\text { cyclothems }\end{array}$ & $0(0)$ & $342(1123)$ \\
\hline \multirow[t]{10}{*}{ Mississippian } & & & & $342(1123)$ & $219(720)$ \\
\hline & Greenbrier $^{a}$ & & $\begin{array}{l}\text { Mainly limestone } \\
\text { and dolomite }\end{array}$ & & $48(159)$ \\
\hline & Pocono & & & & $171(561)$ \\
\hline & & Big Injun ${ }^{a}$ & Siltstone & & $5(18)$ \\
\hline & & & Sandstone & & $15(50)$ \\
\hline & & & Shale & & $46(150)$ \\
\hline & & & Sandstone & & $21(70)$ \\
\hline & & & Interbedded sand & & $70(2.30)$ \\
\hline & & Sunburg & Shale & & $3(10)$ \\
\hline & & Berea $^{a}$ & Sandstone & & $13(43)$ \\
\hline \multirow[t]{6}{*}{ Devonian } & & & & $562(1843)$ & $511(1677)$ \\
\hline & $\begin{array}{l}\text { Upper Devonian } \\
\text { shale }^{b}\end{array}$ & & . & & $424(1392)$ \\
\hline & & Marcellus & Shale & & $22(72)$ \\
\hline & & Huntersville & Cherty limestone & & $28(91)$ \\
\hline & & Oriskany ${ }^{a}$ & Sandstone & & $2(7)$ \\
\hline & & Helderberg & Limestone & & $35(115)$ \\
\hline \multirow[t]{7}{*}{ Silurian } & & & & $1073(3520)$ & $323(1060)$ \\
\hline & Salina & & $\begin{array}{l}\text { Limestone and } \\
\text { dolomite }\end{array}$ & & $116(380)$ \\
\hline & Niagara & & & & $207(680)$ \\
\hline & & McKenzie & Dolomite & & $78(256)$ \\
\hline & & Keifer ${ }^{b}$ & Sandstone & & $9(29)$ \\
\hline & & Rose Hill & Shale & & $89(293)$ \\
\hline & & Tuscarora $^{b}$ & $\begin{array}{l}\text { Sandstone with } \\
\text { basal shale }\end{array}$ & & $31(102)$ \\
\hline \multirow[t]{13}{*}{ Ordovician } & & & & $1396(4580)$ & $865(2838)$ \\
\hline & Upper Ordovician & & & & $357(1170)$ \\
\hline & & Juniata & Shale & & $79(260)$ \\
\hline & & Martinsburg & Shale & & $210(690)$ \\
\hline & & Upper Trenton & $\begin{array}{l}\text { Basal shale } \\
\text { and limestone }\end{array}$ & & $67(220)$ \\
\hline & Mıddle Urdovician ${ }^{2}$ & & & & $284(932)$ \\
\hline & & $\begin{array}{l}\text { Middle and lower } \\
\text { Trenton, Black }\end{array}$ & & & \\
\hline & & River, and Chazy & Limestone & & $272(892)$ \\
\hline & & St. Peter & Sandstone & & $11(36)$ \\
\hline & Lower Ordovician ${ }^{c}$ & & & & $224(736)$ \\
\hline & & Beckmantown & $\begin{array}{l}\text { Upper dolomitic } \\
\text { member }\end{array}$ & & $164(538)$ \\
\hline & . & & I nwer sandstone & & $00(198)$ \\
\hline & & & member & & . \\
\hline \multirow[t]{7}{*}{ Cambrian } & & & & $2261(7418)$ & $347(1140)$ \\
\hline & Upper Csmbrian & & & & $347(1140)$ \\
\hline & & Trempealean $^{c}$ & Dolomite & & $129(422)$ \\
\hline & & $\begin{array}{c}\text { Franconia - } \\
\text { Dresbach }\end{array}$ & Dolomite & & $37(122)$ \\
\hline & & Eau Claire & Shale member & & $\cdot 25(81)$ \\
\hline & & & Dolomite member & & $98(322)$ \\
\hline & & Mt $\operatorname{Sim} n n^{c}$ & Sondstone & & $35(116)$ \\
\hline Pre.Cambrian & & & $\begin{array}{l}\text { Granite wash and } \\
\text { schist or gneiss }\end{array}$ & $2608(8558)$ & $23(77)$ \\
\hline Total depth & & & & $2632(8635)$ & \\
\hline
\end{tabular}

${ }^{a}$ Oil and gas producing horizons in Masnn, .lackson, and Putnam counties.

${ }^{\circ}$ Gas producing horizons. Field stimulation of Devonian shales by explosive fracturing is currently in the test stage. If field stimulation is successful, gas reserves may be considerable.

${ }^{c}$ Oil and gas shows or potential.

Source: W. K. Overbey. 1961. Oil and gas report on Jackson, Mason, and Putnam counties, West Virginia, Bulletin no. 23. Morgantown, W. Va.: West Virginia Geological and Economic Survey. 
Blake describes the entire Pennsylvanian system of the Appalachian Basin as a repetitive sequence of "cyclothems." Each cyclothem is about 3 to $9 \mathrm{~m}$ (10 to $30 \mathrm{ft}$ ) thick. The basal unit of a cyclothem consists of a thin marine limestone (not always present) that is overlain successively by (1) a massive cross-bedded sandstone up to $7.6 \mathrm{~m}(25 \mathrm{ft})$ thick, (2) a thin freshwater limestone, (3) a thin siltstone, and (4) a thin, persistent zone of light gray underclay that is sometimes overlain by (5) a coal seam. Numerous cyclothems have been recognized throughout the $240-\mathrm{m}(800-\mathrm{ft})$ section of the Pennsylvanian section of eastern Gallia County (Blake 1952).

\subsubsection{Tectonic history and seismicity}

The Appalachian Basin was a gently subsiding shallow marine environment throughout much of early Paleozoic time. Near the close of Mississippian time, the basin was emergent, and the uppermost stratigraphic units were being actively eroded. Nearly all of the Mauch chunk and much of the underiying Greenbrier group were relloved (Overbey 1961). Renewed subsidence took place in Pennsylvanian time. The environment shifted back and forth from marine to contisiental as large quantities of sediment were supplied from a rising landmass to the southeast. Characteristic cyclothems developed as the strandine snifted pusitlun. Much of the sediment accumulated in tidal flats, swamps, deltas, and floodplains.

As the Pottsville group of lower Pennsylvanian time was accumulating, the Appalachian Basin was separated (along the hinge line of Fig. 2.12) into northern and southern parts. Rapid subsidence of the southern part produced a wedge of Pottsville strata thickening from a few hundred few to over $1200 \mathrm{~m}(3800 \mathrm{ft})$ in southern West Virginia. Orogenic activity in the adjacent rising Appalachians brought an early end to subsidence in the southern part of the basin. The northern part of the basin subsided more slowly during early Pennsylvanian time, but subsidence continued through the Permian. Deposition was terminated by uplift of the entire area as the northeastern part of the basin was subjected to widespread deformative forces originating from the southeast. Deformation was progressively milder toward the west, being very gentle in Jackson County and dying out compietely in eastern Masun Cuunly; Llierérüe, only the regional dip associated with earlier subsidence remains.

With the exception of gentle uplift, no significant tectonic activity has occurred since the close of Paleozoic time.

According to Algermissen in 1968, Mason County is in a region (zone 1) of minor earthquake risk. Algermissen and Perkins (1976) estimate that there is a $90 \%$ probability that the horizontal acceleration due to an earthquake wi 11 not exceed $0.05 \mathrm{~g}$ in a 50-year period. Figure 2.17 shows the locations ót eartnquakes ranginy up Lu lludlrled Mercalli inteirsity VII for Wcot Virginia and adjacent states from 1758 to 1870. (Rufer. bu Talite 0.4 for the modified Mcrcalli intensity scale.) Mason County is about midway between the main earthquake center connecting Anna and Cleveland, Ohio, and a diffuse linear trend along the central and eastern sides of the Appalachian Mountain range (Algermissen 1968; Algermissen and Perkins 1976; Lessing 1974). 


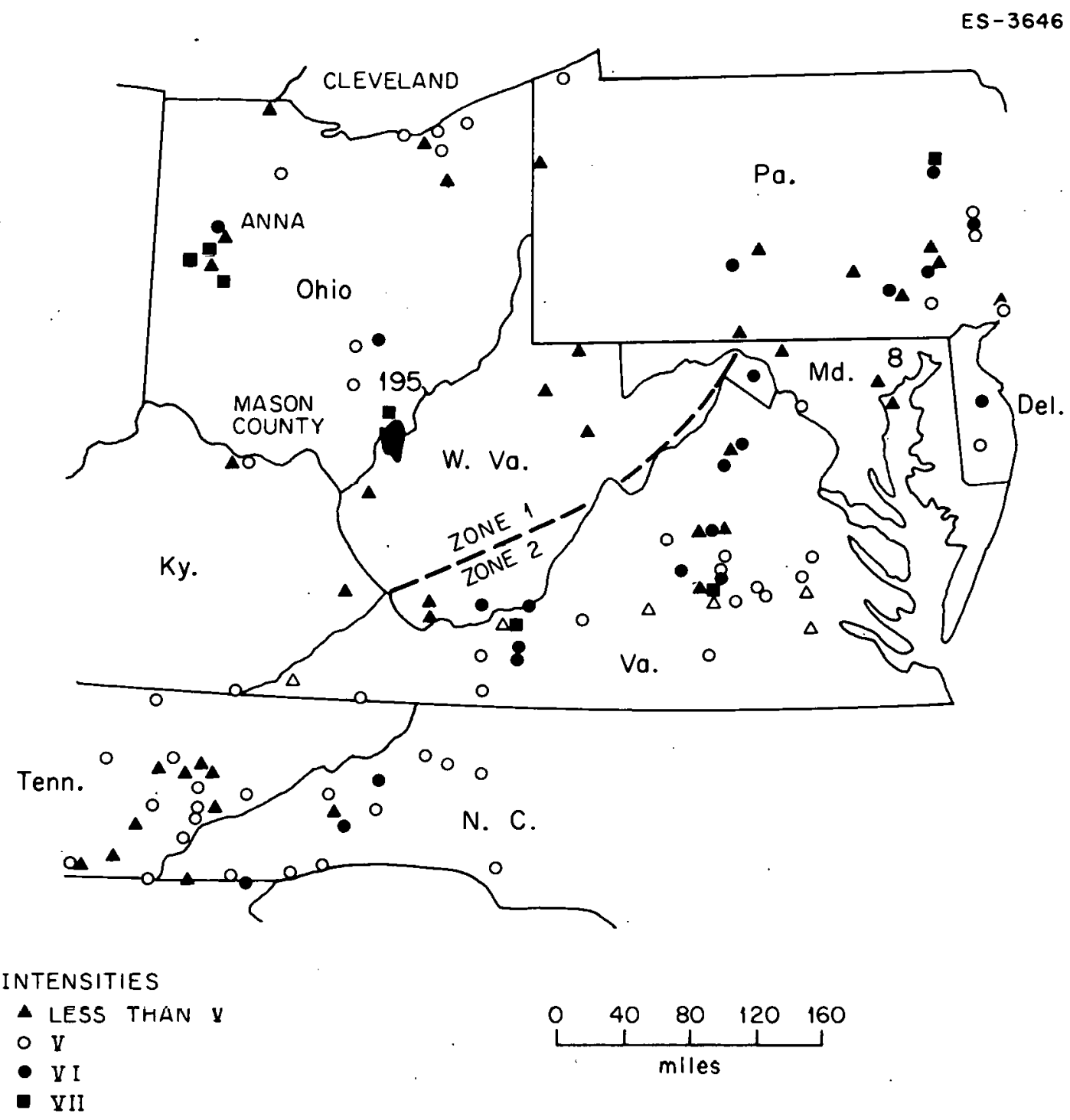

Fig. 2.17. Earthquakes in West Virginia and adjacent states from 1758 to 1970 . Source: P. Lessing. 1974. Earthquake history of West Virginia. Environmental Geology bulletin no. 12. Morgantown, W. Va.: West Virginia Genlngirat and Economic Survey:

\subsubsection{Hydrology}

\subsubsection{Surface water}

\section{Drainage area}

The regional surface waters surrounding the coal conversion site area are the Ohio and Kanawha rivers and Crooked Creek. The drainage area for these rivers is approximately $136,650 \mathrm{~km}^{2}$ $(52,760$ sq miles) at the Point Pleasant gaging station. Upstream of the site area, Crooked Creek drains into the Ohio River, and the Kanawha River empties into the Ohio River downstream of the site. 
Because of Crooked Creek's small size, no data.have been recorded. At Point Pleasant, the Kanawha River has an average flow of approximately $334 \mathrm{~m}^{3} / \mathrm{sec}(11,800 \mathrm{cfs})$ with a maximum flow of $8490 \mathrm{~m}^{3} / \mathrm{sec}(300,000 \mathrm{cfs})$ and a minimum flow of $28.3 \mathrm{~m}^{3} / \mathrm{sec}(1000 \mathrm{cfs})$.

The Ohio River is regulated by an extensive network of reservoirs, dams, and locks to maintain a navigation pool level of $164 \mathrm{~m}(538 \mathrm{ft}) \mathrm{MSL}$ for flows of up to $849 \mathrm{~m}^{3} / \mathrm{sec}(30,000 \mathrm{cfs})$. The minimum depth in the navigation channel is $2.7 \mathrm{~m}(9 \mathrm{ft})$. The maximum stage of record at Point Pleasant, West Virginia, is $176 \mathrm{~m}(577 \mathrm{ft}) \mathrm{MSL}$ with a discharge flow of $14,770 \mathrm{~m}^{3} / \mathrm{sec}$

$(522,000 \mathrm{cfs})$. The minimum observed pool stage at Point Pleasant was $164 \mathrm{~m}(536.6 \mathrm{ft}) \mathrm{MSL}$. Flow information for this event was not made but is estimated to be $90 \mathrm{~m}^{3} / \mathrm{sec}$ ( 3200 cfs) (ERDA 1977).

Average flows are not available at Point Pleasant, but $64 \mathrm{~km}$ (40 miles) downstream at Huntington, West Virginia, the average flow is $2150 \mathrm{~m}^{3} / \mathrm{sec}(75,970 \mathrm{cfs})$. Flow figures at Point Pleasant include the contributions of the Kanawha kiver. Ihe low-flow period for the site area yellerdily is during the summer and early fall (July through October).

\section{Water availability}

Although no specific statutes are applicable to regulating consumptive water use in the site area, current guidelines suggest that consumptive use of water for energy production should not exceed $10 \%$ of the seven-day, once-in-ten-years $\left({ }_{7} Q_{10}\right)$ low flow. Recent studies of the water availability on the Ohio River and its tributaries have established the ${ }_{7} Q_{10}$ at $20 \mathrm{~m}^{3} / \mathrm{sec}$ ( $705 \mathrm{cfs}$ ) for the Kanawha River. For the Ohio River upstream of the Kanawha River, the $7 Q_{10}$ is determined to be $41 \mathrm{~m}^{3} / \mathrm{sec}$ (1450 cfs). Downstream of the Kanawha River, the ${ }_{7} Q_{10}$ is $239 \mathrm{~m}^{3} / \mathrm{sec}$ ( $8450 \mathrm{cfs}$ ) (Shepherd, in preparation). Based on the consumptive water requirements for a demonstration plant, a sufficient amount of water is available for coal conversion.

\subsubsection{Groundwater hydrolegy}

About $90 \%$ of the population in Mason County depends on groundwater for its domestic needs. Pumpage includes other uses such as industrial and commercial, domestic and farm, and public supply. The total groundwater use in Mason County in 1960 averaged about $0.19 \mathrm{~m}^{3} / \mathrm{sec}$ (4.3 Mgd) (Wilmoth 1966). The approximate percentage of the pumpage from each water-bearing unit was: alluvium of Ohio Valley, $76 \%$; alluvium of Kanawha valley, $1 \%$; and consolldated rocks, $23 \%$. Major industrial and commercial uses include cooling, condensing, fire protection and sanitation, and boiler water (ERDA 1977). These demands for industrial and rural use and for public supplies in 1960 were $0.04,0.08$, and $0.07 \mathrm{~m}^{3} / \mathrm{sec}(0.84,1.89$, and $1.55 \mathrm{Mgd})$. Groundwater occurs under water table and artesian conditions. Normal groundwater levels in shallow aquifers fluctuate with a seasonal cycle and have a closer correlation with precipitation and evapotranspiration then the water levels. The groundwater discharge is about $10 \%$ of the precipitation or $26 \%$ of the total runoff. The recharge is estimated to be about $13,100, \mathrm{~m}^{3} / \mathrm{day}-\mathrm{km}^{2}(9.0 \mathrm{Mgd} / \mathrm{sq} \mathrm{mile})$; thus the present daily groundwater withdrawals constitute only a small portion of the total average daily recharge to the aquifers.

The alluvium in the Ohio Valley is the principal source of industrial, municipal, and rural water supplies (Carlston and Graeff 1955). The thickness of the alluvium varies from about 
1.5 to $12 \mathrm{~m}$ ( 5 to $40^{\circ} \mathrm{ft}$ ). The permeability of the alluvium in the Ohio River Valley averages $0.009 \mathrm{~m}^{3}$ day $-\mathrm{cm}^{2}$ (2300 gpd/sq $\mathrm{ft}$ ), whereas that in the Kanawha River Valley is about $0.0018 \mathrm{~m}^{3} /$ day $-\mathrm{cm}^{2}$ (450 gpd/sq ft). Aquifers are capable of yielding 0.01 to $0.03 \mathrm{~m}^{3} / \mathrm{sec}(200$ to $600 \mathrm{gpm}$ ) to individual wells. The water tables range from about 9 to $18 \mathrm{~m}$ ( 30 to $60 \mathrm{ft}$ ) below the land surface and average about $13 \mathrm{~m}(43 \mathrm{ft})$.

The alluvium in the Kanawha River Valley has an average thlckness of about $18 \mathrm{~m}(58 \mathrm{ft})$. The water table ranges from 3 to $9 \mathrm{~m}$ ( 11 to $30 \mathrm{ft}$ ) and averages about $5.5 \mathrm{~m}(18 \mathrm{ft}$ ) below the 1 and surface, and the average saturated thickness is about $12 \mathrm{~m}(40 \mathrm{ft})$. The yield of wells ranges from 0.0006 to $0.0095 \mathrm{~m}^{3} / \mathrm{sec}\left(10\right.$ to $150 \mathrm{gpm}$ ) and averages $0.004 \mathrm{~m}^{3} / \mathrm{sec}(68 \mathrm{gpm})$. The coefficient of transmissivity is about 223.6 to $248.45 \mathrm{~m}^{2} /$ day $(18,000$ to $20,000 \mathrm{gpd} / \mathrm{ft})$.

The Dunkard group of the Permian system is about $174 \mathrm{~m}$ (570 ft) thick, and its yield ranges from 0.004 to $0.08 \mathrm{~m}^{3} /$ day (<1 to $21 \mathrm{gpm}$ ) and averages $0.023 \mathrm{~m}^{3} /$ day $(6 \mathrm{gpm})$. Most of the water from the Dunkard is used for domestic and farm supplies. Many small springs discharge from the Dunkard and are mostly improved for stock use. The Pennsylvanian system contains numerous sandstone beds, some of which are important aquifers. Aquifer tests in the Pennsylvanian rocks near the Kanawha River show some indication of hydraulic connection between the bedrock and the alluvium and/or the river. The water-bearing formations of the Pennsylvanian system consist principally of Monongahela or Conemaugh. The Monongahela group is 70 to $98 \mathrm{~m}(230$ to $320 \mathrm{ft}$ ) thick and is a poor water-bearing formation. The Conemaugh group overlying the Alleghany group is about 146 to $184 \mathrm{~m}$ (480 to $605 \mathrm{ft}$ ) thick and is the principal aquifer in the Kanawha River valley. Most of the water is used for domestic and farm supplies, but some is used for industrial, commercial, or public supplies. Reported average yields of wells in these aquifers is about $0.034 \mathrm{~m}^{3} / \mathrm{min}(9 \mathrm{gpm})$. No large springs in outcrops of this group are known. The transmissivity of the rock ranges from 6.2 to $37.2 \mathrm{~m}^{2} /$ day $(500$ to $3000 \mathrm{gpd} / \mathrm{ft}$ ). No fresh water is known to be withdrawn from the Mississippian system.

\subsubsection{Water quality}

\subsubsection{Surface water}

The Ohio River and its tributaries have been monitored regularly for water quality by the Ohio. River Valley Water Sanitation Commisșion (ORSANCO). Rcsults of Llie 1976 water quality st.udy for the Ohin River and the Kanawlid River are shown in Tables 2.28 and 2.29 respectively (ORSANCO 1977). Measurements were made at Addison, Ohio, for the Ohio River and at Point Pleasant, West Virginia, for the Kanawha.

Water quality druing 1976 violated West Virgina standards in the concentrations of copper, cyanide, lead, phenol, dissolved oxygen, and fecal coliform. The National Sallitation foundation Waler Quality Index (NSF-WQI) for the Ohio and Kanawha rivers is shown in Table 2.30. Overall, the water quality of the Kanawha is considered good, whereas the Ohio main stem is considered medium. The long-term trend in water quality is, however, improving on the Ohio River main stem. 
Table 2.28. Ohio River water quality data as measured in 1976 at Addison, Ohio

\begin{tabular}{|c|c|c|c|c|}
\hline Parameter & Average & Range & $\begin{array}{c}\text { Number of } \\
\text { tests }\end{array}$ & $\begin{array}{c}\text { West Virginia } \\
\text { standard }\end{array}$ \\
\hline Temperature, ${ }^{\circ} \mathrm{C}$ & 14.8 & $29-N^{a}$ & Continuous & $10-32$ \\
\hline $\mathrm{pH}$ & ND & $8.0-6.0$ & Continuous & $8.5-6.0$ \\
\hline Dissolved solids, $\mathrm{mg} / \mathrm{liter}$ & 298 & $222-172$ & 7 & None \\
\hline Dissolved oxygen, $\mathrm{mg} / \mathrm{liter}$ & 9.9 & ND-5.2 & Continuous & 5.0 \\
\hline Ammonia-nitrogen, mg/liter & 0.27 & $0.70-0.10$ & 29 & None \\
\hline Phosphorous, mg/liter & 0.09 & $0.17-0.02$ & 29 & None \\
\hline Phenol, $\mu \mathrm{g} /$ liter & ND & $68-0$ & 29 & 1 \\
\hline Cyanide, $\mu \mathrm{g} /$ liter & NO & $40-0$ & $2 \theta$ & 25 \\
\hline Iron, $\mu \mathrm{g} /$ liter & 1110 & $4300-150$ & 50 & None \\
\hline Manganese, $\mu \mathrm{g} /$ /iter & 510 & $1850-90$ & 50 & None \\
\hline Fecal coliform, mg/liter & ND & $3900-13$ & 26 & 2400 \\
\hline Dissolved chloride, mg/liter & 32 & $55-16$ & 215 & 100 \\
\hline Fluoride, mg/liter & 0.1 & $0.2-0$ & 4 & 1 \\
\hline Nitrate-ni troger', ling/litcr & 0.78 & $1.25-0.04$ & 24 & 45 \\
\hline Cadmium, $\mu \mathrm{g} / \mathrm{liter}$ & ND & $10-0$ & 12 & 10 \\
\hline Chromium, $\mu \mathrm{g} /$ liter & ND & $20-2$ & 12 & 50 \\
\hline Copper, $\mu \mathrm{g} /$ liter & NND & $20 . .8$ & 12 & 10 \\
\hline Lead. $\mu g /$ liter & ive & $23 \cdot .5$ & 12 & 50 \\
\hline Mercury, $\mu \mathrm{g} /$ liter & ND & $<<10-0$ & 3 & 10 \\
\hline Zinc, $\mu g / l i t e r$ & ND & $90-20$ & 12 & None \\
\hline Specific conductance, $\mu \mathrm{mho} / \mathrm{cm}^{2}$ & 379 & 588-ND & Continuous & \\
\hline Turbidity. JTU $b$ & 44 & $450-5$ & 297 & None \\
\hline Dissolved calcium, mg/liter & 33 & $45-20$ & 7 & None \\
\hline Dissolved magnesium, mg/liter & 9.7 & $14.0-5.5$ & 7 & Nunie \\
\hline Dissolved sodium, mg/liter & 27.3 & $78-9.1$ & 14 & None \\
\hline Dissolved potasslum, lig/liter & 2.4 & $3.1-1.8$ & 4 & None \\
\hline Dissolved sulfate, $\mathrm{mg} /$ liter & 95 & $215-65$ & 28 & None \\
\hline Kjeldahl nitrogen, mg/liter & 1.0 & $2.9-3.0$ & 29 & None \\
\hline Arsenic, $\mu \mathrm{g} / \mathrm{liter}$ & ND & $<10$ & 2 & 10 \\
\hline Nickel, $\mu \mathrm{y} /$ liter & ND & $20-4$ & 12 & None \\
\hline Hardness, mg/liter & 139 & $184-73$ & 218 & None \\
\hline Noncarbnnate hardness, mg/liter & 92 & $132-56$ & 211 & None \\
\hline Alkalinity (carbonates), mig/liter & 47 & $74-28$ & 215 & None \\
\hline Five-day ROD. mg/liter & 2.2 & $3.7-0.4$ & 11 & None \\
\hline Suspended solids, mg/liter & 46 & $240-6$ & .29 & Nono \\
\hline Silver, $\mu g / l i t e r$ & ND & $1-0$ & 8 & 50 \\
\hline Barium, $\mu \mathrm{g} /$ liter & ND & $100-0$ & 11 & 50 \\
\hline
\end{tabular}

\subsubsection{Groundwater quality}

Major industrial and combritercial uses of groundwater in Mason County include cooling, condensing, fire protection, sanitation, and process water fur the boiler. Although water in the alluvial deposits is rather hard and is somewhat high in iron, it is generally satisfactory for most uses. Contamination of underlying aquifers by inflltration of liquid wastcs from disposal ponds or lagoons, spillage of wasle vii the ground, and acld mirie wisinnge or dispogal of liquid waste in wells has occurred in industrial areas in Mason County. Results of representative chemical analyses (Wilmoth 1966) of gruundwater samples from various aquifers are listed in Table 2.31. Water from Pennsylvanian strata including the Conemaugh and Monongahela formations in upland areas is generally acidic, sulfurous, and brarkish with excessive amounts of iron and manganese. Water in deeper aquifers [depth of $60 \mathrm{~m}(200 \mathrm{ft})$ or more] is brackish or saline and contains hydrocarbons. 
Table 2.29. Kanawha River water quality data as measured in 1976 at Point Pleasant, West Virginia

\begin{tabular}{|c|c|c|c|c|}
\hline Parameter & Average & Range & $\begin{array}{c}\text { Number of } \\
\text { tests }\end{array}$ & $\begin{array}{c}\text { West Virginia } \\
\text { standard }\end{array}$ \\
\hline Temperature, ${ }^{\circ} \mathrm{C}$ & 15.2 & $28-N D^{a}$ & Continuous & $10-32$ \\
\hline $\mathrm{pH}$ & ND & $8.1-6.2$ & Continuous & $8.5-6.0$ \\
\hline Dissolved solids, $\mathrm{mg} / \mathrm{liter}$ & 114 & $199-77$ & 11 & None \\
\hline Dissolved oxygen, mg/liter & 8.9 & ND-3.0 & Continuous & 5.0 \\
\hline Ammnnia-nitrngen, $\mathrm{mg} /$ liter & 0.35 & $1.2-0.01$ & 32 & None \\
\hline Phosphorous, mg/liter & 0.18 & $1.2-0.3$ & 33 & None \\
\hline Phenol, $\mu \mathrm{g} / \mathrm{liter}$ & ND & $20-0$ & 33 & 1 \\
\hline Cyanide, $\mu \mathrm{g} /$ liter & ND & $10-0$ & 32 & 25 \\
\hline Iron, $\mu \mathrm{g} /$ /iter & ND & $1450-250$ & 5 & None \\
\hline Manganese, $\mu \mathrm{g} /$ liter & ND & $160-60$ & 5 & None \\
\hline Fecal coliform, mg/liter & ND & $1830-0$ & 31 & 2400 \\
\hline Dissulved cliloride, mg/liter & 17 & $32-8.2$ & 10 & 100 \\
\hline Dissolved fluoride, mg/liter & 0.1 & $0.1-0.1$ & 9 & 1 \\
\hline Nitrate-nitrogen, mg/liter & 0.67 & $3.8-0.4$ & 30 & 45 \\
\hline Cadmium, $\mu \mathrm{y} / \mathrm{liter}$ & ND & $3-1$ & 4 & 10 \\
\hline Chromium, $\mu \mathrm{g} /$ liter & ND & $10-4$ & 5 & 50 \\
\hline Copper, $\mu \mathrm{g} /$ /iter & ND & $20-8$ & 5 & 10 \\
\hline Lead, $\mu \mathrm{g} / \mathrm{liter}$ & NU & $330-7$ & 5 & 50 \\
\hline Mercury, $\mu \mathrm{g} /$ liter & ND & $<0.5$ & 5 & None \\
\hline Selenium, $\mu \mathrm{g} / \mathrm{liter}$ & ND & $<10.0$ & 2 & 10 \\
\hline Zinc, $\mu \mathrm{g} / \mathrm{liter}$ & ND & $130-10$ & 5 & None \\
\hline Specific conductance, $\mu \mathrm{mho} / \mathrm{cm}^{2}$ & 214 & 428-ND & Continuous & None \\
\hline Turbidity, mg/liter & 18 & $240-4$ & 251 & None \\
\hline Dissolved calcium, mg/liter & 15 & $23-6.3$ & 37 & None \\
\hline Dissolved magneslum, mg/liter & 5.2 & $11.2-2.5$ & 37 & None \\
\hline Dissolved sodium, mg/liter & 14 & $30-5.3$ & 13 & None \\
\hline Dissolved potassium, mg/liter & 1.8 & $4.5-1.2$ & 10 & None \\
\hline Dissolved sulfate, $\mathrm{mg} / \mathrm{liter}$ & 31 & $83-15$ & 38 & None \\
\hline Kjeldahl nitrogen, mg/liter & 0.95 & $2.4-0.2$ & 32 & None \\
\hline Arsenic, $\mu g /$ liter & ND & $2-0$ & 2 & 10 \\
\hline Nickel, $\mu g /$ liter & ND & $-10-1$ & 4 & None \\
\hline Hardness, mg/liter & 50 & $84-17$ & 281 & None \\
\hline Noncarbonate hardness, mg/liter & 5 & $24-0$ & 250 & None \\
\hline Alkalinity, mg/liter & 29 & $45-19$ & 9 & None \\
\hline Five-day BOD, mg/liter & 1.3 & $2.2-0.5$ & 9 & None \\
\hline Suspended solids, $\mathrm{mg} / \mathrm{liter}$ & 27 & $115-1$ & 33 & None \\
\hline Silver, $\mu \mathrm{g} / \mathrm{ilter}$ & ND & $<1 \ldots 0$ & 3 & 50 \\
\hline Barium, $\mu \mathrm{g} / \mathrm{liter}$ & ND & $100-0$ & 4 & 50 \\
\hline
\end{tabular}

${ }^{a}$ ND, not determined.

Source: Ohio River Valley Water Sanitation Committee. 1977. Ohio River mainstem: assessment of 1976 and future water quality conditions. Cincinnati, Ohio.

Table 2.30. The National Sanitation Foundation water quality index

\begin{tabular}{lcc}
\hline & Ohio main stem & Kanawha \\
\hline Maximum & 74 & 82 \\
Average & 68 & 78 \\
Minimum & 61 & 68 \\
\hline
\end{tabular}

The iron content of the groundwater in the alluvium of the Ohio River ranges from very low to very high. The water is generally hard, but in places it is soft to moderately hard. Although the dissolved solids concentrations ranges from low to high, it is generally moderate. The temperature of alluvial groundwater generally varies from 12 to $17^{\circ} \mathrm{C}\left(53\right.$ to $\left.63^{\circ} \mathrm{F}\right)$ and varies with the temperature of the river water.

Groundwater in the alluvium of Kanawha Valley has a much more variable chemical character than that of the alluvium of the Onio Valley. The water generally is of the sodiun bicarbunate type, 
Table 2.31. Summary of chemical analyses of groundwater, Mason County, West Virginia

\begin{tabular}{|c|c|c|c|c|}
\hline & Chloride & Iron & Hardness & $\mathrm{pH}$ \\
\hline \multicolumn{5}{|l|}{ Conemaugh group } \\
\hline No. of samples analyzed & 206 & 205 & 205 & 203 \\
\hline Median concentration, ppm & 20 & 0.2 & 102 & 7.6 \\
\hline Rangc, ppm & $0-12.100$ & $0.0-33$ & $10-1.920$ & $6.0-8.6$ \\
\hline \multicolumn{5}{|l|}{ Monongahela group } \\
\hline No. of samples analyzed & 106 & 106 & 106 & 106 \\
\hline Median concentration, ppm & 25 & 0.3 & 153 & 7.2 \\
\hline Range, ppm & $5-6.580$ & $0.08-17$ & $2-1.180$ & $6.2-8.0$ \\
\hline \multicolumn{5}{|l|}{ Dunkard group } \\
\hline No. of samples analyzed & 13 & 13 & 13 & 13 \\
\hline Median concentration, ppm & 20 & 0.1 & 153 & 7.9 \\
\hline Range, ppm & $10-75$ & $0.1-4.5$ & $85-278$ & $6.5-8.2$ \\
\hline \multicolumn{5}{|l|}{ Ohio River Valley alluvium } \\
\hline No. of samples arialy<ted & 48 & 12 & 46 & 43 \\
\hline Median concentration, ppm & 9 & 0.6 & 198 & 7.2 \\
\hline Kànge, ppm & $0-56$ & $0-246$ & $16-410$ & $6.0-7.8$ \\
\hline \multicolumn{5}{|l|}{ Kanawha River Valley alluvium } \\
\hline No. of samples analyzed & 33 & 34 & 34 & 34 \\
\hline Median concentration, ppm & 20 & 0.7 & 100 & 6.7 \\
\hline Range, ppm & $0-130$ & $0.1-54$ & $26-408$ & $4.7-8.0$ \\
\hline
\end{tabular}

but in places calcium or magnesium and sulfate may be predominant. The total dissolved solids vary from low to moderately high.

Water from the Dunkard group is of the calcium bicarbonate type and the tat.al dissolved solids is high. Groundwater in the Conemaugh group is commonly moderate to high in total dissolved solids and ranges from soft to very hard. In places fluoride content is as much as $6 \mathrm{ppm}$.

\section{2 .5 Land use}

The surrogate site is near the town of Point Pleasant (population 6122) in Lewis Township, Mason County, West Virginia. The county is about $50 \%$ circumscribed by the ohio River and is approximately bisected by the Kanawha River, which joins the Ohio River at Point Pleasant. Aluny the Ohio River is a tloodplain one-eighth to one mile in width, along which lies a track of the Baltimore \& Ohio Railroad. The Kanawha River has a flnodplain varying from onc. fourth to slightly over one mile in width; along its northern shore lies a Penn Central Railroad track.

The land use of Mason County is shown in Table 2.32. Only 23.3\% of the surface area is in cropland, but woodlands and other lands bring the total land in farms to 55.2\%. Commercial forests occupy a major share of the remaining 51,575 ha $(127,391$ acres; $44.8 \%)$ not in farmland. Urban areas occupy only $2.7 \%$ of the county area. 
Table 2.32. Land use in Mason County, West Virginia

\begin{tabular}{|c|c|c|}
\hline & Hectares (acres) & Percent \\
\hline \multicolumn{3}{|c|}{ Land in farms } \\
\hline Harvested cropland & $10,090 \quad(24,922)$ & 8.8 \\
\hline Cropland for pasture/grazing & $13,050 \quad(32,234)$ & 11.3 \\
\hline Nonharvested cropland & $3,721 \quad(9,192)$ & 3.2 \\
\hline Total croplands & $26,861 \quad(66,348)$ & $(23,3)$ \\
\hline Woodland, pastured or not & $18,789 \quad(46,410)$ & 16.3 \\
\hline Other land, pastured or not & $16,887 \quad(41,710)$ & 14.6 \\
\hline Total woodland and other land & $35,676 \quad(88,120)$ & $(30.9)$ \\
\hline Farmsteads, feedlots, roads & $1,191 \quad(2,941)$ & 1.0 \\
\hline Total land in farms & $63,728(157,409)$ & (55.2) \\
\hline
\end{tabular}

Land not in farms

\begin{tabular}{|c|c|c|}
\hline Federally owned land & (0) & 0.0 \\
\hline Urban areas & $(7,511)$ & 2.7 \\
\hline Small lakes ( $<40$ acres) and rivers & $(500)$ & 0.2 \\
\hline Large lakes (>40 acres) & $(8,000)$ & 2.8 \\
\hline $\begin{array}{l}\text { Remaining land (by difference) } \\
\text { (includes commercial and noncommercial } \\
\text { forests, houses, swamps, railroads, unused } \\
\text { wastelands and others) }\end{array}$ & $45,093(111,380)$ & 39.1 \\
\hline Total land not in farms & $51,575(127,391)$ & $(44.8)$ \\
\hline Grand total surface area & $115,303(284,800)$ & 100.0 \\
\hline
\end{tabular}

Sources: Oak Ridge National Laboratory. 1977. ORNL geoecology data base land use printout for Mason County, West Virginia, March 7, 1977. Oak Ridge, Tenn.; U. S. Department of Agriculture. 1967. Natiunal inventory of soil:and water conservation needs. Statistical bulletin no. 461. Washington, D.C.: U.S. Government Printing Office; U.S. Department of Agriculture. 1975. Agricultural statistics 1975. Washington, D.C.: U.S. Government Printing Office.

The prinripal srops includc $335,300 \mathrm{~kg}(739,227 \mathrm{lb})$ of tobacco, 23,893 metric tons (26,343 tons) of hay or grass for silage raised on 5704 ha $\left(14,091\right.$ acres), and about $20,580 \mathrm{~m}^{3}$ (58,000 bu) of corn rur grain, silage, and grazing raised on 3306 ha (8165 acres). Wheat and soybeans are raised in small amounts. Mules, cattle, hogs, sheep, and chickens are produced to some extent.

A map of the surrogate site area is shown in Fig. 2.11 (West Virginia Department of Highways, 1976).

Major recreational areas include the large Clifton F. MCClintric State Wildife Station north of the site area in Robinson Township with an estimated area of about 1538 ha ( 3800 acres) and Chief Cornstalls Public Hunting Area, south of the Kanawha River, containing an estimated 4291 ha $(10,600$ acres) (Battelle Columbus Laboratories 1976; West Virginia Department of Highways 1976).

\subsubsection{Meteorology and air quality}

Mason County has an annual average precipitation of $107 \mathrm{~cm}$ (42 in.). The average annual snowfall is about $38 \mathrm{~cm}(15 \mathrm{in.})$. The mean temperatures for January are a minimum of $-2.8^{\circ} \mathrm{C}\left(27^{\circ} \mathrm{F}\right)$ and a maximum of $8.3^{\circ} \mathrm{C}\left(47^{\circ} \mathrm{F}\right)$. The mean temperatures for July are a minimum of $18.4^{\circ} \mathrm{C}\left(65^{\circ} \mathrm{F}\right)$ and a maximum of $31.7^{\circ} \mathrm{C}\left(83^{\circ} \mathrm{F}\right)$. 
The wind patterns for Mason County are expected to be similar to those for Huntington, West Virginia, which are shown in Fig. 2.18. The predominant wind direction is south. The wind velocities do not often exceed $5 \mathrm{~m} / \mathrm{sec}(11 \mathrm{mph})$. At nearby Parkersburg, heavy fog occurs on an average of 11 days annually. Tornados occur only rarely in West Virginia (13 in 43 years).

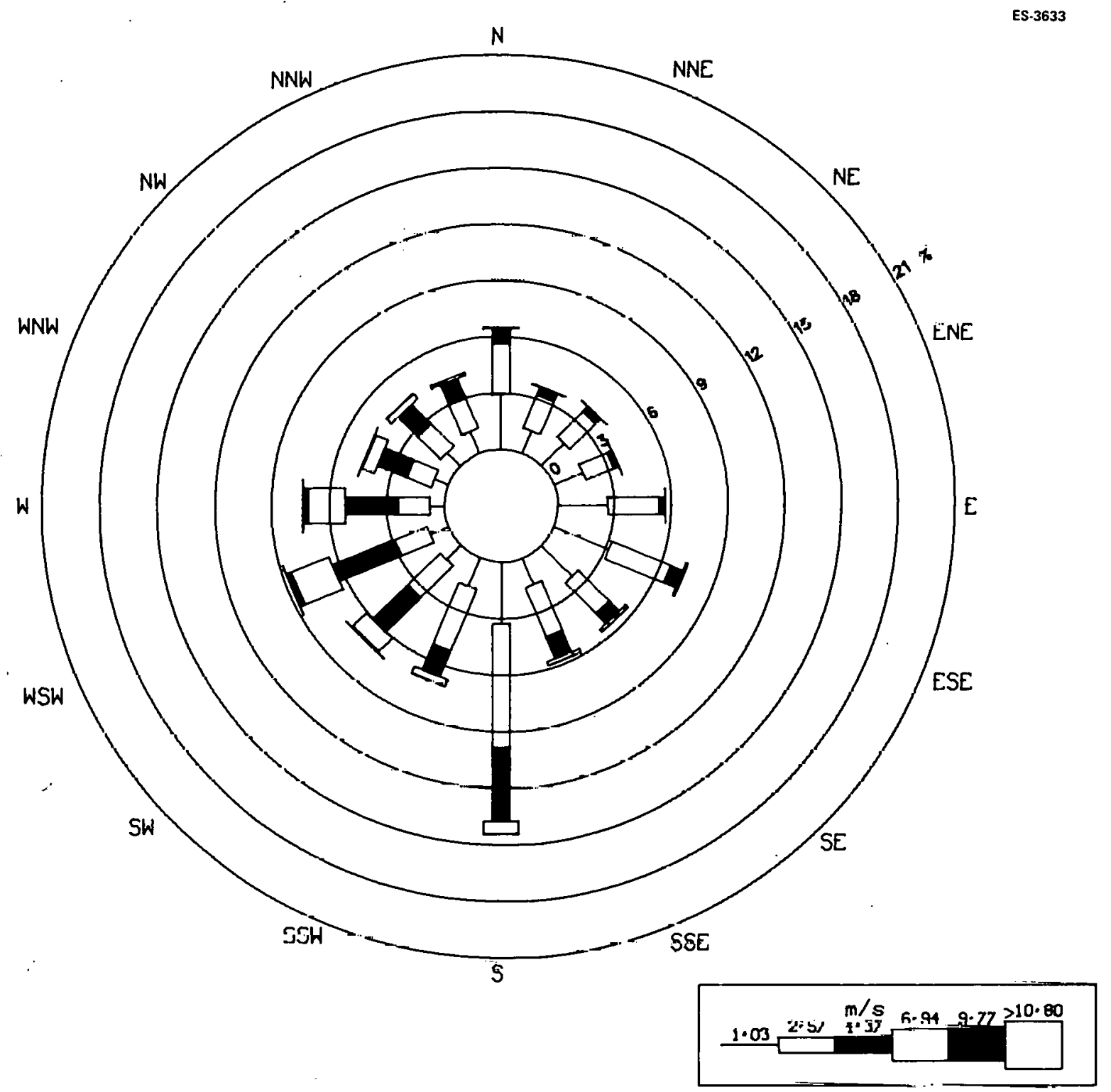

Fig. 2.18. Huntington, West Virgin1a, wind rüse.

In an average year the number of forecast days of high meteorological potential for air pollution (inversions) would not exceed six (Holtzworth 1972). In 1974 at Parkersburg, the average annual concentration (USEPA 1976) of total suspended particulates was $78 \mu \mathrm{g} / \mathrm{m}^{3}$ with a 24-hr maximum of $208 \mu \mathrm{g} / \mathrm{m}^{3}$. The annual average $\mathrm{SO}_{2}$ concentration in 1974 was $27 \mu \mathrm{g} / \mathrm{m}^{3}$ with a 24-hr maximum of $60 \mu \mathrm{g} / \mathrm{m}^{3}$. 


\subsubsection{Noise}

The general noise discussion in Sect. 2.1.7 applies equally here.

There are no noise pollution laws nor enforcement agencies in West Virginia (West Virginia Air Pollution Control Commission 1977).

\subsubsection{Socioeconomic structure (Mason County, West Virginia)}

\subsubsection{Local and regional demography}

Population size and density

In 1970 the population of Mason County was 24,306 (U.S. Bureau of the Census 1976a). With a land area of $1121 \mathrm{~km}^{2}$ (433 sq miles), this gave a population density of 56 persons per square mile (U.S. Bureau of the Census 1976a). Thus Mason County has about the same population density as the nation as a whole. Of the total population of Mason County, however, $78.8 \% 1$ ive in rural areas. The proportion living in urban areas $(25.2 \%)$ is much lower than in St. Clair County, Campbel1 County, or the United States as a whole.

The largest town in Mason County is Point Pleasant, which had a 1970 population of 6122.0 ther incorporated towns and their 1970 populations are Henderson (population 496), Leon (192), Hartford City (527), New Haven (1149), and Mason (1319) (U.S. Bureau of the Census 1970a).

New Haven, Hartford, and Mason are about $10 \mathrm{~km}$ ( 6 miles) apart and about $23 \mathrm{~km}$ (14 miles) north of Point Pleasant. The Mason County area is 64 to $80 \mathrm{~km}$ (40 to 50 miles) from Huntington, West Virginia, and 80 to $105 \mathrm{~km}$ (50 to $65 \mathrm{miles)}$ from Parkersburg. There are about 75,000 people within an approxiniale 40-kı! (25-Illie) radius of the area (U.S. Bureau of the Census 1976a).

\section{Population trends and characteristics}

Between 1960 and 1970 the population of Mason County decreased by $0.6 \%$. The net migration rate was a negative 9.3\%. Mason County is in the Appalachian region, designated by the Appalachian Regionai Commission. Like much of Appalachia, Mason County is economically depressed, with low incomes and high unemployment rates. In 1976 its unemployment rate was 10.4\% (Point Pleasant, West Virginia, Chamber of Commerce 1976) as compared with $8.3 \%$ nationally (U.S. Bureau of the Census 1976b).

The median family income in 1969 was $\$ 6768$ (vs $\$ 9586$ nationally) (U.S. Bureau of the Census 1976a), and $23 \%$ of a 11 families had incomes below the poverty level (vs $10.7 \%$ nationally) (U.S. Bureau of the Census 1971c). The median age in Mason County was 29.4, slightly above the national median of 28.3. The county had a higher proportion of its population over 65 than the United States as a whole (10.4\% vs $9.9 \%$ for the United States). The median education level for persons over 25 was 9.7 years, 2.5 years less than the national median of 12.2 (U.S. Bureau of the Census 1976a, 1971a).

Most of the counties adjacent to Mason County are predominantly rural, with population densities and settlement patterns similar to Mason County's (Table 2.33) (USDA 1967; 1975). Cabell County, 


\begin{tabular}{|c|c|c|c|c|c|}
\hline County & Population & $\begin{array}{c}\text { Percent } \\
\text { rural residence }\end{array}$ & $\begin{array}{l}\text { Median } \\
\text { income } \\
\text { (dollars) }\end{array}$ & $\begin{array}{c}\text { Percent } \\
\text { below poverty level }\end{array}$ & $\begin{array}{l}\text { Median } \\
\text { education }\end{array}$ \\
\hline Mason & 24,306 & 78.8 & 6768 & 23.0 & 9.7 \\
\hline \multicolumn{6}{|c|}{ Ohio counties } \\
\hline Gallia & 25,239 & 70.3 & 6915 & 19.0 & 10.0 \\
\hline Meigs & 19,799 & 69.7 & 6485 & 22.0 & 10.5 \\
\hline \multicolumn{6}{|c|}{ West Virginia counties } \\
\hline Putnam & 27,625 & 82.5 & 8156 & 13.7 & 10.5 \\
\hline Jackson & 20,903 & 65.1 & 7959 & 17.0 & 11.0 \\
\hline Cabell & 106,918 & 33.0 & 8109 & 13.1 & 11.9 \\
\hline
\end{tabular}

Sources: U.S. Bureau of the Census. 1970. General social and economic characteristics: 1970 PC(1).C37, Ohio. Washington, D.C.: U.S. Government Printing Office; U.S. Bureau of the Census. 1970. General social and economic characteristics: 1970. $\mathrm{HC}(1) \cdot \mathrm{C} 5 \mathrm{U}$. West Virginia. Washington, D.C.: U.S. Government Printing Officc.

however, which contains the city of Huntington (1970 population of 74,322 ), is considerably more urban than Mason County. Most of the adjacent counties also have higher income and educational levels than Mason County (Table 2.33) (ORNL 1977; U.S. Bureau of the Census 1970b, 1970c).

As shown in Table 2.34, 1970 unemployment rates in Mason County and in all adjacent counties except Putnam and Cabe 11 counties were above the U.S. rate of $5.4 \%$.

Table 2.34. Unemployment rates by county in 1970

\begin{tabular}{lc}
\hline Lounty & Unempioyment rate (\%) \\
\hline Mason & 6.6 \\
Gallio & 6.0 \\
Mergs & 7.5 \\
Putnam & 3.8 \\
Jackson & 7.9 \\
Cabell & 4.9 \\
\hline
\end{tabular}

Source: U.S. Bureau of the Census. 1976. County and city data book, 1972. Washington, D.C.: U.S. Government Printing Office.

Because Mason County is within commuting distance of many parts of the counties adjacent to it, the local labor pool as defined by Stenehjem and Metzger (1976) (i.e., the currently unemployed plus new labor force entrants) includes some workers from the adjacent counties. Estimates by Stenehjem and Metzger (1976) of the number of available local workers by county are given in Table 2.35. From these estimates of the number of available local workers, it is concluded that a majority of the construction and operational workers needed could commute to Mason County from surrounding areas.

A study of the impacts of siting a 1000-MWe generating facility in Mason or Putnam counties concluded that about $45 \%$ of the construction jobs and $65 \%$ of the operations jobs could be filled by local workers (Battelle Columbus Laboratories 1976, p. 4-19). Mason County, West Virginia, 
Table 2.35. Number of available local workers by county

\begin{tabular}{rrrrrrr}
\hline Year & $\begin{array}{c}\text { Mason } \\
\text { County }\end{array}$ & $\begin{array}{c}\text { Gallia } \\
\text { Coninty }\end{array}$ & $\begin{array}{c}\text { Meigs } \\
\text { County }\end{array}$ & $\begin{array}{c}\text { Putnam } \\
\text { County }\end{array}$ & $\begin{array}{r}\text { Jackson } \\
\text { County }\end{array}$ & $\begin{array}{r}\text { Cabell } \\
\text { County }\end{array}$ \\
\hline 1 & 2035 & 2274 & 1501 & 2193 & 1658 & 4839 \\
2 & 151 & 160 & 122 & 190 & 141 & 719 \\
3 & 196 & 179 & 140 & 222 & 200 & 627 \\
4 & 196 & 179 & 140 & 221 & 200 & 626 \\
5 & 195 & 179 & 140 & 221 & 200 & 626 \\
6 & 195 & 179 & 140 & 221 & 199 & 625 \\
7 & 190 & 179 & 136 & 208 & 194 & 603 \\
8 & 173 & 168 & 130 & 218 & 161 & 575 \\
9 & 173 & 167 & 130 & 218 & 161 & 575 \\
10 & 173 & 167 & 130 & 218 & 161 & 574 \\
\hline
\end{tabular}

Source: E. J. Stenehjem and James E. Metzger. 1976. A framework for projecting employment and population changes accompanying energy development. Washington, D.C.: Energy Research and Development Administration.

does not have as large a local labor pool to draw on as does St. Clair County, Illinois, but it does have more available local workers than Campbell County, Wyoming.

\subsubsection{Industry structure}

The industrial structure of the Mason County, West Virginia, economy is considerably smaller and less diversified than that of St. Clair County, Illinois, but it is relatively more developed than that of Campbe11 County, Wyoming. It is not directly integrated with a large metropolitan area, but it is not isolated from the trade flows of major Eastern cities. As such, it represents an intermediate case for impact analysis purposes.

Befure lhe Luril of the century, the Mason County ernnomy was dominated by the agricultural sector; industrialization began to occur in the early 1900s. Although agriculture and mining continue to be an important part of the economic activity uf Mason County, the manufacturing sector has been the leading contributor to the area's growth. Total employment in the county increased from 6821 in 1960 to 7074 in 1970 and to 7980 in 1976, and about one-fourth of this total was employed in the manufacturing sector. Table 2.36 gives employment figures for major industrial sectors for 1960 arid 1970. The most outstanding features are the rapid decline in agricultural employment $(60.7 \%)$ and the rapid growth of employment in the finance and manufacturing sectors $(24.8 \%$ and $10.1 \%$ respectively). In absolute numbers, the largest growth has been in the manufacturing sector.

The county primarily contains relatively small industrial establishments, with a few manufacturing firms in the larger-size classes (employing 100 or more). Table 2.37 gives the size distribution of the major industrial categories (U.S. Bureau of the Census 1972). Products that are manufactured in the area include ferro and chrome alloys, coal-mining equipment, malleable iron products, boat and barge construction, women's clothing, lumber products, dairy products, sheet meta1, furniture, chemicals, salt, and sodium products. Some of the major employers in the area are given in Table 2.38.

The economic structure of the Mason County site meets the assumptions required for use of the regression multiplier discussed by Stenehjem and Metzger (1976, pp. 50-53). This multiplier has 
Table 2.36. Employment characteristics for Mason County, West Virginia

\begin{tabular}{lllr}
\hline \multicolumn{1}{c}{ Category } & 1960 & 1970 & $\begin{array}{r}\text { Percent } \\
\text { change }\end{array}$ \\
\hline Labor force (civilian) & 7691 & 7576 & 2.3 \\
Unemployed & 870 & 502 & 42.3 \\
Unemployment rate, \% & 11.3 & 6.7 & 40.7 \\
Employed & 6821 & 7074 & 3.7 \\
Agriculture & 842 & 331 & 60.7 \\
Mining & 172 & 182 & 5.8 \\
Construction & 628 & 673 & 7.2 \\
Manufacturing & 1807 & 1989 & 10.1 \\
Transpurtation, communication, and utilities & 919 & 925 & .7 \\
Wholesale and retail trade & 976 & 1007 & 3.2 \\
Finance, insurance, and real estate & 105 & 131 & 24.8 \\
Government & 256 & 193 & 24.6 \\
All other nonagricultural & 1116 & 1643 & $\mathbf{4 7 . 2}$ \\
\hline
\end{tabular}

Source: U.S. Bureau of the Census. 1971. Census of population: detailed characteristics, $1960-1970$. Washington, D.C.: U.S. Government Printing Office.

been estimated to be 1.1 for the manufacturing and construction industries in West Virginia (Stenehjem and Metzger 1976, p. 58). The rclatively sillall s1ze of this multiplier may be attribuled to two considerations. First, unlike St. Clair county, the lack of a well-developed, diversified service sector implies that local sources cannot meet the majority of the increased demands for goods and services which will be imposed by the siting of a major cnergy racil1ty in the area. Second, unlike Campbell County, the proximity of the area to larger supply centers implies that the resulting excess demand can be readily met by importing goods and services from outside the region. The net result is that relatively little secondary employment impacts will be generated within the Mason County area.

\subsubsection{Local infrastructure}

\section{Governmental jurisdictions}

The governing body of Mason County is the county court. The minimum population requirement for incorporation of towns is 100 . Mason County has six incorporated towns (Point Pleasant, Henderson, Leon, Hartford City, New Haven, and Mason). Point Pleasant is the county seat. All of the municipalities have a bipartisan mayor-council form of government (Area Development, Appalachian Power Company 1976, p. 3). School districts are organized on a.county level and have the authority to levy taxes and issue bonds. There are no township governments in west Virginia (U.S. Bureau of the Census 1973).

Housing

In 1970 there were 8193 year-round housing units in Mason County. Of these, 67\% were owner occupied, and $24 \%$ were renter occupied (U.S. Bureau of the Census 1971b). About $25 \%$ of the housing in Mason County was substandard (i.e., lacked sonie ur all plumbing facilities); the national percentage of substandard housing was $5.9 \%$ (U.S. Bureau of the Census 1971a, 1971b). Housing vacancies in the sale and rent categories were, respectively, 1 and $2 \%$; these vacancy rates are below state averages. The vacancy rate for rental properties is especially low as compared with the state average of $7.5 \%$. Although mobile homes account for $6 \%$ of the housing in Mason County, the state average is only 4\% (U.S. Bureau of the Census 1971b). 
Tatle 2.37. First qual ter 1972 employment and payroll, Mason County, West Virginia

\begin{tabular}{|c|c|c|c|c|c|c|c|c|c|c|c|}
\hline \multirow{2}{*}{ Industry } & \multirow{2}{*}{$\begin{array}{l}\text { Number of } \\
\text { employees. } \\
\text { mid-March } \\
\text { pay.Feriod }\end{array}$} & \multirow{2}{*}{$\begin{array}{c}\text { Taxable } \\
\text { payrolls, } \\
\text { January-March } \\
(\times \$ 1000)\end{array}$} & \multirow{2}{*}{$\begin{array}{l}\text {-otal } \\
\text { reporting } \\
\text { anits }\end{array}$} & \multicolumn{8}{|c|}{ Number of reporting units by employment-size class } \\
\hline & & & & 1 to 3 & 4 to 7 & 8 to 19 & 20 to 49 & 50 to 99 & 100 to 249 & 250 to 499 & 500 or more \\
\hline $\begin{array}{l}\text { Total } \\
\text { Agricultural services, foresiry, and fisheries }\end{array}$ & 3800 & 6826 & 270 & 145 & 63 & 33 & 16 & 7 & 3 & 2 & 1 \\
\hline Minirig & $b$ & $b$ & 2 & & & 1 & & 1 & & & \\
\hline Contract construction & 192 & 295 & 24 & 13 & 5 & 4 & 1 & 1 & & & \\
\hline Manufacturing & 1652 & 3696 & 18 & 3 & 3 & 2 & 3 & 4 & 1 & 1 & 1 \\
\hline Transportation and other public utilities & $b$ & $b$ & 12 & 5 & 4 & 1 & & & 1 & 1 & \\
\hline Wholesale trade & 96 & 124 & 12 & 3 & 3 & 5 & 1 & & & & \\
\hline Retail trade & 686 & 720 & 104 & 52 & 31 & 12 & 8 & 1 & & & \\
\hline Finance, insurance. and real estate & 112 & 142 & 20 & 13 & 3 & 2 & 2 & & & & \\
\hline Services & 445 & 446 & 78 & 56 & 14 & 6 & 1 & & 1 & & \\
\hline Unclassified establishments & & & & & & & & & & & \\
\hline
\end{tabular}

${ }^{a}$ Excludes gove-sment employees, railroad employees, self-employed persons. etc.

${ }^{b}$ Not reported $: 0$, reasons of disclosure.

Source: U.S. Bureau of the Census. 1972. County business patterns. Washington, D.C.: U.S. Government Printing Office. 
Table 2.38. Major employers in the Mason County, West Virginia, area

\begin{tabular}{lcl}
\multicolumn{1}{c}{ Firm } & $\begin{array}{c}\text { Number } \\
\text { employed }\end{array}$ & \multicolumn{1}{c}{ Principal product } \\
\hline West Virginia Malleable Iron Co. & 203 & Malleable iron \\
Stauffer Chemical Co. & 187 & Phosphates and lubricants \\
Goodyear Tire \& Rubber Co. & 518 & Polyester resins \\
Foote Mineral Co. & 381 & Ferro.alloys \\
Philip Sporn Power Plant & 295 & Electric utility \\
Pantasote Co. & 93 & Polyvinyl chloride \\
Point Pleasant Marlne Co. & 62 & Boat and barge construction \\
\hline
\end{tabular}

Source: Area Development, Appalachian Power Company. 1976. Community information for Point Pleasant, Mason County, West Virginia. Charleston, W. Va.

The median value of housing units in Mason County in 1970 was near the slale average of $\$ 11,300$. Rental values were also near state averages (U.S. Bureau of the Census 1971b).

\section{Education}

Mason County has 21 public grade schools, two junior high schools, and three senior high schools, with a total enrollment of 6436 students in 1973-1974. Seven nonpublic kindergartens are also in the area (Battelle Columbus Laboratories 1976). The county employs about 350 teachers with degrees and has an average of 26 pupils per classroom. Essentially no excess capacity exists at present.

Vocational education programs are offered in the public schools, and the Mason County VocationalTechnical Center was completed in 1971. This center has a capacity of 250 students and offers instruction in agricultural production and management, food management production and services, accounting, nursing, clerical training, stenographic and secretarial training, automotive mechanics, welding and cutting, and special projects in agriculture and home cconomics for disadvantaged students. Of the 1758 students enrolled in grades nine through twelve, 1061 are enrolled in vocational education.

Although there are no colleges or universities in Mason County, Marshall University offers some extension courses at Point Pleasant, and there are several culleyes williili cuimmuting distance (e.g., Ohio University at Athens, Ohio, and West Virginia State College at Institute, West Virginia). In addition, Mason County offers a variety of instructional programs for adults (Area Development, Appalachian Power Company 1976; Battelle Columbus Laboratories 1976).

\section{Transportation}

Access to the interstate highway system from Mason County is slow and arduous. The major highways serving Mason County are U.S. Routes 33 and 35 and State Routes 2, 17, and 62. State Route 2 runs along the Ohio River connecting Huntington with Parkersburg and Wheeling to the north. Serving the New Haven/Hartford/Mason area are U.S. Route 33, which connects with Ohio to the north and Virginia to the east, and State Route 62, which connects with Point Pleasant to the south. All of the above U.S. and state routes are narrow, winding roads that usually parallel a river. Many of the bridges have only one lane. Rail service in the Mason County area is provided by 
the Penn Central, the $8 \& 0$, and the $C \& 0$ railraods. Barge transportation is available on the Kanawha and Ohio rivers (Battelle Columbus Laboratories 1976, p. 4-13).

Health care

There are four hospitals with a total capacity of 307 beds in the vicinity of Mason County. The hospitals are Pleasant Valley Hospital (137 beds) at Point Pleasant; Holyer Hospital (295 beds) at Gallipolis, Ohio; Meigs Hospital (20 beds); and the Veterans Memorial Hospital (80 beds) at Pomeroy, Ohio. In Mason County, Pleasant Valley Hospital is the only hospital; in 1976 there were 14 physicians and 6 dentists (Area Development, Appalachian Power Company 1976; Battelle Columbus Laboratories 1976).

\section{Police and fire protection}

Each municipality in Mason County maintains its own police force with a county-wide total of 19 policemen operating 14 vehicles. The county sheriff and deputies provide law enforcement and protection in the rural and unincorporated areas, and the West Virginia Department of Public Safety provides highway patrol in the area.

Fire protection is provided by 103 volunteer and 4 regular firemen. Equipment includes 11 firefighting vehicles (some of which are mobile pumping units) and 7 rescue vehicles.

\section{Recreation}

As in most rural areas, the recreational activities in Mason County are somewhat limited. In the Point Pleasant area, there are two recreational parks, one containing 1.2 ha ( 3 acres) and the other 23 ha (57 acres). The latter has an 8.9-ha (22-acre) lake and offers fishing, picnic facilities, and equipped playgrounds. There are two public and two private uutdoor swimming nools, three public golf courses, and a new Mason County Youth Center (Area Development, Appalachian Power Company 1976). A lighted football stadium with a seating capacity of 2000 , a lighted football and baseball park with a seating capacity of 2000, and three lighted baseball parks with a total seating capacity of 850 are also available.

In addition to the above, there are two state parks in the Mason County area, and several reservoir projects offer recreation facilities. A public hunting area and a wildlife station are also nearby.

Water supply and wastewater treatment

Within Mason County the city of Point Pleasant operates the Point Pleasant Water Works, for which the water supply is drawn from deep wells below the Ohio River Basin. This system currently has no excess capacity, but plans provide for a sufficient capacity in the system to permit $100 \%$ population growth.

Water is supplied by the municipalities in the New Haven/Hartford/Mason area. The source of this water is wells that are generally drilled to a depth of about $58 \mathrm{~m}(190 \mathrm{ft})$. These systems can currently produce abuut $70 \mathrm{~m}^{3}(20,000 \mathrm{gal})$ of water per day in excess of needs (Battelle Columbus Laboratories 1976). 
Wastewater treatment is also handled by the individual municipalities. Hartford does not have a sewage treatment plant, but the other municipalities (Point. Pleasant, New Haven, and Mason) do have such facilities.

\section{Historic and archaeological sites}

Only one historic or archaeological site listed in the National Register of Historic Places is located in Mason County. This site is Point Pleasant Battleground, which is located at the confluence of the Ohio and Kanawha rivers at Point Pleasant. Tu-Endie-Wei Park, a state-owned historical site, contains the 1774 battlefield where Indians and settlers fought what has been called the first battle of the Revolution (Battelle Columbus Laboratories 1976, p. 4-18).

\subsubsection{Ecology}

\subsubsection{Terrestrial ecology}

The natural vegetation of Mason County is mixed mesnphytic forest (Broun 195n) I!! diddtion, a alstinct floodplain forest type occurs along the Ohio and Kanawha rivers. Because of the relatively low topography and the presence of good water and rail transportation, the forests of this area have been heavily exploited for timber and agriculture.

Because of the early destruction of the forests in this area, their original composition is uncertain. Existing evidence suggests that oaks and hickories were more dominant in this area than in a typical mixed mesophytic forest (Braun 1950). Dominant species include white oak (Quercus alba), chestnut oak (Q. prinus), black oak (Q. velutina), tulip poplar (Liriodendron tulipifera), shagbark hickory. (Carya ovata), mockernut hickory (Carya tomentosa), white ash (Fraxinus americana), beech (Fagus grandifolia), and sugar maple (Acer sacchamm).

A stand of this forest. type in Tennessee with a total basal area of $21 \mathrm{~m}^{2} / \mathrm{ha}$ had a net produclivity of woody aboveground tissue of $4825 \mathrm{~kg}$ per hectare per year. Leaf production, as indicaled by litter fall, was $4100 \mathrm{~kg}$ per hectare per year (Harris et a1. 1973). The existing forest (which covers $59 \%$ of the county) is immature as a result of cutting or recent abandonment by agriculture. The younger stands (e.g., a 15-year-old clearcut in Graham Township) are dominated by the shade-intolerant pioneer species black locust (Robinia pseudoacacia) and sassafras (Sassafras aZbidum) (U.S. Army C.nrps of Engincers 1975). Some clear-cut land has been replanted in Virginia pine (Pinus virginiana) for pulp production.

Little lowland forest remains in Lewis Township, largely a result of the develnpment of the city uf Point Pleasant on the floodplains of the Ohio and Kanawha rivers. The remaining Kanawha floodplain has undergone agricultural development except where the land is too wet. The dominant lowland tree species are silver maple (Acer saccharinum), with sycamore (Platanus occidentalis), hackberry (Celtis occidentalis), cottonwood (Populers deltoides), and in the wettest areas, black willow (Salix nigra).

Another common natural vegetation type is the old-field vegetation that develops on abandoned agricultural land. In the first few years after abandonment, fields are dominated by weedy annuals and semiannual formes with perennials later gaining dominance. Common species include 
goldenrod (Solidago squarrosa), beggars ticks (Bidens trifida), aster (Aster schreberi), bull thistle (Cirsium vulgare), ragweed (Ambrosia trifida), plantain (Plantago rugelii), and Indian tobacco (Lobelia inflata). 01d-field grasses include broom sedge (Sorghastrum nutons), foxtail (Setaria Zutescens), bluestem (Andropogon girardi), and panic grass (Panicum dichotomiflorum). This meadow-like vegetation is replaced over a period of several years by woody perennials such as blackberry (Rubus occidentalis), honeysuckle (Lonicera japonica), and pioneer trees. Net productivity of old fields is highly variable but is typically much lower than that of forests.

Because of the presence of a variety of habitat types (woodland, cropland, pasture and old field, and wetlands and rivers), the terrestrial fauna is diverse. The most abundant birds in the county during a March survey were the common grackle (Quiscalus quiscuza) and starling (Sturnus vulgris) (U.S. Army Corps of Engineers 1975). Fifteen species were listed as abundant including four species of ducks (Anatinae), the sparrow hawk (Falco sparverius), rock and mourning doves (Columba livia and Zenaidura macroura), the common crow (Corvus brachyrynchus), and seven species of song birds (Passeriformes). An additional 26 species were considered common. Upland forest was found to be the vegetation type that supports the greatest avian species richness.

Small- to medium-size animals dominate the mammalian fauna, which include several species of mice (Cricetidae and Muridae), squirrels (Scuiridae), shrews (Soricidae), bats (Chiroptera), rabbits (Syzvizagus floridenus), and opposums (Didelphis marsupialis). Floodplain forest vegetation supports the greatest mammalian species richness. The area also supports a large number of species of reptiles and amphibians, most of which are either aquatic [e.g., turtles (Chelonia), water snakes (Natrix sp.), salamanders (Cryptobranchidae and Salomondridae), and frogs (Ronidae)], or forest species [e.g., lizards (Scincidae and Sceloporus unduzatus), snakes (primarily Columbridae), terrestrial salamanders (Plethodontidae), and tree frogs (Hyzidae)].

\subsubsection{Aquatic ecology}

As one of the most important interior waterways of the United States, the Ohio River has been subject to both deliberate and accidental human disturbance for over 150 years. Modification of the river for navigation purposes began in 1821. By the early 1900s, locks and dans had been constructed along its entire length, transforming it from a free-flowing stream to a series of turbid, slow-flowing impoundments. The rapid agricultural and industrial development of the Ohio River Basin which occurred during the latter half of the nineteenth century led to an enormous increase in the river's sediment load (caused by runoff from land cleared for agriculture and construction) and to its pollution by municipal, industrial, and mining wastes. The progressive deterioration of the river is partly reflected in commercial fishery statistics that are available for the period from 1894 to 1963 (Table 2.39). Of 15 fish species that made significant fishery contributions in 1894, only seven continued to be important in 1963. (One species, the quillback, entered the fishery statistics after 1894.) The percentage of commercial fishery devoted to carp, buffalo, and catfish increased from about 50 to $90 \%$ during this period. It is believed that the largest catches in the river occurred well before 1894, the first year for which fishery statistics are available. By that time many formerly abundant species, among. them the lake sturgeon, mooneye, grass pickerel, and walleye, had already become scarce (U.S. Army Engineer: Division 1964). 
Tab e a.33. Species composition of the Chio River Basin corrmercial fish catch, 1894-1963

\begin{tabular}{|c|c|c|c|c|c|c|c|c|c|c|c|c|c|c|c|c|}
\hline & \multicolumn{16}{|c|}{ Species composition, by vear (\%) } \\
\hline & 1894 & 1899 & $1 \cdot 303$ & 1908 & $19 \div 2$ & $1 \subseteq 31$ & 1950 & 1954 & 1955 & 1956 & 1957 & 1958 & 1959 & 1960 & 1962 & 1963 \\
\hline Bass, black & 1.3 & 0.8 & D.J & 0.3 & $a$ & & & & & & & & & & & \\
\hline Bas:, other & 1.1 & 0.4 & d & 0.1 & $a$ & $a$ & & & & & & & & & & \\
\hline Buffalo & $1 \cdot 7.4$ & 6.1 & 28.6 & 23.1 & 13.8 & 24.8 & 30.0 & 29.3 & 26.6 & 302 & 30.0 & 22.5 & 16.5 & 21.1 & 31.1 & 31.4 \\
\hline CarJ & .0 .7 & 3.5 & 5.7 & 22.4 & 216 & 29.9 & 25.0 & 21.4 & 30.7 & 28.1 & 27.7 & 21.3 & 156 & 23.0 & 25.5 & 35.4 \\
\hline Catiish & 3.J.7 & 29.0 & 25.9 & 21.3 & 202 & 18.3 & 27.7 & 28.0 & 25.3 & 26.0 & 26.9 & 39.7 & 27.4 & 25.5 & 31.4 & 23.1 \\
\hline Craspie & -3.4 & 0.3 & 2 & 0.3 & $a$ & 0.1 & & $a$ & & & & & & & & \\
\hline Drum & 23.6 & $\geq 2.9$ & 77.6 & 20.5 & 159 & 11.3 & 9.7 & 9.9 & 6.6 & 8.8 & 9.2 & 7.3 & 234 & 21.0 & 3.6 & 2.5 \\
\hline Eel & 3.3 & 0.4 & 0.2 & $a$ & & $a$ & & & & & & & & & & \\
\hline Mooneye & 3.7 & 0.3 & 0.3 & & & $a$ & & & & & & & & & & \\
\hline Padidlefish & 2.0 & 4.1 & 2.1 & 2.7 & 02 & 7.1 & 3.3 & 8.1 & 7.1 & 3.2 & 3.4 & 3.0 & 34 & 4.1 & 3.9 & 3.7 \\
\hline Pike, pickerel & $a$ & $a$ & & & & & & & & & & & & & & \\
\hline Quillback & & & & & 122 & 3.2 & 1.2 & 2.4 & 2.7 & 2.1 & 1.6 & 2.9 & 3.7 & 1.3 & 1.5 & 1.0 \\
\hline Sauger & $a$ & 0.2 & 3.8 & & $a$ & 0.2 & & & & & & & & & & \\
\hline Stu"geon, lake & 3.5 & 0.6 & $\exists$ & & $a$ & & & & & & & & & & & \\
\hline Stu:geon, shovel-nose & 2.9 & 2.6 & $5.1)$ & 4.1 & 2.9 & 1.6 & $0 . ?$ & 0.3 & 0.2 & 0.4 & 0.3 & 0.6 & 0.2 & 0.5 & 0.7 & 0.7 \\
\hline Sucker & 13.2 & 15.4 & 13.1 & 4.2 & 12.9 & 2.8 & 2.3 & 0.8 & 0.9 & 1.1 & 0.8 & 2.7 & $\Xi .0$ & 3.4 & 2.3 & 2.2 \\
\hline Surfish & $a$ & 0.5 & z & 0.2 & $a$ & & & & & & & & & & & \\
\hline Walleye & 2.6 & 0.7 & 0.3 & 0.6 & 0.2 & 0.3 & & & & & & & & & & \\
\hline Perch, yellow & & 1.1 & $\exists$ & & & & & & & & & & & & & \\
\hline Otrer & 0.6 & 0.8 & $\exists$ & & & $a$ & $a$ & & & $a$ & & $a$ & $a$ & & $a$ & $a$ \\
\hline
\end{tabular}

${ }^{a}$ Less than $0.1 \%$

Sourca: U.S. Armụ Eng neer Division. 196.4. Ohio River Basin zcmoretensive survey. vol. VIII, Table 3, p. 68. Cincinnati, Ohio 
The upper two-thirds of the Ohio, above Louisville, Kentucky, has suffered particularly severe degredation and has not supported a commercial fishery since the 1930s; above Hannibal Lock and Dam (RM 125), no commercial harvest has occurred in this century. However, because of pollution control efforts begun after World War II, water quality has been stabilized throughout the Ohio River Basin, and in some areas it has actually improved (Butz et al. 1974). According to the Westinghouse Electric Corporation report (1975), water quality at the site of the Kyger Creek Power Plant near the Mason County site now meets EPA standards for primary recreation and warm water fishery.

The Mason County site is located on the Gallipolis Pool reach of the Ohio between Racine Lock and Dam (RM 237.5) and Gallipolis Lock and Dam (RM 279.2). For several years ecological studies of the Gallipolis Pool have been conducted near the site of the Kyger Creek plant (RM 260). During the course of these studies, the phytoplankton of the pool has been dominated by diatoms and green algae throughout all four seasons (WAPORA 1974, 1975a, b; Westinghouse Electric Corporation 1975). Blue-green algae have been consistently rare, usually constituting $1 \%$ or less of the total cell count. Rotifers have been numerically the most abundant zooplankton form, but copepods and cladocerans, including plankters such as Diaptomus sp., Daphnia sp., and Sida crystazzina (which are more typical of ponds and lakes than of rivers) have been present and occasionally quite abundant.

The Westinghouse Electric Corporation (1975) study reported that two distinct benthic habitat types exist in the Gallipolis Pool. Along the banks and in shallow, protected areas, the bottom is covered with silt, but in the center of the pool there are areas in which the original rock and pebble bed is exposed. In both habitats the abundance and diversity of benthic invertebrates is low. In the Westinghouse study, tubificids accounted for $93 \%$ of the individuals collected in ponar dredge samples from silt-covered areas and for $77 \%$ of the individuals in samples from rocky areas. Benthic collections made by WAPORA $(1975 a, b)$ in the vicinity of the kyger creek plant aiso were dominated by tubificids. These organisms are highly stress tolerant. Their abundance indicates. that benthic habitats in the pool are subject to frequent oxygen depletion. The only other benthic invertebrate that occurred in significant numbers in the Westinghouse and WAPORA collections is the Asiatic clam (Corbicuza manizensis). A large number of other organisms, including crayfish, amphipods, and insects of the orders of Diptera, Trichoptera, Ephemeroptera, Zygoptera, and Coleoptera colonized artificial substrates suspended in the river, but these apparently constitute only a small fraction of the benthic community.

Since the 1950s, several quantitative fish surveys have been conducted in the Ohio River in and around the Gallipolis Pool. Carp, gizzard shad, channel catfish, and emerald shiner have consistently been found to be the most abundant species (Table 2.40). However, a comparison of the 1957-1959 survey by ORSANCO with the 1974-1975 survey by WAPORA indicates that the diversity of fish species in the pool might have increased signficantiy during the last 20 years. In the ORSANCO survey only 15 species, representing 6 families, were collected. The family Centrarchidae, which contains many important game and panfish, was represented by only one species (bluegill) and accounted for only $2.7 \%$ of the fish biomass collected. In the WAPORA survey 36 species, representing 9 families, were collected. Eight of these, constituting more than $11 \%$ of the total biomass, were centrarchids. One, the largemouth bass, was the fourth most abundant fish collected, accounting for $9.2 \%$ of the total catch. In addition to the species listed in Table 2.40, WAPORA has collected three others - the blue catfish, goldfish, and banded killifish - in the vicinity of the Kyger Creek plant. 
Table 2.40. Relative abundance of fish species collected in the Ohio River in and around Gallipolis Pool Percentages of catch

\begin{tabular}{|c|c|c|c|c|c|c|c|c|}
\hline \multirow[t]{2}{*}{ Species } & \multicolumn{2}{|c|}{$\begin{array}{c}\cdot \\
\text { ORSANCO surveys }{ }^{a, b} \\
(1957-1959) \\
\end{array}$} & \multicolumn{2}{|c|}{$\begin{array}{c}\text { Mile point } 231.4^{\circ} \\
\text { (Oct. } 2,1968 \text { ) } \\
\end{array}$} & \multicolumn{2}{|c|}{$\begin{array}{l}\text { Mile point } 279.2^{a} \\
\text { (Oct. } 3,1968 \text { ) } \\
\end{array}$} & \multicolumn{2}{|c|}{$\begin{array}{c}\text { Vicinity of Kyger Creek } \\
\text { Plant (April 1974- } \\
\text { February 1975) } \\
\end{array}$} \\
\hline & Abundance & Weight & Abundance & Weight & Abundance & Weight & Abundance & Weight \\
\hline Longnose gar & & & & & $<0.1$ & 0.3 & 0.6 & 1.8 \\
\hline Skipjack herring & 0.5 & 6.1 & 2.4 & 2.8 & 9.3 & 5.3 & 2.3 & 0.4 \\
\hline Gizzard shad & 1.5 & 27.0 & 35.4 & 51.1 & 3.7 & 7.2 & 22.9 & 20.9 \\
\hline Carp & $<0.1$ & 11.0 & 0.4 & 9.0 & 2.6 & 57.8 & 2.6 & 31.1 \\
\hline Silverjaw minnow & & & & & & & $<0.1$ & $<0.1$ \\
\hline Bluntnose minnow & 0.2 & $<2.0$ & 1.0 & 0.1 & 0.7 & $<0.1$ & 0.4 & $<0.1$ \\
\hline Bullhead minnow & & & & & & & 1.2 & $<0.1$ \\
\hline Silver chub & 1.3 & $<2.0$ & & & 0.3 & $<0.1$ & 0.2 & $<0.1$ \\
\hline Fathead minnow & & & & & & & 0.1 & $<0.1$ \\
\hline Eı11 & 70.0 & 12.0 & 92.2 & 0.8 & 97.0 & 1.0 & 59.0 & 0.1 \\
\hline River shiner & & & & & & & 0.2 & $<0.1$ \\
\hline Common shiner & & & & & & & 0.3 & $<0.1$ \\
\hline Ghost shiner & $0 . \dot{6}$ & $<2.0$ & 11.9 & 0.4 & $<0.1$ & $<0 ̉ .1$ & & \\
\hline Spotfin shiner & 0.4 & $<2.0$ & $<0 ̉ . j$ & $<0.1$ & & & 0.7 & $<0.1$ \\
\hline Sand shiner & & & 0.1 & $<0.1$ & & & 0.8 & $<0.1$ \\
\hline Mimic shiner & 14.0 & $<2.0$ & 6.4 & 0.2 & 15.4 & 0.7 & 1.6 & $<0.1$ \\
\hline River carpsucker & & & & & & & 1.1 & 17.2 \\
\hline Highfin carpsucker & & & & & & & $<0.1$ & 0.2 \\
\hline Northorn hog sucker & & & & & & & $>0.1$ & 0.1 \\
\hline Golden redhorse & $<0.1$ & 2.7 & & & & & 0.2 & 0.7 \\
\hline Spotted sucker & $<0.1$ & 2.4 & & & & & & \\
\hline Smallmouth buffalo & & & $<0.1$ & 2.2 & $<0.1$ & 1.0 & 0.3 & 4.2 \\
\hline Quillback & . & & & & $<0.1$ & 0.1 & $<0.1$ & $<0.1$ \\
\hline American eel & & & & & $<0.1$ & 0.1 & & \\
\hline Channel catfish & 3.4 & 14.0 & 29.2 & 26.8 & 46.0 & 20.2 & 1.1 & 10.4 \\
\hline Brown bullitead & & & 0.1 & 0.4 & 0.2 & 0.3 & $<0.1$ & 0.1 \\
\hline Black bullhead & $<0.1$ & 2.4 & & & & & & \\
\hline Flathead catfish & & & $<0.1$ & $<0.1$ & $<0.1$ & $<0.1$ & $<0.1$ & 0.1 \\
\hline White catfish & & & & & & & $<0.1$ & 0.1 \\
\hline Pıımpkinṣeert & & & & & & & $<.0 .1$ & $<.0 .1$ \\
\hline Bluegill & 1.1 & 2.7 & & & 0.1 & 0.1 & 0.4 & 0.3 \\
\hline Longear sunfish & & & & & $\cdot$ & & $<0.1$ & $<0.1$ \\
\hline Y'ellowbelly sunflsh & & & & & & & $<01.1$ & $<0.1$ \\
\hline Rerdear sınfish & & & & & $<n .1$ & 0.1 & & \\
\hline Spotted bass & & & & & $\dot{U} .1$ & $<U .1$ & 0.2 & 0.3 \\
\hline Largemouth bass & & & 0.2 & 3.2 & $<0.1$ & 0.3 & 2.4 & 9.2 \\
\hline Smallmouth bass & & & & & & & 0.4 & 0.6 \\
\hline White crappie & & & & & & & 0.2 & 0.5 \\
\hline Black crappie & & & $<0.1$ & 0.2 & $<0.1$ & 0.4 & & \\
\hline White bass & & & $<0.1$ & 0.2 & 0.1 & $<0.1$ & 0.2 & 0.3 \\
\hline Sauger & & & $<0.1$ & 1.2 & $<0.1$ & 0.5 & 0.2 & 0.8 \\
\hline Freshwater drum & $<0.1$ & 4.0 & 0.1 & 0.9 & 3.1 & 3.8 & 0.2 & 0.2 \\
\hline
\end{tabular}

a Source: Westinghouse Electric Corp. 1975. Kyger Creek Power Plant thermal discharge study, vol. 1. Modified from . Table 4.4.p. 4.17. Pittsburgh, Pa.: Westinghousc Elcctric Corporation, Environmental Systems Department.

${ }^{b}$ Collected between mile points 200 and 300.

cSource: WAPORA. 1975. Continuing ecological studies of the Ohio River, 1974. Modified from Table VIII-3, p. 108. Washington, D.6.: WAPORA, Inc.

The sampling sites, gear, and effort in the ORSANCO and WAPORA studies were not identical; therefore, their results are not strictly comparable. Nonetheless, the differences between their findings are striking. Since water quality in the Gallipolis Pool is known to have improved significantly in recent years (Westinghouse Electric Corporation 1975), it is reasonable to conclude that the marked increase in fish diversity found by WAPORA at least partially reflects an improvement of the river as a habitat for fish. 
Although many fish species appear to be able to survive in the Gallipolis Pool, it is probable [according to the Westinghouse report (1975) and Butz et al. (1974)] that very little reproduction takes place there. As with the Kaskaskia River, damming and channelization of the Ohio have eliminated the sloughs and backbays that serve as spawning and nursery areas for nest-building fish such as bullheads, sunfishes, and largemouth bass. In addition, the silt that covers the bottom of the river presents spawning by species (such as sauger and smallmouth bass) that deposit their eggs on sand or gravel. Data relating to reproduction in the fish populations that currently inhabit the Ohio River are limited, but existing information suggests that most successful spawning occurs not in the main stem but in small tributary streams (Butz et al. 1974).

\subsubsection{Endangered species}

\section{Terrestrial}

The only endangered mammalian species that is likely to occur in Lewis Township is the Indiana bat (Myotis sodalis) (U.S. Department of the Interior 1976a). Critical habitat for this species consists of large limestone caves. The range of the eastern cougar (Felis concolor cougar) includes Lewis Township, but suitable habitat is not available.

Although the endangered arctic peregrine falcon (Falco peregrinus tundrius) migrates through this area, it is unlikely that this township provides significant resting habitat because of the extensive riverfront development. No other officially endangered or threatened species of bird is expected to be found in Lewis Township.

None of the species on the proposed list of endangered plants are believed to occur in West Virginia (II.S. Department of the Interior 1976b). None of the species on the Smithsonian Institution's list of threatened plants was found in a survey of northern Mason County (U.S. Army Corps of Engirieers 1975; Secretary, Smithsonian Institution 1975).

The State of West Virginia does not have an official list of threatened or endangered species.

\section{Aquatic}

The pink mucket pearly mussel is the only nationally listed endangered aquatic species whose range includes West Virginia (U.S. Department of the Interior 1976a). It has not been collected in recent biological surveys of the Ohio River (WAPORA 1974, 1975a, b; Westinghouse Electric Corporation 1975). West Virginia has no state list of endangered or threatened species. However, three fish species that are officially listed as endangered in Ohio (Ohio Department of Natural Resources 1974), the ghost shiner (Notropis buchanani), silver chub (Hybupsis storeriana), and banded killifish (Fundul.us dimphmus), have been found in the Gallipolis Pool reach of the Ohio River (Table 2.40). 


\section{REFERENCES FOR SECTION 2.2}

Algermissen, S. T. 1968. United States Earthquakes. U.S. Department of Commerce, Washington, D.C.: U.S. Government Printing Office.

Algermissen, S. T., and Perkins, D. M. 1976. A probabilistic estimate of maximum acceleration in rock in the contiguous United States. Open file report no. 76-416. Washington, D.C.: U.S. Geological Survey.

Area Development, Appalachian Power Company, 1976. Community information for Point Pleasant, Mason County, West Virginia. Charleston, W. Va.

Babu, S. P.; Barlow, J. A.; Craddock, L. L.; Hidalgo, R. V.; and Friel, E. 1973. Suitability of West Virginia coals lo cual-conversion processes. Coal-geology hulletin no. 1. Morgantonn, W. Va.: West Virginia Geological and Economic Survey.

Barlow, J. A. 1974. Coal and coal mining in West Virginia. Coal-geology bulletin no. 2. Morgantown, W. Va.: West Virginia Geological and Economic Survey.

Bättēlle Columbus Laburatories. 1976. Technology facility siting characteristics and infrastructure needs. Prepared for the Appalachian Regional Commission, Washington, D.C., Project ARC 75-183/4427. Columbus, Ohio: Battelle Columbus Laboratories.

Blake, 0. D. 1952. Geology of Gazlio County. Unpublished dissertation. Columbus, Ohio: Ohio State University.

Braun, E. L. 1950. Deciduous forests of eastem North America. New York: Hafner Press.

Butz, B. P.; Schreyardus. D. R.; Lewis, R. A.; Policastro, A. J.; and Reisa, J. J. 1974. Ohio River cooling water sthdy. FPA-905/9-74-004. Chicago, I].: U.S. [nvironmenld 1 I'rotection Agency, Reyions IV and V.

Carlston, C. W., and Graeff, G. D. 1955. Crmunthater roscurooo of the Olivio River Viuzey in West Virginia. Morgantown, W. Va.: West Virginia Geological and Economic Survey.

Department of Industrial Relations. 1975. Division of Mines reperrt. Columbus, Ohio: State of Ohio.

Eardlcy, A. J. 1051. Blimelurut yeology of North America. New York: Harper dild Row.

ERDA (Energy Research and Development Administration). 1977. Draft environmental impaet. statement, Portsmouth Gaseous Diffusion Plant site. Report ERDA-1555-D, 2 vols. Washington, D.C.

Harris, W. F.; Goldstein, R. A.; and Henderson, G. S. 1973. Analysis of forest biomass pools, annual primary production and turnover of biomass for a mixed deciduous forest watershed. In Proceedings of the working party on forest biomass, ed. H. Yound, pp. 41-64. Orono: University of Maine Press. 
Holtzworth, G. C. 1972. Mixing heights, wind speeds, and potential for urban air polzution throughout the contiguous United States. EPA AP-101. Washington, D.C.: U.S. Environmental Protection Agency.

Keystone coal industry manual. 1976. New York: McGraw-Hill.

Lessing, P. 1974. Earthquake history of West Virginia. Environmental geology bulletin no. 12. Morgantown, W. Va.: West Virginia Geological and Economic Survey.

Ohio Department of Natural Resources. 1974. (Incomplete reference).

Ohio Division of Geological Survey. 1966. Oil well driller's log, SW 1/4, Sect. 12, Addison Townohip, Gazzio County. Open file report, Columbus, Ohio.

ORNL (Oak Ridge National Laboratory). 1977. ORNL geoecology data base land use printout, March 7, 1977, for Mason County, West Virginia. (Data obtained from U.S. Department of Agriculture statistical bulletin no. 461, 1971). Oak Ridge, Tenn.

ORSANCO (Ohio River Valley Water Sanitation Commission). 1977. Ohio River main stem: assessment of 1976 and future water quality conditions. Cincinnati, Ohio.

Overbey, W. K. 1961. Oil and gas report on Jackson, Mason, and Putnam counties, West Virginia. Bulletin no. 23, Morgantown, W. Va.: West Virginia Geological and Economic Survey.

Point Pleasant, West Virginia, Chamber of Commerce. 1976. Telephone conversation with J. T. Cowan.

Pree, H. L. 1962. Underground water ressurces, Zower Raccoon Creek basin. Columbus: Ohio Division of Water.

Secretary, Smithsonian Institution. 1975. Report on endangered and threatened plant species of the United States. Washington, D.C.: U.S. Government Printing Office.

Shepherd, A. D. No date. Water availability for energy development: a spatial analysis of strean low flows in the Ohio River Basin region. (ORNL report, to be published). Oak Ridge, Tenn.: Oak Ridge National Laboratory.

Stenehjem, E. J., and Metzger, J. E. 1976. A fromework for projecting employment and population changes accompanying energy development. Washington, D.C.: Energy Research and Development Administration.

Stout, W.; Ver Steez, K.; and Lamb, G. F. 1944. Geology of water in Ohio. Bulletin no. 44. Columbus, Ohio: Division of Geological Survey.

U.S. Army Corps of Engineers. 1975. Draft environmental impact statement, project 1301. - Hunlinigton, W. Va.: U.S. Army Engineer District. 
U.S. Army Engineer Division. 1964. Ohio River Basin comprehensive sumey, VIII: fish and wildlife resources. Cincinnati, ohio.

U.S. Bureau of the Census. 1970a. Census of the population, 1970. Vol. 1, part 37, "West Virginia," Table 10. Washington, D.C.: U.S. Government Printing Office.

-1970b. General social and economic characteristics: 1970. PC(1)-C37, Ohio. Washington, D.C.: U.S. Government Printing office.

-1. 1970c. General social and economic characteristics: 1970. PC(1)-C50, "West Virginia." Washington, D.C.: U.S. Government Printing Office.

... 1971a. Census of housing: 14\%0, general housing churacteristics. Final report, $H C(1)-A 1$, United States Summary. Washington, U.C.: U.S. Government Printing Office.

- 1971b. Census of housing, 1970, housing characteristics for states, cities, and counties. Vol. 1, part 37, "West Virginia." Washington, 0.C.: U.S. Government Printing Office.

- 1971c. Statistical abstract of the United States, 1977. Wạshington, D.C.: U.S. Government Printing office.

- 1972. County business patterns. Washington, D.C.: U.S. Government Printing Office.

- 1973. Census of govermments, 1972. Vol. 1. Washington, D.C.: U.S. Government Printing office.

- 1976a. County and city data book, 1972. Washington, D.C.: U.S. Government Printing uffice.

-1976b. Statistical abstract of the Unitod Stateo, 7.076. Washington, D.C.: U.S. Government Printing office.

U.S. Department of Agriculture. 1967. National inventory nf sni.7. ma wator oonocrvation needs. Statistical bulletin no. 461. Washington, D.C.: U.S. Government Printing office.

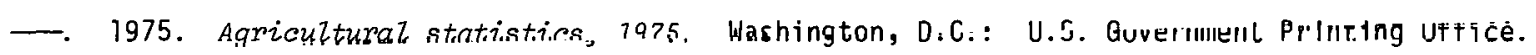

U.S. Department of the Interior. 1976a. Endangered and threatened wildife and plants.

Fed. Regiast. $41(208): 47180-88$.

- 1976b. Endangered and threatened species, plants. Fod. Regist. 41(117):24524-72.

USEPA (United States Environmental Protection Agency). 1976. Mmitoring and air quality trends report, 1974. EPA-450/1-76-001. Rescarch Triangle Park, N.C.

WAPORA. 1974. Continuing ecological studies of the Ohio River, 1973. Washington, D.C.: WAPORA, Inc. 
- 1975a. Continuing ecological studies of the Ohio River, 1974. Washington, D.C.: WAPORA, Inc.

- 1975b. Continuing ecological studies of the Ohio River, 1975 progress report. Washington, D.C.: WAPORA, Inc.

Westinghouse Electric Corporation. 1975. Kyger Creek Power Plant thermal discharge study. Pittshurgh, Pa.: Westinghouse Electric Corporation Environmental Systems Department.

West Virginia Air Pollution Control Commission. May 4, 1977. Private communication to J. N. Baird, Oak Ridge National Laboratory, Oak Ridge, Tenn.

West Virginia Department of Highways. 1976. General Highway Map, Mason County, West Virginia.

Wilmoth, B. M. 1966. Groundwater in Mason and Putnom counties, West Virginia. Bulletin no. 32. Morgantown, W. Va.: West Virginia Geologic and Economic Survey. 


\subsubsection{Site Tocation}

The Wyoming site is located in Township 50N, Range $71 \mathrm{~W}$, the center of which is at $44^{\circ} 18^{\prime} 27^{\prime \prime}$ latitude and $105^{\circ} 26^{\prime} 42^{\prime \prime}$ longitude. The township is near the center of Campbell County, which lies entirely within the Powder River Basin of northeast Wyoming. Gillette, less than 1 mile to the east, is the closest population center and is the county seat and the largest city in Campbel1 County. Wyoming Highway 59, the major north-south route in Campbell County, is just east of the township. Interstate 14/16, the major east-west route, passes through the township (Fig. 2.19). A line of the Burlington Northern Railroad parallels the interstate and serves the Wyodak Coal Mine, which occupies about two sections in the south center of the township.

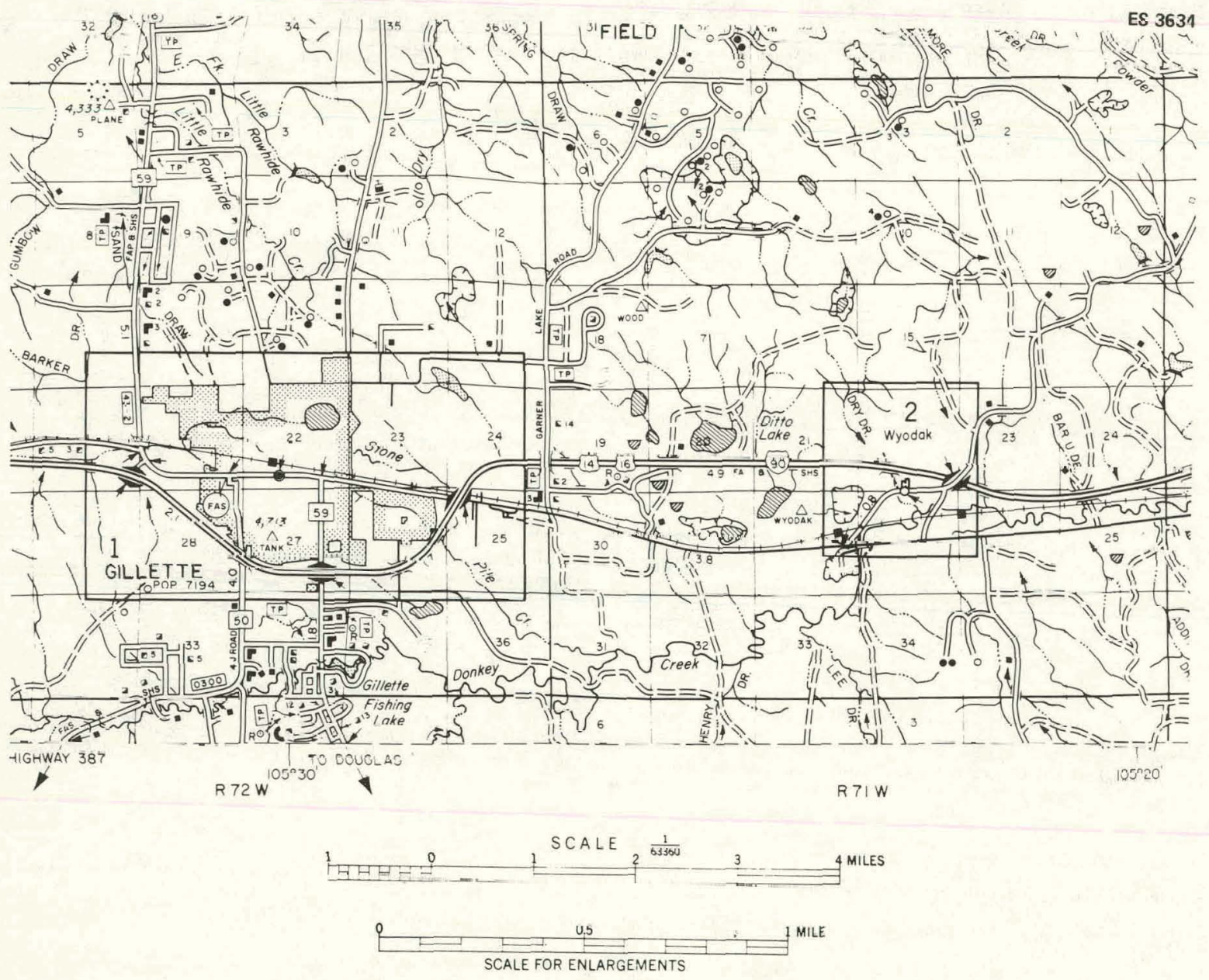

Fig. 2.19. Surrogate site, Township 50N, range 71W, Campbe11 County, Wyoming. Source: Northern Great Plains Resources Program. 1974. Water group (c) water report. Denver, Colo.

The township is on the divide between drainage into the Little Powder River to the northwest and into Donkey Creek and eventually to the Belle Fourche River to the southeast. There is some internal drainage into the playa lakes in the center of the township. In general, the 
topography is gently rolling with scattered low buttes. Elevations range between 1340 and $1420 \mathrm{~m}$ (4400 and $4650 \mathrm{ft}$ ) above sea level.

\subsubsection{Geology}

\subsubsection{Coal reserves}

Camplell County, in the east-central part of the Powder River Basin of northeast Wyoming, has more near-surface coal than any other county in the United States. The Wyodak-Anderson coal bed is the major economically exploitable deposit of the region (Keefer and Hadley 1976). This bed ranges between 15 and $30 \mathrm{~m}$ ( 50 and $100 \mathrm{ft}$ ) thick and 1 ies within $60 \mathrm{~m}(200 \mathrm{ft}$ ) of the surface over a region $160 \mathrm{~km}$ ( $100 \mathrm{miles}$ ) long by 3 to $5 \mathrm{~m}$ ( 2 to 3 miles) wide (Fig. 2.20). It contains an estimated 13.6 billion metric tons (15 billion tons) of subbituminous, low-sulfur coal that can be mined by surface methods. To put Campbell County's surface reserves in proper perspective, the National Petroleum Council (1973) estimates there are 40.8 billion metric tons (45 billion tons) of strippable coal reserves in the entire United States. Thus Campbell County contains about one-third of the nation's total strippable coal reserves (Keefer and Hadley 1976; National Petroleum Council 1973; U.S. Department of the Interior 1974).

In addition to the Wyodak-Anderson coal bed, at least 12 other exploitable coal strata have been identified within the Fort Union formation. Their sum thickness exceeds $60 \mathrm{~m}$ (200 ft) in some localities. Exploitable coal strata are also formed in the Wasatch formation immediately overlying the Fort Union. The precise location of Powder River Basin coal reserves is discussed in detail in the section devoted to regional geology (Keefer and Hadley 1976).

A significant quantity of coal is not expected to be produced from underground mines in the Powder River Basin in the foreseeable future. Although a considerable amount of coal exists as deep as $900 \mathrm{~m}$ (3000 ft) or more, it is contained in soft and permeable strata. Underground wnrk.ings would be subject to roof collapse and flooding.

Al though the technological problems associated with underground mining are not unique to the Powder River Basin, they are likely to be unusually difficult to overcome. Powder River Basin coal is contained in Tertiary strata. Because these strata are relatively young, they are poorly consolidated. Tertiary-age coal is easily stripped, hut it is extrcmely difficult to tunnel Lhrough; the tunnel's ronf must be grouted and supported with numerous rock bolts and pillars.

Comparing the nation's coal reserves with those of the Powder River Basin, the National Petroleum Council (1973) estimates that there are 136 billion metric tons (150 billion tons) of recoverable coal in the United States, including surface and underground coal. The Powrer River Basin lias not recoverable underground coal but has about 13.6 bil1ion metric tons (15 bil1ion tons) of strippable reserves (Keefer and Hadley 1976), which is about $10 \%$ of the nation's tuld l reserves of recuverable coal.

Reserve estimates based on tonnage alone can be misleading. On the positive side, Powder River Basin coal has a low sulfur content. Wyodak-Anderson coal in the Gillette area contains an average of $0.5 \%$ sulfur. By comparison, $46 \%$ of the coal of the Eastern United States contains over $3 \%$ sulfur. Only $11 \%$ of Eastern coal has less than $0.7 \%$ sulfur, and most of it is committed 
ES-3635

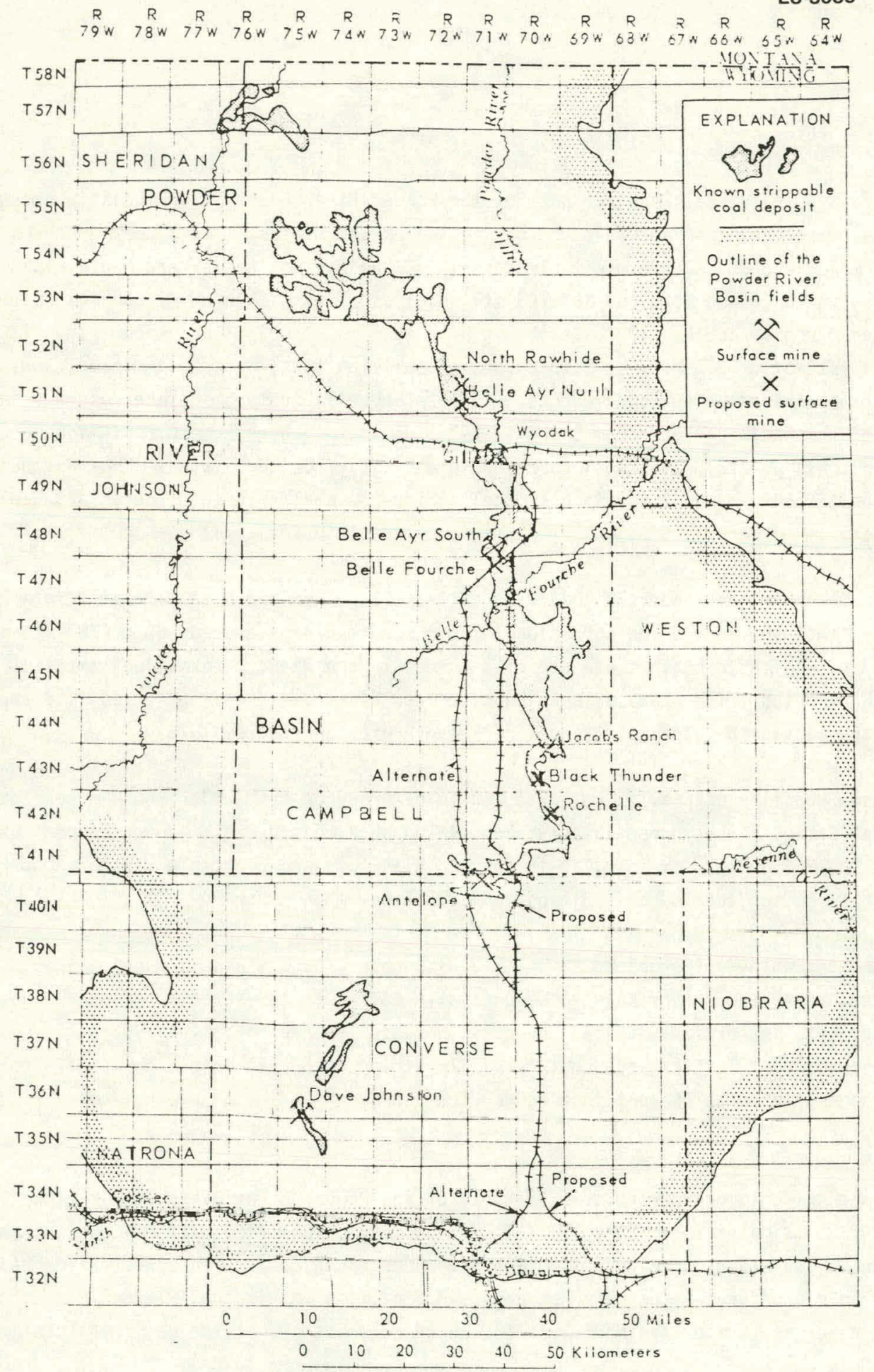

Fig. 2.20. Strippable coal deposits of the eastern Powder River Basin, Wyominq. Source: U.S. Department of the Interior. 1974. Final environmental statement, proposed development of coal resources in the Eastem Powder River Basin. D-18. Washington, D.C. 
to the steel industry. On the negative side, the Wyodak-Anderson coal has an average heat value of $2.1 \times 10^{7} \mathrm{~S} / \mathrm{kg}(8950 \mathrm{Btu} / 1 \mathrm{~b})$, compared with $2.7 \times 10^{7} \mathrm{~S} / \mathrm{kg}(11,500 \mathrm{Btu} / 1 \mathrm{~b})$ for Eastern bituminous coal (National Petroleum Council 1973).

\subsubsection{Regional geology and energy resources of the Powder River Bas in}

The Powder River Basin (Fig. 2.21) is a structural and topographic basin bounded on the west by the Bighorn Range, on the southwest by the Casper Arch, on the south by the Laramie Range and Hartville Uplift, and on the east by the Black Hills. It opens to the north in Montana (Hodson, Pearl, and Druse 1973).

The Powder River Basin is asymmetrical, the deepest part of the basin lying near its southwestern margin parallel to the Bighorn Range and Casper Arch (Sharp et al. 1964). The narrow band of Fort Union exposures near the southwestern margin (Fig. 2.21) and the younger Wasatch formation to the east imply a steep northeast dip. Pre-Tertiary strata on the western flank of the basin range in dip between $30^{\circ}$ and vertical. Strata are locally overturned. On the other hand, the broad band of Fort Union exposures on the east side of the basin reflect gentle west dips on the order of magnitude of tens of meters per kilometer (Sharp et al. 1964).

In the deepest part of the basin, the thickness of strata above the pre-Cambrian reaches a maximum of $4880 \mathrm{~m}(16,000 \mathrm{ft})$. The central part of the basin contains 910 to $1520 \mathrm{~m}$ (3000 to $5000 \mathrm{ft}$ ) of Cenozoic strata. In turn, these strata are underlain by $2260 \mathrm{~m}$ (7400 ft) of Cretaceous rocks, $340 \mathrm{~m}(1100 \mathrm{ft})$ of Jurassic and Triassic rocks, and $761 \mathrm{~m}(2500 \mathrm{ft})$ of Paleozoic rocks. Igneous and metamorphic rocks of pre-cambrian age are exposed only in the uplifted regions - Bighorn Range, Laramie Range, and Black Hills (Fig. 2.21) - that surround the Powder River Basin (U.S. Department of the Interior 1974).

The Wyodak-Anderson coal bed crops out along the contact between the Wasatch and Fur'L Union formaliurs. Most geologists place the Wyodak-Anderson coal near the top of the Fort Union. Because the coal is thick and gently dipping, it is minable by surface methods over a zone 3 to $5 \mathrm{~km}$ (2 to 3 miles) wide (Fig. 2.20) along the exposed Wasatch-Fort Union contact of the eastern side of the Powder River Basin. Much of this band of outcrop lies in eastern Campbell County (Fig. 2.21).

The western margin of the Powder River Basin is not a promising coal province for two reasons: (1) coal beds are thinner, and (2) they dip much more steeply so that the band of strippable coal is very narrow.

Neither is the central part of the Powder River Basin a promising region for coal reserves. The Wasatch formation contains a number of coal beds, but none are nearly as thick ds the WyodakAnderson. While the Wyodak-Anderson coal bed exists in the central part of the basin, the depth of burial beneath the Wasatch formation ranges up to $480 \mathrm{mi}(1600 \mathrm{ft})$. The present economic depth limit for strippable Wyodak-Anderson coal is $60 \mathrm{~m}(200 \mathrm{ft}$ ) (Keefer and Hadley 1976).

In summarizing the coal reserves of the Powder River Basin, the vast majority lies in a narrow band of outcrop in the east-central part of the basin. Much of this coal is exposed in eastern Campbe11 County. 


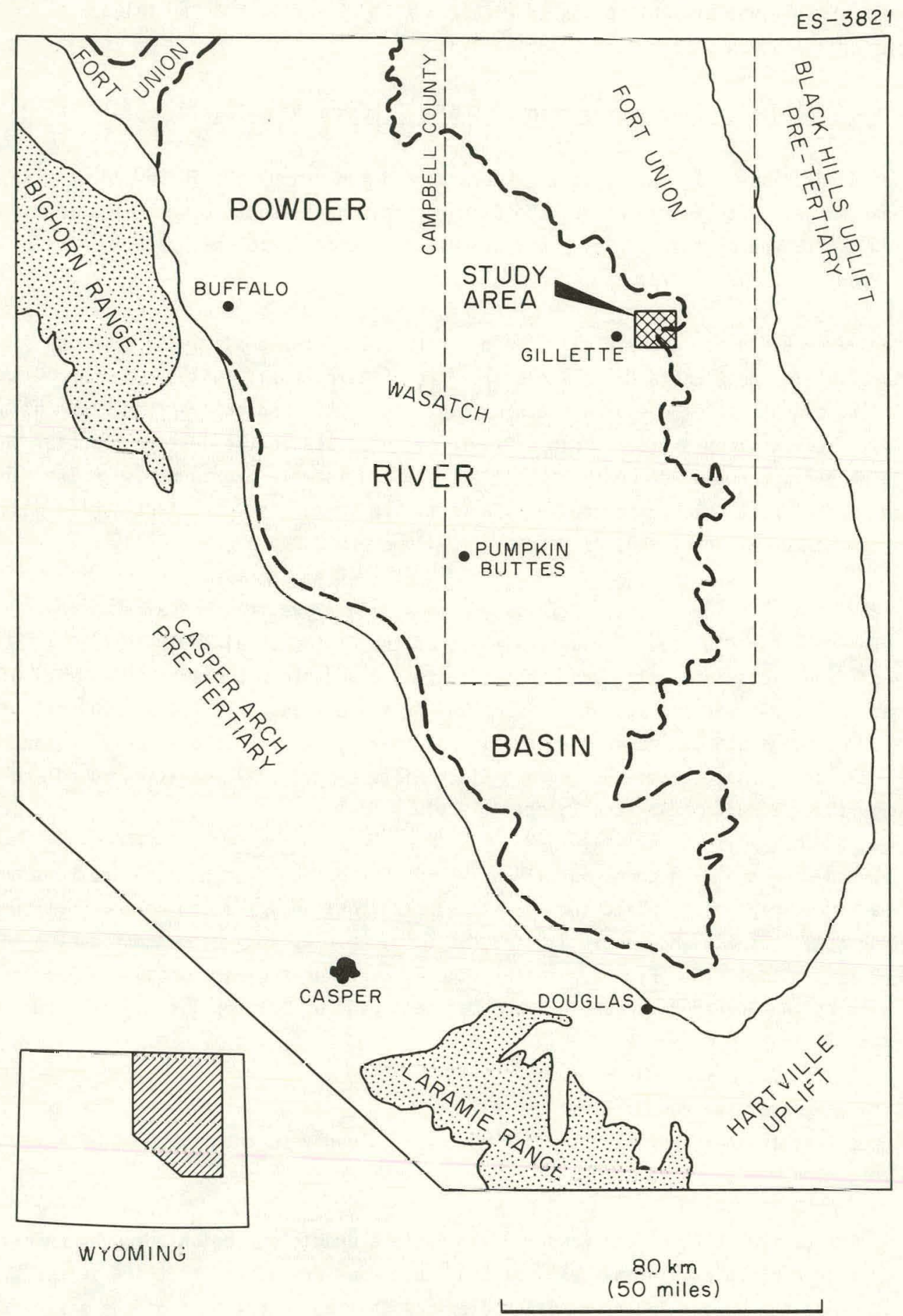

Fig. 2.21. Geologic map of the Wyoming portion of the Powder River Basin. Source: Modified after W. G. Hodson, R. H. Pearl, and S. A. Druse. 1973. Water resources of the Powder River Basin and adjacenl areas, northeastern Wyominq. Hydrologic Investigations Atlas HA-465. Washington, D.C.: U.S. Geologic Survey. 
Major structural features are found only on the margins of the Powder River Basin. Thrust faults are exposed on the eastern flank of the Bighorn Range. Some of these faults probably lie covered beneath unknown Cenozoic strata farther to the east, but apparently they do not extend far out into the basin. A number of small oil and gas fields are associated with tight folds and faults along the bighorn frontal system. By far the most prolific oil production, however, comes from broad domes along the Casper Arch. The giant Salt Creek oil field, the Teapot Dome, and the U.S. Naval Reserve are good examples. Another giant, the Big Muddy oil field near Glenrock, lies alung the southern flank of the Powder River Basin adjacent to the Laramie Range where extensive faulting occurs. Other oil fields are associated with the Hartville Uplift (U.S. Department of the Interior 1974).

The middle of the Powder River Basin is characterized by a number of gentle anticlines and minor faulting. $0 i 1$ and gas are abundant in the basin, but structural traps are not as large as they are on the flanks. Much oil production is associated with lower Cretaceous (Muddy Sandstone member of Thermopolis shale) stratigraphic traps such as "updip pinchouts" or shaleenclosed sand lenses. Some oil and gas have also been found along the Minnelusa-Minnekahta subcrop at the top of the Palezoic section (U.S. Department of the Interior 1974).

The Powder River Basin is also an important uranium mining district. Most of the activity is currently taking place in the south and in the Pumpkin Buttes regions in the central part of the basin (Sharp et a1. 1964). Open pit mines have been developed in the Wasatch formation, but potential also exists for uranium mining of the Fort Union. Recently in situ leaching for uranium ranging in depth to $150 \mathrm{~m}(500 \mathrm{ft})$ has been studied, and at least one pilot project is under way.

\subsubsection{Stratigraphy}

Figure 2.22 shows the stratigraphic relationship between geologic units of the eastern and western parts of the fowder River Basin. The nomenclature varies for the Paleozoic through Mesozoic (below the Lance) because the stratigraphy differs markedly on opposite sides of the basin. From the uppermost Cretaceous (Lance) through the Tertiary, the stratigraphy is similar, and the same nomenclature applies to both sides of the basin (Hodson, Pearl, and Druse 1973).

Table 2.41 indicates thickness ranges and identifies the more important uranium, oil, gas, and water-producing units on the eastern side of the basin. The strata in the western part of the basin are thicker, reflecting the closer proximity of the basin axis. $0 i 1$ and gas found in local sand lenses within major shale units (for example, the Pierre shale) are not indicated in the table because of limited oil production. Although $0 i 1$ and gas are present in many stratigraphic units, $90 \%$ of the production comes from two units in the eastern part of the basin: (1) the Muddy Sandstone member (or Newcastle) of the Thermopolis shale and (2) the Minnelusa fonrmation (U.S. Department of the Interior 1974).

The impacl of surface development on the pre-Tertiary section, which is 550 to $1040 \mathrm{~m}$ (1800 to $3400 \mathrm{ft}$ ) below the surface, will be minimal and restricted to groundwater conditions and possible interference with oil and gas production. Groundwater hydrology is described in a later section; therefore, the details of pre-Tertiary stratigraphy will not be considered here. 

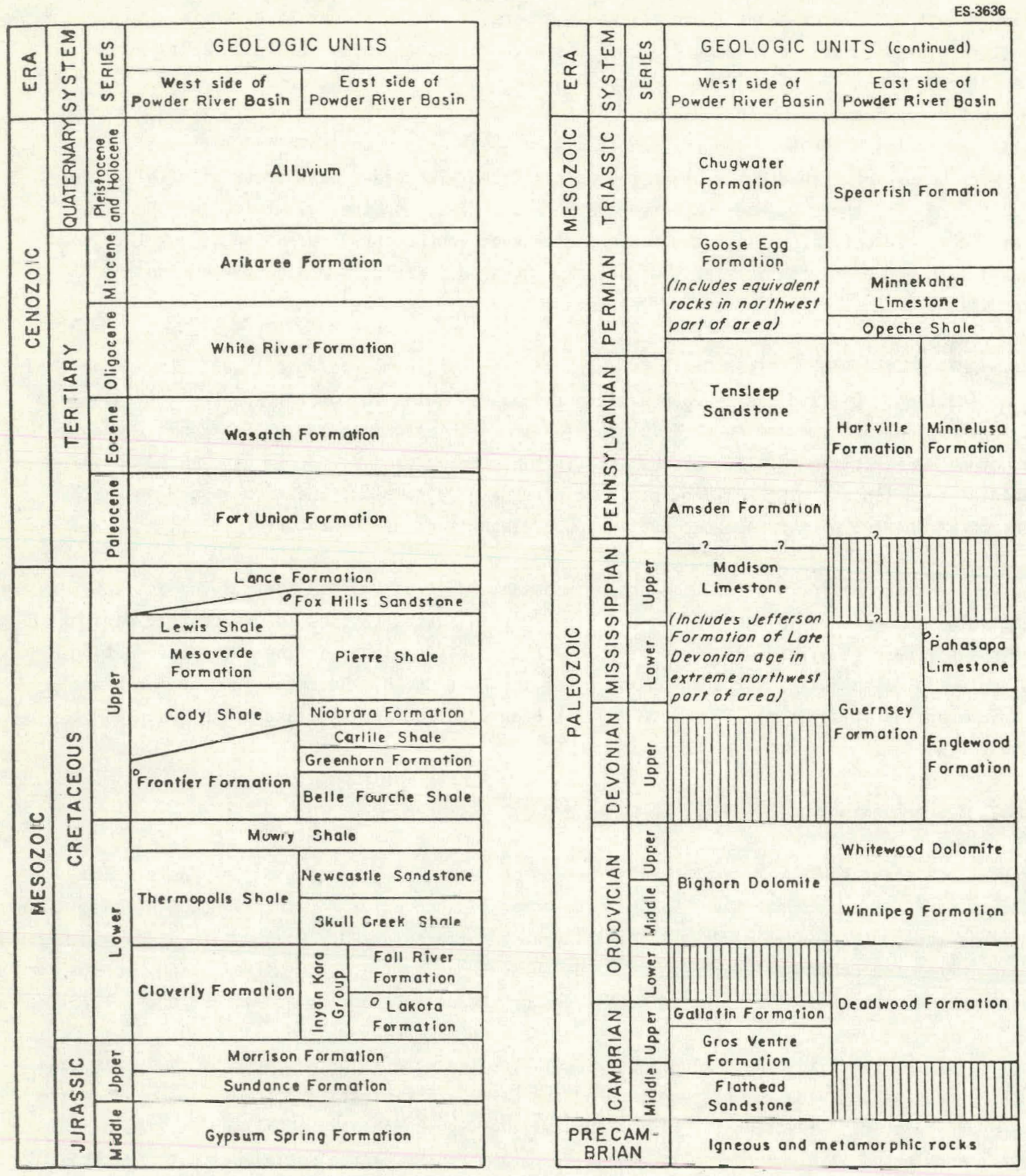

Fiy. 2.22. Stratigraphir relation of geologic units in the eastern Powder River coal hasin and adjacent areas. Source: W. G. Hodson, K. H. Pedrl, and S. A. Druse. 1973. Water resources of the l'owder River Masin and adjacent areas, northeastern Wyoming. Hydrologic Investigations Atlas HA-465. Washington, D.C.: U.S. Geological Survey.

Coal conversion facilities will be located near the mine mouth where the Fort Union-Wasatch contact is exposed. A more detailed descriplion of the Wasatch and Fort Union formations is therefore given.

The wasatch formation is composed of claystone, relatively continuous coal beds, thin-bedded siltstone, fine-grained sandstone, and lense-shaped bodies of medium- to coarse-grained 
Table 2.41. Rock sequence in the eastern Powder River Basin

\begin{tabular}{|c|c|c|c|c|c|}
\hline Era & System & Series & $\begin{array}{c}\text { Formation } \\
\text { or group }\end{array}$ & $\begin{array}{l}\text { Range of thickness } \\
\text { in meters (feet) }\end{array}$ & Resources \\
\hline \multirow[t]{9}{*}{ Cenozoic } & Tertiary & Oligocene & White River & $0-61(0-200)$ & Uranium, oil, gas, and groundwater \\
\hline & & Eocene & Wasatch & $0-307(0-1000)$ & Uranium, oil, gas, groundwater, and coal \\
\hline & + & Paleocene & Fort Union & $552-1043(1800-3400)$ & Uranium, oil, gas, groundwater, and coal \\
\hline & & & Lance & $307-828(1000-2700)$ & Uranium, oil, gas, groundwater, and coal \\
\hline & & & $\begin{array}{l}\text { Fox Hills } \\
\text { sandstone }\end{array}$ & & \\
\hline & & & $\begin{array}{r}\text { sandstone } \\
\text { Pierre shale }\end{array}$ & $\begin{array}{l}38-92(125-300) \\
520-797(1700-2600)\end{array}$ & $\begin{array}{l}\text { Oil, gas, and groundwater } \\
\text { None }\end{array}$ \\
\hline & & & Niobrara & $46-69(150-225)$ & None \\
\hline & Cretaceous & & Carlile shale & $123-200(400-650)$ & None \\
\hline & & Upper & Greenhorn and & $184-276(600-800)$ & None \\
\hline \multirow{8}{*}{ Mesoz̃oic } & & & $\begin{array}{l}\text { Belle Fourche } \\
\text { shale }\end{array}$ & & \\
\hline & & & Mowry shale & $55-70(180-230)$ & None \\
\hline & & & $\begin{array}{l}\text { Newcastle } \\
\text { sandstone }\end{array}$ & $28(90)$ & Oil and gas (major producer) and groundwater \\
\hline & & & $\begin{array}{l}\text { Skull Creek } \\
\text { shale }\end{array}$ & $34-67(110-220)$ & None \\
\hline & & t & $\begin{array}{l}\text { Fa I River- } \\
\text { Lakota }\end{array}$ & $34-92(110-300)$ & None \\
\hline & & & Mcrrison & $31-77(100-250)$ & None \\
\hline & & & Sundance & $54-152(175-495)$ & None \\
\hline & Jurassic & & Gy sum Springs & $0-38(0-125)$ & None \\
\hline \multirow{7}{*}{ Paleozois } & Permian-Triassic & & Spearfish & $92-153(300-500)$ & None \\
\hline & Permian & & $\begin{array}{l}\text { Minnekahta } \\
\text { limestone and } \\
\text { Opieche }\end{array}$ & $61(200)$ & None \\
\hline & Pennsylvanian & & Minelusa & $123-307(400-1000)$ & Oil and gas (major producer) and groundwater \\
\hline & Mississippian & & $\begin{array}{l}\text { Pahasapa } \\
\text { limestone } \\
\text { and Englewood } \\
\text { limestone }\end{array}$ & $61-245(200-800)$ & Groundwater; potential for oil and gas \\
\hline & Devonian & & & & \\
\hline & Ordovician & & $\begin{array}{c}\text { Whitewood } \\
\text { Dolomite }\end{array}$ & $15-92(50-300)$ & None \\
\hline & Ordovician/Cambrian & & $\begin{array}{l}\text { Winnepeg and } \\
\text { Deadwood }\end{array}$ & $15-184(50-600)$ & None \\
\hline \multirow[t]{2}{*}{1} & Cambrian & & & & None \\
\hline & Pre-Cambrian & & Basement & & None \\
\hline
\end{tabular}

Source: U.S. Dapartment of the Interior. 1974. Final environmental statement, proposed development of coal resources in the eastern Powder River Basin. Washington D.C. 
sandstone interbedded with bentonite seams. Sandstone units are not restricted to a few stratigraphic zones but are scattered erratically throughout the vertical section of the Wasatch. Sandstone comprises a maximum of 30\% of the section in the central and southern parts of the Powder River Basin. Along the southern margin of the basin, the Wasatch is conglomeratic, but sandstone becomes finer and less abundant toward the western and eastern margins. Thick coal beds are restricted to the periphery of the interbedded sandstone and claystone facies and to areas where claystone predominates (Sharp et al. 1964).

The Wasatch has a maximum thickness of $490 \mathrm{~m}$ (1600 ft) in the Pumpkin Buttes area east of the Paleozoic axis of the basin. The formation thins toward the margins of the basin, having been completely removed by erosion a few miles east of Gillette where its contact with the underlying Fort Union is exposed at the surface (Sharp et al. 1964).

The Fort Union is similar to the Wasatch except that it can be subdivided into three distinquishable members: (1) the Tunyue Rivel, (2) the Lebo, and (3) the Tullnok. In the Gillette coal field, the Fort Union is about $440 \mathrm{~m}$ (1430 ft) thick (taking the Wyodak cual bed as the top). The Fort Union thickens to about $1040 \mathrm{~m}(3400 \mathrm{ft})$ in the center of the basin (U.S. Department of the Interior 1974; Sharp et a1. 1964).

The Tongue River (upper) member is very sandy and contains most of the codl seams including the thick Wyodak-Anderson coal beds near their upper regions. Some geologists place the contact between the Fort Union and Wasatch at the top of the Wyodak, but most geologists recognize the boundary somewhat higher (92 to $153 \mathrm{~m} ; 300$ to $500 \mathrm{ft}$ ) in the stratigraphic section. The problems in recognizing the contact appear to be threefold: (1) the Wyodak coal bed is not recognizable everywhere in the subsurface, (2) the Fort Union and Wasatch are similar lithologically, and (3) paleontological evidence suggests that some strata above the Wyodak are clearly Paleocene in age, as are Fort Union strata located lower in the section. The upper Wasatch, on thc other hand, is clearly Eocene in age. Thus 1ilhologic boundaries are ill-defined, and they do not coincide with time-rock units. Ihe confusfun uver location of the contact emphasizes the 1ithologic similarities of the Fort Union and Wasatch (U.S. Depdr.Lment of the Interior 1974).

The Lebo (middle) member of the Fort Union is predominantly shale and contains a number of thin and discontinuous coal beds. These beds range from 0.3 to $3 \mathrm{~m}$ ( 1 to $10 \mathrm{ft}$ ) thick, the cumulative total ranging from 4.6 to $7.6 \mathrm{~m}(15$ to $2 \mathrm{~b} \mathrm{tt})$ interbedded with as much as $12 \mathrm{~m}(40 \mathrm{ft}) \mathrm{nf}$ shale. Coal as been mined from the Lebo for local domestic use, but there has been little interest in expanded development. The Tullock (lower) member is more sandy and contains a few coal seams, mainly near its top (U.S. Department of the Interior 19/4).

Coal bers of the Wasatch formation are similar to those found in the Lebo member of the rort Union. They are also mined for local domestic consumption. Une coal bed, Lhe Felix, is as much as $6 \mathrm{~m}(20 \mathrm{ft})$ thick 1ocally. It may eventually be feasible to mine the Felix for customers beyond the local domestic market (U.S. Department of the Interior 1974).

Thick, persistent strippable coal beds are found at or near the top of the Fort Union formation in the eastern part of the Powder River Basin (Fig. 2.20) from the Montana-Wyoming state line through Campbe11 County and into Converse County. These beds, referred to as Wyodak, WyodakAnderson D\&E, or Roland and Smith, lie immediately below the exposed Wasatch-Fort Union contact 
(Fig. 2.21). They are continuous in the subsurface for many miles to the west of their area of outcrop (U.S. Department of the Interior 1974).

Table 2.42 gives a description and average thickness of coal beds for mines and proposed mines (Fig. 2.21) in eastern Powder River Basin. Coal beds occur as one to three beds -3 to $30 \mathrm{~m}$ ( 10 to over $100 \mathrm{ft}$ ) thick - separated by shale units that are a few feet to a few tens of feet thick (U.S. Department of the Interior 1974).

Table 2.42. Average thickness of Wyodak-Anderson (Roland-Smith, or D-E) coal beds in mines and proposed mines in the eastern Powder River Basin

\begin{tabular}{|c|c|c|}
\hline $\begin{array}{l}\text { Name of mine or } \\
\text { proposed mine }\end{array}$ & Company & $\begin{array}{l}\text { Coal bed description and } \\
\text { average thickness }\end{array}$ \\
\hline North Rawhide & The Carter Oil Co. & $\begin{array}{l}\text { Upper coal (Roland) }-7.6 \mathrm{~m}(25 \mathrm{ft}) \text { thick; } \\
\text { shale parting }-0.6 \text { to } 3 \mathrm{~m}(2 \mathrm{to} 10 \mathrm{ft}) \text { thick; } \\
\text { lower coal (Smith) }-25 \mathrm{~m}(82 \mathrm{ft}) \text { thick }\end{array}$ \\
\hline Belle Ayr North & Amax Coal Co. & $\begin{array}{l}\text { Two beds separated by about } 1.8 \mathrm{~m} \text { ( } 6 \mathrm{ft} \text { ) of } \\
\text { shale: lower (Smith) }-15 \text { to } 37 \mathrm{~m} \text { ( } 50 \text { to } 120 \\
\mathrm{ft} \text { ) thick; upper (Roland) }-4.6 \text { to } 24 \mathrm{~m} \mathrm{(15} \\
\text { to } 80 \mathrm{ft} \text { ) thick [coal averages } 33.8 \mathrm{in} \text {. ( } 111 \\
\text { feet) thick] }\end{array}$ \\
\hline Wyodak & $\begin{array}{l}\text { Wyodak Resources } \\
\text { Development Corp. }\end{array}$ & $\begin{array}{l}\text { Upper coal (Wyodak) }-9.8 \mathrm{~m}(32 \mathrm{ft}) \text { thick; } \\
\text { shale parting }-<0.3 \text { to } 7.6 \mathrm{~m}(<1 \text { to } 25 \mathrm{ft}) \\
\text { thick; lower coal (Wyodak) }-16 \mathrm{~m}(52 \mathrm{ft}) \\
\text { thick }\end{array}$ \\
\hline Belle Ayr South & Amax Coal Co. & $\begin{array}{l}\text { One coalbed (Roland-Smith) - } 21.3 \mathrm{~m} \text { (70 } \\
\mathrm{ft} \text { ) thick }\end{array}$ \\
\hline Belle Fourche & Sun Oil Co. & $\begin{array}{l}\text { Three coalbeds, each about } 6.1 \mathrm{~m}(20 \mathrm{ft}) \\
\text { thick, separated by shale about } 0.6 \mathrm{~m}(2 \mathrm{ft}) \\
\text { thick; collectively called Roland }\end{array}$ \\
\hline Jacobs Ranch & Kerr-McGee Coal & $\begin{array}{l}\text { One to three beds totaling } 19.5 \mathrm{~m}(64 \mathrm{ft}) \\
\text { thick, separated by }<0.3 \text { to } 21.3 \mathrm{~m}(<1 \text { to } 70 \\
\mathrm{ft}) \text { of shale and sandstone - called Upper } \\
\text { Wyodak, Lower Wyodak 1, and Lower Wyodak } \\
2\end{array}$ \\
\hline Black Thunder & $\begin{array}{l}\text { Atlantic Kichfield } \\
\text { Co. }\end{array}$ & $\begin{array}{l}\text { One coalbed (Roland) }-18.3 \text { to } 22.3 \mathrm{~m} \text { ( } 60 \text { to } \\
73 \mathrm{ft} \text { ) thick }\end{array}$ \\
\hline Rochelle & Mochelle Cual Co. & One coalbed (Roland) $-16 \mathrm{~m}(53 \mathrm{ft})$ thick \\
\hline Antelope & Brannon Coal Co. & $\begin{array}{l}\text { Two coalbeds, each } 10.7 \mathrm{~m}(35 \mathrm{ft}) \text { thick, } \\
\text { separated by } 22 \mathrm{~m}(72 \mathrm{ft}) \text { of shale and sand- } \\
\text { stone }\end{array}$ \\
\hline
\end{tabular}

Source: U.S. Department of the Interior. 1974. Final environmental impact statement, proposed develupment u cual resuurces in the eastern Powder KIver Basin. Washington, D.C.: U.S. Department of Agriculture.

\subsubsection{Tectonic history}

Pre-late Cretaceous sedimentary rocks were deposited across a broad, shallow marine sea that. advanced and retreated many times across the northern Great Plains from the beginning of Paleozoic time. With the advent of Laramide mountain building during late Cretaceous time, however, a thick section of continental sediments accumulated in the Powder River Basin. These sediments were supplied by the rising mountains of the Bighorn Range, Laramie Range, and Black Hills uplift. Rapid accumulation of sediments continued into Eocene time. Fanglomerates and braided streams developed along the margins of the rising mountain chains. These gave way to broad floodplains with meandering streams in the south-central part of the basin. The central and northern parts of the basin were sites of swamp and deltaic environments respectively. Widespread coal deposits formed in the swamp environment (Keefer 1974). 
During the mountain-building episode, which lasted from late Cretaceous to Eocene time, structural deformation along the margins of the basin took place. Strata in the center of the basin were also mildly deformed at that time. Petroleum became trapped in large structures along the flanks and in smaller structures in the central part of the basin (Keefer 1974).

The Powder River Basin continued to fill with sediments throughout middle and late Tertiary time, but subsequent erosion removed the younger strata.

Tectonic activity was at a peak in late Cretaceous and early Tertiary times, producing the subsiding basin surrounded by rising mountain ranges. More recently the Powder River Basin together with its neighboring mountains was uplifted to its current level (Keefer 1974).

\section{Seismicity}

Earthquakes occur with the greatest freyuency and severity along the boundaries between rigid lithospheric plates that are in motion relative to each other. This motion produces many earthquakes.

The Powder River Basin is a long distance from the nearest plate boundary (the San Andreas fault), but plate interiors are by no means aseismic. "Hot spots" are localized areas where volcanism and its accompanying earthquakes occur within a plate interior. Yellowstone Park has been characterized as a hot spot. Earthquakes with epicenters in Yellowstone Park are likely to create the strongest motions to be experienced in the Power River Basin. Another zone of moderately strong earthquake activity is in northern Utah. Figure 2.23 shows the proximity of the Powder River Basin to these earthquake regions (Coffman and von Hake 1973).

A1though distant earthquakes may produce shock waves felt in the Powder River Basin, the region is considered to have low seismicity (Algermissen 1969). In the past 80 years, only four earthquakps having epicenters within $160 \mathrm{~km}$ (100 miles) of Gillette have becn fclt. The 1897 earthquake (intensity VII) near Casper, Wyoming, was strong enough to cause significanl damage. (See the modified Mercalli intensity scale, Table 2.4).

In the same region only five earthquakes (all of less than $V$ intensity) have been recorded since 1965 (Coffman and von Hake 1973). This data is too Iimited to establish reliable recurrence intervals, but it suggests that an intensity VII earthquake is a rare event. Because intensity VII earthquakes occur perhaps two orders of magnitude less frequently than intensity $V$ earthquakes, their recurrence interval may be 200 years or more.

\subsubsection{Local geology.}

Figure 2.24 is a coal map of the region surrounding Gillette, Wyoming, which shows the approximate locations of the Wyodak-Anderson coal bed lying within $60 \mathrm{~m}(200 \mathrm{ft})$ of the surface.

Labeled contours indicate the cumulative thickness of all tertiary coal seams (U.S. Department of the Interior 1974).

The Fort Union-Wasatch contact is considered by most geologists to lie slightly above the top of the Wyodak. Therefore, the Wasatch formation is exposed immediately west of the Wyodak, and 


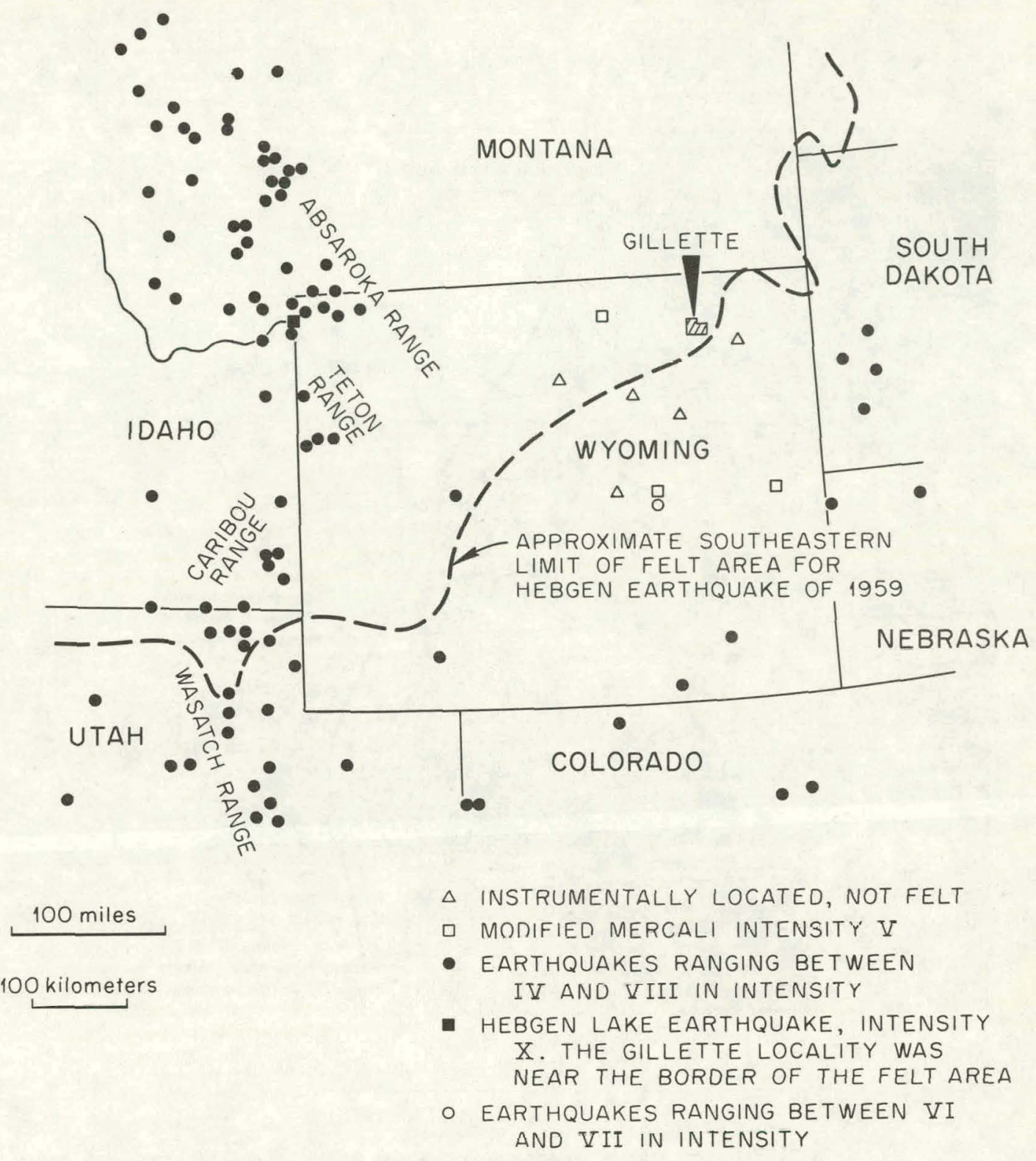

Fig. 2.23. Seismicity map of Wyoming and adjacent regions. Source: J. L. Coffman, and C. A. von Hake, eds. 1973. Earthquake history of the United States. Washington, D.C.: U.S. Department of Commerce, National Oceanic and Atmospheric Administration.

the Fort Union formation is exposed on the east. In the Gillette coal field, the Fort Union is $440 \mathrm{~m}$ (1430 ft) thick. Therefore, slrip mining and coal conversion facilities in the Gillette region will not affect strata beneath the Fort Union.

Deeper strata are, however, sources of groundwater supply and/or potential reinjection sites for waste water. They are also potential producers of oil and gas, as is the Fort Union. Table 2.41 lists the thicknesses and depths of the major arjuifers in the castern Powder River 


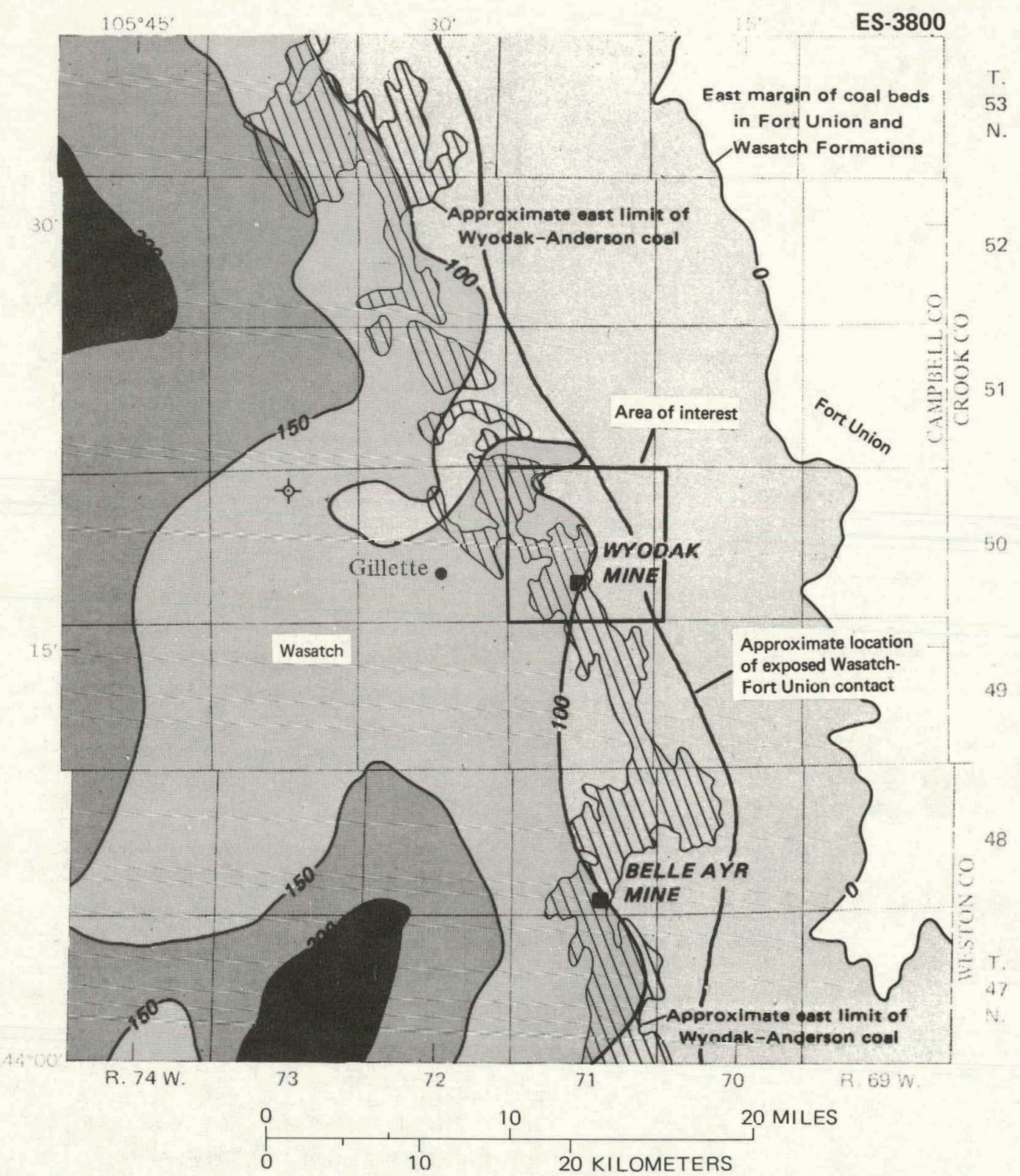

「ig. 2.21. Maj uf Gillette study area showing areas where the Wyouldk-Auderson coal bed lies less than $60 \mathrm{~m}(200 \mathrm{ft}$ ) below the surtace. (Labeled lines indlcale liital thickness, ill feet, of all coal hers in the Fort Union and Wasatch formations.) Source: Modified after W. R. Keefer and R. F. Hadley. 1376. Land cond naturuz resurise informatim and some potential environmental effects of surface mining of coal in the Gillette area, Wyoming. Geological survey clrculai no. 713. Alexandria. Va.: U.S. Geological Survey.

Basin (U.S. Department of the Interior 1974). Important pre-Tertiary aquifers are (from top to bottom) the Lance, Fox Hills, Newcastle, Minnelusa, and Pahasapa (Madison equivalent). Table 2.43 1ists the depths to the tups of thesc important aquifers in the Gillette area (U.S. Department of the Interior 1974; Keefer and Schmidt 1973; Sevenson et a1. 1976). Artesian conditions generally prevail. For example, in the Gillette area the piezometric surface of groundwater from the Pahasapa 1 ies only $240 \mathrm{~m}(800 \mathrm{ft})$ beneath the surface (Sevenson et al. 1976). 
Table 2.43. Depths to the tops of important aquifers in the Gillette area

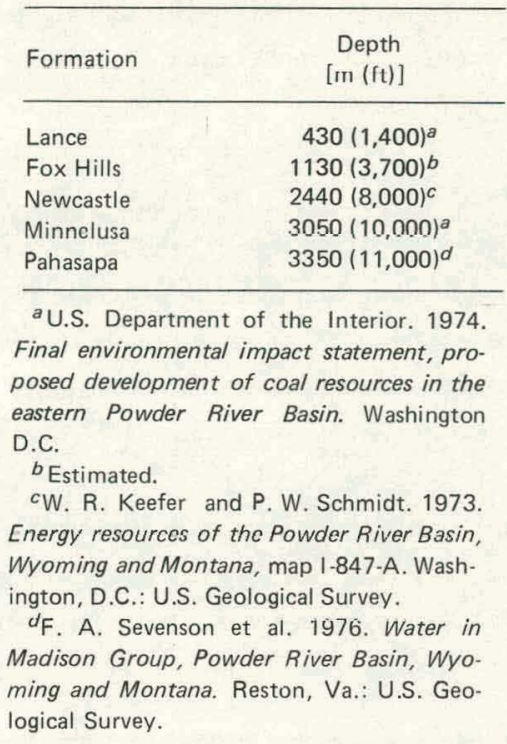

In contrast, the physical top of the Pahasapa lies at a depth of $3850 \mathrm{~m}(11,000 \mathrm{ft}$ ) (Sevenson et a1. 1976). The Madison equivalent of the Pahasapa is a primary source of water for secondary recovery in oil fields in the southern and western parts of the Powder River Basin (Sevenson et a1. 1976). Groundwater from the Pahasapa in the Gillette area is potentially usable for coal conversion and slurry pipelines as well as for secondary recovery operations.

The soils of the Gillette region, though not mapped, are (1) residual soils that are genetically related to the strata nn whirh they form or (2) thin beds of alluvium deposited in washes and creeks. Because of the arid climate and sparse vegetation, residual soils erode rapidiy so that there is little accumulation along interstream divides. Alluvium comprises fine-grained sand, silt, and clay from siltstones and shales that outcrop locally. Hills in the region are capped by "clinker" beds (coal beds that were burned out during Tertiary time). These clinker beds are several meters thick. Mineral grains that were fused together by heat produce clinker that is very resistant to erosion. The clinker beds form resistant blankets that protect underlying strata from erosion. Once the clinker beds are eroded out, however, underlying shales and siltstones (poorly consolidated) erode rapidly in the arid climate (Keefer and Hadley 1976).

\subsubsection{Hydrology}

\subsubsection{Surface water}

Drainage area

The regional surface waters surrounding the coal conversion site are sparse. The area straddles two drainage basins, the Belle Fourche Basin and the Powder River Basin, and is located at the headwaters of the basins.

Donkey Creek is an ephemeral stream with some perennial characteristics in the Belle Fourche Basin. The drainage area of the creek at the gaging station is $0.73 \mathrm{~km}^{2}$ ( $0.28 \mathrm{sq}$ miles). 
All of the remaining surface-water streams within the site are ephemeral. Creek flows normally occur, as a result of snow melt from March through Junc; the creeks are dry for the remainder of the year except for occasional convection thunderstorms, which produce from 2.5 to $15 \mathrm{~cm}$ ( 1 to 6 in.) of rainfall per hour.

Average runoff in the site area is $0.64 \mathrm{~cm}(0.25 \mathrm{in.})$ per year in the low-lying regions and reaches $30 \mathrm{~cm}$ (12 in.) on hilltops. Infiltration in the site area has been determined to be 1 to $10 \mathrm{~cm}$ ( 0.4 to $4.0 \mathrm{in.})$ per hour. Surface runoff is generally contained in impoundments that are numerous in the site area. These impoundments are impervious as a result of siltation, and the pools often become dry due to evaporation. No permanent lakes or reservoirs are in the site region.

Because of the shortage of available surface water, several water projects have been proposed. An extensive study of such projects for the northern fireat Plains has becn completed (Nortlieil Great Plains Resources Program 1974b). A summary of the water project proposals is given in Table 2.44.

Table 2.44. A summary of water project proposals for the northern Great Plains

\begin{tabular}{|c|c|c|c|c|}
\hline $\begin{array}{l}\text { Source of supply } \\
\text { and location }\end{array}$ & $\begin{array}{c}\text { Supply of } \\
\text { water } \\
{\left[\mathrm{m}^{3} \text { (acre-ft/year) }\right]}\end{array}$ & $\begin{array}{l}\text { Time for } \\
\text { construction } \\
\text { (years) }\end{array}$ & $\begin{array}{c}\text { Cost per } \\
\text { acre-ft } \\
\text { (1973 dollars) }\end{array}$ & $\begin{array}{l}\text { Length of } \\
\text { aqueduct } \\
{[\mathrm{km} \text { (miles) }]}\end{array}$ \\
\hline $\begin{array}{l}\text { Bighorn Reservoir } \\
\text { (Hardin, Wyoming) }\end{array}$ & $3.69 \times 10^{7}(30,000)$ & 6 & 310 & $282(175)$ \\
\hline $\begin{array}{l}\text { Moorhead Reservoir } \\
\text { (Moorhead, Montana) }\end{array}$ & $3.69 \times 10^{7}(30,000)$ & 4 & 134 & $336(209)$ \\
\hline $\begin{array}{l}\text { Bighorn Reservoir } \\
\text { (Hardin, Wyoming) }\end{array}$ & $3.69 \times 10^{7}(30,000)$ & 6 & 268 & $658(409)$ \\
\hline $\begin{array}{l}\text { Yellninstone River } \\
\text { (Armells Creek, } \\
\text { Montana) }\end{array}$ & $3.69 \times 10^{7}(30,000)$ & 6 & 328 & 475 (2.95) \\
\hline $\begin{array}{l}\text { Yellninistone River } \\
\text { (Milés City, Muntana) }\end{array}$ & $3.69 \times 10^{7}(30.000)$ & 6 & 256 & $320(199)$ \\
\hline $\begin{array}{l}\text { Bighorn Lake } \\
\text { (Bighorn, Wyoming) }\end{array}$ & $3.69 \times 10^{7}(30,000)$ & 6 & 270 & $423(263)$ \\
\hline $\begin{array}{l}\text { Lake Oahe } \\
\text { (Lake Oahe, North } \\
\text { Dakota) }\end{array}$ & $3.69 \times 10^{7}(30,000)$ & 6 & 325 & $430(267)$ \\
\hline $\begin{array}{l}\text { North Platte } \\
\text { (Douglas, Wyoming) }\end{array}$ & $3.69 \times 1 n^{7}(3 \cap, n n n)$ & 1 & 207 & $114(71)$ \\
\hline
\end{tabular}

Source: Northern Great Plains Resnurres Prngram 1971. Surfaue rosouroos wvik yıun - ieyiunal profile. Denver, Colo.

\section{Water availahility}

The existing surface water in the proposed site is seasonal. Donkey Creek has a maximum annual discharge of less than $0.028 \mathrm{~m}^{3} / \mathrm{sec}$ ( $1 \mathrm{cfs}$ ). The creek has apparent underflow, as do the other ephemeral streams of the site. A convective thunderstorm can cause a runoff event that results in flows greater than the accumulated flow for several years.

The Belle Fourche River has been cited as having no water available for use (Wyoming Water Planning Program 1972). Diversion projects from other drainage basins are not under construction; such projects would require large lead times for completion (Table 2.44). Without construction 
of a water-diversion project, there is no reliable source of surface water for coal conversion use.

\subsubsection{Groundwater hydrology}

The shallow aquifers in the Gillette area lie at depths of less than $150 \mathrm{~m}$ (500 ft) and include both alluvial and bedrock aquifers. They are primarily used for domestic and livestock purposes, whereas water for industrial and municipal use is derived from deeper aquifers. Groundwater occurs under water table conditions in the alluvial aquifers but is generally under confined or artesian conditions in most bedrock aquifers (King 1974). Artesian conditions exist in both the Fox Hills and Lance formations. Most of the Gillette area is a recharge area (Fig. 2.25). Groundwater levels are highest along the high, north-trending drainage divide that separates runoff westward to the Powder River from runoff eastward to the Little Powder and Belle Fourche rivers. Groundwater movement from this high divide is in the direction of the slope of the land surfaces. Groundwater discharge occurs in the areas shown in Fig. 2.25. The principal aquifers are discussed below.

The alluvium aquifers are less than $15 \mathrm{~m}(50 \mathrm{ft})$ thick. Ephemeral flows in Little Rawhide Creek occasionally recharge these shallow aquifers, which are primarily for domestic and livestock uses. Groundwater occurs under water table conditions; depth to water ranges from about 0.9 to $6 \mathrm{~m}$ ( 3 to $20 \mathrm{ft}$ ) below land surface. Water levels fluctuate seasonally with precipitation. Yields of water to individual wells range from a few cubic meters per day to several hundred cubic meters per day.

The Wasatch formation ranges in thickness from a few hundred feet to none at its erosional edge. Wasatch is the principal aquifer in the area; groundwater is mostly used for livestock. Water levels in the wells range from 15 to $45 \mathrm{~m}$ ( 50 to $150 \mathrm{ft}$ ) below the land surface. Yields of at least $0.03 \mathrm{~m}^{3} / \mathrm{sec}(500 \mathrm{gpm}$ ) are possible from properly constructed and adequately developed wells where a sufficient thickness of the aquifer is open to the well. Transmissivities are estimated to be about $74.53 \mathrm{~m}^{2} /$ day $\left(6000 \mathrm{gpd} / \mathrm{ft}\right.$ ) and vary from 12.42 to $124.22 \mathrm{~m}^{2} /$ day $(1000$ to $10,000 \mathrm{gpd} / \mathrm{ft}$ ). Storage coefficients are estimated to range between $10^{-1}$ to $10^{-4}$. Recharge to the Wasatch is from local precipitation.

The Fort Inion formation is about $610 \mathrm{~m}$ (2000 ft) thick, and the potential recharge areas are the high lands in eastern Campbell County. Recharge also occurs from Little Rawhide Creek alluvium and from precipitation and consequent downward percolation of water from the overlying Wasatch. Yields of at least $0.03 \mathrm{~m}^{3} / \mathrm{sec}(500 \mathrm{gpm})$ are possible from properly constructed and adequately developed wells in the Fort Union.

The Lance formation is about $457 \mathrm{~m}$ (1500 ft) thick, and the Fox Hills Sandstone formation is about $61 \mathrm{~m}(200 \mathrm{ft})$ thick. The depth to water in the Lance ranges from a few meters to nearly $152 \mathrm{~m}$ (500 ft.) helow land surface. Water table levels indicale a northeasterly hydraulic gradient of about $2.9 \mathrm{~m} / \mathrm{km}(15 \mathrm{ft} / \mathrm{mile})$. Transmissivity is estimated to be about $1.24 \mathrm{~m}^{2} /$ day $(100 \mathrm{gpd} / \mathrm{ft})$. Yields of as much as $0.63 \mathrm{~m}^{3} / \mathrm{sec}(1000 \mathrm{gpm})$ are believed possible. Recharge is from downward movement of water from the overlying rocks. Depth to water in the Fox Hills may vary from a few to about $61 \mathrm{~m}(200 \mathrm{ft})$. Artesian conditions exist in both the Lance formation and Fox Hills. 


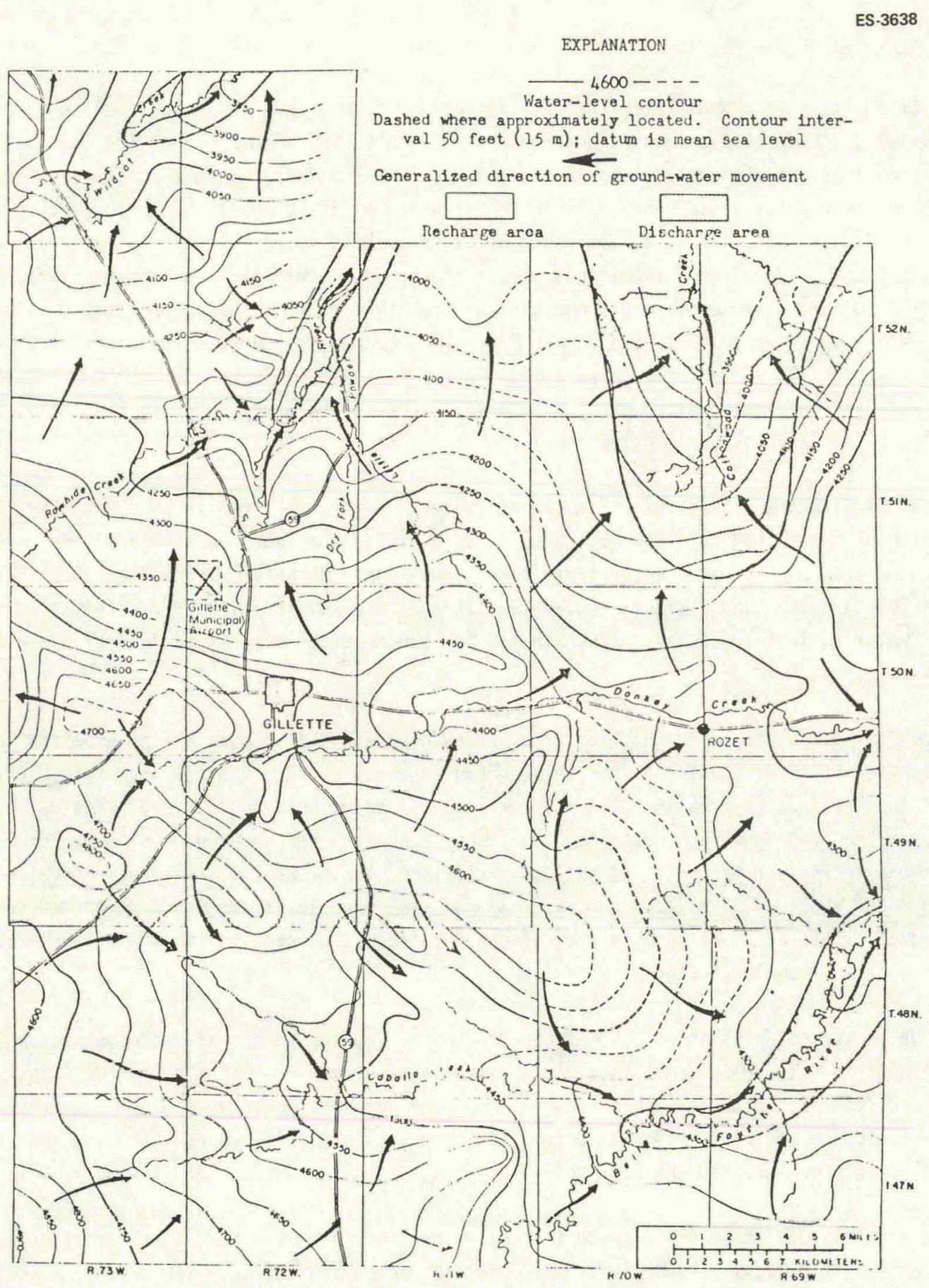

Fig. 2.25. Water levels and direction of groundwater. Source: U.S. Geological Survey. 1974. Shallow groundwater in selected areas in the Fort Union coal region. Open file report 74-48. Helena, Mont. 
Deep aquifers belonging to the Inyan Kara group yield about 0.003 to $0.001 \mathrm{~m}^{3} / \mathrm{sec}$ (50 to $20 \mathrm{gpm}$ ), but yields of $0.006 \mathrm{~m}^{3} / \mathrm{sec}(100 \mathrm{gpm})$ or more are possible (U.S. Department of the Interior 1974). The thickness varies from 67 to $137 \mathrm{~m}(220$ to $450 \mathrm{ft}$ ). The Sundance formation can yield as much as $0.006 \mathrm{~m}^{3} / \mathrm{sec}(100 \mathrm{gpm})$ in some places and is about $122 \mathrm{~m}$ (400 ft) thick. The Mennelusa formation is about 213 to $274 \mathrm{~m}$ (700 to $900 \mathrm{ft}$ ) thick. Yields ranging from $0.0013 \mathrm{~m}^{3} /$ sec. to several cubic meters per second are possible where fracturing has increased the permeability. The Madison Limestone or its equivalent, Pahasapa Limestone, is about $183 \mathrm{~m}$ $(600 \mathrm{ft})$ thick; depth to the formation is about $3048 \mathrm{~m}(10,000 \mathrm{ft})$. An average yield of $0.2394 \mathrm{~m}^{3} / \mathrm{sec}\left(3800 \mathrm{gpm}\right.$ ) and a range of 0.03 to $0.57 \mathrm{~m}^{3} / \mathrm{sec}$ (430 to $9000 \mathrm{gpm}$ ) have been obtained. Recharge to the Madison occurs on the outcrop areas from precipitation and runoff. The potentiometric surface of about $1220 \mathrm{~m}(4000 \mathrm{ft}) \mathrm{MSL}$ in the Madison area indicates that the Black Hills area provides a considerable source of recharge. Much of the discharge, other than from water wells, is believed to be into overlying rocks by upward percolation.

\subsubsection{Water quality}

\subsubsection{Surface water}

Water quality investigations of Donkey Creek were made by the U.S. Geological Survey (USGS 1974, 1975). Samples were collected at four different sites. Gillette Fishing Lake is $1.6 \mathrm{~km}$ (1 mile) south of Gillette and $3.2 \mathrm{~km}$ (2 miles) upstream from the coal conversion site. The second set of samples was collected in the site area upstream from the existing Wyodak Mine. The third set of data was collected downstream from the Wyodak Mine and within the site area. The last data sample was obtained at Rozet, Wyoming. The data collected are shown in Table 2.45. Sulfate concentrations and dissolved solids are high; however, the water quality of Donkey Creek is good, and no problems are present upstream or downstream from the existing strip mine.

\subsubsection{Groundwater quality}

Data are limited on the quality of groundwater in the Wasatch and Fort Union aquifers in the Gillette area. Chemical analysis of groundwater from the Wasatch formation (Amax 1974, 1975) indicates that calcium, magnesium, sodium, bicarbonate, sulfate, fluoride, and dissolved solids exceed the Wyoming Water Resources Research Institute (WRRI, no date) multiple-use standards. The resulls of analyses are summarized as follows (USGS 1975, Hodson 19/1):

1. slightly basic (pH less than 7.8);

2. well buffered; high in dissolved solids with sodium, magnesium, bicarbonate, calcium, and sulfates;

3. low iron and sulfide and high nitrate;

4. high reduced carbons and nitrogen;

5. generally low trace-metal concentrations;

6. acceptable boron levels;

7. excessive hardness; and

8. no excessive COD, suspended solids, or oil and grease concentrations. 
Table 2.45. Water quality of Donkey Creek

\begin{tabular}{|c|c|c|c|c|}
\hline \multirow[b]{2}{*}{ Parameter } & \multicolumn{4}{|c|}{ Sample sites } \\
\hline & $\begin{array}{l}\text { Gillette } \\
\text { Fishing } \\
\text { Lake }\end{array}$ & $\begin{array}{c}\text { Above } \\
\text { Wyodak } \\
\text { Mine }\end{array}$ & $\begin{array}{c}\text { Below } \\
\text { Wyodak } \\
\text { Mine }\end{array}$ & $\begin{array}{c}\text { Rozet, } \\
\text { Wyoming }\end{array}$ \\
\hline Number of samples & 2 & 2 & 1 & 2 \\
\hline Temperature, ${ }^{\circ} \mathrm{C}$ & 18.1 & 17.5 & 17 & 18.7 \\
\hline Specific conductance, $\mu \mathrm{mho}$ & 3410 & 3000 & 3000 & 1,920 \\
\hline $\mathrm{pH}$ & 8.7 & 8.0 & 8.1 & 8.8 \\
\hline Turbidity, JTUa & 63 & 10 & 2 & 20 \\
\hline Dissolved oxygen, $\mathrm{mg} / \mathrm{liter}$ & 8.3 & 9.6 & 9.2 & 7.6 \\
\hline Dissolved calcium, $\mathrm{mg} /$ liter & 490 & 230 & 210 & 155 \\
\hline Dissolved magnesium, mg/liter & 390 & 180 & 140 & 120 \\
\hline Dissolved sodium, $\mathrm{mg} / \mathrm{liter}$ & 185 & 300 & 400 & 215 \\
\hline Dissolved potassium, $\mathrm{mg} / \mathrm{liter}$ & 26 & 19 & 24 & 18 \\
\hline Bicarbonate, mg/liter & .3 .35 & 180 & 412 & 390 \\
\hline Carbonate, mg/liter & 1 & 0 & 0 & 0 \\
\hline Dissolved sulfate, $\mathrm{mg} / \mathrm{liter}$ & 2800 & 1500 & 1300 & 855 \\
\hline Dissolved chloride, $\mathrm{mg} /$ /iter & 9.7 & 170 & 240 & 145 \\
\hline nişolved fluoride, mýliteı & U.3b & 0.8 & 1.1 & 0.7 \\
\hline Nitrate-nitrate, mg/liter & 0.01 & 0.01 & 0.01 & 0.015 \\
\hline Ammonia-nitrogen, $\mathrm{mg} /$ liter & 0.01 & 0.02 & 0 & 0.11 \\
\hline Kjeldahl nitrogen, mg/liter & 3.7 & 1.5 & 1.5 & 3.2 \\
\hline Nitrogen, mg/liter & 3.7 & 1.5 & 1.5 & 3.2 \\
\hline Phosphorus, mg/liter & 0.27 & 3.0 & 3.9 & 1.5 \\
\hline Aluminum, $\mu \mathrm{g} /$ liter & 1900 & 130 & 1600 & 665 \\
\hline Dissolved aluminum, $\mu \mathrm{g} /$ liter & 0 & 0 & 0 & 0 \\
\hline Iron, $\mu \mathrm{g} /$ liter & 3750 & 510 & 2100 & 975 \\
\hline Dissolved iron, $\mu \mathrm{g} / \mathrm{liter}$ & 30 & 80 & 20 & 5ก \\
\hline Manganese, $\mu \mathrm{y} /$ liter & 1445 & 200 & 110 & 660 \\
\hline Arsenic, $\mu \mathrm{g} / \mathrm{liter}$ & 310 & 4 & 6 & 5 \\
\hline Dissolved arsenic, $\mu \mathrm{g} /$ liter & 1 & & 2 & 6 \\
\hline Beryllium, $\mu \mathrm{g} /$ liter & $<10$ & 0 & $<10$ & $<10$ \\
\hline Dissolved beryllium, $\mu \mathrm{g} /$ liter & $<10$ & & $<10$ & $<10$ \\
\hline Dissolved boron, $\mu \mathrm{g} / \mathrm{liter}$ & 240 & 520 & 680 & 375 \\
\hline Cadmium, $\mu \mathrm{g} /$ liter & 10 & $<10$ & $<10$ & $\ll 10$ \\
\hline Dissolved cadmıum, $\mu \mathrm{g} /$ liter & 0 & & 0 & 0 \\
\hline Chromium, $\mu \mathrm{g} /$ liter & 10 & 0 & 10 & 5 \\
\hline Dissolved chromium, $\mu \mathrm{q} /$ liter & 20 & & 10 & 20 \\
\hline C.npper, $\mu \mathrm{g} /$ liter & 30 & 20 & 10 & 20 \\
\hline Dissolved copper, $\mu \mathrm{g} /$ liter & 1 & & 2 & 5 \\
\hline Lead, $\mu \mathrm{g} /$ liter & 150 & 100 & 100 & 100 \\
\hline Dissolved lead, $\mu \mathrm{g} /$ liter & 0 & & 0 & 1 \\
\hline Lithium, $\mu \mathrm{g} /$ liter & 330 & 130 & 70 & 60 \\
\hline Dissolved lithium, $\mu \mathrm{g} /$ liter & 440 & & 90 & 130 \\
\hline Mercury, $\mu \mathrm{g} / \mathrm{liter}$ & 0.15 & 0 & 0 & 0.1 \\
\hline Dissolved mercurv. $\mu \mathrm{g} /$ liter & 0 & & u & 0 \\
\hline Molybdenum, $\mu \mathrm{g} /$ /iter & 8 & 3 & 4 & 2 \\
\hline Nickel. $\mu \mathrm{g} /$ liter & 50 & su & 50 & $<50$ \\
\hline Selenium, $\mu \mathrm{g} /$ liter & 0 & 1 & 1 & 1 \\
\hline Zinc, $\mu \mathrm{g} /$ liter & 50 & 20 & 80 & 275 \\
\hline Dissolved silica, $\mu \mathrm{g} /$ liter & 4.2 & 0.4 & 14 & ? \\
\hline Dissolved solids, $\mathrm{mg} / \mathrm{liter}$ & 4120 & 2490 & 2530 & 1,700 \\
\hline Hardness, ma/liter & 2850 & 1300 & 1100 & 890 \\
\hline Noncarbonate hardness, $\mathrm{mg} /$ /iter & 2550 & 1200 & 760 & 560 \\
\hline Phytoplanklum, number $/ \mathrm{ml}$ & 9350 & $55 \cup 0$ & ? & 12,000 \\
\hline
\end{tabular}

a JTU, Jackson turbidity units.

Sources: U.S. Geological Survey. 1974. Shallow groundwater in selected areas in the Fort Union coal region. Open file report 74-48. Helena, Mont.: U.S. Geological Survey. 1975. Draft envirnnmental statement proposed mining and reclamation plan, Eagle Butte Mine, Amax Coal Company Coal leasc W-0310773. Campbell County, Wyo.

Water from Fort Union is usable as a domestic supply, although the dissolved solids content exceed's the recommended maximum. The water is unsuitable for irrigation use because of high sodium and bicarbonate contents. Water from the Wasatch is usable for domestic purposes, but it generally does not meet suggested domestic water standards for iron, manganese, sulfate, and 
dissolved-solids contents. Hydrogen sulfide occurs in the water from both of the formations (USGS 1974). Water from both the Wasatch and Fort Union is good to fair for livestock consumption. Water from the Fox Hills Sandstone generally contains 500 to $1000 \mathrm{mg}$ of dissolved solids per liter but may contain as much as $3000 \mathrm{mg} / 1$ iter. Dominant ions are sodium and bicarbonate. Water from the Lance formation contains 500 to $2000 \mathrm{mg} / 1$ iter of dissolved solids with no apparent dominant water type. In Fort Union and Wasatch formations, the dissolved solids range from 300 to $2000 \mathrm{mg} / 1 \mathrm{iter}$. The best quality of water with less than $500 \mathrm{mg} / 1 \mathrm{iter}$ of dissolved solids is obtained from clinker beds. Water from coal beds contains 1000 to $2000 \mathrm{mg} / 1$ iter of dissolved solids. Although there is no dominant water type in the Fort Union and Wasatch formations, these aquifers generally yield a calcium and/or magnesium sulfate water. As depth increases, calcium and magnesium give way to sodium ions, and sulfate is replaced by bicarbonate ions. Water from the alluvium is characteristically hard; dissolved solids concentration ranges from about 500 to $2000 \mathrm{mg} / 1 \mathrm{iter}$ but generally ranges from 1000 to 1500 $\mathrm{mg} / 1$ iter. Dominant ions are calcium, magnesium, and sulfate. Dissolved solids in water from the Pahasapa range from about 250 to about $3000 \mathrm{mg} / 1$ iter. In general, water from the Madison is of good quality for domestic, irrigation, and livestock use. Water of springs issuing from clinker beds generally contains less than $350 \mathrm{mg} / 1 \mathrm{iter}$ and seldom exceeds $500 \mathrm{mg} / 1$ iter of dissolved solids. The chemical analyses of groundwater from several aquifers are summarized in Table 2.46 (U.S. Department of the Interior 1974).

Table 2.46. Chemical analyses of groundwater in Campbell County, Wyoming

\begin{tabular}{|c|c|c|c|c|}
\hline & Alluvium & Wasatch & Fort Union & Madison \\
\hline Well depth, $m(\mathrm{ft})$ & $12(40)$ & 27 to 116 (90 to 380$)$ & 53 to $177(173$ to 580$)$ & 2074 to 2031 (6803 to 6664 ) \\
\hline Temperature, ${ }^{\circ} \mathrm{C}\left({ }^{\circ} \mathrm{F}\right)$ & & 11 to 12 (52 to 54 ) & 12 to 14 (54 to 57$)$ & \\
\hline \multicolumn{5}{|l|}{ Minerals, mg/liter } \\
\hline Silica & 13 & 1.3 to 19 & 6.9 to 9.6 & \\
\hline Calcium & 84 & 25 to 594 & 2.3 to 379 & 143 to 270 \\
\hline Magnesium & 23 & 14 to 218 & 0.7 to 319 & 16 to 66 \\
\hline Sodium & 58 & 9.1 to 306 & 254 to 890 & 406 to 826 \\
\hline Potassium & 4.7 & 4.9 to 14 & 1.1 to 21 & \\
\hline Bicarbonate & 394 & 46 to 1120 & 468 to 1350 & 245 to 410 \\
\hline Carbonate & 14 & 0 & 0 to 22 & 24 \\
\hline Sulfate & 74 & 2.4 to 2480 & 206 to 3560 & 858 to 2359 \\
\hline Chloride & 1.4 & 1.2 to 19 & 1.5 to 10.0 & 32 to 54 \\
\hline Fluoride & 0.4 & 0.3 to 1.9 & 0.2 to 2.8 & \\
\hline Nitrate & 0.1 & 0.0 to 4.6 & 0.0 to 9.0 & \\
\hline Dissolved solids, $\mathrm{mg} / \mathrm{liter}$ & 467 & 430 to 3660 & 661 to 5620 & 1679 to 3698 \\
\hline Hardness, mg/liter & 303 & 120 to 2380 & 9 to 2420 & \\
\hline Boron, $\mu \mathrm{g} / \mathrm{liter}$ & 80 & 0.0 to 360 & 30 to 330 & \\
\hline Specific conductance, $\mu \mathrm{mho}$ & 753 & 667 to 3600 & 1060 to 5890 & \\
\hline $\mathrm{pH}$ & 8.5 & 7.0 to 8.4 & 7.5 to 8.8 & \\
\hline
\end{tabular}

Source: U.S. Department of the Interior, Bureau of Land Management. 1974. Final environmental impact statement; Eastern Powder River Coal Basin of Wyoming. Washington, D.C.

\subsubsection{Land use}

The surrogate site borders the city of Gillette, which is near the center of Campbell County in the eastern Powder River Basin of Wyoming.

The terrain of the Gillette area is level to moderately rolling. Prominent topography features are narrow isolated ridges, hills, and buttes, the tops of which are capped by erosion-resistant red and purple clinker beds. (Clinker is the noncombustible material within coal plus the hard-baked and fused materials from rocks that were directly above a burning coal bed.) Extensive burning of coal, chiefly by natural causes, was a common occurrence in the Gillette area during prehistoric time (Keefer and Hadley 1976). 
A landform map of the Gillette area is shown in Fig. 2.26. The map shows the distribution of different areas of terrain, indicates general slope conditions, and provides a measure of the erosion that has taken place. Landscape characteristics are important because they indicate the relative ease or difficulty involved in restoring mined lands to their appropriate original contour, that is, the premining surface configuration of the land, though not necessarily the premining elevation. For example, highly dissected badland terrain could not be restored after mining to anything approaching its original slope, yet gently rolling moderately dissected areas would be less difficult to duplicate. Surface-mine spots, other than flat or gently rolling, would be subject to erosion unless carefully terraced and revegetated. Pending Federal legislation may prohibit or curtail mining on alluvial valley floors. These areas are generally underlain by unconsolidated stream-laid deposits for which water is available to support agriculture.

Despite the vast mining possibilities in Campbell County, the principal land uses are for rangeland and cropland. Figure 2.27 is a land-use map of the Gillette area. Planimeter measurements and visual estimates of this map yield the following percentages.

\begin{tabular}{lc}
\multicolumn{1}{c}{ Land use } & Percentage \\
\cline { 2 - 2 } Cropland, hayland, and pasture & 20.9 \\
Residential, commercial, and services & 1.9 \\
Recreation & 0.2 \\
Strip coal mine & 0.2 \\
Rangeland (by difference) & $\underline{76.8}$ \\
Total & 100.0
\end{tabular}

Ihe Gillette area lies near the eastern border of a prnpnsed Middle Fork Roscrvoir, for which a right-of-way application has been filed by the Powder River Reservoir Corporation of Kaycce, Wyoming. This impoundment wi11, inundate 470 ha (116ก arres) at the normal high watel 1 iliê ur private and national resource land. The national resource 1 and 1 ies west of Kaycee, Wyoming, and is under Bureau of Land Management jurisdiction. The principal purpose of the reservoir would be to provide water to the Middle Fork Irrigation District. Irrigation is the current largest use of water in the Powder River Basin. As of November 30, 1971, irrigation water rights in good standing covered a total of 67.3 .31 ha (16h, 3n8 acres) (U.S. Departmcnt of the InLeriur 1976a).

Existing and proposed coal mines in preparation in Campbell County involving Federal leases total 25,313 ha $(62,523$ acres) (Table 2,47 and Fig. ?.28). Ahnut one-third of this mining area lies in the Gillette area (USGS 1976a). About 60\% of the 1 and in Campbell County is under the jurisdiction of the U.S. Bureau of Land Management (Wyoming Land Use Commission 1977).

\subsubsection{Meteorology and air quality}

Calmple11 County has an annual average precipitation of $41 \mathrm{~cm}$ (16 in.), about one-half of which comes as snow during the winter months. The mean temperatures for January are a minimum of $-13^{\circ} \mathrm{C}\left(8^{\circ} \mathrm{F}\right)$ and a maximum of $0^{\circ} \mathrm{C}\left(32^{\circ} \mathrm{F}\right)$. The mean temperatures for July are a minimum of $13^{\circ} \mathrm{C}$ $\left(56^{\circ} \mathrm{F}\right)$ and a maximum of $31^{\circ} \mathrm{C}\left(88^{\circ} \mathrm{F}\right)$. 


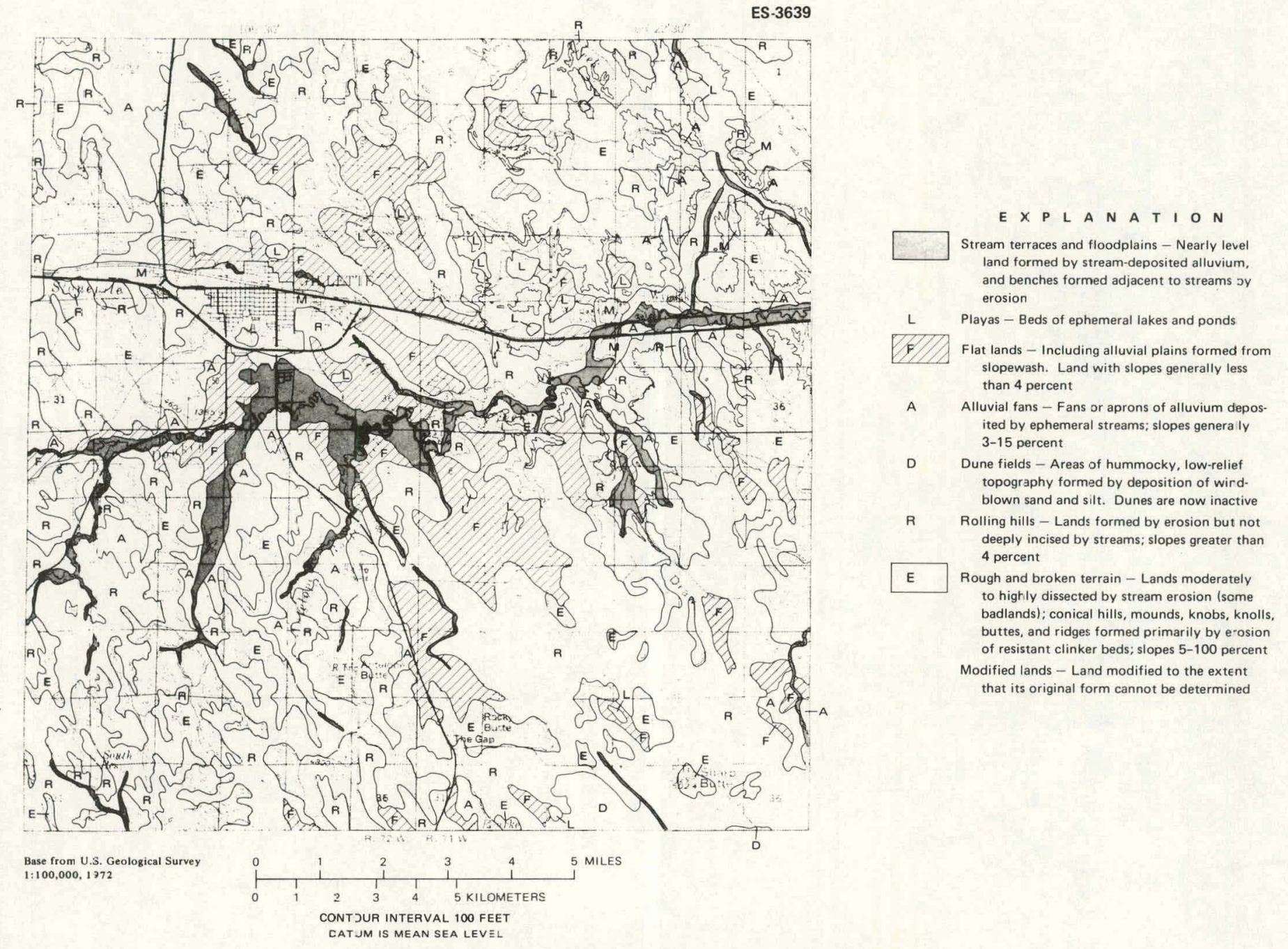

Fig. 2.26. Map showing landforms, Gi lette and four-township vicinity. Source: W. R. Keefer and R. F. Hadley. 1976. Land and natural resource information and some potential environmental effects of surface miring of coal in the Gillette area, Wyoming. Circular no. 743. Alexandria, Va.: U.S. Geologica Survey. 
ES-3640

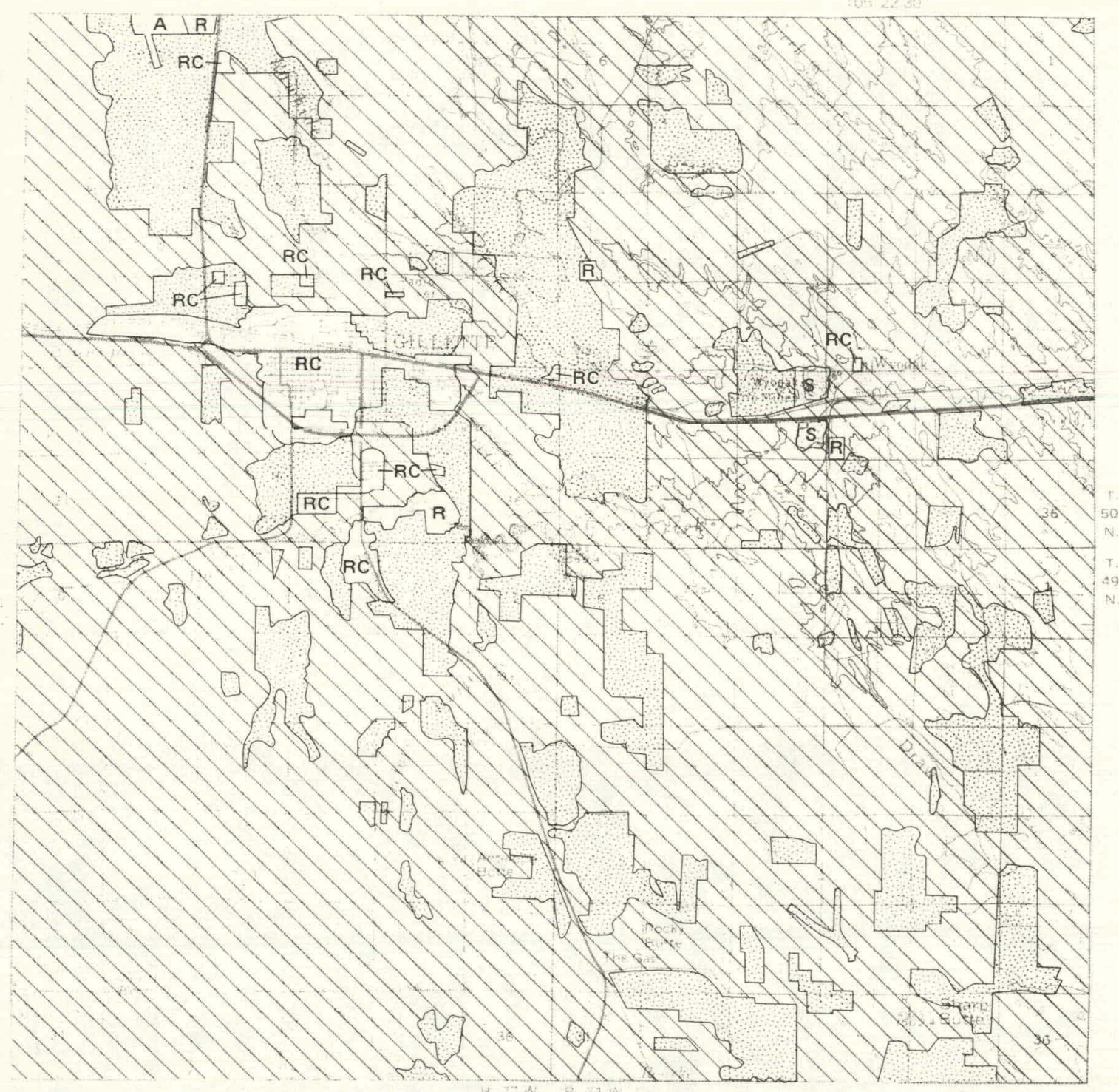

Base from U.S. Geological Survey $1: 100,000,1972$

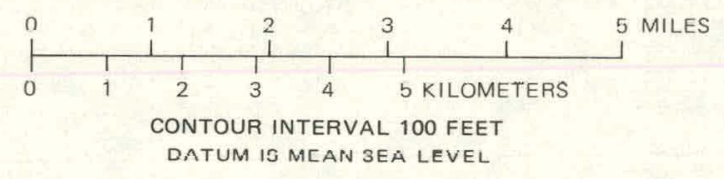

EXPLANATIÓN

\begin{tabular}{|c|c|c|c|}
\hline & Rangeland & $\mathrm{R}$ & Recreation \\
\hline & Cropland, hayland, pasture & $\mathrm{s}$ & Strip coal mine \\
\hline $\mathrm{RC}$ & Residential, commercial, services & A & Airport \\
\hline
\end{tabular}

Fig. 2.27. Land-use map of Gillette, Wyoming, and vicinity, 1970. Source: W. R. Keefer and R. F. Hadley. 1976. Land and natural resource information and some potential environmental effects of surface mining of coal in the Gillette area, Wyoming. Circular no. 743. Alexandria, Va.: U.S. Geological Survey. 
Table 2.47. Estimates of existing and proposed coal mines in Campbell County, Wyoming, that involve Federal coal leases

\begin{tabular}{|c|c|c|c|c|}
\hline $\begin{array}{l}\text { Company, mine name, } \\
\text { and EIS status }\end{array}$ & $\begin{array}{c}\text { Total coal } \\
\text { reserves at } \\
\text { leasehold } \\
\text { [millions of } \\
\text { metric tons } \\
\text { (millions of tons) }{ }^{b}\end{array}$ & $\begin{array}{c}\text { Average annual } \\
\text { production from } \\
\text { each mine } \\
\text { [millions of } \\
\text { metric tons } \\
\text { (millions of tons) }{ }^{a}\end{array}$ & \multicolumn{2}{|c|}{$\begin{array}{c}\text { Total surface } \\
\text { acreage of } \\
\text { each leasehold } \\
{\left[\mathrm{m}^{2} \times 10^{3} \text { acres }\right]^{c}}\end{array}$} \\
\hline $\begin{array}{l}\text { Amax (Belle Ayr South) } \\
\text { FES } 75-86 \text { completed } \\
\text { Oct. } 7,1975\end{array}$ & $300(331)$ & $13(15)$ & 11,696 & $(2,890)^{d}$ \\
\hline $\begin{array}{l}\text { Amax (Eagle Butte) } \\
\text { DES } 76-36 \text { completed } \\
\text { Sept. } 23,19 / 6\end{array}$ & $513(566)$ & $18(20)$ & 12,449 & $(3,076)^{e}$ \\
\hline $\begin{array}{l}\text { A. R. Co. (Black Thunder) } \\
\text { FES } 74-55 \text { completed } \\
\text { Oct. } 18,1974\end{array}$ & $657(724)$ & $9(10)$ & 26,403 & $(6,524)^{e}$ \\
\hline $\begin{array}{l}\text { A. R. Co. (Coal Creek) } \\
\text { DES in preparation }\end{array}$ & $308(340)$ & $9(10)$ & 27,196 & $(6,720)^{f}$ \\
\hline $\begin{array}{l}\text { Carter Oil (Caballo) } \\
\text { DES in preparation }\end{array}$ & $652(719)$ & $11(12)$ & 29,304 & $(1,241)^{f}$ \\
\hline $\begin{array}{l}\text { Carter Oil (Rawhide) } \\
\text { FES } 74-55 \text { completed } \\
\text { Oct. } 18,1974\end{array}$ & $682(752)$ & $5(5)$ & 21,923 & $(5,417)^{d}$ \\
\hline $\begin{array}{l}\text { Kerr-McGee (East Gillette) } \\
\text { DES in preparation }\end{array}$ & $308(340)$ & $9(10)$ & 17,576 & $(4,343)^{g}$ \\
\hline $\begin{array}{l}\text { Kerr-McGee (Jacobs Ranch) } \\
\text { FES } 74-55 \text { completed } \\
\text { Oct. } 18,1974\end{array}$ & $272(300)$ & $8(9)$ & 17,613 & $(4,352)^{g}$ \\
\hline $\begin{array}{l}\text { Mobil Oil-Consolidation Coal } \\
\text { DES in preparation }\end{array}$ & 397 (438) & $5(5)$ & 16,512 & $(4,080)^{d}$ \\
\hline $\begin{array}{l}\text { Peabody (Rochelle) } \\
\text { DES in preparation }\end{array}$ & $702(774)$ & $10(11)$ & 48,564 & $(12,000)^{d}$ \\
\hline $\begin{array}{l}\text { Sun Oil (Cordero) } \\
\text { FES } 76-22 \text { completed } \\
\text { April } 30,1976\end{array}$ & 306 (337) & $11(12)$ & 15,379 & $(3,800)^{g}$ \\
\hline $\begin{array}{l}\text { Wyodak } \\
\text { FES } 74-55 \text { completed } \\
\text { Uct. } 18,19 / 4\end{array}$ & $145(160)$ & $5(5)$ & 8,418 & $(2,080)^{f}$ \\
\hline Total & $5,243(5,781)$ & $112(124)$ & 253,033 & $(62,523)$ \\
\hline
\end{tabular}

a The approved or proposed mining and reclamation plan may not include all of the total coal reserves indicated.

${ }^{b}$ Full production will not occur at many mines until the mid-1980s.

${ }^{c}$ The approved or proposed mining and reclamation plan may not affect all of the total surface acreage indicated.

${ }^{d}$ The leaselıuld includes reder al cual leases and privately owncd (fec) coal.

${ }^{o}$ The leasehold includes Federal and state coal leases.

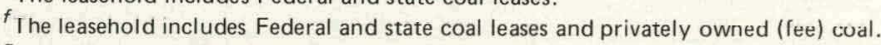

${ }^{g}$ The leasehold comprises Federal coal leases.

Source: U.S. Geological Survey, 1976. Draft environmental statement: Proposed mining and reclanation plan, East Gillette Mine. Kerr-McGee Corporation coal leases W-311810, W-312311, and W-313668. Campbell County, Wyo.

The wind patterns for Campbell County would be expected to be similar to those for Casper, Wyoming, which are shown in Fig. 2.29. The winds are predominantly from the west to the southsouthwest quadrant, with some exceeding $10 \mathrm{~m} / \mathrm{sec}(23 \mathrm{mph})$. At Casper, heavy fog occurs on an average of 9 days annually. Wyoming has an average of only two tornadoes annually. Hailstorms cause more destruction than do tornadoes.

In an average year only 2 days of high meteorological potential for air pollution (inversions) would be forecast (Dalstead, Leistritz, and Hertsgaard 1974). At Gillette in 1974, the annual average concentration of total suspended particulates was $31 \mathrm{\mu g} / \mathrm{m}^{3}$, with a 24-hr maximum of 
ES-3641

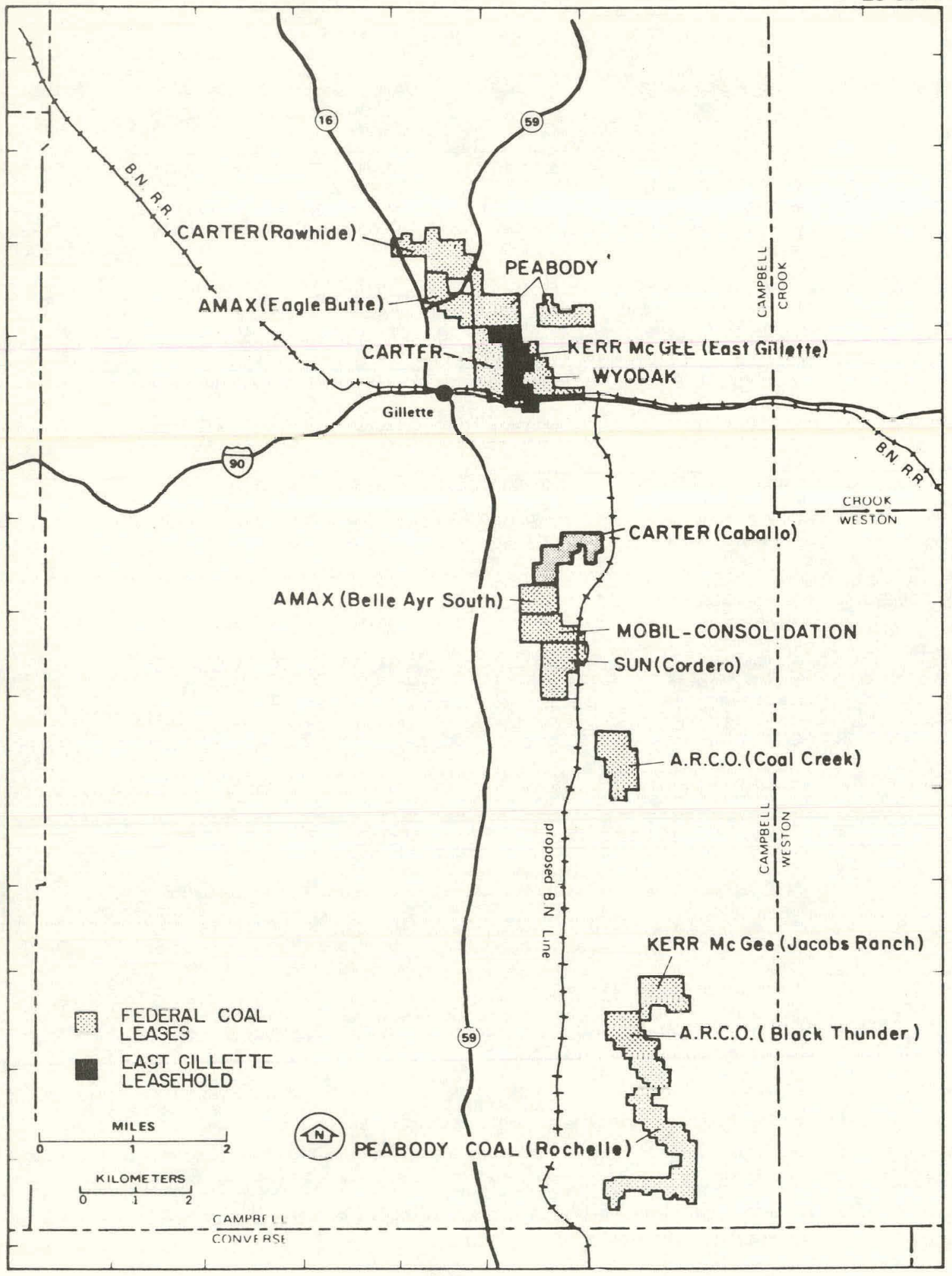

Fig. 2.28. Location of the East Gillette Mine and other operating, proposed, or anticipated coal mines involving Federal coal leases in Campbell County, Wyoming. Source: U.S. Geological Survey. 1976. Draft environmental statement-proposed mining and reclamation plan, East Gillette Mine. Coa1 leases W-311810, W-312311, and W-313668. Campbel1 County, Wyo.: Kerr-McGee Corporation. 
ES-3642

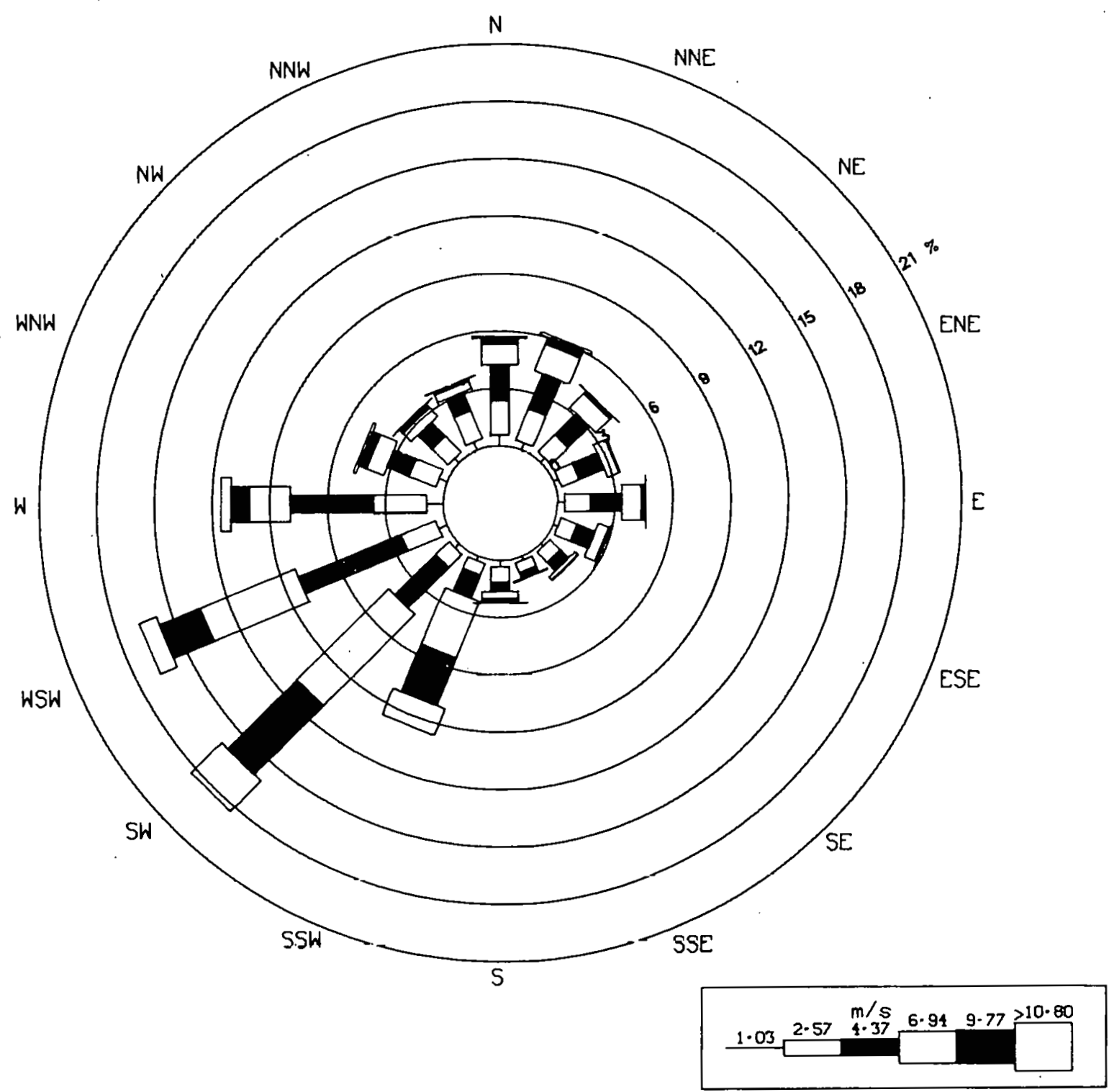

Fig. 2.29. Casper, Wyoming, annual wind rose.

$118 \mu \mathrm{g} / \mathrm{m}^{3}$ (U.S. Department of the Interior 1974). At nearby Casper in 1974, the average annual $\mathrm{SO}_{2}$ concentration was $3 \mu \mathrm{g} / \mathrm{m}^{3}$, with a $24-\mathrm{hr}$ maximum of $19 \mu \mathrm{g} / \mathrm{m}^{3}$.

\subsubsection{Noise}

The general noise discussion in Sect. 2.1.7 applies equally here.

No State requirements exist concerning noise in Wyoming (Wyoming Department of Environmental Quality 1977). 


\subsubsection{Socioeconomic structure (Campbell County, Wyoming)}

\subsubsection{Local and regional demography}

\section{Population size and density}

In 1970 the population of Campbell County was 12,957 (U.S. Bureau of the Census 1973b). Thus with a land area of $12,313 \mathrm{~km} 2$ (4756 sq miles), the county's population density is three persons per sq mile (U.S. Bureau of Census 1973b). The counties adjacent to Campbell County are also sparsely settled. In 1975 Campbell County's population was about 14,000, and about 9500 (68\%) lived in Gillette (Hayen and Watts 1975). Sheridan (1970 population of 10,856) and Casper (1970 population of 39,361) are the only cities within $161 \mathrm{~km}$ (100 miles) of Gillette which are larger than Gillette. Thus Gillette is a small city in a rural, isolated location.

\section{Population trends}

Between 1960 and 1970, Campbell County's population increased from 5861 to 12,957; the rate of increase was 121\%. Net migration added about 5860 of the 7096 new residents, and the net migration rate was nearly 100\% (U.S. Bureau of the Census 1973b). From 1970 to 1974, Gillette's population increased from 7194 to 9500, a growth rate of 32\% (Hayen and Watts 1975). Most of this growth was caused by an influx of workers for several construction and mining projects in the area. Employment in energy-related projects is expected to continue to rise until at least 1985, and, if this occurs, Campbel1 County's population will reach 27,000 by 1985; 20,275 of these people will live in Gillette (Hayen and Watts 1975).

\section{Population characteristics}

Because of the rapid influx of construction workers into Gillette, Campbell County had, in 1970, a younger (medium age 23.2) and more prosperous population (median family income $\$ 11,301$ ) than the rest of Wyoming. It also had a younger and more prosperous population than the nation as a whole (national median age in 1970 was 28.3 , and national median family income was \$9586) (U.S. Department of Housing and Urban Development 1976). Only 4.9\% of Campbell County's population was over 65 (U.S. Bureau of the Census 1973b) in 1970 vs $14.9 \%$ for the United States (U.S. Bureau of the Census 1971b). The percentage of families below poverty level was 5.2 vs $14.9 \%$ for the United States (U.S. Department of Housing and Urban Development 1976). The median educational level for persons over 25 was exactly the same as the national median of 12.2.

The percentage of black inhabitants of the county was not reported because the census does not show percentage figures if less than 400 persons are in the category (U.S. Bureau of the Census $1973 \mathrm{~b})$.

The unemployment rate in Campbel1 County in 1970 was $2.6 \%$, which was less than one-half of the U.S. rate of $5.4 \%$ (U.S. Bureau of the Census 1973b; U.S. Bureau of the Census 1971b). According to Stenehjem and Metzger (1976), only a few hundred new workers will be available locally.

Stenehjem and Metzger (1976, p. 97) estimated the number of new local workers in Campbel1 County's labor pool (see the description of St. Clair County's labor pool for a brief summary of their procedure) over the next 10 years as follows: 


$\begin{array}{cc}\frac{\text { Year }}{1} & \text { Number of new local workers } \\ 2 & 611 \\ 3 & 99 \\ 4 & 122 \\ 5 & 122 \\ 6 & 122 \\ 7 & 122 \\ 8 & 117 \\ 9 & 130 \\ 10 & 130\end{array}$

Because Campbell County has a large land area and is sparsely settled, few workers will commute to the site. Most plant workers will therefore have to move into Gillette.

\subsubsection{Industry structure}

The industry structure of the Campbell County, Wyoming, economy is the smallest, least diversified of the three sites considered in this report. The number and size of existing industries in the area is quite limited, making local supplies insufficient to meet the increased demands created by the siting of major energy facilities. At the same time, the relative isolation of the area increases the difficulty and cost of importing needed goods and services from outside the region. Consequently, disequilibrium situations created by the increased demands of the gasification facility are likely to be both more severe and of longer duration at this location than at either of the other two sites.

Total employment for the eight-county region of the Wyoming Powder River Basin was 41,253 in 1970 (an increase of $7.1 \%$ from 1960). Within this region the primary employment sources were the petrochemicals industry $(12.4 \%$ of tot.al employment), agriculture ( $9.2 \%)$, and construction $(7.7 \%)$. Throughout the area the most noticeable trend has been the declining employment in the historically important agricultural sector. Table 2.48 gives employment figures by major sectors for the eight-county region.

Similar information is provided for Campbell County in Table 2.49. Here, total employment increased by $111 \%$ during the 1960-1970 period. The major contributors to this growth were the petrochemicals industry, which increased in employment by $509 \%$, and the "other residentiaries" classification, which increased in employment by $110 \%$. The primary cause of this growth was the oil boom that took place during the 1960s. With the exception of the other residentaries category, the petrochemicals industry and the agricultural sector are the principal sources of employment in the county. The "other manufacturing" sector (which includes manufacturing activity that is not directly related to energy mining and fuel production) experienced an increase in employment of 628\% over the 10-year period, largely as a result of the general boom conditions created by 0 il-industry growth in the area. Manufacturing, however, remains relatively unimportant in the region's economy, accounting for less than $3 \%$ of the total county employment (U.S. Department of the Interior 1974).

The size distribuliun of the existing establishments is given in Table 2.50. As can be seen from this table, there are no firms in the two largest classes (250 or more employees) and 
Table 2.48. Employment in the eight-county Wyoming Powder River Basin

\begin{tabular}{|c|c|c|c|c|}
\hline Sector & $\begin{array}{l}\text { Employment, } \\
1960\end{array}$ & $\begin{array}{l}\text { Percentage of } \\
\text { total }\end{array}$ & $\begin{array}{c}\text { Employment, } \\
1970\end{array}$ & $\begin{array}{l}\text { Percentage of } \\
\text { total }\end{array}$ \\
\hline Agriculture & 4,861 & 12.6 & 3,784 & 9.2 \\
\hline $\begin{array}{l}\text { Petrochemicals: petroleum and } \\
\text { natural gas }\end{array}$ & 4,964 & 12.9 & 5,135 & 12.4 \\
\hline \multicolumn{5}{|l|}{ Synthetic gas } \\
\hline Coal mining & 95 & 0.2 & 224 & 0.5 \\
\hline Uranium mining and milling & 136 & 0.3 & 572 & 1.4 \\
\hline Power generation & 193 & 0.5 & 221 & 0.5 \\
\hline Other mining & 126 & 0.3 & 269 & 0.7 \\
\hline Other manufacturing & 1,150 & 3.0 & 931 & 2.3 \\
\hline Railroads & 518 & 1.3 & 305 & 0.7 \\
\hline Construction & 3,677 & 9.5 & 3,196 & 7.7 \\
\hline Other residentiaries & 22,799 & 59.2 & 26,616 & 64.5 \\
\hline Total employment & 38,519 & & 41,253 & \\
\hline
\end{tabular}

Source: U. S. Department of the Interior. Bureau of Land Manayeruent. 1974. vol. 1, p. 1-399. In Final environmental impact statemenl; Eastern Fowder River Cool Basin of Wyoming. Washington, D.C.: II.S. Government Printing Office.

Table 2.49. Employment summary, Campbell County, Wyoming

\begin{tabular}{|c|c|c|c|c|}
\hline Sector & $\begin{array}{c}\text { Employment, } \\
1960\end{array}$ & $\begin{array}{l}\text { Perceritaye of } \\
\text { total }\end{array}$ & $\begin{array}{l}\text { Cmployment, } \\
1970\end{array}$ & $\begin{array}{c}\text { Percentage of } \\
\text { total }\end{array}$ \\
\hline Agriculture & 670 & 29.4 & 601 & 12.5 \\
\hline $\begin{array}{l}\text { Petrochemicals: petroleum and } \\
\text { natural gas }\end{array}$ & 224 & 9.8 & 1,364 & 28.4 \\
\hline \multicolumn{5}{|l|}{ Synthetic gas } \\
\hline Coal mining & 32 & 1.4 & 32 & 0.7 \\
\hline Uranium mining and milling & 2 & 0.1 & & \\
\hline \multicolumn{5}{|l|}{ Power generation } \\
\hline \multicolumn{5}{|l|}{ Other mining } \\
\hline Uther manhuracturing & 18 & 0.0 & 131 & 2.7 \\
\hline Railroads & 22 & 1.0 & 11 & 0.3 \\
\hline Construction & 189 & 8.3 & 268 & 5.6 \\
\hline Othor rocidentiaries & 1,120 & 49.2 & 2,356 & 49.1 \\
\hline IUtai enipluymerı & 2,277 & & 1,803 & \\
\hline
\end{tabular}

Source: U.S. Department of the Interior, Bureau of Land Management. 1974. vol. 1, p. I-400. In Final environmental impoct stotcment; Eastern Powder River Coal Basin of Wyominy. Washington, D.C.: U.S. Guver rument Printing Office.

only two mining concerns in the third largest (100 to 249 employees) (U.S. Bureau of the Census 1971a). Major firms providing employment are Exeter Drilling (65 employees), Amax Coal Company (86 employees), Getter Trucking (50-99 employees), Halliburton Service (50-99 employees), Morrison-Knudsen (50-99 employees), Wyodak and Black Hills Power and Light (65 employees), Dowell Division of Dow (31 employees), Atlantic Richfield (28 employees), and Farmers Co-op (40 employees) (Wyoming Department of Economic Planning and Development 1976).

The structure of the Campbel1 County, Wyoming, economy may thus be characterized as one that is undiversified and is dominated primarily by the agriculture and energy-production sectors. It is relatively isolated from the major trade centers and contains an undeveloped industrial infrastructure. Consequently, in attempting to estimate the secondary employment effects of an increase in basic employment, the regression multiplier suggested by Stenehjem and Metzger (1976, pp. 50-53) appears appropriate. This multiplier has been estimated to be 1.7 for the 
Table 2.50. First quarter 1971 employment and payroll, Campbell County, Wyoming

\begin{tabular}{|c|c|c|c|c|c|c|c|c|c|c|c|}
\hline \multirow[b]{2}{*}{ Industry } & \multirow{2}{*}{$\begin{array}{l}\text { Number of } \\
\text { employees } \\
\mathrm{mid} \cdot \text { March } \\
\text { pay period }\end{array}$} & \multirow{2}{*}{$\begin{array}{c}\text { Taxable } \\
\text { payrolls } \\
\text { January-March } \\
(\$ 1000) \\
\end{array}$} & \multirow{2}{*}{$\begin{array}{l}\text { Total } \\
\text { reporting } \\
\text { units }\end{array}$} & \multicolumn{8}{|c|}{ Number of reporting units, by employment size class } \\
\hline & & & & 1 to 3 & 4 to 7 & 8 to 19 & 20 to 49 & 50 to 99 & 100 to 249 & 250 to 499 & 500 or more \\
\hline Totai & 2717 & 4212 & 318 & 150 & 70 & 71 & 20 & 5 & 2 & & \\
\hline Agric Itural services, forestry, and fisheries & $b$ & $b$ & 2 & 1 & 1 & & & & & & \\
\hline Mining & 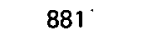 & 1860 & 49 & 18 & 8 & 14 & 4 & 3 & 2 & & \\
\hline Coritract construction & 194 & 370 & 36 & 21 & 7 & 6 & 2 & & & & \\
\hline Manufacturing & 27 & 31 & 3 & & 2 & 1 & & & & & \\
\hline Transficrtation and other public utilities & 215 & 349 & 31 & 16 & 5 & 6 & 4 & & & & \\
\hline Wholesale trade & 124 & 273 & 17 & 5 & 4 & 7 & 1 & & & & \\
\hline Retail irade & 718 & 716 & 86 & 33 & 21 & 25 & 6 & 1 & & & \\
\hline Finance, insurance, and real estat $\epsilon$ & 76 & 106 & 11 & 8 & 1 & 1 & 1 & & & & \\
\hline Services & 447 & 468 & 77 & 45 & 19 & 10 & 2 & 1 & & & \\
\hline Undassified establishments & $b$ & $b$ & 6 & 3 & 2 & 1 & & & & & \\
\hline
\end{tabular}

${ }^{a}$ Excludes, for example, government enployees, railroad employees and self-employed persons.

${ }^{\text {DN }} \mathrm{Not}$ reported for reasons of disciosure.

Source: U.S. Bureau of the Census. 19?1. County business patterns. Washington, D.C.: U.S. Government Printing Office. 
manufacturing and construction industries in Wyoming (Stenehjem and Metzger 1976, p. 55), which implies that, in equilibrium, there will be 0.7 secondary (or service-sector) jobs created for every basic job introduced by the siting of the gasification facility. This figure is smaller than that estimated for the St. Clair County, Illinois, site because of the relative lack of existing industry in the area. At the same time, however, it is larger than that estimated for the Mason County, West Virginia, site because of the relative difficulty and expense of importing goods and services from outside the region.

\subsubsection{Local infrastructure}

\section{Governmental jurisdictions}

The county governing body is a three-person Board of Commissioners, which is elected at large and has responsibility for county budgets, roads, and special projects. Gillette, the county seat, is incorporated and guverned by a mayor-council system. The council is composed of two representatives from each of the city's three wards. There are no township governments in Wyoming. Areas outside of incorporated towns and cltles are under che jurisdiction of the county government and whatever special districts the inhabitants choose to form. Campbe11 County has three special districts and one school district. The only municipal government is that of Gillette (U.S. Bureau of the Census 1973a).

The city of Gillette has become the first user of the Wyoming Human Services Project. In 1976 seven people worked in city administration, city legal service, public health, mental health, recreation, day care, and public assistance. The 1 -year project was supported by the Economic Development Administration (Title IX) and the State Department of Public Assistance and Social Services usinq Title 20 revenue-sharing funds (U.S. Department of Housing and Urban Development 1976, p. 55). State and Federal aid for growth management will probably continue to be available to Gillette in the future.

Housing

In 1970 there were 3937 housing units in the greater Gillette area. Between 1965 and 1973 the percentage of mobile homes in the Gillette area (city and nearby parts of Campbell County) rose from $32 \%$ to $42 \%$ (Hayen and Watts 1975). The "Gillette-Campbell County Comprehensive Plan Update," prepared by the Gillette-Campbeil County Planning Orfice in 19\%3, predicted that by $197950 \%$ of the housing in Gillette would be mobile homes (Hayen and Watts 1975, p. 48). The Gillette Community Profile, prepared by the Industrial Development Division of the Wyoming Department of Economic Planning and Development in 1976, reported the housing figures given in Tahle 2.51.

In 1976 the estimated cost of a new $102-\mathrm{m}^{2}\left(1100-\mathrm{ft}^{2}\right)$ single-family home in Gillette was estimated at $\$ 45,000$. Average rental on a house of similar size was $\$ 350 /$ month. (Wyoming Department of Economic Planning and Development 1976, p. 1). Housing costs in Gillette rose at an average of $5.1 \%$ annually between 1965 and 1973. The average yearly increase is projected at $8 \%$ from 1973 to 1979 (Hayen and Watts 1975, p. 49). Because of high costs and shortages of conventional housing, a high proportion of newcomers are expected to continue to choose to live in mobile homes. 
Table 2.51. Housing in the Giltette city limits in 1976

\begin{tabular}{lrr}
\hline Type of unit & Number & Percentage \\
\hline Single-family & 1317 & 45 \\
Two-family & 101 & 4 \\
Multiple-family & 422 & 15 \\
Mobile homes & 1027 & 38 \\
Total & 2867 & \\
\hline
\end{tabular}

Source: Wyoming Department of Economic Planning and Development, Industrial Development Division. 1976. Gillette community profile. Cheyenne, Wyo.

\section{Education}

The Campbell County Unified School District had a total enrollment of 3060 students in the fall of 1973 with an average student-to-teacher ratio of 15:1. The system contains 19 elementary schools, 1 junior high school, and 1 senior high school; and it had the highest assessed valuation $(\$ 48,288$ ) per pupil in the state in the 1972-1973 school year (U.S. Department of the Interior 1974). Total enrollment during the 1974-1975 school year was 3200 students with about 1720 enrolled in grades $K-6,800$ in grades $7-9$, and 680 in grades 10-12. The physical facilities existing in that year had estimated capacities of about 2000 elementary students and 1000 high school students. The junior high school enrollment in that year exceeded capacity, but a new building (costing $\$ 3.5$ million) was completed and occupied in 1976. In addition, a bond issue was recently passed for the construction of new grammar school facilities. Consequently, the existing and planned educational facilities for the county district have capacities of 2550 in grades $K-6,1100$ in grades $7-9$, and 1000 in grades $10-12$.

With in the city of Gillette, there were five elementary schools, one junior high'school, and one senior high school in 1974. Table 2.52 gives enrollments and capacities for these schools. At that time $13.8 \%$ excess capacity existed in the elementary schools, and $45.4 \%$ excess capacity existed in the senior high school. Enrollment in the junior high school exceeded capacity by $7.5 \%$, but this situation has recently been corrected with the construction of the new facility mentioned above. The present student-to-teacher ratio averages 15:1 (U.S. Department of Commerce 1974).

Additionally, there exist 14 rural schools and 33 teachers with a combined enrollment of 322 students. These schools, often quite smal1,.serve grades $K-8$. Students in higher grades are generally bussed to public schools in Gillette. For the most part, the rural schools have some existing excess capacity (U.S. Department of the Interior 1974).

\section{Transportation}

Interstate 90, which runs east and west through northern Wyoming, and Wyoming 59, a north-south highway, both pass through Gillette. Campbell County is also served by U.S. 14 and 16 and Wyoming 50. With the exception of parts of I-90, all highways in the county are two-lane, and several are in serious disrepair. Most of the highways were not designed to handle heavy traffic (Hayen and Watts 1975, p. 12). The streets of Gillette can handle current traffic loads, but many areas are in disrepair. Two railroad crossings in the town create traffic congestion (Hayen and Watts 1975). 
Table 2.52. Public schools in Gillette, Campbell County, Wyoming, 1974

\begin{tabular}{|c|c|c|c|c|c|c|}
\hline $\begin{array}{l}\text { Type and nanite of } \\
\text { public school }\end{array}$ & $\begin{array}{l}\text { Grade } \\
\text { levels }\end{array}$ & $\begin{array}{l}\text { Current } \\
\text { enroliments }\end{array}$ & $\begin{array}{c}\text { Maximism } \\
\text { enrollment } \\
\text { capacity }\end{array}$ & $\begin{array}{l}\text { Maximum } \\
\text { enrollment } \\
\text { capacity } \\
\text { (\%) }\end{array}$ & $\begin{array}{c}\text { School } \\
\text { site } \\
\text { [ha (acres)] }\end{array}$ & Structural type \\
\hline \multicolumn{7}{|c|}{ Elementary } \\
\hline Hillcrest & $1-6$ & 293 & 350 & 83.7 & $2.4-2.8(6-7)$ & Permanent, built in 1971 \\
\hline Northside & $K-6$ & 307 & 350 & 87.7 & $1.2(3)$ & Permanent, built in 1971 \\
\hline Stocktrail & $4-6$ & 242 & 350 & 69.1 & $3.6(9)$ & Permanent, built in 1971 \\
\hline Westside & $1-3$ & 226 & 225 & 100.4 & $0.8(2)$ & Octagon and mobile modulc units \\
\hline Eastside ${ }^{a}$ & $K-6$ & 332 & 350 & 94.7 & & Temporary, mobile trailers \\
\hline Subtotal & . & 1400 & 1625 & 86.2 & & \\
\hline \multicolumn{7}{|c|}{ Junior High } \\
\hline Campbell County ${ }^{b}$ & $7-9$ & 699 & 650 & 107.5 & $4.9(12)$ & Seven separate buildings \\
\hline \multicolumn{7}{|c|}{ Senior High } \\
\hline Compliell Courity & $10-12$ & 601 & 1 1 & 51.6 & $16.2(40)$ & Ferindient, Luilt in 1972 \\
\hline lotals & 2700 & 3375 & 80.0 & & & \\
\hline
\end{tabular}

W Will be replaced by new 350-student-capacity elementarv schanl an 1 2-ha (2-arre) site in fall 1876.

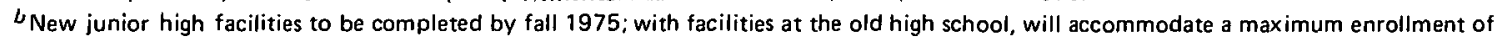
1100 pupils.

${ }^{c}$ Existing facility can be expanded to accommodate an additional 400 students.

Source: U.S. Department of the Interior, Bureau of Land Management. 1974. Final environmental impact statement; Eastern Powder River Coal Basin of Wyoming. Washington, D.C.: U.S. Government Printing Office.

\section{Health care}

Campbell County Memorial Hospital, located in Gillette, is operated by the Lutheran Hospital and Homes Society of Fargo, North Dakota. The hospital was built in 1951 and has a 31-bed capacity. Use in recent years has averaged about $60 \%$, partly because of a shortage of physicians in the county. A new county-supported 80-bed hospital has been proposed. If this new hospital is built, it should meet the immediate needs of the county's population (Hayen and Watts 1975, p. 14).

In 1970 Campbell County was short of personnel in ali health manpower categories, and shortages were expected to continue into the future. Health manpower for 1970 and projected neers are shown in Table 2.53. Since 1970 health manpower has increased. In 1976 Gillette had nine physicians and four dentists. But the increases have not been large enough or rapid enough to meet the needs. Many residents of Campbell County currently go to Sheridan for medical care. Sheridan, Wyoming, is $16 i \mathrm{~km}$ (100 miles) east of Gillette and has a 90-bed hospital and over 20 physicians (Hayen and Watts 1975, p. 14).

\section{Police and fire protection}

The city of Gillette had a police force of 16 full-time uniformed-officers, 1 part-time policeman, and 6 full-time civilians in 1973. This translates into 2.22 policemen per 1000 populations, which compares favorably to the State (1.64) and national (2.0) averages (U.S. Department of the Interior 1974). The police force total staff was listed at 31 regular members in 1976 (Wyoming Department of Economic Planning and Development 1976). New office facilities were recently constructed for police department use, and the city maintains a 12-person jail facility. 
Table 2.53. Present and projected needs for health manpower in Campbell County

\begin{tabular}{lcccc}
\hline & $\begin{array}{c}\text { Existing, } \\
1970\end{array}$ & 1970 & 1980 & 1990 \\
\cline { 4 - 5 } & 7 & $6-7$ & $25-28$ & $43-48$ \\
Physicians & 3 & $3-5$ & $12-17$ & $21-28$ \\
Dentists & 30 & $15 \cdot 30$ & $03-121$ & $147-207$ \\
Registercd nurses & 7 & 4 & 21 & 36 \\
Pharmacists & 2 & 0 & 2 & 4 \\
Public health nurses & & & \multicolumn{3}{c}{ Deficiency } \\
\hline
\end{tabular}

Sources: Wyoming health profiles. 1972. Department of Health and Social Services, reported in pp. I-587 to I-590, U.S. Department of the Interior, Bureau of Land Management. 1974. Final environmental impact statement; Eastern Powder River .Coal Basin of Wyoming. Washington, D.C.: U.S. Government Printing Office.

The Campbell County Sheriff's Department has a staff consisting of eight full-time officers, a full-time jailer, a matron, and several support personnel. Headquarters for the Sheriff's Department is in the new county building, which also contains a jail facility with a capacity of about 40 persons. In addition, there is a minimum-security facility with an existing capacity of eight persons.

The fire department in Campbel 1 County is operated on a volunteer basis under a joint city/ county agreement. A new fire department building contains approximately $372 \mathrm{~m}^{2}\left(4000 \mathrm{ft}^{2}\right)$ of space and houses eight fire-fighting vehicles (three supplied by the city of Gillette and five by the county). The pumping capacity of the city vehicles is $0.11 \mathrm{~m}^{3} / \mathrm{sec}(1750 \mathrm{gpm})$, and the county vehicles have a carrying capacity of $285 \mathrm{~m}^{3}$ (75,000 gal) each (Hayen and Watts 1975).

\section{Recreation}

The Campbel1 County Recreation Department offers more than 60 -activities to area residents. These activities include basketbal1, swimming, baseball, tennis, archery, gymnastics, bowl ing, football, and skiing. This department emplays approximately 30 part-time employees over the year. There are almost 81 ha (200 acres) of developed recreational land within the county, and the construction of a recreational center with indoor-outdoor swimming pools, a day training center, an arts and crafts center, and a community eating room has been approved (Wyoming Department of Economic Planning and Development 1976).

Gillette itself has a rifle range, tennis courts, baseball fields, a nine-hole golf course, an ice rink, and an outdoor basketball court. In addition, the public can use the school system gymnasium during certain periods (Wyoming Department of Economic Planning and Development 1976).

\section{Water supply and wastewater treatment}

The municipal water supply for the city of Gillette is drawn from 28 wells. These wells have a combined source capacity of $0.12 \mathrm{~m}^{3} / \mathrm{sec}(2.8 \mathrm{Mgd})$ with a storage capacity of $7.6 \times 10^{3} \mathrm{~m}^{3}$ (2 million gal). Water transmission facilities have a capacity of $0.11 \mathrm{~m}^{3} / \mathrm{sec}(2.5 \mathrm{Mgd})$, and peak demand in 1976 was $0.11 \mathrm{~m}^{3} / \mathrm{sec}(2.4 \mathrm{Mgd}$ ) (Wyoming Department of Economic Planning and Development 1976). Rates that were applied to industrial customers in 1976 were 


First 3,000 gallons
Next 7,000 gallons
Next 20,000 gallons
Next 20,000 gallons
Next 50,000 gallons

Gillette has entered into a joint-powers agreement with Campbell County to develop future water supplies (Wyoming Department of Economic Planning and Development 1976).

The existing wastewater treatment facility for Gillette has a capacity of $0.096 \mathrm{~m}^{3} / \mathrm{sec}(2.2 \mathrm{Mgd})$. Since 1970 this capacity has been $0.066 \mathrm{~m}^{3} / \mathrm{sec}(1.5 \mathrm{Mgd})$ below peak. Consequently, even without additional population, the existing facility is inadequate to satisfy peak demand (Hayen and Watts 1975).

\section{Historic and archaeological sites}

There are no historic or archaeological sites listed for Campbell County in the Nationaz Register of Historic Places, 1976. The 1977 updates in the Federal Register for January, February, and March also contain no listings for Campbell County.

\subsubsection{Ecology}

\subsubsection{Terrestrial ecology}

Flora

Vegetation of the Wyoming site is controlled by the topography, the soil type, and the semiarid climate. Kuchler (1964) classifies most of the Powder River Basin as shrub steppe. Near the Gillette area the dry rolling uplands are typically short-and mid-grass prairie and scattered low shrubs predominated by big sagebrush (Artemisia tridentata). This community comprises over 75\% of the total unmined land area. Blue grama (Bouteloua gracilis) and western wheatgrass (Agropyron smithii) are the characteristic dominant grasses. Other grasses are needle-andthread grass (Stipa comata), green needlegrass (Stipa viridula), prairie junegrass (Koeleria cristata), and introduced bromegrasses (Bromus sp.). Common forbs are prickly pear cactus (Opuntia polyacantha), which may form dense stands in some areas; threadleaf sedge (Carex filifolia); miner's candle (Crypthonta brondburiana); and vetches (Astragalus sp.). Although big sagebrush is by far the most prevalent shrub, rabbitbrush (Chrysotharnus spp.) is also common; in alkaline areas, four-wing saltbush (Atriplex canescens) and greasewood (Sarcobatus vermiculatis) may be the dominant shrubs. On the more moist slopes in draws, dense stands of big sagebrush develop, with an understory of western wheatgrass.

Closer to the stream channels, the dense shrub growth includes silver sage (Artemisia cana), wild rose (Rosa woodsii), snowberry (Symphoricarpos occidentalis), and currant (Ribes sp.) all valuable forage species. Along the stream channels proper grow scattered large-plains cottonwood trees (Populus sargentii) and willows (Salix spp.). In very wet situations along the bottom of the stream channels and at the numerous livestock watering impoundments, there are well-developed stands of a variety of grasses, sedges, and rushes. Riparian plant communities probably cover about $5 \%$ of the total unmined land area. 
The dry, exposed slopes of buttes and ridges support a bunch grass-cushion plant community dominated by blue-bunch wheatgrass (Agropyron spicatum) and little bluestem (Andropogon scoparius) with scattered wild buckwheat (Eriogonum spp.). In the shelter of rock outcrops along the buttes where trapped snow provides more moisture, shrubs such as rabbitbrush, sagebrush, and skunkbush sumac (Ribes trilobata) grow. The rock outcrops and scattered shrubs provide excellent cover for small mammals. This plant community may cover between 5 and $10 \%$ of the total area.

Other plant communities of small areal extent that occur near the site are playa grasslands, seeded hay meadows, and disturbed habitats along roads and pipeline rights-of-way and around drill pads. Playa lake beds are normally filled with water in spring and early summer but support stands of foxtail barley (Hordeum jubatum), poverty sumpweed (Iva axilzaris), and saltgrass (Distichlis stricta) when the water evaporates by midsummer. Crested wheatgrass (Agropyron desertorum) is an introduced species abundant in seeded hay meadows and in disturbed but revegetated areas. Disturbed soil that is not planted in crested wheatgrass supports poor stands of Russian thistle (Salsola kali), pigweed (Amaranthus spp.), and other annual weeds.

The Wyodak coal mine (a surface mine that is currently operating) occupies approximately $5 \mathrm{~km}^{2}$ (2 sq miles) of the township. Some spoilbanks have been regraded and were seeded in 1972 with a mixture of crested wheatgrass, green needlegrass, western wheatgrass, and four-wing saltbush (Packer 1974). The seeding was mostly successful, and stands of these plants now exist on previously mined land. Other species of plants that have in all likelihood naturally recolonized spoilbanks include annual weeds, especially Russian thistle and buffalo bur (Solanum rostration), and the introduced undesirable cheatgrass (Bromus tectorm).

Fauna

Game species. The extensive and sparsely populated Powder River Basin is nationally known for its outstanding hunting resource of pronghorn antelope and, to a lesser extent, mule deer (Northern Great Pláins Resource Program 1976). According to Sundstrom et a1. (1973), there were about 420,000 pronghorn in the contiguous United States, of which about 200,000 were in Wyoming. Inasmuch as pronghorn are native only to North America, Wyoming's pronghorn represent approximately $48 \%$ of the world pronghorn population. The Wyoming Game and Fish Northeast Management Unit, in which Campbell County is located, comprises about $25 \%$ of the total state area but contributes from 45 to $b 0 \%$ of the total annual state harvest of pronghorns (Fautin 1977).

Pronghorn antelope are year-round residents near the site. In winter they concentrate in large herds that may number up to 200 , but, during the spring fawning season and throughout the summer and fall breeding season, they occur in smaller bands of from 5 to 20 animals (0akes 1976). Pronghorn densities near Gillette during a 1975 study were found to range between 10 and 25 animals per square mile (0akes 1976). Big sagebrush is by far the most important forage species for pronghorn, although they also eat rabbitbrush, greasewood, and sagewort (Wyoming Game and Fish 1976). Forbs are important in the diet during spring and early summer, but grasses constitute only a small percentage of the diet during any season (Wyoming Game and Fish 1976). Pronghorn require unobstructed, open terrain throughout the year. During fawning, sites are selected that have undulating topography, shrub cover, and available water (0akes 1976; Wyoming Game and Fish $(9 / 6)$. A year-round pronghorn range must have dependable water supplies, which 
are provided by the many small impoundments for livestock purposes that are scattered throughout the area.

Mule deer are found throughout the area near the site and are probably present all year. Herds may range from 5 to 30 or more animals. Topographical features such as scattered boulders, gullies and draws, lee sides of ridges, and rimrock provide the cover required by mule deer. Habitats near the site that produce the highest deer population are those having sufficient cover and browse, such as dense shrub communities along intermittent stream channels and in. draws leading to side drainages and along rough rocky slopes. Deer also require a permanent source of water on summer range, which is provided by the many smal1 water impoundments for livestock use near the site. Important deer forage species found in the region near the site include big sagebrush, black sagebrush, rabbitbrush, and a varity of Ribes species.

Upland game such as sage grouse (Centrocerous urophasianus), mourning dove (Zenaida macroura), and cottontail rabbits (Sylvizagus sp.) are also important in northeast Wyoming. Sage grouse are widely distributed throughout the Powder River Basin. Critical areas for sage grouse are their strutting grounds and brooding areas, which are generally near drainages in good sagebrush cover (Oakes 1976). Sage grouse depend heavily on sagebrush for food. Doves are dispersed tinroughout the Powder River Basin but prefer trees along stream channels as nesting places. of minor importance as game is the desert cottontai) rabbit (Syzvizagus auduboni), classified as a small-game species in Wyoming. Waterfowl are a minor hunting resource in northeast Wyoming near Gillette. Common ducks that nest near the permanent livestock water impoundments include gadwall (Anas strepera), American widgeon (A. comericana), mallard (A. platyrhynchos), pintail (A. acuta), shoveler (A. clypeata), and blue-winged teal (A. discors) (Oakes 1976).

\section{Nongame species}

Nongame birds that are abundant near the site are those typical of sagebrush grasslands. Common breeding passerines include the horned lark (Eremophila alpestris), western meadowlark (Stumezza neqlecta), vesper sparrow (Pooecestes arcamineus), lark bunting (Calamospiza mezanocorys), and Brewer's sparrow (Spizella breweri) (Fautin 1977; 0akes 1976). Many wading birds and shorebirds use small impoundments and inundated playa lake beds as breeding areas and migration stopovers; the commonest is the killdeer (Charadrius vociferus). The riparian communities provide nesting and perching sites for birds such as the common flicker (Colaptes auratus cafer), loggerhead shrike (Lanius Zudovicianus), and western kingbird (Tyrannus nastian\}uol.

Birds of prey are conspicuous members of the grassland/sagebrush community, often hunting from perches on utility poles and ridges. The great horned owl (Bubo virginianus), Swainson's hawk (Buteo swainsoni), and the small sparrowhawk (Falco sparverius) commonly nest in trees in riparian habitat (Fautin 1977; 0akes 1976). Red-tailed hawks (Buteo jomaicensis) also occur and often nest atop rocky buttes, while rough-legged hawks (Buteo Zagopus) winter in large numbers near Gillette. Wyoming has a large concentration of wintering golden eagles (Aquila chrysaetos) and bald eages (Haliaeetus leuococephalus). In 1973 a survey estimated that 600 bald, 9000 golden, and 900 unidentified eagles were wintering in Wyoming (Wrakestraw, no date).! Many golden eagles remain to nest in the Powder River Basin near Gillette where there is abundant prey such as jackrabbits, cottontails, and ground squirrels. Golden eagles usually nest in 
isolated trees or on the tops of rocky ridges. Bald eagles are known to nest only along the North Platte River near Casper (Northern Great Plains Resource Program 1976).

$c$

Rodents that occur near Gillette are those common to the western grasslands such as the deer mouse (Peromyscus maniculatus), thirteen-lined ground squirrel (Citellus tridecemlineatus), and northern pocket gopher (Thomomys talpoides). Northern grasshopper mice (Onychomys leucogaster), Ord's kangaroo rat (Dipodomys ordi), and pocket mice (Perognathus spp.) are less common (Fautin 1977; 0akes 1976). The rare sagebrush vole (Lagurus curtatus) is found only in well-developed stands of sagebrush (Fautin 1977). Rodent densities near Gillette probably range from less than 10 to 35 per hectare (Fautin 1977; Oakes 1976). White-tailed jackrabbits (Lepus townoendi) and cottontails are abundant throughout the Powder River Basin. Small mallulal diversity and density are highest in rimrock and riparian habitats where either rock overhangs or shrubs and dead logs provide excellent cover (Fautin 1977).

Common predators that occur near Gillette include the badger (Taxidea taxus), long-tailed weasel (Mustela frenata), coyote (Canis Zatrans), and red fox (Vulpes fulva). Striped skunks (Mephitis mephitis) are numerous and widely dispersed, and racoons (Procyon Zotor) are common near stream channels. Both skunks and racoons are frequent visitors to garbage cans at local ranches.

\subsubsection{Aquatic ecology}

According to the Wyoming Game and Fish Commission (1971), all of the streams in Campbell County are unproductive, and most are incapable of supporting sport fisheries. Most of the creeks in the site area are ephemeral, flowing only in response to spring snowmelt and to infrequent spring and summer rainstorms. Donkey Creek (Fig. 2.30), a first-order tributary of the Belle Fourche River, is the most important stream in the township.

Although this creek - like others in the township - is intermittent, its flow regime is more regular than the others, and there are pools in its channel that contain standing water even where there is no surface flow (USGS 1976b). Streams of this type frequently support surprisngly diverse aquatic communities, including representatives of most of the major taxonomic groups that inhabit permanent streams (Hynes 1972) such as a variety of insects, crustaceans, mollusks, and 01 iguchateas that either aestivate during dry periods or burrow down into the substratum, which may remain moist throughout the year. In addition, the presence of permanent pools permits some fish species to survive in the stream. No specific biological studies of Donkey Creek could be located. However, permanent pools in the channel of Caballo Creek, a similar stream (also a tributary of the Belle Fourche River) about $16 \mathrm{~km}$ (10 miles) south of Donkey creek, have been studied and found to contain six species of fish (Table 2.54).

Livestock ponds, constructed to provide reliahle sources of water for cattle, are a major aqualic habitat throughout Campbel l county. These impoundments are colonized by a diverse assemblage of pond-adapted plants and animals, all of which possess remarkably efficient (usually airborne) dispersal mechanisms. For example, ten stock ponds in Campbell and Converse counties were surveyed by SERNCO (1974); these ponds contained most of the major taxonomic and trophic groups that are typically found in ponds (Fig. 2.31). Although SERNCO did not collect tadpoles or salamander larvae, some livestock ponds undoubtedly serve as a spawning habitat for the six species of amphibians that are common in the Powder River Basin (U.S. Department of the 


\section{ES-3637}

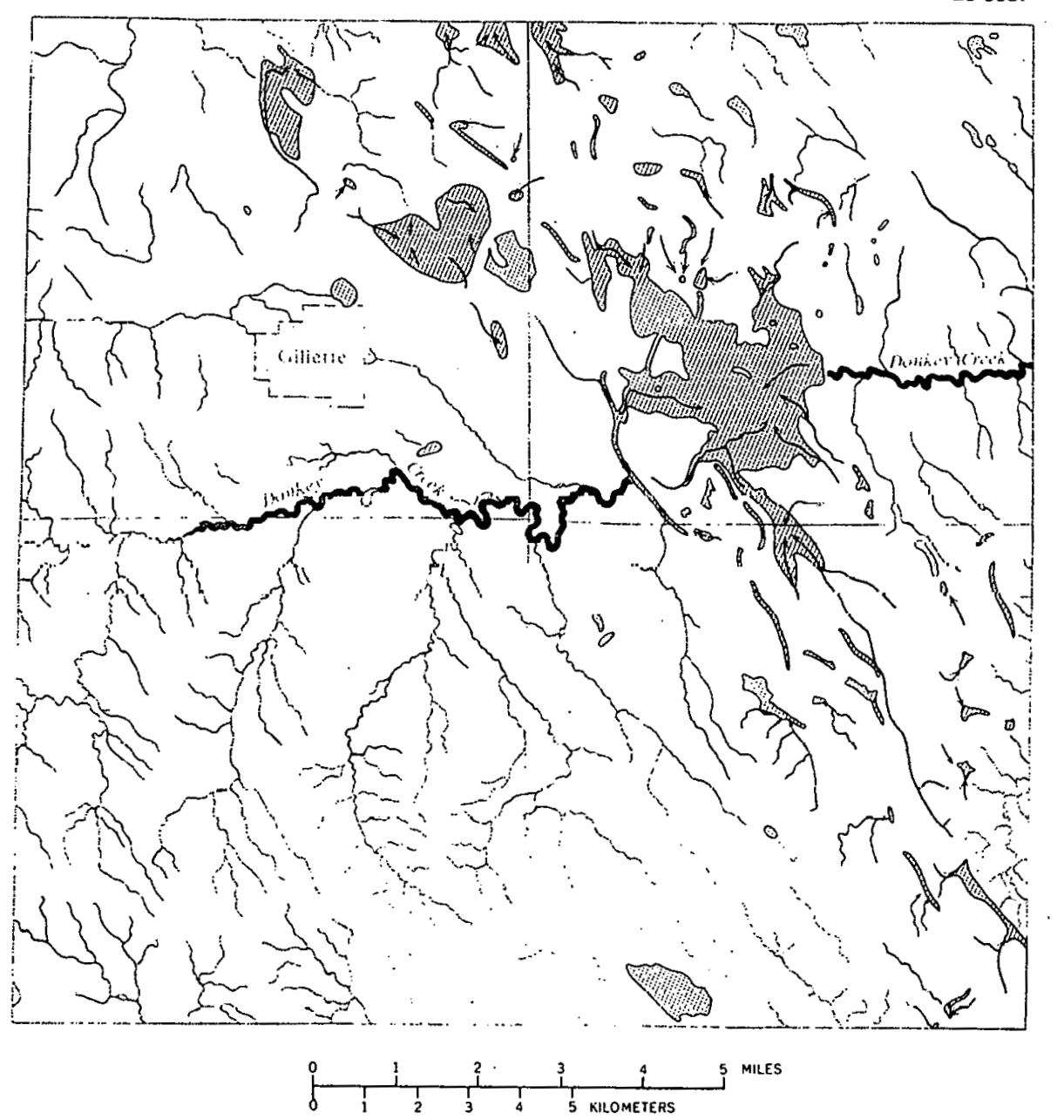

Fig. 2.30. Donkey Creek. Suurce: U.S. Genlngirai Survey. 19\%6. Land and natunal resource information and some potential environmental effects of surface mining of coal in the Gillette area, Wyoming. Circular no. 743. Washington, D.C.

Table 2.54, Fish species collected from pools in the channel of Caballo Crcck, Camphell Coninty, Wynming

\begin{tabular}{ll}
\hline Fathead minnow (Pimephales promelas) & White sucker (Catostomus commersoni) \\
Carp (Cyprinus carpio) & Black bullhcad (lctolurus melas) \\
Sand shiner (Notropis stramineus) & Green sunfish (Lepomis cyanellus) \\
\hline
\end{tabular}

Source: U.S. Department of the Interior. 1975. Final environmental statement, proposed

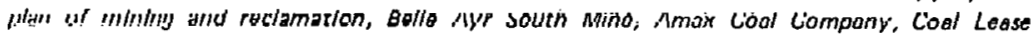
W-0317682, Campbell County, Wyoming. FES 75-86. Washington, D.C.: U.S. Geological Survey.

Interior 1974): the tiger salamander (Ambystoma tigrinum), plains spadefoot toad (Scaphiopus bombifrons), Great Plains toad (Bufo cognatus), Woodhouse's toad (Bufo woodhousei), chorus frog (Pseudacris triseriata), and leopard frog (Rana pipiens). 


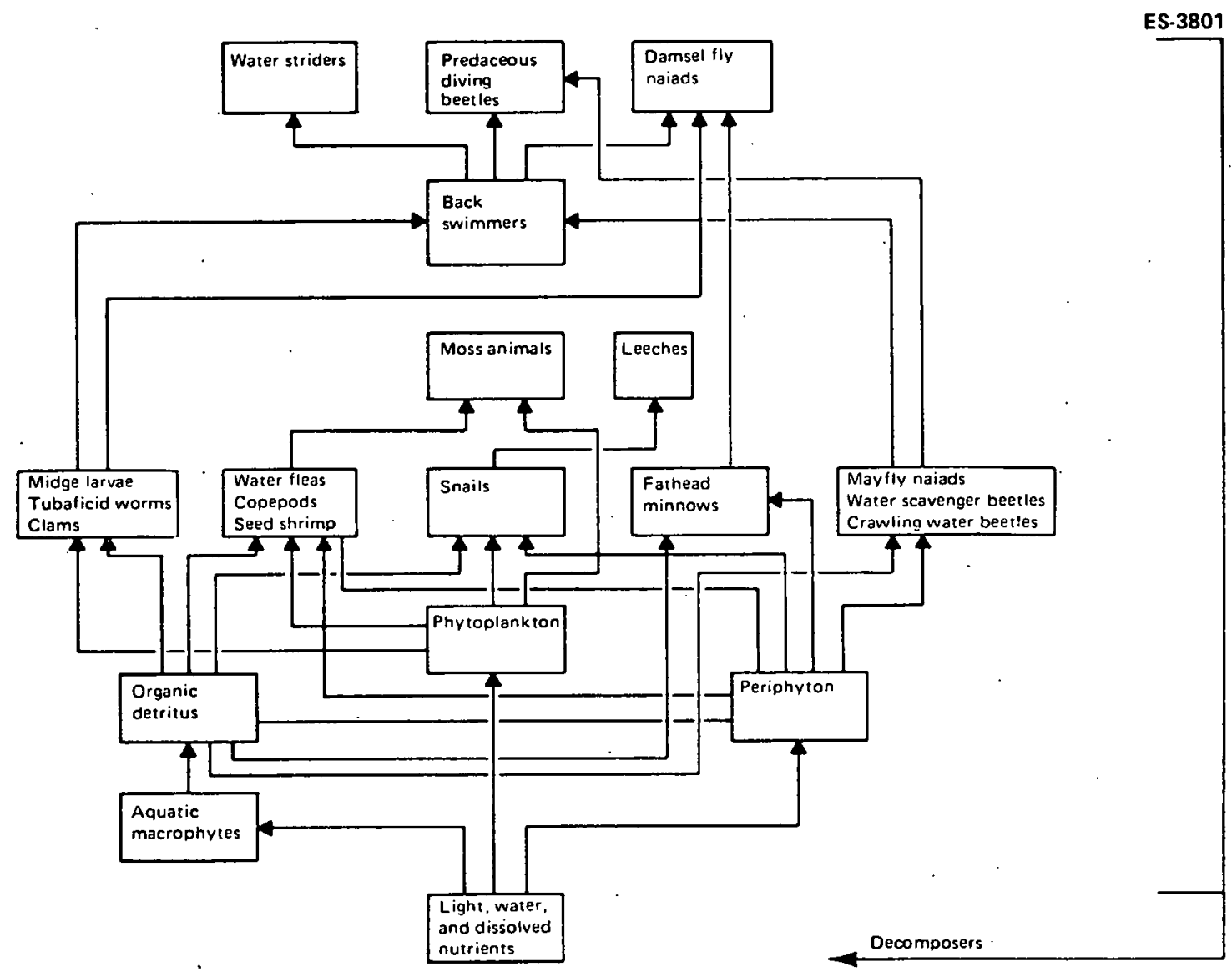

Fig. 2.31. Typical food web of livestock ponds in Campbell and Converse counties. Source: SERNCO. 1974. Applicant's environmental assessment for a proposed gasification projest in Comphe 1.7. and Converse counties, Wyoming. Prepared for Wyoming Coal Gas Company and Rochelle Coal Company by SERNCO, Inc.

In addition to natural colonization, these ponds are frequently stocked with fish. In the Belle Fourche River Basin alone, more than 50 ponds have been planted with trout, and more than 100 with largemouth bass (U.S. Department of the Interior 1974). Bullheads and green sunfish have al so been widely stocked (U.S. Department of the Interior 1974).

\subsubsection{Endangered species}

Aquatic

Three nationally listed endangered aquatic species, the humpback chub (Gila cypha), Colorado River squawfish (Ptychocheilus lucious), and Kendall Warm Springs dace (Rhinichthys osculus thermalis), occur in Wyoming (U.S. Department of the Interior 1976b). However, none of these are believed to occur in the eastern Powder River Basin (U.S. Department of the Interior 1974, Appendix $($ ). Six fish species that are officially considered rare in Wyoming, the shovelnose sturgeon (Scaphirhynchus platorynchus), goldeye (Hiodon alosoides), sturgeon chub (Hybopsis gelida), pearl dace (Semotilus margarita), finescale dace (Chrosomus neogaeus), and silvery minnow (Hybognathus nuchalis), are found in the basin (Northern Great Plains Resources Program 1974b). Only the silvery minnow occurs in the Belle Fourche drainage system. 


\section{Terrestrial}

Animals listed on the latest Federal list of endangered species whose range includes the Gillette area are the black-footed ferret (Mustela nigripes), the American peregrine falcon (Falco peregrinus anatum), and the bald eagle (Haliaeetus leucocephalus). Sheer cliffs, which serve as breeding habitats for the peregrine falcon, do not occur near the Gillette site, but falcons may be occasional visitors or migrants near the site. A sighting of a bald eagle has recently been documented approximately $56.33 \mathrm{~km}$ (35 miles) south of Gillette (Fautin 1977). Bald eagles may winter in the region of the Powder River Basin near Gillette. Nesting habitats for them may exist south and east of Gillette along the Belle Fourche River, but it is not known if any nest there. Black-footed ferrets are found associated exclusively with prairie dog towns. Generally, prairie dog towns are not common near Gillette, but are found closer to the Black Hills to the northeast several miles from Gillette. Therefore, black-footed terrets are not likely to occur near Gillette. 
Algermissen, S. T. 1969. Seismic risk cnalysis in the United States: proceedings 4th world conference on earthquake engineering. Vol. 1, sect. A-1, pp. 14-27. Santiago, Chile: Asociacion Chileno de Sismolgio e Ingerieria Antisismica.

Amax Coal Company, Continuing Environmental Research Institute. 1974. Preliminary results of dust survey at the proposed North Gizlette mine site. Indianapolis, Ind.

Amax Coal Company, Division of Amax, Inc. 1975. Plan of mining and reclomation for the North Gizlette Mine. Indianapolis, Ind.

Coffman, J. L., and von Hake, C. A., eds. 1973. Earthquake history of the United States. Washington, D.C.: Department of Commerce, National Oceanic and Atmospheric Administration.

Dalstead, N. T.; Leistritz, L.; and Hertsgaard, T. A. 1974. Energy resources development in the northern Great Plains: a summary of economic impacts. Prepared for the Northern Great Plains Resources Program, Denver, Col. Fargo, N.D.: State University, Department of Agricultural Economics.

Fautin, R. W. 1977. Terrestrial vertebrates. In Final environmental assessment, Black Thunder Mine site, Campbell County, Wyoming, eds. H. L. Bergman and H. D. Marcus. Chap. X.

Hayen, R. T., and Watts, G. L. 1975. A description of potential socioeconomic impacts from energy-rezated developments on CompbezZ County, Wyoming. Prepared for the U.S. Department of the Interior, Office of Minerals Policy Development. University Station, Laramie, Wyo.: Resource Management Systems.

Hodson, W. G. 1971. Chemical analyses of groundwater in the Powder River Basin and adjacent areas, northeastern Wyoming. Cheyenne, Wyo.: Department of Economic Planning and Development.

Hodson, W. G., Pearl, R. H., and Druse, S. A. 1973. Water resources of the Powder River Dasin and adjalenll dreas, nurtheastern Wyoming. Hydrologic Investigations Attas HA-465. Washington, D.C.: U.S. Geological Survey.

Hynes, H. B. N. 1972. The ecology of running waters. Toronto: University of Toronto Press.

Keefer, W. R. 1974. Regional topography, physiography, and geology of the northern Great Plains. Open file report 74-50. Washington, D.C.: U.S. Geological Survey.

Keerer, W. R., and Hadley, R. F. 1976. Land and natural resource information and some potential environmental effects of surface mining of coal in the Gillette area, Wyoming. Geological Survey circular no. 743. Alexandria, Va.: U.S. Geological Survey.

Keefer, W. R., and Schmidt, P. W. 1973. Energy resources of the Powder River Basin, Wyoming and. Montrana. Map I-847-A. Washington, D.C.: U.S. Geological Survey. 
King, N. J. 1974. Occurrence of groundwater in the Gillette area, Campbell County, Wyoming. USGS Miscellaneous Inventory Map I-848E. Washington, D.C.: U.S. Geological Survey.

Kuchler, A. W. 1964. Potential natural vegetation of the conterminous United States. Special publication no. 36. New York: American Geographical Society.

National Petroleum Counci1. 1973. U.S. energy outlook - coal availability. Washington, D.C.: National Petroleum Council.

Northern Great Plains Resources Program. 1974a. Water Group (C) water report. Denver, Colo.

- 1974b. Surface resources work group - regional profile. Denver, Colo.

- 1976. Surface resources work group - regional profile report. Denver, Colo.

Oakes, K. M. 1976. Vertebrates of Coal Creek, Wyoming. Unpublished masters thesis. Laramie: University of Wyoming.

Packer, P. E. 1974. Rehabilitation potentials and limitations of surface-mined land in the northerm Great. Plains. USDA Forest Service general technical report INT-14. 0dgen, Utah: U.S. Forest Service.

SERNC0. 1974. Applicant's environmental assessment for a proposed gasification project in Compbezl and Converse counties, Wyoming. Prepared for Wyoming Coal Gas Company and Rochelle Coal Company. SERNCO, Iric.

Sevenson, F. A.; Miller, W. R.; Hodson, W. G.; and Visher, F. N. 1976. Water in Madison Group, Powder River Basin, Wyoming and Montana. Reston, Va.: U.S. Geological Survey.

Sharp, W. N.; McKay, E. J.; McKeown, F. A.; and White, A. M. 1964. Geology and uranium deposits of the Prompkin Buttes area of the Powder River Basin, Wyoming. Bulletin no.-1107-H. Washington, D.C.: U.S. Geological Survey.

Stenehjem, E. J., and Metzger, J. E. 1976. A fromework for projecting employment and population changes accompanying energy development. Washington, U.L.: United States tnergy Research and Development Administration.

Sundstrom, C.; Hepworth, W.-.G.; and Diem, K. L. 1973. Abundance, distribution, and food hulitis uf turumbiuin: -Bulletin no. 1?: Cheyenne, Wya.: Wyaming Game and Fish Commissian.

U.S. Bureau of the Census. 1971a. County business patterns. Washington, D.C.: U.S. Government Printing office.

- 1971b. Statistical abstract of the United States: 1071. Washington, D.C.: U.S. Government Printing Office. 
U.S. Bureau of the Census. 1973a. Governmental Organization. Census of govermments, 1972. Vol. I. Washington, D.C.: U.S. Government Printing Office.

-. 1973b. County and city data book, 1972. Washington, D.C.: U.S. Government Printing office.

U.S. Department of Housing and Urban Development, Office of Community Planning and Development. 1976. Rapid growth from energy products ideas for state and local action. Washington, D.C.: U.S. Government Printing Office.

U.S. Department of the Interior, Bureau of Land Management. 1974. Final environmental impact statement; Eastern Powder River Coal Basin of Wyoming. Washington, D.C.: U.S. Government Printing office.

- 1976a. Draft environmental impact statement for the proposed reservoir on the middi.e. fork of Powder River. Washington, D.C.: U.S. Government Printing Office.

U.S. Department of the Interior. 1976b. Endangered and threatened wildlife and plants. Fed. Regist. 41(208): 47180-98.

USGS (U.S. Geological Survey). 1974. Shazlow groundwater in selected areas in the Fort Union coal region. Open file report 74-48. Helena, Mont.

- 1975. Draft environmental statement - proposed mining and reclomation plon, Eagle Butte Mine, Amax Coal Company. Coal Lease W-0313773. Campbel1 County, Wyo.

- 1976a. Draft environmental statement - proposed mining and reclamation plan, East Gillietre. Mi.ne. Kerr-MrGe Corporation coal lcascs $W 311810, W-312311$, and $W=313663$, Campbell County, Wyo. Billings, Mont.: U.S. Department of the Interior, Geological Survey.

- 1976b. Land and natural resource information and some potential environmental effects of surface mining of coal in the Gillette area, Wyoming. U.S. Geological Survey Circular no. 743. Washington, D.C.: U.S. Geological Survey.

Wrakestraw, G. F. No date. Wyoming bald and golden eagle survey. Cheyenne: Wyoming Game and Fish Commission.

WRRI (Wyoming Water Resources Research Institute). No date. Hydrology, Laramie: University of Wyoming.

Wyoming Department of Environmental Quality. May 4, 1977. Private communication to J. N. Baird, Oak Ridge National Laburatory, Oak Ridge, Ténn.

Wyoming Department of Economic Planning and Development, Industrial Development Division. 1976. Gillette community profile. Cheyenne, Wyo. 
Wyoming Game and Fish Commission. 1971. Wyoming stream fishery classification. Cheyenne, Wyo.: Fish Division.

- 1976. Considerations for wildlife in industrial development and reclamation. Cheyenne, Wyo.

Wyoming Land Use Commission. April 22, 1977. Private communication to J. N. Baird, Oak Ridge National Laboratory, 0ak Ridge, Tenn.

Wyoming Water Planning Program. 1972. Water and related Zand resources in northeastem Wyoming. Report no. 10. Cheyenne, Wyo. 


\subsubsection{Physical environment}

\subsubsection{Physical impacts of site preparation and construction on land use}

Land use during construction is affected by clearing and grubbing, cut-and-fill operations, and construction of temporary and permanent facilities.

\section{Clearing and grubbing}

Potential clearing and grubbing, the purpose of which is to remove trees and stumps and other significant vegetation where necessary so that surveys and plant layouts can be made and elevations determined, is as follows:

1. On reclaimed strip-mined lands of New Athens Township, little clearing and grubbing should be required because the land has already been disturbed once. Clearing and grubbing of native areas will be similar to Mason County described in item 2.

2. In the generally wooded areas of Mason County, West Virginia, the merchantable timber would be cut, after which the remaining trees and shrubs would be cleared. If open burning is permitted, permits would be obtained before disposing of slash by burning. The ultimate impacts would be loss of vegetation with the probable result of increased rain runoff and. erosion.

3. In Campbell County, Wyoming, vegetation should be so sparse that no clearing and grubbing would be required.

Cut-and-fill and excavation

Culling and fllling essentially establishes the contours and drainage patterns of the plant site, including significant earthworks such as retaining dikes, ponds, and bridge abutments. Excavations for building footings, foundations, heavy equipment foundations, and basements and subbasements generally produce considerable fill that must be worked into the new contours or deposited in spoil banks. In dry weather this type of work frequently produces dusting, which is usually mitigated by sprinkling with water. When excavations are deep and penetrate the water table, they become subject to flooding. "Dewatering" of the excavation, that is, removing the water by pumping, can have two serious consequences: (1) if the pumped-out water, which is usually silty, enters a nearby water course, it can produce a suspended solids problem, and (2) the dewatering can remove water from an aquifer so that water levels in neighboring wells are affected. 
These effects can be mitigated by: (1) pumping the silt-bearing water into a retention pond so that the silt settles out before the clear effluent overflows to a watercourse and (2) monituring nearby wells and adjusting the pumping rate of dewatering to avoid drawing down the aquifer. Dewatering difficulties would disappear after completion of the foundations. Storm drainage from a newly contoured area usually contains much silt from erosion. This drainage should also be held in a retention pond before flowing to a water course. Deep excavation could result in the following:

1. In New Athens Township, the proximity to the Kaskaskia River and a high water table would probably require close attention to dewatering.

2. In Mason County, West Virginia, the proximity of the Ohio and Kanawha rivers would generally raise the water table and make dewatering a problem.

3. In Campbell County, Wyoming, dusting during excavation might be a problem because of the scarcity of water. For excavationis of moderace depen, there snould be nu dewatering problem, also because of a scarcity of water.

\section{Construction of temporary facilities}

Certain temporary construction features such as lay-down areas, cement batch plants, roads, warehouses, and sheds can increase the rainfall runoff as compared to the site in its preconstruction condition. These construction features will also have some visible impact as long as they exist. After their removal the land will be available for other purposes. The effectiveness of the land for growing vegetation will depend on its rehabilitation, which would hold true for the three surrogate sites selected.

\section{Construction of permanent facilities}

Permanent facilities would include process buildings and equipment, oftice buildings, cank farms, holding ponds, gas holders, compressor facilities, feeder pipelines, coal treatment and transportation equipment, and permanent warehouses, roads, and parking lots. The land occupied by these structures would be withdrawn permanently from its original purpose, which very likely would have been agriculture, forestry, or grazing. Rainfall runoff would be accentuated, but proper contouring and drainage could mitigate the effect.

The visual impacts of these facilities could be significant but indeterminate. Landscaping and vegetation might serve to improve the relationship between the works of man and works of nature. In Campbell County, Wyoming, the difficulty of revegetating and landscaping the property might heighten the visuạ impact.

\subsubsection{Hydrology}

\section{Surface water}

Impacts to the surface water arising during construction of a demonstration-size coal conversion facility are due primarily to disturbance of the land. An estimated 40 ha (100 acres) is to be cleared during construction. Potential impacts include infiltration, increased runoff, decreased evapotranspiration, increased erosion, and increased sedimentation. The erection of temporary 
structures such as cofferdams for intake structures and the disturbance of existing river banks can impact the hydrology and utility of the waterways. The impact of greatest concern is the increased erosion caused by the clearing of land.

At the New Athens Township site, the river currently has spoil banks that will be disturbed by the construction of intake structures. This construction and the low-lying area along the river, which will be subjected to increased erosion, could impact the Kaskaskia River. An estimate of the increase in erosion from the site can be made using a cleared slope length of $300 \mathrm{~m}$ ( $1000 \mathrm{ft}$ ) with a slope of $1 \%$. The expected sheet erosion from the construction site is estimated to be 2450 metric tons (2700 tons) per year without erosion control. If erosion control is implemented by the erection of an erosion control basin with a 2-ha (5-acre) bank, a 15-m (50-ft) slope length, and a $10 \%$ slope, the estimated sheet erosion is reduced to 410 metric tons ( 450 tons) per year. The method of arriving at this estimate is explained in the Appendix. The effect of increased erosion on the water quality is discussed in Sect. 3.1.1.4. The erosion load on the Kaskaskia River can be considerably reduced by erosion control. Without control, erosion could cause a localized sedimentation problem in the Kaskaskia navigation channel. Temporary structures such as cofferdams can also impede navigation.

At the Mason County, West Virignia, site, the plant site area is located near the valley floor on gently sloping ground. An estimate of the increased erosion during construction is 2270 metric tons (2500 tons) per year without erosion control. With an erosion bank to control the runoff, the erosion can be reduced to 370 metric tons (410 tons) per year. Uncontrolled erosion may cause some localized impact on the Ohio River. Temporary structures are not likely to be a problem on the Ohio River navigation channel.

At the Campbell County, Wyoming, site, the only surface water in the area is Donkey Creek. Making the worst-case assumption that the coal conversion plant construction is to be on the banks of Donkey Creek, an occasionally ephemeral stream, the increase in the annual erosion load for 40 ha (100 acres) cleared for construction was estimated as 270 metric tons ( 300 tons) per year without erosion control for a $1 \%$ slope, $300 \mathrm{~m}(1000 \mathrm{ft})$ long. With an erosion containment bank of $10 \%$ slope, $15 \mathrm{~m}$ (50 ft) long, and 2 ha ( 5 acres) in size, the erosion load can be estimated at 40 metric tons ( 45 tons) per year. Without erosion control, Donkey Creek would be inundated with eroded soil as a result of construction.

The annual average increase in suspended solids in the waterways of each site can be estimated using Einstein's bed-load transport theory. The resulting increases suggest that the Wyoming site is the only site that would experience a significant increase in average suspended solids as a result of construction. The analysis in the Appendix is valid only far downstream from the construction site and neglects the consideration of local effects.

Changes in runoff, infiltration, and evapotranspiration that occur as a result of construction activities are difficult to assess, but they are not likely to be significant for any of the sites considered.

\section{Groundwater hydrology}

Construction activitics can affect groundwatẹ. Characteristics such as permeability, water table level, storage capacity, water availability, recharge, discharge, and direction and 
movement of groundwater are vulnerable. Water needs as high as $2.5 \times 10^{-3}$ to $3.2 \times 10^{-3} \mathrm{~m}^{3} / \mathrm{sec}$ (40 to $50 \mathrm{gpm}$ ) during construction can be met by using either surface water or groundwater from shallow aquifers. Pumping this quantity of water from aquifers would have only minor local effects on other users of groundwater in the site areas. The important impact on groundwater is caused by the disruption of the soil at the site areas, such as removal of overburden, construction of roads and pavements, surface drainage facilities, piping and clearing of vegetation, etc. The major activities affecting groundwater characteristics and the nature of impacts at the different sites are summarized in Table 3.1.

Table 3.1. Potential impacts on groundwater during construction

\begin{tabular}{|c|c|c|c|}
\hline Construction activities & $\begin{array}{l}\text { Process/substances impacting } \\
\text { groundwater } \\
\end{array}$ & Potential impacts on groundwater & $\begin{array}{c}\text { Site areas significantly } \\
\text { affected }^{a}\end{array}$ \\
\hline $\begin{array}{l}\text { Temporary facilities such as shops } \\
\text { and storage sheds, access roads } \\
\text { and parking lots, and sanitary } \\
\text { facilities }\end{array}$ & $\begin{array}{l}\text { Watewater, solid wastes, pesticides, } \\
\text { and aerosols }\end{array}$ & $\begin{array}{l}\text { Decrease in permeability; reduction in } \\
\text { infiltration of woter - long term }\end{array}$ & Gịllette, New Athens, Lewis \\
\hline $\begin{array}{l}\text { Earth work, excavation, grading. } \\
\text { trenching, and soil treatment }\end{array}$ & $\begin{array}{l}\text { Dust, sediment, wood wastes, } \\
\text { solid wastes, pesticides, and } \\
\text { chemicals }\end{array}$ & $\begin{array}{l}\text { Soil compaction: fracturiuy aquifer: } \\
\text { changes in permeability and } \\
\text { infiltration - long-term water } \\
\text { quality }\end{array}$ & Gillette, Lewis, New Atheris \\
\hline $\begin{array}{l}\text { Foundation drainage, dewatering, } \\
\text { well points, and stream channel } \\
\text { relocation }\end{array}$ & & $\begin{array}{l}\text { Decrease of volume of water for } \\
\text { short and long periods of time }\end{array}$ & New Athens, Lewis, Gillette \\
\hline Landscaping & Nutrients and pesticides & $\begin{array}{l}\text { Increases intiltration rate and } \\
\text { storage capacity - long-term water } \\
\text { quality }\end{array}$ & Gillette, Lewis, New Athens \\
\hline 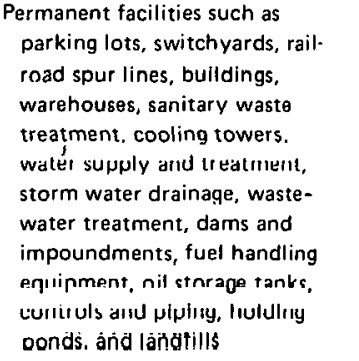 & $\begin{array}{l}\text { Solid wastes, chemical wastes, } \\
\text { and sediment spillage }\end{array}$ & $\begin{array}{l}\text { Waste discharge; leaching of trace } \\
\text { elements, chemicals; water } \\
\text { quallty change in permeability } \\
\text { and infiltration rate; and ground- } \\
\text { water contamination }\end{array}$ & Lewis, Gillette, New Athens \\
\hline
\end{tabular}

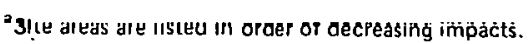

Removal of overburden and vegetation changes the infiltration characteristics of the topsoil, thereby changing the recharge to the aquifers. Construction of pavements, roads, and surface runoff drainage, buildings, and ponds will decrease the infiltration rate and can reduce the groundwater availability. Depending upon the depth of cut, the permeability of the aquifers can change and this can affect storage capacity and water availability. Removal of overburden could increase the artesian pressure in the underlying aquifers causing additional upward discharge. Dewatering can result in a depression of the water table. Fracturing of the aquifer will establish new hydraulic connections with adjoining aquifers and can affect groundwater direction with possible adverse impact. For example, the direction of groundwater flow might be reversed toward the river, and the aquifers that normally gained water from the river might now lose water to the river, causing a reduction in water levels and spring flow. This might affect agricultural and domestic uses as well as wildlife populations. This situation is serious in the Gillette area where most of the water comes from groundwater. On the other hand, it may be less serious in the New Athens and the Lewis Township areas where groundwater can be recharged from the nearby rivers. 
The direction of groundwater flow can also be accentuated toward the aquifer. A reduction in streamflow will affect aquatic life and vegetation dependent on streamflow. This situation may be more serious in the Gillette area than in the other two areas. However, these changes are likely to affect the shallow aquifers but not the deeper ones unless the cut is very deep. Shallow aquifers are the principal source of water in the New Athens and Lewis areas; somewhat deeper aquifers are the main source of water in the Gillette area. Again, in both the Gillette and Lewis areas, the dowriward movement of groundwater is slow in shallow aquifers because of the low permeability of the underlying aquifers. Therefore, the bedrock or the deeper aquifers may not be affected. In the New Athens area, both the shallow and the bedrock aquifers might be affected.

Construction of impoundments for water can raise the water table; this can be accompanied by a reduction in the hydraulic gradient and velocity of groundwater flow. The area of influence can be as far as 1 mile from the point of construction activities.

\subsubsection{Air quality}

The construction phase of the coal gasification plant can produce airborne material such as dust stirred up by vehicular traffic and earth-moving operations as well as gases emitted from vehicle exhausts. Because these sources will be near ground level, impact on air quality should be confined to the immediate vicinity of the site and should be of short duration.

\subsubsection{Water quality}

Surface water

Construction activities tend to increase the amount of suspended solids and decrease dissolved oxygen in nearby waters. Estimates of the increase in annual average suspended solids concentration for the three proposed site areas are shown in Table 3.2. The method for estimating lhe increase is explained in the Appendix. The impact of construction on the West Virginia and Illinois site areas is likely to be small. Although the annual average does not reflect peak concentrations, these maximum values are likely to be small because of the small predicted increases in the annual average concentrations.

Table 3.2. Estimated increase in annual averaye cuncentration of suspended solids in surface water ot the three proposed sites

In milligrams per liter

\begin{tabular}{llcc}
\hline & West Virginia & Illinois & Wyoming \\
\hline $\begin{array}{l}\text { Concentration of suspended solids } \\
\text { withuiul eriusiuri culıtrul }\end{array}$ & $2.5 \times 10^{-2}$ & 0.32 & 297 \\
$\begin{array}{l}\text { Concentration of suspended } \\
\text { solids with erosion control }\end{array}$ & $4.1 \times 10^{-3}$ & 0.053 & 45 \\
\hline
\end{tabular}

In the Wyoming site area the impact of construction is significant. The large increases in suspended solids assumes that the construction will be adjacent to the creek. Locating the construction away from the creek will prevent large increases in the concentration of suspended solids. 
Some hazard to water quality exists from the possibility of grease and oil being washed into the waterway. However, with the introduction of runoff control by catch basins, this impact is likely to be minimized.

\section{Impact of construction on groundwater quality}

Construction activities that affect groundwater quality are listed in Table 3.1. Natural groundwater quality will change as a result of the leaching of contaminants from the land surface. Changes in the permeability and the infiltration rate and the dilution and attenuation properties of the soil caused by construction activities will influence the leachate movement into the groundwater. It is assumed that construction activities include temporary storing of coal, oil, gases, and other chemicals. Leaked or spilled chemical products, ash disposal areas, coal piles, and holding ponds are sources of groundwater contamination. Waslewaler rrüi lemporary chemical and sanitary facilities might infiltrate the aquifer, affecting groundwater quality. Impoundment facilities in the site area, dust, and sediment production might cause excessive total dissoived solids and increases in bacterial and virus pathogens.

Leaching of toxic trace elements and mineral constituents needs attention. Landscaping in the site area can introduce nutrients and pesticides into the yruundwater and increase the infiltration rate, thus contaminating the groundwater. Changes in groundwater quality should not be serious in the Gillette area because of slow downward movement and because of relatively impermeable underlying shale. The quality of water in deeper aquiters should not be affected. Il Is likely that leachate will eventually move downgradient toward discharge points along Little Rawhide Creek or Dry Fork Little Powder River. This discharge of water could result in lower water quality in these rivers. Acid wastes should not be a problem in the Gillette area because the natural groundwater is generally slightly basic and because only a small amount of pyrite and other sulfides are present in the coal and the overburden. However, these problems may be serious in the Lewis and New Athens areas. The drawdown of water level in a well in the Lewis area may cause a decreased yield of domestic and rural water supplies in the vicinity of the plant site.

\subsubsection{Impacts on the biological environment}

\subsubsection{Impacts caused by destruction of habitat - construction phase}

General

A demonstration pipeline gas facility will result in the acquisition of from 60 to 160 ha (150 to 400 acres) of land (Sect. 1.2.1). During the construction phase of development, much of the existing habitat will be damaged, destroyed, or replaced iby llall-llade structures and construction related activities. Construction activities can induce both direct and indirect, short-term and long-term impacts on the terrestrial environment (Table 3.3).

Following completion of construction activities, vegetation can be reestablished on suitable areas; however, the vegetation type may not be the same as before construction. Permanent facilities (e.g., the plant complex, coal storage areas, holding.ponds, landfills, parking lots, and roads) will cover land that will not be available for use by most plants and animals during the operating life of the facility. When the facility ceases operation, reclamation efforts 
Table 3.3. Potential environmental impacts resulting from construction practices

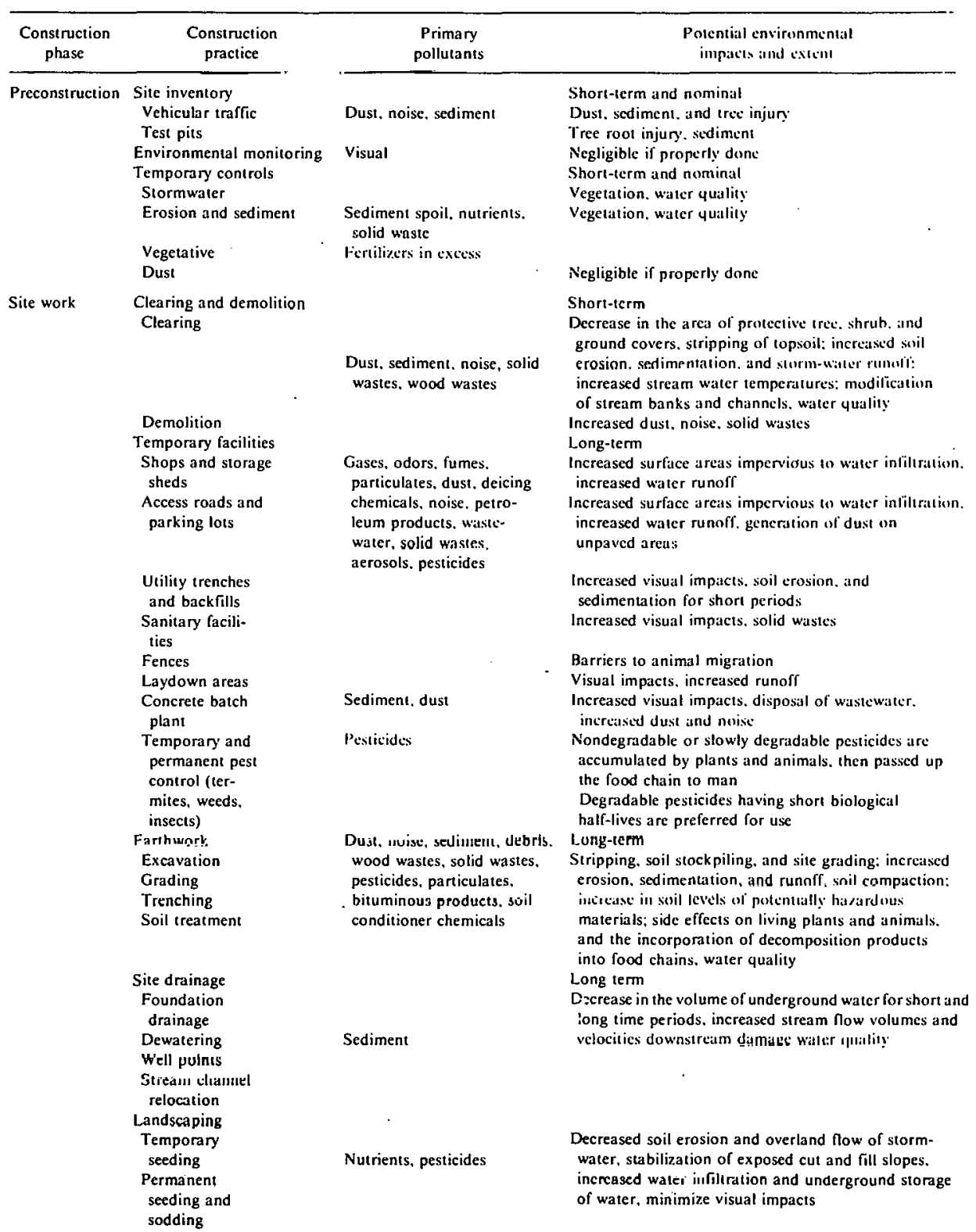


Table 3.3 (continued)

\begin{tabular}{|c|c|c|c|}
\hline $\begin{array}{l}\text { Construction } \\
\text { phase }\end{array}$ & $\begin{array}{l}\text { Construction } \\
\text { practice }\end{array}$ & $\begin{array}{l}\text { Primary } \\
\text { pollutants }\end{array}$ & $\begin{array}{l}\text { Potential cnvironmental } \\
\text { impacts and extent }\end{array}$ \\
\hline \multirow[t]{18}{*}{$\begin{array}{l}\text { Permanent } \\
\text { facilities }\end{array}$} & \multirow{5}{*}{\multicolumn{2}{|c|}{$\begin{array}{l}\text { Transportation and } \\
\text { heavy Iraffic areas } \\
\text { Parking lots } \\
\text { Switchyard } \\
\text { Railroad spur line } \\
\text { Buildings } \\
\text { Warehouses }\end{array}$}} & Long-term \\
\hline & & & Siorm-water runoff \\
\hline & & & Visual impacts, sediment, runoff \\
\hline & & & Storm-water runolf \\
\hline & & & $\begin{array}{l}\text { Long-term } \\
\text { Impervious surfaces, storm-water runoff. solid } \\
\text { wastes, spillages }\end{array}$ \\
\hline & $\begin{array}{l}\text { Sanitary waste } \\
\text { treatment }\end{array}$ & \multirow[t]{4}{*}{ Solid wastes } & Odors, discharges, bacteria, viruses \\
\hline & Cooling towers & & Visual impacts \\
\hline & Related facilities & & Long-term \\
\hline & $\begin{array}{l}\text { Cooling water intake } \\
\text { and discharge }\end{array}$ & & $\begin{array}{l}\text { Shoreline changes, bottom topography changes, fish } \\
\text { migration. benthic fauna changes }\end{array}$ \\
\hline & $\begin{array}{l}\text { Water supply and } \\
\text { treatment }\end{array}$ & Waste discharges & Water quality \\
\hline & Storm-water drainage & \multirow{6}{*}{$\begin{array}{l}\text { Sediment. trace elements, } \\
\text { noise, caustic chemical } \\
\text { wastes, sediment spoil, } \\
\text { flocculants, particulates, } \\
\text { fumcs, solid wastes } \\
\text { s) }\end{array}$} & Sediment, water quality \\
\hline & Wastewater treatment & & Sedimeul, water quality, trace clements \\
\hline & Dams and impoundments & & Dredging. shoreline erosion \\
\hline & $\begin{array}{l}\text { Rreakwaters, jetties. etc. } \\
\text { Futel handling equipment } \\
\text { Oil storage tanks, controls, } \\
\text { and piping }\end{array}$ & & $\begin{array}{l}\text { Circulation patterns in the waterway } \\
\text { Spllages, tire, and vissial impacts } \\
\text { Visual limpacis }\end{array}$ \\
\hline & $\begin{array}{l}\text { Conveving systems (çranes, } \\
\text { livislu, cliütsó) }\end{array}$ & & Visual impacts \\
\hline & $\begin{array}{l}\text { Waste handling equipment } \\
\text { (incinerators, wood } \\
\text { chippers. trash compactors) }\end{array}$ & & Noise and visual impacts \\
\hline & Sccurity fencing & \multirow[b]{2}{*}{ Sediments, wood wastes } & Long-term \\
\hline & $\begin{array}{l}\text { Access road } \\
\text { Fencing }\end{array}$ & & $\begin{array}{l}\text { Increased runoff } \\
\text { Barriers to animal movements }\end{array}$ \\
\hline \multirow[t]{10}{*}{$\begin{array}{l}\text { Project } \\
\text { closeout }\end{array}$} & $\begin{array}{l}\text { Removal of temporary } \\
\text { offices and shops }\end{array}$ & & Short-term \\
\hline & Demolition & \multirow{2}{*}{ Noise, dust, solid wastes } & Noise, solid waste, dusi \\
\hline & Relocation & & Storm-water runoff, trafuc blockages, soil compaction \\
\hline & Site restoration & \multirow[t]{2}{*}{. } & Shorl-term \\
\hline & Finish grading & & Sediment, dust, soil compaction \\
\hline & Topsoiling & \multirow[t]{4}{*}{ Sediment, dust } & Erosion. sediment \\
\hline & Fcrilizing. & & Nutrient runotf, water quality \\
\hline & Sediment controls & & Vcgctation \\
\hline & Preliminary startup & & Short-term \\
\hline & $\begin{array}{l}\text { Cleaning } \\
\text { Flushing }\end{array}$ & $\begin{array}{l}\text { Nuirients, petroleum } \\
\text { products }\end{array}$ & Watèr quality, oils, phosphate and other uutrtents \\
\hline
\end{tabular}

Source: M. S. Salk and S. G. DeCicco. 1978. Environmental monitoring handbook for coal conversion jacilities. UKNL-\$3 i9, i iable 3.1.1, p. 3.1.1-2. Oak Ridge Tcnn.: Oak Ridgo National Laboratory.

can restore the affected land to various vegetation types if another use is not found for the existing facilities.

Although some organisms may be able to use habttats crealed during cunstruction activity, removal or damage of vegetation and related harassment will result in negative impacts to many animails. Many vertebrates will be torced tó leave the conslirucllun drea, alld cailiying capaci ties of adjacent or nearby areas may not be sufficlent to sustaln bulh disjilaced and resident animals. Some of the more mobile animals that disperse from the site during the period of greatest construction activity may be able to return as construction ceases and landscaping is completed, but it is reasonable to assume that an unquantifiable number of animals that originally resided within the plant boundary will be lost.

Construction activities are also likely to cause some animal mortality by road kills (Galayda 1970; Hodson 1960). Barriers such as fencing, canal ditches, tall stacks, large buildings and other man-made obstacles can be expected to cause additional mortality (Avery et al. 1976; 
Cochran and Graber 1958; Stout and Cornwe11 1976). Other impacts may be induced by clearing rights-of-way for pipelines, new roads, and other off-site facilities; by mowing; by dust and sediment from access roads; by accidental leaking or spilling of petroleum or other toxic subslances; and by the use of pesticides and herbicides to control unwanted pests and weeds (Buffington 1974; Dustman and Stickel 1966; Friend and Trainer 1970; George 1960; Tucker and Crabtree 1970; U.S. Environmental Protection Agency 1976).

If construction activities coincide with major reproduction and/or migration seasons, greater mortality to some organisms is likely. Potential impacts identified herein should be minor if proper control measures are taken.

The construction of a demonstration facility can be expected to result in an increase in human population for the affected area (Sect. 3.3). Greater population density will magnify potential impacts to terrestrial biota. Such impacts may include (1) greater hunting pressure (Neil et al. 1975); (2) destruction of habitat by four-wheel drive vehicles (Neil et al. 1975); (3) increased demand and development of recreational facilities, shopping centers, and other businesses;

(4) problems of waste disposal; and/or (5) other problems.

Area impacts

Terrestrial biota at any of the three proposed areas in Illinois, West Virginia, and Wyoming (Sects. 2.1, 2.2, and 2.3, respectively) are not expected to be irreversibly affected as a result of habitat destruction during the construction phase of development. Understandably, some loss of habitat and animal mortality will be unavoidable, but it is assumed that existing populations in and around the proposed plant areas will be sufficient to maintain viable populations of all affected biota.

Careful siting of the facilities at each of the three proposed areas will lessen some of the biological impacts. Ideally, the facilities should be constructed on previously disturbed land (e.y., nonreclaimed surface-mined land), because the use of an already disturbed area means that another relatively undisturbed area will not be needed for the project. Habitat to be lost should be the most common within the proposed areas so that the rarer habitat types are protected as much as possible (Sects. 2.1.1, 2.2.1, and 2.3.1). Using these criteria, the best plant sites in St. Clair County (Illinuis) ale ayricullural flelds or surtace-moned lands; in Mason County (West Virginia), old fields or agricultural fields; and, in Campbell County (Wyoming), short- and midgrass prairle or surface-mined lands. Efforts should be made to protect riparian forests in all three counties because this habitat type is relatively rare and important to many of the local animals (Sects. 2.1.9.7, 2.2.9.1, and 2.3.9.1).

Several endangered species have ranges that include St. Clair (Illinois), Mason (West Virginia), and Campbell (Wyoming) counties. However, surveys have revealed no threatened or endangered species within any of the tuwnships in question, and suitable habitat for most of them is either not available or is very limited (Sects. 2.1.9.3, 2.2.9.3, and 2.3.9.3). Damage or destruction of any habitat considered to be critical to the survival of a species should be avoided. Such habitats and associated species include: 
1. prairie-dog towns (Wyoming) - black-footed ferret (Mustella nigripes);

2. riparian woodlands along the Belle Fourche (Wyoming), Mississippi, and Kaskaskia (Illinois) rivers - southern bald eagle (Halialltus Zeucocephalus);

3. limestone covers or other potential hibernating, roosting, or wintering areas (Illinois and West Virginia) - Indiana bat (Myotis sodalis);

4. deep caves or other potential hibernating, roosting, or wintering areas (Illinois) gray bat (Myotis grisescens); and

5. Sheer cliffs along the Mississippi River (Illinois) - peregrine falcon (Falco peregrinus).

If critical habitats are avoided, the construction of a demonstration facility is not expected to contribute to the decline of any threatened or endangered species in the three proposed areas.

In the Campbell County, Wyoming, area, the sage grouse (Centrocercus urophasianus) and the pronghorn (Antizocapra americana) deserve special consideration because of their population status and habitat requirements. Although not listed as threatened or endangered, both are important game species within the area. Locally, the sage grouse population is sinall and Is dependent on established strutting grounds for courtship and copulation behavior and on riparian habitat for brooding areas (Fautin 1976): Thus efforts should be made to identify and protect both established strutting grounds and riparian habitat. Northwestern Wyuming contains about one-haif of the nation's pronghorn population, and Campbell county is an important management area. Because floodplain and ravine habitats are recognized as being important areas for food and cover (Fautin 1976), they should be protected whenever possible. Pronghorns also require unobstructed open terrain as a basic component of their life style. Fencing of antelope movement areas can be disastrous to pronghorns, and advanced planning to document movement routes is recommended. If fencing is necessary, the least restrictive type is a three- or four-wire fence with a smooth bottom wire at least $40 \mathrm{~cm}$ (16 in.) from the ground (Wyoming Game and Fish Department 1976).

\subsubsection{Impacts caused by noise - construction phase}

Noise during construction at the three proposed areas (Sects. 2.1.1, 2.2.1, and 2.3.1) can originate from operation of heavy equipment, use of loudspeaker systems, blowing of whistles and horns, riveting, use of jackhammers, blasting, etc. (Sect. 2.1.7). All noise levels resulting from construction activities will be regulated by the Noise Control Act. of 1972, the 0ccupational safety and Health Act of 1970, and other applicable Federal, state, and local regulations (Sect. 2.1.7).

Potential biological impacts inciude harassment and increased levels of stress in wildlife. Some species of wildlife may respond to noise by dispersing to other areas. Competition for available resources within areas receiving dispersed animals could result in decreased survival.

High-intensity noises from blasting, horns, whistles, or other sources of annoyance can interfere with sleeping patterns of local residents. Such potential impacts during construction should be minor, especially if noise levels are minimized by appropriate control measures (Sect. 3.1.5). Additional information on potential noise impacts is presented in Sect. 3.2.2.2. 


\subsubsection{Potential biological impacts caused by atmospheric effluents - construction phase}

During the construction of a demonstration pipeline gas facility, sources of air pollution at the three proposed areas may include:

1. fugitive dust created by excavation, wind erosion of exposed land, and movement of vehicles over dirt roads;

2. dust and particulate matter from concrete plants;

3. increased vehicular traffic;

4. burning of waste materials such as felled trees, brush, and garbage; and

5. application of pesticides and herbicides for control of pests and weeds.

Potential biological impacts from air emissions can be minimized by strict compliance with all Federal, state, and local regulations (Sects. 2.1.6, 2.2.6, and 2.3.6). Although some sensitive individuals may be adversely affected by fugitive dust, particulates, or other emissions, biological impacts should be short-term and localized. No significant long-term impacts at the species or community level are expected. Caution is advised, however, in the use of persistent pesticides or herbicides because these may be passed through food chains and accumulate to potentially harmful levels in some high-level consumers (Buffington 1974; Dustman and Stickel 1966). Whenever possible, the use of nonpersistent pesticides or herbicides is recommended (Sect. 3.1.5).

\subsubsection{Construction impacts on the aquatic environment}

Potential ecological impacts on aquatic environments from construction activities for a pipeline gas demonstration plant are summarized in Table 3.4. The majority of potentially adverse effects are associated with the clearing of land, which alters patterns of runoff and can cause erosion and siltation in streams and rivers downstream from the facility site. Additional impacts are associated with excavation, trenching, operation of heavy equipment, use and discharge of water, and landscaping activities.

\section{Potential impacts of erosion and sedimentation}

Construction activities that introduce large sediment loads càn adversely affect aquatic communities. In addition to being aesthetically displeasing, turbidity reduces ligh penetration, thereby reducing primary productivity. Because turbid waters absorb sunlight nearer the surface, they warm more rapidly at the surface than do clearer waters. In addition to sediments, construction runoff can introduce nutrients, organic matter, and sometimes toxic substances such as pesticides into receiving waters. These materials (and reduced primary productivity) often cause depletion of oxygen downstream from construction sites. Deposition of suspended solids can eliminate certain benthic communities by burying plants and animals, altering the substrate, and clogging gills and food-collecting structures of aquatic insects (Gammon 1970; Cordone and Kelley 1961; Chutter 1969).

The effects of suspended sediments on fish are summarized by Jones (1964) and the European Inland Fisheries Advisory Commission (EIFAC 1965). Such effects include (1) damage and thickening of gill epithelia, causing impaired respiratory and salt-regulatory function; (2) reduction 
Table 3.4. Summary of potential impacts of construction on the aquatic environment

\begin{tabular}{|c|c|c|}
\hline Perturhation & Physical and chemical impacts & Hiological and ccological impacts \\
\hline \multirow[t]{7}{*}{$\begin{array}{l}\text { Land clearing and vegeta. } \\
\text { tion removal }\end{array}$} & $\begin{array}{l}\text { More rapid runoff } \\
\text { Higher peakflows in streams } \\
\text { Scouring and channel erosion }\end{array}$ & Washout of benthic organisms \\
\hline & $\begin{array}{l}\text { Reduced filtration of precipitation, } \\
\text { producing higher concentrations of } \\
\text { air pollutants and lower } \mathrm{pH} \text { of run- } \\
\text { off }\end{array}$ & $\begin{array}{l}\text { Toxic effects of rainwater } \\
\text { contaminants }\end{array}$ \\
\hline & $\begin{array}{l}\text { Increased runoff } \\
\text { Decreased infiltration to ground- } \\
\text { water }\end{array}$ & \\
\hline & $\begin{array}{l}\text { Lower baseflow, producing reduced } \\
\text { dilution capacity, higher tempera- } \\
\text { tures, and lower dissolved oxygen }\end{array}$ & $\begin{array}{l}\text { Sublethal or lethal effects on } \\
\text { aquatic biota; shifts in com- } \\
\text { munity structure }\end{array}$ \\
\hline & Erosion & \\
\hline & $\begin{array}{l}\text { Siltation and sedirnent deposition } \\
\text { downstream. causine } \\
\text { Turbidity and reduced light pene- } \\
\text { tration }\end{array}$ & $\begin{array}{l}\text { Smothering of flsh eggs and benthic } \\
\text { nrganisms, rnverino nf mar.rnnhyte } \\
\text { beds, habitat destruction } \\
\text { Reduced primary productivity }\end{array}$ \\
\hline & Nutrient mobilization & Stimulatiun ol plante growth \\
\hline Excavation and trenching & Groundwater disruption & $\begin{array}{l}\text { Impacts vary with type of distur- } \\
\text { bance }\end{array}$ \\
\hline Heavy equipment operation & $\begin{array}{l}\text { Discharge of oil and grease } \\
\text { Erosion impacts (sec above) }\end{array}$ & Toxicity and aesthetic effects \\
\hline \multirow[t]{2}{*}{ Water use and discharge } & $\begin{array}{l}\text { Discharge of alkaline limewater from } \\
\text { concrete batch plant }\end{array}$ & $\begin{array}{l}\text { Population changes or death of } \\
\text { organisms }\end{array}$ \\
\hline & Discharge of sanitary wastes & Nutrient enrichment \\
\hline Landscaping & $\begin{array}{l}\text { Release of nutrients, herbicides, and } \\
\text { pesticides }\end{array}$ & $\begin{array}{l}\text { Enrichment of streams; eutro- } \\
\text { phication of lakes; toxicity } \\
\text { effects }\end{array}$ \\
\hline
\end{tabular}

in resistance to other stresses such as disease, toxic chemicals, reduced dissolved oxygen, and increased temperature; (3) reduced food availability and impaired feeding behavior; (4) depressed growth rates; and (5) potential reduction in reproductive capability caused by blocked migration. siltation of spawning beds, suppression of breeding behavior, and by increased egg mortalities as a result of burial and reduced dissolved oxygen availability.

In 1972 the National Academy of Sciences (NAS 1973) established water quality criteria for suspended solids. The NAS cited work by EIFAC (1965) and Buck (1956) indicating that waters with turbidities above 80 to $100 \mathrm{mg} / \mathrm{liter}$ were unlikely to support good freshwater fisheries:

Aquatic communities should be protected if the following maximum concentrations of suspended solids exist:
High level of protection
Moderate protection
$26 \mathrm{mg} / 1 \mathrm{itch}$
Low level of protection
$80 \mathrm{mg} / 1$ iter
Very low level of protection
$400 \mathrm{mg} / 1$ iter
$>400 \mathrm{mg} / 1$ iter

Estimates of the average annual increase in sediment loadings for the three sites are given in the Appendix for the case in which no erosion controls are applied and the case in which erosioncontrol embankments are constructed. 'These estimates indicate that the sediment loadings caused by construction would be most significant for the Wyoming site where, if the facility were located near Donkey Creek, sediment loadings would increase by $297 \mathrm{mg} / 1 \mathrm{iter}$ in the uncontrolled case. This is an annual average and does not reflect peak loadings resulting from precipitation events. 
Erosion controls were projected to reduce the average increase in sediment loadings to about $45 \mathrm{mg} / 1$ iter. Erosion could be minimized to an even greater extent, however, by avoiding or limiting land clearing near Donkey Creek.

For the West Virginia and Illinois sites, the projections in the Appendix indicate that, because of the substantial flows and dilution capacity, erosion from construction would increase turbidity less than $1 \mathrm{mg} / \mathrm{liter}$. Although effects on aquatic biota would be locally restricted, erosion would contribute substantial tonnages of sediments to the Ohio and Kaskaskia rivers, which contributes to the filling of channels and basins.

In summary, the projected sediment loadings at all three sites warrant measures to control erosion. With adequate erosion control measures, impacts on aquatic systems of increased sedimentation resulting from construction activities should be localized and limited to the construction period.

Potential impacts of sanitary wastes and other construction activities

During construction sanitary wastes will most likely be handled by chemical toilets. Eventually the pipeline gas demonstration plant's wastewater treatment system will handie sanitary wastes with process wastes, but this waste-treatment system is unlikely to become operational during the construction period. Waste loadings are calculated as follows: a person excretes roughly $75 \mathrm{~g} /$ day dry weight of organic matter, $8 \mathrm{~g} /$ day of nitrogen, and $1.3 \mathrm{~g} /$ day of phosphorous (Fair et a1. 1968). Assuming that the construction work force, at a peak of 1500 to 2000 persons, leaves $50 \%$ of its daily waste load at the construction site, waste loadings contributed to. chemical toilets or the wastewater system would be roughly: 56.2 to $75.3 \mathrm{~kg} /$ day (124 to $166 \mathrm{lb} /$ day) of organic matter (ultimate BOD), 5.9 to $8 \mathrm{~kg} /$ day $(13$ to $18 \mathrm{lb} /$ day) of nitrogen, and 1.0 to $1.3 \mathrm{~kg} /$ day $(2.2$ to $2.9 \mathrm{lb} /$ day $)$ of phosphorous.

The impact of these waste loadings will depend on the means of disposal. Because the ultimate disposal of waste from chemical toilets is unknown, this impact cannot be predicted.

The impacts of construction activities will depend largely on the practices employed. Waste oil and lubricants should be handled properly and not disposed of on the construction site. Wastewater derived from concrete production and/or washing operations should be discharged to stormwater holding basins and neutralized if necessary. Use of pesticides and herbicides in landscaping should be avoided or kept to a minimum. Fortunately, measures to control erosion will also limit the dispersal of grease, oil, and biocides that are unavoidably released during construction.

Excavation and trenching may cause localized disruption of groundwater. Such impacts are relatively minor and should be minimized by proper site planning and preconstruction monitoring. 


\subsubsection{Socioeconomic effects}

\subsubsection{Employment and population changes}

\section{Direct employment}

About 1500 to 3000 man-years over a 3-year period will be required to construct a demonstration plant (see Sect. 1.2.1.1 for a description of the type of plant, in terms of daily output, water requirements, etc., that would need this amount of construction manpower). Assuming that the work force over the 3-year period is distributed in the proportions of $0.2,0.4$, and 0.4 by year, the annual employment at the plant will be as shown in column 2 of Table 3.5. Peak employment will be reached in the second year; the level of employment will therefore not increase in year 3 (column 3 of Table 3.5).

Table 3.5. New jobs creared for St. Clair Lounty, Illịnọ̣s (çonstruction ohasel

\begin{tabular}{cccccc}
\hline Year & $\begin{array}{c}\text { racility } \\
\text { employment }\end{array}$ & $\begin{array}{c}\text { Change in } \\
\text { basic employment }\end{array}$ & Mul liplier & $\begin{array}{c}\text { Change in } \\
\text { total employment }\end{array}$ & $\begin{array}{c}\text { Total } \\
\text { new jobs }\end{array}$ \\
\hline 1 & $300-600$ & $300-600$ & 1.75 & $525-1050$ & \\
2 & $600-1200$ & $300-600$ & 1.75 & $525-1050$ & $1050-2100$ \\
3 & $600-1200$ & 0 & 1.75 & 0 & $1050-2100$ \\
\hline
\end{tabular}

\section{Secondary employment}

Employment multipliers estimated by Stenehjem and Metzger (1976) for St. Clair, Mason, and Campbell countics are, respectively, 2.5, 1.1, and 1.7 (Sect. 2). Employment multiplier effects are usually fully realized only in the operations phase. Construction employment is too short lived to create as much secondary employment as operations employment. But it seems likely that some secondary employment increases will occur in the construction phase. Accordingly, it is assumed that the amount of secondary employment created for each new construction job at the plant will be half the amount created for each new operations job. In other words, the multipliers for the construction phase are assumed to be 1.75, 1.05, and 1.35 for St. Clair, Mason, and Campbell counties respectively. The results of applying these multipliers to basic construction employment estimates for a plant are shown in Tables 3.5, 3.6, and 3.7.

Table 3.6. New jobs created for Mason County, West Virginie (construction phase)

\begin{tabular}{ccccccc}
\hline Year & $\begin{array}{c}\text { Facility } \\
\text { employment }\end{array}$ & $\begin{array}{c}\text { Change in } \\
\text { basic employment }\end{array}$ & Multiplier & $\begin{array}{c}\text { Change in } \\
\text { total employment }\end{array}$ & $\begin{array}{c}\text { Total } \\
\text { new jobs }\end{array}$ \\
\hline 1 & $300-600$ & $300-600$ & 1.05 & $315-630$ & $315-630$ \\
2 & $000-1200$ & $300-600$ & 1.05 & $315-630$ & $630-1260$ \\
3 & $600-1200$ & 0 & 1.05 & 0 & $630-1260$ \\
\hline
\end{tabular}

Table 3.7. New jobs created for Campbell County, Wyoming (construction phase)

\begin{tabular}{cccccc}
\hline Year & $\begin{array}{c}\text { Facility } \\
\text { employment }\end{array}$ & $\begin{array}{c}\text { Change in } \\
\text { basic employment }\end{array}$ & Multiplier & $\begin{array}{c}\text { Change in } \\
\text { total employment }\end{array}$ & $\begin{array}{c}\text { Total } \\
\text { new jobs }\end{array}$ \\
\hline 1 & $300-600$ & $300-600$ & 1.35 & $405-810$ & $405-810$ \\
2 & $600-1200$ & $300-600$ & 1.35 & $405-810$ & $810-1620$ \\
3 & $600-1200$ & 0 & 1.35 & 0 & $810-1620$ \\
\hline
\end{tabular}


Estimates of the total new population that will result from plant construction were obtained as follows: (1) the total number of new jobs (both basic and secondary) caused by plant construction was compared to the estimated number of local (i.e., in the county) employables, (2) the difference between the number of new jobs and the number of local employables gave an estimate of the number of nonlocal (i.e., out of the county) workers who will be employed at the plant, and (3) the number of nonlocal workers was multiplied by a factor (1.9) suggested by Stenehjem and Metzger (1976) that estimates the number of family members who will accompany the workers if they move into the area.

Estimates of the total number of new jobs were presented in Tables 3.5, 3.6, and 3.7 above. Estimates of the number of local employables, which are given in Tables 3.8, 3.9, and 3.10, were calculated by (1) taking one-fourth of Stenejhem's and Metzger's (1976) estimates of local employables in each county (these estimates are given in Sects. 2.1.9, 2.2.9, and 2.3.9) and (2) subtracting the number of new jobs created annually by the plant out of the pool of one-

fourth of the local employables. Only one-fourth of Stenejhem's and Metzger's (1976) estimate of local employables was used because not all of the local employables will be able or wish to fill the jobs created by the plant. One-fourth of the total local employables is probably a low estimate of the number who could or would take plant or plant-generated employment. Using this assumption might therefore tend to overestimate the number of workers coming from outside the county.

The amount of population increase associated with the nonlocal work force may also be overestimated if some of the nonlocal workers will commute from adjacent counties. In St. Clair County, for example, all of the nonlocal work force could be expected to commute. Even though the method used would overestimate the population increase for St. Clair County, no population increase is predicted. Thus it is relatively certain that St. clair county will experience no population change as a result of plant construction.

The amount of population change predicted for Mason County, like that for St. Clair County, may tend to be an overestimate because of Stenejhem's and Metzger's (1976) definition of local workers as only in-the-county workers. Because it is likely that some of the nonlocal (i.e., out of Mason County) work force will be supplied by commuting workers, the upper end of the range of estimated population increase is unlikely to be reached. Population increases of the magnitudes at the lower end of the estimated range are much more likely.

Because of the large size of Campbell County and the isolated location of Gillette, very few workers will commute from outside Campbell County. In contrast to St. Clair County and Mason County, almost all of the nonlocal work force will move into Campbell County. Thus the upper end of the range of estimated population increase will probably be reached in Campbell County. Another reason to expect larger plant-generated population increases in Campbell County is that there are a number of current and planned energy development projects in the county. The supply of local labor will go not only to these projects but also to a demonstration plant; making it necessary to recruit a higher proportion of nonlocal labor. 
Table 3.8. Population change for St. Clair County, Illinois (construction phase)

\begin{tabular}{|c|c|c|c|c|c|c|}
\hline \multirow[b]{2}{*}{ Year } & \multicolumn{2}{|c|}{ New Jobs } & \multirow[b]{2}{*}{$\begin{array}{c}\text { Total local } \\
\text { employables }^{a}\end{array}$} & \multirow{2}{*}{$\begin{array}{l}\text { Nonlocal } \\
\text { workers }\end{array}$} & \multicolumn{2}{|c|}{ New population } \\
\hline & $\begin{array}{l}\text { Annual } \\
\text { change }\end{array}$ & $\begin{array}{c}\text { Annual } \\
\text { total }\end{array}$ & & & $\begin{array}{l}\text { Annual } \\
\text { change }\end{array}$ & $\begin{array}{c}\text { Annual } \\
\text { total }\end{array}$ \\
\hline 1 & $525-1050$ & $525-1050$ & 2400 & 0 & 0 & 0 \\
\hline 2 & $525-1050$ & $1050-2100$ & $2343-1818$ & 0 & 0 & 0 \\
\hline 3 & 0 & $1050-2100$ & $2396-1346$ & 0 & 0 & 0 \\
\hline
\end{tabular}

${ }^{a}$ Calculated by adding one-fourth new local employables to the number given by $E$. J. Stenehjem and J. E. Mctzger (1J76. A tramework for projecting employment and population changes accompanying energy development. Prepared for the Enerav Research and Dcvclonment Administration.) and subtracting annual changes in new jobs available. Washington, D.C.

Table 3.9. Population change for Mason County, West Virginia (construction phase)

\begin{tabular}{cccccccc}
\hline Year & \multicolumn{2}{c}{ Now jobs } & & Total local & Nonlocal & \multicolumn{2}{c}{ New population } \\
\cline { 2 - 5 } & $\begin{array}{c}\text { Annual } \\
\text { change }\end{array}$ & $\begin{array}{c}\text { Annual } \\
\text { total }\end{array}$ & & employables & workers & $\begin{array}{c}\text { Annual } \\
\text { change }\end{array}$ & $\begin{array}{c}\text { Annual } \\
\text { total }\end{array}$ \\
\hline 1 & $315-630$ & $315-630$ & 509 & $0-121$ & $0-230$ & $0-230$ \\
2 & $315-630$ & $630-1260$ & $232-38$ & $83-592$ & $158-1125$ & $158-1355$ \\
3 & 0 & $630-1260$ & $49-49$ & 0 & 0 & $158-1355$ \\
\hline
\end{tabular}

${ }^{\theta}$ Calculated by adding one-fourth new local employables to the number given by $E$. J. Stenehjem and J. E. Metzger (1976. A framework for projecting employment and population changes accompanying energy development. Prepared for the Ënergy Research and Development Administration.) and subtracting annual changes in new jobs available., Washington, D.C.

Table 3.10. Population change for Campbell County, Wyoming (construction phase)

\begin{tabular}{|c|c|c|c|c|c|c|}
\hline \multirow[b]{2}{*}{ Year } & \multicolumn{2}{|c|}{ New jobs } & \multirow{2}{*}{$\begin{array}{l}\text { Total local } \\
\text { emnlnyahlesa }\end{array}$} & \multirow{2}{*}{$\begin{array}{l}\text { Nonlocal } \\
\text { wnrkers }\end{array}$} & \multicolumn{2}{|c|}{ New population } \\
\hline & $\begin{array}{l}\text { Annual } \\
\text { change }\end{array}$ & $\begin{array}{c}\text { Annual } \\
\text { total }\end{array}$ & & & $\begin{array}{l}\text { Annual } \\
\text { change }\end{array}$ & $\begin{array}{c}\text { Annual } \\
\text { total }\end{array}$ \\
\hline 1 & $405-810$ & $405-810$ & 153 & $252-657$ & $479-1248$ & $479-1248$ \\
\hline 2 & $405-810$ & $810-1620$ & 25 & $380-785$ & $722-1492$ & $1201-2740$ \\
\hline 3 & 0 & $810-1620$ & 31 & 0 & 0 & $1201-2740$ \\
\hline
\end{tabular}

acaloulated by adding one-four hh new lucal employabies to the number given by $t . J$. Stenehjem and J. E. Metzger (1976. A framework for proiecting emplovment and population changes accompanying energy development. Prepared for the Energy Research and Development Administration.) and subtracting annual changes in new jobs available. 'Washington, D.C. 


\subsubsection{Impacts on surrogate sites}

The assessment of socioeconomic impacts proceeds on the basis of a comparison between likely increases in the demands for local goods and services (both public and private) brought about by the population inflow that is directly or indirectly attributable to the gasification demonstration facility and the perceived ability of the local economic and community structure to respond to these increased demands. Section 3.1.3.1 provides the basic information needed to assess the likely increase in demands, and the community descriptions of Sect. 2 provide the required information for supply-side judgments. These two sources of information are combined here to arrive at conclusions concerning the probable impacts of siting the conversion demonstration facility in the three counties selected as surrogate sites. For convenience, the areas of potential impact for each county are classified as those that are expected to experience a significant effect and those that are not. Again, we emphasize that the procedures that lead to these conclusions involve many assumptions and abstractions. Consequently, the results of such analysis should always be interpreted with caution.

\section{St. Clair County}

The results reported in Sect. 3.1.3.1 indicate that St. Clair County will experience no inflow of population as a result of locating a coal gasification demonstration facility there. Consequently, significantly increased demands for housing, health care, school facilities, and other necessities will not be generated. Instead, the primary socioeconomic impacts of facility construction will be the favorable effects of decreasing unemployment and overall stimulation of local industries that are directly or indirectly linked to the input needs of the proposed facility. This lack of adverse socioeconomic impact stems, of course, from the relatively developed state of the industrial and public service capacities of the area.

Mason County

The addition of between 315 and 630 new jobs in the first year of construction followed by the 630 to 1260 jobs created by the facility in the following 2 years should stimulate the depressed economy of the Mason County site, which should reduce the high unemployment rate characteristic of the area and slow or possibly reverse the net migration out of the region. The additional income and employment opportunities represent a favorable socioeconomic impact attributable to the siting of the demonstration facility in this area.

Against this beneficial effect must be weighed the potentially adverse effects that a population inflow of between 0 and 230 persons in the first year of construction followed by an additional 158 to 1125 persons in the second year might exert on the local community. Although this possible inflow does not appear to be large in absolute terms, the relatively small size of the existing communities in the county makes it potentially important. For example, the upper limit of this range in the second year of construction is $18 \%$ of the population of Point pleasant, the largest town in Mason County; and it is approximately $5 \%$ of the total population of the county as a whole in 1970. Therefore, while the siting decision is not likely to result in boom-town growth conditions, it is possible that some adverse impacts may be generated.

The principal areas in which excess demands are likely to occur are housing and education. Figures reported in Sect. 2 indicate vacancies of only 82 sale and 164 rental housing units. 
Table 3.9 in Sect. 3.1.3.1 indicates that as many as 592 nonlocal workers might relocate in the Mason County area during the second year of construction. With one-fourth of the existing units classified as substandard and a relatively large proportion of trailers, a shortage of housing may develop in the area.

With regard to the increase in the demand for educational services that might be generated, the maximum projected inflow of 713 workers in the first 2 years of the construction period would imply an additional 559 children if we apply the average percent of relocating workers that bring their families (49\%) and the average number of children per family (1.6) reported in The Constmuction Worker Profile (Mountain West Research 1975, pp. 18-24). This figure represents $.8 .6 \%$ of the total school enrollment for Mason County as a whole. Section 2 indicates that the school system currently contains no excess capacity; such an inflow could therefore place strains on the educational systems in the area.

Other components of the local infrastructure which might be affected by the population inflow include the transportation network, the health care delivery system, the police and fire protection system, the existing recreational facilities, and the water supply and wastewater treatment systems. The likelihood and severity of the potential impacts in these areas, however, are expected to be considerably less than those that are anticipated in the areas of housing and educational services. The transportation system in the region is not well developed (Sect. 2), so that some additional strains may be expected. Similarly, the existing health care facilities may experience some overcrowding, but additional facilities are available in ohio within driving distance. Some expansion of police and fire protection services might be required if maximum inflows are experienced. Recreational opportunities, water supply, and wastewater treatment facilities appear to be adequate with existing capacities and plans for expansion. Overall, the adverse socioeconomic impacts expected to result from construction of a gasification demonstration facility in Mason County range from relatively small to moderate, depending on the actual magnitude of the population inflow experienced.

Campbell County

A demonstration plant located in Campbell County would probably increase the population of the county by 1200 to 2700 people. From baseline descriptions of Campbell County (Sects. 2.3.8, 2.3.9, and 2.3.10), it is clear that a number of service areas are inadequate to meet the demands of the present population. Added population will put further stress on these areas. The currently inadequate service areas include housing, sewerage, and health care. Housing rents and prices are high, and mobile homes are the only available option for most newcomers. Sewers cannot currently handle peak demands. There are shortages of all types of health care personnel, and present residents often commute long distances to obtain health care.

Recreation facilities, water supply, police and fire protection, and the condition of roads were described as marginally adequate at present. The addition of new population may create more demand than can be supplied in these areas also.

Schools would probably be affected least by construction of the plant. Schools now have an excess capacity of 280 at the elementary level and of 320 at the high school level. Junior high schools are currently overcrowded, but planned expansions will add an excess capacity of 
300 at these grade levels. Planned expansions will also add a capacity for 550 more students at the elementary level and 320 more at the high school level.

Construction of a plant would increase employment opportunities in Campbell County. Because unemployment is already at a low level there, however, such opportunities would benefit Campbell

County less than more economically depressed areas. More diversification of the economy, which is currently based almost entirely on agriculture and energy developments, would be desirable for the long-term stability of Campbell County. A demonstration plant, however, would not provide such diversification.

A number of other energy projects are now under construction, are operating, or are planned for Campbell County. While the impacts of constructing a demonstration plant would be smaller than would the impacts of larger-scale projects, the cumulative impacts of all the projects together are likely to be substantial.

\subsubsection{Summary of construction-related socioeconomic impacts}

Socioeconomic impacts are generated by increased demands for the goods and services required by the gasification facility and its employees. To the extent that local supply sources exist and are capable of responding to these increased demands, the community will experience the generally beneficial impacts of increased sales, income, and employment. But to the extent that local supply sources do not exist or are poorly developed, supply/demand imbalances will be created, and the community will experience the adverse impacts associated with boom-town growth (overcrowded schools, unavailability of housing, health care, municipal services, etc.). Consequently, net beneficial effects are more likely to be realized in a developed region that exhibits some excess capacity in the existing infrastructure and that is capable of supplying the labor needs of the gasification facility from a pool of local unemployed workers. Conversely, net adverse effects are more likely to be realized in isolated undeveloped communities that are not equipped to adjust to the rapidly increasing demands generated by the facility and that are unable to supply a sufficient number of workers for plant construction and operation.

With regard to the three surrogate sites discussed above, the socioeconomic settings vary between these extremes. St. Clair County contains a diversified economic base and a relatively large number of unemployed workers with a variety of skilis. Mason County contains soime industrial activity and a moderate number of unemployed workers with a limited variety of skills. Campbell County contains almost no supportive industires and very few unemployed workers. Consequently, we conclude that the net socioeconomic impacts generated during the construction phase of the project will probably be beneficial in St. Clair County, neutral or slightly adverse in Mason County, and seriously adverse in Campbell County.

\subsubsection{Impacts on archaeological, historic, and paleontological sites}

Construction can result in two types of potential impacts on an archaeological or historic resource: direct impacts (e.g., destruction during excavation) and indirect impacts (e.g., visual impacts and noise). No direct impacts of construction are anticipated for any of the surrogate sites. St. Clair County has a number of historic and archaeological sites listed in the Nulionul Register of Iliatomic Plaoss (Sect. 2.1.8.3), but none of the St. Clair County sites 
are on or in close proximity to potential project sites. The nearest historic and archaeological sites are about $32 \mathrm{~km}$ (20 miles) from project site areas. Point Pleasant Battlefield in Mason County is within the township designated for project siting, but a specific location can be chosen that will not impact the battlefield area. Campbell County has no historic or archaeological sites listed in the National Register of Historic Places. Indirect impacts could occur in Mason County unless care is exercised in choosing a specific location or mitigating measures are taken during construction. Indirect impacts are unlikely to occur in St. Clair County and cannot occur in Campbell County.

\subsubsection{Mitigating measures - construction phase}

Plans for restoring and stabilizing areas affected by construction activities should be developed early. The preconstruction site survey should provide detailed information that should be incorporated into the tinal planning of the project to minimize or prevent potential impacts as much as possible. Such plans should include erosion and sediment control; identification and protection of habitat types that are unique or critical to the survival of threatened, endangered, or other "important" species; and thoughtfui placement of both temporary and permanent facilities relative to these areas.

Site preparation and erosion impacts can be reduced by restricting vegetation removal to a minimum. Topsoil should be stored for reuse. Exposed terrain should be stabilized with vegetation as quickly as possible to minimize erosion and sedimentation. Application of fertilizers, mulches, or other amendments that may facilitate revegetation are recommended. Installation of sediment basins, diversion dikes, riprap, controlled conduits, and other measures to control runoff may be needed. Access and haul roads should be designed to follow the natural contours wherever possible. If unpaved roads are used, they should be watered periodically to prevent or reduce fugitive dust. Organic wastes from land clearing should be shredded and used as mulch, disposed of in an approved landfill, or burned under controlled conditions. Selling timber and pulpwood, if possible, will reduce the amount of solid wastes to be disposed of. A border of woodlands, if they exist as in St. Clair and Mason counties, should be left around the plant, both for screening the facility and to prevent erosion by acting as a natural filter. If these measures are taken, impacts should be kept to a minimum.

During construction, air emissions will be minimized by strict compliance with all Federal. state, and local regulations. Additionally, some suggested control measures include the folluwing:

1. Water sprinkling to control fugitive dust from dirt roads, concrete plants, or other sources.

2. Revegetation or covering of exposed areas or storage piles as soon as possible to stabilize the material and prevent wind erosion.

3. Regular maintenance and inspection of air emissions control devices on all vehicles.

4. Conformance to all Federal, state, and local regulations on burning or disposal of waste materials; if burning is allowed, it should be done when atmospheric conditions are favorable (i.e., not during an inversion or air stagnation period). 
5. If applications of pesticides or herbicides are required, the use, whenever possible, of those that break down rather rapidly in the environment and are mostly not translocated to higher trophic levels; label instructions as well as all applicable legal regulations should be followed.

Habitat requirements of all threatened, endangered, and important species should be identified, and these habitats should be protected. Whenever possible, construction activities should not coincide with critical periods (e.g., breeding, nesting, or rearing of young) in the life cycles of these animals. Label instructions should be followed for the proper use of pesticides and herbicides. Wastes from construction should be disposed of in an approved landfill or according to EPA regulations.

Careful siting of temporary and permanent facilities can avoid many potential impacts to terrestrial biota. The least impact should result if the facilities are constructed on previously disturbed land such as nonreclaimed surface-mined lands or abandoned industrial areas. Otherwise, the most common habitat within the area should be used so that the rarer habitat types are protected as much as possible. Movement patterns and migration routes of animals should be identified, and structures should not be placed so as to create barriers or potential hazards to animals.

During construction, compliance with applicable Federal, state, and local regulations (Sect. 2.1.7) governing noise levels will be required. Additionally, potential biological impacts can be minimized by control measures such as:

1. maintaining a buffer zone, for example, a windrow of trees between the construction areas and off-site areas;

2. restricting most noise-emitting activities to daytime hours;

3. using the minimum explosive charge size for blasting;

4. using noise control devices on rock drills, compressors, jackhammers, heavy equipments, etc.; and

5. equipping all vehicles with quality noise mufflers.

Efforts should be made to make the facility as aesthetically pleasing as possible. A buffer zone around the facility is recommended. When possible, a border of woodlands around the plant can reduce erosion and screen the facility from outside view. Pipelines, new roads, and other rights-of-way should be routed parallel to existing rights-of-way to avoid creating unsightly scars across the landscape.

Because of the nature of this analysis, it is not possible to specify exactly what methods will be used to mitigate construction impacts. Measures for avoiding and controlling construction impacts are described in detail by USEPA (1973). If the above measures are taken, biological impacts caused by construction activities should be kept to a minimum. 
Avery, M; Springer, P. F.; and Cassel, J. F. 1976. The effects of a tall tower on nocturnal bird migration - a portable ceilometer study. Auk. 93: 281-91.

Buck, D. H. 1956. Effects of turbidity on fish and fishing. Trans. N. Am. Wizdl. Conf. 21: $249-61$.

Buffington, J. C. 1974. Assessment of the ecological consequences of herbicide use along transmission line rights-of-way and recomendation for such use, pp. 19-22. ANL/ES-34. Argonne, I11.: Argonne National Laboratory.

Chutter, F. M. 1969. The effects of silt and sand on the invertebrate fauna of streams and rivèrs. Hydrobiologia $34: 5 \%-76$.

Cochran, W. W., and Graber, R. R. 1958. Attraction of nocturnal migrants by lights on a television tower. Wiloon Buiz. 70: 378-80.

Cordone, A. J., and Kelley, D. W. 1961. The influence of inorganic sediment on the aquatic life of streams. Calif. Fish Game 47(2): 189-228.

Dustman, E. H., and Stickel, L. F. 1966. Pesticide residues in the ecosystem, pp. 109-21. Special publication no. 8. Madison, Wis.: American Society of Agronomy.

EIFAC (European Inland Fisheries Advisory Commission) working party on water quality criteria. for European freshwater fish. 1965. Report on finely divided solids and inland fisheries. Air water Polzut. 9(3): 151-68.

Fair, B. M.; Geyer, J.; and Okun, D̄. A. 196்̄. Water and wastewater engineering. Vol. 2. New York: Wiley.

Fautin, R. W. 1976. Terrestrial vertebrates. In Final environmental assessment, Black Thunder Mine Site, Campbezz County, Wyoming, eds. H. L. Bergman and H. D. Marcus, pp. X-1-X-50. (Incomplete reference).

Fi iend, M., and Tralmer, D. 0 . 1970. Sume effects uf sublethal levels of insecticides on vertebrates. J. Wizdz. Dis. 6: 335-42.

Gáláyda, J. Iy/U. Special study shows increased car-kill of animals. New Jersey Outdoors 20: $22-23$.

Gamon, J. R. 1970. The effect of inorganic sediment on strecom biota. Environmental Protection Agency, Water Quality Office, Water Pollution Control Research Series, 18050 DWC 12/70 (GPO no. 5501-0074). Washington, D.C.: U.S. Government Printing Office. 
George, J. L. 1960. Some primary and secondary effects of herbicides on wildife. In Herbicides and their use in forestry, pp. 40-73. University Park: Pennsylvania State University.

Hodson, N. L. 1960. A survey of vertebrate road mortality/1959. Bird Study 7: 224-31.

Jones, J. R. E. 1964. Suspended matter. In Fish and river pollution, pp. 169-75. Lunduri: Butterworths.

Mountain West Research, Inc. 1975. The construction worker profile. Prepared for the 01d West Regional Commission. Denver, Colo.

NAS (National Academy of Sciences), 1973. Water quality criteria 1972. EPA-R3/73-003. Washington, D.C.: U.S. Government Printing Office.

Neil, P. H.; Hoffman, R. W.; and Gill, R. B. 1975. Effects of harassment on wild animals an annotated bibliography of selected references. Colorado Division of Wildlife special report no. 37 . Denver, Colo.

Stenehjem, E. J., and Metzger, J. E. 1976. A framework for projecting employment and population changes accompanying energy development. Washington, D.C.: Energy Research and Development Administration.

Stout, J. I., and Cornwell, G. W. 1976. Nonhunting mortality of fledged North American waterfowl. J. Wizal. Manage. 40: 681-93.

Tucker, R. K., and Crabtree, D. G. 1970. Handbook of toxicity of pesticides to wildlife. Resources publication no. 84. Washington, D.C.: U.S. Fish and Wildlite service.

USEPA (U.S. Environmental Protection Agency). 1973. Processes, procedures, and methods to control pollution resulting from all constmuction activity. EPA 430/0-73-007. Washington, D.C.: U.S. Environmental Protection Agency.

-1976. Erocion and sedimont control: surface mining in the eastern U.S. EPA-625/3-76-006. Washington, D.C.: U.S. Environmental Protection Agency.

Wyoming Game and Fish Department. 1976. Considerations for wizdlife in industrial development and reclamation. Cheyenne, Wyo. 


\subsection{EFFECTS OF OPERATION OF A HIGH-BtU (PIPELINE) GAS PLANT}

\subsubsection{Physical environment}

\subsubsection{Impacts of operation on land use}

After construction is complete, temporary structures and parking lots removed, and landscaping instituted, the impacts of construction on land use will have been mitigated; thereafter, remaining impacts on the land will result primarily from coal storage and deposition of wastes developed by plant operation.

The land area occupied by the coal storage pile would not be available for other purposes and would be subject to leaching by natural precipitation although a proper arrangement of drainage and a lined holding basin for rainwater runoff would mitigate this effect.

Solid wastes produced daily will include 580 to 1250 metric tons (640 to 1380 tons) of rock and similar refuse from the primary size-reduction operation, about 270 metric tons ( 300 tons) per day of mostly pyritic materials from the coal-washing process and lesser amounts $(\approx 140 \mathrm{~kg}$; $\approx 300 \mathrm{lb}$ ) of dust from collecting devices in the process. At an $80 \%$ capacity factor and an estimated density of $2690 \mathrm{~kg} / \mathrm{m}^{3}\left(168 \mathrm{lb} / \mathrm{ft}^{3}\right)$, this would amount to about $12.7 \times 10^{4} \mathrm{~m}^{3}$ (103 acre-ft) per year. This material would probably be worked back into land restoration if obtained from a strip mine. Otherwise, it would probably end up in a culm or gob pile at some selected place, in which case it would be subject to leaching by natural precipitation.

If a wet cooling tower were operated in conjunction with the plant, the small amount of liquid drift would generally be dispersed, according to the prevailing meteorological conditions before impacting the land. Usually this effect is negligible, but it should be considered if critical crops or conditions exist in the environs.

If a steam generating station were operated in conjunction with the plant to provide process heat and electricity, further solid wastes of fly ash, bottom ash, and a throwaway flue-gas scrubber lime sludge could be expected. These wastes could be mixed or kept separate as they are pumped, sluiced, or hauled to drainage ponds of landfills. The wastes require compaction and/or stabilization before they can become load-bearing. They would require covering with soil before veqetation could be started.

\subsubsection{Hydpology}

\section{Surface water}

Surface water is to be withdrawn for consumptive use at the 111 inois and West Virginia sites. The water requirements in Sect. 1.2.1.1 indicate a maximum average water use of $0.18 \mathrm{~m}^{3} / \mathrm{sec}$ (6.5 cfs). Using the $7 Q_{10}$ (7-days, once-in-10-years) low flow figures for the 111 inois and West Virginia sites, water consumption of the $7 Q_{10}$ is $7 \%$ and $0.45 \%$ respectively. These low consumption rates would have a small impact on the existing hydrology and would conform to existing governmental requirements.

A potential impact to the surface water is generated by scouring and silting caused by the changes in current patterns near the intake structure. Because of the low withdrawal rate of 
surface water, a well-designed intake structure with inlet velocities of less than $0.02 \mathrm{~m} / \mathrm{sec}$ $(0.5 \mathrm{fps})$ would mitigate any undesirable impacts. If the inlet velocity were increased beyond $0.02 \mathrm{~m} / \mathrm{sec}(0.5 \mathrm{fps})$, undesirable local scouring or silting might occur.

Other potential impacts to the surface water might include impaired navigation and incidents such as flooding or plant accidents. Little impact to existing navigation channels can be expected because of the low water withdrawal rates. Floods or large runoff events could discharge grease, oil, sediment, ash, coal fines, and other undesirable materials to the waterway if adequate containment facilities are not incorporated in the plant design. Runoff containment banks should be an important consideration in plant design at each of the three sites. Settling ponds should be located above the floodplain to prevent unwanted discharges during floods. Impacts to the surface water arising from backwashing of filters, dredging of intake canals, and other potential incidents are not likely to affect the hydrology of the surface waters. The effects of such incidents, however, may be significant to the existing aquatic ecology.

Groundwater

Water requirements of a gasification plant with a capacity of $1.4 \times 10^{6} \mathrm{~m}^{3} /$ day (STP) (50 $\times 10^{6}$ $\mathrm{scfd}$ ) are estimated to range from $10.1 \times 10^{5}$ to $5.8 \times 10^{6} \mathrm{~m}^{3} /$ year (820 to $4700 \mathrm{acre}-\mathrm{ft} /$ year) (Table 1.3, Sect. 1.2.1.1). During plant operation, changes to groundwater flows and levels may occur by either direct withdrawal of water or discharge to the ground. Withdrawal of this water from groundwater resources will have both short-and long-term effects on the groundwater availability; again, the effects may be local or regional. Water levels may be lowered, and this may affect other supplies such as domestic and rural supplies in the vicinity of the plant site. The discharge into the streams might also be affected, especially during low flows. The direction and velocity of groundwater movement will change. Subsidence of land may take place, depending on the rate of withdrawal. The effect may be short-or long-term, depending on the net recharge into the groundwater system. The springs may dry up, thus affecting the wildlife and fish in the vicinity of the plant area. These effects, however, depend on the specific hydrologic properties of the aquifers in the site areas. Direct discharge of wastewater and accidental discharges to the ground would change water levels. The discharge of sanitary water would not affect groundwater, but a large unlined holding pond could significantly raise the groundwater flows and levels. Such discharges would contaminate the groundwater and might increase its chemical concentration. The movement of contaminants depends on the soil and aquifer characteristics and the amount and type of contaminants, which will change the direction and rate of the groundwater flow. Consumptive use by a pipeline gas plant may have little effect on groundwater outside the site boundaries, but such effects must be ascertained by monitoring the groundwater levels, flows, and water quality. Use for sanitary and potable water supplies is generally small. Once-through cooling systems require large volumes of water, and groundwater alone may not meet this requirement. closed-cycle systems can be provided with conjunctive use of both surface water and groundwater. The impact on the groundwater levels is normally small if the well-field is in the vicinity of a river.

Water requirements of a gasification plant in the Lewis and New Athens areas can be met by using surface water, which occurs in sufficient quantity in both of these areas. Although groundwater may be used for drinking and sanitation purposes, the impacts on the groundwater system will be minimum. However, in the Gillette area where surface water availability is questionable, groundwater resources might be needed to meet the consumption requirements of a gasification plant. 
The operational impacts on the groundwater system in the Campbell County, Wyoming, area are discussed below.

In the Gillette area, about 0.006 to $0.063 \mathrm{~m}^{3} / \mathrm{sec}(100$ to $1000 \mathrm{gpm}$ ) of groundwater can be obtained from several upper aquifers and about $0.19 \mathrm{~m}^{3} / \mathrm{sec}(3000 \mathrm{gpm})$ from a well that is exposed to all aquifers from the Fort Union formation to the base of the Madison Limestone. Depth to the base varies from 2400 to $3700 \mathrm{~m}(8000$ to $12,000 \mathrm{ft})$ in Campbell County. With a well at the center of a 16-ha (40-acre) tract at a distance of $400 \mathrm{~m}(1320 \mathrm{ft})$ between wells and an assumed average yield of $0.13 \mathrm{~m}^{3} / \mathrm{sec}(2000 \mathrm{gpm})$ per well, each $2.6 \mathrm{~km}^{2}$ (sq mile) would yield more than $6.4 \times 10^{7} \mathrm{~m}^{3}$ per year $(52,000$ acre-ft/year). Also, irrigation water requirements are becoming less as more lands are acquired for industries. Some waters, though not suitable for municipal, domestic, and bniler-fepd water, can be used for cooling. Disposal of cooling wastewater with a high concentration of dissolved solids may be accomplished by cvaporation ponding, oil field flooding, or injection intu deep aqulfers containing highly saline water. Solid waste and sewage effluent disposal still present problems.

Water levels will be lowered as a result of pumping. The areal extent of water level changes will depend on the aquifer geology and the rate and length of pumping. This is particularly true if water is pumped from the Wasatch and Fort Union formations. Effects of pumping from the Fox Hills Sandstone, Lance formation, and the lower part of the Fort Union formation and Madison will take many years to be transmitted to the outcrop areas and to other shallow domestic and stock wells. Drawdown for a given distance and time depends on the discharge and storage coefficient (U.S. Department of Commerce 1974) but flows of streams, springs, and seeps in the plant vicinity mught be affected. There may be a reversal of groundwater gradient, and streams that were gaining water from groundwater may lose water toward groundwater. A reduction in stream flow will have serious effects on aquatic life and vegetation. There may be an economic impact on private owners to drill deeper wells to get groundwater. Subsidence may result from heavy pumping from thick sand and shalé aquifers. Increased use of groundwater might decrease spring flows. Changes in water use for agriculture and irrigation will occur. These changes will have adverse impacts on farming, grazing, and recreation as well as on fish and wildlife. Withdrawal of water for the plant operation increases salinity problems that would reduce potable water supplies and interfere with agricultural applications. Because of mutual well interface and low aquifer permeability, well fields producing significant amounts of groundwater would have to be spread out over several tens of square miles. Because the Madison aquifer is quite deep, withdrawals would not have much effect on spring flow. The area of extensive influence can be as much as 1 mile from the point of pumping. The vertical component of groundwater movement is' downward, and the horizontal component is generally northward toward the points of discharge along the lower reaches of Wildcat Creek, the Little Powder River, Cottonwood Creek, and the Belle Fourche River. Downward movement of groundwater is small, however, a result of the low permeability of the shales in the Wasatch and Fort Union formations. Bedrock aquifers are filled to the lowest levels where they crop out in the stream valleys. Moreover, the aquifers are discharging sufficient water to maintain a near surface level of saturation in the alluvium along the large stream valleys. Water level observations in a well $98 \mathrm{~m}$ (320 ft) deep within 1 mile of the well field that supplies water for Gillette showed no.decline that could be attributed to pumping during the period 1950 to 1965. Since 1965, however, the water level has declined steadily in response to significant increased pumping from the well field. Total decline of the water level over a period of about 8 years has been about $1.5 \mathrm{~m}(5 \mathrm{ft})$ (U.S. Department of the Interior 1974). 


\subsubsection{Impacts caused by atmospheric effluents}

The Atmospheric Transport Model (ATM) (Culkowski and Patterson 1976) has been used to estimate the effect on air quality in the vicinity of a coal gasification plant attributable to airborne effluents released from the plant. The ATM is basically a Gaussian plume model for computing the ground-level concentrations and depositions of airborne gases and particulates at varying distances from a source. The model is capable of treating several sources at once; these sources may be points (such as smoke stacks), areas (such as cities), or lines (such as highways). For each source it is necessary to know the emission rate, source height, and location, relative to a receptor point. For particulate emissions, the size and density of the particles are needed. Meteorological data are also required to run the ATM. It is necessary to know the fraction of time that the wind blows from a given direction with a given velocity under certain stability conditions.

Because the actual amount and type of effluent from the proposed coal gasification plant will depend on the process used, the effluent rate (for modeling purposes) was taken to be $450 \mathrm{~kg}$ (1000 1b) per day of either $\mathrm{SO}_{2}$ or particulates. The particulates were assumed to have a density of $2 \mathrm{~g} / \mathrm{cm}^{3}$ and a diameter of $10 \mu \mathrm{m}$. Because the ground-level concentration at a particular location is proportional to the effluent rate for a given stack height, it is possible to use the computed results to obtain concentrations resulting from rates other than $450 \mathrm{~kg} / \mathrm{day}$ $(1000 \mathrm{lb} /$ day $)$.

Because more than one stack may be present (the heights of which are not known), air concentrations were computed for heights of 30,60 , and $90 \mathrm{~m}(100,200$, and $300 \mathrm{ft})$. Within this range of heights, it should be possible to interpolate results for other heights of interest.

The meteorolngiral data were obtained as "star" programs from the National Climatic Center in Asheville, North Carolina. They represent 5-year averages and are broken down into 16 directions (N, NNE, NE, etc.), 6 wind-speed categories, and 6 stability classes. Although seasonal data were available, we have used only the annual averages here. The annual wind roses, with all stabilities summed together, are shown in Figs. 2.5, 2.18, and 2.29 for St. Louis, Missouri; Huntington, West Virginia; and Casper, Wyoming. These sites are the nearest to the proposed locations for the pipeline gas plants for which air data were readily available.

For each site, model calculations were made for a stack height of $90-\mathrm{m}(300-\mathrm{ft})$ at 80 points surrounding the site (distances of $0.5,1,2,4$, and $8 \mathrm{~km}$ along each of the 16 directions). The results were later combined for easier interpretation to given computed concentrations in only eight directions ( $N, N E, E$, etc.), each representing a $45^{\circ}$ segment of the circle. These results are shown in Figs. A.4-A.9 in the Appendix. Thus the value shown at a given distance "E" in reality includes half of ENE and half of ESE. In general, the results for $\mathrm{SO}_{2}$ and total suspended particulates (TSP) are similar. The concentrations decrease by an order of magnitude as the distance increases from $0.5 \mathrm{~km}$ to $8 \mathrm{~km}$. The close-in concentrations $(0.5 \mathrm{~km})$ are the highest for the Wyoming site because of the high percentage of wind from the southwest.

Once the exact effluent rate and stack height are known for a given plant, they can be used to make an analysis of the plant's effect on air quality. The results for $\mathrm{SO}_{2}$ can also apply to $\mathrm{NO}_{2}$. If more than one stack is present at a given site or more than one effluent is coming from 
a single stack, the combined effect can be obtained by superimposing the appropriate figures. For example, a plant might have the following daily effluent: $230 \mathrm{~kg}$ (500 $\mathrm{lb}$ ) of particulates, $900 \mathrm{~kg}(2000 \mathrm{lb})$ of $\mathrm{SO}_{2}$, and $680 \mathrm{~kg}(1500 \mathrm{lb})$ of $\mathrm{NO}_{2}$ from a $30-\mathrm{m}(100-\mathrm{ft})$ stack, and $680 \mathrm{~kg}$ (1500 lb) of particulates, $2300 \mathrm{~kg}(5000 \mathrm{lb})$ of $\mathrm{SO}_{2}$, and $1800 \mathrm{~kg}(4000 \mathrm{lb})$ of $\mathrm{NO}_{2}$ from a $90 \mathrm{-m}$ $(300-\mathrm{ft})$ stack. Assuming St. Louis air data, the ground-level concentration at a point $4 \mathrm{~km}$ east of the plant would be $1.59 \mu \mathrm{g} / \mathrm{m}^{3} \mathrm{TSP}, 5.49 \mu \mathrm{g} / \mathrm{m}^{3} \mathrm{SO}_{2}$, and $4.28 \mu \mathrm{g} / \mathrm{m}^{3} \mathrm{NO}_{2}$. The figures can also be used to estimate the maximum effluent that a plant could emit without exceeding a certain concentration for a given stack at a given distance.

\subsubsection{Water quality}

Surface water

The impact of coal conversion plant operation on the surface-water quality at the various sites is highly dependent on a large number of unknowns such as the nature of the percolitinn and surface runotf in the environs surrounding the plant sites. The best assessment that can be made at this time is an estimate of the potential vulnerability of the surface waters at each site to possible plant wastes from dispersal locations. A further consideration that will influence the water quality at the various sites is the projected trends in water quality improvement on the surface waters surrounding the surrogate sites.

The long-term goals for witer quality, shown in Table 3.11, were established by the American Water Works Association for potable water. Specific plans for water quality improvement at the three site areas call for the identification of regional water quality problems by local agencies on upstream tributaries, including the identification of diffuse sources. Specific progralls are being formulated in keeping with Federal mandates.

The effluents from a coal conversion facility located at any of the three sites are difficult lu specify because of their diffuse nature. Likely sources of efflucnts are the seepace from wast. ponds and the leachate from coal piles. Current data on possible effluents from these sources are in Sects. 1.2.4 and 1.2.3. The quantity and the composition of thesc effluents as they reach! the surface waters are unknown. Additional effluents might occur at the West Virginia and Illinois sites'from dewatering activities. For both of these sites, the quality of the water that is to be dewatered is unknown. It is more likely that the dewatering activities will present an impact in the Illinois site area.

The lllinois site is most vulnerable to surface water quality degradation. The amount of dewatering that is needed at the 11 linois site is likely to introdure water-quality-related impacls to the Kaskaskia River. Surface runoff may also be dewatered if significant rainfall occurs. The Wyuiliny $s$ te is the second site that would possibly experience water quality degradation. Percolation or runoff of plant effluent could degrade the water quality of Donkey Creek because of its small size. Presuming runoff is effectively contained by banks and settling basins, only the impact of effluent percolation into Donkey Creek would occur. Estimates of the amount of effluent percolation likely to occur are not available. The West Virginia site is least likely to be impacted by the presence of a pipeline gas plant. This conclusion is based on the large flows of the Ohio River. It can be assumed that the Ohio River would probably dilute any effluent that might reach the river to the extent that no measurable change in water quality would be noticeable. 
Table 3.11. Potable water quality goals ${ }^{a}$

American Water Works Association

\begin{tabular}{|c|c|}
\hline Characteristic & Goal \\
\hline \multicolumn{2}{|c|}{ Physical factors } \\
\hline Turbidity & Less than 0.1 unit \\
\hline Nonfilterable residue & Less than $0.1 \mathrm{mg} /$ liter \\
\hline Macroscopic and nuisance organisms & No such organisms \\
\hline Color & Less than 3 units \\
\hline Odor & No odor \\
\hline Taste & No taste objectionable \\
\hline \multicolumn{2}{|c|}{ Chemical factors (mg/liter) } \\
\hline Aluminum (Al) & $<0.05$ \\
\hline Iroii $(\mathrm{Fe})$ & $<0.05$ \\
\hline Manganese (Mn) & $<0.01$ \\
\hline Copper $(\mathrm{Cu})$ & $<0.2$ \\
\hline $\operatorname{Zin}\left(Z_{i n}\right)$ & $<1.0$ \\
\hline Filterable residue & $<200.0$ \\
\hline Carbon chloroform extract (CCE) & $<0.04$ \\
\hline Carbon alcohol extract (CAE) & $<U .10$ \\
\hline Methylene blue active substances (MBAS) & $<0.20$ \\
\hline \multicolumn{2}{|c|}{ Corrosion and scaling factors } \\
\hline Hardness (as $\mathrm{CaCO}_{3}$ ) & $\begin{array}{l}80 \mathrm{mg} / \mathrm{liter} \text {; a balance between deposition } \\
\text { and corrosion characteristics is necessary; } \\
\text { a level of } 80 \mathrm{mg} / \mathrm{liter} \text { seems best, generally, } \\
\text { considering all the quality facturs; huwwever, } \\
\text { for some supplies, a goal of } 90 \text { or } 100 \mathrm{mg} \text {, } \\
\text { liter may be deemed desirable }\end{array}$ \\
\hline Alkalinity (as $\mathrm{CaCO}_{3}$ ) & $\begin{array}{l}\text { Change of not more than } 1 \mathrm{mg} / \mathrm{liter} \text { (decrease } \\
\text { or increase in distribution system, or after } \\
12 \mathrm{hr} \text { at } 54^{\circ} \mathrm{C}\left(130^{\circ} \mathrm{F}\right) \text { in a closed plastic } \\
\text { bottle. followed by filtration) }\end{array}$ \\
\hline \multicolumn{2}{|l|}{ Coupon tests (incrustation } \\
\hline and loss by corrosion) & $\begin{array}{l}\text { 90-day tests (incrustation on stainless steel } \\
\text { not to exceed } 0.05 \mathrm{mg} / \mathrm{cm}^{2} \text {, loss by corro. } \\
\text { sion of galvanized iron not to exceed } 5.00 \\
\mathrm{mg} / \mathrm{cm}^{2} \text { ) }\end{array}$ \\
\hline \multicolumn{2}{|c|}{ Bacteriological factors } \\
\hline $\begin{array}{l}\text { Colıform organisms (by multiple } \\
\text { fermentation techniques) }\end{array}$ & Nú cúlifórm organisms \\
\hline $\begin{array}{l}\text { Coliform orgainsms (bv membrane } \\
\text { filter techniques) }\end{array}$ & No coliform organisms \\
\hline
\end{tabular}

${ }^{a}$ For all health-related constituents not stated herein, these goals shall require cumplete curipipliaike with all recommendod and mandatory limite rnntained in rarrent USPHS Drinklng Water Staridards. Untess uther methods are indicated, analyses shall be made in conformance with the latest editiun of Standard Methods of Examination of Water and Wastewater.

Source: R. G. Bond and C. P. Straub. 1973. C. R. C. handbook of environmental control, vol. III. Cleveland, Ohio: C. R. C. Press.

Groundwater

Groundwater quality can be affected by (1) withdrawal of large amounts of water and (2) leaching of chemicals from the land surface into aquifers. Withdrawal of groundwater in excess of recharge to aquifers will affect the water quality and may render the water more saline, particularly if the water is withdrawn from shallow aquifers. Pumping of groundwater can cause contaminated water to flow from a surface source to a well and can cause a freshwater aquifer to be contaminated by saline water from underlying aquifers (Deutsch 1963). Dewatering might 
result in similar effects. Poor well construction techniques, including well screens and/or perforated casing, might aid in interconnection of two separate aquifers and leakage between aquifers. Surface runoff from ash and coal storage, stockpiles, and holding and evaporative ponds can be major sources of leaching into aquifers. Additionally, cooling water that reaches the ground is high in total dissolved solids and could contaminate the groundwater for domestic purposes.

The movement of contaminants in the groundwater depends on the soil and aquifer characteristics and is yoverned by such mechanisms as ion exchange capacity, dilution, adscrption, chemical reaction decay, and dispersion. For a discussion of environmental and health aspects of 1 andfill solid waste disposal, see Braunstein 1978. Concentrations of such elements as $\mathrm{Fe}, \mathrm{F}, \mathrm{Se}, \mathrm{B}, \mathrm{NO}_{3}$, $\mathrm{Mg}$, and $\mathrm{Al}$ might increase in groundwater as a consequence of leaching. Leaching of common mineral constituents; toxic trace elements (selenium, lead, benzo[a]pyrene, aldehydes, zinc, nicke), cadmium, and molybdenum); dissolved salts from waste treatment plants, carbon, coal particulates, and pyrites; sediment, oil, and organic matter from coal storage and roal preparation can all have potential impacts on groundwater. Sludge from $\mathrm{SO}_{2}-$ scrubbing contains potential groundwater pollutants such as $\mathrm{Ca}, \mathrm{Mg}$, $\mathrm{Na}, \mathrm{K}$, sulfates, sulfites, chlorides, and bicarbonates.

\section{New At.hens area}

Water in the New Athens area is generally saline below a depth of $150 \mathrm{~m}$ (500 ft). Most of the groundwater must be obtained from the shallow aquifers in the Kaskaskia River floodplain where yields are relatively higher compared with deeper carbonaceous aquifers. Where aquifers discharge into streams, leaching of contaminants will degrade not only the groundwater but also the river downstream of the plant. Depression in water level caused by heavy pumping will create water quality problems such as increased salinity. If the groundwater wells penctrate the carbonaceous aquifers, the water quality in these deeper aquifers can also be affected.

\section{Lewis area}

Contamination of underlying aquifers by infiltration of waste fruin disposal ponds or lagoons, by spillage of wastes on the ground, and by acid mine drainage or deep well injection has occurred in Mason County, and this problem will be present with pipeline gas plants. The natural groundwater is generally hard and acidic. Heavy pumpage might result in the loweriny of watei levels and the reversal of groundwater movement. Leachate movement into the shallow alluvial aquifers will! contaminat.e nnt only the groundwatcr. hil. al sil l! oh ohlo and kabrawho riveis, particuarly during low flows, at which time aquatic life is especially affected. Contaminated spring flow miaht affect wildife nopulation, and contaminated shalluw aquirers might affect the domestic and rural uses of groundwater. Lcaching mny not afrucl the dccper aquifers, liuwever, because of relatively impermeable Mississippian sandstone and shale.

\section{Gillette area}

Changes in the quality of water should not be serious in the Gillette area because of the slow downward movement of groundwater and the relatively impervious shale. The overlying sandstone discharges water into the bottom of the stream valleys at the lowest point of the outcrop area and is a primary source of underflow in the valley. Therefore, pumping should not greatly alter the chemical characteristics of the underflow downstream from the plant site. The deeper 
aquifers may not be affected. Leaching or infiltration of water will occur and will affect the chemical quality. This water will eventually move downgradient toward a discharge point along the Little Rawhide Creek, Dry Fork, or Little Powder. River and will lower the water quality: Acid wastes may not be a serious problem because the natural water of the area is generally slightly basic. Withdrawal of water will increase salinity problems, which will reduce potable water supplies and interfere with agricultural applications.

\subsubsection{Impacts on the biological environment}

\subsubsection{Impacts caused by destruction of habitat}

General

Many of the potential environmental impacts caused by destruction of habitat will occur during. the construction of the demonstration plant (Sect. 3.1.2.1), and some of these impacts will continue throughout the life of the project. The removal of vegetation during the construction of buildings, roads, parking lots, etc., may result in a potentially long-term, but minor, loss of biological primary production. Destruction or damage to vegetation will result in habitat changes that will be beneficial to some animals but detrimental to others. Animals that are displaced to adjacent areas will be forced to compete with already-established animals for a place to live. Such competition will result in increased mortalities until a new balance is reached. Destruction of habitat will also decrease the maximum potential population size of adversely affected animals on the impacted area.

Construction of roads, fences, ditches, and other obstructions may interfere with the travel routes of some animals. It can be expected that increased vehicular traffic will result in more animals being killed while crossing the roads (Galayda 1970; Helms and Stains 1966; Hodson 1960). The presence of buildings, emicsion stacks, cooling towers, telephone lines, etc., may be a minor collision hazard to birds, especially at night, in fog, on overcast nights, or during high winds (Willard and Willard 1978; Avery et al. 1976; Cochran and Graber 1958; Brewer and Ellis 1957; Howell 1954). A study of Anderson (1978) revealed that from 200 to 400 waterfowl ( 0.2 to $0.4 \%$ of maximum number present) were killed each fall, 1973-75, by. colliding with transmission lines at the Kincaid Power Plant in central Illinois. Stout and Cornwell (1976) also reported on a survey of nonhunting mortality of wild waterfowi. Collision mortality represented $0.1 \%$ of the total sample $(n=2,108,880)$ and was reported most commonly from the central flyway. Utility wires and automobiles were the most frequent causes of collision mortality.

During the operation of the demonstration facility, the presence of several sources of environmental pollutants could result in the modification of habitat types, changes in species composition, and incorporation and translocation of toxic chemicals into the ecosystem via food-chain pathways. The most obvious concern is the release of air emissions (Sect. 3.2.2.3).

Although not likely to occur, the accidental release of effluents from storage tanks, holding ponds, refuse piles, and pipelines is a possibility (Sect. 1.2.3). Holding or evaporation ponds that contain toxic chemicals could represent a threat to animals using the water. The use of pesticides and/or herbicides to control unwanted pests and weeds around the facility iiight result in acute or r.hronic toxicity to certain nontarget organisms. The bioaccumulation and toxicities of various pesticides and herbicides is well documented (e.g., Buffington 1974; 
Friend and Trainer 1970; Korschgen 1970; Tucker and Carbtree 1970; Miller and Berg 1969; Stickel 1968; Dustman and Stickel 1966; George 1965; George 1960; and DeWitt et al. 1960).

Habitat destruction and related environmental impacts caused by offsite developments, which can be attributed, at least in part, to the operation of the demonstration plant, deserve evaluation. Such developments include surface mining (to supply coal for plant operation) and construction of new homes, businesses, transportation systems, and other supportive systems needed to accommodate the increase in human population attributable to operation of the facility (Sect. 3.3).

Offsite developments will result in additional losses of habitat and environmental pollution and subsequent animal displacements and mortalities. The larger human population will contribute to the harassment and possible mortality of some animals (Neil, Hoffillan, and Gill 1975). For example, it can be expected that in many arcas huntilly pressure on game species will increase slightly in relation to local population growth. Also, groatcr vchicular tiaffic and mowing along highways will cause additional animal deaths.

Area impacts

Environmental impacts caused by habitat destruction resulting from the operation of a single demonstration facility are not expected to affect irreversibly the biota at any of the three proposed areas. It is assumed that existing populations of biota in and around the proposed plant areas will be sufficient to maintain viable populations of all affected biota. Furtherutore, revegetation and recolonization of affected areas to similar physical and biotic conditions after closing of the facility is a definitc possibility.

The operation of a demonstration facility is not expected to contribute to the extinction of any threatened ur endangered terrestrial species inasmuch as none have been resorifer within any ur llie three proposed townships (Sects. 2.1.9.3, 2.2.9.3, dild ,.3.4.3). At the Wyoming area, bald eagles (Halialztus Zeucocephalus) may winter in the Powder River Basin near Gillette, and nesting habitat for them may exist south and east of Gillette along the Belle Fourche River; however, no nests have been recorded within the area (Fautin 1976).

Of some concern are the effects of offsite developments, especially surface milling, on terrestrial biota. The amount of land that could be surface mined in any one year to supply coal for the operation of a demonstration farility varios according lu lhe llickness of the coal seam, density of the coal, and the amount of coal needed for the facility. An estimated 56, 104, and 5 ha $(139,257$. and 13 acres) at the I1liluis, West virginia, and Wyoming sites, respectively, would be surface mined each year if nne ossumlys that

1. the facility will require about 4535 metric tons (5000 tons) of coal per day (Sect. 1.2);

2. the density of the coal is $1.5 \mathrm{~g} / \mathrm{cm}^{3}$ (Weast 1976); and

3. the thickness of the coal seams is 2,1 , and $21 \mathrm{~m}(6.5,3.5$, and $70 \mathrm{ft})$ at the Illinois, West Virginia, and Wyoming areas respectively (Illinois Department of Mines and Minerals 1975a; Evans and Bitler 1975; and Orr 1975). 
The amount of land that could be surface mined in any one year will probably have little adverse effect on the long-term survival of the various species within the proposed areas. However, over the years the cumulative effects of coal conversion developments and related activities such as surface mining, road and other construction, and all types of human activities will result in some reduction of habitat and biota within the regions.

In Illinois, mining activities related to the operation of a coal conversion facility may adversely affect some agricultural lands. The Illinois Surface-Mired Land Conservation and Reclamation Act and the Federal Surface Mining Control and Reclamation Act of 1977 require that agricultural lands be reclaimed for agricultural purposes if agricultural use is determined to be the optimum future use of the affected land (I1linois Department of Mines and Minerals 1975b; U.S. Congress, 1977a). The Federal act requires special performance standards for prime and unique farmlands (U.S. Department of the Interior 1977, Sect. 716.7), and such lands must be restored to an equivalent or better productivity than prior to mining (U.S. Congress 1977a). However, the success of such reclamation in terms of comparable yields per acre before and after mining has not been adequately determined.

Neither the Illinois surface-mining law nor the Federal act provide an incentive for the reclamation of mined land to forest or woodland. Thus most woodland areas that have been surface mined have been reclaimed for agricultural purposes. Other development activities have contributed to the piecemeal loss of woodland areas. Within New Athens Township, the remaining woodland areas are important to many species of wildlife (Sect. 2.1.9.1 and Hardin et a1. 1976), and the wooded tracts should be preserved whenever possible.

Biological impacts resulting from the operation of a demonstration facility within Lewis Township, West Virginia, are not expected to be severe. Related surface mining will create some problems of habitat destruction and mine drainage and erosion. However, the reclamation requirements stipulated by law (U.S. Congress 1977a) should adequately correct these problems (Imhoff et al. 1976).

In Lewis Township, little lowland forest remains, largely because of urban development and agricultural activities. Because lowland forests are relatively scarce but are important habitat for wildlife (Sect. 2.2.9.1), these forest areas should be preserved whenever possible.

Within the proposed Wyoming area, the Little Thunder Creek floodplain and nearby ravine areas provide needed habitat for several important species (Fautin 1976). The local sage grouse (Centrocercus urophasianus) population is small and is dependent on the floodplain habitat for hreeding. Also, the northwestern Wyoming area contains about one-half $(200,000)$ of the pronghorn (Antilocapra americana) in the nation, and the Little Thunder. Creek and adjacent ravines within Campbell County are important management areas (Fautin 1976).

Projected surface mining within Campbell County is expected to disturb about 10\% of the 1 and area (Orr 1975). Additional loss of habitat caused by coal conversion developments, other industrial growth, and increasing human populations can be expected to have a negative impact on many species, especially the sage grouse and pronghorn. However, remaining habitat within the county should be sufficient to ensure the survival of all species.

Because of the importance of Little Thunder Creek and adjacent ravine habitat to local animals, development plans. for the area should be aimed at maintaining the quality of this habitat type. 


\subsubsection{Impacts caused by noise}

Sources of noise resulting from the daily operation of a demonstration pipeline gas facility have been identified in Sect. 1.2.3. Site differences are not discussed because specific site parameters have not been identified in this analysis. Statements herein concerning potential biological impacts from noise apply to all three proposed areas (Sects. 2.1.1, 2.2.1, and 2.3.1).

Under authority provided by the Noise Control Act (NCA) of 1972 (PL 92-574), the U.S. Environmental Protection Agency (EPA) has specified environmental noise levels for several areas of concern and has provided estimated margins of safety considered necessary to prevent adverse health or welfare effects (Sect. 2.1.7, Table 2.8). Although these criteria provide a basis for assessment, the biological effects of noise are not well understood, and potential environmental impacts are difficult to quantify.

Berkau et a1. (1975) identified seven categories of potential noise effects as (1) noiseinduced hearing loss, (2) nonauditory health effects, (3) individual behavior cffects, (4) noise effects on sleep, (5) communication interference, (6) community or collective response, and (7) effects on domestic animals and wildlife.

Noise-induced hearing loss

Hearing damage resulting from exposure to noise is well established. However, the exact relationships between temporary or permanent hearing loss and the intensity and duration of noise have not been clearly defined (Berkau et al. 1975).

The National Institute of Occupational Safety and Health (NIOSH) has set a 90-decibel, A-weighted $[\mathrm{dB}(A)]$ limit for an $8-\mathrm{hr}$ work day and has recommended a reduction to $85 \mathrm{~dB}(\mathrm{~A})$ when technologically feasible (U.S. Department of Health, Education. and Welfare, 1972, cited by Berkau et al. 1975).

\section{Nonauditory health effects}

Research evidence supports the idea that exposure tn noise of sufficient intensity and duration can elicit stress-related responses by altering the function of the endocrine, cardiovascular, and neurological systems (Memphis State University 1971, pp. 10-21). Howover, such evidence does not clearly relate physiological response to noise levels that are likely to be encountered in normal human activity or within an area affected by a demonstration facility. Evidence is also lacking to support an argument that irreversible phyainlogical changes other than noisc induced hearing loss can result from exposure to noise.

Individual behavior effects

Exposure to noise can disrupt work performance and mental concentration. Evaluation of individual behavioral reponses is complicated by the interaction of psychological, social, and other factors (Berkau et al. 1975). 


\section{Noise effects on sleep}

Disturbance of sleep has often been reported as the major reason for annoyance due to noise (Berkau et al. 1975). Excessive noise can prevent sleep, awaken one from sleep, or change one's pattern of sleep. High-intensity noises of rather short duration (e.g., noise from pressure release valves, whistles, horns, or blasting) are likely to be very disturbing. For sleeping, a background level (indoors) of $35 \mathrm{~dB}(A)$ is desirable, whereas peak levels should not exceed $45 \mathrm{~dB}(\mathrm{~A})$ (Dickerson 1973).

Communication interference

In addition to noise-induced hearing loss, noise can interfere directly with speech communication and can affect behavior and performance during waking hours. MacFarlane et al. (1975) reported that, within an operating facility, a 1 imit of $65 \mathrm{~dB}$ is required for speech communication at $0.9 \mathrm{~m}(3 \mathrm{ft})$. In an $85-\mathrm{dB}$ noise background, only shouted speech can be heard at this distance. In residential areas where conversation out of doors is anticipated, the level of noise at $3.7 \mathrm{~m}(12 \mathrm{ft}$ ) should not exceed $55 \mathrm{~dB}(A)$ (USEPA 1971b, cited by Dickerson 1973).

\section{Community or collective response}

The tolerance or intolerance of a community to noise is expected to differ from individual responses, although the extent of differences is unknown. Community annoyance responses may be social, political, or economic, and the degree of noise tolerance may not be related to any identified biological impacts (Berkau et al. 1975).

Special consideration should be given to potential sites where noise levels will be increased substantially above preexisting levels, even if expected levels do not exceed recommended or legal maximum levels (USEPA 197la, cited by Dickerson 1973). Potential noise increases were categorized according to expected community response as follows:

1. up to $5 \mathrm{~dB}(A)$ - few complaints if gradual increase,

2. 5 to $10 \mathrm{~dB}(A)$ - more complaints, especially if there is a conflict with sleeping hours, and

3. over $10 \mathrm{~dB}(\dot{A})$ - substantial number of cumplaints.

\section{Effects on domestic animals and wildlife}

In general, the potential effects of noise (e.g., hearing loss or other physiological changes that affect size, weight, reproduction, or behavior) on domestic animals and wildlife should be similar to those observed or expected in humans. However, noise-induced impacts to animals other than humans are likely to be more critical to survival of the affected organisms.

Within the area affected by the facility, it is not likely that any animals will be subjected to noises of sufficient intensity or duration to produce permanent hearing losses. Animals with low mobility and/or those that rely on auditory signals to find mates, "mark territories, recognize young, detect and locate prey, and evade predators may be adversely affected within the houndary of the site and along railroads or other roads (Memphis State University 1971). 
For those animals that are disturbed by noise and that respond by dispersing to other areas with suitable habitat, some density-dependent mortality can be expected. The extent of these impacts is unknown.

It is assumed that noise levels resulting from the operation of a demonstration plant will comply with all requirements of the Noise Control Act of 1972, the Occupational Safety and Health Act of 1970, and other applicable Federal, state, and local regulations (Sect. 2.1.7). As a result, biological impacts caused by noise exposure related to plant operation are expected to be minor. However, it should be emphasized that stress-related noise effects on animals have not been clearly defined and that additional research is needed.

Apparently, many of the potential noise-related impacts could be minimized or eliminated by applying current technology. Technologically feasible noise limits can be applied to the manufacture of equipment needed to operate the facility. Sufficient insulation can be installed to reduce noise within the plant, which would alsn rerlure noise lovele outsidc the facility. Noise-emitting equipment can be placed and used at a distance from sensitive areas whenever pussible. Edch factlity căni incorporate a huffer zone of sufficicnt size so that lióisc levels reaching local residents are within previous ambient levels.

\subsubsection{Impacts caused by atmospheric effluents}

\section{General}

The operation of a demonstration pipeline gas facility will result in the release of air pollutants such as oxides of sulfur and nitrogen, particulates, hydrocarbons, trace metals, and various compounds produced from interactions between the emissions and the atmosphcre (Sect. 1.2). Air emissions will be controlled by Federal regulations (Tables 3.12 and 3.13 ) promulgated on the basis of existing knowledge of human health and environmental quality. Present regulations require the facility to employ the best available control technology for minimizing ellissions. Furthermore, the operation of the facility must nnt. result in a significant deterioration of air quality as defined by the Clean Air Act Amendments of 1977 (Environmental Research 1977; U.S. Congress 1977b).

Current standards specify allowable ambient air quality ceilings and increments over baseline levels for some pollutants, but not for all (Tables 3.12 and 3.13 ). Regulations have not yet been promulgated for potentially harmful trace metals known to escur in coal (Tobles 3.14 arral 3.15) or for other undesirable products such as polycyclic aromatic hydrocarbons, toxic phenols, aromatic amines, metal carbonyls, and others that may be formed as a result of the chemical nature of coal and the reaction ronditions under which gosification uccurs (Shriner et di. 1977; Jahnig and Bertrand 1976; Koppenaal and Manahan 1976; Williams 1976). Potential biological impacts resulting from long-term exposure to these and other unidentified air emissions is mostly unknown. In most of these cases, existing knowledge of toxicity to organisms is based on short-term, high dose exposures.

Another consideration is the potential environmental effects of the release of water vapor and heat from the plant's cooling system. When weather conditions are suitable, evaporation from cooling ponds and dissipated heat and water vapor from cooling towers can result in local increase in temperature, fogging, and icing. During the winter, icing could cause some 
Table 3.12. National ambient air quality standards

\begin{tabular}{|c|c|c|}
\hline Pollutant ${ }^{2}$ & Time period/standard & $\begin{array}{l}\text { Maximum permissible } \\
\text { c concentration }\end{array}$ \\
\hline Total suspended particulates (TSP) & $\begin{array}{l}\text { Annual, secondary } \\
\text { Annual, primary } \\
\text { 24-hour, secondary } \\
\text { 24-hour, primary }\end{array}$ & $\begin{array}{r}60 \mu \mathrm{g} / \mathrm{m}^{3} \\
75 \mu \mathrm{g} / \mathrm{m}^{3} \\
150 \mu \mathrm{g} / \mathrm{m}^{3} \\
260 \mu \mathrm{g} / \mathrm{m}^{3}\end{array}$ \\
\hline Sulfur oxides (measured as $\mathrm{SO}_{2}$ ) & $\begin{array}{l}\text { Annual, primary } \\
24 \cdot \text { hour, primary } \\
\text { 3.hour, secondary }\end{array}$ & $\begin{array}{r}80 \mu \mathrm{g} / \mathrm{m}^{3} \\
365 \mu \mathrm{g} / \mathrm{m}^{3} \\
1300 \mu \mathrm{g} / \mathrm{m}^{3}\end{array}$ \\
\hline Carbon monoxide (CO) & $\begin{array}{l}\text { 1-hour, primary } \\
\text { 8-hour, primary }\end{array}$ & $\begin{array}{l}40 \mathrm{mg} / \mathrm{m}^{3} \\
10 \mathrm{mg} / \mathrm{m}^{3}\end{array}$ \\
\hline Oxidants/ozone $\left(\mathrm{O}_{x} / \mathrm{O}_{3}\right)$ & 1-hour, primary & $160 \mu g / m^{3}$ \\
\hline Nitrogen dioxide $\left(\mathrm{NO}_{2}\right)$ & $\begin{array}{l}\text { Annual, primary } \\
\text { Annual, secondary }\end{array}$ & $\begin{array}{l}100 \mu \mathrm{g} / \mathrm{m}^{3} \\
100 \mu \mathrm{g} / \mathrm{m}^{3}\end{array}$ \\
\hline Hydrocarbons $(\mathrm{HC})^{d}$ & 3-hour, primary, secondary & $160 \mu \mathrm{g} / \mathrm{m}^{3}$ \\
\hline
\end{tabular}

${ }^{\theta}$ Additional standards have been proposed for asbestos, boryllium, mercury, and lead; they are being prepared for fluorides, polycyclic organic compounds, odors (including hydrogen sulfide). chlorine, hydrogen chloride, arsenic, cadmium, copper, manganese, nickel, vanadium, zinc, barium, boron, chromium, selenium, pesticides, radioactive substances, and aeroallergens.

oprimary: to protect public health.

'Secondary: to protect public welfare.

${ }^{d}$ Hydrocarbons: hydrocarbon standard does not have to be met if oxidant standard is met.

Source: U.S. Department of Energy and U.S. Environmental Protection Agency. 1978. Energy/environment fact book: decision series. EPA-600/9-77-041, p. 7. Washington, D.C.

Table 3.13. Ceilings and increments allowable over baseline air quality levels ${ }^{a}$

\begin{tabular}{|c|c|c|c|c|c|}
\hline \multirow{2}{*}{ Pollutant } & \multirow{2}{*}{$\begin{array}{c}\text { Class I } \\
\text { increment } \\
\left(\mu \mathrm{g} / \mathrm{m}^{3}\right)\end{array}$} & \multirow{2}{*}{$\begin{array}{l}\text { Class II } \\
\text { increment } \\
\left(\mu \mathrm{g} / \mathrm{m}^{3}\right)\end{array}$} & \multirow{2}{*}{$\begin{array}{c}\text { Class III } \\
\text { increment } \\
\left(\mu \mathrm{g} / \mathrm{m}^{3}\right)\end{array}$} & \multicolumn{2}{|c|}{$\begin{array}{c}\text { NAAOS }^{b} \\
\left(\mu \mathrm{g} / \mathrm{m}^{3}\right)\end{array}$} \\
\hline & & & & Primary & Secondary \\
\hline \multicolumn{6}{|l|}{ Particulate matter } \\
\hline Annual geomotrio moan & 5 & 10 & 37 & 75 & 60 \\
\hline 24-hr maximum & 10 & 37 & 75 & 260 & 150 \\
\hline \multicolumn{6}{|l|}{ Sulfur dıoxide } \\
\hline Annual arithmetic mean & 2 & 20 & 40 & 80 & \\
\hline 24-hr maximum & 5 & 91 & 182 & 365 & \\
\hline 3-hr maximum & 25 & 512 & 700 & & 1300 \\
\hline
\end{tabular}

${ }^{a}$ Source: Environmental Research Technology, Inc. 1977. Workshop on the 1977 clean air act amondmonts. Nrtohor 1977. Bosțan, Mạss.

$b$ National Ambicnt Nir Quality Standard.

vegetation damage. Also, excess humidity might cause heavier than normal frosts during the winter. However, during early spring and late fall there may be a reduction of local frosts because of the dissipated heat from the cooling system. Greater humidity in the vicinity of the facility could potentially reduce transpiration in vegetation during the dry seasons of the year. Such potential impacts are not expected to be major (MacFarlane et al. 1975).

The loss of water droplets from cooling systems also has the potential for producing airborne solids as the droplets evaporate. Particles of less than $0.2 \mu \mathrm{m}$ (Aitken particles) may act as condensation nuclei for rain-droplet formation (Institute of Ecology 1974). Although the effects of such particles on weather conditions are not clearly understood, there is a potential for altering amount.s of precipitation within an affected area. A substantial change in annual or seasonal precipitation could have a significant impact on biuta. 
Table 3.14. Mean analytical values for trace elements found in 101 coals

In parts per million

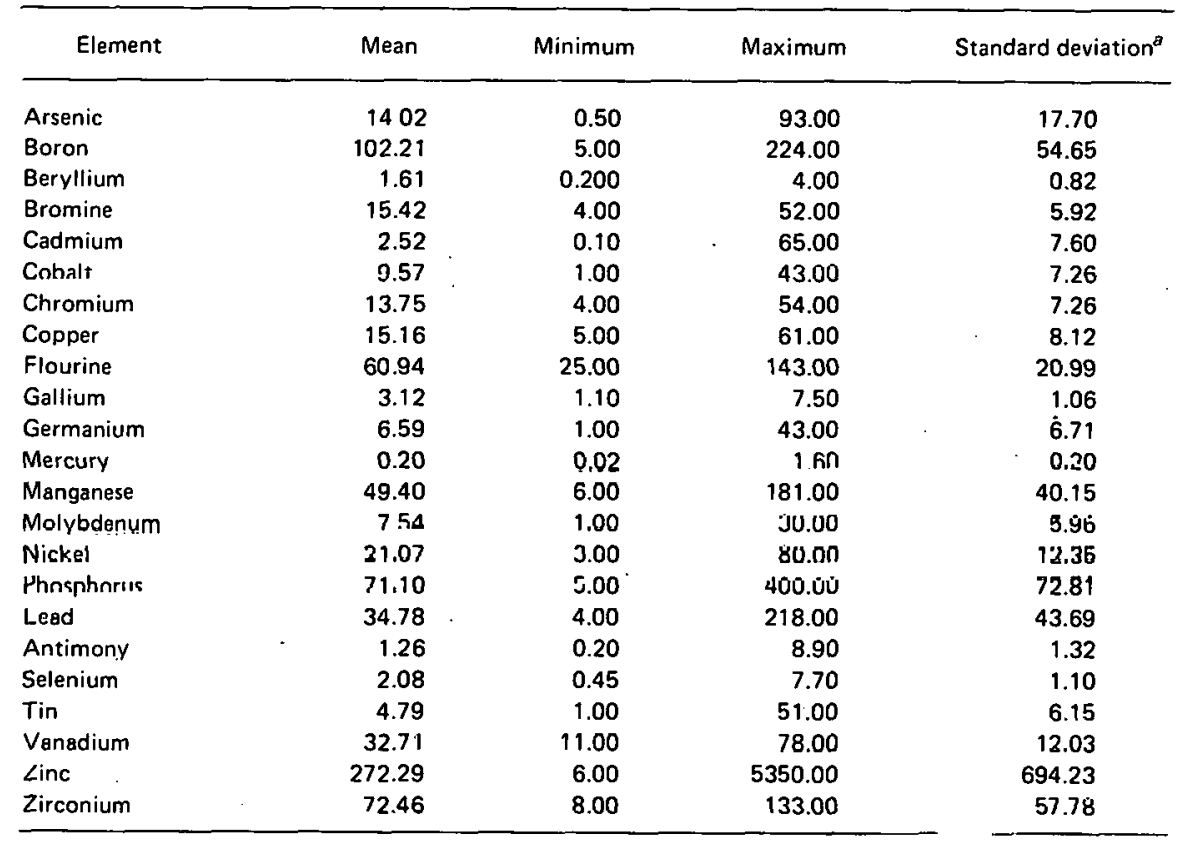

aStandard deviation of 101 values from 101 coals.

Source: Data from R. R. Ruch, H. J. Gluskoter, and N. F. Shimp. 1974. Occurrence and distribution of potentially volatile trace elements in coal. Environmental Geology Note Series 72. Urbana: Illinois State Geological Survey.

Table 3.15. Distribution of environmentally hazardous trace elements in coal

\begin{tabular}{|c|c|c|c|c|}
\hline \multirow{2}{*}{ Element } & \multicolumn{3}{|c|}{ In parts per million } & \multirow{2}{*}{$\begin{array}{l}\text { Appalachian } \\
\text { Ieylun }\end{array}$} \\
\hline & $\begin{array}{c}\text { Powder River } \\
\text { Basin }\end{array}$ & $\begin{array}{c}\text { Western interior } \\
\text { reginn }\end{array}$ & $\begin{array}{c}\text { Eastern interinr } \\
\text { rcgion }\end{array}$ & \\
\hline Antimeny & 0.67 & 3.5 & 1.3 & 1.2 \\
\hline Arsenic, & 3 & 16 & 14 & 18 \\
\hline Beryllium, & 0.7 & 2 & 1.8 & 2.0 \\
\hline Cądmium, & 2.1 & 20 & 2.3 & 0.2 \\
\hline Mercury. & 0.1 & 0.13 & 0.19 & 0.16 \\
\hline Lead, & 72 & & 34 & 12 \\
\hline Sclenium. & 0.73 & 5.7 & 2.5 & 5.1 \\
\hline Żiı:. & 33 & & $2 b u$ & 13 \\
\hline
\end{tabular}

Source: P. Zubovic. 1976. Geochemistry nf trare aloments in oogl. Table 3, is. 12A, ill 3ympus/um proceedings: environmental aspects of fuel conversion technology 11 , compiler, Frank A. Ayers. EPA-640/2-7-1 10. St. Louis, Mo.: U.S. Environmental Protection Agency.

A possibility also exists for emission of harmful chemicals (e.g., toxic trace metals, carcinogenic hydrocarbons, etc.) to the atmosphere in the water vapor released from cooling towers (Jahnig and Bertrand 1976; Koppenaal and Manahan 1976; MacFarlane et al. 1975;

Sather et al. 1975). Small particles of potentially toxic materials could adhere to water droplets and be carried out with drift from the cooling towers. As the droplets evaporate, these chemicals could be deposited over a relatively large area, depending on their dispersion with the drift plume. Depending on the types of chemicals and their quantities, there could be deleterious effects to local agricultural crops, human health, or other biota. Identification, containment, and neutralization of potentially harmful chemicals in cooling water is warranted. However, additional research is needed to define potential problems and their solutions. Ohter areas of technical wekaness are given in Table 3.16. 
Table 3.16 Some areas of technical weakness and research needs with regard to air emissions from a coal conversion facility (not meant to be all-inclusive)

\footnotetext{
1. Better identification and evaluation of specific sources, chemical forms, and particle sizes of air emissions; and effectiveness of current control technology are needed.

2. Chemical transformations within the plume and during atmospheric transport need to be delineated.

3. Studies of biological responses and sensitivities of various organisms to pollutants (including synergistic effects) within ranges likely to be encountered in the environment are needed.

4. Studies dealing with the long-term chronic exposure of organisms to specitic pollutants by inhalation, ingestion, diffusion, and other modes of entry are needed.

5. Mobility and translocation of potentially harmful emissions in the ecosystem, including food webs leading to man, should be systematically studied.

6. Potential effects of all air emissions on local and regional weather and climate should be investigated.

7. Additional information is needed concerning the economic effects of air pollution.

8. Biological impacts of air emissions resulting from regional coal development, rather than from the operation of a single conversion facility, should be evaluated.

9. Better models are needed for predicting long-term effects of various pollutants to biological systems.

10. Health standards for man and other biota should be improved as additional information becomes available.
}

Sources: (1) D. S. Shriner. 1976. Research needs related to air pollution from coal conversion processes. Proceedings of the A/ChE 82nd national meeting. Atlantic City, N.J., pp. 1-10. New York: AlChE. (2) B. E. Vaughn et al. 1975. Review of potential impacts on health and environmental quality from metals entering the environment as a result of coal utilization. $75 \mathrm{pp}$. Pacific Northwest Laboratories. Richland, Washington: Batelle Memorial Institute; (3) W. W. Heck. 1973. Air pollution and the future of agricultural production. pp. 118-29. J. A. Naegele ed. In Air pollution damage to vegetation. $137 \mathrm{pp}$ Washington, D.C.: American Chemical Society.

Obviously, air emissions from a coal gasification facility warrant careful examination in the future for detection of significant biological impacts. Strict compliance with current Federal regulations may tempt one to assume that facility operations will not produce concentrations of air pollutants likely to result in a significant impact on any biological system. Such an assumption may prove to be correct, but it does not seem appropriate at this stage of uur knowledge.

Although there is a recognized need for additional research and data analysis, acute and chronic injury to many types of sensitive vegetation and detrimental effects to human health from many of the pollutants that are likely to be released to the atmosphere during operation of a pipeline gas facility are well documented (Colucci 1976; Mansfield 1976; Auerbach Iy/5; Commission on Natural Resources et al. 1975; Gordon and Tourangeau 1975; Mudd and Kozlowski 1975; Wadden as cited by MacFarlane et al. 1975; Finkel 1974; Naegele 1973; Nash 1973). Some examples of potential biological impacts are summarized in Fig. 3.1 and.Tables 3.17 and 3.18.

Scientific data are sufficient, to suspect some negative impacts to biota from the operation of a demonstration facility. However, the significance of suspected impacts to blological systems cannot be quantified at this time. Levels of various pollutants in the atmosphere will depend on such factors as the chemical composition of the coal used by the facility, the type of conversion process employed, and the effectiveness of the applied control measures. Furthermore, tolerance to various air emissions and biological response mechanisms of different species are known to vary. Thus to some extent potential impacts will depend on the type of biota within the affected area. In general, reduced growth, reduced reproduction, and increascd mortality could lead to long-term community efferts that might include simplification 


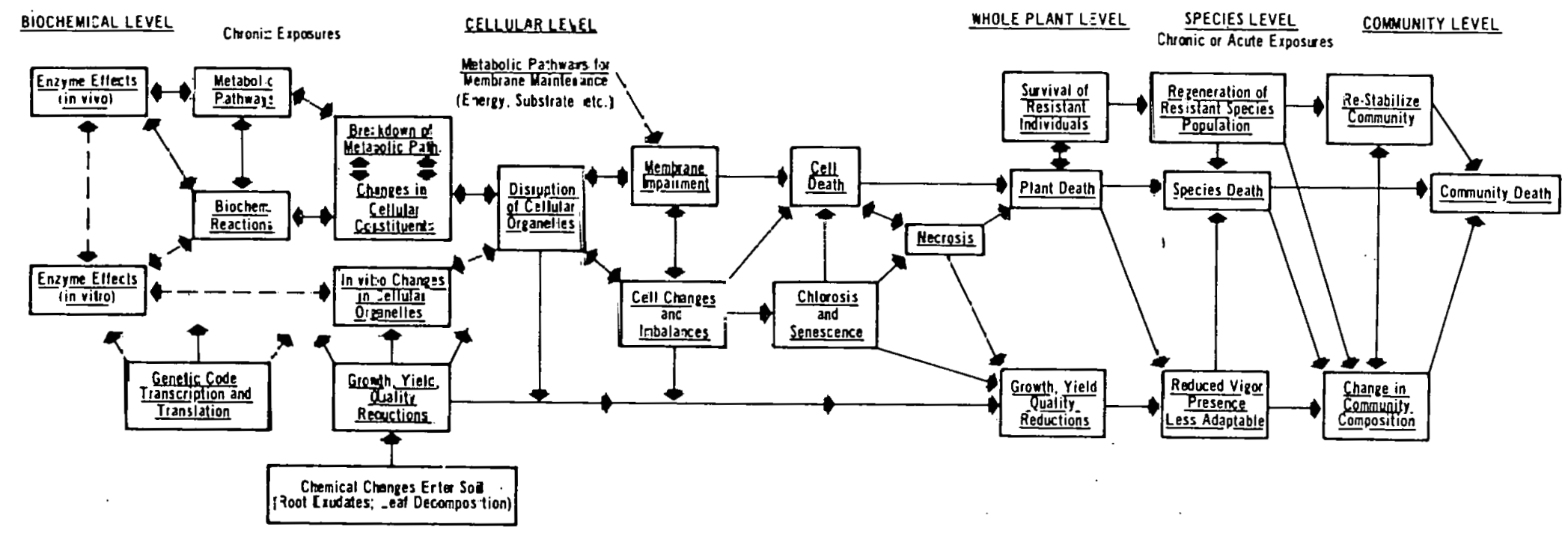

Fig. 3.1. Potential Effects oi air pollutants con plant communities (chronic or acute exposures). Source: W. W. Heck. 1973. Air pollution and the future of agriculture production. In Air pollu'ion damage to vegetation, ed. J. A. Naegele, pp. 118-29. Washington, D.C.: American Chemical Society. 
Table 3.17. Types of chronic low-level vegetational effects and probable mechanisms involved

\begin{tabular}{|c|c|c|}
\hline Type of effect & Probable mechanisms & Pollutants involved ${ }^{a}$ \\
\hline \multirow[t]{13}{*}{ Reduced growth } & Decreased photosynthesis & $\mathrm{SO}_{2}, \mathrm{O}_{3}, \mathrm{NO}_{x}, \mathrm{HF}, \mathrm{PAN}, \mathrm{Pb}$ \\
\hline & Increased respiration & $\mathrm{HF}, \mathrm{SO}_{2}$ \\
\hline & Biochemical changes & \\
\hline & $\begin{array}{l}\text { Enzyme inhibition } \\
\text { Electron (energy) transport } \\
\text { Effects on photopigments }\end{array}$ & $\begin{array}{l}\mathrm{SO}_{2}, \mathrm{O}_{3}, \text { PAN, HF, As } \\
\mathrm{HF}, \mathrm{O}_{3}, \text { PAN } \\
\mathrm{SO}_{2}, \mathrm{HF}, \mathrm{O}_{3}, \text { PAN, NO } \mathrm{NO}_{x}\end{array}$ \\
\hline & Stomatal function & $\mathrm{SO}_{2}, \mathrm{O}_{3}$ \\
\hline & Membrane permeability & $\mathrm{O}_{3}, \mathrm{PAN}, \mathrm{SO}_{2}, \mathrm{HF}$, metals \\
\hline & Premature senescence of leaves & $\mathrm{SO}_{2}, \mathrm{O}_{3}, \mathrm{PAN}, \mathrm{NO}_{2}$ \\
\hline & Physical changes & \\
\hline & UV reflectivity & Acid rain \\
\hline & Heat exchange & Acid rain \\
\hline & Gas exchange & Acid rain \\
\hline & Changes in symbiosis & $\mathrm{O}_{3}$, acid rain \\
\hline & Effects on nutrient flux & $\mathrm{SO}_{2}$, acid rain \\
\hline \multirow[t]{5}{*}{ Reduced reproduction } & $\begin{array}{l}\text { Reduced carbohydrate availability for } \\
\text { reproductive structures }\end{array}$ & $\begin{array}{l}\mathrm{SO}_{2}, \mathrm{O}_{3}, \mathrm{HF}, \mathrm{PAN}, \mathrm{Pb} \\
\quad \mathrm{NO}_{2}\end{array}$ \\
\hline & Effects on reproductive processes & \\
\hline & $\begin{array}{l}\text { Flower or fruit production } \\
\text { Pollen germination or tube } \\
\text { elongation }\end{array}$ & $\begin{array}{l}\mathrm{Smog}, \mathrm{HF}, \mathrm{SO}_{2} \\
\mathrm{SO}_{2}, \mathrm{O}_{3}, \mathrm{HF}\end{array}$ \\
\hline & Mutagenesis & $\mathrm{SO}_{2}$ \\
\hline & Effects on pollinating insects & $H F$ \\
\hline Increased morbidity & $\begin{array}{l}\text { Inadequate carbohydrate supply to } \\
\text { support autotrophic respiration } \\
\text { and resist disease. Reduced growth } \\
\text { and loss of ability to compete with } \\
\text { other vegetation }\end{array}$ & $\begin{array}{l}\mathrm{SO}_{2}, \mathrm{O}_{3}, \mathrm{HF}, \mathrm{PAN}, \mathrm{NO}_{2} \\
\text { heavy metals }\end{array}$ \\
\hline
\end{tabular}

${ }^{a}$ Includes pollutants for which specific effects have been documented and those whose biochemical symptomatology strongly implicate them as probable causal agents.

Source: S. I. Auerbach. 1975. Testimony presented to Subcommittee on Environment and the Atmosphere. U.S. House of Representatives: Hearing on costs and effects of chromic low-level environmental pollution. Oak Ridge, Tenn.: Oak Ridge National I aboratory, Environmental 3ciences Division.

of ecosystem structure. Species diversity at more than one trophic level may be affected, and some very sensitive species (e.g., lichens) may be temporarily or permanently eliminated from the polluted area.

The probability of significant impacts to biological systems should increase as a function of the amounts of harmful pollutants released to the atmosphere. Thus a coal development proyram that proceeds from a single demonstration facility to one or more large commercial facilities can be expected to result in greater impacts. Long-term effects of all air emissions resulting from or related to roal development (c.g., surface Imining activities, increased automobile emissions, increased industrial growth, etc.) should also be considered.

\section{Area impacts}

Whether or not environmiental impacts caused by air emissions from a gasification facility will be more severe in the semiarid Wyoming area than in the temperate Illinois and West Virginia areas is difficult to determine. Within the proposed areas, potential biological 
Table 3.18. Human populations at high risk to coal gasification plant pollutants

\begin{tabular}{|c|c|}
\hline Wastes & High-risk groups and health effects \\
\hline $\mathrm{SO}_{2}, \mathrm{H}_{2} \mathrm{~S}$, and other sulfur compounds & Children, asthmatics, chronic lung disease sufferers \\
\hline $\mathrm{NH}_{3}$ & $\begin{array}{l}\text { Extreme irritation of mucous membranes of respiratory tract. } \\
\text { Those suffering from conjunctivitis or other eye diseases }\end{array}$ \\
\hline $\mathrm{HCN}$ & $\begin{array}{l}\text { Protoplasmic poison; very toxic gas on inhalation, ingestion, } \\
\text { or skin absorption }\end{array}$ \\
\hline \multicolumn{2}{|l|}{ Trace metals } \\
\hline Mercury & Liver and kidney disorders \\
\hline Cadmium & Hypertensives (possible), cancer of prostate, emphysema \\
\hline Beryllium & Those with lung ailments \\
\hline Lead. & $\begin{array}{l}\text { Children; anemics; those with peripheral neuropathy, liver, } \\
\text { and kidney dysfunction }\end{array}$ \\
\hline Vanadium & Tobacco smokers \\
\hline Arsenic & Carcinoma of prostate \\
\hline \multicolumn{2}{|l|}{ Nickel } \\
\hline \multicolumn{2}{|l|}{ Chromium } \\
\hline \multicolumn{2}{|l|}{ Hydrucar buris } \\
\hline Pheno!, xylênnls & $\begin{array}{l}\text { Those with eculcal norvous syetem, liver, and kinney } \\
\text { Jisurdor's }\end{array}$ \\
\hline Toluene & May involve irreversible damage on irslıalation \\
\hline \multicolumn{2}{|r|}{ 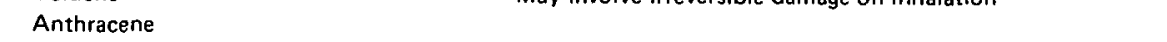 } \\
\hline Cresols & $\begin{array}{l}\text { Corrosive action on skin and mucous membranes; kidney } \\
\text { and liver damage }\end{array}$ \\
\hline Renzene & $\begin{array}{l}\text { Toxic action on blood-forming tissues; cumulative action; } \\
\text { marrow depression; kidney damage }\end{array}$ \\
\hline Phetlarilhrene & Allergenic, carcinogenic \\
\hline Benzo[0] pyrene and other polycyclics & Carcinngenic. \\
\hline Nitrngen oxides & Cardiopulmonary and cardiovascular disability \\
\hline
\end{tabular}

Source: Modified from D. R. MacFarlane et al. 1975. Power facility siting in the state of /linois. Part /I - environmental impacts of large energy conversion facilicies. Chicago: lllinois Institute for Environmental Quality.

impacts wili be influenced by numerous factors such as the types and quantities of emissions, ambient air quality, climate, types of biota, land-use practices, and human population density.

Location of major coal- and oil-fired power plants, hullan pupulation, ambient levels of air pollutants, meteorological conditions likely to cause prolonged periods of air stagnation, and occurrence of major crop and forest areas are more predominant in the eastern half of the United States than in the Midwest (Figs. 3.2-3.5). Even when there is strict compliance with all applicable emisstons standards, problems of significant deterioration of air quality from coal development and use are likely to be more serious in Wyoming and the Powder River Basin than in Illinnis or West Virginia (Environmental Research 1977; Stern 1977; U.S. Congress 1977b; Rubin and McMichael 1975). 


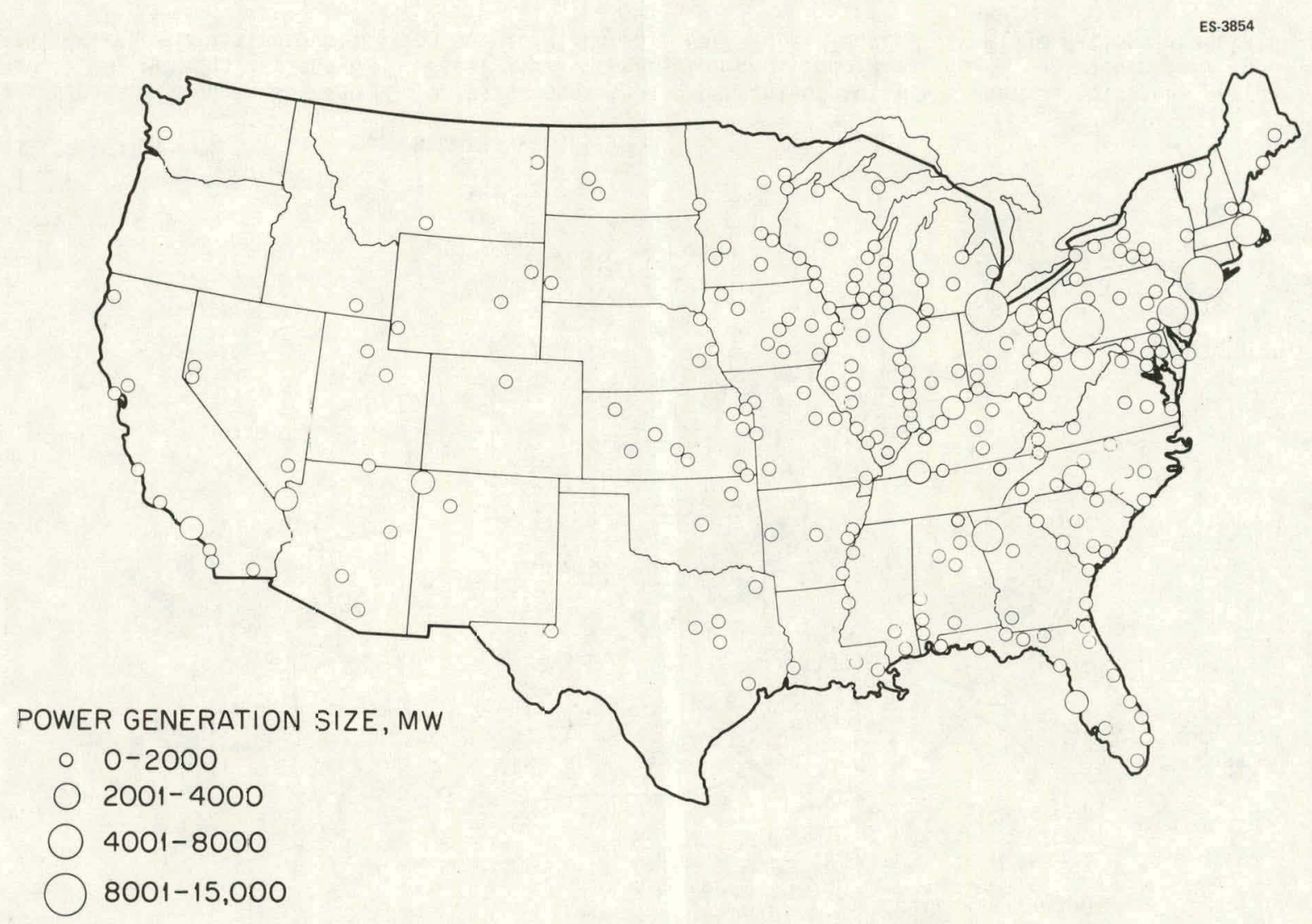

Fig. 3.2. Location of major coal- and oil-fired power units, 1971. Source: D. S. Shriner, S. B. McLaughlin, and C. F. Baes. 1977. Character and transformation of pollutants from major fossil fuel energy sources. Environmental Sciences Division publication no. 1049,28 pp. Oak Ridge, Tenn.: Oak Ridge National Laboratory, Environmental Sciences Division. 
TIP NO. $=$ TOTAL $\mathrm{SO}_{2}-\mathrm{NO}_{2}$ EMISSIONS/AIR QUALITY REGION $\left(10^{6}\right.$ tons $\left.\mathrm{yr}^{-1}\right)$

BOT-OM NO. $=\%$ OF TOTAL CONTRIBUTED BY FOSSIL FUEL UTILIZATION

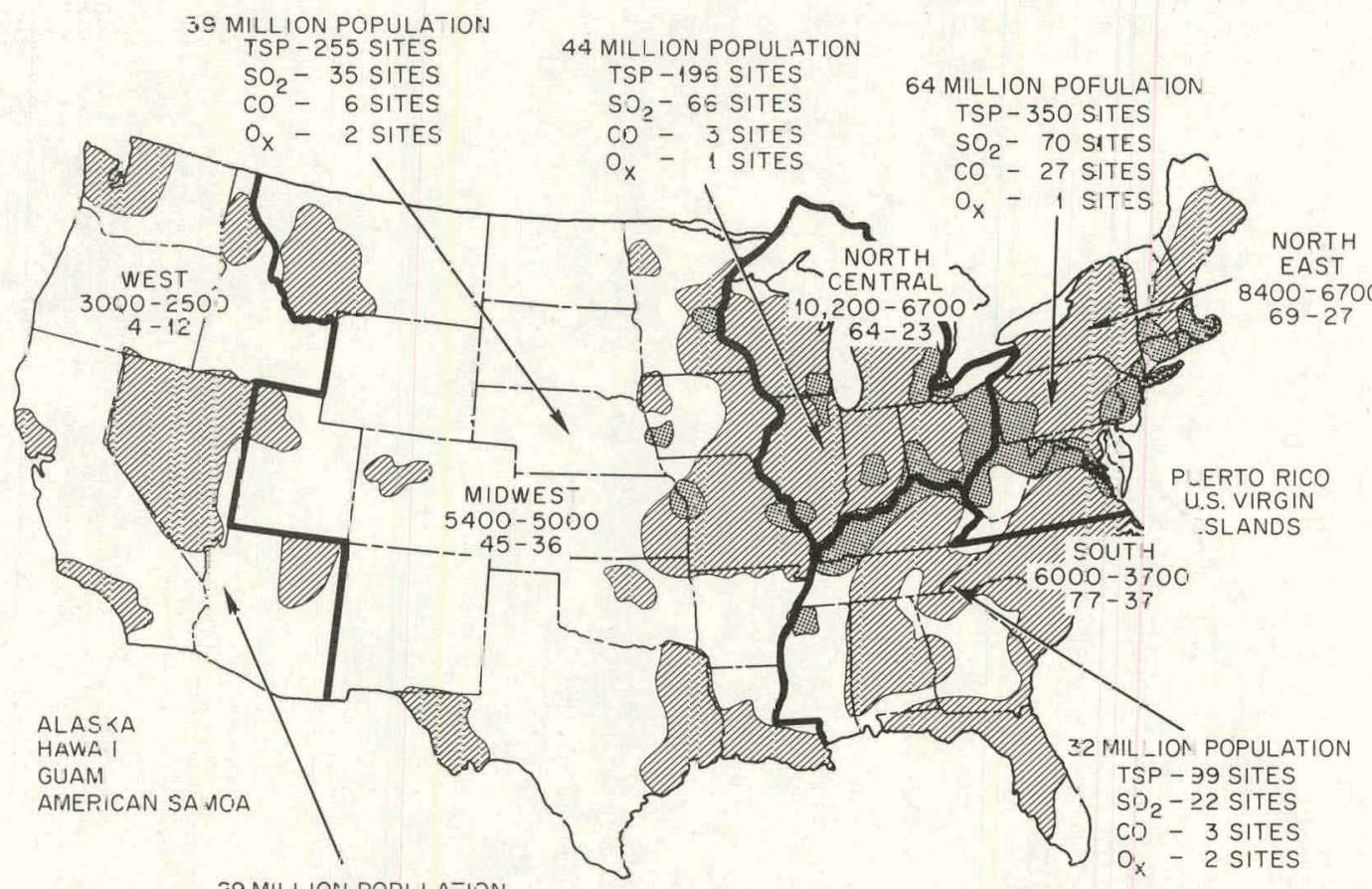

Fig. 3.3. Geographic variazion in $\mathrm{SC}_{2}$ and $\mathrm{NO}_{x}$ emission density and percent of total $\mathrm{SO}_{2}$ and $\mathrm{NC}_{x}$ emissions per air quality region. Source: D. S. Shriner, S. B. McLaughtin, and C. F. Baes. 1977. Character and transformation of pstiutants from major fossit fuet energis sources. Environmental Sciences Division publication no. 1049, 2̇8 pp. Oak Ridge, Tenn.: Oak Ricge Ilational Laboratory, Environmental Sciences Division.

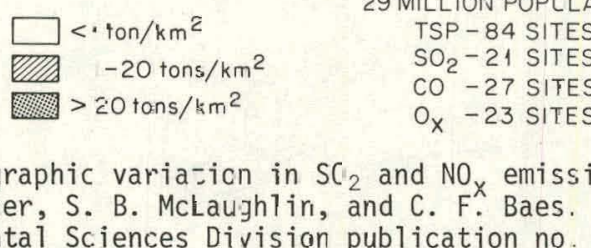

$$
\text { SP }-84 \text { SITES }
$$

255 SITES

TSP-195 SITES TSP- 350 SITES

- 27 


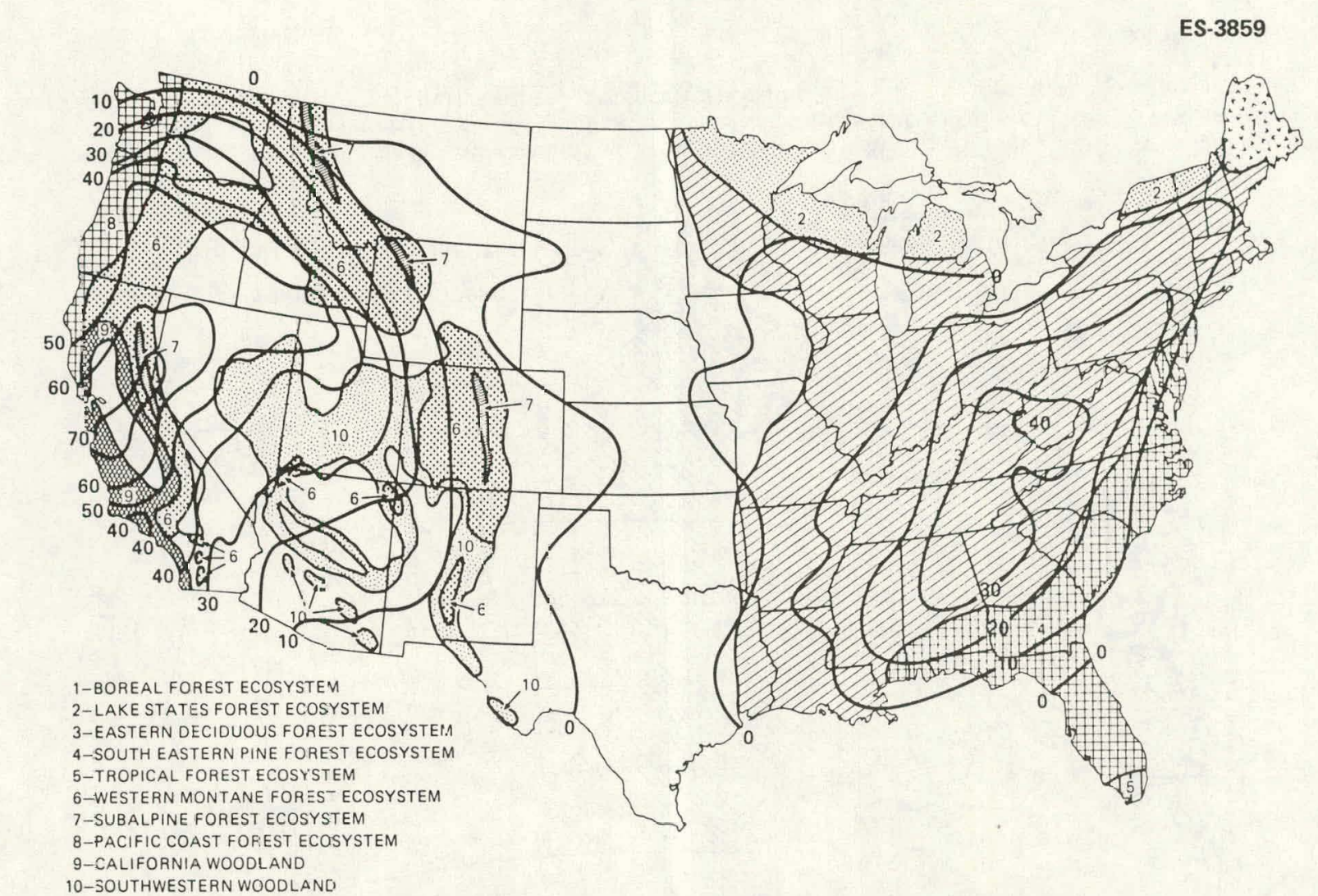

Fig. 3.4. Isopleths of total number of forecast-day's of high meteorological potential for air pollution in a 5-year period compared with bourdaries of forest ecosystems. Source: P. R. Miller and J. R. McBride. 1975. Effects of air pollutants on forests. In Response of plarits to air pollution, eds. J. B. Mudd and T. T. Kozlowski, pp. 195-236. New York: Academic Press, Inc. 


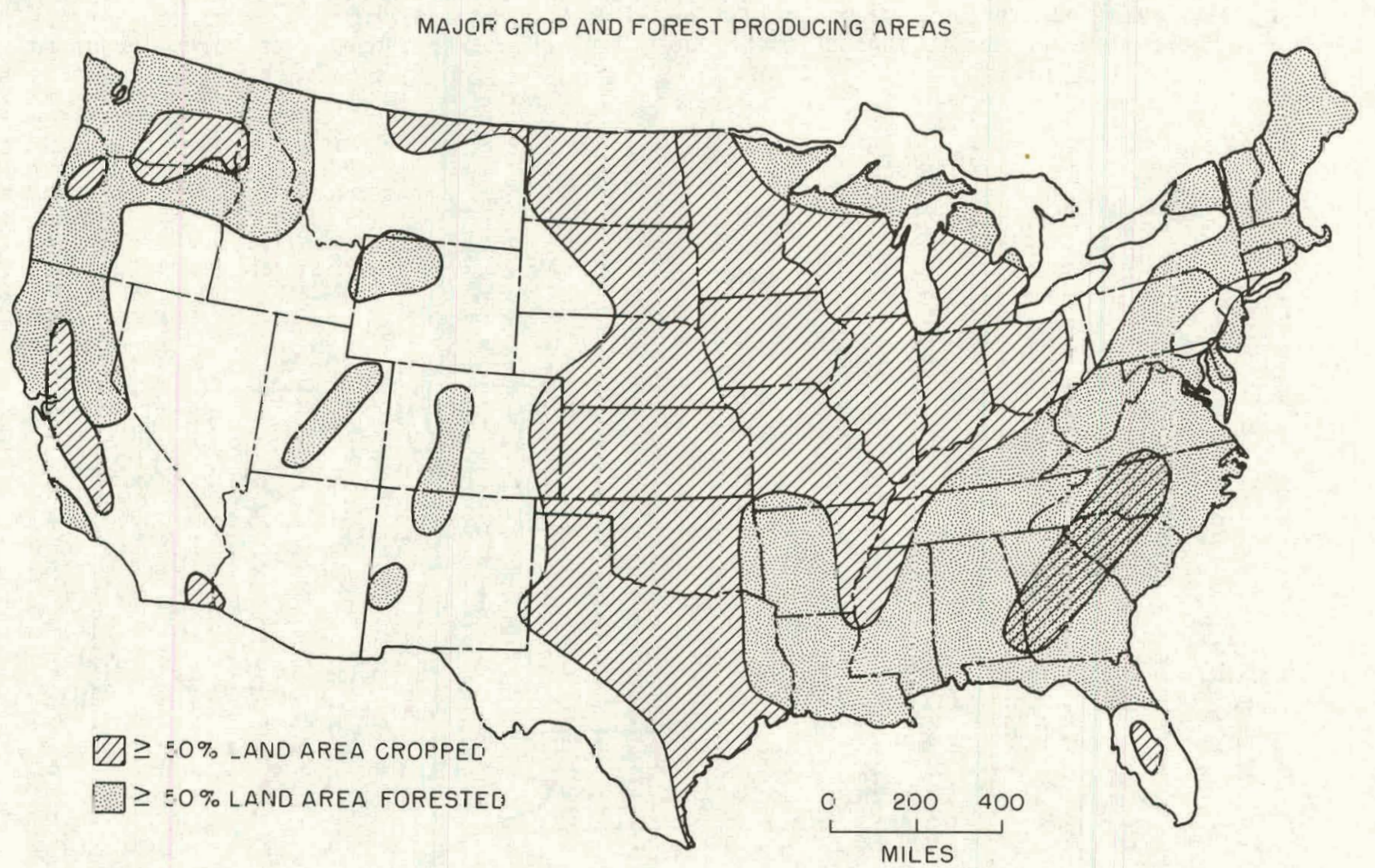

Fig. 3.5. Major crop and forest producing areas of tre United States. Source: S. D. Shriner, S. B. McLaughlin, and C. R. Baes. 1977. Character ard transformation of poïutants from major fossit fuel ene:gy sources. Environmental Sciences Division publication no. 1049,28 pp. Oak Ridge, Tern.: Dak Ridge National Lasoratory, Environmental S=iences Division. 
In the Wyoming area and other semiarid and arid climates, certain adverse environmental conditions appear to reduce the injurious effects of air pollutants on plants (Bridgmon and Lang 1976; Heck 1973). Bridgmon and Lang (1976) reported that sagebrush-grass and saltbushgreasewood associations of the Northern desert-shrub ecosystem were very resistant to sulfur dioxide injury. Also, grasses were more resistant than forbs and shrubs. Apparentiy, the adaptive features of these stressed plants that live in dry climates make many of them more tolerant to at least some pollutants. On the other hand, if heavy particulate loading of the atmosphere from facility emissions should prove to affect the amounts of precipitation within the region, significant effects on flora and fauna can be expected (Institute of Ecology 1974).

Bioaccumulation of toxic trace metals and/or other harmful substances could also be a problem. For example, Christianson (as cited by the Institute of Ecology 1974) has clocumented evidence of molybdenosis in cattle from food-chain concentration of molybdenum from an uraniferous lignite ashing plant in North Dakota. Also, some trace elements such as selenium can accumulate in specific piants (e.g., Astragalus spp. and Conopsis spp.) to levels as high as 10,000 ppm (Peterson 1971). Forage plants containing $5 \mathrm{ppm}$ of selenium are considered potentially hazardous to grazing animals (Hemphill 1972). Much more research is needed to determine the significance of these and other potential impacts to biological systems.

Injury to agricultural crops and forests within the Eastern United States from air pollution is well documented (Mudd and Kozlowski 1975). Reduction of photosynthesis, increased mortality, and other types of damage caused by fumigation with sulfur dioxide and several other identified emissions have been reported for such crops as barley (Hordewom vulgare), alfalfa (Medicago. sativa), wheat (Triticum aestivum), soybeans (Glycine max), tobacco (Nicotiana spp.) and others [Jager and Klein (no date); Auerbach 1975; Rich 1975; Bennett and Hill 1973; Davis 1972 ].

A 2-year study conducted during 1969 and 1970 estimated that between 100 and 125 million doilars were lusl dumudly in the United States Because of reduction in crop yield resulting from air pollution (Heck 1973). Furthermore, if there were a way to assess the total impact of air pollution on crop yield when visible injury is not found or recognized, annual losses amounting to billions of dollars could be expected on forest production, ornamentals, human health, and natural ecosystems (Leaderer et al. 1976; Heck 1973).

In the northeast, centraī, and lake states, injury to Eastern. white pines (Pinus strobus), Scotch pine (Pinus sylvestris), and other conffers has been recognized for many years. For example, in the vicinity of a coal-burning power plant at Mount Storm, West Virginia, Christmas tree growers, in 1968, first complained of injury to their crops which included such species as Eastern white pine, Scotch pine, Virginia pine (Pinus virginiana), Douglas fir (Pseudotsuga. menziesii), and Norway spruce (Picea abies). Damage was found regularly as far as 10 miles from the power plant and affected 30 commercial growers in a two-county area (USEPA 1971c, cited by Miller and McBride 1975).

It is now generally believed that low-level chronic exposure of genetically susceptible species to sulfur dioxide and ozone, acting independently or possibly synergistically, has been responsible for much of the observed damage (Miller and McBride 1975). Apparently, hardwoods are more tolerant to such injury than conifers (Hedgcock 1914, cited by Miller and McBride 1975). 
The release of sulfur dioxide and nitrogen dioxide into the atmosphere from fossil fuel combustion can result in the production of acid rain. The acidity of rain in the Eastern United States has increased significantly in recent years (Miller and McBride 1975). Likens et al. (1972) have suggested effects on forest ecosystems such as changes in rates of leaching of nutrients in soils and plant foliage. A number of other investigations have indicated a progressive decline in coniferous and hardwood forests caused by acidic precipitation (Gordon and Tourangeau 1975). However, the full significance of acid precipitation to forest or other ecosystems remains to be assessed.

In summary, the potential effect of any increase in air pollution loads is difficult to forecast. Probably the operation of a single demonstration facility will not have a significant impact on any biological system unless effluents are concentrated in the immediate vicinity of the plant. However, long-term biological impacts from the release of toxic trace metals, hydrocarbons, and other harmful substances are essentially unknown. It is also reasonable to assume that at some unknown level of pollution the genetic resistance of a species may not be sufficient to cope with any additional pollution insult. Thus in areas that already have rather high levels of air pollution, such as those within the proposed Illinois and West Virginia areas, only a slight increase in ambient levels of certain pollutants could significantly increase biological impacts to sensitive species. Some researchers also believe that vegetation growing under the humid conditions of the Eastern United States could be severely injured if oxidant concentration were to reach levels (daily peaks from 0.3 to $0.6 \mathrm{ppm}$ ) commonly experienced in the less humid areas of California (Miller and MCBride 1975). However, the capability of living systems to adapt to such impacts has not been adequately determined (Heck 1973).

\subsubsection{Aquatic impacts}

At this stage in the development of coal conversion technology, only approximate predictions can be made about the impact on aquatic biota of a pipeline gas facility. The design specifications of these plants have not yet been completed, and the potential effluents have not been finally characterized, either quantitatively or qualitatively. Moreover, the impact of any effluent may vary considerably depending on the physical, chemical, and biological characteristics of the receiving waters. A complete assessment of the impact on aquatic biota of a pipeline gas facility will require an accurate description of all potential effluents and the initiation of a comprehensive, site-specific environmental monitoring program.

Types of impact

All of the plant designs considered in this study call for closed-cycle cooling, with blowdown water used for ash sluicing. Consequently, therc should bc no significant release of heated water and no significant thermal impacts. However, even with closed-cycle cooling, a gasification plant requires large quantities of process and cooling water. If surface water is used, impacts on aquatic biota may result: phytoplankton, zooplankton, and ichthyoplankton may be entrained in the intake stream, and fish may be impinged on intake trash screens. nniy the Masnn rounty, West Virginia, and St. Clair County, Illinois, planls wuuld be designed to consume surface water. The intake rates of these plants (about $0.23 \mathrm{~m}^{3} / \mathrm{sec} ; 8 \mathrm{cfs}$ ) are extremely small in comparison with the flow rates of the Ohio (annual average flow $1420 \mathrm{~m}^{3} / \mathrm{sec} ; 50,000 \mathrm{cfs}$ ) and Kaskaskia (annual average flow $120 \mathrm{~m}^{3} / \mathrm{sec} ; 4200 \mathrm{cfs}$ ) rivers (Sects. 2.1.3.1 and 2.2.3.1); therefore, it is extremely unlikely that significant entrainment or impingement impacts will occur. 
Although a variety of potential chemical contaminants are produced in a gasification plant, some are amenable to standard wastewater treatment methods (e.g., phenols and ammonia). 0ther waste streams have not been completely characterized chemically at this time (e.g., spent catalysts and acid-gas treatment chemicals), nor have final treatment schemes been specified. Two types of contaminants that have received considerable attention as potential environmental hazards from the operation of pipeline gas plants are trace metals (Jahnig and Bertrand 1976) and polynuclear aromatic hydrocarbons (Herbes et al. 1976). These particular contaminants are regarded as significant because (1) they are toxic to aquatic organisms at extremely low concentrations, (2) when present in the environment in sublethal amounts, many accumulate to high concentrations in the tissues of aquatic organisms, and (3) until recently their effects have received little study, and the amounts that can be safely released to aquatic systems are not known. Because of their toxicity or carcinogenicity, some of these substances are also hazardous to man.

The ash fraction (6 to 12\%) of coal contains a variety of trace metals (Hall et al 1974). Many of these have been identified in liquid effluents from coal conversion pilot plants (Hildebrand et al. 1976). Data compiled from the literature by Cushman et. al. (1977) and shown in Table 3.19 reveal that most have been found, at least under some experimental conditions, to be lethal to aquatic organisms in concentrations of $1 \mathrm{ppm}$ or less. Many of these metals, even if not present in the environment in toxic quantities, may be absorbed and concentrated by organisms. Concentration factors (i.e., the ratio of the concentration of a substance in an organism to its concentration in the environment) greater than 1000 have been reported for many of the trace metals that are present in coal (Thompson et al. 1972). Because aquatic animals can absorb metals both from solution and from their food (Bryan 1976), even if only one component of an ecosystem (e.g., benthic invertebrates) is directly exposed to trace metals, their impact will spread to organisms at higher trophic levels.

The significalle lu ecusystems of the bioaccumulation of trace metals is not known, but its significance to human health may be considerable. The importance of contaminated fish and shellfish as sources of human exposure to mercury is well known (Wood 1972). More recently it has been observed that food is an important source of human exposure to cadmium, and some researchers (e.g., Kjellstrom 1977) believe that human dietary intake of this metal may already be dangerously high. Other metals and metalloids that are highly toxic to man (e.g.. arsenir., beryllium, lead, and selenium) are contained in coal and coul conversion errluents and are accumulated by edible aquatic organisms (Hildebrand et a1. 1976). Whether the ingestion of small quantities of these elements in food constitutes a hazard to human health is not yet known.

Polynuclear aromatic hydrocarbons (PAHs) are produced by both coal conversion and combustion (Herbes et a1. 1976; National Academy of Sciences 1972). Many of these compounds, unlike most organic wastes, are extraordinarily stable and are highly resistant to degradation by activated sludges (Malaney et al. 1967). Polynuclear aromatic hydrocarbons are known to be toxir. to aquatic animals, especially to larvae, in concentrations as low as $100 \mathrm{ppb}$ (Moore and Dwyer 1974). However, perhaps more important than their toxicity to aquatic life is the fact that many PAHs are carcinogenic (National Academy of Sciences 1972). Polynuclear aromatic hydrocarbons are only slightly soluble in water, but like organic pesticides they are freely soluble in plant and animal tissue and can accumulate in edible aquatic animals, particularly in mollusks, to 1000 t.imes their concentration in water (Neff 1975; Stegeman and leal 1973; Herbes et al. 1976). 
Table 3.19. Concentrations of trace elements found to be toxic to aquatic organisms

Lowest lethal concentrations found by Cushman et al. 1977, in parts per million or less

\begin{tabular}{|c|c|c|c|}
\hline $\begin{array}{c}\text { Trace } \\
\text { element }\end{array}$ & Concentration & $\begin{array}{c}\text { Trace } \\
\text { element }\end{array}$ & Concentration \\
\hline $\mathrm{Ag}$ & 0.0003 & $\mathrm{Mg}$ & 17.0 \\
\hline $\mathrm{Al}$ & 0.07 & $M n$ & 0.35 \\
\hline As & 0.022 & $\mathrm{Ni}$ & 0.05 \\
\hline$A u$ & 0.4 & $\mathrm{~Pb}$ & 0.007 \\
\hline B & 0.69 & $\mathbf{R b}$ & 14.0 \\
\hline $\mathrm{Ba}$ & 8.0 & $\mathrm{Sb}$ & 9.0 \\
\hline $\mathrm{Be}$ & 0.15 & $\mathrm{Se}$ & 1.0 \\
\hline $\mathrm{Br}$ & 0.18 & Sn & 1.0 \\
\hline r.t. & ก กกก9 & $\mathrm{Sr}$ & 0.2 \\
\hline $\mathrm{Ce}$ & 0.14 & Th & 0.4 \\
\hline $\mathrm{Cu}$ & 0.021 & 'lì & 2.0 \\
\hline : & 0.008 & TI & 0.00 \\
\hline Ciu & บ.บับบอ๋ & U & 1.7 \\
\hline $\mathrm{Fe}$ & 0.02 & $v$ & 4.8 \\
\hline Ily & 0.003 & $w$ & 110.0 \\
\hline La & 0.015 & $Z_{\prime \prime}$ & 0.0001 \\
\hline $\mathrm{Li}$ & 2.6 & $\mathbf{Z r}$ & 14.0 \\
\hline
\end{tabular}

Source: R. M. Cushman, S. G. Hildebrand, R. H Strand, and $\mathrm{A}$. Anderson. 1977. The toxicity of 35 trace e/cmonts in cool to freshwater biota: a data base with automated retrieval capabilities. ORNL/ TM-5793 (in press). Oak Ridge, Tenn.: Oak Ridge National Laboratory:

\section{Effluent sources}

In theory, coal conversion plants are designed to minimize, and ideally to eliminate, the del iberate release of liquid effluents. However, even if it is assumed that all liquid wastes will be converted to solid form for landfill disposal, impacts to aquatic systems are still possible. In addition to potential point sources, the following are believed to be the major nonpoint sources of such impacts: (1) runoff of rainwater from exposed coal piles, (2) overflow and seepage from settling ponds, (3) leaching from landfills, and (4) deposition of airborne particulates.

Unfortunately, it is not possible to predict a priori the quantities of trace metals and PAHs that will enter aquatic environments from any of the above sources. Landfills will be the largest potential source, because ideally these will be the final disposal sites for nearly $100 \%$ of all the contaminants produced. The mobilities of metals and PAHs in the 1 andfill environment are unknown. Accidental discharges from coal piles and settling ponds could result in major releases, but it is not possible to predict either the frequency or the seriousness of such events. A gasifier-utility boiler complex would, under the assumptions made for this study, emit between 122 and $544 \mathrm{~kg}$ (270 and $1200 \mathrm{lb}$ ) per day, or about 45 to 180 metric tons (50 to 200 tons) per year (Sect. 1.2.3), of airborne particulates, primarily coal dust and fly ash. The fraction of this dust and ash which might eventually be deposited in surface water is unknown. 
Impact to the Ohio River of the Mason County, West Virginia, plant

Because of its size and history of pollution, the Ohio River is the least likely of the three systems to suffer significant damage from the operation of a pipeline gas facility. The annual average flow of the Ohio River at the Mason County site, $1420 \mathrm{~m}^{3} / \mathrm{sec}(50,000 \mathrm{cfs})$, is 11.9 times that of the Kaskaskia River at New Athens, I1linois, and 250,000 times that of Donkey Creek, the stream most likely to be implemented by the Campbell County, Wyoming, plant.

Although the spatial distribution of introduced trace metals and PAHs will probably be far from uniform, the Ohio River clearly has a relatively large dilution capacity. Moreover, the amounts of contaminants that could be released by the plant must be small in comparison with the existing load imposed by mining and industry in the upper Ohio River Basin. Of all the 16 basins studied by Kopp and Kroner (1967), the Ohio River Basin was second only to Lake Erie in terms of trace metal loading. The Ohio River accounted for 81 of the 177 violations of water quality criteria observed during the years 1962-67, including 58 of the 74 violations of manganese standards, 15 of the 41 arsenic violations, 6 of the 27 lead violations, and 2 of 6 cadmium violations. The potential contamination from a pipeline gas demonstration plant may also be small in comparison with that of the four large coal-fired generating stations currently operating or projected to operate by 1983 which are located within $32 \mathrm{~km}$ (20 miles) of the Mason County site. These plants (Philip Sporn, Gavin, Kyger Creek, and Project 1301) have a current generating capacity of $3500 \mathrm{MW}$ and a projected capacity by 1983 of more than $6000 \mathrm{MW}$ (Butz et a1. 1974; U.S. Army Corps of Engineers 1975).

Even if no ecological damage occurs as a result of the operation of a pipeline gas facility on the Ohio River, bioaccumulation of trace metals and PAHs may occur. The data in Table 2.40 show that many edible fish occur near the plant site, including popular sport fish such as the channel catfish and largemouth bass. Although no commercial fishery exists in the area, it must be assumed that sport fishing does occur and that contamination of the river will result in an increase in the exposure of the local human population to carcinogenic raHs and ioxic trare metals.

Impact to the Kaskaskia River of the St. Clair County, Illinois, plant

Because of its smaller size and lower flow rate, the Kaskaskia River is much more likely to be adversely affected by contamination from a pipeline gas facility than is the Ohio River. For any given amount of contaminant released, the concentration in sediment and water columi should be higher and the fraction of the total habitat impacted larger in the Kaskaskia than in the Ohio. In addition, the St. Clair County, Illinois, site contains important and vulnerable aquatic habitats: the backwaters created by the Corps of Engineers. These serve as spawning grounds for many of the fish populations of the Kaskaskia (Coalcon 1977). These backwaters are small in size compared to the main channel, and contaminants discharged into them will not be dispersed. Moreover, the concentrations of many metals that inhibit fish reproduction are lower than those that are toxic to adults (Sprague 1971); and larvae of aquatic organisms, including fish, are generally more sensitive to PAHs than are adults (Moore and Dwyer 1974). The contamination of backwaters would reduce further the amount of spawning habitat available to these fish, which has already been greatly reduced by human alteration of the Kaskaskia.

Even if damage to the Kaskaskia ecosystem does not occur, its contamination could, through bioaccumulation, result in increased exposure of human populations to carcinogens and toxic trace metals. 
Impact to Donkey Creek of the Campbell County, Wyoming, plant

Because of its extremely small size, Donkey Creek is probably the most sensitive of the three streams to contamination from a pipeline gas demonstration facility. Because this creek has a mean annual flow of only $0.01 \mathrm{~m}^{3} / \mathrm{sec}(0.2 \mathrm{cfs})$, even a relatively small population incident such as leakage from a settling pond could result in the destruction of aquatic life in the impacted segment of the stream. Significant fishing is not likely in Donkey Creek, so that contamination is not 1 ikely to result in increased human exposure to toxicants and/or carcinogens. However, a major flash flood, particularly one that involved the inundation of a settling pond, would carry contaminated sediment and/or ash particles into the Belle Fourche River and eventually into Keyhole Reservoir, a major warm-water fishery about $48 \mathrm{~km}$ (30 miles) downstream from the plant site.

Summary of operational impacts on receiving water biota

1. Thermal impacts are expected to be negligible.

2. Entrainment/impingement impacts are expected to be negligible.

3. The major impacts are expected to result frum the release of chemical contaminants. Two classes of contaminants, trace metals and PAHs, warrant spectal concern.

4. Even if plant designs eliminate point source release of aqueous effluents, nonpoint source effluents may still be important.

5. Of the three streams discussed, Donkey Creek (Campbell County, Wyoming) is the most sensitive to operational impacts from a pipeline gas facility, and the Ohio River (Mason County, West Virginia) is the least sensitive.

6. Precise predictions of the operational impact of a pipeline gas facility cannot be made until the plant design has been completed, potential effluents have been characterized, and sitè-specific envirnnmental monitoring program lias been intilated.

\subsubsection{Socioeconomic effects}

\subsubsection{Employment and population changes}

\section{Direct emplovment}

A typical demonstration plant will require an operating work force of 400 to 500 (see Sect. 1.2.1.1 for a description of the type of plant, in terms of daily nutput, food ooal and water requirements, etc., that would need this amount of operating manpnwer). Unlike the construetion wirk furce, the operating work force will remain the same size for all years of operation.

\section{Secondary employment}

Mult1pliers estimated by Stenejhem and Metzger (1976) for St. Clair, Mason, and Campbell counties were applied to the operating work force to estimate the total number of jobs created by plant operation. The results of these calculations are given in the third column of Table 3.20. 
Table 3.20. Employment and population changes (operations phase)

\begin{tabular}{lccc}
\hline & St. Clair County & Mason County & Campbell County \\
\hline Facility employment & $400-500$ & $400-500$ & $400-500$ \\
Employment multiplier & 2.5 & 1.1 & 1.7 \\
Total new jobs & $1000-1250$ & $440-550$ & $680-850$ \\
Total local employables $^{\theta}$ & $3237-2449$ & $256-413$ & $265-467$ \\
Nonlocal workers $^{b}$ & 0 & $27-294$ & $213-585$ \\
Average family size & 2.4 & 2.4 & 2.6 \\
Total new population & 0 & $65-706$ & $554-1521$ \\
\hline
\end{tabular}

\footnotetext{
${ }^{a}$ Local employables from third year of construction phase (Sect. 3.1.3.1) plus one-fourth of third-year construction work force plus one-fourth of new local employables in year four.

${ }^{b}$ Maximum potential range generated by assuming low constiuction work force with high operations work force and high construction work force with low operations work force.

Source: From E. J. Stenejhem and J. E. Metzger. 1976. A framework for projecting employment and population changes accompanying energy development. Washington, D.C.: U.S. Energy Research and Development Administration.
}

Total population changes

Estimates of the total new population that will result from plant operation, given in the last column of Table 3.20, were obtained as follows: (1) the total number of new jobs (both basic and secondary) due to plant operation was compared to the estimated number of local (i.e., inthe-county) employables; (2) the difference between the number of new jobs and the number of local employables gave an estimate of the nonlocal (i.e., out-of-the-county) workers who will be employed by the plant; and (3) the number of nonlocal workers was multiplied by the average family size in each county as given by Stenejhem and Metzger (1976).

Estimates of the number of local employables, given in the fourth row of Table 3.20 , were calculated by summing the following components: (1) the number of local employables estimated for the last year of the construction phase (see Sect. 3.1.3.1 for a discussion of how these estimates of local employables were obtained); (2) one-fourth of the construction work force present in the last year of construction (Sect. 3.1.3.1, Tables 3.8, 3.9, and 3.10); and (3) one-fourth of the number of additions to the labor force estimated by Stenejhem and Metzger (1976) for the fourth year of a project. More than one-fourth of the construction work force and/or the new additions to the labor force may take employment in plant operation. Basing estimates on only one-fourth of these potential local plant employees could therefore produce an over-estimate of the number of workers that will come from outside the county. But since our purpose is to project impacts and since the severity of impacts increases with the rate of population increase, it seems desirable to make worst-case assumptions, as we have done.

The amount of population increase also may be overestimated if some of the nonlocal workers commute from adjacent courties (see sect. 3.1 .3 for a discussion of commuting potentials for each county). In general, because operations workers will be employed for longer time periods than construction workers, they are less likely to commute and more likely to move to homes close to the plant site. As a result, the estimates of total population increases a re less likely to be overestimates for the operations phase than for the construction phase. 


\subsubsection{Impacts on surrogate sites}

The socioeconomic impacts generated during the operation phase of a project are more likely to be beneficial to the local community than are those generated during the construction phase. The reason for this is twofold. First, the labor and intermediate product demands that are generated during the operating phase are more permanent in nature, lasting over the life of the project. Because these demands are continuing, there is an economic incentive for permanent suppiy sources to develop or expand. During construction, situations of excess demand (with attendant rationing problems) are allowed to persist because sharply decreasing demands are anticipated before capacity adjustment expenditures (in the form of new capital equipment) can be paid off. The typical operating phase of a project, however, is of sufficient duration to permit needed capacity adjustment. As a result, local markets are allowed to equilibrate. Nonlocal workers tend to relocate rather than to commute, and they are more likely to bring their familips and become a part of the community. Consequently, there is a permanent expansion in the size of the local labor force. Firms liat supply matcrials or services to the farility have an incentive to adjust capacities upward, and new firms may enter thè market. Also, lucal officials are able to justify needed expansions, such as in schools, roads, police, and fire protection services. Consequently, the entire economic base and local infrastructure expand, and an increased potential for future growth is created.

Second, the capability of the local government to respond to the increased demands on the public service sector expands considerably during the operating phase of the project. The increased economic activity and the expansion of the community's population enlarges the existing tax base and thereby increases local government revenues. Similarly, tax receipts from the facility itself (assuming that the facility is located within the community's taxing district) are realized as operations are begun. The financing of new capital expenditures is facilitated by the enlarged tax base because bond flotations can be paid for out of increased revenues. Thus a permanent increase both in demand and in potential supply of local government services occurs during this phase. The resulting expansion of public services alleviates much of the difficulty encountered during the construction phase.

Because of this increased incentive and ability for supply responses to occur, beneficial impacts are likely to be realized more often than adverse impacts. Income and employment expansions can occur without imposing supply shortages on the original inhabitants of the area. Our discussion of the operation phase socioeconomic impacts is therefore confined to pointing out those areas in which capacity adjustments are likely to be needed and those areas in which existing capacities appear to be adequate.

\section{St.. Clair County}

The results reported in Table 3.20 indicate that St. Clair County will experience no inflow of population during the operating phase of the project. Consequently, beneficial employment and income impacts will be generated without the adverse impacts created by significantly increased demands for housing, health care, and school facillties. Aydill, this result is attributable to the large diversified economic structure and developed service sector in this area. 
Mason County

Table 3.20 indicates a facility-related population inflow of between 65 and 706 persons for the operating phase at the Mason County site. The income and employment effects associated with this inflow should be beneficial because the area is characterized by high unemployment and depressed economic conditions. Moreoever, Mason County should be able to assimilate the additional population without experiencing severe supply shortages of needed materials or services. It will be necessary to expand capacity in several areas, however, to preserve (or perhaps improve) existing standards of community services.

The principal areas in which expansion will be required are housing and education. The former is provided by private industry, whereas the latter is a public service. Table 3.20 indicates a maximum inflow of almost 300 workers who will. seek permanent residence in the area. The pressure exerted on the single-family owner-occupied housing market is likely to result in increased prices until the market has time to respond. As Sect. 2 indicated, excess capacity is nonexistent in the school system; the additional population will create the need for expansion in this area also. Some or most of this capacity adjustment can occur during the construction phase of the project, but the longer-term users of the system will pay for most of the expansion expense during the operating phase.

Other areas in which some capacity adjustments may be required are transportation, health care, police and fire protection, recreation, and water supply and wastewater treatment systems. Again, however, the extent of expansion required in these areas is likely to be considerably less than that needed in the housing and educational service areas. As in the construction phase, the adverse socioeconomic impacts resulting from facility operations are expected to be small to moderate in the Mason County area.

Campbel1 County

In Campbcll County, the service areas likely to lieed inust expansion are housing, sewerage, health care, recreation, water supplies, police and fire protection, and roads. Increases in the school age population caused by a demonstration plant alone would probably not require more expansion of schools than is already planned. If a number of new projects develop at the same time, however, the cumulative growth would require more educational facilities. Cumulative impacts of a number of energy developments also are likely to change the composition and character of the population, economy, and the social and political systems of the area. Campbell County has been, until recently, a rural agricultural area. As more development takes place, Campbell County will continue to become more urbanized and industrialized.

\subsubsection{Summary of operation phase sociner.nnnmir imparts}

As a result of the flexibility provided by a large diversified industrial structure and a developed service sector, St. Clair County is likely to experience an overall beneficial socioeconomic impact during the operating phase of the project. Increased income and employment should be generated without imposing significant shortages of essential goods and services.

Mason County, while experiencing some shortages (particularly in the areas of housing and education), should be able to respond to increasing demands for local goods and services. As 
a result, the added economic stimulus created by facility operations should generate net benefits to the local community.

Campbell County is likely to experience a relatively prolonged period of adjustment, during which negative impacts may be felt. Prior planning and budgeting decisions, however, could help to mitigate much of this adverse effect.

\subsubsection{Impacts on archaeological, historic, and paleontological sites}

Operations impacts on historic and archaeological sites are not anticipated for either St. Clair or Campbell Counties. Like indirect construction impacts (Sect. 3.1.4), operations impacts could occur in Mason County. Operations impacts can be avoided in Mason County, however, if an appropriate location is chosen in the preconstruction phase and/or mitigating action is taken in the operating phase.

\subsubsection{Mitigating measures - operational}

Mitigating measures should be an important part of initial planning for the operation of a demonstration pipeline gas facility. Such planning involves prior recognition of potential problems (including related impacts from such activities as surface mining, industrial growth, and population growth) and the development of programs for their solution.

Many of the potential impacts could be eliminated or reduced by selection of sites appropriate for the operation, by application of the best available control technology, and by strict compliance with all Federal and state regulations. For example, site selection must take into consideration the Air Quality Maintenance Areas (AQMA) recognized by the EPA so that emissions resulting from facility operations, combined with all other existing or predicted emissions, will not result in a significant deterioration of air quality (Environmental Research 1977, U.S. Congress 1977b). Other control measures might include (1) incorporatiun of a buffer zone around the facility to reduce offsite noise to acceptable levels and to improve aesthetics, (2) siting of noise-emitting equipment away from sensitive sites such as residential areas,

(3) using proper insulation to reduce noise within the facility to acceptable levels, and

(4) requiring manufacturers of equipment to meet emission specifications.

Once trace metals, PAHs, or other aqueous contaminants have entered receiving waters, there may be little that can be done to mitigate their impact. Mitigating measures should therefore be aimed at minimizing the release, by design or by accident, of hazardous effluents. In general, such measures should inciude (1) constructing drainage systems for coal storage and handling facilities so that runoff water may be collected and routed to wastewater treatment facilities and (2) siting coal storage facilities and settling ponds above floodplains and water tables.

Special attention should be given to preventing the release of effluents to sensitive and/or ecologically important aquatic habitats. For example, the St. Clair County, Illinois, plant and its auxiliary facilities should be sited and constructed such that the possibility of effluents entering the Kaskaskia River backwaters is minimized.

Evidence indicates that considerable research is needed to establish practical and environmentally safe control methods. New legal standards and control techniques may have to be promulgated 
for prevention of biological impacts mostly unique to the coal gasification industry. The ultimate fate of all potentially harmful chemicals used or produced during the conversion process should be accurately documented and plans developed for their control. Implementation of an early warning system to detect the presence of trace metals, carcinogenic hydrocarbons, and/or other potentially dangerous contaminants in air emissions, cooling waters, refuse piles, etc., is recommended.

In cases in which low-level amounts of potentially harmful materials will be released even after employment of the best available technology, long-term biological studies are needed. The importance of obtaining predevelopment baseline data cannot be overemphasized. This should include the establishment of several control or reference areas.

Reclamation plans should be available for consideration when the facility ceases operation. Various options such as converting the land to agricultural use, rangeland, recreational use, and wildlife habitat, and/or use of the existing facilities by industry or others should be considered in relation to the environmental features of the area. For example, if reciamation plans call for return of the land to wildlife habitat, revegetation programs that emphasize habitat diversity and specific needs of the species expected to use the area should be implemented. Barriers to animal dispersal such as canal ditches and fences should be removed whenever possible. In all cases, proper disposal or reclamation of refuse areas according to 1 aw must be enforced, which should include periodic inspection of such areas for accidental leaking or emissions of potentially dangerous contaminants to adjacent areas.

\subsubsection{Potential accidents}

Accidents may take many forms and could originate from a vast number of sources ranging from fugitive emissions to major failures of pressure vessels.

Fugitive emissions will probably occur, especially where high pressures exist. Sources may include pumps, valves, coinpressors, heat exchangers, piping and ducts, evaporation from ponds and lagoons, vapor breathing in storage tanks, and leaks in storage vessels. Emissions may also result from internal failures in baghouses and particulate removal devices; plugging of flue gas desulfurization units; flashing from depressurizing high-pressure sour gas streams; transferring by-product tar, $0 i 1$, phenol, or ammonia; and the release of contaminated steam from ash quenching. This list is rot complete but does point out the enormity of potential fugitive emission surces in a gasification complex.

Major accidents could result from failure of a vessel or transfer line between the gasifier and the methanation reactor. A rupture would release raw synthesis gas containing sulfur compounds, phenols, trace elements, tars, oils, ammonia, cyanide, and cyanates. Included in some of these categories (the phenols, oils, and tars, for example) are hundreds of organic compounds ranging from innocuous to highly toxic or carcinogenic. It is difficult to determine the duration or extent of such a process disruption. Process designers should address this problem and be prepared with emergency procedures to minimize the escape of liquids and gases, not only during the upset but during the subsequent cleanup as well (or during a system purge if it becomes necessary). It should be noted that any contaminants that cover the ground could find their way to the groundwater system during rainstorms or into surface waters. 
Similarly, a major failure in the wastewater treatment section could pose serious environmental threats. A major process upset (such as described above) could seriously overburden the wastewater treatment facility and result in overflow of raw wastewater or, possibly, extermination of the biological media. Holding and blending tanks upstream of the treatment facility have been suggested as a means of regulating heavy slugs or streams of specific contaminants. Standby systems, such as activated carbon beds, have also been proposed to alleviate the burden on the biological oxidation system or even replace it in the event of an accident. It should be clear from the discussion of wastewater (Sect. 1.2.7) that the release of untreated wastewater may be a serious environmental threat. Such a contaminated stream could find its way to the groundwater system or to the atmosphere if the cooling tower receives its makeup water from the discharge of the wastewater treatment plant. 


\section{REFERENCES FOR SECTION 3.2}

Anderson, W. L. 1978. Water fowl collisions with power lines at a coal-fired power plant. Wizdl. Soc. Bulz. 6(2): 77-83.

Auerbach, S. I. 1975. Testimony presented to Subcommittee on Environment and the Atmosphere. U.S. House of Representatives: Hearings on costs and effects of chronic low-level environmental polzution. Oak Ridge, Tenn.: Oak Ridge National Laboratory.

Avery, M.; Springer, P. F.; and Cassel, J. F. 1976. The effects of a tall tower on nocturnal bird migration - a portable ceilometer study. Auk. 93: 281-91.

Bennett, J. H., and Hill, A. C. 1973. Inhibition of apparent photosynthesis by air pollutants. J. Environ. Qual. 2: 526-30.

Berkau, E. E.; Cordle, S. R.; Hart, F. D.; and Simon, G. R. 1975. An assessment of the Federal noise research, development and demonstration activities, FY73-FY75. EPA 600/2-75-010. Washington, D.C.: U.S. Environmental Protection Agency.

Braunstein, H. M. 1978. Environmental and health aspects of disposal of solid wastes from coal conversion: an information assessment. ORNL-5361. Oak Ridge, Tenn.; Oak Ridge National Laboratory.

Brewer, R., and Ellis, J. A. 1957. An analysis of migrating birds killed at a television tower in east-central I1linois, September 1955-May 1957. Auk. 75: 400-14.

Bridgmon, G. H., and Lang, R. L. 1976. Resistance of desert plants of Wyoming to $\mathrm{SO}_{2}$ injury. In Proceedings of the American Phytopathological Society, vol. 3, p. 225. St. Paul, Minn.: American Phytopathological Society.

Bryan, G. W. 1976. Some aspects of heavy metal tolerance in aquatic organisms. In Effects of pollutants on aquatic organisms, ed. A. P. M. Lockwood. Cambridge: Cambridge University Press.

Buffington, J. C. 1974. Assessment of the ecological consequences of herbicide use along transmission line rights-of-way and recommendation for such use. ANL/ES-34, pp. 19-22. Argonne, 111.: Argonne National Laboratory.

Butz, B. P.; Schregardus, D. R.; Lewis, B. A.; Policastro, A. J.; and Reisa, J. J. 1974. Ohio River cooling water study. EPA-905/9-74-004. Washington, D.C.: U.S. Environmental Protection Agency.

Christianson, G. A. 1974. North Dakota State Department of Health unpublished paper. Cited by Institute of Ecology. 1974. A scientific and policy review of the draft environmental impact statement for the proposed Federal coal leasing progrom of the Bureau of Land Management. Department of the Interior. Washington, D.C.: The Institute of Ecology, Environmental Impact Assessment Project. Coalcon: environmental analysis report for the clean boiler fuel demonstration plant progrom at New Athens, Izlinwis. 1977. Prepared for the Energy Research and Development Administration, Division of Fossil Demonstration Plants. West Chester, Pa.: Roy F. Weston, Inc. 
Cochran, W. W., and Graber, R. R. 1958. Attraction of nocturnal migrants by lights on a television tower. Wizson Buzz. 70:378-80.

Colucci, A. V. 1976. Sulfur oxides: current status of knowledge. San Rafael, Calif.: Greenfield, Attaway and Tyler, Inc.

Commission on Natural Resources, National Academy of Sciences, National Academy of Engineering, and National Research Council. 1975. Air quality and stationary emission control. Washington, D.C.: U.S. Government Printing Office.

Culkowski, W. M., and Patterson, M. R. 1976. A comprehensive atmospheric tronsport and diffusion model. ORNL/NSF/EATC-17. Oak Ridge, Tenn.: Oak Ridge National Laboratory.

Cushman, R. M.; Hildelurand, S. G.: Strand, R. H.; and Anderson, R. 1977. Tho toxicity of 35 trase elements in coal to freshrwter biota: a data base with automated rotrioval capabilitites. ORNL/TM-5793. Oak Ridge, Tenn.: Oak Ridge National Laboratory.

Davis, C. R. 1972. Sulfur dioxide fumigation of soybeans: effect on yield. J. Air Polzut. Control Assoc. 22: 964-66.

Deutsch, M. 1963. Groundwater contamination and legal controls in Michigon. U.S. Geological Survey water supply paper 1691. Washington, D.C.: U.S. Government Printing Office.

DeWitt, J. B.; Menzie, C. M.; Adomaitis, V. A.; and Reichel, W. L. 1960. Pesticide residues in animal tissues. In Trans. 25th North Am. Wildz. Conf., pp. 277-85. Washington, D.C.: Wildlife Mạagement Institute.

Dickerson, W. D. 1973. Highway projects. In Guidelines for review of environmental impact stalemenls, vol. 1. Washington, D.C.: U.S. Environmental Protection Agency.

Dustman, E. H., and Stickel, L. F. 1966. Pesticide residues in the ecosystem. American Society of Agronomy spec. publ. no. 8, pp. 109-21. Madison, Wis.: American Society of Agronomy.

Environmental Research Laboratory, Inc. 1977. Workshop on the 1977 clean air act amendments. October 1977. Bostun, Mass.

Evans, R. J., and Bitler, J. R. 1975. Coal surface mining reczamation costs. U.S. Bureau of Mines information circular $8695.50 \mathrm{pp}$. Washington, D.C.: U.S. Government Printing office.

Fautin, R. W. 1976. Terrestrial vertebrates. In Final environmental assessment, Black Thunder Mine Site, CompbelZ County, Wyoming, eds. H. L. Bergman and H. D. Marcus, pp, X-1-X-50. (Incomplete reference).

Finkel, A. J., ed. 1974. Fnergy, the environment, and human health. American Medical Association Congress on Environmental Health: Energy, the Environment, and Human Health. Acton, Mass.: Publishing Sciences Group, Inc. 
Friend, M., and Trainer, D. 0. 1970. Some effects of sublethal levels of insecticides on vertebrates. J. Wildl. Dis. 6: 335-42.

Galayda, J. 1970. Special study shows increased car-kill of animals. New Jersey Outdoors 20: 22-23.

George, J. L. 1965. Pesticide-wildlife studies by states, provinces, and voniversities - an annotated list of investigations through 1964. U.S. Fish and Wildilife Service circuiar no. 224. Washington, D.C.: U.S. Government Printing Office.

- 1960. Some primary and secondary effects of herbicides on wildlife. Herbicides and their uae in forectry. University Park: Pennsylvania State University.

Gordon, C. C., and Tourangeau, P. C. 1975. Terestrial ecosystems section. In Proceedings of the Fort Union coal fiezd symposium, vol. 5, pp. 509-30. Billings, Mont.: Montana Academy of Sciences.

Hal1, H. J.; Varga, G. M.; and Magee, E. M. 1974. Trace elements and potential pollutant effects in fossil fuels. In Symposium proceedings: environmental aspects of fuel conversion technology (May 1974, St. Louis, Missouri), ed. F. A. Ayer. EPA-650/2-74-118. Washington, D.C.: Office of Research and Development, U.S. Environmental Protection Agency.

Hardin, M. E.; KostelC, D. R.; Peterjohn, B. G.; Casson, J.; Hardin, J. W.; and Klimstra, W. D. 1976. A field study of selected fauna for the Coalcon clean liquid boiler fuels demonstration plant site: New Athens, Illinois. Carbondale, Ill.: Illinois Cooperative Wildlife Research Laboratory, Southern Illinois University.

Heck, W. W. 1973. Air pollution and the future of agriculture production. In Air pozzution damage to vegetation, ed. J. A. Naegele, pp. 118-29. Washington, D.C.: American Chemical Society.

Hedgcock, G. G. 1914. Injury by smelter smoke in southeastern Tennessee. J. Wash. Acad. Sci. 4: 70-71. Cited by Miller, M. W., and McBride, J. R. 1975. Effects of air pollutants on forests. In Responses of plants to air pollution, eds. J. B. Mudd and T. T. Kozlowski, pp. 195-236. New York: Academic Press, Inc.

Helms, D. R., and Stains, H. J. 1966. Kill of mammals and birds and entrapment of turtles on railroad tracks. Trans. IZ2. State Acad. Sci. 59: 297.

Hemphil1, D. D. 1972. Availability of trace elements to plants with respect to soil-plant interaction. Ann. N. Y. Acad. Sci. 199: 46-61.

Herbes, S. E.; Southworth, G. R.; and Gehrs, C. W. 1976. Organic contaminants in aqueous coal conversion effluents: environmental consequences and research priorities. In Trace, substances in environmental health $-X$, ed. D. D. Hemphill. Columbia, Mo.: University of Missouri.

Hildebrand, S. G.; Cushman, R. M.; and Carter, J. A. 1976. The potential toxicity and bioaccumulation in aquatic systems of trace elements present in aqueous coal conversion effluents. In Trace substances in environmental health $-X$, ed. D. D. Hemphill. Columbia, Mo.: University of Missouri. 
Hodson, N. L. 1960. A survey of vertebrate road mortality/1959. Bird Study 7: 224-31.

Howel1, J. C. 1954. Bird mortality at airport ceilometers. Wizson Buzz. 66: 207-15.

Illinois Department of Mines and Minerals. 1975a. 1974 annual coal, oil and gas report. Springfield: State of Illinois.

- 1975b. Surface-mined land conservation and reclamation act (PA 78-1295/Effective

July 1, 1975): miles and regulations. Springfield: State of Illinois.

Imhoff, E. A.; Friz, T. 0.; and LaFevers, J. R. 1976. A guide to state programs for the reclamation of surface mines areas. U.S. Geological Survey circular no. 731. Washington, D.C.: U.S. Government Printing office.

Institute of Ecology. 1974. A scientific and policy review of the draft environmental impaot statement for the proposed Federal coal leasing progrom of the Bureau of Land Management, Department of the Interior. Washington, D.C.: The Institute of Ecology, Environmental Impact Assessment Project.

Jager, H. J., and Klein, H. 1977. Biochemical and physiological detection of sulfur dioxide injury to pea plants (Piswm sativum). J. Air Pollut. Control Assoc. 27(5): 464-66.

Jahnig, C. E., and Bertrand, R. R. 1976. Environmental aspects of coal gasification. Chem. Eng. Prog. $72(8): 57-56$.

Kjellstrom, T. 1977. Calculations of exposure limits for the prevention of cadmium-induced health effects. Paper presented at the First International Cadmium Conference, San Francisco, Cálifurrià, Jan. 31-Feb. 2, 1977.

Kopp, J. F., and Kroner, K. C. 196\%. Trace metals in waters of the United States - a five-year sumary of trace metals in rivers and lakes of the United States. Washington, D.C.: U.S. Department of the Interior, Federal Water Pollution Control Administration.

Koppenaal, D. W., and Manahan, S. E. 1976. Hazardous chemicals from coal conversion processes. Divizivil. Sui. Teuluwi. 10: 1104-07.

Korschgen, L. J. 1970. Soil-food-chain-pesticide wildlife relationships in aldrin-treated fields. J. Wildz. Manage. 34: 186-99.

Leaderer, B. P.; Zagraniski, R. T.; and Stolwijk, J. A. J. 1976. Estimates of health benefits due to reductions in ambient $\mathrm{NO}_{2}$ levels. Environ. Manage. 1: 31-37.

Likens, G. E.; Bormann, F. H.; and Johnson, N. M. 1972. Acid rain. Environment 14: 33-40.

MacFarlane, D. R.; Hoglund, B. M.; Roberts, P. A.; and Yates, J. J. 1975. Power facility siting in the State of. Illinois: part II - environmental impacts of large energy conversion facilities. Chicago: Illinois Institute for Environmental Quality. 
Malaney, G. W.; Lutin, P. A.; Cibulka, J. J.; and Hickerson, C. H. 1967. Resistance of carcinogenic organic compounds to oxidation by activated sludge. J. Water Polzut. Control Fed. 39(12): 2020-29.

Mansfield, T. A., ed. 1976. Effects of air polzutants on plants. Cambridge, Mass.: Cambridge University Press.

Memphis State University. 1971. Effects of noise on wildlife and other animals. Washington, D.C.: U.S. Environmental Protection Agency, Office of Noise Abatement and Control.

Miller, M. W., and Berg, G. G. 1969. Chemical fallout/current research on persistent pesticides. Springfield, I11.: Charles C. Thomas.

Miller, P. R., and McBride, J. R. 1975. Effects of air pollutants on forests. In Responses of plonts to air polzution, eds. J. B. Mudd and T. T. Kozlowski, pp. 195-236. New York: Academic Press, Inc.

Moore, S. F., and Dwyer, R. L. 1974. Effects of oil on marine organisms: a critical assessment of published data. Water Res. 8(10): 819-27.

Mudd, J. B. and Kozlowski, T. T., eds. 1975. Responses of plants to air polzution. New York: Academic Press, Inc.

Naegele, J. A., ed. 1973. Air pollution damage to vegetation. Washington, D.C.: American Chemical Society.

Nash, T. H., III. 1973. The effects of air pollution on other plants, particularly vascular plants. In Air. puzzuliun uril Ziclitiss, ed. B. W. Fepry, pp. 192-223. Toronto: Toronto University Press.

National Academy of Sciences. 1972. Particulate polycyclic organic matter. Washington, D.C.: National Research Council Committee on Biologic Effects of Atmospheric Pollutants, National Academy of Sciences.

Neff, J. M. 1975. Accumulation and release of petroleum-derived aromatic hydrocarbons by marine animals. Symposium on the chemistry, occurrence, and measurement of polynuclear aromatic hydrocarbons. ACS Petrol. Chem. Div. Prepr. 20(4): 839-50.

Neil, P. H.; Hoffman, R. W.; and Gill, R. B. 1975. Effects of harassment on wild animals - an annotated bibliography of selected references. Special report no. 37. Denver, Colo.:. Colorado Division of Wildlife.

Orr, H. K. 1975. Mine spoil reclamation research at the Belle Ayr Mine, northeast Wyoming. In Proceedings of the Fort Union Coal Field Symposium, vol. 3, pp. 304-07. Billings, Mont.: Eastern Montana College.

Peterson, P. J. 1971. Unusual accumulations of elements by plants and animals. Sci. Prog. (Oxf.) 59: 505-26. 
Rich, S. 1975. Interactions of air pollution and agricultural practices. In Responses of plants to air polzution, eds. J. B. Mudd and T. T. Kozlowski, pp. 335-60. New York: Academic Press, Inc.

Rubin, E. S., and McMichael, F. C. 1975. Impact of regulations on coal conversion plants. Environ. Sci. and Technol. 9: 112-17.

Ruch, R. R.; Gluskoter, H. J.; and Shimp, N. F. 1974. Occurrence and distribution of potentially volatile trace elements in coal. Environmental geology note, Series 72. Urbana: Illinois State Geological Survey.

Sather, N. F.; Swift, W. M.; Jones, J. R.; Beckner, J. L.; Addington, J. H.; and Wilburn, R. L. 1975. Potential trace element emissions from the gasification of Illinois coal. Chicago, I11.: I1linois Institute for Environmental Quality.

Shriner, D. S. 1976. Research needs related to air pollution from coal conversion processes. In Proceedings of AICHE 82nd national meeting, Atlantic City, N.J., pp. 1-10. New York: American Institute of Chemical Engineers.

Shriner, D. S.; McLaughlin, S. B.; and Baes, C. F. 1977. Character and transformation of pollutants from major fossil fuel energy sources, $28 \mathrm{pp}$. Environmental Sciences Division publication no. 1049. Oak Ridge, Tenn.: Oak Ridge National Laboratory.

Sprague, J. B. 1971. Measurement of pollutant toxicity to fish-III. Sublethal effects and "safe" concentrations. Water Res. 5: 245-66.

Stegeman, J. J., and Teal, J. M. 1973. Accumulation, release, and retention of petroleum hydrocarbons by the oyster, Crassostrea virginica. Mar. Bioz. 22: 37-44.

Stenehjem, E. J., and Metzger, J. E. 1976. A fromework for projecting employment and population changes accompanying energy development. Washington, D.C.: Energy Research and Development Administration.

Stern, A. C. 1977. Prevention of significant deterioration: a critical review. J. Air Polzut. Control Assoc. 27: 440-53.

Stickel, L. F. 1968. OrganochZorine pesticides in the environment. U.S. Fish and Wildlife Service special șcientific report no. 19. 32 pp. Washington, D.C.: U.S. Fish and Wildlife Service.

Stout, J. I., and Cornwell, G. W. 1976. Nonhunting mortality of fledged North American waterfowl. J. Wildl. Manage. 40: 681-93.

Inompson, S. L.; Burton, C. A.; Uuinn, U. J.; and Ng, Y. C. 1972. Concentration factors of chemical elements in edible aquatic organisms. UCRL-55064 (Rev. 1). Livermore, Calif.: Lawrence Livermore Laboratory, Bio-Medical Division. 
Tucker, R. K., and Crabtree, D. G. 1970. Hondbook of toxicity of pesticides to wildlife. U.S. Fish and Wildlife Service resource publication no. 84. Washington, D.C.: U.S. Fish and Wildlife Service.

U.S. Army Corps of Engineers. 1975. Draft environmental impact statement, project 1301 (new power plant on the Ohio River, New Haven, West Virginia). Huntington, W. Va.: U.S. Army Engineer District.

U.S. Congress. 1977a. The surface mining control and reclamation act of 1977. Public Law 95-87. August 3. Washington, D.C.

U.S. Congress. 1977b. The clean air act (as amended) Public Law 95-95 (7 Aug.).

U.S. Department of Commerce. 1974. Final environmental impact statement: Easterm Powder River Coal Basin of Wyoming, vol. II. U.S. Department of Commerce, Bureau of Land Management. Washington, D.C.: U.S. Government Printing Office.

U.S. Department of Health, Education, and Welfare. 1972. Occupational exposure to noise. Cited by Berkau, E. E.; Cordle, S. R.; Hart, F. D.; and Simon, G. R. 1975. An Assessment of the Federal noise research, deveZopment and demonstration activities, FY 73-FY 75. EPA 600/2-75-010. Washington, D.C.: U.S. Environmental Protection Agency.

U.S. Department of the Interior. 1977. Surface mining reclamation and enforcement provision. Office of Surface Mining Reclamation and Enforcement. Fed. Regist. 42(239): 62639-62716.

U.S. Department of the Interior. 1974. Shazlow groundwater in selected areas in the Fort Union coal region. Open file report 74/48. Helena, Mont.: U.S. Department of the Interior, Gcological Survey.

- 1971a. Community noise. NTID 300.3. C1ted by Dickersun, W. D. 1973. Highway Project. In Guidelines for review of environmental impact statements. Vol. 1. Washington, D.C.: U.S. Environmental Protection Agency.

USEPA (U.S. Environmental Protection Agency). 1971b. Effects of noise on people. NTID 300.7. Cited by Dickerson, W. D. 1973. Highway Projects. In Guidelines for review of environmental impact statements. Vol. 1. Washington, D.C.: U.S. Environmental Protection Agency.

- 1971c. Preconference report: official air pollution abatement activity, Mt. Storm, West Virginia - Gorman, Maryland. Air Polzut. Contr. off. Publ. no. 1, pp. 21-48. APTD-0656. Cited by Miller, P. R., and McBride, J. R. 1975. Effects of air polzutants on forests. In Responses of plants to air pollution, eds. J. B. Mudd and T. T. Kozlowski, pp. 195-236. New York: Acadenitc Press, Inic.

Vaughan, B. E.; Abel, K. H.; Cataldo, D. A.; Hales, J. M.; Hane, C. E.; Rancitelli, L. A.; Routson, R. C.; Wildung, R. E.; and Wolf, E. G. 1975. Review of potential impact on health and environmental quality from metals entering the environment as a result of coal utilization. Richland, Wash.: Pacific. Northwest Laboratories, Batelle Memorial Institute. 
Wadden, R. A. 1975. Cited by MacFarlane, D. R.; Hoagland, B. M.; Roberts, P. A.; and Yates, J. J. 1975. Power facility siting in the State of Illinois: Part II-environmental impacts. of large energy conversion facilities. Chicago: Ilinois Institute for Environmental Quality.

Weast, R. C., ed. 1976. Handbook of chemistry and physics, p. F-1. Cleveland: Chemical Rubber Co.

Willard, D. E., and Willard, B. J. 1978. The interaction between some human obstacles and birds. Environ. Manage. 2(4): 331-340.

Williams, M. D. 1976. Potential production of photochemical oxidants from coal gasification facilities. Los Alamos, N.M.: Los Alamos Scientific Laboratory.

Wood, J. M. 1972. A progress report on mercury. Environment 14(1): 33-39.

Zubovic, P. 1976. Geochemistry of trace elements in coal. In Symposium proceedings: environmental aspects of fuel conversion technology. II, December 1975, Hollywood, Florida, pp. 47-64, compiler F. A. Ayer. EPA-600/2-76-149. Research Triangle Park, N.C.: U.S. Environmental Protection Agency. 
Appendix

METHOD FOR ASSESSING THE EFFECT OF EROSION ON AQUATIC BIOTA

[rosion load on a waterway

The construction of a pipeline gas facility requires the clearing of a large portion of land. The primary concern to the water near the construction site is the effect of erosion, characterized as either sheet erosion or gully erosion. For this analysis, it is assumed that the construction time will be so short that the majority of the erosion load will arise from sheet erosion. The determination of sheet erosion is made using the method of Wischmeir (1965). The sheet erosion load $(E)$ in tons per acre per year is determined using the equation

$$
E=R K L S C P,
$$

where

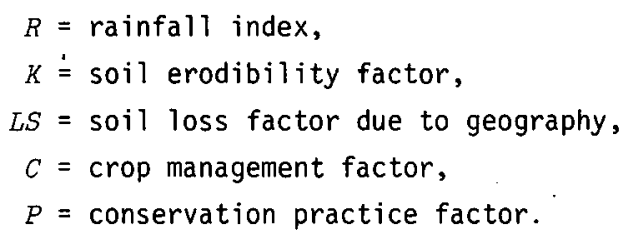

For this analysis, it is assumed that no crop management or conservation practice is employed at the construction site. Hence,

$$
c-p-1.0
$$

The values for the rainfall index, as determined from annual trends determined by wischmeir (1965), are shown in Table A.1. The soil erodibility factor, also shown in Table A.1, is determined by using a nomograph due to Wischmeir and the soil data available from the Soil Conservation Service (U.S. Department of Agriculture 1939; Smith and Smith 1938). The soil loss factor is determined using a figure due to Wischmeir.

Reasonable assumptions are needed to utilize the erosion equation. Thus the construction site is assumed to have a $1 \%$ slope that borders on the existing waterway, whereas the sloped length is assumed to be $305 \mathrm{~m}$ (1000 ft) long. The resulting soil loss factor represents a construction site without erosion control. If erosion control takes the form of a $10 \%$ bank, $15 \mathrm{~m}$ (50 ft) long, the resulting values and the erosion load can be calculated (see Table A.1). The construction site for the demonstration plant is assumed to have a cleared area of 40.5 ha (100 acres) that is subject to erosion. The resulting erosion for an uncontained construction site is shown in Table A.1. For a contained construction site the cleared area on the erosion bank is assumed to be 2 ha ( 5 acres). The erosion resulting from a contained construction site is shown below. 
A-2

Table A. 1. Values for the factors involved in sheet erosion

\begin{tabular}{|c|c|c|c|}
\hline & West Virginia & Illinois & Wyoming \\
\hline Crop management factor $/(C)$ & 1.0 & 1.0 & 1.0 \\
\hline Conservation practice factor $(P)_{i}$ & 1.0 & 1.0 & 1.0 \\
\hline Rainfall index $(R) i$ & 175 & 200 & 30 \\
\hline Soil erodibility factor $(K)$, & 0.47 & 0.45 & 0.3 \\
\hline $\begin{array}{l}\text { Soil loss factor due to geography } \\
\text { (LS), without containment }\end{array}$ & 0.3 & 0.3 & 0.3 \\
\hline $\begin{array}{l}\text { Soil loss factor due to geography } \\
(\angle S) \text {, with containment }\end{array}$ & 1.0 & 1.0 & 1.0 \\
\hline $\begin{array}{l}\text { Sheet erosion load } \\
(E) \text {, tons/acre-year, without } \\
\text { containment }\end{array}$ & 25 & 27 & 3 \\
\hline $\begin{array}{l}\text { Sheet erosion load } \\
\text { (E), tons/acre-year with } \\
\text { containment }\end{array}$ & 82 & 90 & 9 \\
\hline $\begin{array}{l}\text { Erosion load, } \\
\text { turis/year, withoul contaiminent }\end{array}$ & 2500 & 2700 & 300 \\
\hline $\begin{array}{l}\text { Frnsinn Inar, } \\
\text { tún's/yeál, witlı cunladainlliterit }\end{array}$ & $\Delta 19$ & $45 n$ & 45 \\
\hline
\end{tabular}

\section{Suspended sediment load}

The transfer of the erosion load into suspended sediment in the waterway can be assessed using the method of Einstein (1950). Prior to determining the suspended sediment concentration, the suspended sediment transport must be assessed. The vertically integrated transport of suspended sediment is determined by integrating the product of velocity and the suspended concentration from two representative grain diameters above the bed to the free surface. Einstein has shown the resuiting cxpression to be

$$
q_{S}=5.75 u_{\star} \mathrm{dC} a\left(\frac{A}{1-A}\right)^{z}\left[\log _{10}\left(\frac{30.2 \mathrm{~d} x}{D_{65}}\right) \times \int_{\Lambda}^{1}\left(\frac{1-y}{y}\right)^{z} d y+\int_{A}^{1}\left(\frac{1-y}{y}\right) z \log _{10} y d y,\right.
$$

where

$$
\begin{aligned}
q_{s} & =\text { rate of sediment load transport, } \\
u_{\star} & =\text { total friction velocity, } \\
d & =\text { depth of water, } \\
c_{a} & =\text { concentration of sediment at distance } a \text { above channel bed: } \\
A & =\frac{r}{r}=\frac{7 n_{\mathrm{C}}}{\lambda}, \\
x & =\text { concentration factor for channel roughness, } \\
D_{65} & =\text { particle diameter of which } 65 \% \text { of the material by weight is finer, } \\
z & =v_{s} / 0.4 u_{\star}, \\
v_{s} & =\text { settling velocity of a particle (chosen particle size is } D_{65} \text { ). }
\end{aligned}
$$

In this expression, the concentration of particles at $a$ is determined from the bed load characteristics. A particle in the bed will go into suspension if $z<5$. Assuming that movement occurs in the bed, the concentration has been determined by Einstein (1950) to be 


$$
c_{\alpha}=C \frac{i_{B} q_{B}}{2 D_{65} u_{\star}}
$$

where

$$
\begin{aligned}
C & =\text { experimental constant }=\frac{1}{11.6}, \\
i_{B} q_{B} & =\text { the bed load rate, } \\
i_{B} & =\text { fraction of bed load in a partirular size, } \\
q_{B} & =\text { bed load per unit time. }
\end{aligned}
$$

For this analysis it is assumed that the ability of a channel to suspend sediment is limited by the supply. Also, it is assumed that the erosion load is transformed to a bed load that is uniformly distributed across the channel width. This last assumption may be invalid at the site itself, but downstream of the site turbulent mixing should result in a uniform suspended sediment. Hence, $i_{B} q_{B}$ represents that portion of the erosion load which will be suspended per unit time. Because channels are, in general, hydraulically rough, the correction factor $x=1.0$.

To determine $q_{s}$, the cross section of the water body at each site must be modeled. Figure A.l is an illustration of the assumed cross-sectional profiles for each channel during a typical storm runoff event from which an erosion load on the waterway would be introduced.

The remaining information required to determine $q_{s}$ is obtained from soil data (Smith and Smith 1938). To find $v_{s}$, $U_{\star}$ must be determined. By definition,

$$
U_{*}^{2}=U_{\star}^{\prime 2}+U_{\star}^{\prime \prime 2}
$$

where

$$
\begin{aligned}
& U_{*}^{\prime}=\text { friction velocity due to surface drag, } \\
& U_{\alpha}=\text { friction velnoity doe to shape drag. }
\end{aligned}
$$

The resulls of Nikuradse (1933) for rough channels gives

$$
\frac{U}{U_{\star}^{\top}}=5.75 \log _{10}\left(12.27 \frac{R_{b}^{\prime} \mathrm{x}}{D_{65}}\right)
$$

where

$$
\begin{aligned}
U & =\text { average velucity for runoff event }, \\
R_{b}^{\prime} & =\text { hydraulic radius. }
\end{aligned}
$$

Again $x=1.0$ is assumed. The value for $D_{65}$ is determined from the available soil data (Figs. A.2, A.3) (Smith and Smith 1938). The determination of $U_{\star}^{\prime \prime}$ requires an expression for the friction velocity because of shape resistance arising from channel irregularities. Such an expression is difficult to determine without exterisive effort for this problem. If it is assumed that some shape resistance will be generated by the sediment deposit arising from the erosion during construction, a reasonable assumed value based on Einstein's work (1950) is

$$
\frac{U^{\prime \prime}}{U}=0.12
$$



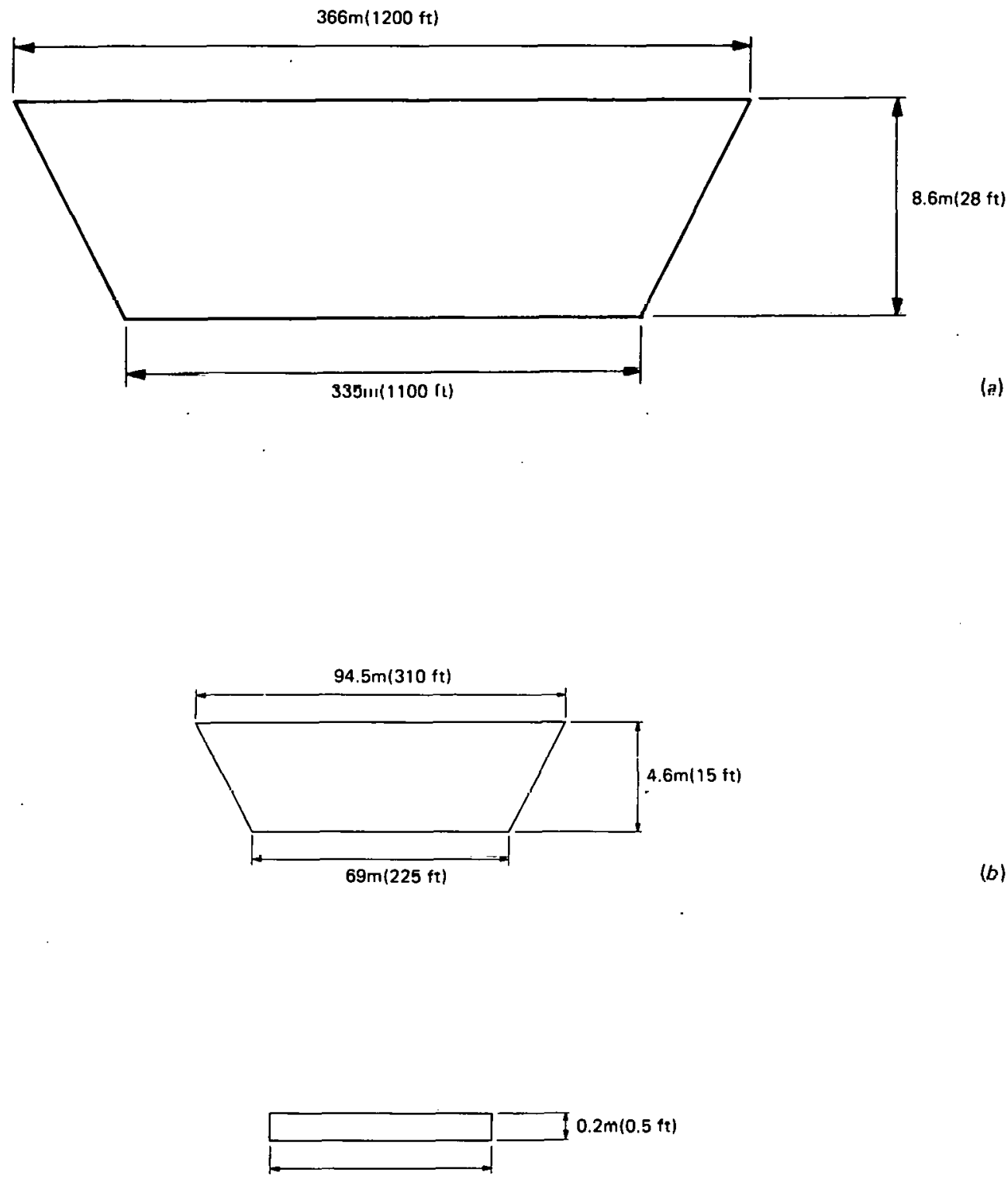

$1.2 \mathrm{~m}(4 \mathrm{ft})$

NOT TO SCALE

Fig. A.1. Cross sections of the water body available at each site: (a) Ohio River-West Virginia site; (b) Kaskaskia River-Illinois site; (c) Donkey Creek-Wyoming site. 


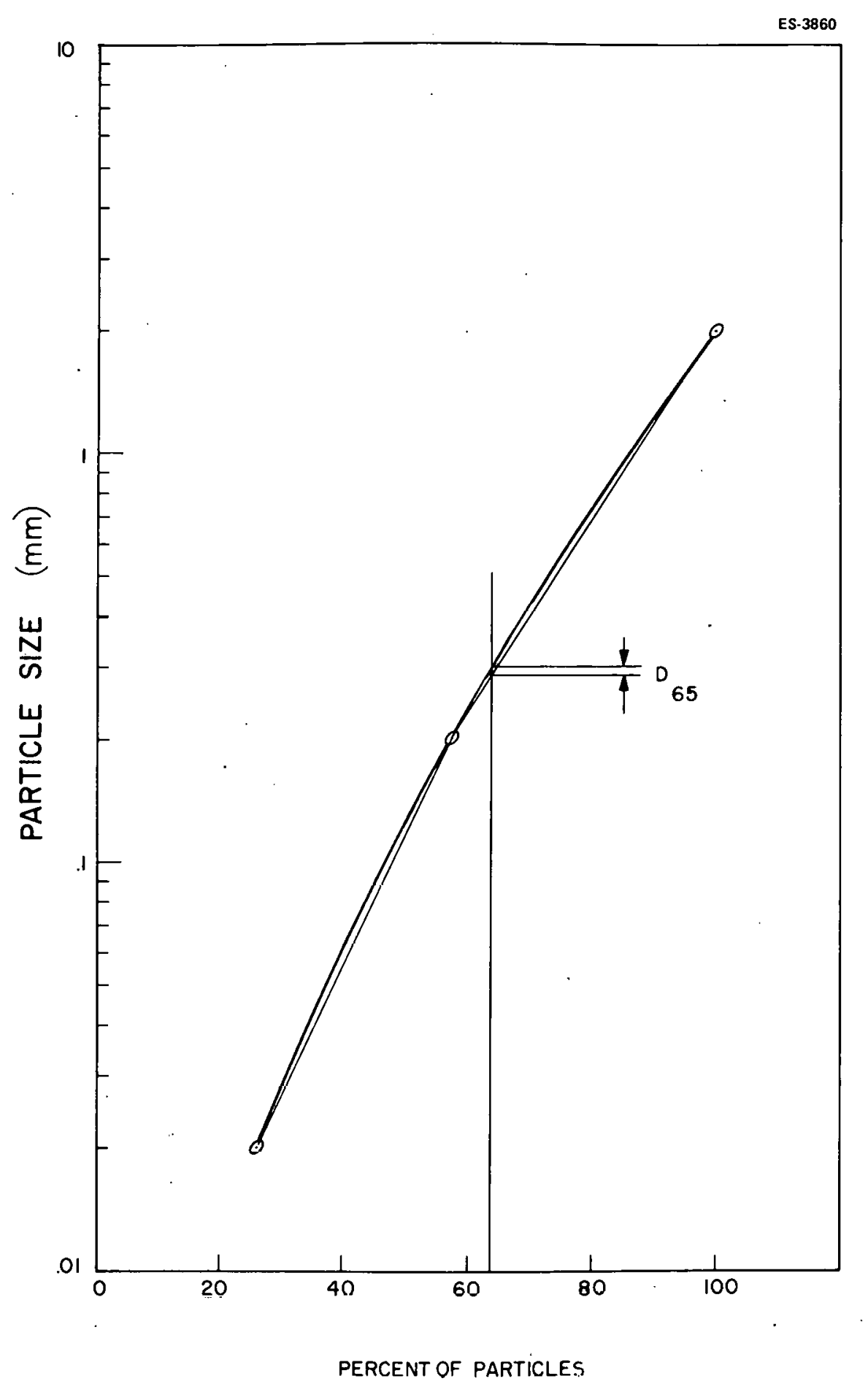

Fig. A.2. Determination of $D_{65}$ particle size range for Wyoming site. 


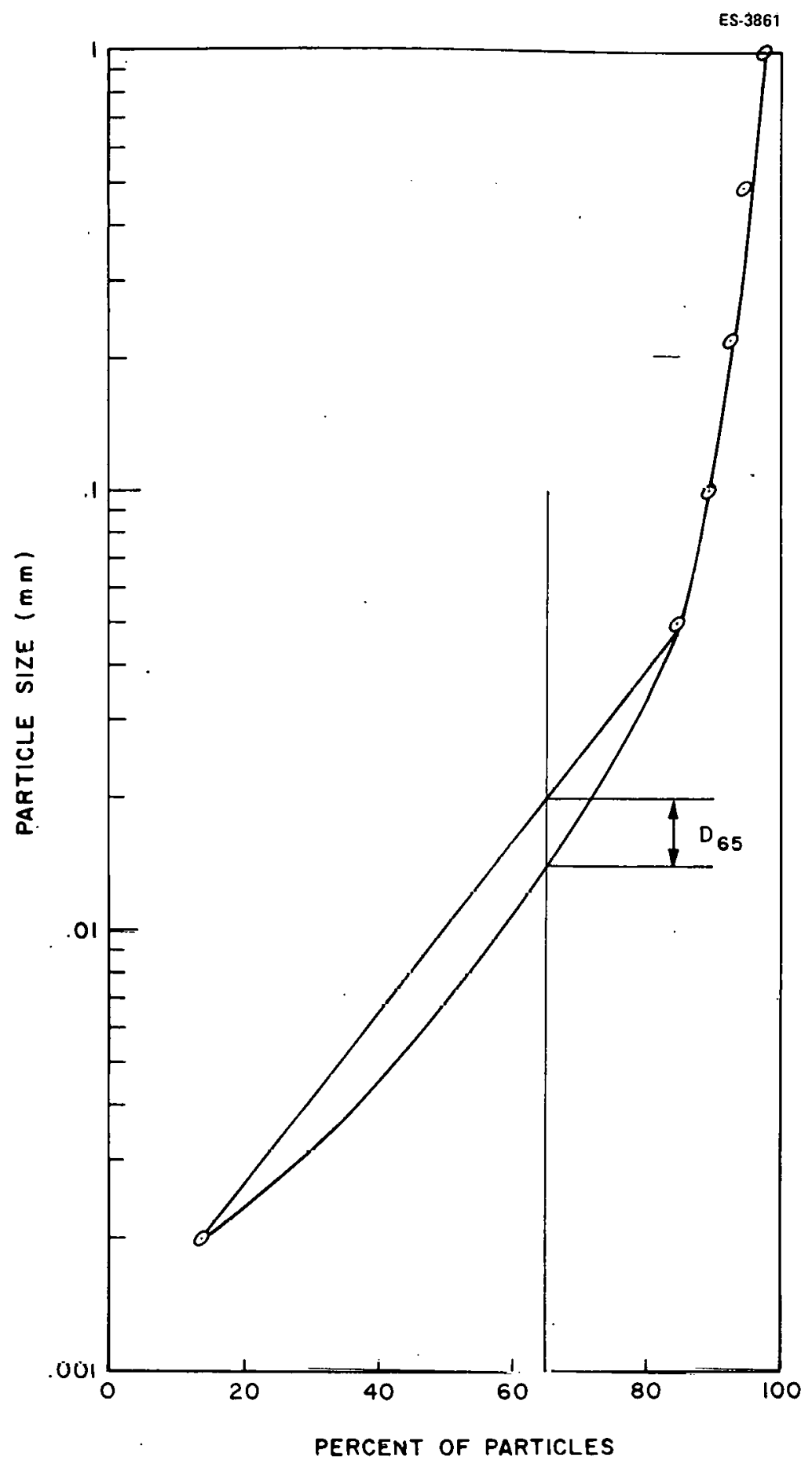

Fig. A.3. Determination of $D_{65}$ particle size range for Illinois and West Virginia sites. 
Using data from Chow (1964), $v_{s}$ can be determined, which can then be used to determine $i_{B}$. values used to compute $q_{s}$ are shown in Table A.2.

Table A. 2. Values for computing the sediment load transport ${ }^{\theta}$

\begin{tabular}{|c|c|c|c|}
\hline Parameter & West Virginia & Illinois & Wyoming \\
\hline$A_{b} \cdot \mathrm{ft}^{2}$ & 32200 & 4012 & 2 \\
\hline $\mathrm{b}, \mathrm{ft}$ & 1100 & 225 & 4 \\
\hline $\mathrm{D}_{65}, \mathrm{~mm}$ & 0.02 & 0.02 & 0.30 \\
\hline$R_{b}^{\prime}, f t$ & 29.3 & 17.8 & 0.5 \\
\hline$\frac{U_{*}^{\prime}}{U}$ & 0.0225 & 0.0231 & 0.0368 \\
\hline$\frac{U_{*}}{U}$ & 0.1221 & 0.1221 & 0.1225 \\
\hline$Q_{\text {STOAM }}, \mathrm{cfs}$ & 100000 & 100000 & 1 \\
\hline $\mathrm{U}, \mathrm{ft} / \mathrm{sec}$ & 3.11 & 2.49 & 0.5 \\
\hline U..ft/sec & 0.38 & 0.3046 & 0.0628 \\
\hline$v_{s}, \mathrm{ft} / \mathrm{sec}$ & 0.758 & 0.609 & 0.126 \\
\hline $\mathrm{D}, \mathrm{mm}$ & 4 & 2 & 0.28 \\
\hline$i_{B}$ & 1.00 & 1.00 & 0.62 \\
\hline$i_{B} q_{B}$ (without containment), tpy & 2500 & 2700 & 186 \\
\hline$i_{B} q_{B}$ (with containment), tpy & 410 & 450 & 27.9 \\
\hline d. $\mathrm{ft}$ & 28 & 15 & 0.5 \\
\hline A & $9.27 \times 10^{-5}$ & $8.75 \times 10^{-5}$ & $3.68 \times 10^{-4}$ \\
\hline$q_{s}$ (without containment), tpy & 1224 & 1330 & 58.5 \\
\hline$q_{s}$ (with containment), tpy & 201 & 221 & 8.3 \\
\hline$Q_{A V G}, c f s$ & 50000 & 42000 & 0.2 \\
\hline $\mathrm{C}_{\mathrm{s}}$ (without containment), $\mathrm{mg} /$ /iter & $2.5 \times 10^{-2}$ & 0.32 & 297 \\
\hline$C_{\mathrm{s}}^{\mathrm{s}}$ (with containment), $\mathrm{mg} / \mathrm{liter}$ & $4.1 \times 10^{-3}$ & 0.053 & 45 \\
\hline
\end{tabular}

${ }^{\circ}$ Compiled from: (1) G. D. Smith and L. H. Smith. 1938. St. Clair County soils. Urbana, III.: University of lllinois Agricultural Experiment Station; (2) U.S. Department of Agriculture. 1939. Soil survey, Campbell County, Wyoming. USDA Soil Conservation Service Series 1939, no. 22. Washington D.C.: U.S. Government Printing Office. (3) ..... 1957, Suil survey, Jacksun anu Masun countles, West virglnia. USUA Soil Conservation Service Series 1957, no. 11. Washington, D.C.: U.S. Government Printing, Office.

Knowing $q_{s}$, the average increase in the concentration of suspended particles can be estimated by $c_{s}=q_{s} / u$, where $u$ is the average annual streamflow. The resultant concentrations are an order of magnitude estimate of the resulting increase in average concentration far downstream from the construction site (Table A.2). The assumption inherent in this estimation is that annual suspended sediment transport has a unique correspondence to the flow velocity.

This is to assume that no phase lag occurs between a rainfall-runoff event and the increase in streamflow. Existing data indicate that a phase lag of varying amounts exists for different watersheds. The influence of this assumption on the results requires further study.

$$
\text { RE.SILTS OF COMPUTED CONCENTRATIONS OF IMPACTS CAUSED BY ATMOSPHERIC EFFLUENTS }
$$

Annual average ground-level concentrations of $\mathrm{SO}_{2}$ and total suspended particulates of selected conditions (St. Louis, Huntington, and Casper wind roses) are shown in Figs. A.4-A.9. 


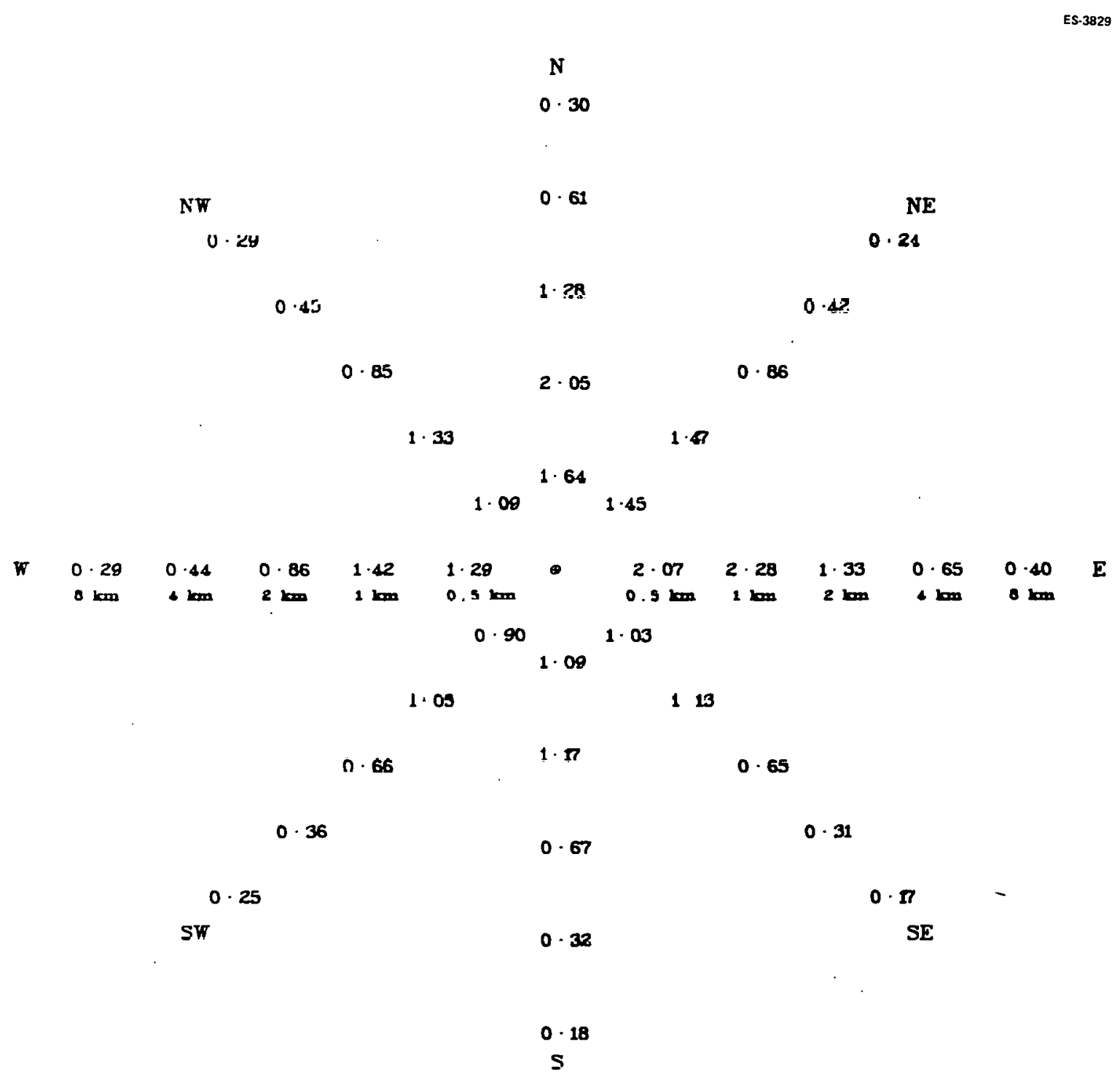

Fig. A.4. Annual àverage ground-level cuncenlrdallun uf lulal suspended particulateg ( $\mu g / \mathrm{m}^{3}$ ) from the release of $450 \mathrm{~kg} /$ day $(1000 \mathrm{~h} /$ day) nf particulates from a $90-\mathrm{m}$ (300-ft) stack (St. Louis wind rose). 


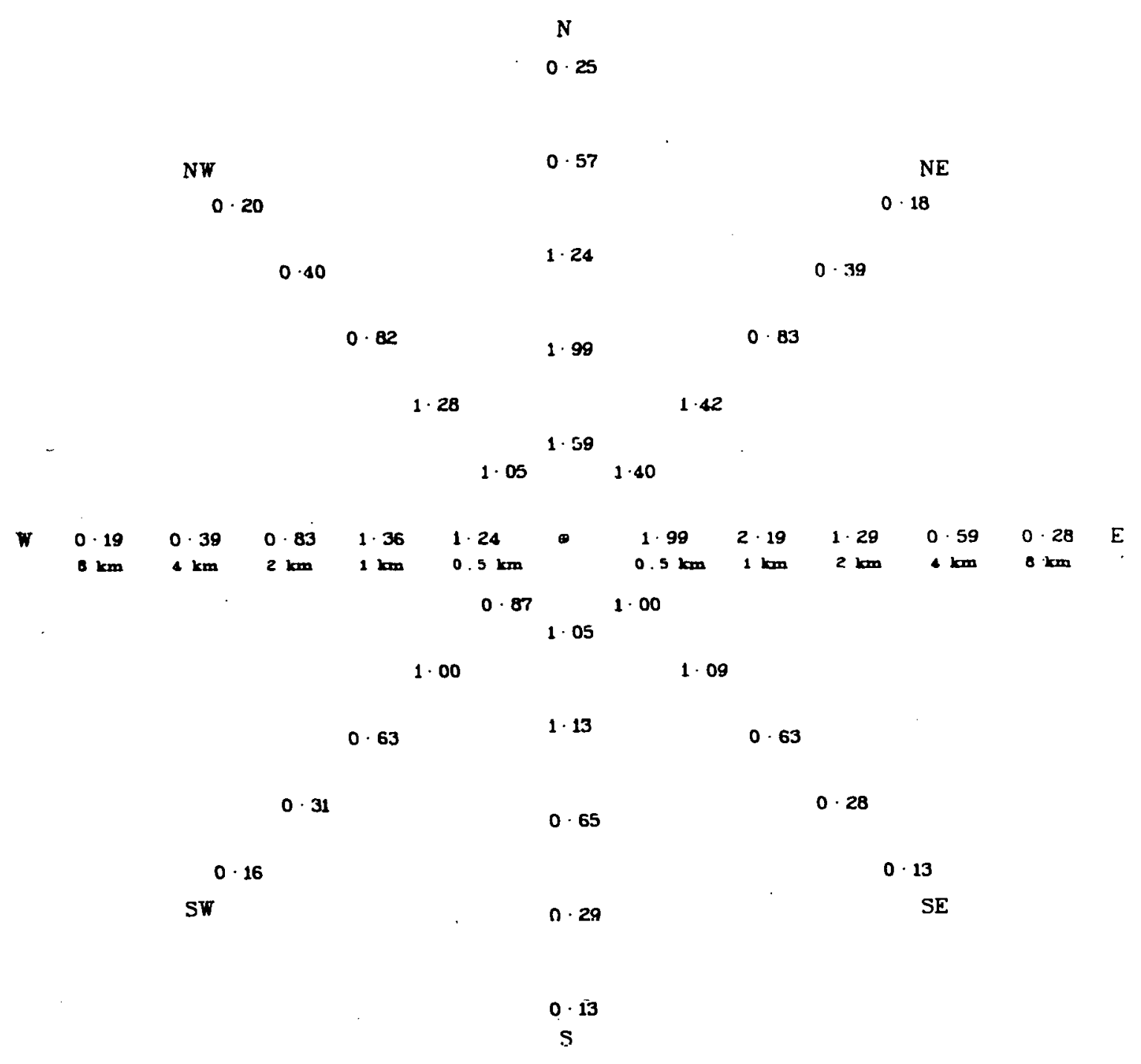

Fis. A.5. Annual average ground-level concentration of $\mathrm{SO}_{2}\left(\mu \mathrm{g} / \mathrm{m}^{3}\right)$ from the release of $450 \mathrm{~kg} /$ day $(1000 \mathrm{lb} /$ day) of sulfur from a $90-\mathrm{m}(300-\mathrm{ft})$ stack (St. Louis wind rose). 


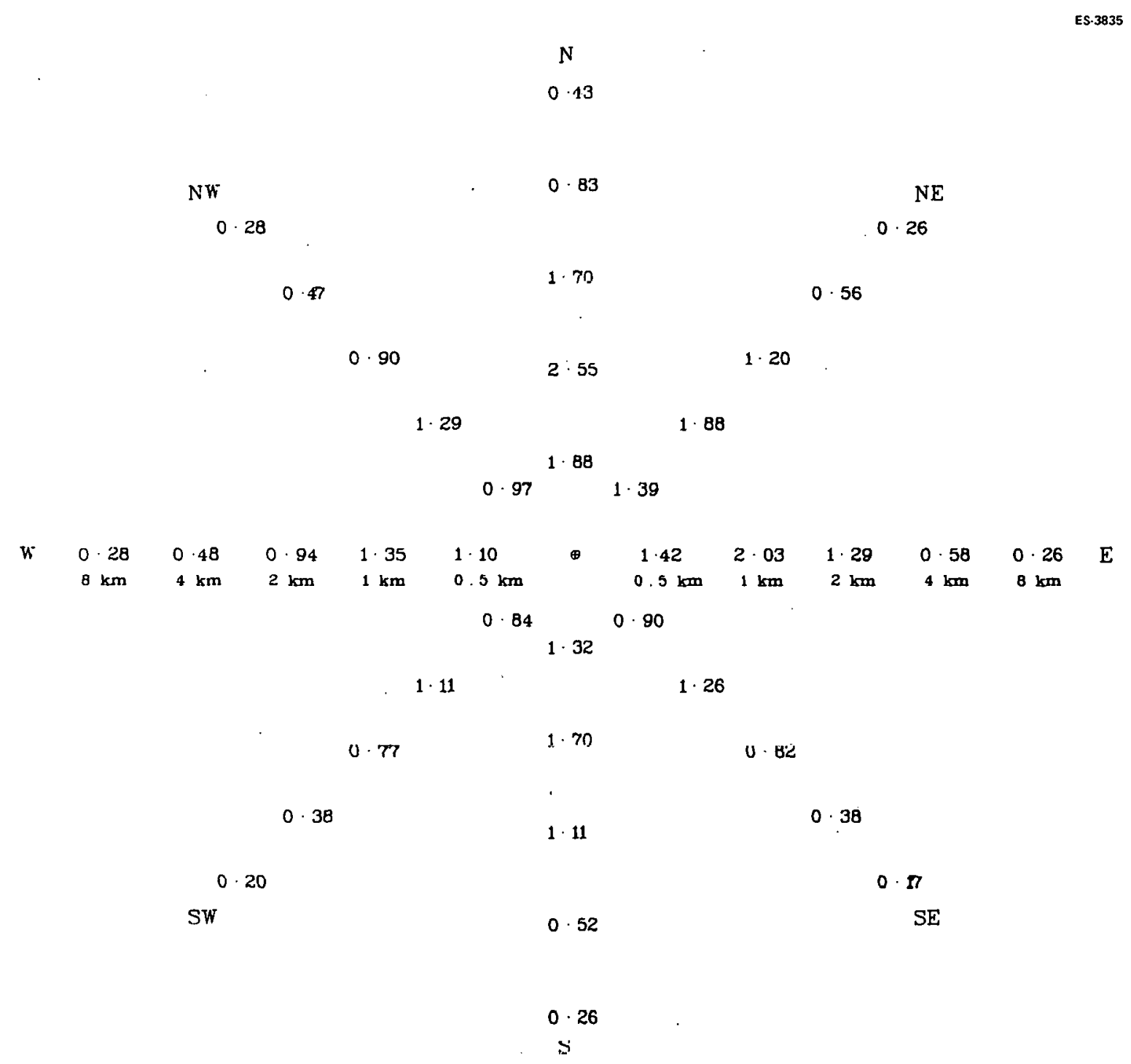

Fig. A.6. Annual average ground-level concentration of $\mathrm{SO}_{2}\left(\mu \mathrm{g} / \mathrm{m}^{3}\right)$ from the release of. $450 \mathrm{~kg} /$ day $(1000 \mathrm{lb} /$ day) of sulfur from a $90-\mathrm{m}(300-\mathrm{ft}$ ) stack (Huntington wind rose). 


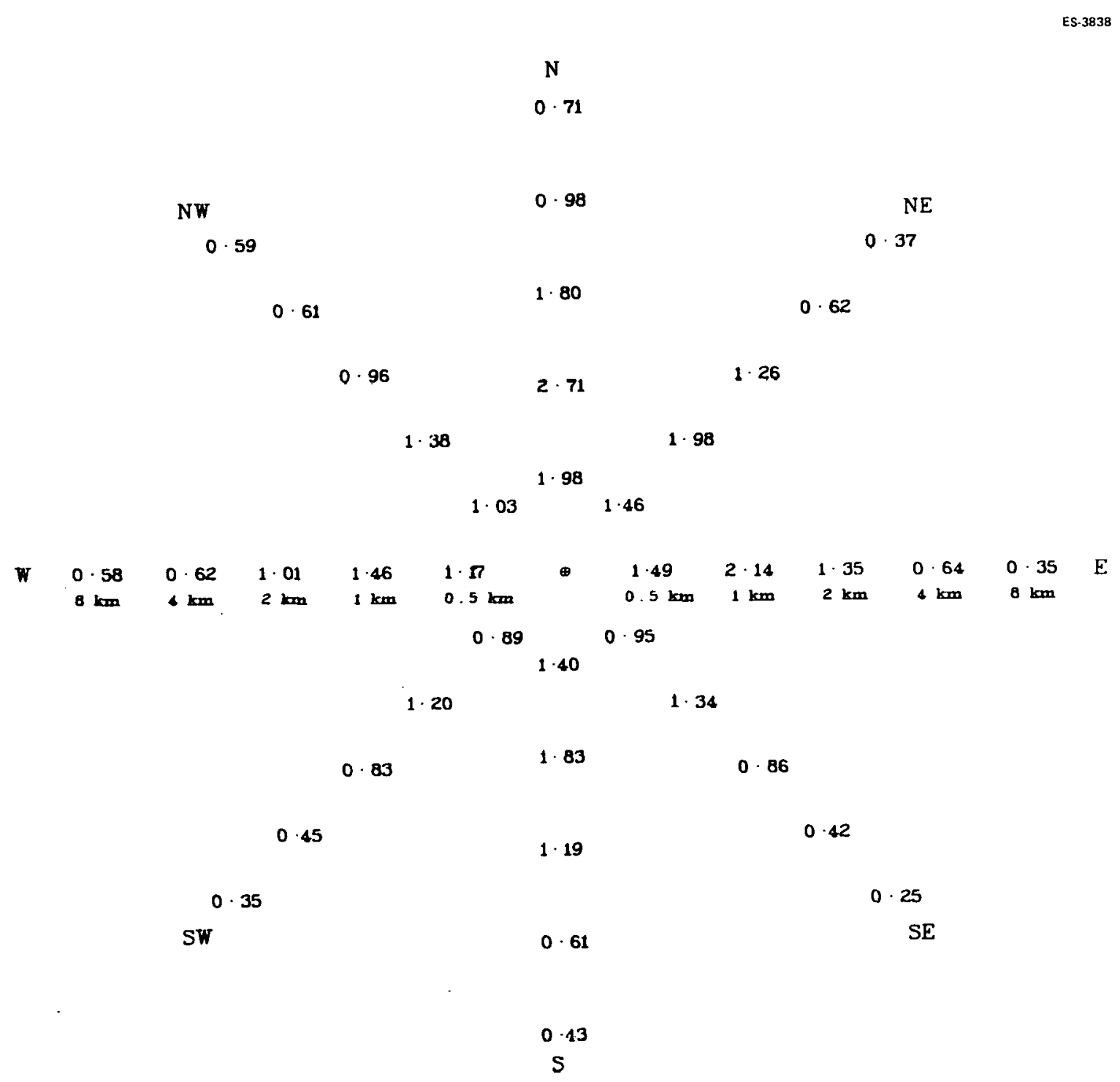

Fig. A.7. Annual average ground-level concentration of total suspended particulates $\left(\mu \mathrm{g} / \mathrm{m}^{3}\right)$ from the release of $450 \mathrm{~kg} /$ day $(1000 \mathrm{lb} /$ day $)$ of particulates from a $90-\mathrm{m}(300-\mathrm{ft})$ stack (Huntington wind rose). 


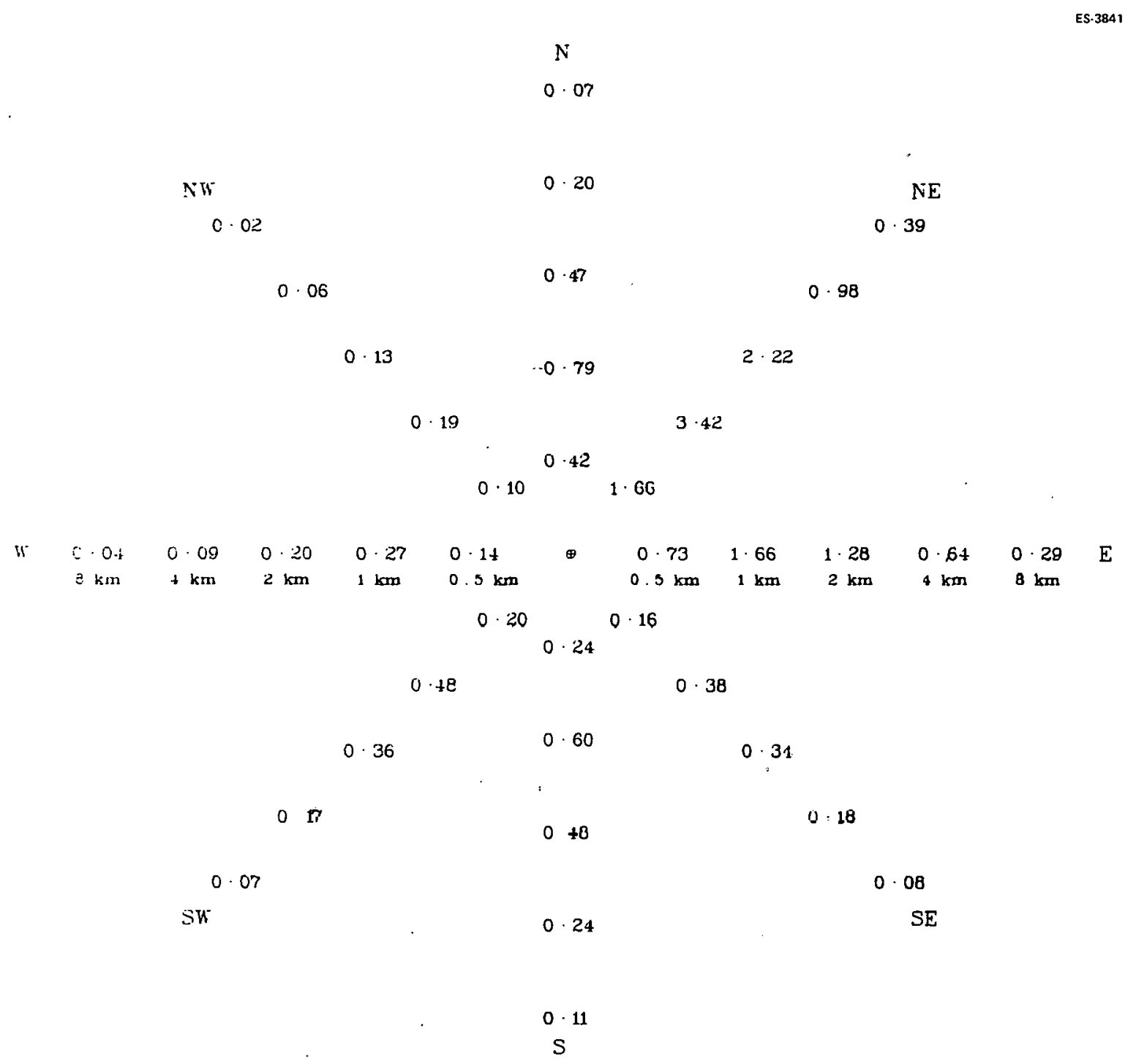

Fig. A.8. Annual average ground-level concentration of $\mathrm{SO}_{2}\left(\mu \mathrm{g} / \mathrm{m}^{3}\right)$ from the release of $450 \mathrm{~kg} /$ day $(1000 \mathrm{lb} /$ day) of sulfur from a 90-m (300-ft) stack (Casper wind rose). 


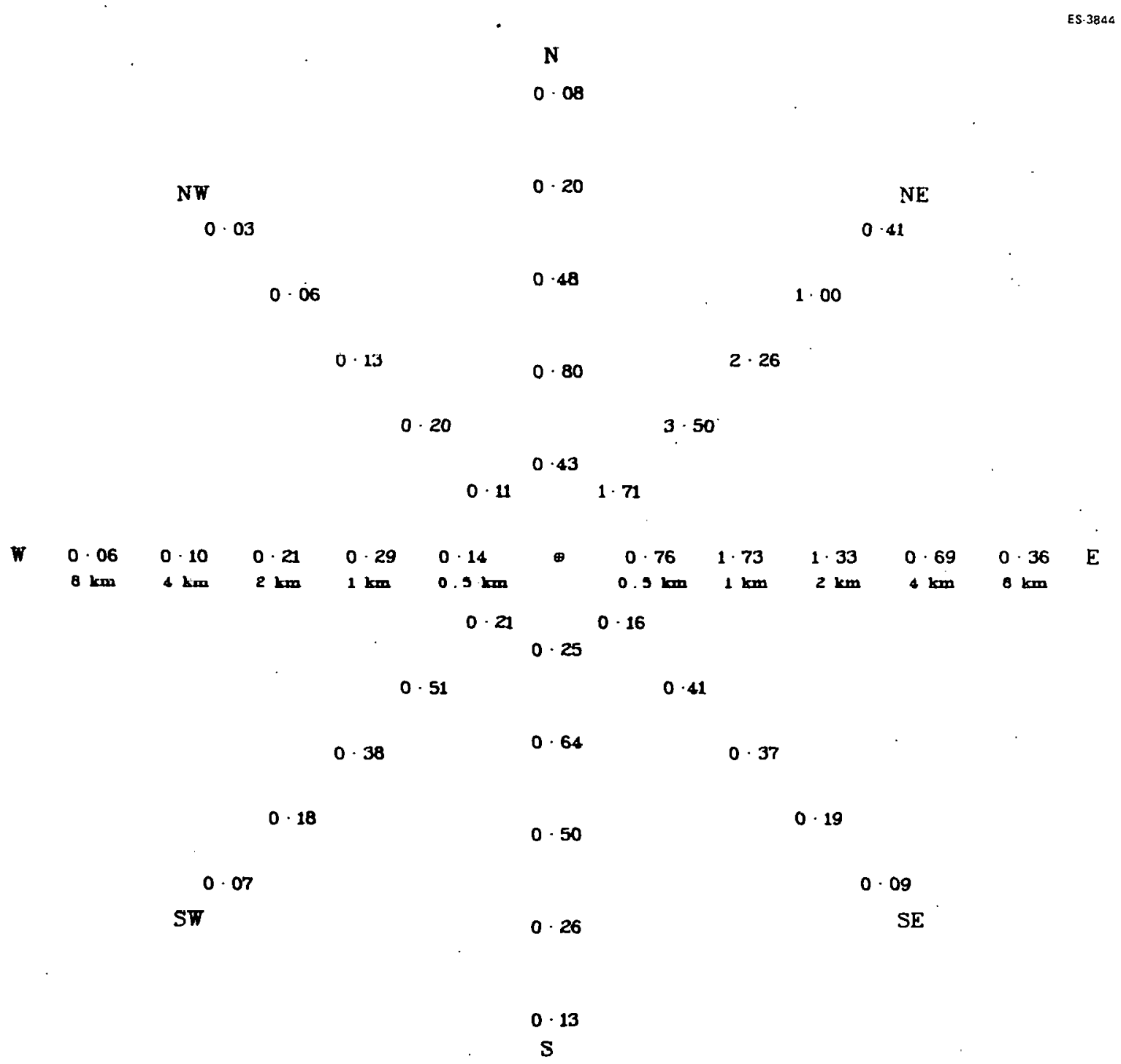

Fig. A.9. Annual average ground-level concentration of total suspended particulates $\left(\mu \mathrm{g} / \mathrm{m}^{3}\right)$ from the release of $450 \mathrm{~kg} /$ day $(1000 \mathrm{lb} /$ day) of particulates from a $90-\mathrm{m}(300-\mathrm{ft})$ stack (Casper wind rose). 
Chow, V. T. 1964. Applied hydrology. New York: McGraw-Hill.

Einstein, H. A. 1950. The bed-Load function for sediment transportation in open channel flows. USDA Soil Conservation Service Technological Bulletin no. 1026. Washington, D.C.: U.S. Government Printing Office.

Nikuradse, J. 1933. Stromungsgesetze in rauhen Röhren. Verein deutscher Ingenieure Forschungscheft no. 316. Berlin.

Smith, G. D., and Smith, L. H. 1938. St. Clair County soils. Urbana, I11.: University of Illinois Agricultural Experiment Station.

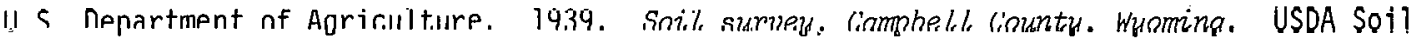
Conservation Service Series 1939, no. 22. Washington, D.C.: U.S. Government Prinling Orfice.

- 1957. Soil survey, Jackson and Mason counties, West Virginia. USDA Soil Conservation Service Series 1957, no. 11. Washington, D.C.: U.S. Government Printing Office.

Wischmeir, W. H., and Smith, D. D. 1965. Predicting rainfall-erosion losses from cropland east of the Rocky Mountains. USDA Soil Conservation Service Handbook no. 282: Washington, D.C.: U.S. Government Printing Office. 
INTERNAL DISTRIBUTION

1. S. I. Auerbach

2. L. W. Barnthouse

3. I. G. Rerry

4. W. J. Boegly

5-12. C. R. Boston

13. H. M. Braunstein

14. K. E. Cowser

15. S. G. DeCicco

16. W. Fulkerson

17. R. J. Haynes

18. S. G. Hildebrand

19. D. L. Kaserman

20. R. S. Konkel

21. R. L. Kroodsma

22. D. W. Lee

23. H. A. McLain

24. L. E. McNeese

25. B. D. Murphy

26. K. M. Oakes

27. R. G. S. Rao
28. R. J. Raridon

29. C. R. Richmond

30. L. W. Rickert

31. R. D. Roop

32. M. W. Rosenthal

33. T. H. Row

34. M. S. Salk

35. F. S. Sanders

36. W. P. Staub

37-38. L. H. Stinton

39. E. G. Struxness

40. G. W. Suter

41. E. K. Triegel

42. T. J. Wilbanks

43. D. J. Wilkes

44. Patent Office

45. Laboratory Records, ORNL R.C.

46-47. Laboratory Records

48-49. Central Research Library

Document Reference Section

EXTERNAL DISTRIBUTION

50. U.S. Department of Energy, Oak Ridge Operations, P.0. Box E, Oak Ridge, TN 37830: Research and Technical Support Division

51. U.S. Department of Energy, Office of Environment, 20 Massachusetts Ave., NW, Room 6128, Washington, D.C. 20545: W. G. Wilson

U.S. Department of Energy, Energy Technology, The Office of Fossit Energy Programs, 20 Massachusetts Ave., Nw, Washington, D.C. 20545:

52. J. i. Johnison

53. D. K. Jones

54-58. H. T. Jones

59-85. U.S. Department of Energy, Technical Information Center, Oak Ridge, TN 37830 